\title{
Inovação, Gestão e \\ Sustentabilidade na \\ Agroindústria
}

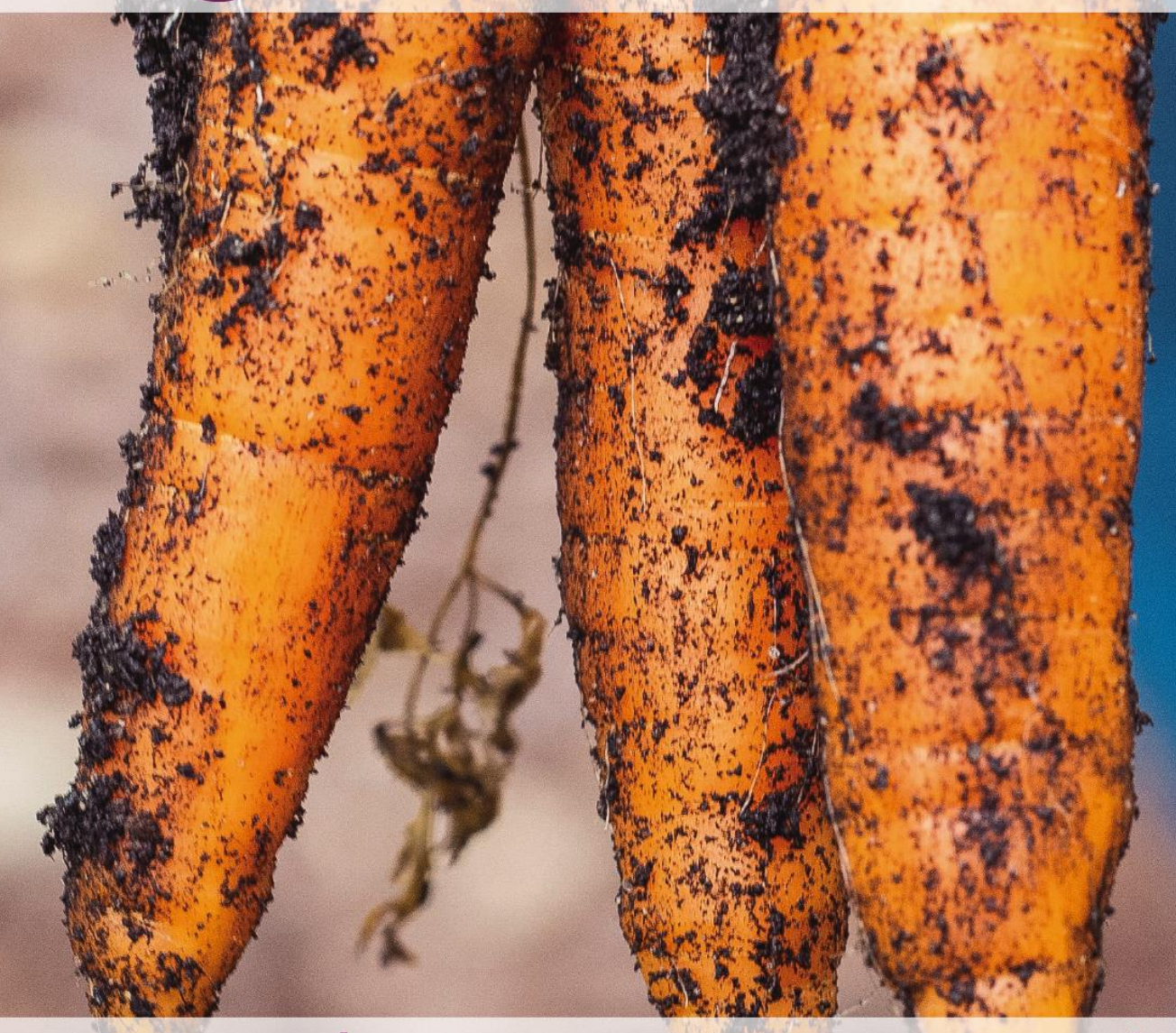

EURÍDICE RIBEIRO DE ALENCASTRO (org.) ERICK VIANA DA SILVA (org.) KRAUSE GONÇALVES SILVEIRA ALBUQUERQUE (org.)

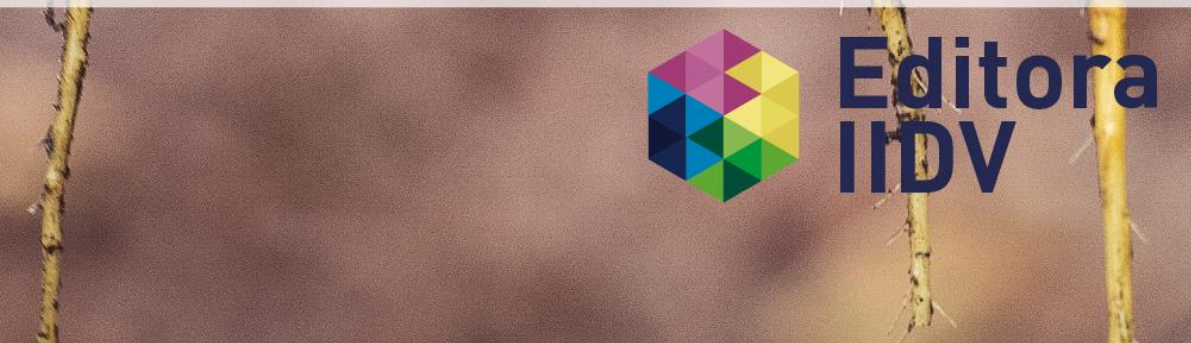


Dados Internacionais de Catalogação na Publicação (CIP)

(Câmara Brasileira do Livro, SP, Brasil)

Inovação, gestão e sustentabilidade na

agroindústria [livro eletrônico] : vol.3 /

organização Eurídice Ribeiro de Alencastro ,

Erick Viana da Silva , Krause Gonçalves

Silveira Albuquerque. -- 3. ed. -- Recife, PE :

Editora IIDV, 2021.

PDF

Vários colaboradores.

ISBN 978-65-88970-19-5

1. Agricultura 2. Agroindústria 3. Gestão de negócios 4. Inovação tecnológica 5. Tecnologia I. Alencastro, Eurídice Ribeiro de. II. Silva, Erick Viana da. III. Albuquerque, Krause Gonçalves Silveira.

$21-75985$ CDD-338.1

Índices para catálogo sistemático:

1. Agroindústria : Gestão 338.1

Aline Graziele Benitez - Bibliotecária - CRB-1/3129 


\section{Inovação, Gestão e Sustentabilidade na Agroindústria}

VOLUME 03

Recife - PE - Brasil

INSTITUTO INTERNACIONAL DESPERTANDO VOCAÇÕES 


\section{DA AGROINDÚSTRIA - CIAGRO 2021}

TÍTULO: Inovação, Gestão e Sustentabilidade na Agroindústria

ORGANIZADORES: Eurídice Ribeiro de Alencastro

Erick Viana da Silva

Krause Gonçalves Silveira Albuquerque

VOLUME: 03

EDITOR: Ayrton Matheus da Silva Nascimento

DIAGRAMAÇÃO: Ana Beatriz Rocha de Barros David

Luana Negromonte Marinho Capiberibe

Mariana Almeida Ferreira de Lima

ISBN: 978-65-88970-19-5

DOI: https://doi.org/10.31692/978-65-88970-19-5

EDITORA: Instituto Internacional Despertando Vocações (IIDV)

Edição Digital 2021. Direitos exclusivos reservados para todos os países. Proibida sua reprodução total ou parcial, para uso privado ou coletivo, em qualquer meio impresso ou eletrônico de acordo com as leis de Propriedade Intelectual.

Digitalizado no Brasil / Digitalizado en Brasil/ Digitized in Brazil. 
Em 2021, ainda em meio à crise social gerada pela pandemia causada pelo Coronavírus, que levou a população a manter um distanciamento social, o CIAGRO foi planejado, conduzido e vivenciado dentro do cenário crescente de temas que envolvem a agroindústria mundial. Com o tema norteador "Inovação Gestão e Sustentabilidade na Agroindústria” o CIAGRO 2021 contemplou o que há de mais moderno para a agroindústria na atualidade.

O Congresso Internacional da Agroindústria - CIAGRO 2021 é um evento, concebido no âmbito das atividades desenvolvidas no Programa Internacional Despertando Vocações para as Ciências Agrárias (PDVAgro) e realizado pelo Instituto Internacional Despertando Vocações (IIDV) que tem compromisso com a democratização do conhecimento e com uma educação de qualidade.

O e-book volume 03 do CIAGRO 2021, está dividido em 26 capítulos que enfatiza os diversos elos da agroindústria, evidenciando alternativas para o desenvolvimento de pesquisas, desafios e expectativas para a cadeia produtiva dos alimentos, dividindo experiências nas áreas de Biotecnologia na produção de alimentos, Produção sustentável, Bioeconomia e Economia Circular.

O CIAGRO 2021 teve como objetivo discutir os caminhos e visões referentes à aplicabilidade de toda a cadeia produtiva do alimento, no cenário nacional e internacional, e além disso trouxe a divulgação de conteúdos e resultados de pesquisas; estabelecendo trocas de experiências entre indivíduos do Brasil, de diferentes instituições, e do exterior; estimulando a geração de novas redes de cooperação multicêntricas entre a indústria e a área acadêmica e de pesquisa, contribuindo com o enriquecimento na formação de estudantes e profissionais, que atuam nos diferentes setores da agroindústria em diferentes países.

Dra . Anny Kelly Vasconcelos de Oliveira Lima Presidente da organização do CIAGRO 2021 II Congresso Internacional da Agroindústria - CIAGRO 


\section{CONSELHO EDITORIAL}

\section{PRESIDÊNCIA}

Dr. ${ }^{a}$ Kilma da Silva Lima Viana - Instituto Federal de Pernambuco (IFPE) | Instituto Internacional Despertando Vocações (IIDV)

\section{CONSELHEIROS}

Dr. Airton José Vinholi Júnior - Instituto Federal de Mato Grosso do Sul (IFMS)

Dr. Alexander Patrick Chaves de Sena - Instituto Federal de Pernambuco (IFPE)

Dr. $^{a}$ Ana Patrícia Siqueira Tavares Falcão - Instituto Federal de Pernambuco (IFPE)

Dr. Arquimedes José de Araújo Paschoal - Instituto Federal de Pernambuco (IFPE)

Dr. Dewson Rocha Pereira - Universidade Federal de Pernambuco (UFPE)

Dr. Edísio Raimundo Silva - Instituto Federal de Pernambuco (IFPE)

Dr. ${ }^{a}$ Francisca da Rocha Barros Batista - Instituto Federal do Piauí (IFPI)

Dr. ${ }^{a}$ Iraneide Pereira da Silva - Instituto Federal de Pernambuco (IFPE)

Dr. Jaime Patrício Leiva Nuñez - Universidad de Playa Ancha (UPLA)

Dr. Jeymesson Raphael Cardoso Vieira - Universidade Federal de Pernambuco (UFPE)

Dr. José Ângelo Peixoto da Costa - Instituto Federal de Pernambuco (IFPE)

Dr. José Ayron Lira dos Anjos - Universidade Federal de Pernambuco (UFPE)

Dr. Jose Cuauhtemoc Ibarra Gamez - Instituto Tecnológico de Sonora, Ciudad Obregón (ITSON)

Dr. ${ }^{a}$ Lastenia Ugalde Meza - Universidad de Playa Ancha (UPLA)

Dr. ${ }^{a}$ Renata Cristine de Sá Pedrosa Dantas - Instituto Federal de Pernambuco (IFPE)

Dr. Roberto Gómez Fernández - Ministério da Educação de Luxemburgo

Dr. ${ }^{a}$ Suzana Pedroza da Silva - Universidade Federal Rural de Pernambuco (UFRPE)

Dr. ${ }^{a}$ Maria Trinidad Pacherrez Velasco - Instituto Federal do Rio Grande do Norte (IFRN)

Dr. Thales Ramon de Queiroz Bezerra - Instituto Federal de Pernambuco (IFPE)

Dr. ${ }^{\text {a }}$ Viviane da Silva Medeiros - Universidade Federal do Rio Grande do Norte (UFRN)

Coordenação Executiva

MSc. Erick Viana da Silva- Instituto Federal de Pernambuco (IFPE) | Instituto Internacional Despertando Vocações (IIDV)

\section{COORDENAÇÃO ADMINISTRATIVA}

Esp. Ayrton Matheus da Silva Nascimento - Instituto Internacional Despertando Vocações (IIDV)

Esp. Douglas Salgado da Silva - Instituto Internacional Despertando Vocações (IIDV) 


\section{SETOR COMERCIAL/MARKETING}

Cynthia Alice Canuto de Oliveira - Instituto Federal de Pernambuco (IFPE)

Heloisa de Barros Dantas - Universidade Federal de Pernambuco (UFPE)

Kaline Soares da Silva - Instituto Federal de Pernambuco (IFPE)

Larissa Amanda Pereira da Silva - Instituto Internacional Despertando Vocações (IIDV)

Mariana Almeida Ferreira Lima - Instituto Federal de Pernambuco (IFPE)

Misael Tomaz de Araújo - Universidade Federal Rural de Pernambuco (UFRPE)

\section{COORDENAÇÃO TÉCNICA EDITORIAL}

Vinícius de Barros Monteiro - Instituto Federal de Pernambuco (IFPE)

\section{ASSISTENTES EDITORIAIS}

Anderson Soares da Silva - Instituto Federal de Pernambuco (IFPE)

Carlos Augusto Brandão - Universidade Federal de Pernambuco (UFPE)

Cecília Lima Siqueira - Instituto Federal de Pernambuco (IFPE)

Danielly Francielly dos Santos Silva - Instituto Federal de Pernambuco (IFPE)

Jussara Ricardo da Silva Rodrigues - Instituto Federal de Pernambuco (IFPE)

Karoliny Paula da Silva - Centro Universitário Guararapes (UNIFG)

Palloma Joyce de Aguiar Silva - Instituto Federal de Pernambuco (IFPE) 


\section{CAPÍTULO 1}

PRODUÇÃO DE LACASE POR Oudemansiella canarii E APLICAÇÃO EM SÍNTESE ORGÂNICA Camila Gabriel Kato; Emanueli Backes; Thaís Marques Uber, Gisella Maria Zanin, Rosane M. Peralta DOI: https://doi.org/10.31692/978-65-88970-19-5.1-14

\section{CAPÍTULO 2}

ANTIMICROBIANOS NATURAIS NA CONSERVAÇÃO DE ALIMENTOS - UMA REVISÃO

Éllen Francine Rodrigues; Afonso Henrique da Silva Júnior; Carlos Rafael Silva de Oliveira; Luís Antonio Lourenço; Lisandro Simão

DOI: https://doi.org/10.31692/978-65-88970-19-5.15-33

\section{CAPÍTULO 3}

OTIMIZAÇÃO DA PRODUÇÃO DE LACASES POR Trametes versicolor EM FERMENTAÇÃO EM ESTADO SÓLIDO COM RESÍDUOS AGROINDUSTRIAIS

Emanueli Backes; Camila Gabriel Kato; Thaís Marques Uber, Adelar Bracht, Rosane M. Peralta

DOI: https://doi.org/10.31692/978-65-88970-19-5.34-47

\section{CAPÍTULO 4}

PRODUÇÃO DE LACASES POR FUNGOS DA PODRIDÃO BRANCA E APLICAÇÃO NA DESCOLORAÇÃO DO CORANTE VERDE MALAQUITA

Thaís Marques Uber; Gabriel Bruno da Silva; Emanueli Backes; Vinicius M. S. Cheute; Rosane M. Peralta

DOI: https://doi.org/10.31692/978-65-88970-19-5.48-62

\section{CAPÍTULO 5}

PROTEASES E SUAS APLICAÇÕES BIOTECNOLÓGICAS NAS INDÚSTRIAS ALIMENTÍCIAS

Maria Clara do Nascimento; Viviane do Nascimento e Silva Alencar; Thiago Pajeú Nascimento; Juanize Matias da Silva Batista; Ana Lúcia Figueiredo Porto

DOI: https://doi.org/10.31692/978-65-88970-19-5.63-82

\section{CAPÍTULO 6}

USO DE POLÍMERO HIDRORETENTOR E AZOSPIRILLUM BRASILIENSE NA PRODUÇÃO DE MILHO SAFRINHA EM TANGARÁ DA SERRA-MT

Tulio Martinez-Santos; João Felipe Barbosa da Silva; Adrielle da Conceição Dias; Ilio Fealho de Carvalho; Roberto Antonio Savelli Martinez

DOI: https://doi.org/10.31692/978-65-88970-19-5.83-97

\section{CAPÍTULO 7}

FERMENTAÇÃO EM ESTADO SÓLIDO E SUBMERSO PARA PRODUÇÃO DE CELULASE: REVISÃO BIBLIOGRÁFICA

DOI: https://doi.org/10.31692/978-65-88970-19-5.98-112

\section{CAPÍTULO 8}

CERVEJA ARTESANAL: COMPONENTES E PROCESSOS PRODUTIVOS

Higo Moreira de Assis; Mônica Tejo Cavalcanti; Mônica Correia Gonçalves; Thamirys Lorranne Santos Lima; Inês Maria Barbosa Nunes Queiroga

DOI: https://doi.org/10.31692/978-65-88970-19-5.113-132 
CAPÍTULO 9

PRODUÇÃO DE COMPOSTOS FENÓLICOS POR FERMENTAÇÃO EM ESTADO SÓLIDOS COM O USO DE RESİDUOS AGROINDUSTRIAIS: REVISÃO BIBLIOGRÁFICA

Adryelen Cassiano Martins; Letícia Souza Silva; Juliana Bueno Ruiz; Larine Kupski

DOI: https://doi.org/10.31692/978-65-88970-19-5.133-145

\section{CAPÍTULO 10}

AVALIAÇÃO DA TOXICIDADE IN VITRO DO EXTRATO ENZIMÁTICO DO LÁTEX DA EUPHORBIA MILII PARA PROCESSAMENTO DE ALIMENTOS

Iris Barbosa de Souza; Graziela Domingues Almeida Lima; Erika Valente de Medeiros; Keila Aparecida Moreira; Ana Lucia Porto Figueiredo

DOI: https://doi.org/10.31692/978-65-88970-19-5.146-158

\section{CAPÍTULO 11}

UMA MINI REVISÃO SOBRE APROVEITAMENTO INTEGRAL DO PESCADO COMO ALTERNATIVA AO DESCARTE

Nilson Fernando Barbosa da Silva; Quesia Jemima da Silva; Julyanne Victória Dos Santos Ferreira; Ana Lúcia Figueiredo Porto; Vagne Melo Oliveira.

DOI: https://doi.org/10.31692/978-65-88970-19-5.159-177

\section{CAPÍTULO 12}

MONITORAMENTO TECNOLÓGICO DE PATENTES ENVOLVENDO PREBIÓTICOS NO CENÁRIO GLOBAL E BRASILEIRO

Wanessa Braz da Silva; Maria Eduarda Menezes Rocha; Nathan Gabriel Barbosa Moura; Rodrigo Lira de Oliveira; Tatiana Souza Porto

DOI: https://doi.org/10.31692/978-65-88970-19-5.178-197

\section{CAPÍTULO 13}

COMPORTAMENTO DA ATIVIDADE DAS ENZIMAS POLIFENOLOXIDASE (PPO), PEROXIDASE (PO), PECTINAMETILESTERASE (PME) NOS ENSAIOS DA FERMENTAÇÃO DO CACAU (THEOBROMA CACAO L).

Adriane Ferreira de Miranda; Maricely Uría Toro

DOI: https://doi.org/10.31692/978-65-88970-19-5.198-211

\section{CAPÍTULO 14}

PURIFICAÇÃO DE PROTEASES DE Aspergillus heteromorphus URM 0269 POR SISTEMA DE DUAS FASES AQUOSAS PEG-Citrato

Maria Eduarda Menezes Rocha; Yuri Matheus Silva Amaral; Rodrigo Lira de Oliveira; Wanessa Braz da Silva; Tatiana Souza Porto

DOI: https://doi.org/10.31692/978-65-88970-19-5.212-230

\section{CAPÍTULO 15}

ACÚMULO E PARTIÇÃO DA MATÉRIA SECA NAS BRAQUIÁRIAS BRIZANTHA E DECUMBENS, NA REGIÃO DE CORURIPE, AL

Dalmo de Freitas Santos; Wesley Oliveira de Assis; José Valdemir Ferreira Júnior; Terezinha Bezerra Albino Oliveira; Mauro Wagner de Oliveira

DOI: https://doi.org/10.31692/978-65-88970-19-5.231-236

\section{CAPÍTULO 16}

A INSERÇÃO DA MANTA DE CARNEIRO NA AGROINDÚSTRIA DE PEQUENO PORTE: UM RELATO DE EXPERIÊNCIA

Francisca Giselle da Cruz; João Paulo Arcelino do Rêgo; Priscila Izidro de Figueirêdo; Wagner Pessanha Tamy; Alfredo Tavares Fernandez

DOI: https://doi.org/10.31692/978-65-88970-19-5.237-241 
CAPÍTULO 17

PRODUÇÃO SUSTENTÁVEL DE ALIMENTOS UTILIZANDO ZEÓLITAS COMO FERTILIZANTES DE LIBERAÇÃO LENTA: UMA REVISÃO

Lisandro Simão; Carlos Rafael Silva de Oliveira; Luís Antonio Lourenço; Afonso Henrique da Silva Júnior; Éllen Francine Rodrigues

DOI: https://doi.org/10.31692/978-65-88970-19-5.242-264

\section{CAPÍTULO 18}

APROVEITAMENTO ENERGÉTICO DE BAGAÇO DE LARANJA E CASCA DE MARACUJÁ IN NATURA DA AGROINDÚSTRIA DE SUCO PARA PRODUÇÃO METANO

Liliana Andréa dos Santos; Carollinni Roberta de Melo Oliveira; André Felipe de Melo Sales Santos; José Fernando Thomé Jucá

DOI: https://doi.org/10.31692/978-65-88970-19-5.265-279

\section{CAPÍTULO 19}

ALIMENTOS COMO FONTES NATURAIS PARA O CONTROLE BIODINÂMICO DE INSETOS E PRAGAS Juliana Dias Maia

DOI: https://doi.org/10.31692/978-65-88970-19-5.280-297

\section{CAPÍTULO 20}

ESTIMATIVA DA PRODUÇÃO DE BIOGÁS PARA GERAÇÃO DE ENERGIA ELÉTRICA ATRAVÉS DE DEJETOS DE ANIMAIS DA PECUÁRIA NO BRASIL

Fábio Ferreira Batista; Milla Gomes Albuquerque; Valmir Cristiano de Arruda Marques; André Felipe de melo Sales Santos

DOI: https://doi.org/10.31692/978-65-88970-19-5.298-316

\section{CAPÍTULO 21}

INVESTIGAÇÃO DAS PROPRIEDADES FISÍCO-QUÍMICAS E MORFOLÓGICAS DA CASTANHA DE CERU (ALLANTOMA LINEATA) PARA APLICAÇÃ̃O EM BISCOITO

Edgardi Silva Contente, Ildes Ribeiro Alves; Giselle Cristine Melo Aires; Suane Corrêa Barbosa; Diego Aires da Silva

DOI: https://doi.org/10.31692/978-65-88970-19-5.317-338

\section{CAPÍTULO 22}

ELABORAÇÃO E CARACTERIZAÇÃO FÍSICO-QUÍMICA E SENSORIAL DE GELEIA FORMULADA A PARTIR DO APROVEITAMENTO DO ALBEDO DO MARACUJÁ AMARELO

Raissa Nathércia Fernandes Costa; Álvaro Gustavo Ferreira da Silva; Bruno Fonsêca Feitosa Emanuel Neto Alves de Oliveira; Érica Milô de Freitas Felipe Rocha

DOI: https://doi.org/10.31692/978-65-88970-19-5.339-353

\section{CAPÍTULO 23}

DESAFIOS DA PRODUÇÃO DE CAFÉ ORGÂNICO: CERTIFICAÇÃO, MERCADO E SUSTENTABILIDADE

Maria Vitória Lima Costa Donato; Wallysson Wagner Vilela Santos; Ana Letícia Toté Medeiros; Suzana Pedroza da Silva

DOI: https://doi.org/10.31692/978-65-88970-19-5.354-368

\section{CAPÍTULO 24}

REAPROVEITAMENTO DE RESÍDUOS NA CADEIA AGROINDUSTRIAL DO PESCADO: UMA REVISÃO

Diana Carla Fernandes Oliveira; Francielly Corrêa Albergaria; Anderson Henrique Venâncio; Maria Emília de Sousa Gomes; Rilke Tadeu Fonseca de Freitas

DOI: https://doi.org/10.31692/978-65-88970-19-5.369-388 
CAPÍTULO 25

AGRICULTURA 4.0: UMA VISÃO GERAL DAS INOVAÇÕES TECNOLÓGICAS NO AUMENTO DA PRODUTIVIDADE AGRÍCOLA

Afonso Henrique da Silva Júnior; Éllen Francine Rodrigues; Lisandro Simão; Luís Antonio Lourenço; Carlos Rafael Silva de Oliveira

DOI: https://doi.org/10.31692/978-65-88970-19-5.389-404

\section{CAPÍTULO 26}

AVALIAÇÃO DO CUSTO DE PRODUÇÃO DE CELULOSE BACTERIANA USANDO SUBPRODUTOS AGROINDUSTRIAIS

Pires, M.C. S; Souza, E.F.; Gottschalk, L.M.F.

DOI: https://doi.org/10.31692/978-65-88970-19-5.405-410 


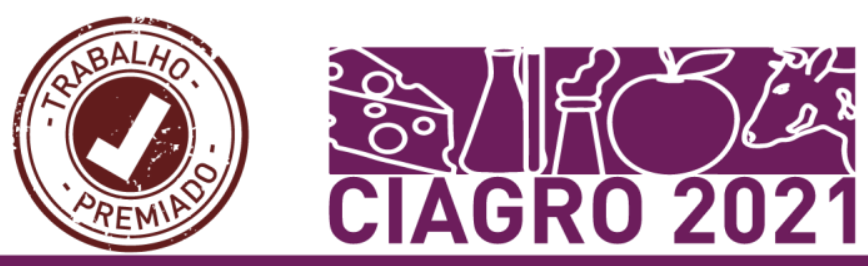

CAPÍTULO 01: PRODUÇÃO DE LACASE POR Oudemansiella canarii E APLICAÇÃO EM SÍNTESE ORGÂNICA

\title{
CAPÍTULO 01: PRODUCCIÓN DE LACASA POR Oudemansiella canarii Y APLICACIÓN EN SÍNTESIS ORGÁNICA
}

\section{CHAPTER 01: LACASE PRODUCTION FROM Oudemansiella canarii AND APPLICATION IN ORGANIC SYNTHESIS}

\author{
Camila Gabriel Kato ${ }^{1}$; Emanueli Backes ${ }^{2}$; Thaís Marques Uber ${ }^{3}$, Gisella Maria Zanin ${ }^{4}$, Rosane M. Peralta ${ }^{5}$
}

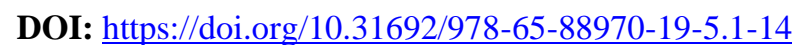

\begin{abstract}
RESUMO
As lacases (EC 1.10.3.2) são enzimas capazes de catalisar a remoção de um elétron de fenóis para produzir radicais fenoxi concomitantemente reduzindo o oxigênio molecular à água. Atualmente, as lacases têm sido grandemente estudadas em síntese orgânica para o desenvolvimento de novos produtos dentro do conceito de química "verde". Tem-se muito interesse na descoberta de novos compostos fenólicos que apresentem propriedades antioxidantes e que sejam estáveis ao calor, luz e oxigênio. Oligomerização dos radicais para formar novos compostos com propriedades antioxidantes são objetos de vários estudos. Os objetivos desse projeto foram 1. avaliar a produção de lacase por um fungo ainda pouco estudado, Oudemansiella canarii e 2. avaliar o uso da enzima em síntese orgânica visando a obtenção de dímeros e trímeros fenólicos com atividade antioxidante a partir do ácido cafeico. A produção da lacase foi realizada através de cultivos em estado sólido utilizando diferentes resíduos como substrato e a atividade lacase foi determinada utilizando 2,2-azinobis (ácido 3etilbenztiazolina-6-sulfônico). Os produtos formados a partir da oxidação do ácido cafeico foram monitorados por cromatografia em camada delgada e as atividades antioxidantes foram avaliadas pelos métodos FRAP e DPPH. Entre os vinte diferentes substratos de cultivo utilizados, os melhores resultados foram obtidos nos cultivos utilizando farelo de trigo $(21,745$ $\pm 1,837 \mathrm{U} / \mathrm{g}$ de substrato), seguido da coroa de abacaxi (11,006 $\pm 0,024 \mathrm{U} / \mathrm{g}$ de substrato). A lacase de $O$. canarii atuou sobre o ácido cafeico e pelo menos um novo composto fenólico com atividade antioxidante foi produzido nas condições utilizadas neste trabalho.
\end{abstract}

Palavras-Chave: Lacases, Basidiomicetos, Síntese orgânica, Antioxidantes.

\section{RESUMEN}

Las lacasas (EC 1.10.3.2) son enzimas capaces de catalizar la eliminación de un electrón de los fenoles para producir radicales fenoxi que reducen concomitantemente el oxígeno molecular a agua. Actualmente, las lacasas han sido ampliamente estudiadas en síntesis orgánica para el desarrollo de nuevos productos dentro del concepto de química "verde". Hay mucho interés en el descubrimiento de nuevos compuestos fenólicos que tengan propiedades antioxidantes y que sean estables al calor, la luz y el oxígeno. La oligomerización de los radicales para formar nuevos compuestos con propiedades antioxidantes es objeto de varios estudios, y los objetivos de este proyecto fueron 1. evaluar la producción de lacasa por un hongo aún poco estudiado, Oudemansiella canarii y 2. evaluar el uso de la enzima en síntesis orgánica con el objetivo de obtener dímeros y trímeros fenólicos con actividad

\footnotetext{
${ }^{1}$ Faculdade de Ciências Farmacêuticas, Alimentação e Nutrição, Universidade Federal do Mato Grosso do Sul, camila.kato@ufms.br

${ }^{2}$ Programa de Pós-Graduação em Ciência de Alimentos, Universidade Estadual de Maringá, emanuelibackes@outlook.com

${ }_{3}^{3}$ Programa de Pós-Graduação em Bioquímica, Universidade Estadual de Maringá, thaisuber@gmail.com

${ }^{4}$ Programa de Pós-Graduação em Engenharia Química, Universidade Estadual de Maringá, giselladeq@ gmail.com

${ }^{5}$ Programa de Pós-Graduação em Ciência de Alimentos, Universidade Estadual de Maringá, rmperalta@uem.br
} 
antioxidante a partir del ácido cafeico. La producción de lacasa se llevó a cabo mediante cultivos en estado sólido usando diferentes residuos y la actividad de lacasa se determinó usando ácido 2,2-azinobis (3-etilbenztiazolina-6-sulfónico) como sustrato. Los productos formados a partir de la oxidación del ácido cafeico fueron monitoreados por cromatografía en capa fina y las actividades antioxidantes fueron evaluadas por los métodos FRAP y DPPH. Entre los veinte diferentes sustratos de cultivo utilizados, los mejores resultados se obtuvieron en los cultivos que utilizaron salvado de trigo $(21.745 \pm 1.837 \mathrm{U} / \mathrm{g}$ de sustrato), seguido de la corona de piña (11.006 $\pm 0.024 \mathrm{U} / \mathrm{g}$ de sustrato). La lacasa de $O$. canarii actuó sobre el ácido cafeico y se produjo al menos un nuevo compuesto fenólico con actividad antioxidante en las condiciones utilizadas en este trabajo.

Palabras Clave: Lacasas, Basidiomicetos, Síntesis orgánica, Antioxidantes.

\section{ABSTRACT}

Laccases (EC 1.10.3.2) are enzymes capable of catalyzing the removal of an electron from phenols to produce phenoxy radicals with a concomitant reduction of molecular oxygen to water. Currently, laccases have been frequently used in organic syntheses for the development of new products within the concept of "green" chemistry. There is great interest in the discovery of new phenolic compounds that have antioxidant properties and that are stable against excessive heat, light and oxygen. Oligomerization of the radicals to form new compounds with antioxidant properties are the object of several studies. The objectives of the present project were 1. to evaluate the laccase production by a fungus still scarcely studied, Oudemansiella canarii, and 2. to evaluate the use of the enzyme in organic synthesis aiming at obtaining phenolic dimers and trimers from caffeic acid with antioxidant activity. The laccase production was carried out through solid state conditions with different residues and the laccase activity was determined using 2,2-azinobis (3-ethylbenzthiazoline-6-sulfonic acid) as substrate. The products formed by the oxidation of caffeic acid were monitored by thin layer chromatography and the antioxidant activities were evaluated by the FRAP and DPPH methods. Among the twenty different substrates used in the cultivation, the best results were obtained with the wheat bran cultures $(21.745 \pm 1.837 \mathrm{U} / \mathrm{g}$ of substrate), followed by the pineapple cultures (11.006 $\pm 0.024 \mathrm{U} / \mathrm{g}$ of substrate). The $O$. canarii laccase acted on caffeic acid and at least one new phenolic compound with antioxidant activity was produced under the conditions used in this work.

Keywords: Laccases, Basidiomycetes, Organic synthesis, Antioxidants.

\section{INTRODUÇÃO}

As lacases (EC 1.10.3.2) são oxidases encontrada em plantas, insetos, bactérias e fungos (GUZIK et al., 2014). As mais estudadas são as lacases de fungos basidiomicetos, tais como Pleurotus ostreatus, Trametes versicolor, Pycnoporus cinnabarinus, Pycnoporus sanguineus além de diversos ascomicetos e alguns deuteromicetos, como Trichoderma sp. (RIVERAHOYOS et al., 2013; BRUGNARI et al., 2018).

Lacases são cobre-oxidases capazes de catalisar reações de oxidação monoeletrônica de diversos substratos tais como anilinas, fenóis, aminas aromáticas, aminofenóis, metoxifenóis, polifenóis, poliaminas e derivados de lignina (JEON et. al., 2010; BRUGNARI et. al., 2018; WELLINGTON, GOVINDJEE e STEENKAMP, 2018). Pelo fato das enzimas utilizarem o oxigênio como aceptores de elétrons, a água é o único subproduto da reação.

Devido à sua atividade oxidativa, as lacases apresentam potencial aplicação em diversas áreas, incluindo modificação de polímeros, branqueamento têxtil, processamento de alimentos, 


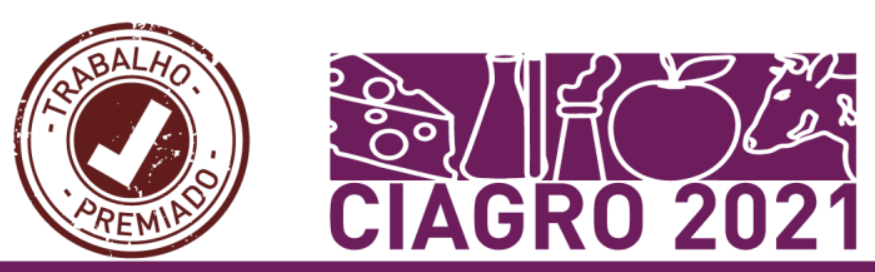

síntese orgânica, indústrias de transformação e biorremediação de uma infinidade de compostos xenobióticos incluindo hidrocarbonetos aromáticos policíclicos, pesticidas, corantes sintéticos e produtos farmacêuticos como diclofenaco (BILAL et al., 2019; KUNAMNENI et al., 2008; MIKOLASCH e SCHAUER, 2009; TAHERAN et al., 2017; BARRIOS- ESTRADA et al., 2018).

Nos últimos anos, as lacases têm sido avaliadas como catalisadores na síntese orgânica para o desenvolvimento de novos produtos dentro do conceito de química verde. As lacases podem catalisar de forma eficiente a polimerização de unidades fenólicas que é iniciada pela formação de radicais cátionicos seguidos por ataque intermolecular para a produção de dímeros a partir fenólicos tais como ácido gálico, ácido ferúlico e ácido cafeico (JEON et. al., 2010; 2012; RAN et al., 2008). A partir dos dímeros pode ocorrer a síntese de oligômeros e polímeros, sendo nestes casos necessário um maior tempo de reação (JEON et. al., 2010; JEON et. al., 2012).

Oudemansiella canarii, um cogumelo comestível comum em vários biomas brasileiros, incluindo a Mata Atlântica, Floresta Amazônica e Pantanal (BONONI et al., 2008, ROSA \& CAPELARI, 2009, RUEGGER et al., 2001), é considerado um fungo decompositor da madeira, mas até agora o conhecimento sobre suas enzimas lignocelulósicas, incluindo as lacases, ainda é limitado. Recentemente nosso grupo publicou dois artigos com as lacases de $O$. canarii. No primeiro, a lacase de $O$. canarii foi utilizada na degradação de um azo corante, o vermelho do Congo (IARK et al., 2019). No segundo artigo, a lacase foi imobilizada por reticulação e utilizada na degradação do corante antraquinônico azul brilhante de Remazol $\mathrm{R}$ (UBER et al., 2020).

O objetivo desse trabalho foi produzir a lacase de Oudemansiella canarii em cultivos em estado sólido utilizando diversos resíduos agro-industriais e utilizar a enzima em síntese orgânica visando a obtenção de dímeros e trímeros fenólicos com atividades antioxidantes a partir do ácido cafeico.

\section{FUNDAMENTAÇÃO TEÓRICA}

Os compostos fenólicos sintéticos ou naturais são conhecidos por minimizar os efeitos deletérios da oxidação de proteínas e lipídios que causam efeitos deletérios aos alimentos reduzindo o tempo de prateleira dos alimentos (SHAHIDI \& AMBIGAIPALAN, 2015). Entretanto, o uso dos compostos fenólicos é muitas vezes limitado devido à baixa solubilidade em meio aquoso e suscetibilidade ao calor, luz e oxigênio (NEMADZIVA et. al., 2018). 
A modificação dos fenólicos naturais através de enzimas se torna interessante devido

à fraca capacidade antioxidante de alguns fenólicos naturais quando comparados aos fenólicos sintéticos tais como BHT e BHA, ineficiência da síntese química e a necessidade de melhorar a biodisponibilidade de compostos fenólicos (ADELAKUN et. al., 2012a). Dessa forma, a modificação permitiria uma ampliação de suas funcionalidades, permitindo o enriquecimento de alimentos com esses novos compostos antioxidantes mais resistentes à temperatura e outros fatores.

As lacases são enzimas promissoras na melhoria da capacidade antioxidante de compostos fenólicos através de dimerização (ADELAKUN et. al., 2012a; ADELAKUN et. al., 2012b; GAVEZZOTTI et. al., 2014) ou polimerização para compostos de maior peso molecular (NEMADZIVA et. al., 2018).

\section{METODOLOGIA}

A pesquisa realizada foi de natureza quantitativa experimental. O fungo Oudemansiella canarii (EF72) foi obtido da Coleção de Basidiomicetos da Embrapa (Empresa Brasileira de Pesquisa Agropecuária), Colombo, PR, Brasil, e mantida em laboratório através de repiques sucessivos em ágar de extrato de malte ( $2 \%$ dextrose, $2 \%$ de extrato de malte, $0,1 \%$ peptona, ágar 2\%).

Para a produção de enzima lacase a partir do $O$. canarii, $5 \mathrm{~g}$ de diferentes substratos ou misturas de substratos e $15 \mathrm{~mL}$ de solução de sal de Vogel diluído 1:50 (VOGEL, 1956) foram acondicionados em frascos Erlenmeyer de $250 \mathrm{~mL}$. Nesta condição, obtem-se uma umidade inicial de $80 \%$. Essas misturas foram esterilizadas em autoclave por 15 min a 121 ${ }^{\circ} \mathrm{C}$. Os inóculos dos fungos foram colocados diretamente nos frascos. Eles consistiam de três plugs miceliais obtidos das culturas agarificadas. As culturas foram mantidas a $28{ }^{\circ} \mathrm{C}$ e na ausência de luz por 10 dias (IARK et. al., 2019).

Para extração das enzimas, um volume de $30 \mathrm{~mL}$ de água foi adicionado aos frascos que foram mantidos em agitação de $100 \mathrm{rpm}$ por $30 \mathrm{~min}$. Em seguida as misturas foram filtradas primeiramente em gaze e posteriormente as frações solúveis foram centrifugadas a $1500 \mathrm{~g}$ por $15 \mathrm{~min}$. Os sobrenadantes límpidos foram considerados como extratos enzimáticos brutos.

A atividade da lacase foi testada usando $1 \mathrm{mmol} / \mathrm{L}$ do substrato 2,2-azinobis (ácido 3-etilbenztiazolina-6-sulfônico) (ABTS) preparado em $50 \mathrm{mmol} / \mathrm{L}$ de acetato de sódio (pH $5,0)$. A reação de oxidação do substrato foi monitorada por 5 min a $40{ }^{\circ} \mathrm{C}$ a $420 \mathrm{~nm}(\varepsilon=36.000$ 


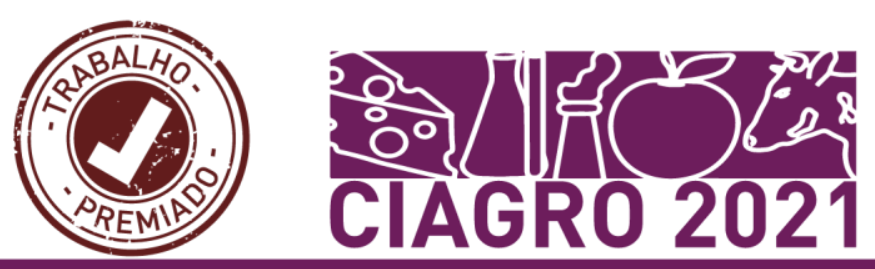

$\left.\mathrm{M}^{-1} \mathrm{~cm}^{-1}\right)$. A atividade enzimática foi expressa em unidades enzimáticas internacionais. Uma unidade internacional $(\mathrm{U})$ foi definida como a quantidade de enzima que transforma $1 \mathrm{mmol}$ de substrato por minuto (MOTA et al., 2015).

Para a oxidação do ácido cafeico com a lacase do O.canarii, foi adotada a metodologia descrita por Nemadziva et. al., (2018) com algumas modificações. As reações de oxidação continham tampão acetato de sódio (T) $50 \mathrm{mM}$ pH 5,0, ácido cafeico $20 \mathrm{mM}$ (AC) (concentração inicial), acetato de etila (AE) e duas diferentes concentrações da lacase nativa (LC) (120,8 U/L e $3480 \mathrm{U} / \mathrm{L})$. Como controles negativos, frascos foram mantidos em paralelo utilizando lacase desnaturada (5 min em fervura) (LD). Todos os frascos foram mantidos por $8 \mathrm{~h}$ em agitador $\left(28{ }^{\circ} \mathrm{C}, 100 \mathrm{rpm}\right)$. E as amostras foram mantidas em estufa a $40{ }^{\circ} \mathrm{C}$ para remoção do acetato de etila, congelados, liofilizados e mantidos a $-20{ }^{\circ} \mathrm{C}$.

Os produtos da reação de oxidação do ácido cafeico foram monitorados em cromatografia em camada delgada usando placas de sílica 60 F254 TLC (Sigma). Como fase móvel utilizou-se um sistema contendo acetato de etila, metanol, água e ácido fórmico (8: 1: 1: $0,02 \mathrm{v} / \mathrm{v}$ ). As manchas foram visualizadas sob luz ultravioleta a $254 \mathrm{~nm}$ (NEMADZIVA et. al., 2018).

Para avaliação das atividades antioxidantes dos produtos obtidos, utilizou-se o ensaio FRAP (do inglês ferric reducing antioxidant power) e a atividade sequestrante de radicais livres (DPPH, do inglês 2,2-diphenyl-1-picrylhydrazyl conforme descrito previamente (KOEHNLEIN et al., 2016).

As análises foram realizadas em quadruplicata para cada amostra. Os resultados foram expressos como as médias \pm desvio padrão. O software Graphpad Prism.VERSÃO 8.0 foi utilizado para a construção das figuras.

\section{RESULTADOS E DISCUSSÃO}

Primeiramente foram realizados experimentos para obtenção da lacase do fungo Oudemansiella canarii em sistema de estado sólido no qual foram testados 20 tipos de substratos como casca de abacaxi, farelo de trigo, sabugo de milho, bagaço de cana, entre outros e todos foram realizados em duplicata para posteriormente obter a média da atividade da enzima. O aproveitamento de resíduos agroindustriais como substrato em bioprocessos com o objetivo de produzir enzimas encaixa-se dentro do conceito de economia circular que busca o aproveitamento máximo dos recursos naturais com um mínimo de impacto ambiental (UBANDO et al., 2020). Conforme observado no Quadro 01, o melhor substrato para a 


\section{produção de lacases foi farelo de trigo.}

canarii.

Quadro 01: Efeito do substrato utilizado no cultivo em estado solido na produção de lacase por $O$.

\begin{tabular}{|l|c|}
\hline Substrato & $\begin{array}{c}\text { Atividade média } \\
\text { lacase } \\
\text { (U/g substrato) }\end{array}$ \\
\hline Farelo de trigo & $21,745 \pm 1,837$ \\
\hline Bagaço de cana & $1,275 \pm 0,005$ \\
\hline Farelo de trigo + bagaço de cana $(1: 1)$ & $12,904 \pm 0,071$ \\
\hline Serragem de eucalipto + bagaço de cana $(1: 1)$ & $0,842 \pm 0,080$ \\
\hline Casca de soja & $0,703 \pm 0,089$ \\
\hline Casca de soja + bagaço de cana $(1: 1)$ & $3,869 \pm 0,122$ \\
\hline Sabugo de milho & $3,543 \pm 0,000$ \\
\hline Sabugo de milho + bagaço de cana $(1: 1)$ & $4,709 \pm 0,047$ \\
\hline Manipueira & $4,322 \pm 0,122$ \\
\hline Manipueira + bagaço de cana $(1: 1)$ & $1,355 \pm 0,071$ \\
\hline Serragem de eucalipto & $1,595 \pm 0,099$ \\
\hline Serragem de eucalipto + farelo de trigo $(1: 1)$ & $7,759 \pm 0,141$ \\
\hline Coroa de abacaxi & $11,006 \pm 0,024$ \\
\hline Coroa de abacaxi + bagaço de cana $(1: 1)$ & $9,707 \pm 0,212$ \\
\hline Bagaço de laranja & $0,483 \pm 0,005$ \\
\hline Bagaço de laranja + bagaço de cana $(1: 1)$ & $1,818 \pm 0,019$ \\
\hline Casca de maracujá & $0,629 \pm 0,005$ \\
\hline Casca de maracujá + bagaço de cana $(1: 1)$ & $4,362 \pm 0,066$ \\
\hline Casca de abacaxi & $5,961 \pm 0,122$ \\
\hline Casca de abacaxi + bagaço de cana $(1 ; 1)$ & $5,321 \pm 0,047$ \\
\hline
\end{tabular}

Fonte: Própria (2021)

A enzima lacase pode ser obtida por fermentação submersa e em estado sólido (RODRIGUEZ-COUTO, 2018). Entretanto, a fermentação em estado sólido possui muitas vantagens quando comparada com a fermentação submersa, incluindo baixo custo energético, a possibilidade de usar subprodutos e resíduos de alimentos e agroindústrias como substratos, e alta produtividade (NILADEVI et al., 2007; SOCCOL et al., 2017). Uma mistura de farelo de trigo-bagaço já foi utilizada como substrato para cultivos de $O$. canarii para produção de lacases (IARK et al., 2019), mas neste trabalho, os melhores resultados foram obtidos utilizando-se somente o farelo de trigo como substrato. Para os demais experimentos realizados, foram utilizados os extratos enzimáticos dos cultivos desenvolvidos com farelo de trigo.

O Quadro 02 identifica as siglas usadas com as específicas condições de cada 
Quadro 02: Condições definidas para a oxidação do ácido cafeico e dimerização/trimerização pela lacase de O.canarii

\begin{tabular}{|c|c|c|}
\hline Amostras & SIGLA & Condições experimentais \\
\hline 1 & $\begin{array}{l}\text { Controle } \\
\text { Padrão } \\
\text { (ACP) }\end{array}$ & $\begin{array}{l}18 \mathrm{~mL} \text { de acetato de etila }+27 \mathrm{~mL} \text { de tampão } \\
\text { acetato }\end{array}$ \\
\hline 2 & $\begin{array}{l}\text { Controle } \\
\text { negativo } \\
\text { (AC) }\end{array}$ & $\begin{array}{l}18 \mathrm{~mL} \text { de ácido cafeico }(\mathrm{AC})+9 \mathrm{~mL} \text { de tampão } \\
\text { acetato }(\mathrm{T})+18 \mathrm{~mL} \text { de extrato contendo lacase } \\
\text { desnaturada }(\mathrm{LD})\end{array}$ \\
\hline 3 & ACLC & $\begin{array}{l}18 \mathrm{~mL} \text { de ácido cafeico (AC) }+9 \mathrm{~mL} \text { de tampão } \\
\text { acetato }(\mathrm{T})+18 \mathrm{~mL} \text { extrato de lacase (LC) com } \\
\text { atividade de } 3,48 \mathrm{U} / \mathrm{mL}\end{array}$ \\
\hline 4 & $\begin{array}{l}\text { ACLCA } \\
\text { E }\end{array}$ & $\begin{array}{l}18 \mathrm{~mL} \text { de ácido cafeico }(\mathrm{AC})+4,5 \mathrm{~mL} \text { de } \\
\text { tampão acetato }(\mathrm{T})+4,5 \mathrm{~mL} \text { de acetato de etila } \\
(\mathrm{AE})+18 \mathrm{~mL} \text { extrato de lacase (LC) com } \\
\text { atividade de } 3,48 \mathrm{U} / \mathrm{mL}\end{array}$ \\
\hline 5 & ACLD & $\begin{array}{l}18 \mathrm{ml} \text { de ácido cafeico (AC) }+9 \mathrm{~mL} \text { de tampão } \\
(\mathrm{T})+18 \mathrm{~mL} \text { de extrato de lacase (LC) com } \\
\text { atividade de } 0,13 \mathrm{U} / \mathrm{mL}\end{array}$ \\
\hline 6 & $\begin{array}{l}\text { ACLDA } \\
\text { E }\end{array}$ & $\begin{array}{l}18 \mathrm{~mL} \text { de ácido cafeico }(\mathrm{AC})+4,5 \mathrm{~mL} \text { de } \\
\text { tampão acetato }(\mathrm{T})+4,5 \mathrm{~mL} \text { de acetato de etila } \\
(\mathrm{AE})+18 \mathrm{~mL} \text { de extrato de lacase }(\mathrm{LC}) \mathrm{com} \\
\text { atividade de } 0,13 \mathrm{U} / \mathrm{mL}\end{array}$ \\
\hline
\end{tabular}

Fonte: Própria (2021)

Após 8 horas, as reações foram interrompidas. Os aspectos macroscópicos dos meios reacionais são apresentados na Fig. 01. Em todas as amostras que continham lacase com maior atividade ocorreu alteração da cor do meio reacional após 8 h. A amostra 1 (controle), não houve alteração na cor, como era esperado, pois não foi colocado a enzima, assim como na amostra 2 já que nestes frascos, a enzima estava presente na forma desnaturada.

O meio reacional onde os compostos fenólicos são substratos em geral necessita de um solvente orgânico, uma vez que muitos fenólicos, incluindo o ácido cafeico, são pouco solúveis em água (NEMADZIVA et. al., 2018). De acordo com Adelakun et al., (2012), a presença de solventes orgânicos ajuda a minimizar a polimerização. Os aspectos mais escuros dos meios onde a reação foi desenvolvida na presença do acetato de etila, sugere que transformações oxidativas foram mais pronunciadas nestes frascos (amostra 5 e 6). 


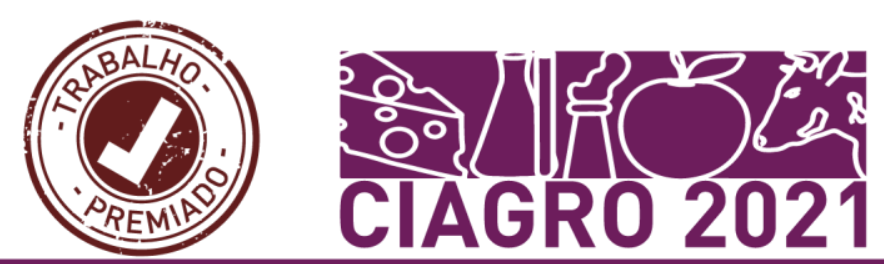

Figura 01: Aspecto das preparações contendo lacase de $O$. canarii e ácido cafeico nas diferentes condições testadas Imagens das condições testadas (ver Quadro 01) no tempo zero e após 8 h de reação.

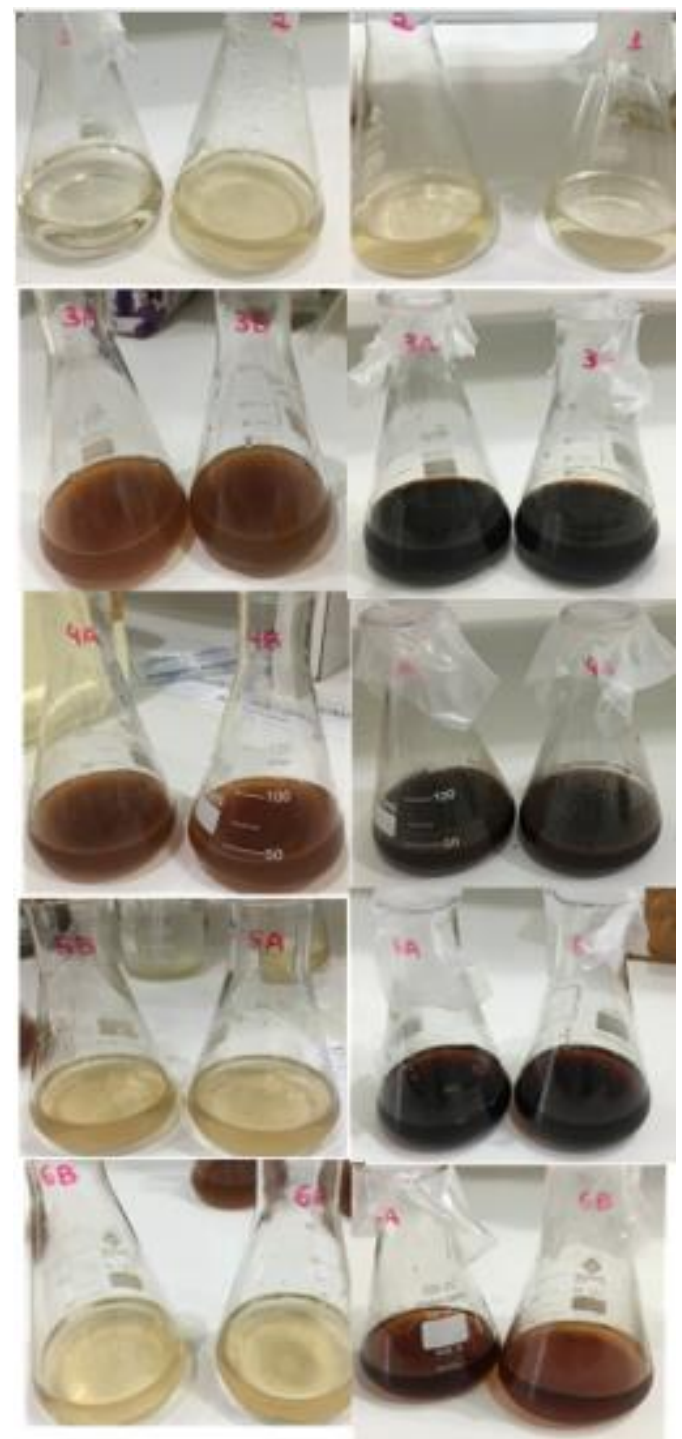

Fonte: Própria (2021)

As amostras foram em seguida submetidas a uma cromatografia em camada delgada (TLC) (Fig. 02). A TLC é um método de separação eficaz e econômico que permanece popular na pesquisa orgânica. TLC envolve a separação de compostos com base em suas distribuições entre 2 fases (fase móvel e fase estacionária). Para este estudo, foram utilizadas placas de F254 TLC. A matriz de $\mathrm{SiO}_{2}$ nas placas F254 torna a fase estacionária polar (NEMADZIVA et. al., 2018). A separação de compostos por TLC pode ser determinada por três fatores; (i) polaridade e tamanho da molécula; (ii) polaridade da fase estacionária; (iii) polaridade do solvente (fase móvel). Nesse estudo, apenas a polaridade da fase móvel poderia ser controlada porque os compostos sendo separados eram novos e de características de polaridade e peso molecular desconhecidos. 
Figura 02: Cromatografia em camada delgada (TLC) dos produtos da reação da lacase utilizando ácido cafeico como substrato em diferentes condições. 1- ácido cafeico; 2-ácido cafeico+ lacase desnaturada; 3- ácido cafeico+ lacase 3,48 U/mL em tampão; 4-ácido cafeico+lacase 3,48 U/mL em tampão +acetato de etila; 5 . Ácido cafeico+ lacase $0,13 \mathrm{U} / \mathrm{mL}$ em tampão. 6 . Ácido cafeico + lacase $0,13 \mathrm{U} / \mathrm{mL}$ em tampão + acetato de etila.

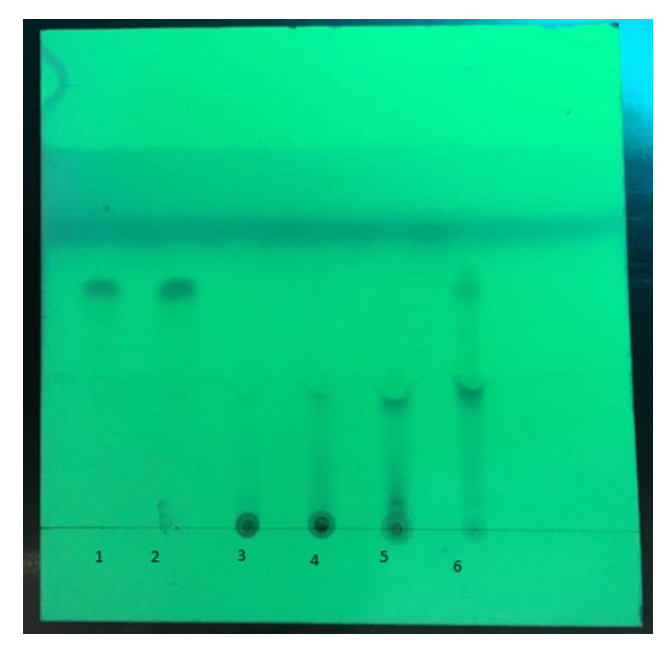

Fonte: Própria (2021)

A interação de produtos de acoplamento com fase estacionária sugeriu que os produtos gerados eram mais polares do que os substratos. Os fenólicos são considerados compostos polares, devido ao seu grupo hidroxila. Após as reações de acoplamento, espera-se que os produtos da reação sejam mais polares, uma vez que os produtos de acoplamento podem teoricamente ter grupos funcionais mais polares (SHERMA \& FRIED, 2003). Portanto, para separar os produtos de acoplamento, foram empregados sistemas de solventes polares.

Pela análise da Figura 02 concluímos que nas amostras 3, 4, 5 e 6 houve o surgimento de pelo menos uma mancha com Rf (distância percorrida pelo composto/distância percorrida pelo solvente) de 0,46, diferente de ácido cafeico ( $\mathrm{Rf}$ do ácido cafeico=0,75), mostrando ter menor afinidade pelo solvente móvel utilizado. Também foi possível observar uma outra mancha que não saiu da origem de aplicação $\mathrm{Rf}=$ zero, mais evidente nas amostras 3,4 e 5.

Todas as amostras, após secagem foram utilizadas para determinação da atividade antioxidante, pelos métodos FRAP e DPPH. Os ensaios FRAP e DPPH são métodos baseados na transferência de um único elétron contudo, cada método possui seu mecanismo de ação. $\mathrm{O}$ ensaio DPPH é um ensaio simples e barato no qual utiliza-se um radical de cor púrpura estável contendo nitrogênio, que é reduzido por antioxidantes naturais ou compostos redutores a uma hidrazina de cor amarelo claro (MOHD AZMAN et al., 2013). Sendo assim, os antioxidantes reduzem o radical DPPH estável para formar DPPH-H, ou seja, as atividades de eliminação de antioxidantes do DPPH estão relacionadas com a habilidade de doação de hidrogênio (LIU et al., 2010). O método FRAP está relacionado com a capacidade do antioxidante, na presença do TPTZ, em reduzir o $\mathrm{Fe}^{+3}$ em Fe${ }^{+2}$, desta forma, o potencial antioxidante está relacionado 
com a habilidade da doação de elétrons para quebrar as reações de cadeia de radicais livres (XIE et al., 2014).

As amostras apresentaram resultados diferentes para os dois métodos (DPPH e FRAP) utilizados para avaliar a atividade antioxidante (Quadro 03).

Quadro 03: Atividade antioxidantes das amostras determinadas pelos métodos DPPH E FRAP.

\begin{tabular}{|c|c|c|}
\hline Amostra & $\begin{array}{c}\text { DPPH ( } \mu \text { mol } \\
\text { TE/g liofilizado) }\end{array}$ & $\begin{array}{c}\text { FRAP (u } \mu \text { mol } \\
\text { TE/g liofilizado) }\end{array}$ \\
\hline $2 \mathrm{AC}$ & $1063,58 \pm 57,71(*)$ & $1932,80 \pm 17,83(*)$ \\
\hline 3 ACLC & $156,26 \pm 26,87$ & $230,31 \pm 11,66$ \\
\hline 4 ACLCAE & $215,46 \pm 4,61$ & $411,28 \pm 16,16$ \\
\hline 5 ACLD & $601,52 \pm 0,92$ & $844,37 \pm 28,97$ \\
\hline 6 ACLDAE & $1267,24 \pm 7,30$ & $2344,84 \pm 34,84$ \\
\hline
\end{tabular}

(*) com extrato enzimático desnaturado

Fonte: Própria (2021)

A amostra contendo apenas ácido cafeico em tampão também teve a atividade antioxidante analisada. Entretanto, estes valores não podem ser comparados com os obtidos pelas amostras 2 a 6 . O peso destas amostras foi muito superior ao obtido na amostra 1 pelo fato delas conterem os extratos enzimáticos brutos. Consideramos por isto os valores de atividade antioxidante encontrados na amostra 2, que continha o ácido cafeico e também o extrato enzimático bruto desnaturado (mas presente em massa) para fazer algumas considerações. Comparando as atividades antioxidantes das amostras 3 a 6 com a amostra 2, podemos observar que maiores atividades antioxidantes nos frascos onde a lacase estava presente em sua forma ativa foram observados nas amostras 5 e 6 , onde a reação foi conduzida na presença do acetato de etila. O fato da amostra 6 ter apresentado os maiores valores de DPPH e FRAP sugere que a molécula com $\mathrm{Rf}=0,46$ seja promissora em termos de atividade antioxidante.

A descoberta de novas moléculas com capacidade antioxidante é muito atrativa e interessante pois na indústria alimentícia os mesmos auxiliam na prevenção da oxidação lipídica e na deterioração de carnes suína e bovina, auxiliando na conservação da carne (YOO et al., 2008; KIM et al., 2016). Moléculas com atividade antioxidante são muito úteis na indústria farmacêutica e de cosméticos, pois podem ser adicionados a cremes ou medicamentos que auxiliam na proteção do corpo humano contra os radicais livres, prevenindo e/ou retardando o envelhecimento e o progresso de doenças crônicas (LIU et al., 2010). 
Conclui-se que se pode utilizar diversos resíduos agroindustriais para a produção de lacase a partir de fungos, dentro do conceito de economia circular. O fungo Oudemansiella canarii mostrou ser um excelente produtor de lacase com potencial uso em síntese orgânica de novos compostos fenólicos. Os dados obtidos neste estudo sugerem que os produtos formados pela ação da lacase de $O$. canarii sobre o ácido cafeico possuem atividade antioxidante, mas serão necessários mais experimentos para otimização do processo e identificação destes compostos.

\section{REFERÊNCIAS}

ADELAKUN, O. E.; KUDANGA, T.; PARKER, A., GREEN, I. R.; ROES-HILL, M. L.; BURTON, S.G. Laccase catalyzed dimerization of ferulic acid amplifies antioxidant activity, Journal of Molecular Catalysis B: Enzymatic 74, 29-35, $2012 \mathrm{a}$.

ADELAKUN, O.E.; KUDANGA, T.; GREEN, I.R.; ROES-HILL, M. L.; BURTON, S.G. Enzymatic modification of 2,6-dimethoxyphenol for the synthesis of dimers with high antioxidant capacity, Process Biochemistry 47, 1926-1932, 2012 b.

BARRIOS-ESTRADA, C.; ROSTRO-ALANIS, M. DE J.; MUÑOZ-GUTTIÉRREZ, B.D.; IQBAL, H.M.N.; KANNAN, S.; PARRA-SALDÍVAR, R. Emergent contaminants: endocrine disruptors and their laccase-assisted degradation - a review. Science of the Total Environment 612, 1516-1531, 2018.

BILAL, M.; RASHEEDB, T.; NABEELB, F.; IQBALC, H.M.N.; ZHAO, Y. Hazardous contaminants in the environment and their laccase-assisted degradation - A review. Journal of Environmental Management, 234, 253-264, 2019.

BONONI, V.L.R.; A.K.M. OLIVEIRA, A.K.M.; QUEVEDO, J.R.; GUGLIOTTA, A.M. Fungos macroscópicos do Pantanal do Rio Negro, Mato Grosso do Sul, Brasil. Hoehnea, v. 35, p. 489-511, 2008.

BRUGNARI, T.; PEREIRA, M.G.; BUBNA, G.A.; FREITAS, E.N.; CONTATO, A.G.; CORRÊA, R.C.G.; CASTOLDI, R.; SOUZA, C.G.M.; POLIZELI, M.L.T.M.; BRACHT, A.; PERALTA, R.M. A highly reusable MANAE-agarose- immobilized Pleurotus ostreatus laccase for degradation of bisphenol A. Science of the Total Environment, v. 634, p.13461351, 2018.

GAVEZZOTTI, P.; VAVŘÍKOVÁ, E.; VALENTOVÁ, K.; FRONZA, G.; KUDANGA, T.; KUZMA, M.; RIVA, S.; BIEDERMANN, D.; KŘEN, V.; Enzymatic oxidative dimerization of silymarin flavonolignans, Journal of Molecular Catalysis B: Enzymatic v.109, p. 24-30, 2014. 

for improving enzyme properties-application to oxidoreductases. Molecules, v.19, p. 89959018, 2014.

IARK, D.; BUZZO; A. J. R.; GARCIA, J. A. A. G.; CÔRREA, V.G.; HELM, C.V.; CORREA, R.C.G.; PERALTA, R.A.; MOREIRA, R.F.P.M.; BRACHT, A.; PERALTA, R.M. Enzymatic degradation and detoxification of azo dye Congo red by a new laccase from Oudemansiella canarii. Bioresource Technology, v.289, 121655, 2019.

JEON, J-R.; KIM, E-J.; MURUGESAN, K.; PARK, H-K.; KIM, Y-M.; KWON, J-H.; KIM, W-G.; LEE, J-Y.; CHANG, Y-S. Laccase-catalysed polymeric dye synthesis from plantderived phenols for potential application in hair dyeing: Enzymatic colourations driven by homo- or hetero-polymer synthesis. Microbial Biotechnology,v.3, p.324-335, 2010.

JEON, J-R.; BALDRIAN, P.; MURUGESAN, K.; CHANG, Y-S. Laccase-catalysed oxidations of naturally occurring phenols: from in vivo biosynthetic pathways to green synthetic applications. Microbial Biotechnology, v.5(3), p.318-332, 2012.

KIM, H. W. et al. Effects of edible films containing procyanidin on the preservation of pork meat during chilled storage. Korean Journal for Food Science of Animal Resources, v.36, n. 2, p. 230-236, 2016.

KOEHNLEIN, E. A.; KOEHNLEIN, É. M.; GOMES, R. C.; NISHIDA, V. S.; CORREA, V. G.; BRACHT, A.; PERALTA, R. M. Analysis of a whole diet in terms of phenolic content and antioxidant capacity: effects of a simulated gastrointestinal digestion. International Journal of Food Science and Nutrition, v.67, p. 614-623, 2016.

KUNAMNENI, A.; CAMARERO, S.; GARCÍA-BURGOS, C. A; PlOU, F. J. Engineering and Applications of fungal laccases for organic synthesis. Microbial Cell Factories, p.7-32, 2008.

LIU, J.; LUO, J.; YE, H.; SUN, Y.; LU, Z.; ZENG, X. In vitro and in vivo antioxidant activity of exopolysaccharides from endophytic bacterium Paenibacillus polymyxa EJS-3. Carbohydrate Polymers, v. 82, n. 4, p. 1278-1283, 2010.

MIKOLASCH, A.; SCHAUER, F. Fungal laccases as tools for the synthesis of new hybrid molecules and biomaterials. Applied Microbiology and Biotechnology v. 82, p. 605-624, 2009.

MOHD AZMAN, A.N; S. HUSNI, S.; ALMAJANO, P.M.; GALLEGO, G.M. Solvent effect on antioxidant activity and total phenolic content of Betula alba and Convolvulus arvensis. International Journal of Biological, Veterinary, Agricultural and Food Engineering, v.7 (5), p.152-157, 2013.

MOTA, T.R.; KATO, C.G.K.; PERALTA, R.A.; BRACHT, A.; MORAIS, G.R.; BAESSO, M.L.; SOUZA, C.G.M.; PERALTA, R.M. Decolourization of congo red by Ganoderma lucidum laccase: evaluation of degradation products andtoxicity. Water, Air, and Soil Pollution v.226, p.351-362, 2015. 
NEMADZIVA, B.; ROES-H, M. L.; KOORBANALLY, N.; KUDANGA, T. Small laccasecatalyzed synthesis of a caffeic acid dimer with high antioxidant capacity. Process Biochemistry, v.69, p. 99-105, 2018.

NILADEVI, K.N.; SUKUMARAN, R.K.; PREMA, P. Utilization of rice straw for laccase in solid state fermentation. Journal of Industrial Microbiology and Biotechnology v.34, p.665674, 2007.

RAN, N.; ZHAO, L.; CHEN, Z., TAO, J. Recent applications of biocatalysis in developing green chemistry for chemical synthesis at the industrial scale. Green Chemistry v.10, p.361372, 2008.

RIVERA-HOYOS, C.M., MORALES-ÁLVAREZ, E.D., POUTOU-PIÑALES， R.A., PEDROSA-RODRIGUEZ, A.M., RODRIGUEZ-VÁSQUEZ, R., DELGADO-BOCADA, J.M. Fungal laccases. Fungal Biology Review v.27, p.67-82, 2013.

RODRIGUEZ-COUTO, S. Solid-state fermentation for laccases production and their applications. Curr. Develop. Biotechnol. Bioeng. Curr. Adv. Solid-State Ferment. p. 211234, 2018.

ROSA, L.H.; CAPELARI, M. Agaricales fungi from Atlantic rain Forest fragments in Minas Gerais, Brazil. Brazilian Journal of Microbiology, v. 40, p. 846-851, 2009.

RUEGGER, M.J.S.; TORNISIELO, S.M.T.; BONONI, V.R.L.; CAPELARI, M. Cultivation of the edible mushroom Oudemansiella canarii (Jungh.) Höhn. in lignocellulosic substrates. Brazilian Journal of Microbiology, v. 32, p. 211-214, 2001.

SHAHIDI, F.; AMBIGAIPALAN, P. Phenolics and polyphenolics in foods, beverages and spices: Antioxidant activity and health effects - A review. Journal of Functional Foods, v. 18, p. $820-897,2015$

SHERMA, J.; FRIED, B. Handbook of thin-layer chromatography, CRC press, 2003.

SOCCOL, C.R.; COSTA, E.S.F.; JR, LETTI, KARP, S.G.; WOICIECHOWSKI, A.L.; VANDENBERGHE, L.P.S. Recent developments and innovations in solid state fermentation. Biotechnology Research and Innovation v.1, p. 52-71, 2017.

UBANDO, A. T.; FELIX, C. B.; CHEN, W. H. Biorefineries in circular bioeconomy: A comprehensive review. Bioresource Technology, v. 299, artigo 122585, 2020

UBER, T. M.; BUZZO, A. J. R.; SCARATTI, G.; AMORIM, S. M.; HELM, C.V.; MACIEL, M. G.; PERALTA, R. A.; MOREIRA, R.F.P.M.; BRACHT, A.; PERALTA, R. M. Comparative detoxification of Remazol Rrilliant Blue R by free and immobilized laccase of Oudemansiella canarii. Biocatalysis and Biotransformation, v. 38, p. 1-12, 2020.

VOGEL, H.J. A convenient growth medium for Neurospora (Medium N), Microbial Genetic Bulletin. v.13, p. 42-43, 1956.

XIE, M. et al. Grafting of Gallic Acid onto Chitosan Enhances Antioxidant Activities. Journal Agricultural and Food Chemistry v.62 (37), p.9128-9136, 2014. 


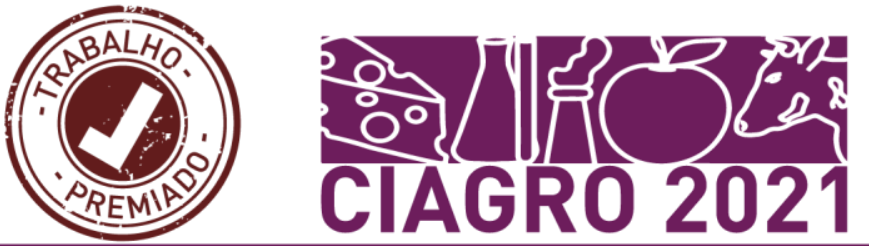

YOO, E. A. et al. Evaluation of antioxidant, antinociceptive, and anti-inflammatory activities of ethanol extracts from Aloe saponaria Haw. Phytotherapy Research, v. 22, n. 4, p. 544-549, 2008.

WELLINGTON, K.W.; GOVINDJEE, V.P.; STEENKAMP, P. A laccase-catalysed synthesis of triaminated cyclohexa-2,4-dienones from catechol. Journal of Catalysis, v.368, p.306-314, 2018. 


\title{
CAPÍTULO 02: ANTIMICROBIANOS NATURAIS NA CONSERVAÇÃO DE ALIMENTOS - UMA REVISÃO
}

\section{CAPÍTULO 02: ANTIMICROBIANOS NATURALES EN LA CONSERVACIÓN DE ALIMENTOS - UNA REVISIÓN}

\section{CHAPTER 02: NATURAL ANTIMICROBIALS IN FOOD CONSERVATION - A REVIEW}

\author{
Éllen Francine Rodrigues ${ }^{1}$; Afonso Henrique da Silva Júnior ${ }^{2}$; Carlos Rafael Silva de Oliveira ${ }^{3}$; Luís Antonio \\ Lourenço ${ }^{4}$; Lisandro Simão ${ }^{5}$
}

DOI: https://doi.org/10.31692/978-65-88970-19-5.15-33

\begin{abstract}
RESUMO
A produção de alimentos seguros e de alta qualidade tornou-se um desafio para a indústria de alimentos, devido a deterioração dos alimentos, que é causada pelo crescimento indesejável de microrganismos patogênicos/deteriorantes. Essa deterioração pode levar à perda e ao desperdício dos alimentos. Para a redução das perdas a indústria de alimentos utiliza conservantes sintéticos para controlar o crescimento microbiano com o intuito de estender a vida útil de prateleira, a qualidade e a segurança dos alimentos. No entanto, alguns aditivos químicos quando ingeridos em grandes quantidades podem causar reações indesejáveis aos consumidores. $\mathrm{O}$ aumento da preferência dos consumidores por aditivos alimentares mais naturais e a preocupação com a segurança dos conservantes sintéticos incentivaram a indústria de alimentos a procurar alternativas ecologicamente corretas. Assim, surgiu o intuito de substituir o uso de conservantes sintéticos tradicionais por antimicrobianos naturais nos alimentos. O presente trabalho tem como objetivo apresentar alguns conservantes naturais com propriedades antimicrobianas, enfatizando a importância do seu uso na produção de alimentos e possíveis aplicações em alimentos. Além disso, uma classificação baseada na origem dos antimicrobianos naturais é apresentada considerando as fontes de origem para as principais categorias: plantas, animais e microbiana. As propriedades antimicrobianas dos compostos de origem natural devem-se principalmente à presença de bioativos (como os ácidos fenólicos, terpenos, aldeídos e flavonoides, entre outros). Essas substâncias bioativas podem ser considerados uma alternativa viável para resolver os problemas críticos da resistência microbiana e impedir os efeitos negativos dos compostos sintéticos tradicionalmente utilizados, e ao mesmo tempo atender aos requisitos de segurança alimentar e não exercer impacto negativo sobre os aspectos nutricionais e sensoriais dos alimentos.
\end{abstract}

Palavras-Chave: Antimicrobianos, Biopreservação, Compostos bioativos, Conservantes naturais.

\section{RESUMEN}

La producción de alimentos seguros y de alta calidad se ha convertido en un desafío para la industria alimentaria, debido al deterioro de los alimentos, que es causado por el crecimiento indeseable de microorganismos patógenos/deteriorantes. Este deterioro puede provocar la pérdida y el desperdicio de alimentos. Para reducir las pérdidas, la industria alimentaria utiliza conservantes sintéticos para controlar el crecimiento microbiano con el fin de prolongar la vida útil, la calidad y la seguridad de los alimentos. Sin embargo, algunos aditivos químicos cuando se ingieren en grandes cantidades pueden causar

\footnotetext{
${ }^{1}$ Engenheira de Alimentos (Universidade de Passo Fundo - UPF), Doutora em Engenharia Química (UFSC), ellenfrodrigues@gmail.com

${ }^{2}$ Engenheiro Agroindustrial-Agroquímico (Universidade Federal do Rio Grande - FURG), Estudante de mestrado em Engenharia Química (UFSC), afonso.silva@ posgrad.ufsc.br

${ }^{3}$ Engenheiro Têxtil (Universidade Estadual de Maringá - UEM), Doutor em Engenharia Química (UFSC), carlos.oliveira@ufsc.br

${ }^{4}$ Curso de Engenharia Química, Instituto Latino-Americano de Tecnologia, Infraestrutura e Território (ILATIT), Universidade Federal da Integração Latino-Americana (UNILA), luis.lourenco@unila.edu.br

${ }^{5}$ Engenheiro Ambiental (Universidade do Extremo Sul Catarinense - UNESC), Doutor em Ciência e Engenharia de Materiais (UFSC), lisandrosima@gmail.com
} 


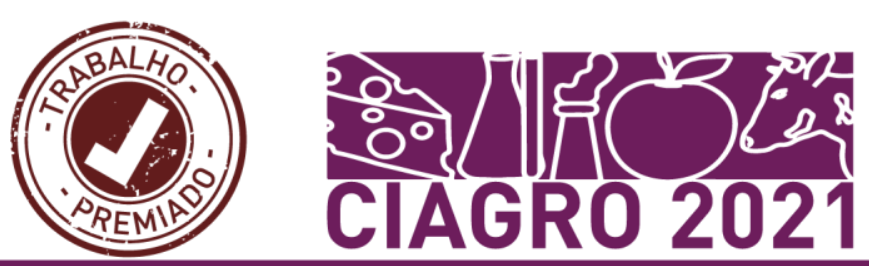

reacciones indeseables a los consumidores. La creciente preferencia de los consumidores por aditivos alimentarios más naturales y la preocupación por la seguridad de los conservantes sintéticos han animado a la industria alimentaria a buscar alternativas ecológicas. Así, surgió la intención de sustituir el uso de conservantes sintéticos tradicionales por antimicrobianos naturales en los alimentos. El presente trabajo tiene como objetivo presentar algunos conservantes naturales con propiedades antimicrobianas, destacando la importancia de su uso en la producción de alimentos y sus posibles aplicaciones en los alimentos. Además, se presenta una clasificación basada en el origen de los antimicrobianos naturales considerando las fuentes de origen para las principales categorías: plantas, animales y microbianos. Las propiedades antimicrobianas de los compuestos de origen natural se deben principalmente a la presencia de sustancias bioactivas (como ácidos fenólicos, terpenos, aldehídos y flavonoides, entre otros). Estas sustancias bioactivas pueden considerarse una alternativa viable para solucionar los problemas críticos de resistencia microbiana y prevenir los efectos negativos de los compuestos sintéticos tradicionalmente utilizados, cumpliendo al mismo tiempo los requisitos de seguridad alimentaria y no teniendo un impacto negativo en la nutrición y sensoriales aspectos de los alimentos.

Palabras Clave: Antimicrobianos, Biopreservación, Compuestos bioactivos, Conservantes naturales.

\begin{abstract}
The production of safe and high-quality food has become a challenge for the food industry, due to food spoilage, which is caused by the undesirable growth of pathogenic/deteriorating microorganisms. This deterioration can lead to the loss and waste of food. To reduce losses, the food industry uses synthetic preservatives to control microbial growth in order to extend shelf life, food quality, and safety. However, some chemical additives when ingested in large quantities can cause undesirable reactions to consumers. Increased consumer preference for more natural food additives and concern for the safety of synthetic preservatives have encouraged the food industry to look for environmentally friendly alternatives. Thus, the intention arose to replace the use of traditional synthetic preservatives with natural antimicrobials in foods. The present work aims to present some natural preservatives with antimicrobial properties, emphasizing the importance of their use in food production and possible applications in food. In addition, a classification based on the origin of natural antimicrobials is presented considering the sources of origin for the main categories: plants, animals, and microbial. The antimicrobial properties of compounds of natural origin are mainly due to the presence of bioactive substances (such as phenolic acids, terpenes, aldehydes, and flavonoids, among others). These bioactive substances can be considered a viable alternative to solve the critical problems of microbial resistance and to prevent the negative effects of synthetic compounds traditionally used, while at the same time meeting food safety requirements and not having a negative impact on the nutritional and sensory aspects of foods.
\end{abstract}

Keywords: Antimicrobials, Biopreservation, Bioactive compounds, Natural preservatives.

\title{
INTRODUÇÃO
}

Os produtos alimentícios naturais são perecíveis e necessitam de proteção contra a deterioração durante os processos de preparação, armazenamento e distribuição para ter uma vidá-útil de prateleira prolongada. A demanda por produtos alimentícios frescos minimamente processados representam um grande desafio para a segurança e a qualidade dos alimentos, devido estarem sujeitos à contaminação por microrganismos (bactérias e fungos) (FERREIRA et al., 2020).

A contaminação indesejada por microrganismos patogênicos e/ou deteriorantes podem causar reações que deterioram o sabor, o odor, a cor, as propriedades sensoriais dos alimentos, além de causa de doenças transmitidas por alimentos após a ingestão de alimentos 
contaminados (FERREIRA et al., 2020; QUINTO et al., 2019).

Em alimentos frescos minimamente processados o crescimento microbiano é afetado por diferentes fatores intrínsecos, como $\mathrm{pH}$ e presença de oxigênio ou por fatores extrínsecos associados às condições de armazenamento, incluindo temperatura, tempo e umidade relativa. Para inibir o crescimento desses microrganismos responsáveis pela deterioração de alimentos, a indústria de alimentos tem investido cada vez mais em métodos de preservação. Muitos dos métodos utilizados fazem uso de conservantes químicos e sintéticos por serem de baixo custo e de fácil obtenção (BASSOLÉ; JULIANI, 2012; SILVA; DOMINGUES, 2017).

No entanto, os conservantes sintéticos são conhecidos por causar problemas de saúde, podendo estar associados a possíveis efeitos cancerígenos ou reações alérgicas devido a presença de compostos como nitratos, benzoatos, sulfitos, sorbatos, formaldeído e antioxidantes fenólicos que são utilizados ((BASSOLÉ; JULIANI, 2012; SILVA; DOMINGUES, 2017; SOUZA et al., 2005; TIWARI et al., 2009).

Nos últimos anos, houve um crescimento na conscientação dos consumidores sobre a presença e utilização de aditivos químicos sintéticos nos alimentos, assim, o uso de alimentos conservados com aditivos naturais se tornaram mais populares. Muitos estudos têm sido realizados com o intuito de obter agentes conservantes de fontes naturais. Esses conservantes naturais devem prolongar a vida útil e garantir a segurança dos alimentos, além de substituir os conservantes sintéticos convencionalmente utilizados pelas indústrias alimentícias (BASSOLÉ; JULIANI, 2012; THIELMANN; KOHNEN; HAUSER, 2017) .

A utilização de conservantes naturais antimicrobianos (biopreservação) para garantir a segurança e a qualidade dos alimentos, pode ser uma alternativa a outros sistemas de preservação, como os químicos ou térmicos, além disso, sua incorporação direta a diversos alimentos de origens distintas, como carnes ou vegetais, bem como à sua embalagem, confere, como resultado, o prolongamento de sua vida útil de prateleira (AZIZ; KARBOUNE, 2016; GYAWALI; IBRAHIM, 2014; PISOSCHI et al., 2018).

A biopreservação utiliza conservantes naturais com o intuito de inibir o crescimento de inúmeros microrganismos patogênicos/deteriorantes em alimentos; esses conservantes naturais podem ser de origem animal, vegetal ou microbiana (bactérias, cogumelos, algas e vírus) (GYAWALI; IBRAHIM, 2014).

Considerando a abordagem descrita acima, observa-se o potencial da substituição dos conservantes sintéticos tradicionais utilizados na indústria de alimentos por antimicrobianos de origem natural. Nesta revisão, será apresentada uma visão geral dos antimicrobianos de origem natural, apresentando os seguintes tópicos: Antimicrobianos naturais de origem microbiana, 


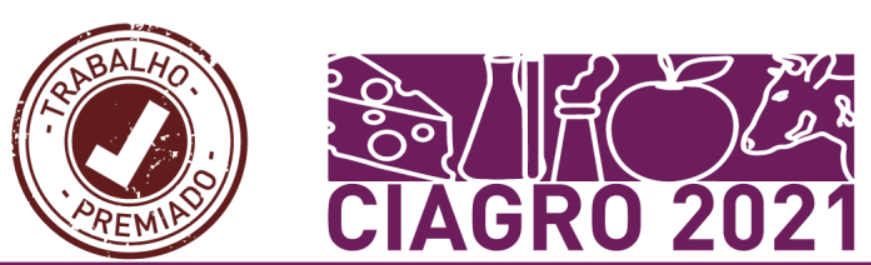

animal e de plantas, e suas possíveis aplicações em alimentos. Os termos descritos nos tópicos foram pesquisados nas principais bases de dados e os principais artigos encontrados foram analisados e sintetizados de acordo com a abordagem proposta no presente trabalho.

\section{FUNDAMENTAÇÃO TEÓRICA}

\section{ANTIMICROBIANOS DE FONTES NATURAIS}

Os microrganismos patogênicos responsáveis pela deterioração de alimentos têm sido considerados uma das principais causas de doenças transmitidas por alimentos e diminuição da qualidade dos alimentos, o que resulta em muitas intoxicações alimentares e perdas econômicas significativas a cada ano (OVER et al., 2009).

Embora hoje a segurança alimentar seja uma preocupação mundial para a saúde, na maioria das vezes os aspectos de processamento e preservação de alimentos passam despercebidos não apenas nos países em desenvolvimento, mas também nos países desenvolvidos.

Dentre as técnicas de preservação disponíveis, está a aplicação de aditivos químicos e/ou conservantes que são usados para combater microrganismos patogênicos e deteriorantes que se desenvolvem nas superfícies dos alimentos. Porém atualmente, o aumento da conscientização sobre a saúde atraiu os consumidores para consumir alimentos naturais com maiores benefícios para a saúde sem conservantes químicos adicionados. Assim, a indústria de alimentos está enfrentando desafios devido às regulamentações rigorosas e à demanda dos consumidores por alimentos naturais com maior qualidade e vida útil de prateleira (LAHIRI et al., 2020).

A biopreservação (utilização de antimicrobianos naturais em alimentos) está focada no uso de conservantes naturais de fontes como bactérias, fungos, plantas, animais, tendo a capacidade de garantir a segurança alimentar devido à sua atividade antimicrobiana exercida contra um amplo espectro de microrganismos patogênicos e deteriorantes de origem alimentar (GYAWALI; IBRAHIM, 2014). A Figura 01 apresenta uma visão geral de alguns antimicrobianos naturais de fonte animal, vegetal ou microbiana que serão descritos nos subitens abaixo. 


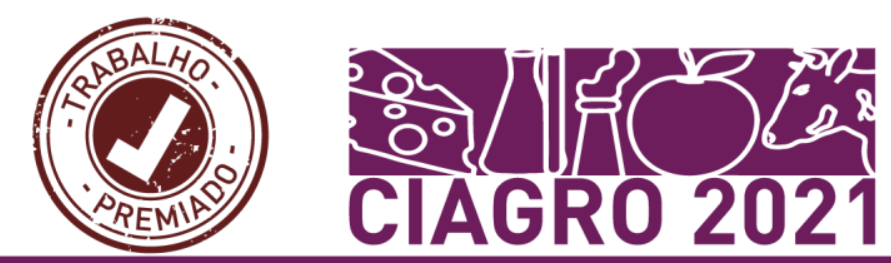

Figura 01: Fontes naturais de obtenção de antimicrobianos.

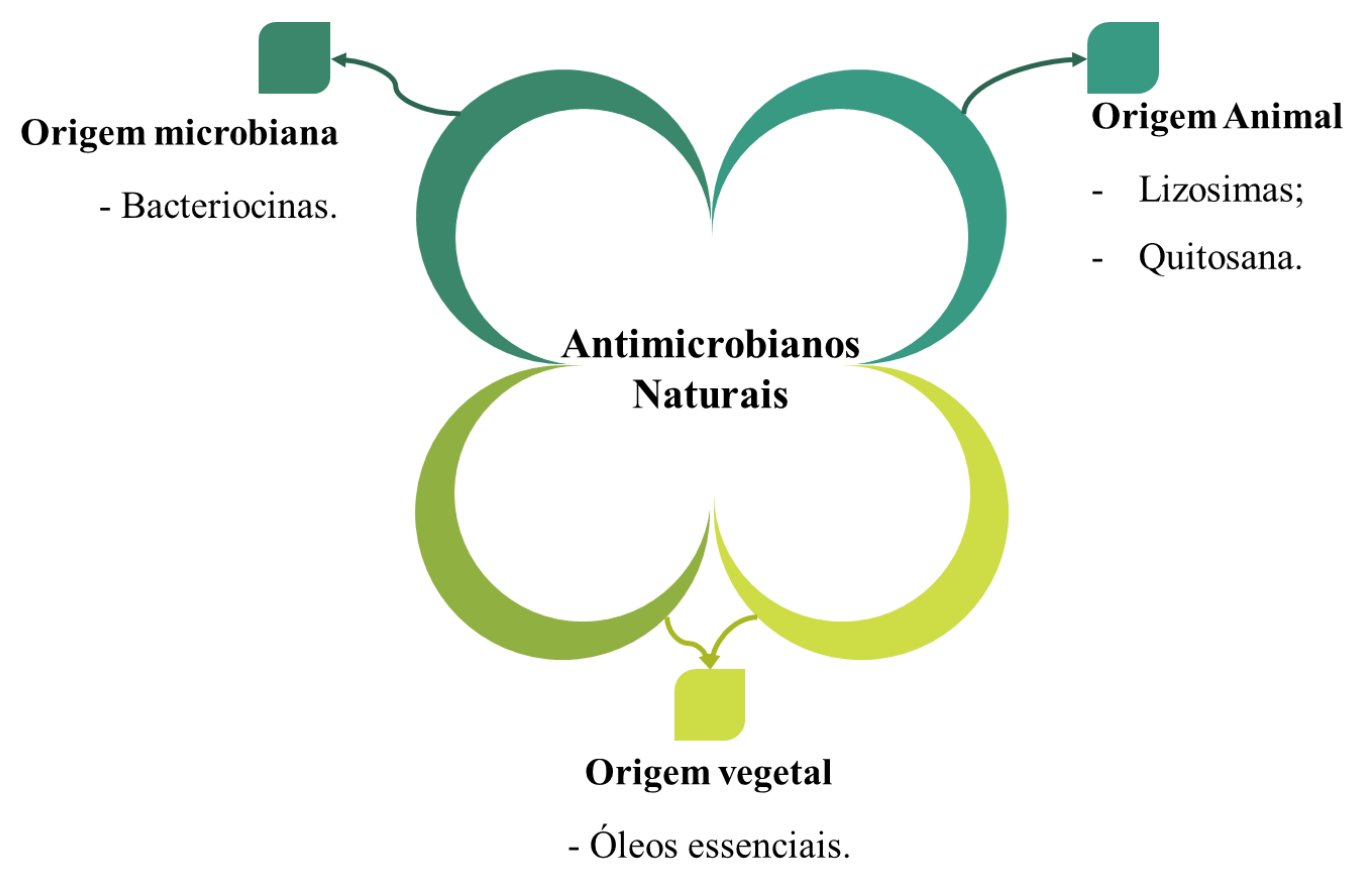

Fonte: Autores (2021).

\section{Antimicrobianos naturais de fontes microbianas}

Alguns microrganismos possuem a capacidade de produzir substâncias que podem ser responsáveis pela inibição de crescimento de outros microrganismos (Tabela 1). A produção de antimicrobianos por microrganismos é relatada desde os anos 50. Quando se fala o termo antimicrobiano, a maior ênfase é dada as bacteriocinas, que são peptídeos antimicrobianos sintetizados nos ribossomos e atuam contra bactérias Gram-positivas e Gram-negativas, sendo a bactéria produtora portadora de mecanismos de imunidade específicos que protegem a sua própria bacteriocina (COTTER; ROSS; HILL, 2013).

São bacteriocinas as nisinas, carnobacteriocinas, pediocinas, plantaricinas, lacticinas, enterocinas, lactococinas, leuconocinas, entre outras. Podendo ser classificadas em 4 classes de acordo com suas características bioquímicas e genéticas (Figura 02) (COTTER; ROSS; HILL, 2013). 


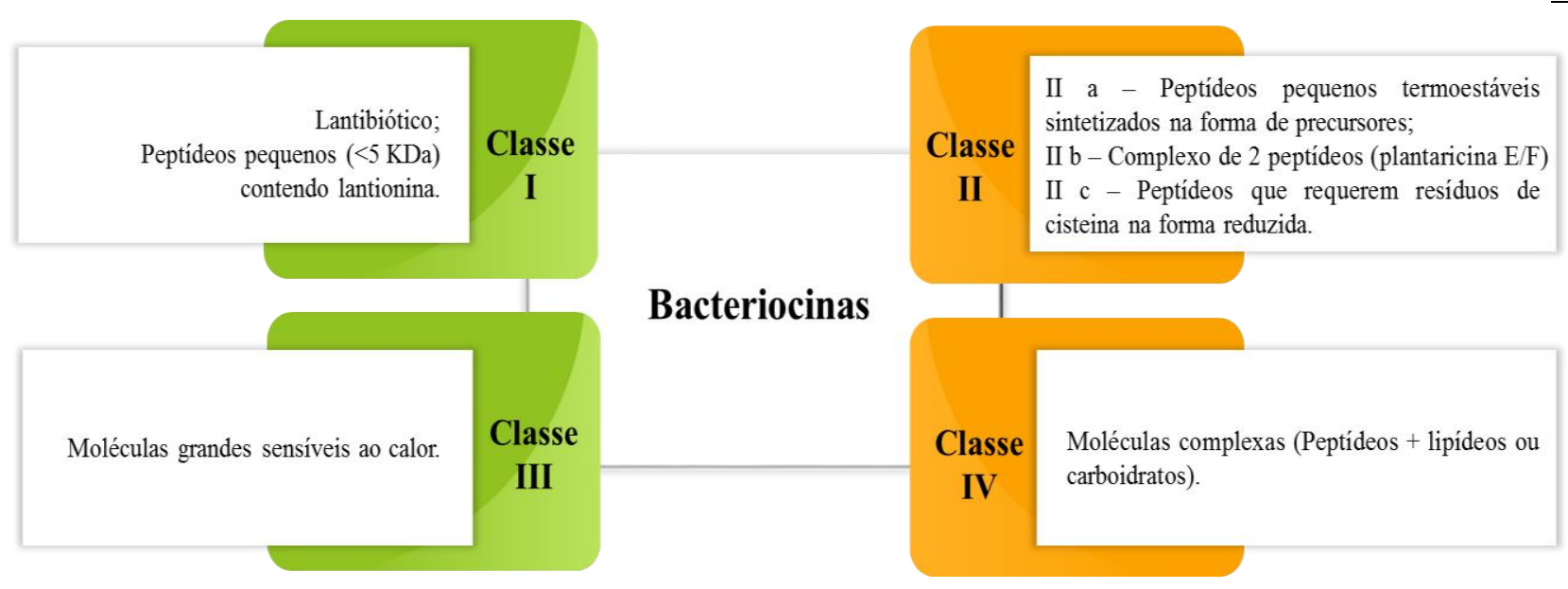

Fonte: Cotter, Ross e Hill (2013).

Em geral, as bacteriocinas são catiônicas e exibem propriedades anfipáticas, sendo a membrana bacteriana, na maioria das vezes, o alvo de sua atividade. São conhecidas diversos tipos de bacteriocinas, diferindo-se em tamanho, alvo microbiano, modo de ação, liberação e mecanismos de imunidade (GILLOR; ETZION; RILEY, 2008; OGAKI; FURLANETO; MAIA, 2015). Embora sejam conhecidas, a função estrutural, a biossíntese e o modo de ação de algumas bacteriocinas ainda permanecem desconhecidos.

As primeiras bacteriocinas descritas foram as colicinas de bactérias Gram-negativas (oriundas de Escherichia coli), as colicinas apresentaram capacidade de interferir por efeito bactericida ou bacteriostático, no crescimento de outras bactérias de espécies relacionadas (OGAKI; FURLANETO; MAIA, 2015). Desde sua descoberta, as colicinas de Escherichia coli têm sido as bacteriocinas Gram-negativas mais estudadas, servindo como um sistema modelo para investigar os mecanismos de estrutura/função da bacteriocina, organização genética, ecologia e evolução (CASCALES et al., 2007). 
Tabela 01: Bacteriocinas utilizadas no controle do crescimento microbiano.

\begin{tabular}{ccc}
\hline Microrganismo produtor & Bacteriocina & Alvo microbiano \\
Bacillus sp. & Mersacidina & Streptococcus pneumonia \\
& & Staphylococcus aureus resistentes à meticilina \\
Lactococcus lactis & Nisina & Bacillus cereus \\
& & Streptococcus pneumoniae \\
Staphylococcus aureus & Aureocina A53 & Listeria monocytogenes \\
& & Streptococcus agalactiae \\
Staphylococcus hyicus & Hyicina 3682 & Listeria monocytogenes \\
& & Staphylococcus aureus \\
& & Bacillus cereus \\
\hline
\end{tabular}

Fonte: Cotter, Ross e Hill (2013); Xiang et al. (2021).

Estudos relacionados aos agentes antibacterianos naturais como bacteriocinas em aplicações alimentares tem atraído atenção, principalmente para as bacteriocinas derivadas do gênero Bacillus. As bacteriocinas obtidas a partir de Bacillus apresentam resistência a altas temperaturas e forte tolerância a ácido-base, indicando amplas perspectivas de aplicação para preservação e conservação de alimentos (XIANG et al., 2021).

Entre as substância antimicrobianas produzidas por microrganismos está a nisina. A nisina é o única substância com ação bactericida aprovada em mais de 50 países. É sintetizado por Lactoccocus lactis e atua contra bactérias Gram-positivas e formadoras de esporos. Os principais microrganismos que são inibidos pela nisina são patógenos Gram-positivos de origem alimentar ou bactérias deteriorantes como Staphylococcus aureus, Micrococcus luteus e Bacillus cereus (HONDRODIMOU; KOURKOUTAS; PANAGOU, 2011).

A nisina inibe também o crescimento de leveduras e bolores em alimentos como azeitonas, quando utilizada em combinação com a natamicina (HONDRODIMOU; KOURKOUTAS; PANAGOU, 2011). Apresenta atividade aumentada contra bactérias Grampositivas e controla o desenvolvimento de Clostridium spp. em queijo (O'SULLIVAN, 2012). O caráter catiônico geral dessa bacteriocina explica a geração de poros através das membranas celulares e a fácil interação com bactérias Gram-positivas que possuem níveis elevados de lipídios aniônicos na membrana (CHEN; HOOVER, 2003).

O ácido lático é o agente antimicrobiano predominante em sobrenadantes de bactérias láticas e é um dos principais ácidos orgânicos encontras em produtos fermentados, além de ser amplamente distribuído na natureza. Nos Estados Unidos o ácido lático é utilizado em alimentos e reconhecido como Generally Recognized as Safe (GRAS) (ALAKOMI et al., 2000). 
A ação bactericida do ácido lático esta atribuída a moléculas não dissociadas presentes em pH 4,0 (40 \%) e em pH 3,60 (60 \%) (ALAKOMI et al., 2000). A dissociação ácida dentro da célula bacteriana é acompanhada pelo acúmulo de ânions tóxicos, estresse sobre a homeostase celular, inibição de reações metabólicas e dependendo da extensão do efeito gerado de inibição da divisão, até mesmo a morte. A ação antibacteriana dos ácidos orgânicos ocorre devido às suas formas não dissociadas, as quais têm como objetivo as funções metabólicas dos microrganismos, tais como a produção de proteína, a inibição de ATP e um aumento na pressão osmótica (ASKARI et al., 2012; KÖHLER; ASSEFA; REID, 2012; LUES; THERON, 2012).

Além do ácido lático, os ácidos acético e propiônico também apresentam mecanismo de biopreservação (ALAKOMI et al., 2000; STANOJEVIĆ-NIKOLIĆ et al., 2016).

\section{Antimicrobianos naturais de fonte animal}

Os agentes antimicrobianos de origem animal são caracterizados por polissacarídeos, lipídeos e peptídeos antimicrobianos como pleurocidina, lactoferrina, defensinas e protamina. Os peptídeos antimicrobianos são considerados uma alternativa viável como antimicrobiano, pois alguns desses compostos são capazes de destruir rapidamente as membranas da bicamada lipídica celular de microrganismos de crescimento rápido e, além do seu efeito antibacteriano contra bactérias Gram-positivas e Gram-negativas, também apresentam atividades antifúngicas e antivirais (AIRES et al., 2009; TIWARI et al., 2009).

As lisozimas de origem animal são amplamente distribuídas na natureza e apresentam ação antimicrobiana, essa enzima possui ação bactericina contra microrganismos que são responsáveis pela deterioração dos alimentos. A lisozima têm sido aplicada em diversos modelos de estudos devido a sua ampla capacidade de aplicação (BEAUSSART et al., 2021).

As principais aplicações são como conservantes para preservar frutas, vegetais, molhos e alimentos infantis. Também é capaz de inibir o desenvolvimento de esporos de Clostridium tyrobutyricum em queijos. As bactérias Gram-positivas são o principal alvo da lisozima, pois a parede celular é composta por peptidoglicanos (BEAUSSART et al., 2021; LEŚNIEROWSKI; YANG, 2021).

Outra substância de origem animal com função antimicrobiana é a quitosana, a quitosana é um polissacarídeo derivado da quitina, não antigênico, não tóxico e apresenta altas

atividades antioxidantes e antimicrobianas. É um polímero natural abundante, presente no exoesqueleto de crustáceos, insetos, e artrópode. A quitosana é um ingrediente alimentar aprovado no Japão, Coréia, EUA e Europa (AHSAN et al., 2018). 
As propriedades antimicrobianas da quitosana são dependentes de fatores essenciais, incluindo o tipo de patógeno, $\mathrm{pH}$ do meio, propriedades estruturais, fonte e concentração de quitosana (GOY; BRITTO; ASSIS, 2009). O pH do meio é um fator fundamental para a atividade antimicrobiana e os melhores valores são abaixo de 6,5. Provavelmente, esse comportamento é atribuído à presença de uma quantidade significativa de grupos amino no polímero, onde os grupos $\mathrm{NH}^{+3}$ carregados positivamente aumentam a ligação a constituintes da membrana das bactérias patogênicas que são carregadas negativamente (GOY; BRITTO; ASSIS, 2009; HOSSEINNEJAD; JAFARI, 2016).

A quitosana apresenta atividade antimicrobiana contra bactérias Gram-negativas (Salmonella typhimurium, Escherichia coli, Pseudomonas aeruginosa, Pseudomonas fluorescens, Vibrio parahaemolyticus, Enterobacter aerogenes e Vibrio cholera), bactérias Gram-positivas (Bacillus cereus, Staphylococcus aureus, Bacillus megaterium, Lactobacillus plantarum, Listeria monocytogenes, Lactobacillus brevis e Lactobacillus bulgaricus), além da atividade antimicrobiana, a quitosa possui atividade antifúngica contra fungos e leveduras, como Fusarium oxysporum, Botrytis cinerea, Rhizoctonia solani, Candida lambica, Phomopsis asparagi (ABD EL-HACK et al., 2020; GOY; BRITTO; ASSIS, 2009; HOSSEINNEJAD; JAFARI, 2016; SAHARIAH; MÁSSON, 2017).

\section{Antimicrobianos naturais derivados de plantas}

As plantas comestíveis, medicinais, fitoterápicas e os respectivos óleos essenciais e subprodutos como hidrossol, assim como metabólitos secundários, são capazes de retardar ou inibir o desenvolvimento de bactérias, leveduras e bolores. Esses antimicrobianos de origem natural podem ser encontrados e identificados a partir de vários componentes das folhas das plantas, cascas, caules, raízes, flores e frutos (ALEKSIC SABO; KNEZEVIC, 2019).

Os óleos essenciais são misturas naturais de hidrocarbonetos, contendo oxigênio (álcoois, aldeídos, cetonas, ácidos carboxílicos, ésteres, lactonas) e substâncias orgânicas contendo enxofre (sulfuretos, dissulfeto, trissulfuretos). São obtidos principalmente de plantas por destilação a vapor, extração com dióxido de carbono supercrítico, prensagem a frio ou extração (maceração). Geralmente apresentam um odor agradável e às vezes um sabor distinto e, portanto, são usados em quantidades significativas nas indústrias de aromatizantes e perfumaria (BURT, 2004; KELKAR et al., 2006).

As características antimicrobianas dos produtos derivados de plantas são geralmente acompanhadas por capacidades antioxidantes (devido aos derivados de ácido fenólico, como 


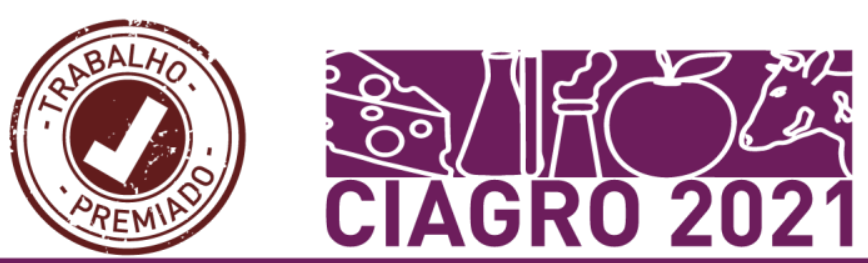

ácido cafeico, flavonóides, cumarinas, terpenóides, lignanas e polissacarídeos), que completa

os benefícios farmacológicos desses extratos. A combinação dos potenciais antioxidantes e antimicrobianos em uma molécula o torna ainda mais eficaz para a biopreservação de alimentos (AZIZ; KARBOUNE, 2016; PISOSCHI et al., 2016).

Os efeitos antimicrobianos dos óleos essencias foram avaliados contra uma ampla gama de microrganismos ao longo dos anos, no entanto, os mecanismos de ação envolvidos ainda não foram completamente compreendidos. Vários mecanismos têm sido propostos para explicar as ações dos compostos químicos contidos nos óleos essenciais (BURT, 2004).

Pesquisadores propuseram que a ação antimicrobiana dos óleos essencias pode estar atribuída à sua capacidade de penetrar através das membranas bacterianas para o interior da célula e exibir atividade inibitória nas propriedades funcionais da célula e às suas propriedades lipofílicas (KELKAR et al., 2006; LI et al., 2011).

A natureza fenólica dos óleos essenciais também induz uma resposta antimicrobiana contra bactérias patogênicas transmitidas por alimentos. Os compostos fenólicos rompem a membrana celular resultando na inibição das propriedades funcionais da célula e, eventualmente, causam vazamento do conteúdo interno da célula. Os mecanismos de ação podem estar relacionados à capacidade dos compostos fenólicos de alterar a permeabilidade celular microbiana, danificar as membranas citoplasmáticas, interferir no sistema de geração de energia celular (ATP) e interromper a força motriz do próton. A permeabilidade interrompida da membrana citoplasmática pode resultar na morte celular (BAJPAI; BAEK; KANG, 2012; BURT, 2004; KELKAR et al., 2006; LI et al., 2011).

Entre as substâncias de origem vegetal estão os óleos cítricos que são aprovados como compostos geralmente reconhecidos como seguros (GRAS) pela Food and Drug Administration (FDA), devido ao seu papel natural como agentes aromatizantes em sucos cítricos. Aproximadamente 400 compostos de óleos cítricos já foram identificados e os principais fatores que podem afetar a sua composição são: tipo de cultivar, bem como dos métodos de separação e extração (CHIKHOUNE et al., 2013).

O óleo obtido do limão é rico em limoneno, e este têm se mostrado eficaz contra os microrganismos Staphylococcus aureus, Listeria monocytogenes, Salmonella enterica e Saccharomyces bayanus, bem como outros microrganismos. No entanto, como o limoneno é um produto químico muito hidrofóbico e, portanto, é difícil de dispersar na água, grandes concentrações devem ser usadas para que o limoneno seja eficaz nos alimentos; o limoneno também é suscetível à degradação oxidativa, que causa perda de atividade (CHIKHOUNE et al., 2013; LI; CHIANG, 2012; TAO et al., 2009). 
Os óleos essenciais têm sido realatado como agentes antimicrobianos eficazes contra

microrganismos patogênicos de origem alimentar, incluindo Escherichia coli O157:H7, Salmonella Typhimurium, Staphylococcus aureus, Listeria monocytogenes, Campylobacter, entre outros. Demonstrou-se na literatura que os antimicrobianos oriundos de plantas apresentam melhor atividade contra bactérias Gram-positivas do que Gram-negativas, sendo as bactérias mais resistentes Pseudomonas aeruginosa e Proteus mirabilis (CALLAWAY et al., 2011).

\section{APLICAÇÕES DOS ANTIMICROBIANOS NATURAIS EM ALIMENTOS}

\section{Antimicrobianos naturais de fontes microbianas}

A nisina é efetivamente usada pela indústria de queijos contra microrganismos resistentes ao calor, como Bacillus e Clostridium (TIWARI et al., 2009). Economou et al. (2009) testaram o uso de nisina incorporada sozinha ou em combinação com outros agentes antimicrobianos em produtos alimentícios. Sob condições de embalagem em atmosfera modificada, a vida útil da carne de frango fresca usando uma concentração de 500 UI/g de nisina e $50 \mathrm{mM}$ de EDTA foi estendida por 13-14 dias quando comparada com as amostras de controle (sem tratamento).

Além da utilização de antimicrobianos de fontes microbianas nos alimentos, há uma tendência promissora para a aplicação de bacteriocinas produzidas por bactérias láticas em embalagens. Scannel et al. (2000) aplicaram Laticina 3147 e nisina (Nisaplin®) em embalagens de polietileno/poliamida e estas foram capazes de reduzir o crescimento de microrganismos Listeria innocua, Staphylococcus aureus e Lactococcus lactis em até 2 ciclos log em queijo embalado a vácuo durante o armazenamento em temperaturas de refrigeração.

Nesse tipo de embalagem, o sistema da embalagem é capaz de inibir o crescimento de microrganismos patogênicos e deteriorantes de alimentos, a fim de prolongar a vida útil do produto, manter a qualidade e segurança dos alimentos, através do aumento da fase de latência e redução da taxa de crescimento dos microrganismos. Estas embalagens inteligentes são obtidas incorporando compostos antimicrobianos ao material de embalagem e/ou usando polímeros antimicrobianos que atendem os requisitos das embalagens convencionais (LA STORIA, 2008).

A fim de controlar e inibir a deterioração de alimentos, o filme antimicrobiano da embalagem deve entrar em contato com a superfície do alimento para que as bacteriocinas 


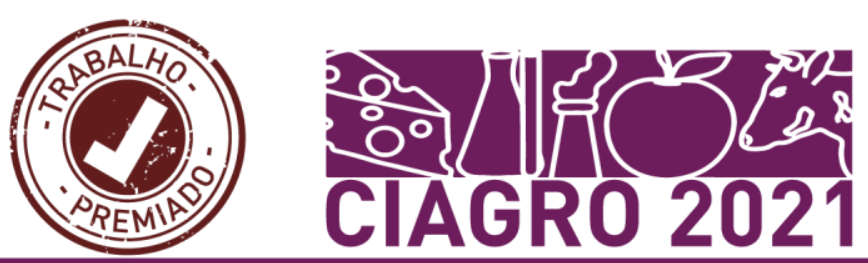

possam se difundir para a superfície do produto, o que é acompanhado pela liberação gradual

de bacteriocinas do filme da embalagem para a superfície do alimento. Isso é considerado uma vantagem sobre outros métodos de interação alimentar com bacteriocinas, como mergulhar e pulverizar alimentos com bacteriocinas, porque a bacteriocina pode ser diluída, desativada ou ter sua atividade reduzida pelos componentes dos alimentos (LA STORIA, 2008).

Duas técnicas têm sido comumente usadas para preparar filmes de embalagem à base de bacteriocina, a primeira é incorporar bacteriocinas diretamente em polímeros, como a incorporação de nisina em filmes de proteína biodegradáveis, e a segunda é incorporar bacteriocinas em filmes de embalagem por revestimento ou adsorção de bacteriocinas em superfícies de polímero. A maioria das investigações conduzidas usando ambas as técnicas resultaram em uma vida útil estendida dos produtos alimentícios porque contagem de microrganismos que deterioram os alimentos foram reduzidas (LA STORIA, 2008; PILEVAR et al., 2020).

\section{Antimicrobianos naturais de fonte animal}

A quitosana é um antimicrobiano de origem animal que vem sendo usado para prevenir a deterioração e atuar como um antioxidante natural devido à quelação de íons metálicos em alimentos contendo lipídios, prolongando assim a vida útil do produto (JEON; KAMIL; SHAHIDI, 2002).

Revestimentos comestíveis de quitosana e embalagens de alimentos comestíveis têm sido relatado em diversos estudos devido à sua capacidade de inibir o crescimento de diferentes cepas de fungos, exceto aqueles que incluem quitosana em sua parede celular. Os revestimentos/filmes comestíveis formam uma barreira protetora ao redor das frutas e vegetais que prolongam a vida útil de prateleira e podem ser consumidos junto com o produto revestido (GOY; BRITTO; ASSIS, 2009; JEON; KAMIL; SHAHIDI, 2002; RIBEIRO et al., 2007; SAHARIAH; MÁSSON, 2017).

Ribeiro et al. (2007) aplicaram um revestimento de quitosana comestível aos morangos após a colheita para prolongar a vida útil e investigaram as propriedades superficiais, molhabilidade e permeabilidade ao oxigênio. Verificou-se que o revestimento diminuiu a taxa de crescimento microbiano do morango em comparação com os experimentos controle (sem revestimento).

A eficácia da lisozima e do EDTA para a conservação de queijos mussarela foi estudada por Sinigaglia et al. (2008). O queijo mussarela foi embalado em salmoura que continha 


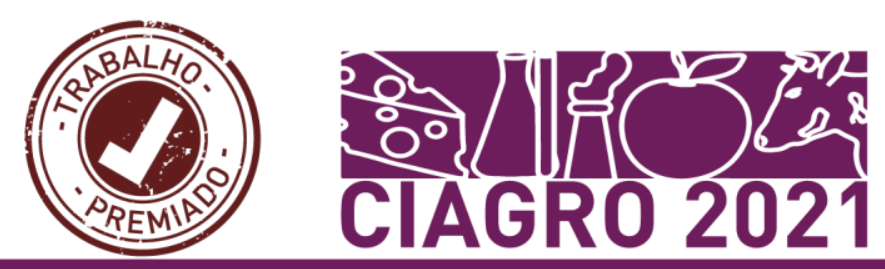

lisozima $\left(0,25 \mathrm{mg} \cdot \mathrm{mL}^{-1}\right)$ e diferentes quantidades de EDTA $\left(10,20\right.$ e 50 mmol. $\left.\mathrm{L}^{-1}\right)$ e posteriormente foi armazenado a $4 \pm 1^{\circ} \mathrm{C}$ por 8 dias. $\mathrm{O}$ sistema de embalagem inibiu significativamente o crescimento de coliformes e Pseudomonadaceae, sem afetar as bactérias láticas benéficas presentes no produto.

Conte, Brescia e Del Nobile (2011) também avaliaram os efeitos da lisozima e do EDTA em queijos burrata embalados em embalagem com atmosfera modificada (95:5 $\left.\mathrm{CO}_{2}: \mathrm{N}_{2}\right)$, os resultados demonstraram que as substâncias são válidas para prolongar a vida útil do queijo, especialmente em altas concentrações de lisozima.

\section{Antimicrobianos naturais derivados de plantas}

Os óleos essenciais possuem atividades antibacterianas e antifúngicas contra vários microrganismos associados à carne, incluindo bactérias Gram-negativas e Gram-positivas. Muitos estudos foram realizados para examinar os efeitos dos óleos essenciais obtidos de fontes como orégano, alecrim, tomilho, sálvia, manjericão, açafrão, coentro, gengibre, alho, nozmoscada, cravo, maça, salgado e erva-doce, quando usados sozinho ou em combinação com outros óleos essenciais e/ou métodos de preservação, a fim de melhorar as qualidades sensoriais e estender a vida útil de carnes e produtos cárneos (GOULAS; KONTOMINAS, 2007; KARABAGIAS; BADEKA; KONTOMINAS, 2011).

O efeito antimicrobiano do óleo essencial extraído do tomilho em níveis de adição de 0,3\%, 0,6\% ou 0,9\% sobre a bactéria Escherichia coli O157:H7 foi investigado em carne picada por Solomakos et al. (2008). O tratamento da carne picada com óleo essencial de tomilho $(0,6 \%)$ inibiu o crescimento de Escherichia coli O157: $\mathrm{H} 7$ durante o armazenamento a $10{ }^{\circ} \mathrm{C}$, mas não a $4{ }^{\circ} \mathrm{C}$. Além disso, os pesquisadores observaram um efeito bacteriostático ou bactericida do óleo de tomilho em Escherichia coli O157: H7 em níveis baixos de 0,12 \% e $0,25 \%$, respectivamente (FRATIANNI et al., 2010).

Os óleos essenciais de tomilho e bálsamo apresentaram redução na contagem de microflora natural presente na carne de peito de frango. Isso evita a deterioração da carne de frango e prolonga a vida útil do produto fresco quando armazenado a $4{ }^{\circ} \mathrm{C}$. Óleo essencial de tomilho na concentração de $0,5 \%$ limitou significativamente o crescimento de Escherichia coli, enquanto o óleo essencial de bálsamo na concentração de $0,5 \%$ inibiu efetivamente o crescimento de Salmonella spp.; além disso, a carne de frango tratada com óleo de bálsamo e óleo de tomilho teve contagens microbianas totais mais baixas do que as amostras de controle (sem tratamento do óleo essencial). Foi relatado que a carne de frango tratado com óleo 
essencial de tomilho apresentou notável inibição do crescimento de bactérias do ácido lático até

o final do armazenamento (FRATIANNI et al., 2010).

-Ur-Rehman et al. (2007) estudaram diferentes aplicações de óleos essenciais de casca de frutas cítricas (malta (Citrus sinensis) e mossumbi (Citrus sinensis)), em pães. Os resultados obtidos demonstraram que os óleos essenciais influenciaram as características sensoriais e retardaram o crescimento microbiano. O efeito inibitório máximo contra fungos (Aspergillus spp., Penicillium, Rhizopus e Neurospora) e bactérias foi alcançado pulverizando óleo essencial sobre a casca do pão.

\section{CONSIDERAÇÕES FINAIS}

Muitos produtos alimentícios frescos necessitam de técnicas de conservação que sejam seguras para melhorar a qualidade sem causar perdas nutricionais e organolépticas durante o armazenamento. Nesse contexto, a aplicação de antimicrobianos naturais vêm ganhando interesse da pesquisa e da indústria de alimentos, devido ao potencial de proporcionar benefícios de qualidade e segurança, com menor impacto a saúde humana. Além disso, a utilização de agentes ativos naturais promove os critérios aceitos de sustentabilidade alimentar. As diversas aplicações de óleos essenciais, enzimas, bacteriocinas, quitosanas e ácidos orgânicos nos alimentos perecíveis frescos são adequados para serem utilizados como conservantes em alimentos e podem ser uma alternativa atrativa aos aditivos alimentares sintéticos/químicos.

\section{REFERÊNCIAS}

-UR-REHMAN, S.; HUSSAIN, S.; NAWAZ, H.; MUSHTAQ AH, M.; ANJUM MURT, M.; JAFFAR RIZ, A. Inhibitory Effect of Citrus Peel Essential Oils on the Microbial Growth of Bread. Pakistan Journal of Nutrition, v. 6, n. 6, p. 558-561, 15 out. 2007.

ABD EL-HACK, M. E.; EL-SAADONY, M. T.; SHAFI, M. E.; ZABERMAWI, N. M.; ARIF, M.; BATIHA, G. E.; KHAFAGA, A. F.; ABD EL-HAKIM, Y. M.; AL-SAGHEER, A. A. Antimicrobial and antioxidant properties of chitosan and its derivatives and their applications: A review. International Journal of Biological Macromolecules, v. 164, p. 2726-2744, dez. 2020.

AHSAN, S. M.; THOMAS, M.; REDDY, K. K.; SOORAPARAJU, S. G.; ASTHANA, A.; BHATNAGAR, I. Chitosan as biomaterial in drug delivery and tissue engineering. International Journal of Biological Macromolecules, v. 110, p. 97-109, abr. 2018. 
AIRES, A.; MOTA, V. R.; SAAVEDRA, M. J.; ROSA, E. A. S.; BENNETT, R. N. The antimicrobial effects of glucosinolates and their respective enzymatic hydrolysis products on bacteria isolated from the human intestinal tract. Journal of Applied Microbiology, v. 106, n. 6, p. 2086-2095, jun. 2009.

ALAKOMI, H.-L.; SKYTTÃ, E.; SAARELA, M.; MATTILA-SANDHOLM, T.; LATVAKALA, K.; HELANDER, I. M. Lactic Acid Permeabilizes Gram-Negative Bacteria by Disrupting the Outer Membrane. Applied and Environmental Microbiology, v. 66, n. 5, p. 2001-2005, 2000.

ALEKSIC SABO, V.; KNEZEVIC, P. Antimicrobial activity of Eucalyptus camaldulensis Dehn. plant extracts and essential oils: A review. Industrial Crops and Products, v. 132, p. 413-429, jun. 2019.

ASKARI, G. AL; KAHOUADJI, A.; KHEDID, K.; CHAROF, R.; MENNANE, Z. Screenings of lactic acid bacteria isolated from dried fruits and study of their antibacterial activity. Middle East Journal of Scientific Research, v. 11, n. 2, p. 209-215, 2012.

AZIZ, M.; KARBOUNE, S. Natural antimicrobial/antioxidant agents in meat and poultry products as well as fruits and vegetables: A review. Critical Reviews in Food Science and Nutrition, v. 58, n. 3, p. 1-26, 20 jul. 2016.

BAJPAI, V. K.; BAEK, K.-H.; KANG, S. C. Control of Salmonella in foods by using essential oils: A review. Food Research International, v. 45, n. 2, p. 722-734, mar. 2012.

BASSOLÉ, I. H. N.; JULIANI, H. R. Essential Oils in Combination and Their Antimicrobial Properties. Molecules, v. 17, n. 4, p. 3989-4006, 2 abr. 2012.

BEAUSSART, A.; RETOURNEY, C.; QUILÈS, F.; DOS SANTOS MORAIS, R.; GAIANI, C.; FIÉROBE, H. P.; EL-KIRAT-CHATEL, S. Supported lysozyme for improved antimicrobial surface protection. Journal of Colloid and Interface Science, v. 582, p. 764-772, 2021.

BURT, S. Essential oils: their antibacterial properties and potential applications in foods - a review. International Journal of Food Microbiology, v. 94, n. 3, p. 223-253, ago. 2004.

CALlAWAY, T. R.; CARROLL, J. A.; ARTHINGTON, J. D.; EDRINGTON, T. S.; ANDERSON, R. C.; RICKE, S. C.; CRANDALL, P.; COLLIER, C.; NISBET, D. J. Citrus Products and Their Use Against Bacteria: Potential Health and Cost Benefits. In: Nutrients, Dietary Supplements, and Nutriceuticals. Totowa, NJ: Humana Press, 2011. p. 277-286.

CASCALES, E.; BUCHANAN, S. K.; DUCHÉ, D.; KLEANTHOUS, C.; LLOUBÈS, R.; POSTLE, K.; RILEY, M.; SLATIN, S.; CAVARD, D. Colicin Biology. Microbiology and Molecular Biology Reviews, v. 71, n. 1, p. 158-229, mar. 2007.

CHEN, H.; HOOVER, D. G. Bacteriocins and their Food Applications. Comprehensive Reviews in Food Science and Food Safety, v. 2, p. 82-100, 2003.

CHIKHOUNE, A.; HAZZIT, M.; KERBOUCHE, L.; BAALIOUAMER, A.; AISSAT, K. Tetraclinis articulata (Vahl) Masters essential oils: chemical composition and biological activities. Journal of Essential Oil Research, v. 25, n. 4, p. 300-307, ago. 2013. 
CONTE, A.; BRESCIA, I.; DEL NOBILE, M. A. Lysozyme/EDTA disodium salt and modified-atmosphere packaging to prolong the shelf life of burrata cheese. Journal of Dairy Science, v. 94, n. 11, p. 5289-5297, nov. 2011.

COTTER, P. D.; ROSS, R. P.; HILL, C. Bacteriocins - a viable alternative to antibiotics? Nature Reviews Microbiology, v. 11, n. 2, p. 95-105, 24 fev. 2013.

ECONOMOU, T.; POURNIS, N.; NTZIMANI, A.; SAVVAIDIS, I. N. Nisin-EDTA treatments and modified atmosphere packaging to increase fresh chicken meat shelf-life. Food Chemistry, v. 114, n. 4, p. 1470-1476, jun. 2009.

FERREIRA, M. J. G.; NOGUEIRA, P. C. D. N.; DIAS, F. G. B.; SILVA, L. M. R. DA; SILVEIRA, E. R.; FIGUEIREDO, E. A. T. DE. Antimicrobial activity and chemical characterization of the bark decoction of cumaru stem. Ciência Rural, v. 50, n. 3, p. 1-6, 2020.

FRATIANNI, F.; DE MARTINO, L.; MELONE, A.; DE FEO, V.; COPPOLA, R.; NAZZARO, F. Preservation of Chicken Breast Meat Treated with Thyme and Balm Essential Oils. Journal of Food Science, v. 75, n. 8, p. M528-M535, out. 2010.

GILLOR, O.; ETZION, A.; RILEY, M. A. The dual role of bacteriocins as anti- and probiotics. Applied Microbiology and Biotechnology, v. 81, n. 4, p. 591-606, 1 dez. 2008.

GOUlAS, A. E.; KONTOMINAS, M. G. Combined effect of light salting, modified atmosphere packaging and oregano essential oil on the shelf-life of sea bream (Sparus aurata): Biochemical and sensory attributes. Food Chemistry, v. 100, n. 1, p. 287-296, jan. 2007.

GOY, R. C.; BRITTO, D. DE; ASSIS, O. B. G. A review of the antimicrobial activity of chitosan. Polímeros, v. 19, n. 3, p. 241-247, 2009.

GYAWALI, R.; IBRAHIM, S. A. Natural products as antimicrobial agents. Food Control, v. 46, p. 412-429, dez. 2014.

HONDRODIMOU, O.; KOURKOUTAS, Y.; PANAGOU, E. Z. Efficacy of natamycin to control fungal growth in natural black olive fermentation. Food Microbiology, v. 28, n. 3, p. 621-627, maio 2011.

HOSSEINNEJAD, M.; JAFARI, S. M. Evaluation of different factors affecting antimicrobial properties of chitosan. International Journal of Biological Macromolecules, v. 85, p. 467475, abr. 2016.

JEON, Y.-J.; KAMIL, J. Y. V. A.; SHAHIDI, F. Chitosan as an Edible Invisible Film for Quality Preservation of Herring and Atlantic Cod. Journal of Agricultural and Food Chemistry, v. 50, p. 5167-5178, 2002.

KARABAGIAS, I.; BADEKA, A.; KONTOMINAS, M. G. Shelf life extension of lamb meat using thyme or oregano essential oils and modified atmosphere packaging. Meat Science, v. 88, n. 1, p. 109-116, maio 2011. 


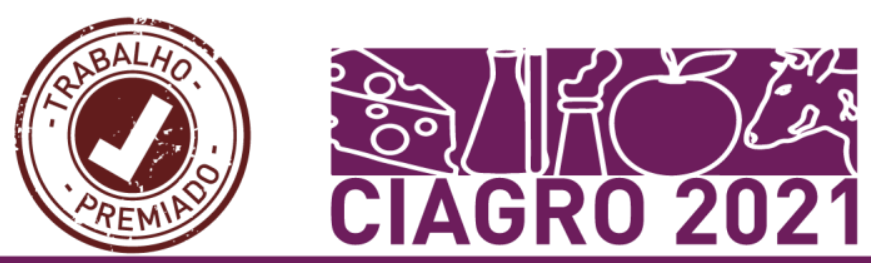

KELKAR, V. M.; GEILS, B. W.; BECKER, D. R.; OVERBY, S. T.; NEARY, D. G. How to recover more value from small pine trees: Essential oils and resins. Biomass and Bioenergy, v. 30, n. 4, p. 316-320, abr. 2006.

KÖHLER, G. A.; ASSEFA, S.; REID, G. Probiotic Interference of Lactobacillus rhamnosus GR-1 and Lactobacillus reuteri RC-14 with the Opportunistic Fungal Pathogen Candida albicans. Infectious Diseases in Obstetrics and Gynecology, v. 2012, n. 4, p. 1-14, 2012.

LA STORIA, A. Development and application of antimicrobial food packaging. [s.1.] UNIVERSITÀ DEGLI STUDI DI NAPOLI FEDERICO II, 2008.

LAHIRI, D.; CHAKRABORTI, S.; JASU, A.; NAG, M.; DUTTA, B.; DASH, S.; RAY, R. R. Production and purification of bacteriocin from Leuconostoc lactis SM 2 strain. Biocatalysis and Agricultural Biotechnology, v. 30, n. October, p. 101845, nov. 2020.

LEŚNIEROWSKI, G.; YANG, T. Lysozyme and its modified forms: A critical appraisal of selected properties and potential. Trends in Food Science \& Technology, v. 107, n. August 2020, p. 333-342, jan. 2021.

LI, M.; MUTHAIYAN, A.; A. O'BRYAN, C.; E. GUSTAFSON, J.; LI, Y.; G. CRANDALL, P.; C. RICKE, S. Use of Natural Antimicrobials from a Food Safety Perspective for Control of Staphylococcus aureus. Current Pharmaceutical Biotechnology, v. 12, n. 8, p. 1240-1254, 1 ago. 2011.

LI, P.-H.; CHIANG, B.-H. Process optimization and stability of d-limonene-in-water nanoemulsions prepared by ultrasonic emulsification using response surface methodology. Ultrasonics Sonochemistry, v. 19, n. 1, p. 192-197, jan. 2012.

LUES, J. F. R.; THERON, M. M. Antimicrobials Against Selected Poultry-Borne Listeria monocytogenes Strains In Vitro. FOODBORNE PATHOGENS AND DISEASE, v. 9, n. 12, p. 1126-1129, 2012.

O'SUllivan, D. J. Developing antimicrobial dairy ingredients. Food Technology Magazine, p. 44-50, 2012.

OGAKI, M. B.; FURLANETO, M. C.; MAIA, L. F. Revisão: Aspectos gerais das bacteriocinas. Brazilian Journal of Food Technology, v. 18, n. 4, p. 267-276, dez. 2015.

OVER, K. F.; HETTIARACHCHY, N.; JOHNSON, M. G.; DAVIS, B. Effect of Organic Acids and Plant Extracts on Escherichia coli O157:H7, Listeria monocytogenes, and Salmonella Typhimurium in Broth Culture Model and Chicken Meat Systems. Journal of Food Science, v. 74, n. 9, p. M515-M521, nov. 2009.

PILEVAR, Z.; HOSSEINI, H.; BEIKZADEH, S.; KHANNIRI, E.; ALIZADEH, A. M. Application of Bacteriocins in Meat and Meat Products: An Update. Current Nutrition \& Food Science, v. 16, n. 2, p. 120-133, 14 fev. 2020.

PISOSCHI, A. M.; POP, A.; CIMPEANU, C.; PREDOI, G. Antioxidant Capacity Determination in Plants and Plant-Derived Products: A Review. Oxidative Medicine and Cellular Longevity, v. 2016, p. 1-36, 2016. 


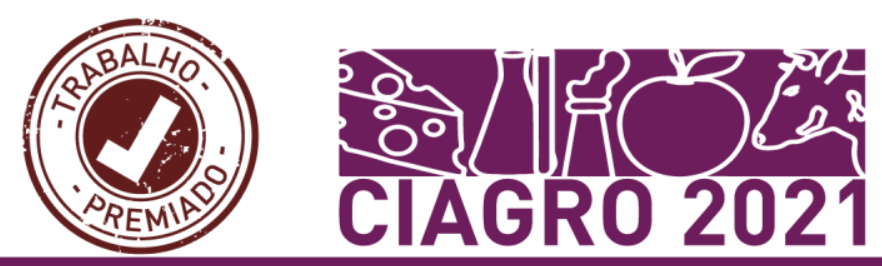

PISOSCHI, A. M.; POP, A.; GEORGESCU, C.; TURCUŞ, V.; OLAH, N. K.; MATHE, E. An overview of natural antimicrobials role in food. European Journal of Medicinal Chemistry, v. 143, p. 922-935, jan. 2018.

QUINTO, E. J.; CARO, I.; VILLALOBOS-DELGADO, L. H.; MATEO, J.; DE-MATEOSILLERAS, B.; REDONDO-DEL-RÍO, M. P. Food Safety through Natural Antimicrobials. Antibiotics, v. 8, n. 4, p. 208, 31 out. 2019.

RIBEIRO, C.; VICENTE, A. A.; TEIXEIRA, J. A.; MIRANDA, C. Optimization of edible coating composition to retard strawberry fruit senescence. Postharvest Biology and Technology, v. 44, n. 1, p. 63-70, abr. 2007.

SAHARIAH, P.; MÁSSON, M. Antimicrobial Chitosan and Chitosan Derivatives: A Review of the Structure-Activity Relationship. Biomacromolecules, v. 18, n. 11, p. 3846-3868, 13 nov. 2017.

SCANNELL, A. G. .; HILL, C.; ROSS, R. .; MARX, S.; HARTMEIER, W.; ARENDT, E. K. Development of bioactive food packaging materials using immobilised bacteriocins Lacticin 3147 and Nisaplin®. International Journal of Food Microbiology, v. 60, n. 2-3, p. 241249, set. 2000.

SILVA, F.; DOMINGUES, F. C. Antimicrobial activity of coriander oil and its effectiveness as food preservative. Critical Reviews in Food Science and Nutrition, v. 57, n. 1, p. 35-47, 2 jan. 2017.

SINIGAGLIA, M.; BEVILACQUA, A.; CORBO, M. R.; PATI, S.; DEL NOBILE, M. A. Use of active compounds for prolonging the shelf life of mozzarella cheese. International Dairy Journal, v. 18, n. 6, p. 624-630, jun. 2008.

SOLOMAKOS, N.; GOVARIS, A.; KOIDIS, P.; BOTSOGLOU, N. The antimicrobial effect of thyme essential oil, nisin and their combination against Escherichia coli O157:H7 in minced beef during refrigerated storage. Meat Science, v. 80, n. 2, p. 159-166, out. 2008.

SOUZA, E. L. DE; STAMFORD, T. L. M.; LIMA, E. DE O.; TRAJANO, V. N.; BARBOSA FILHO, J. M. Antimicrobial effectiveness of spices: an approach for use in food conservation systems. Brazilian Archives of Biology and Technology, v. 48, n. 4, p. 549-558, jul. 2005.

STANOJEVIĆ-NIKOLIĆ, S.; DIMIĆ, G.; MOJOVIĆ, L.; PEJIN, J.; DJUKIĆ-VUKOVIĆ, A.; KOCIĆ-TANACKOV, S. Antimicrobial Activity of Lactic Acid Against Pathogen and Spoilage Microorganisms. Journal of Food Processing and Preservation, v. 40, n. 5, p. 990 998, out. 2016.

TAO, N. G.; LIU, Y. J.; TANG, Y. F.; ZHANG, J. H.; ZHANG, M. L.; ZENG, H. Y. Essential oil composition and antimicrobial activity of Citrus reticulata. Chemistry of Natural Compounds, v. 45, n. 3, p. 437-438, 12 maio 2009.

THIELMANN, J.; KOHNEN, S.; HAUSER, C. Antimicrobial activity of Olea europaea Linné extracts and their applicability as natural food preservative agents. International Journal of Food Microbiology, v. 251, p. 48-66, jun. 2017. 


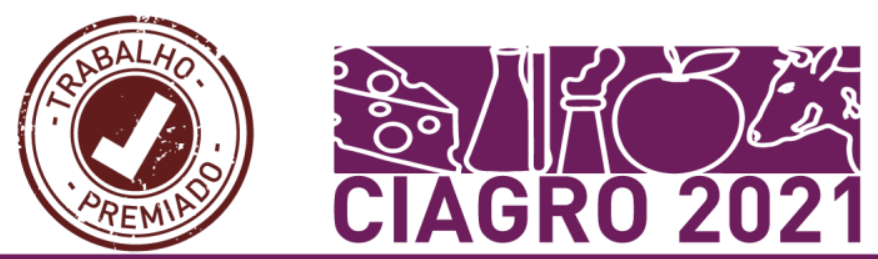

TIWARI, B. K.; VALDRAMIDIS, V. P.; O’ DONNELL, C. P.; MUTHUKUMARAPPAN, K.;

BOURKE, P.; CULLEN, P. J. Application of Natural Antimicrobials for Food Preservation. Journal of Agricultural and Food Chemistry, v. 57, n. 14, p. 5987-6000, 22 jul. 2009.

XIANG, Y.-Z.; ZHANG, Y.-M.; LIU, Y.-Y.; ZHANG, M.; LIN, L.-B.; ZHANG, Q.-L. Purification, characterization, and antibacterial and antibiofilm activity of a novel bacteriocin against Salmonella Enteritidis. Food Control, v. 127, n. February, p. 108110, set. 2021. 

versicolor EM FERMENTAÇÃO DE ESTADO SÓLIDO COM RESIDUOS AGROINDUSTRIAIS

\author{
CAPÍTULO 03: OPTIMIZACIÓN DE LA PRODUCCIÓN DE LACASAS POR \\ Trametes versicolor EN ESTADO SÓLIDO FERMENTACIÓN CON RESIDUOS \\ AGROINDUSTRIALES
}

\title{
CHAPTER 03: OPTIMIZATION OF LACASE PRODUCTION BY Trametes versicolor IN SOLID STATE FERMENTATION WITH AGROINDUSTRIAL WASTES
}

\author{
Emanueli Backes ${ }^{1}$; Camila Gabriel Kato ${ }^{2}$; Thaís Marques Uber ${ }^{3}$, Adelar Bracht $^{4}$, Rosane M. Peralta $^{5}$
}

DOI: https://doi.org/10.31692/978-65-88970-19-5.34-47

\begin{abstract}
RESUMO
A valorização de resíduos agroindustriais como substratos para obtenção de enzimas microbianas vem sendo foco de estudo nos últimos anos, uma vez que estes estão disponíveis em grande quantidade e permitirem o crescimento de microrganismos com um mínimo de suplementações. Lacases (EC 1.10.3.2) são cobre-oxidases que catalisam a oxidação de fenólicos e aminas aromáticas com concomitante redução do $\mathrm{O}_{2}$ à água, apresentando diversas aplicações biotecnológicas. Fungos da podridão branca da madeira são produtores de lacases com elevado potencial redox e apresentam grande potencial tecnológico. O fungo Trametes versicolor (L.) Lloyd é um basidiomiceto ligninolítico largamente distribuído em diversos biomas ao redor do mundo. É de fácil cultivo e considerado um excelente produtor de lacases com alto potencial redox. O objetivo deste trabalho foi otimizar a produção de lacase por Trametes versicolor em cultivo em estado sólido através da abordagem one-factor-at-thetime. Fatores ambientais (tipo de substrato, tempo de cultivo e porcentagem de umidade inicial) e de composição do meio (concentração de sais, carbono e nitrogênio) foram investigados. Diversos resíduos - agrícolas e alimentares - comuns à região do desenvolvimento deste trabalho foram avaliados como potenciais substratos. $\mathrm{O}$ substrato capaz de gerar maior produção de lacase foi selecionada para processo de otimização. ABTS (2,2'-azinodi- [3-etil-benzo-tiazolina-sulfonato]) foi utilizado para determinação da atividade da lacase e os resultados foram expressos em U/g de substrato. A produção máxima de lacase foi obtida ao utilizar coroa de abacaxi como substrato. Um aumento de mais de 6 vezes na atividade da lacase foi atingido nas condições otimizadas (7 dias de cultivo, $90 \%$ de umidade inicial e meio mineral Vogel diluído 1:50 e suplementado com 5\% de glicose e 1,5\% de extrato de levedura), que resultou em 32,93 $\pm 2,59 \mathrm{U} / \mathrm{g}$. Estes resultados evidenciam a valorização promissora de resíduos agroindustriais para obtenção de produtos de alto valor agregado. Ademais, as etapas de otimização levaram à obtenção de lacases com elevada atividade, o que possibilita a segurança e diminuição de custos dos processos biotecnológicos em que são aplicadas.
\end{abstract}

Palavras-Chave: Lacase, Otimização, Fermentação em estado sólido, Fungos, Resíduos.

\section{RESUMEN}

La valorización de residuos agroindustriales como sustratos para la obtención de enzimas microbianas ha sido el foco de estudio en los últimos años, ya que se encuentran disponibles en grandes cantidades y permiten el crecimiento de los microrganismos con un mínimo de suplementos. Las lacasas (EC 1.10.3.2) son oxidasas de cobre que catalizan la oxidación de fenólicos y aminas aromáticas con una reducción concomitante de $\mathrm{O}_{2}$ en agua presentando varias aplicaciones biotecnológicas. El hongo

\footnotetext{
${ }^{1}$ Programa de Pós-Graduação em Ciência de Alimentos, Universidade Estadual de Maringá, emanuelibackes@outlook.com

${ }^{2}$ Faculdade de Ciências Farmacêuticas, Alimentação e Nutrição, Universidade Federal do Mato Grosso do Sul, camilagkato@hotmail.com

${ }^{3}$ Programa de Pós-Graduação em Bioquímica, Universidade Estadual de Maringá, thaisuber@gmail.com

${ }^{4}$ Programa de Pós-Graduação em Ciência de Alimentos, Universidade Estadual de Maringá, abracht@uem.br

${ }^{5}$ Programa de Pós-Graduação em Ciência de Alimentos, Universidade Estadual de Maringá, rmperalta@uem.br
} 
Trametes versicolor (L.) Lloyd es un basidiomiceto ligninolítico ampliamente distribuido en varios biomas alrededor del mundo. Es fácil de cultivar y se considera un excelente productor de lacasas con alto potencial redox. En ese contexto, el objetivo de este trabajo fue optimizar la producción de lacasa por Trametes versicolor en cultivo en estado sólido a través del enfoque de un factor a la vez. Se investigaron factores ambientales (tipo de sustrato, tiempo de cultivo y porcentaje de humedad inicial) y composición del medio (concentración de sales, carbono y nitrógeno). Se evaluaron como potenciales sustratos varios residuos -agrícolas y alimentarios- comunes a la región del desarrollo de este trabajo. Para el proceso de optimización se seleccionó el sustrato capaz de generar una mayor producción de lacasa. ABTS (2,2'-azinodi- [3-etil-benzo-tiazolina-sulfonato]) se utilizó para determinar la actividad lacasa y los resultados se expresaron en U/g de sustrato. La producción máxima de lacasa se obtuvo utilizando corona de piña como sustrato. Se logró un aumento de más de 6 veces en la actividad de lacasa en condiciones optimizadas ( 7 días de cultivo, $90 \%$ de humedad inicial y medio mineral Vogel diluido 1:50 y suplementado con 5\% de glucosa y 1,5\% de extracto de levadura), lo que resultó en 32,93 $\pm 2,59 \mathrm{U} / \mathrm{g}$. Estos resultados muestran la prometedora recuperación de residuos agroindustriales para obtener productos de alto valor agregado. Además, los pasos de optimización han llevado a la obtención de lacasas con alta actividad, lo que permite incrementar la seguridad y reducir los costos de los procesos biotecnológicos en los que se aplican.

Palabras Clave: Lacasa, Optimización, Fermentación en estado sólido, Hongos, Residuos.

\begin{abstract}
Valorization of agro-industrial residues as substrates for microorganism enzyme obtainment has been the focus of study in recent years because they are available in large quantities and allow the growth of ligninolytic fungi with a minimum of supplements. Laccases (EC 1.10.3.2) are copper oxidases that catalyze the oxidation of phenolics and aromatic amines with a concomitant reduction of $\mathrm{O}_{2}$ to water, presenting several biotechnological applications. The fungus Trametes versicolor (L.) Lloyd is a ligninolytic basidiomycete widely distributed in several biomes around the world. It is easy to grow and is considered an excellent producer of laccases with high redox potential. Within this context, the objective of this work was to optimize the laccase production by Trametes versicolor in solid-state fermentation using the one-factor-at-the-time approach. The influence of environmental factors (type of substrate, time of cultivation, and percentage of initial moisture) and medium composition (concentration of salts, carbon, and nitrogen) was investigated. Several residues - agricultural and food - common to the region of the development of this work were evaluated as potential substrates. The substrate capable of generating greater laccase production was selected for the optimization process. ABTS (2,2'-azinodi- [3-ethyl-benzo-thiazoline-sulfonate]) was used to determine laccase activity and the results were expressed in U/g of substrate. The maximal laccase production was obtained by using the pineapple crown as substrate. A more than 6-fold increase in laccase activity was achieved under optimized conditions ( 7 days of cultivation, $90 \%$ initial moisture, and a 1:50-diluted Vogel mineral medium supplemented with $5 \%$ glucose and $1.5 \%$ yeast extract), with a final absolute yield of $32.93 \pm$ $2.59 \mathrm{U} / \mathrm{g}$. These results represent a promising valorization of an agro-industrial waste for obtaining products with high added value. In addition, the optimization steps led to the obtainment of laccases with high activity, contributing to safe and cost- attractive applications of the enzyme to biotechnological processes.
\end{abstract}

Keywords: Laccase, Optimization, Solid-state fermentation, Fungi, Residues.

\title{
INTRODUÇÃO
}

Os materiais ligninocelulósicos são os mais abundantes resíduos agrícolas no mundo e o Brasil, com sua economia baseada na agro-indústria, é um grande produtor deste tipo de resíduo. Diversas aplicações biotecnológicas vêm sendo desenvolvidas para reaproveitar estes resíduos para a obtenção de produtos de alto valor agregado como etanol, cogumelos, proteínas 
e enzimas, tais como hidrolases (celulases e xilanases) e oxidases (lacases e peroxidases), através do cultivo submerso e em estado sólido de fungos e bactérias (NANDAL et al., 2013; MANSOUR et al., 2016; BHATI et al., 2020). Embora a fermentação submersa seja mais utilizada industrialmente para obtenção de enzimas, algumas vantagens associadas aos cultivos sólidos vem tornando este tipo de cultivo objeto de pesquisas em várias áreas. Fermentações em estado sólido (FES) não requerem sistemas mecânicos e de controle complexos, além de fornecer alto rendimento dos produtos com baixo consumo de energia. A possibilidade do uso de resíduos como substratos é outro fator que diminui os custos do processo (XU et al., 2020).

Lacases são cobre-oxidases que catalisam a oxidação de fenólicos e aminas aromáticas com concomitante redução do $\mathrm{O}_{2}$ à água (WATTANAKITJANUKUL et al., 2020). Diversos fungos ligninolíticos secretam lacases - entre outras enzimas ligninolíticas - durante seu crescimento. As lacases fúngicas tem a habilidade de degradar a lignina dos resíduos lignocelulósicos, tornando mais acessíveis tanto a celulose quanto as hemiceluloses à ataques pelas celulases e hemicelulases, gerando a produção de açúcares fermentescíveis. Estas característica permite o uso de diversos resíduos agroindustriais como substratos para crescimento fúngico e a geração de importantes enzimas e outros bioativos fúngicos. Dada sua capacidade de produção de lacases, especial atenção tem sido dada aos fungos dos gêneros Trametes, Pleurotus e Ganoderma sp. (MANSOUR et al., 2016). Dessa forma, os objetivos deste estudo foram (1) avaliar a produção da lacase por Trametes versicolor em cultivos em estado sólido utilizando diferentes substratos e (2) otimizar a produção da enzima através da abordagem one-factor-at-the-time, nos cultivos desenvolvidos no substrato mais promissor.

\section{FUNDAMENTAÇÃO TEÓRICA}

A FES pode ser definida como qualquer processo de fermentação que permite o crescimento de microrganismos em materiais sólidos úmidos na ausência de água corrente (ZILLY et al., 2012). Este tipo de processo tem sido amplamente utilizado para produzir compostos industrialmente relevantes, incluindo antioxidantes fenólicos, ácidos orgânicos, polímeros, enzimas e antibióticos (MARTINS et al., 2011; MANSOUR et al., 2016).

Estima-se que $60 \%$ dos custos da produção de enzimas para uso industrial derivam, principalmente, dos componentes do meio de cultura (WATTANAKITJANUKUL et al., 2020). Dessa forma, a FES se apresenta como uma tecnologia interessante a ser aplicada na produção de enzimas proporcionando menores custos de energia de esterilização, aeração mais fácil e custos reduzidos ou eliminados para agitação (KARP et al., 2015). 


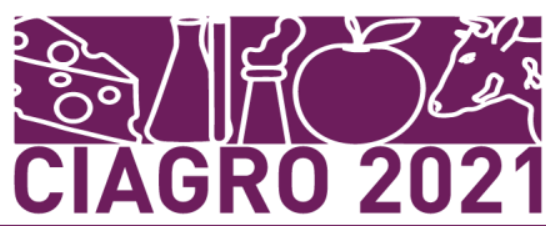

Concomitante, torna-se possível a valorização de resíduos alimentares. Com custo de aquisição praticamente nulos, estas matérias-primas apresentam composição nutricional (fontes de carbono e nitrogênio) ricas para serem utilizadas como substratos no crescimento de microrganismos. Ademais, em larga escala, esta abordagem permitiria mitigar, de forma mais econômica, os problemas associados ao tratamento e depósito de resíduos de indústrias de alimentos (BILAL e IQBAL, 2019).

Os fungos ligninolíticos aparecem como candidatos naturais para serem cultivados em processos de FES (GHORAI et al., 2009). Esses fungos têm a capacidade peculiar de sintetizar uma série de enzimas extracelulares hidrolíticas e oxidativas relevantes, como celulases, xilanases, lacases e peroxidases (PERALTA et al., 2017). A aplicação potencial dessas enzimas em biotecnologia tem estimulado investigações para selecionar promissores produtores de enzimas e encontrar substratos convenientes para obter grandes quantidades de enzimas a baixo custo (COUTO, 2008).

O farelo de trigo é o substrato mais comumente usado para o cultivo de fungos da podridão-branca. No entanto, a lista de possibilidades é muito grande e inclui vários resíduos lignocelulolíticos, como bagaço de cana, sabugo de milho, palha de trigo, palha de aveia, palha de arroz e resíduos de processamento de alimentos, como casca de banana, casca de kiwi, casca de maracujá e resíduos de laranja (HOLKER et al., 2004; COUTO, 2008). A busca por novos substratos tem sido foco de diversos estudos, principalmente se estiverem disponíveis em grande quantidade, permitirem o crescimento de fungos ligninolíticos com um mínimo de suplementações e possibilitarem a obtenção de elevadas quantidades das enzimas desejadas.

Lacases (EC 1.10.3.2) são oxidases multicobre capazes de oxidar uma ampla gama de compostos aromáticos incluindo monofenóis, $o$ - e p-difenóis, aminofenóis e compostos diaminoaromáticos (PERALTA et al., 2017). Graças à capacidade de oxidar vários substratos, as lacases apresentam aplicações biotecnológicas em distintos setores que incluem transformações em alimentos, polpa e papel, têxtil, farmacêutica e química, além de atuarem no setor ambiental na degradação de diversos xenobióticos (COELHO-MOREIRA et al., 2018; IARK et al., 2019).

As lacases são glicoproteínas, geralmente extracelulares, pertencentes a família de multi-cobre oxidases, assim como manganês oxidase, ascorbato oxidase, entre outras. Porém, as lacases utilizam o oxigênio molecular como aceptor final de elétrons da oxidação de uma variedade de compostos orgânicos e inorgânicos, liberando apenas água como subproduto (Figura 01), ao contrário das peroxidases, que utilizam, por exemplo, o peróxido de hidrogênio $\left(\mathrm{H}_{2} \mathrm{O}_{2}\right)$ (MUÑIZ-MOURO et al., 2017). 


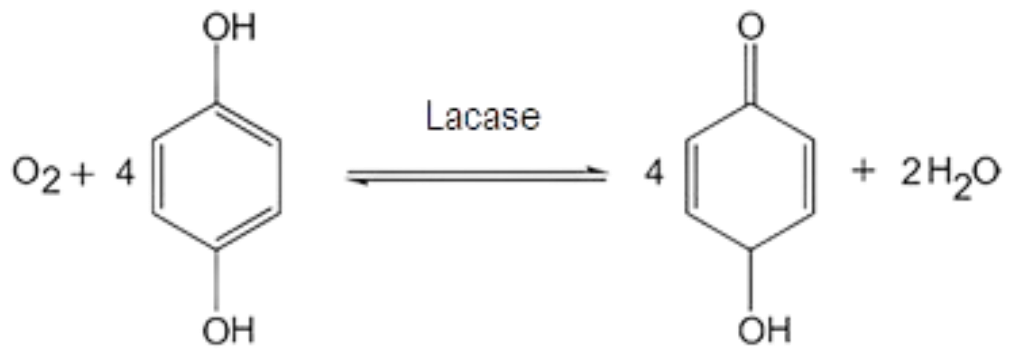

Fonte: Própria (2021).

Uma das características mais importantes das lacases é o seu potencial redox $\left(\mathrm{E}^{\mathrm{o}}\right)$ (JANUSZ et al., 2020). A capacidade de oxidação da lacase é proporcional à diferença de potencial redox entre o átomo de cobre T1 (um dos quatro átomos de cobre presentes no sítio ativo da enzima) e o substrato. De acordo com o potencial redox, as lacases são classificadas em três grupos: potencial redox baixo $(0,4-0,5 \mathrm{~V})$, médio $(0,5-0,6 \mathrm{~V})$ e alto $(0,7-0,8 \mathrm{~V})$. Lacases bacterianas e vegetais apresentam, frequentemente, redox baixo, enquanto o das lacases fúngicas é, geralmente, médio ou alto. Além disso, valores mais elevados de potencial redox são observados em lacases produzidas por basidiomicetos de podridão-branca o que permite a oxidação de uma gama muito maior de substratos e aumentam suas aplicações industriais em diversos campos (CASTROVILLI et al., 2019; ZERVA et al., 2019).

Neste cenário, as espécies Pleurotus ostreatus, Trametes versicolor, Pycnoporus cinnabarinus e Pycnoporus sanguineus, por exemplo, têm recebido bastante atenção (MATE e ALCALDE, 2015). Por conta de seu alto potencial redox e elevada capacidade de produção de lacase, diversos estudos são conduzidos com grande eficiência utilizando Trametes versicolor (L.) Lloyd, um basidiomiceto largamente distribuído em diversos biomas ao redor do mundo (XIN \& GENG 2011; AYDINOGLU \& SARGIN, 2013; XU et al., 2020).

As aplicações biotecnológicas das lacases têm sido objetivo de pesquisa há mais de 30 anos e, devido ao espectro de atividade, abrangem um amplo escopo de possibilidades. Indústrias de alimentos, rações, papel e celulose, cosméticos, fármacos, indústria têxtil e processos de biorremediação, por exemplo, são alguns dos segmentos os quais as pesquisas com lacase fazem-se intensas (ZERVA et al., 2019). Na indústria de alimentos, em especial, a utilização de lacases é realizada em produtos de panificação, laticínios, bebidas e ingredientes (síntese de novos compostos antioxidantes e antimicrobianos). Estas enzimas atuam na melhoria dos parâmetros sensoriais de alimentos, controle de odores, realce de sabor e novas funcionalidades, bem como para a remoção de compostos indesejáveis em certos produtos 
alimentícios, entre outras possibilidades (MAYOLO-DELOISA et al., 2020).

É sabido que a síntese de lacases pela maioria dos fungos necessita de indução, que ocorre pela presença de compostos fenólicos e/ou íons de metais pesados. Porém, o uso de indutores tóxicos levanta preocupações quanto ao tratamento dos resíduos, uma vez que são contaminantes do meio ambiente. Assim, estudos de otimização são necessários para se obter uma máxima produção de enzimas, com elevada atividade, em condições que tornem o processo seguro e barato (AYDINOGLU e SARGIN, 2013; XU et al., 2020).

\section{METODOLOGIA}

A pesquisa realizada foi de natureza quantitativa experimental. Trametes versicolor foi obtido da Coleção de Basidiomicetos do Laboratório de Bioquímica de Microrganismos e de Alimentos do Departamento de Bioquímica da Universidade Estadual de Maringá e mantido em laboratório através de repiques sucessivos em ágar-batata-dextrose. Partindo de conhecimentos prévios sobre o comportamento do fungo, o sistema de FES foi otimizado para o máximo da produção de lacase por fatores ambientais (tipo de substrato, tempo de cultivo e porcentagem de umidade inicial) e composição do meio (concentração de sais, carbono e nitrogênio). Todos os cultivos foram realizados em frascos Erlenmeyer de $250 \mathrm{~mL}$ com $5 \mathrm{~g}$ de substrato e a $28^{\circ} \mathrm{C}$ no escuro. Durante cada nível de otimização do fator, todos os fatores, exceto o fator particular em consideração, foram mantidos constantes.

Para selecionar o substrato, diferentes resíduos agroindustriais obtidos na região de Maringá, Paraná, foram avaliados, nomeadamente farelo de trigo (FT), bagaço de cana (BC), casca de soja (CS), sabugo de milho (SM), serragem de eucalipto (SE), coroa de abacaxi (CA), casca de abacaxi (CAS), bagaço de laranja (BL) e casca de maracujá (CM). O substrato capaz de gerar maior produção de lacase foi selecionada para processo de otimização. A umidade inicial foi ajustada a $80 \%$ através da adição de meio mineral Vogel (VOGEL, 1956). Os cultivos foram mantidos a $28{ }^{\circ} \mathrm{C}$ por 7 dias. Para otimizar o tempo de cultivo, foram utilizadas $5 \mathrm{~g}$ do substrato selecionado na etapa anterior. Os cultivos, com $80 \%$ de umidade inicial foram mantidos a $28{ }^{\circ} \mathrm{C}$ e atividade da lacase foi avaliada nos tempos 3, 5, 7 e 9 dias. Para otimizar a umidade inicial níveis de 70, 80 e $90 \%$ foram avaliados no tempo de cultivo otimizado a $28{ }^{\circ} \mathrm{C}$.

Determinadas as condições ambientais ótimas, procedeu-se com a otimização da composição do meio de cultura. Para otimizar a concentração de sais, cultivos com distintas concentrações de meio mineral Vogel. O meio mineral foi diluído 1:50, 1:25 e 1:10 e utilizado para obtenção das umidades iniciais selecionadas. Em seguida, avaliou-se o efeito da 
suplementação do meio base com duas diferentes concentrações de glicose (5 e 10\%) e cinco concentrações distintas de extrato de levedura $(0,1 ; 1,5 ; 2,5 ; 3,5$ e $5 \%)$.

Após preparo, todos os meios foram autoclavados à $121{ }^{\circ} \mathrm{C}$ por 15 minutos. Três discos de ágar $(7 \mathrm{~mm})$ colonizados com o micélio de T. versicolor foram utilizados como inóculo. Todos os experimentos foram realizados em duplicata.

Os cultivos foram interrompidos adicionando-se $30 \mathrm{~mL}$ de água destilada a cada frasco. Os frascos foram macerados e agitados a $100 \mathrm{rpm}$ por $30 \mathrm{~min}$ a $15{ }^{\circ} \mathrm{C}$. As misturas foram filtradas em gaze e, em seguida, centrifugadas (8000 rpm por 10 minutos). Os sobrenadantes foram considerados como sendo os extratos enzimáticos brutos e foram avaliados quanto a atividade da lacase.

Para a determinação da atividade da lacase foi utilizado o substrato ABTS (2,2'-azinodi[3-etil-benzo-tiazolina-sulfonato]) (BRUGNARI et al., 2018). Os resultados foram expressos em U/g de substrato, onde uma unidade de atividade da lacase (U) é a quantidade de enzima que catalisa a transformação de $1 \mu \mathrm{mol}$ de substrato por minuto.

Todos os resultados foram analisados utilizando-se o teste t-Tukey utilizando-se o programa GraphPad versão 8.0 com 95\% de confiança. O mesmo programa gráfico foi utilizado para confecção das figuras. A estrutura química apresentada foi desenhada utilizando o programa ChemDraw 12.0

\section{RESULTADOS E DISCUSSÃO}

Diferentes fontes de carbono foram inicialmente investigadas como potenciais substratos para a produção de lacase por T. versicolor. Nas condições em que os ensaios foram conduzidos, nota-se a alta atividade da lacase obtida nos cultivos onde a coroa de abacaxi foi utilizada como substrato $(5,40 \pm 0,01 \mathrm{U} / \mathrm{g}$ de substrato), seguida do farelo de trigo $(4,22 \pm 0,29$ U/g de substrato) (Figura 02). Ademais, a utilização da coroa de abacaxi favoreceu a produção de lacase comparativamente à casca da mesma fruta - também um resíduo do seu processamento. De forma geral, observa-se que o uso de resíduos frutícolas favoreceu a produção de lacase, comparativamente aos demais substratos. Sabe-se que pequenas mudanças na composição do substrato podem afetar sua capacidade de induzir a produção de lacase. Neste caso, supõe-se que o elevado conteúdo de compostos fenólicos presente nestes tipos de resíduos sejam os responsáveis pela maior produção de lacase, uma vez que estes atuam como indutores da enzima (SOUZA et al., 2004; TEODORO et al., 2018). Dessa forma, a coroa de abacaxi foi selecionada como substrato principal para novos experimentos de otimização dos demais 


\section{fatores.}

Figura 02: Produção de lacases por Trametes versicolor em FES utilizando diferentes resíduos como substrato. FT: Farelo de trigo; BC: Bagaço de cana; CS: Casca de soja; SM: sabugo de milho; SE: Serragem de eucalipto; CA: Coroa de abacaxi; CAS: Casca de abacaxi; BL: Bagaço de laranja; CM: Casca de maracujá.

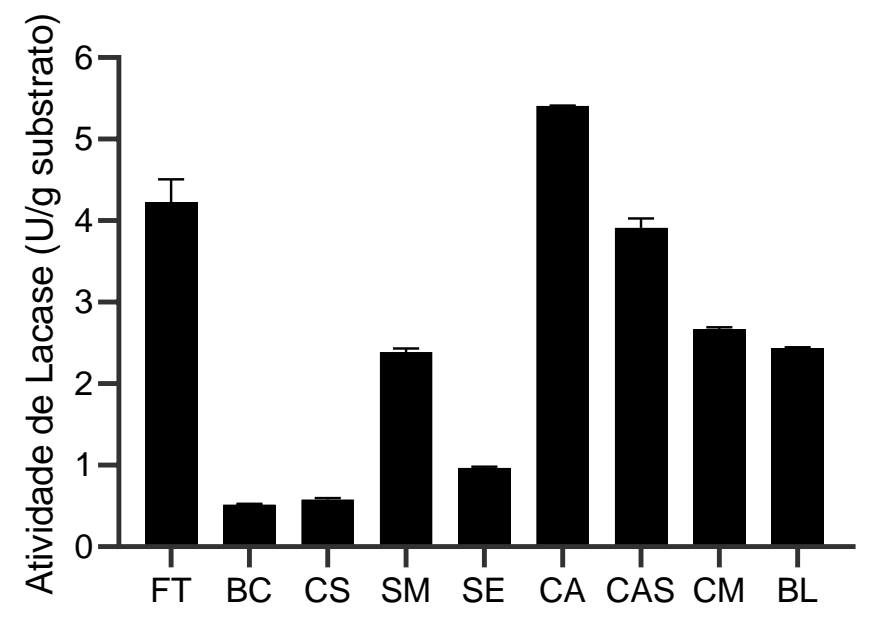

Fonte: Própria (2021).

A cinética de produção de lacase foi utilizada para determinar o tempo ótimo de cultivo para produção da enzima (Figura 3A). Incrementos gradativos na atividade foram observados até o sétimo dia de cultivo (pico de produção, 5,41 $\pm 0,02 \mathrm{U} / \mathrm{g}$ ), que decaiu significativamente no nono dia $(4,44 \pm 0,03 \mathrm{U} / \mathrm{g})$. O mesmo comportamento (tempo de cultivo ótimo de 7 dias) tem já sido reportado em cultivos em estado sólido de Trametes versicolor utilizando como substratos resíduos de chá e resíduos de horticultura (XIN e GENG, 2011; XU et al., 2020).

Diversos fatores como, por exemplo, biodisponibilidade de nutrientes, fonte de carbono e estirpe fúngica, podem influenciar neste valor. Lacases são reportadas como enzimas de metabolismo primário, isto é, são dependentes do crescimento do fungo e expressas em períodos iniciais do cultivo. Dessa forma, supõe-se que a queda da atividade após o sétimo dia de cultivo deve-se ao rápido consumo do substrato na fase exponencial do crescimento, que acarreta diminuição dos nutrientes para manutenção da síntese de lacase. Para a otimização dos demais fatores, o tempo de cultivo de 7 dias foi estabelecido.

A umidade inicial ótima para produção de lacase foi determinada pela avaliação de três níveis distintos, nomeadamente 70, 80 e 90\% (Figura 3B). A produção de lacase aumentou conforme aumento da umidade inicial atingindo valor máximo na condição de $90 \%(11,45 \pm$ 0,45 U/g). Valores superiores a $90 \%$ não foram investigados pois o volume de líquido adicionado descaracterizaria o aspecto sólido do cultivo. 
Figura 03: Efeito do tempo de cultivo (A) e da umidade inicial (B) na produção de lacases por T. versicolor cultivado em coroa de abacaxi. Em (A) os cultivos foram desenvolvidos a $28^{\circ} \mathrm{C}$ e umidade inicial de $80 \%$. Em

(B) os cultivos foram desenvolvidos a $28{ }^{\circ} \mathrm{C}$ por 7 dias.
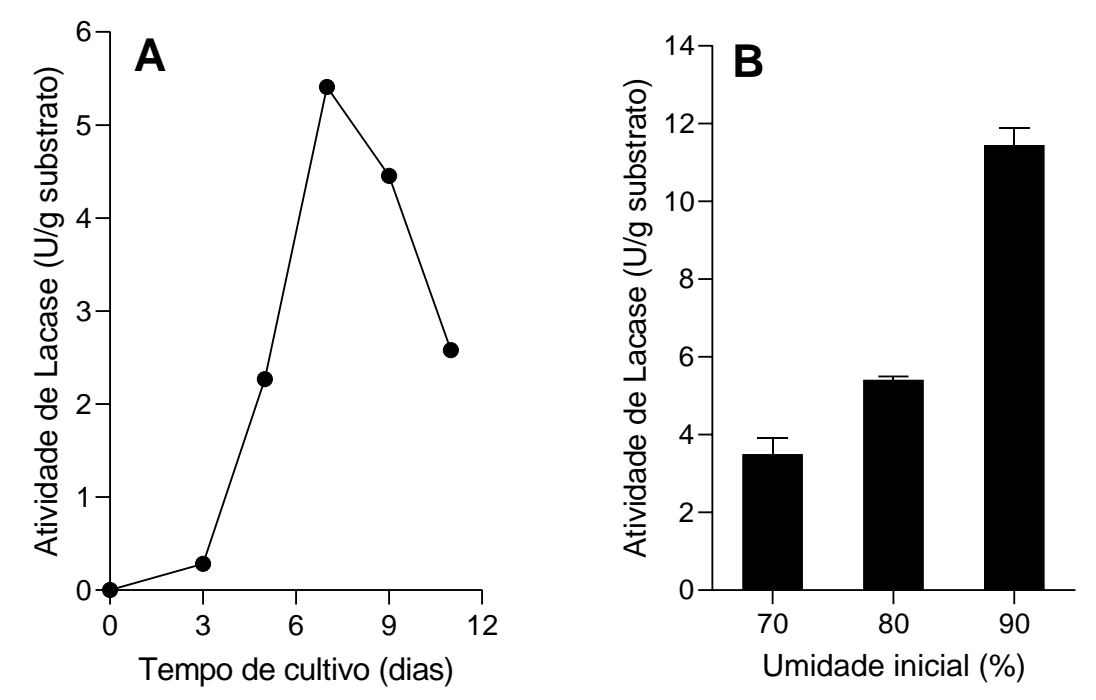

Fonte: Própria (2021).

Cultivos em estado sólido combinam as fases sólida, líquida e gasosa, sendo a correlação entre elas crucial para o crescimento fúngico. O teor de umidade inicial é um dos principais fatores que interferem no crescimento do microrganismo e na produção de enzimas por este microrganismo na FES, considerando que a disponibilidade de água em menor ou maior quantidade pode afetar adversamente a atividade microbiana (SINGHANIA et al., 2009). Em cenários de umidades iniciais mais baixas ocorrem possivelmente efeitos adversos que inibem o crescimento do fungo e a consequente produção enzimática, dada a limitação na transferência de nutrientes. Da mesma forma, em umidades iniciais muito elevadas, é comum ocorrer a compactação do substrato, impedindo a transferência de oxigênio (aeração).

Geralmente, quando substratos de granulometria baixa são utilizados, este fenômeno de compactação é observado em porcentagens de umidades iniciais inferiores. Um valor ótimo de $80 \%$ de umidade inicial foi encontrado para a produção de lacase por Xylaria sp ao se utilizar como substrato cachos de palmeira triturado e peneirado em tela de $3,8 \mathrm{~mm}$ (WATTANAKITJANUKUL et al., 2020). De forma semelhante, uma umidade inicial de 70\% foi encontrada em cultivos com farelo de trigo para a produção de lacases por Ganoderma sp (REVANKAR et al., 2007). Entretanto, as partículas de coroa de abacaxi utilizadas no presente estudo apresentavam tamanho médio de $1 \mathrm{~cm}^{2}$. Este tamanho maior permitiu a aeração adequada do cultivo mesmo em condições mais elevadas de umidade, favorecendo também o transporte dos nutrientes. 
Considerando-se outros substratos utilizados para o cultivo de $T$. versicolor, maior

produção de lacase foi obtida com $85 \%$ de umidade inicial utilizando-se resíduos de horticultura como substrato (XIN \& GENG, 2011), 80\% de umidade inicial quando o substrato foi folhas de oliveira (AYDINOGLU \& SARGIN, 2013) e 75\% de umidade inicial quando o substrato foi caule de milho pré-tratado por explosão a vapor (ADEKUNLE et al., 2017).

Otimizadas as condições ambientais (tipo de substrato, tempo de cultivo e umidade inicial) para produção da lacase, o estudo focou na otimização de alguns componentes do meio de cultura. Sabe-se que a presença de minerais é importante para suprir as necessidades nutricionais dos fungos, auxiliando no crescimento e manutenção de suas atividades metabólicas. O efeito da concentração de minerais na produção da lacase foi avaliada através do cultivo com diferentes diluições de meio mineral Vogel (1:50, 1:25 e 1:10). Ao se utilizar o meio de Vogel diluído 1:50 e 1:25 a produção de lacase não variou significativamente, obtendo-se atividades de 11,96 $\pm 0,20$ e 12,24 $\pm 1,24 \mathrm{U} / \mathrm{g}$ de substrato, respectivamente ( $p$-valor $<0,05)$. Entretanto, ao utilizar-se o meio mineral na diluição 1:10, observou-se visualmente uma inibição no crescimento do fungo, provavelmente pelo aumento da força iônica do meio, e redução significativa da lacase produzida $(8,55 \pm 0,61 \mathrm{U} / \mathrm{g}$ de substrato). Dessa forma, estabeleceu-se a utilização do meio mineral Vogel na diluição 1:50 para a otimização dos demais fatores.

A suplementação do meio de cultura com glicose e extrato de levedura também foi avaliada (Figura 04). De forma geral, todos os níveis de suplementação investigados geraram amento significativo na produção de lacase $(p$-valor < 0,05). Os maiores níveis de lacase foram observados nas condições de 5\% G + 1,5\% EL (32,93 $\pm 2,59 \mathrm{U} / \mathrm{g}$ de substrato), $5 \% \mathrm{G}+3,5 \%$ EL $(31,79 \pm 2,76 \mathrm{U} / \mathrm{g}$ de substrato $), 5 \% \mathrm{G}+5 \% \mathrm{EL}(34,36 \pm 3,51 \mathrm{U} / \mathrm{g}$ de substrato $)$ e $10 \% \mathrm{G}+$ $1,5 \%$ EL (31,00 $\pm 1,40 \mathrm{U} / \mathrm{g}$ de substrato), que não diferiram significativamente entre si. Portanto, pode-se operar em condições de desprendimento mínimo dos custos operacionais, neste caso $5 \% \mathrm{G}+1,5 \% \mathrm{EL}$ e, ainda, gerar respostas estatisticamente iguais.

As etapas do processo de otimização conduzidas neste estudo permitiram aumentar a produção de lacase mais de 6 vezes, atingindo um valor ótimo de 32,93 $\pm 2,59$ U/g de substrato, sem a necessidade de utilização de indutores. Todos os fatores, nomeadamente, tipo de substrato, tempo de cultivo, umidade inicial e composição do meio de cultura, influenciaram diretamente no resultado obtido e possibilitaram que tal valor fosse atingido. 


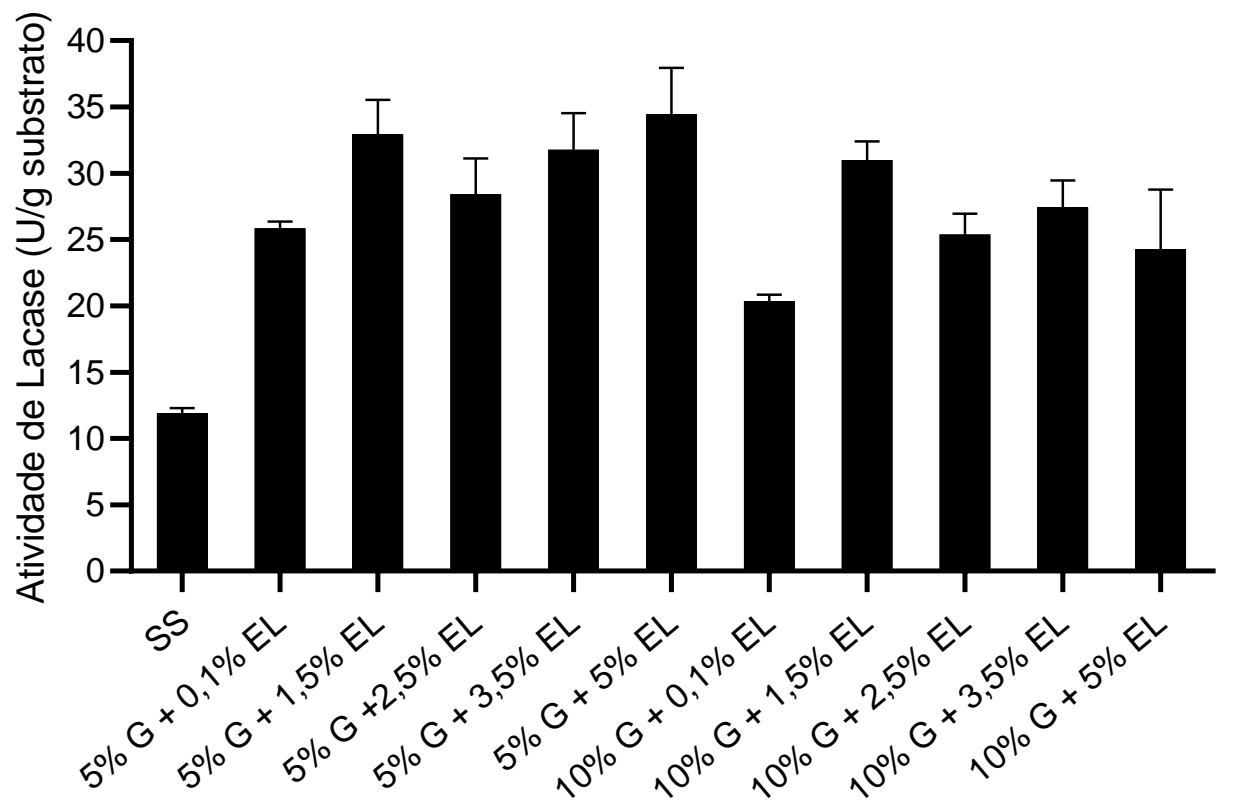

Condição de suplementação

Fonte: Própria (2021).

Pelo que se sabe, este é o primeiro estudo que valoriza a coroa do abacaxi como substrato para produção de lacase por Trametes versicolor. Ademais, o resultado obtido foi superior aos encontrados em estudos que utilizaram outros fungos e/ou condições de cultivo. $\mathrm{O}$ processo de otimização conduzido por Xu et al. (2020), por exemplo, ao utilizar resíduo de chá como substrato no cultivo de Trametes, resultou em uma atividade de 25,7 U/g. Já a produção de lacase por Xylaria sp. atingiu valor ótimo de 16,3 U/g, utilizando frutos de palma como substrato (WATTANAKITJANUKUL et al., 2020). Outrossim, para produzir o valor ótimo de 8,6 U/g, álcool veratrílico foi utilizado como indutor da produção de lacase de Trametes versicolor cultivado em resíduo agroindustrial (XIN \& GENG, 2011). O valor superior encontrado neste estudo demonstra a importância da seleção dos fatores e condições corretas para maximizar a produção de lacases.

\section{CONCLUSÕES}

Os dados apresentados aqui sugerem que a coroa de abacaxi possa ser efetivamente utilizada como substrato por Trametes versicolor para a produção de lacase em condições de fermentação em estado sólido. A suplementação do meio com nitrogênio orgânico (extrato de levedura) e carboidrato simples (glicose), permitiu obtenção de lacase com atividade máxima 
de 32,93 $\pm 2,59 \mathrm{U} / \mathrm{g}$ nas condições otimizadas, sem adição de indutores. Os resultados

promissores obtidos neste estudo abrem o caminho para uma efetiva utilização de um resíduo pouco aproveitado na obtenção de um produto de alto valor agregado, a enzima lacase com várias aplicações biotecnológicas.

\section{REFERÊNCIAS}

ADEKUNLE, A. E.; ZHANG, C.; GUO, C.; LIU, Z.-Z. Laccase production from Trametes versicolor in solid-state fermentation of steam-exploded pretreated corn stalk. Waste Biomass Valorization, v. 8, p. 153-159, 2017.

AYDINOGLU, T.; SARGIN, S. Production of laccase from Trametes versicolor by solid-state fermentation using olive leaves as a phenolic substrate. Bioprocess and Biosystems Engineering, v. 36, p. 215-222, 2013.

BHATI, N.; SHREYA; SHARMA, A. K. Cost-effective cellulase production, improvement strategies, and future challenges. Journal of Food Process Engineering, v. 44, e13623, 2020.

BILAL, M.; IQBAL, H. M. N. Sustainable bioconversion of food waste into high-value products by immobilized enzymes to meet bio-economy challenges and opportunities - A review. Food Research International, v. 123, p. 226-240, 2019.

BRUGNARI, T.; PEREIRA, M. G.; BUBNA, G. A.; FREITAS, E. N.; CONTATO, A. G.; CORRÊA, R. C. G.; CASTOLDI, R.; SOUZA, C. G. M.; POLIZELI, M. L. T. M.; BRACHT, A.; PERALTA, R. M. A highly reusable MANAE-agarose-immobilized Pleurotus ostreatus laccase for degradation of bisphenol A. Science of the Total Environment, v. 634, p. 1346-1351, 2018.

CASTROVILLI, M. C.; CHIARINELLI, P. B. J.; AVALDI, L.; CARTONI, A.; CALANDRA, P.; TEMPESTA, E.; GIARDI, M. T.; ANTONACCI, A.; ARDUINI, F.; SCOGNAMIGLIO, V. Electrospray deposition as a smart technique for laccase immobilization on carbon blacknanomodified screen-printed electrodes. Biosensors and Bioelectronics, v. 163, 112299, 2020.

COELHO-MOREIRA, J. S.; BRUGNARI, T.; SÁ-NAKANISHI, A. B.; CASTOLDI, R.; SOUZA, C. G. M.; BRACHT, A.; PERALTA, R. M. Evaluation of diuron tolerance and biotransformation by the white-rot fungus Ganoderma lucidum. Fungal Biology, v. 122, p. 471-478, 2018.

COUTO, S. R. Exploitation of biological wastes for the production of value-added products under solid-state fermentation conditions. Biotechnology Journal, v. 3, p. 859-870, 2008.

GHORAI, S.; BANIK, S. P.; VERMA, D.; CHOWDHURY, S.; MUKHERJEE, S.; KHOWALA, S. Fungal biotechnology in food and feed processing. Food Research International, v. 42, p. 577-587, 2009. 
HOLKER, U.; HOFER, M.; LENZ, J. Biotechnological advantages of laboratory-scale solidstate fermentation with fungi. Applied Microbiology and Biotechnology, v. 64, p. 175-186, 2004.

IARK, D.; BUZZO, A. J. R.; GARCIA, J. A. A.; CORREA, V. G.; HELM, C. V.; CORRÊA, R. C. G.; PERALTA, R. A.; MOREIRA, R. F. P. M.; BRACHT, A., PERALTA, R. M. Enzymatic degradation and detoxification of azo dye Congo red by a new laccase from Oudemansiella canarii. Bioresource Technology, v. 89, 121655, 2019.

JANUSZ, G.; PAWLIK, A.; SWIDERSKA-BUREK, U.; POLAK, J.; SULEJ, J.; JAROSZWILKOŁAZKA, A.; PASZCZYNSKI, A. Laccase properties, physiological functions, and evolution. International Journal of Molecular Sciences, v. 21, p. 1-25, 2020.

KARP, S. C.; FARACO, V.; AMORE, A.; LETTI, L. A. J.; SOCCOL, V. T.; SOCCOL, C. R. Statistical optimization of laccase production and delignification of sugarcane bagasse by Pleurotus ostreatus in solid-state fermentation. BioMed Research International, v. 2015, $181204,2015$.

MANSOUR, A. A.; ARNAUD, T.; LU-CHAU, T. A.; FDZ-POLANCO, M.; MOREIRA, M. T.; RIVERO, J. A. C. Review of solid state fermentation for lignocellulolytic enzyme production: challenges for environmental applications. Reviews in Environmental Science and Bio/Technology, v. 15, p. 31-46, 2016.

MARTINS, S.; MUSSATO, S. I.; MARTÍNEZ-AVILA, G.; MONTAÑEZ-SAENZ, J.; AGUILAR, C. N.; TEIXEIRA, J. A. Bioactive phenolic compounds: Production and extraction by solid-state fermentation. A review. Biotechnology Advances, v. 29, p. 365-373, 2011.

MATE, D. M.; ALCALDE, M. Laccase engineering: From rational design to directed evolution. Biotechnology Advances, v. 33, p. 25-40, 2015.

MAYOLO-DELOISA, K.; GONZÁLEZ-GONZÁLEZ, M.; RITO-PALOMARES, M. Laccases in food industry: bioprocessing, potential industrial and biotechnological applications. Frontiers in Bioengineering and Biotechnology, v. 8, p. 222-230, 2020.

MUÑIZ-MOURO, A.; OLIVEIRA, I. M.; GULLÓN, B.; LÚ-CHAU, T. A.; MOREIRA, M. T.; LEMA, J. M.; EIBES, G. Comprehensive investigation of the enzymatic oligomerization of esculin by laccase in ethanol: water mixtures. RSC Advances, v. 7, p. 38424-38433, 2017.

NANDAL, P.; RAVELLA, S. R.; KUHAD, R. C. Laccase production by Coriolopsis caperata RCK2011: Optimization under solid state fermentation by Taguchi DOE methodology. Scientific Reports, v. 3, 1386, 2013.

PERALTA, R. M.; SILVA, B. P.; CÔRREA, R. C. G.; KATO, C. G.; SEIXAS, F. A. V. S.; BRACHT, A. Enzymes from Basidiomycetes: peculiar and efficient tools for biotechnology G. Brahmachari, A.L. Demain, J.L. Adrio (Eds.), Biotechnology of Microbial EnzymesProduction, Biocatalysis and Industrial Applications, Elsevier (2017), pp. 119-150.

REVANKAR, M. S.; DESAI, K. M.; LELE, S. S. Solid-state fermentation for enhanced production of laccase using indigenously isolated Ganoderma sp. Applied Biochemistry and Biotechnology, v. 143, p. 16-26, 2007. 
SINGHANIA, R. R.; PATEL, A. K.; SOCCOL, C. R.; PANDEY, A. Recent advances in solid state fermentation. Biochemical Engineering Journal, v. 44, p. 13-18, 2009.

SOUZA, C. G. M.; TYCHANOWICZ, G. K.; SOUZA, D. F.; PERALTA, R. M. Production of laccase isoforms by Pleurous pulmonarius in response to presence of phenolic and aromatic compounds. Journal of Basic Microbiology, v. 44, p. 129-136, 2004.

TEODORO, T. S.; OLIVEIRA, F.; CAROLINE POFFO, C.; BRAGA, L. P.; ARBIGAUS, A.; RAMPINELLI, J. R.; WISBECK, E.; BONATTI-CHAVES, M.; FURLAN, S. A. The influence of Tween 80 on laccase production by Pleurotus sajor-caju and the efficiency of crude enzyme broth in the removal of bisphenol-A. Arquivos do Instituto Biológico, v. 85, e1022017, 2018.

VOGEL, H. J. A convenient growth medium for Neurospora (Medium N). Microbial Genetic Bulletin, v. 13, p. 42-43, 1956.

XIN, F.; GENG, A. Utilization of horticultural waste for laccase production by Trametes versicolor under solid-state fermentation. Applied Biochemistry and Biotechnology, v. 163, p. 235-246, 2011.

XU, L.; SUN, K.; WANG, F.; ZHAO, L.; HU, J.; MA, H.; DING, Z. Laccase production by Trametes versicolor in solid-state fermentation using tea residues as substrate and its application in dye decolorization. Journal of Environmental Management, v. 270, 110904, 2020.

WATTANAKITJANUKUL, N.; SUKKASEM, C.; CHIERSILP, B.; BOONSAWANG, P. Use of palm empty fruit bunches for the production of ligninolytic enzymes by Xylaria sp. in solid state fermentation. Waste and Biomass Valorization, v. 11, p. 3953-3964, 2020.

ZERVA, A.; SIMIC, S.; TOPAKAS, E.; NIKODINOVIC-RUNIC, J. Applications of microbial laccases: patent review of the past decade (2009-2019). Catalysts, v. 9, p. 1023-1049, 2019.

ZILlY, A.; BAZANELlA, G. C. S.; HELM, C. V.; ARAÚJO, C. A. V.; SOUZA, C. G. M.; BRACHT, A.; PERALTA, R. M. Solid-state bioconversion of passion fruit waste by white-rot fungi for production of oxidative and hydrolytic Enzymes. Food and Bioprocess Technology, v. 5, p. 1573-1580, 2012. 
MALAQUITA

\title{
CAPÍTULO 04: PRODUCCIÓN DE LACASAS POR HONGOS DE LA PUDRICIÓN BLANCA Y APLICACIÓN EN LA DECOLORACIÓN DE COLORANTE VERDE MALAQUÍTA
}

\author{
CHAPTER 04: PRODUCTION OF LACASES BY WHITE ROT FUNGI AND \\ APPLICATION IN THE DISCOLORATION OF GREEN MALACHI DYE
}

Thaís Marques Uber ${ }^{1}$; Gabriel Bruno da Silva²; Emanueli Backes³; Vinicius M. S. Cheute ${ }^{4}$ Rosane M. Peralta ${ }^{5}$

DOI: https://doi.org/10.31692/978-65-88970-19-5.48-62

\begin{abstract}
RESUMO
Lacases são óxido-redutases com ampla especificidade de ação podendo oxidar diferentes substratos, incluindo diferentes grupos de xenobióticos, como corantes, herbicidas, fármacos e pesticidas. $\mathrm{O}$ potencial redox padrão das lacases geralmente não é grande o suficiente para oxidar vários compostos xenobióticos, porém sua ação oxidativa pode ser melhorada com a utilização de mediadores. Estes são pequenas moléculas facilmente oxidáveis que podem atuar como intermediários redox entre o sítio ativo da enzima e o substrato que a enzima sozinha é incapaz de oxidar. O verde malaquita (VM) é um corante trifenilmetano utilizado como fungicida que é altamente tóxico para células de mamíferos. A degradação do VM por diferentes lacases de fungos ligninolíticos têm sido relatada. Neste contexto, os objetivos deste trabalho foram: primeiro, cultivar Pleurotus ostreatus, Pleurotus pulmonarius e Trametes versicolor para produzir lacases; segundo, estudar o potencial de biorremediação do VM por essas lacases na ausência e presença de três diferentes mediadores- acetilacetona, ácido violúrico e hidróxibenzotriazol (HBT). Para obtenção das lacases, os fungos foram cultivados em estado sólido utilizando resíduo da pupunheira como substrato. Após 6 dias de cultivo, as lacases foram extraídas com água, filtradas em gaze e centrifugadas a $1800 \mathrm{~g}$ por $15 \mathrm{~min}$. Os sobrenadantes límpidos foram considerados como extratos brutos de lacase. Para avaliar a ação das lacases na degradação do VM, as enzimas foram adicionadas a soluções contendo $100 \mathrm{ppm}$ do VM e as misturas foram incubadas a $40{ }^{\circ} \mathrm{C}$ por até $24 \mathrm{~h}$. Periodicamente a absorbância da solução foi avaliada em espectrofotômetro a $620 \mathrm{~nm}$. Os melhores resultados foram obtidos utilizando-se ácido violúrico como mediador. Os testes de toxicidade foram realizados com sementes de alface (Lactuca sativa). Após 5 dias, avaliou-se o crescimento das radículas na presença do corante sem tratamento e com o corante pós tratamento com lacase de $T$. versicolor ou com lacase de T. versicolor + ácido violúrico. As análises com sementes de alface mostraram uma redução significativa da fitoxicidade do VM após os dois tratamentos, mas o ácido violúrico apresentou por si só discreta fitotoxicidade.
\end{abstract}

Palavras-Chave: Biodegradação, Corantes industriais, Oxidases, Fungos ligninolíticos, Lacases.

\section{RESUMEN}

Las lacasas son óxido reductasas con una amplia especificidad de acción que pueden oxidar diferentes sustratos, incluidos diferentes grupos de xenobióticos, como colorantes, herbicidas, medicamentos y pesticidas. El potencial redox estándar de las lacasas generalmente no es lo suficientemente grande como para oxidar varios compuestos xenobióticos, pero su acción oxidativa puede mejorarse con el uso de mediadores. Esos son pequeñas moléculas fácilmente oxidables que pueden actuar como intermediarios

\footnotetext{
${ }^{1}$ Programa de Pós-graduação em Bioquímica, Universidade Estadual de Maringá, thaisuber@gmail.com

${ }^{2}$ Bacharelado em Bioquímica, Universidade Estadual de Maringá, ra101830@uem.br

${ }^{3}$ Programa de Pós-graduação em Ciência de Alimentos, Universidade Estadual de Maringá, emanuelibackes@outlook.com

${ }^{4}$ Programa de Pós-graduação em Bioquímica, Universidade Estadual de Maringá, vinimateusopo@gmail.com

${ }^{5}$ Departamento de Bioquímica, Universidade Estadual de Maringá, rmperalta@uem.br
} 
redox entre el sitio activo de la enzima y el sustrato que la enzima sola no puede oxidar. El verde de malaquita (VM) es un tinte de trifenilmetano que se usa como fungicida y es altamente tóxico para las células de mamíferos. La degradación de VM por lacasas de hongos ligninolíticos ha sido reportada. En este contexto los objetivos de este trabajo fueron: primero, cultivar Pleurotus ostreatus, Pleurotus pulmonarius y Trametes versicolor para producir lacasas; segundo, estudiar el potencial de biorremediación de VM por esas lacasas en ausencia y presencia de tres diferentes mediadores: acetilacetona, ácido violúrico y hidroxibenzotriazol (HBT). Para obtener las lacasas, los hongos se cultivaron en estado sólido utilizando como sustrato residuo de palma melocotón. Después de 6 días de cultivo, las lacasas se extrajeron con agua, se filtraron a través de una gasa y se centrifugaron a $1800 \mathrm{~g}$ durante 15 min. Los sobrenadantes transparentes se consideraron extractos de lacasa en bruto. Para evaluar la acción de las lacasas en la degradación de VM, se agregaron enzimas a soluciones con 100 ppm de VM y las mezclas se incubaron a $40^{\circ} \mathrm{C}$ hasta por $24 \mathrm{~h}$. La absorbancia de la solución se evaluó periódicamente en un espectrofotómetro a $620 \mathrm{~nm}$. Los mejores resultados se obtuvieron utilizando ácido violúrico como mediador. Se realizaron pruebas de toxicidad con semillas de lechuga (Lactuca sativa). Después de 5 días, se evaluó el crecimiento de la raíz en presencia del tinte sin tratar y con el tinte después del tratamiento con lacasa de T. versicolor o con lacasa de $T$. versicolor + ácido violúrico. Los análisis con semillas de lechuga mostraron una reducción significativa en la fitoxicidad de VM después de los dos tratamientos, pero el ácido violúrico solo mostró una leve fitotoxicidad.

Palabras Clave: Biodegradación, Tintes industriales, Oxidasas, Hongos Ligninolíticos, Lacasas.

\begin{abstract}
Laccases are oxidoreductases with a wide specificity of action that can oxidize an ample number of substrates including different groups of xenobiotics, such as dyes, herbicides, drugs and pesticides. The standard redox potential of the laccases is generally not large enough to oxidize various xenobiotic compounds, but their oxidative action can be improved by the use of mediators. The latter are small easily oxidizable molecules that can act as redox intermediates between the active site of the enzyme and the substrate which the enzyme alone is unable to oxidize. Malachite green (MG) is a triphenylmethane dye used as a fungicide that is highly toxic to mammalian cells. MG degradation has been reported to be catalyzed by several laccases of ligninolytic fungi. Within this context the objectives of this work were: first, to grow the fungi Pleurotus ostreatus, Pleurotus pulmonarius and Trametes versicolor for producing laccases; and, second, to study the potential of these enzymes in degrading MG in the absence and presence of three different mediators: acetylacetone, violuric acid and hydroxybenzotriazole (HBT). To obtain the laccases, the fungi were grown under solid state conditions using peach palm residues as substrate. After 6 days of cultivation, the laccases were extracted with water, filtered through gauze and centrifuged at $1800 \mathrm{~g}$ for $15 \mathrm{~min}$. The clear supernatants were considered as crude laccase extracts. To assess the degradation of MG by the laccases, the enzymes were added to solutions containing $100 \mathrm{ppm} \mathrm{MG}$ and the mixtures were incubated at $40{ }^{\circ} \mathrm{C}$ for up to $24 \mathrm{~h}$. The absorbance of the solution was periodically evaluated in a spectrophotometer at $620 \mathrm{~nm}$. The best results were obtained using violuric acid as mediator. Toxicity tests were performed with lettuce seeds (Lactuca sativa). After 5 days, root growth was evaluated in the presence of the untreated dye and with the dye after treatment with $T$. versicolor laccase or with $T$. versicolor laccase + violuric acid. The analyses with lettuce seeds showed a significant reduction in the phytotoxicity of MG after both treatments, but violuric acid by itself showed a slight phytotoxicity.
\end{abstract}

Keywords: Biodegradation, Industrial dyes, Oxidases, Ligninolitic Fungi, Laccase.

\title{
INTRODUÇÃO
}

Fungos causadores da podridão branca da madeira são um grupo diverso e abundante da classe dos Agaricomicetos. Esses fungos degradam todos os componentes da madeira, celulose, hemicelulose e lignina a partir dos quais obtém energia para seu crescimento e reprodução. Na natureza existem vários organismos capazes de produzir celulases e 
hemicelulases e hidrolisar os polissacarídeos celulose e hemicelulose em monossacarídeos. No

entanto, quando esses polissacarídeos são complexados com lignina, eles são resistentes à hidrólise enzimática. Por essa razão, os fungos da podridão branca são os mais aptos microrganismos capazes de metabolizar completamente a lignina, sendo essenciais nos ecossistemas das florestas. Entre as espécies mais comumente estudadas de fungos da podridão branca estão as espécies: Trametes versicolor, Pleurotus ostreatus e Pleurotus pulmonarius (PERALTA et al., 2017).

A capacidade de degradar a lignina, o polímero orgânico mais abundante da natureza, vem da capacidade destes fungos em produzir um conjunto de enzimas chamadas enzimas ligninolíticas. Peroxidases e lacases são as mais importantes enzimas deste grupo. São óxidoredutases, com especificidade ampla de ação, podendo oxidar diferentes substratos. As lacases (EC 1.10.3.2) podem catalisar a oxidação de grande variedade de substratos orgânicos e inorgânicos, incluindo mono-, di- e polifenóis, metoxifenóis, aminas aromáticas e ascorbato por um mecanismo de transferredução de uma molécula de oxigênio para duas moléculas da água e a oxidação concomitante de quatro moléculas de substrato para produzir quatro radicais (RIVA, 2006) (Fig. 1). As peroxidases capazes de oxidar a lignina são a lignina peroxidase, peroxidase dependente de manganês e versátil peroxidase (PERALTA et al., 2017).

Corantes sintéticos são utilizados extensivamente nas indústrias têxtil, de papel, lã, algodão e cosméticos (SAJAB et al., 2011). Cerca de 10-15\% da produção total de corantes é descartada em efluentes industriais (ARANTES et al., 2006). Verde de malaquita $\left(\mathrm{C}_{23} \mathrm{H}_{25} \mathrm{ClN}_{2}\right.$ ), massa molecular 364,9 g/mol) é um corante trifenilmetano utilizado na indústria de seda, lã, juta e couro (Fig. 2). Devido à sua elevada toxicidade para muitos microrganismos, a sua biodegradação é difícil em águas residuais (PAPINUTTI et al., 2006). O descarte do verde malaquita e outros corantes em córregos tem o efeito de inibir a penetração da luz solar e diminuir a atividade fotossintética, que pode ser tóxico para a vida aquática (VASANTH KUMAR et al., 2006). 
Figura 01: Reação geral da lacase (A) e representação esquemática da oxidação do substrato pela lacase na presença de um mediador químico (B)

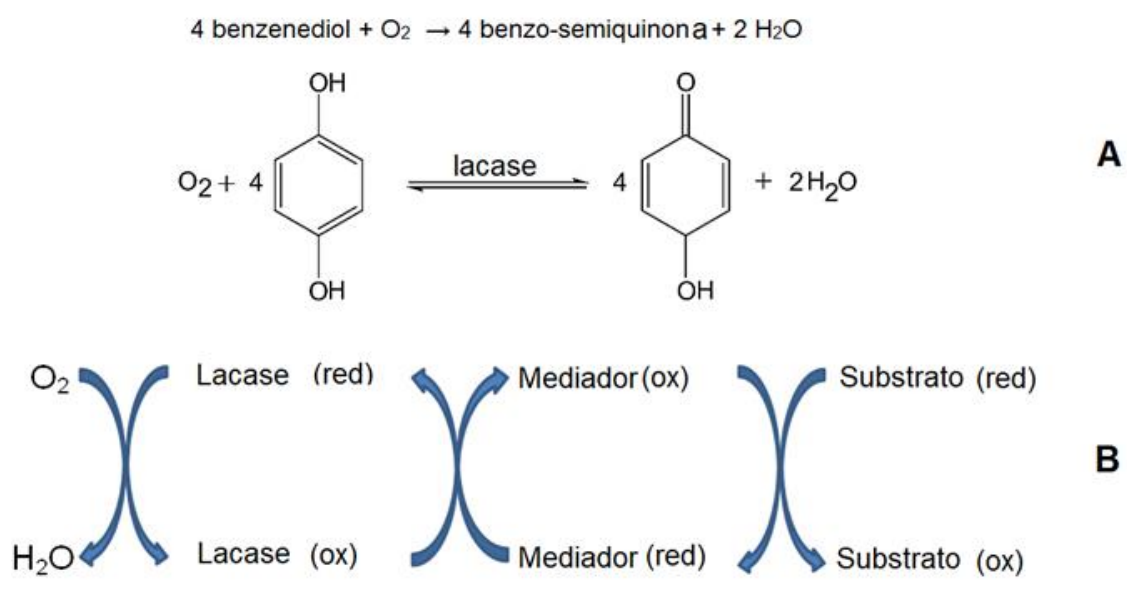

Fonte: PERALTA et al., 2017 com modificações

Figura 02: Estrutura do corante sintético verde malaquita<smiles></smiles>

Fonte: Própria (2021)

Os objetivos deste trabalho foram produzir lacases através de cultivos dos fungos ligninolíticos em estado sólido utilizando resíduo da pupunheira como substrato e avaliar a aplicação dos extratos enzimáticos ricos em lacases na degradação do corante verde malaquita. Esforços foram realizados para comparar a fitotoxicidade do verde de malaquita antes e após o tratamento com as lacases.

\section{FUNDAMENTAÇÃO TEÓRICA}

Lacases e peroxidases possuem ampla especificidade de ação podendo atuar em diferentes grupos de xenobióticos quimicamente semelhantes à lignina incluindo corantes, herbicidas, fármacos e pesticidas (PERALTA et al., 2017, IARK et al., 2019). Entretanto, o potencial redox padrão da lacase geralmente não é grande o suficiente para oxidar vários 
compostos xenobióticos, porém sua ação oxidativa pode ser melhorada com a utilização de

mediadores, pequenas moléculas facilmente oxidáveis que podem atuar como intermediários redox entre o sítio ativo da enzima e um substrato que a enzima sozinha é incapaz de oxidar. (MAJEAU et al., 2010). Mediadores são compostos orgânicos de baixa massa molecular que primeiro são oxidados pela lacase e depois oxidam os compostos não fenólicos que a lacase sozinha não é capaz de oxidar (Fig. 1B) (CHRISTOPHER et al., 2014).

Três destes mediadores são a acetilacetona, o ácido violúrico e 1-hidroxibenzotriazol (HBT) (Fig. 3). Estas moléculas já foram descritas como mediadores excelentes em vários processos de biodegradação utilizando lacases. Ácido violúrico foi descrito como excelente mediador na degradação de corantes recalcitrantes pela lacase de Trametes hirsuta (COUTO \& SANROMÁN, 2007) e na degradação de pesticidas pela lacase de Trametes versicolor (JIN et al., 2016). A degradação de poluentes orgânicos pela lacase de Trametes versicolor foi significativamente aumentada em presença de acetilacetona (YANG et al., 2015a). HBT aumentou a degradação do herbicida isoproturon pela lacase de T. versicolor (ZENG et al., 2017).

Figura 03: Estruturas químicas dos mediadores acetilacetona, ácido violúrico e HBT<smiles>CC(=O)CC(C)=O</smiles>

Acetilacetona<smiles>O=C1NC(=O)C(=NO)C(=O)N1</smiles>

Ácido violúrico<smiles>On1nnc2ccccc21</smiles>

HBT

Fonte: Própria (2021)

Para a produção de lacases, cultivos em estado sólido utilizando resíduos agroindustriais e florestais como substratos tem recebido grande atenção devido à facilidade, baixo custo e obtenção de extratos enzimáticos com elevadas atividades (SOCCOL et al., 2017). Os principais resíduos utilizados nos cultivos em estado sólido são o farelo de trigo, bagaço de cana, casca de arroz, serragem de eucalipto, entre vários outros. Pesquisas que incluam outros substratos que possibilitem rápido crescimento dos fungos e elevada produção da enzima são de grande importância, pois podem baratear a obtenção das lacases.

A pupunheira é uma palmeira nativa da região amazônica que têm seu cultivo difundido nos estados Santa Catarina, Paraná, Rio Grande do Sul, Rio de Janeiro e Espírito Santo (SEBEN et al., 2012). O palmito e o fruto são as partes da pupunheira mais exploradas comercialmente, 
restando, após a extração do palmito, cerca de $80 \%$ a 90\% do seu peso bruto como resíduo. Os

resíduos agroindustrias exibem alto potencial poluente, no entanto não podem ser considerados como lixo, pois possuem valor econômico agregado e podem ser tratados e aproveitados no próprio setor agroindustrial (PEDROSA et al., 2013). Por serem basicamente fibras lignocelulósicos, os resíduos da pupunheira possuem potencial aplicação como substrato para crescimento de fungos lignocelulolíticos.

\section{METODOLOGIA}

A pesquisa realizada foi de natureza quantitativa experimental. Os fungos da podridão branca Pleurotus ostreatus, Pleurotus pulmonarius e Trametes versicolor foram obtidos da Coleção de Basidiomicetos do Laboratório de Bioquímica de Microrganismos e Alimentos da Universidade Estadual de Maringá. Os fungos foram mantidos em laboratório através de repiques sucessivos em ágar batata dextrose ou ágar extrato de malte.

Os resíduos da pupunheira (bainha interna e casca) foram gentilmente cedidos pela EMBRAPA-FLORESTAS. Os materiais foram secos ao sol, moídos para dar um tamanho de partícula de 2-3 mm de espessura e usados como matéria-prima neste estudo. Os materiais foram avaliados pela técnica da fibra em detergente ácido (FDA) para obtenção dos percentuais de celulose, hemicelulose e lignina, e fibra em detergente neutro (FDN) para a porcentagem de lignocelulose (VAN SOEST et al., 1991). A composição média da bainha interna da pupunheira foi de $34,2 \pm 4 \%$ celulose, $19 \pm 2 \%$ hemiceluloses e $23 \pm 2 \%$ lignina. A composição média da casca de pupunha foi $36,0 \pm 4 \%$ celulose, $20 \pm 4 \%$ hemiceluloses e $20 \pm 3 \%$ lignina.

Para produção das lacases foi utilizada a técnica de cultivo em estado sólido. Cinco gramas dos resíduos de pupunha (bainha interna ou casca) foram colocados em frascos Erlenmeyer e um volume de $15 \mathrm{~mL}$ de meio mineral de Vogel (MONTENECOURT \& EVEILEIGH, 1977) foi adicionado para a obtenção de uma umidade inicial de 75\%. Em alguns cultivos glicose a $1 \%$ foi adicionado ao meio mineral. Os frascos foram autoclavados por 15 min. Após resfriamento, 3 discos de micélio de cada fungo foram uniformemente distribuídos nos frascos em condições assépticas. Os frascos foram mantidos em estufa a $28{ }^{\circ} \mathrm{C}$ no escuro. Os cultivos foram interrompidos após 6 dias adicionando-se $20 \mathrm{~mL}$ de água destilada a cada frasco. Os frascos foram mantidos em geladeira por cerca de $4 \mathrm{~h}$, filtrados em gaze e centrifugados em centrífuga refrigerada a $2000 \mathrm{rpm}$. Os sobrenadantes foram considerados como sendo os extratos enzimáticos brutos. 
A atividade da lacase foi avaliada utilizando-se o substrato 2,2'-azino-bis (3etilbenzotiazolina-6-sulfônico) (ABTS) em $50 \mathrm{mM}$ de tampão acetato de sódio pH 5.0. A oxidação do ABTS foi determinada pelo aumento da absorbância a $420 \mathrm{~nm}$ ( $\varepsilon=36 \mathrm{mM}-1 \mathrm{~cm}$ 1) (MOTA et al., 2015). As atividades enzimáticas foram determinadas a $40^{\circ} \mathrm{C}$ e expressas em unidade enzimática internacional (U) obtidas por g de substrato (U/g substrato).

Para a avaliação da habilidade das lacases brutas degradarem o corante verde de malaquita, os ensaios foram realizados nas seguintes proporções: um volume de $18 \mathrm{~mL}$ do corante verde malaquita na concentração de 100 ppm foi acondicionado em frasco Erlenmeyer de $50 \mathrm{~mL}$. Um volume de $100 \mu \mathrm{L}$ do extrato enzimático bruto (para obtenção de uma atividade final de lacase de $1 \mathrm{U} / \mathrm{mL}$ de lacase), $100 \mu \mathrm{L}$ de um dos mediadores (acetilacetona, ácido violúrico, HBT na concentração final de $0,5 \mathrm{mM}$ ) foram adicionados ao frasco contendo o corante. Nos ensaios onde não foi adicionado um mediador, um volume de $100 \mu \mathrm{L}$ de água destilada foi adicionado para manutenção do volume de reação. As misturas reacionais foram mantidas a $40^{\circ} \mathrm{C}$ sem agitação. Periodicamente um volume de $2 \mathrm{~mL}$ das misturas foi introduzido na cubeta do espectrofotômetro e realizado um espectro de absorção da mistura na faixa do visível (400 a $700 \mathrm{~nm}$ ). Para cálculo do percentual de descoloração, foi utilizado o valor da absorbância obtida no comprimento de onda $620 \mathrm{~nm}$.

A avaliação da toxicidade foi realizada utilizando-se sementes de alface (Lactuca sativa). O bioensaio foi conduzido usando verde malaquita não tratado e tratado com lacase diluídos convenientemente para obtenção do corante na concentração de 100 ppm. Placas de Petri (90 mm de diâmetro), contendo papel de filtro saturado com $3 \mathrm{~mL}$ das várias amostras ou água (controle), receberam vinte sementes de alface. As placas foram mantidas no escuro a 28 ${ }^{\circ} \mathrm{C}$. Após 5 dias, os comprimentos das radículas foram medidos e expressos como alongamento da raiz em cm (COELHO-MOREIRA et al., 2018).

Os dados foram submetidos a ANOVA com teste post hoc de Tukey. Valores de $\mathrm{p} \leq$ 0,05 foram adotados para significância. O software GraphPad Prism (versão 8.0) foi utilizado para as análises de ANOVA e também para a confecção das figuras deste trabalho.

\section{RESULTADOS E DISCUSSÃO}

Os fungos Trametes versicolor, Pleurotus pulmonarius e Pleurotus ostreatus apresentaram os primeiros sinais de crescimento micelial já no segundo dia de cultivo, apresentando colonização completa do substrato após 5 dias de cultivo. A Tabela 01 mostra a produção de lacases no $6^{\circ}$ dia de cultivo. Analisando-se os dados obtidos, podemos concluir 
que as culturas de $P$. ostreatus e $T$. versicolor produziram atividades de lacase maiores em tempos menores de cultivo, quando as atividades foram comparadas.

Tabela 01: Produção de lacases pelos fungos ligninolíticos em cultivos em estado sólido utilizando resíduo de pupunha como substrato

\begin{tabular}{clc}
\hline $\begin{array}{l}\text { Fungo } \\
\text { pesíduo de } \\
\text { pupunha }\end{array}$ & $\begin{array}{c}\text { Lacase } \\
(6 \text { dias de cultivo })\end{array}$ \\
\hline T. versicolor & casca & U/g de substrato \\
$T$. versicolor & interno & $10,80 \pm 1,13^{\mathrm{a}}$ \\
$P$. ostreatus & casca & $31,56 \pm 2,80^{\mathrm{b}}$ \\
$P$. ostreatus & interno & $13,83 \pm 1,50^{\mathrm{a}}$ \\
$P$. pulmonarius & casca & $17,67 \pm 1,90^{\mathrm{c}}$ \\
$P$. pulmonarius & interno & $14,21 \pm 0,55^{\mathrm{a}}$ \\
\cline { 2 - 2 } Médias identificadas com letras diferentes são estatisticamente diferentes $(\mathrm{p} \leq 0,05)$.
\end{tabular}

Fonte: Própria (2021)

Os resultados indicam que os resíduos da pupunheira (bainha externa e interna) são bons substratos para o crescimento e produção de lacases pelos fungos T. versicolor, $P$. ostreatus e $P$. pulmonarius, tendo-se obtido valores significativamente mais altos de lacase $(\mathrm{p} \leq 0,05)$ quando a bainha interna da pupunha foi utilizada como substrato. A utilização destes resíduos como substratos para cultivos dos fungos reduzem o potencial poluente dos resíduos de pupunheira ao serem utilizados para a geração de produtos de alto valor agregado, neste caso as lacases, sendo um exemplo de economia circular (UBANDO et al., 2020).

Das três lacases, a mais efetiva na degradação do verde de malaquita sem a presença de um mediador, foi a enzima do T. versicolor. Utilizando $1 \mathrm{U} / \mathrm{mL}$ da lacase de $T$. versicolor, a solução de verde malaquita na concentração de 100 ppm foi descolorida $60 \%$ após 24 h (Fig. 4). Utilizando a lacase de $P$. ostreatus e $P$. pulmonarius, o percentual de descoloração foi inferior a $20 \%$. A maior ou menor capacidade da lacase em oxidar um substrato está associada ao seu potencial redox. As lacases são classificadas em 3 grupos quanto ao potencial redox: as de alto potencial redox $(0,7-0,8 \mathrm{~V})$, as de médio potencial redox $(0,5-0,6 \mathrm{~V})$ e as de baixo potencial redox (0,4-0,5 V) (UZAN et al., 2010). As lacases de Trametes sp são considerada de alto potencial redox, enquanto as de Pleurotus sp são consideradas de potencial redox médio (PERALTA et al., 2017) 
Tem sido relatado que lacases de diferentes fungos são hábeis na descoloração do verde

malaquita. Por exemplo, lacase (30 U/mL) de Ganoderma sp foi capaz de descolorir mais de 90\% de uma solução 100 ppm de VM após 12 h (SHARMA et al., 2015). Uma lacase de Trametes pubescens (300 U/L ou 0,3 U/mL) descoloriu 41\% e 96\% de uma solução de VM (33 ppm) após 4 e 21 h, respectivamente (OSMA et al., 2007).

Figura 04: Porcentagem de descoloração do corante verde malaquita pelas lacases de Trametes versicolor, Pleurotus ostreatus e Pleurotus pulmonarius. Os meios reacionais continham $1 \mathrm{U} / \mathrm{mL}$ de lacase (concentração final)

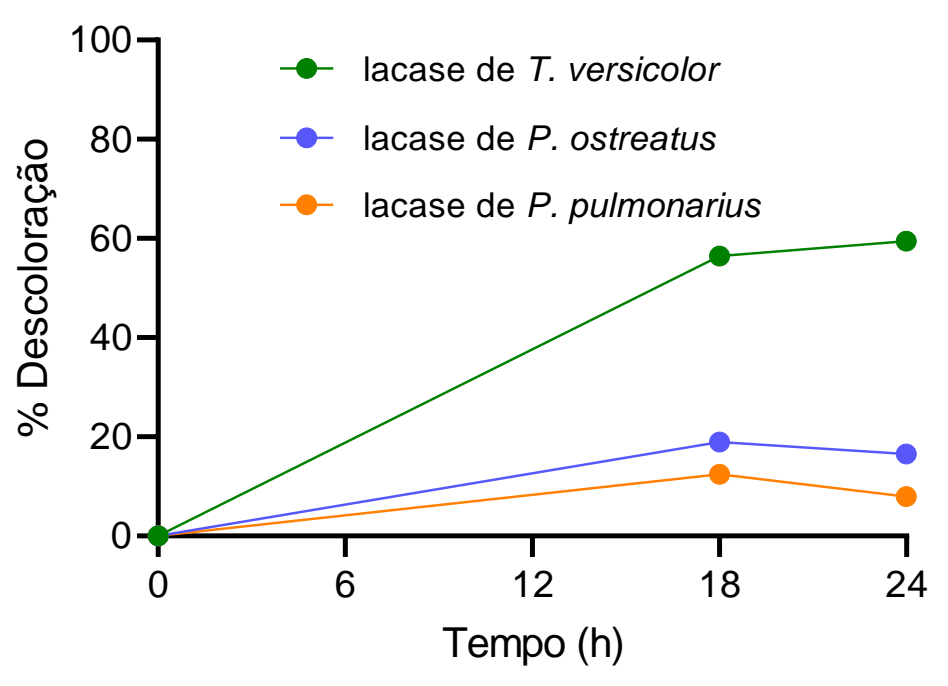

Fonte: Própria (2021)

A Figura 05 exibe os resultados do ensaio enzimático de descoloração do verde malaquita pelas lacases de $T$. versicolor, $P$. ostreatus e $P$. pulmonarius na presença dos mediadores ácido violúrico, HBT e acetilacetona. O tempo do ensaio foi reduzido para um máximo de 4 horas. Maior descoloração foi observada quando a lacase de T. versicolor foi utilizada com ácido violúrico a 0,5 mM como mediador: 100\% de descoloração foi observado após incubação de $1 \mathrm{~h}$. O HBT aumentou a capacidade de descoloração no extrato de $T$. versicolor, mas não aumentou a descoloração causada pelas lacases de $P$. ostreatus $e P$. pulmonarius. O mediador acetilacetona não aumentou a descoloração do verde malaquita para nenhuma das lacases testadas.

A descoloração do verde malaquita foi medida utilizando-se diferentes concentrações do ácido violúrico. O efeito do ácido violúrico na descoloração do verde malaquita é dose dependente para todas as lacases testadas (Fig. 6). Após $1 \mathrm{~h}$ a descoloração do corante foi próxima a $100 \%$ ao se utilizar as lacases de T. versicolor e de P. ostreatus e cerca de $80 \%$ ao 


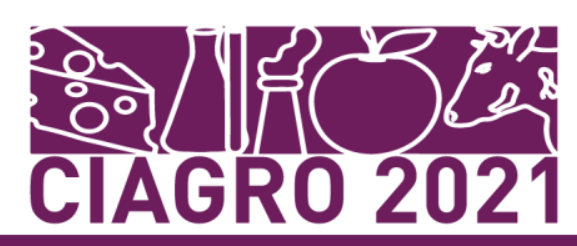

se utilizar a lacase de $P$. pulmonarius. Ao redor de $50 \%$ de descoloração do verde de malaquita foi obtida ao se utilizar o ácido violúrico nas concentrações de 0,16, 0,18 e 0,25 mM em associação com as lacases de T. versicolor, P. ostreatus e P. pulmonarius, respectivamente.

Figura 05: Porcentagem de descoloração do corante verde malaquita (100 ppm) lacases de T. versicolor, $P$. ostreatus e P. pulmonarius (lacase na concentração final de $1 \mathrm{U} / \mathrm{mL}$ ) com adição dos mediadores ácido violúrico, 1-hidroxibenzotriazol (HBT) e acetilacetona todos na concentração final de 0,5 mM.
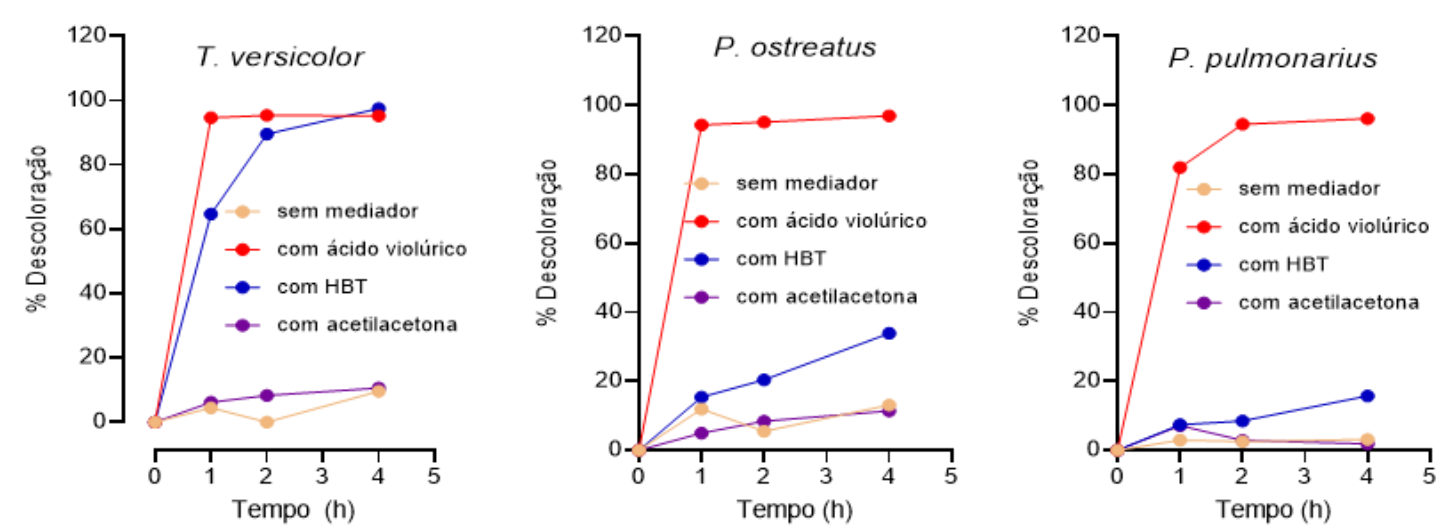

Fonte: Própria (2021)

Figura 06: Efeito da concentração do ácido violúrico sobre a descoloração do verde malaquita pelas lacases de $T$. versicolor, $P$. ostreatus e $P$. pulmonarius. O tempo reacional foi de $1 \mathrm{~h}$ utilizando verde de malaquita $100 \mathrm{ppm}$

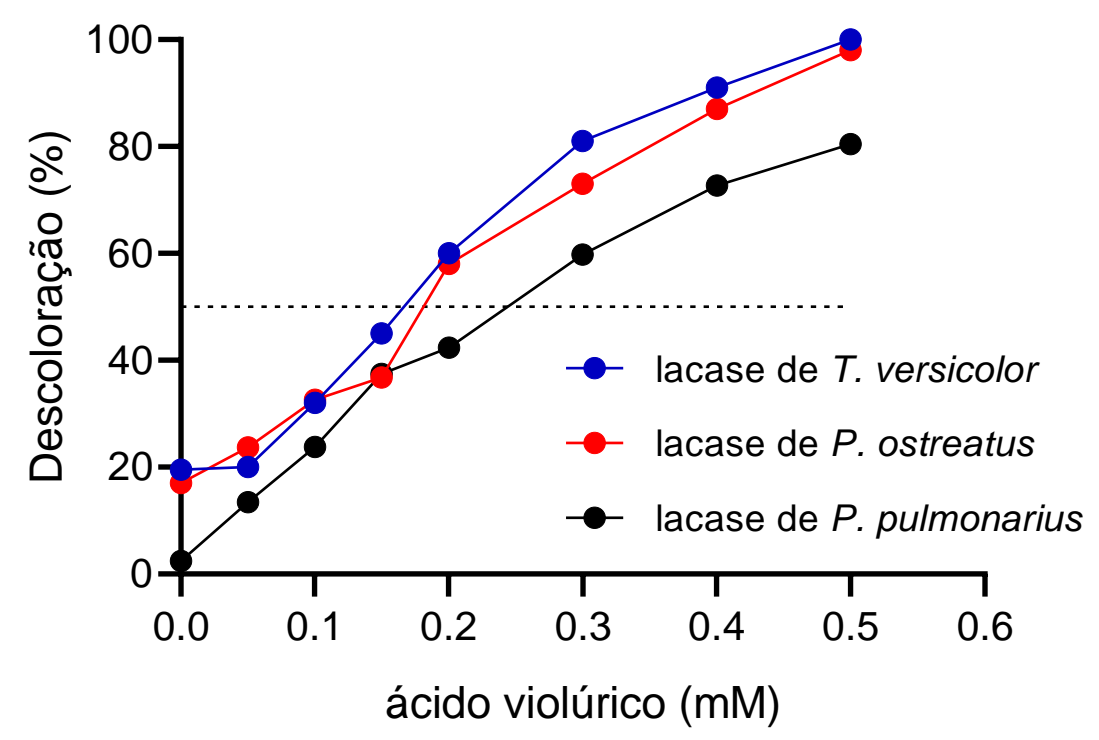

Fonte: Própria (2021)

Para verificar se a descoloração do verde malaquita é acompanhada ou não de redução da fitotoxicidade, foram realizados experimentos utilizando sementes de alface e avaliando-se o crescimento da radícula na presença de água, verde malaquita sem tratamento, verde 
malaquita com enzima, verde malaquita com mediador e verde malaquita com enzima e

mediador. Para este experimento, utilizou-se o extrato enzimático de T. versicolor. Comparando com a água (controle) a solução com corante foi fitotóxica, visto que o comprimento médio das radículas foi reduzido de 50 para $15 \mathrm{~mm}$ ((Fig. 7). As soluções descoloridas (corante + lacase e corante + lacase + ácido violúrico) apresentaram menor fitotoxicidade. A solução de ácido violúrico e corante exibiu maior fitotoxicidade do que o corante sozinho, o que sugere que ácido violúrico também apresentou fitotoxicidade.

Figura 07: Análise da fitotoxicidade do corante verde malaquita. A fitotoxicidade foi avaliada com sementes de alface, medindo-se o comprimento das radículas após 5 dias
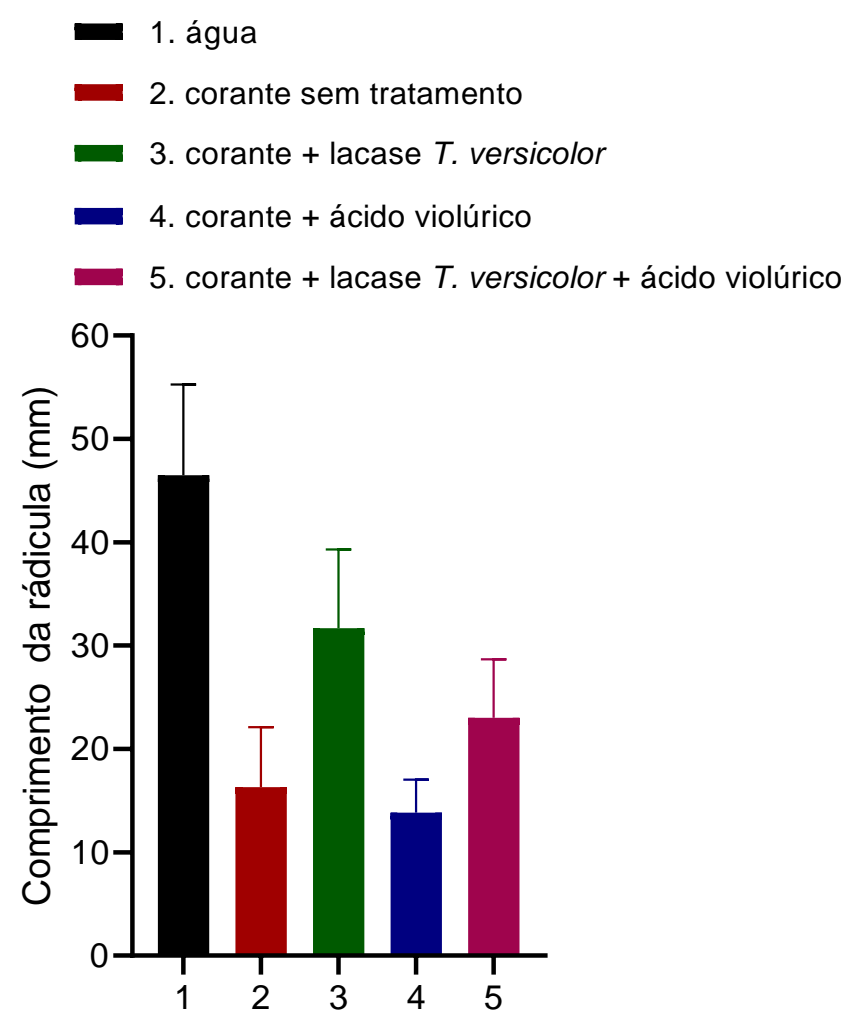

Fonte: Própria (2021)

A fim de avaliar a fitotoxicidade do ácido violúrico foi realizado um novo teste apenas com o mediador em diferentes concentrações. À medida que as sementes foram expostas à concentrações mais elevadas de ácido violúrico, o tamanho das radículas foi menor (Fig. 8).

Diversos trabalhos tem avaliado o efeito positivo do ácido violúrico na degradação de corantes. A adição de $1 \mathrm{mM}$ de ácido violúrico aumentou de 2 a 30 vezes a degradação de diferentes corantes pela lacase de Trametes hirsuta (YANTO et al., 2019, RODRIGUEZCOUTO \& SANROMÃN, 2007). O uso do ácido violúrico como mediador da lacase de Pleurotus ostreatus também aumentou a degradação de diversos corantes (POGNI et al., 2007). 
Entretanto, em função dos resultados obtidos que mostram uma redução do crescimento das

radículas das sementes de alface pelo ácido violúrico, os estudos de degradação de dorantes utilizando sistemas lacase-ácido violúrico devem ser monitorados quanto a toxicidade e se priorizar o uso de concentrações baixas deste mediador.

Figura 08: Efeito da concentração de ácido violúrico no comprimento das radículas de alface

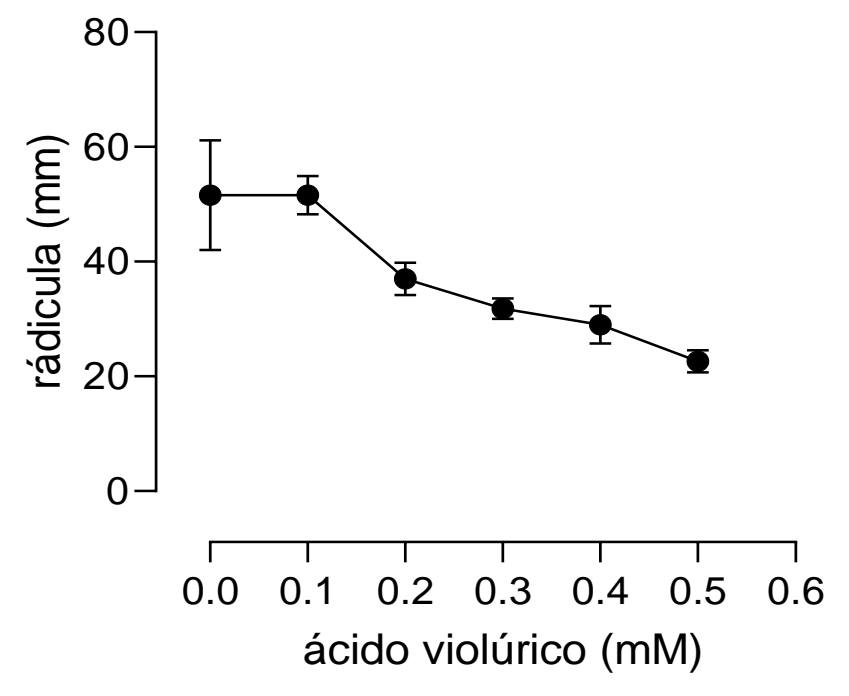

Fonte: Própria (2021)

\section{CONCLUSÕES}

Os resíduos da pupunheira foram substratos adequados para crescimento dos fungos $P$. ostreatus, $P$. pulmonarius e T. versicolor. Maiores atividades de lacase foram obtidas com $T$. versicolor cultivado na bainha interna da pupunheira. As lacases dos três fungos foram eficientes na degradação do corante verde de malaquita. A adição do mediador ácido violúrico aumentou a eficiência do processo de degradação do corante, diminuindo o tempo necessário para completa descoloração. No entanto, o ácido violúrico apresentou certa fitotoxicidade que deve ser considerada na sua associação com lacases quando o objetivo for degradação e detoxificação de xenobióticos. 
ARANTES, V., BALDOCCHI, C., MILAGRES, A. M. F. Degradation and decolorization of a biodegradable-resistant polymeric dye by chelator-mediated Fenton reactions. Chemosphere, v. 63 , p. 1764-1772, 2006.

CHRISTOPHER, L. P.; YAO, B.; \& JI, Y. Lignin biodegradation with laccase-mediator systems. Frontiers in Energy Research, v. 2, artigo 12, 2014.

COELHO-MOREIRA, J.S.; BRUGNARI, T.; SÁ-NAKANISHI, A. B.; CASTOLDI, R.; SOUZA, C.G.M.; BRACHT, A.; PERALTA, R.M. Evaluation of diuron tolerance and biotransformation by the white-rot fungus Ganoderma lucidum. Fungal Biology, v. 122, p. 471-478, 2018.

COUTO, S.R.; SAMROMÁN, M.A. The effect of violuric acid on the decolourization of recalcitrant dyes by laccase from Trametes hirsuta. Dyes and Pigments, v. 74, p. 123-126, 2007.

IARK, D.; BUZZO, A.J.R.; GARCIA, J.A.A.; CORRÊA, V.G.; HELM, C.V.; CORRÊA, R.C.G.; PERALTA, R.A.; PERALTA MUNIZ MOREIRA, R.F.; BRACHT, A.; PERALTA, R.M. Enzymatic degradation and detoxification of azo dye Congo red by a new laccase from Oudemansiella canarii. Bioresource Technology, v. 289, artigo 121655, 2019.

JIN, X.; YU, X.; ZHU, G.; ZHENG, Z.; FENG, F.;ZHANG, Z. Conditions optimizing and application of laccase-mediator system (LMS) for the laccase-catalyzed pesticide degradation. Scientific Reports, v. 6, artigo 35787, 2016.

MAJEAU, J. A.; BRAR, S. K.; TYAGI, R. D. Laccases for removal of recalcitrant and emerging pollutants. Bioresource Technology, 101, 2331-2350, 2010.

MONTENECOURT, B.S.; EVELEIGH, D.E. Preparation of mutants of Trichoderma reesei with enhanced cellulase production. Applied Environmental Microbiology, v. 34, p. 777-782, 1977.

MOTA, T.R.; KATO, C.G.; PERALTA, R.A.; BRACHT, A.; MORAIS, G.R.; BAESSO, M.L.; SOUZA, C.G.M.; BRACHT, A.; PERALTA, R.M. Decolourization of Congo Red by Ganoderma lucidum Laccase: evaluation of degradation products and toxicity. Water, Air, \& Soil Pollution, v. 226, p. 351-362, 2015.

OSMA, J.F.; HERRERA, J.L.T.; COUTO, S.R. Banana skin: a novel waste for laccase production by Trametes pubescens under solid-state conditions. Application to synthetic dye decolouration. Dyes and Pigments, v. 75, p. 32-37, 2007.

PAPINUTTI, L.; MOUSO, N.; FORCHIASSIN, F. Removal and degradation of the fungicide dye malachite green from aqueous solution using the system wheat bran-Fomes sclerodermeus. Enzyme and Microbial Technology, 39, 4, 848-853, 2006.

PEDROSA, T. D.; FARIAS, C. A. S.; PEREIRA, R. A.; DO RÊGO FARIAS, E. T. Monitoramento dos parâmetros físico-químicos na compostagem de resíduos agroindustriais. Nativa, v. 1, p. 44-48, 2013. 
PERALTA, R.M.; SILVA, B.P.; CORREA, R.C.G.; KATO, C.G.; SEIXAS, F.A.V.; BRACHT, A. 2017. Enzymes from basidiomycetes: peculiar and efficient tools for biotechnology. Biotechnology of Microbial Enzymes. Ed. G. BRAMACHARI, A.L. DEMAIN \& J.L. ADRIO. Elsevier, pp 119-150.

POGNI, R.; BROGIONI, B.; CAMILLA BARATTO, M.; SINICROPI, A.; GIARDINA, P.; PEZZELLA, C.; SANNIA, G.; BASO, R. Evidence for a radical mechanism in biocatalytic degradation of synthetic dyes by fungal laccases mediated by violuric acid. Biocatalysis and Biotransformation, v. 25, p. 269-275, 2007

RIVA, S. Laccases: blue enzymes for green chemistry. Trends Biotechnology, v. 24, p. 219226, 2006.

RODRIGUEZ COUTO, S.; SANROMÂ, M. A. The effect of violuric acid on the decolourization of recalcitrant dyes by laccase from Trametes hirsuta. Dyes and Pigments, v. 74 , p. 123-126, 2007

SAJAB, M. S.; CHIA, C. H.; ZAKARIA, S.; JANI, S. M.; AYOB, M. K.; CHEE, K. L.; KHIEW, P. S.; CHIU, W. S. Citric acid modified kenaf core fibres for removal of methylene blue from aqueous solution. Bioresource Technology, v. 102, p. 7237-7243, 2011.

SEBEN, L.; DE PAULA, I. C.; VIANA S. G. Análise do processo de beneficiamento da Palmeira Real da Austrália (palmito em conserva) para determinação das variáveis que influenciam as operações de valorização de seus resíduos. Produto \& Produção, v. 13, p. 7592, 2012.

SHARMA, A.; SHRIVASTAVA, B.; KUHAD, R.C. Reduced toxicity of malachite green decolorized by laccase produced from Ganoderma sp. rckk-02 under solid-state fermentation. 3 Biotech, v. 5, p. 621-631, 2015.

SOCCOL, C.R.; COSTA, E.S.F.; LETTI, L.A.J.; KARP, S.G.; WOICIECHOWSKI, A.L., VANDENBERGHE, L.P.S. Recent developments and innovations in solid-state fermentation. Biotechnology Research and Innovation, v. 1, p. 52-71, 2017.

UBANDO, A.T.; FELIX, C.B.; CHEN, W.H. Biorefineries in circular bioeconomy: A comprehensive review. Bioresource Technology, v. 299, artigo 122585, 2020.

UZAN E.; NOUSIAINEN P.; BALLAND V.; SIPILA J.; PIUMI F.; NAVARRO D.; ASTHER M.; RECORD E.; LOMASCOLO, A. High redox potential laccases from the lignolytic fungi Pycnoporus coccineus and Pycnoporus sanguineus suitable for white biotechnology: from gene cloning to enzyme characterization and applications. Journal of Applied Microbiology, v. 108, p. 2199-2213, 2010

VAN SOEST, P.J.; ROBERTSON, J.B.; LEWIS, B.A.: Methods for dietary fiber, neutral detergent fiber, and nonstarch polysaccharides in relation to animal nutrition. Journal of Dairy Science v. 74, p. 35-83, 1991

VASANTH KUMAR, K.; RAMAMURTHI, V.; SIVANESAN, S. Biosorption of malachite green, a cationic dye onto Pithophora sp., a fresh water algae. Dyes and Pigments, v. 69, p. 102-107, 2006. 
YANG, H.; SUN, H.; ZHANG, S.; WU, B.; PAN, B. Potential of acetylacetone as a mediator for Trametes versicolor laccase in enzymatic transformation of organic pollutants. Environmental Science and Pollution Research, v. 22, p. 10882-10889, 2015a.

YANG J.; YANG X.; LIN Y.; NG T.B.; LIN J.; YE X. Laccase-catalyzed decolorization of malachite green: performance optimization and degradation mechanism. PLoS One, v.10, p. $1-14,2015 b$.

YANTO, D. H. Y. Y.; AULIANA, N.; ANITA, S. H.; WATANABE, T. Decolorization of synthetic textile dyes by laccase from newly isolated Trametes hirsuta EDN084 mediated by violuric acid. The 8th International Symposium for Sustainable Humanosphere. IOP Conf. Series: Earth and Environmental Science v. 374, artigo 012005, 2019

ZENG, S.; QIN, X.; XIA L. Degradation of the herbicide isoproturon by laccase-mediator systems. Biochemical Engineering Journal, v. 199, p. 92-100, 2017. 


\title{
CAPÍTULO 05: PROTEASES E SUAS APLICAÇÕES BIOTECNOLÓGICAS NAS INDÚSTRIAS ALIMENTÍCIAS
}

\section{CAPÍTULO 05: PROTEASAS Y SUS APLICACIONES BIOTECNOLÓGICAS EN LAS INDUSTRIAS ALIMENTARIAS}

\section{CHAPTER 05: PROTEASES AND THEIR BIOTECHNOLOGICAL APPLICATIONS IN THE FOOD INDUSTRIES}

\author{
Maria Clara do Nascimento ${ }^{1}$; Viviane do Nascimento e Silva Alencar ${ }^{2}$; Thiago Pajeú Nascimento ${ }^{3}$; Juanize \\ Matias da Silva Batista ${ }^{4}$ Ana Lúcia Figueiredo Porto ${ }^{5}$
}

DOI: https://doi.org/10.31692/978-65-88970-19-5.63-82

\begin{abstract}
RESUMO
Enzimas são proteínas capazes de acelerar reações químicas e podem ser organizadas em seis classes de acordo com seu sítio ativo. Na Classe 3 estão as proteases, enzimas que atuam na hidrólise de ligações peptídicas e indispensáveis na coagulação, digestão de alimentos e até mesmo o melhoramento de produtos industrializados, como em detergentes, medicamentos e couro por exemplo. Por agir em muitas reações, as proteases se tornam uma grande aliada das indústrias de alimentos que utilizam essas enzimas para otimizarem seus produtos, modificando seu sabor, cor, forma, textura ou até mesmo a funcionalidade nutricional. O objetivo desta revisão é descrever características das proteases e o modo como elas são aplicadas em alguns ramos da indústria de alimentos. No setor de carnes as proteases são frequentemente utilizadas no amaciamento de carnes, sua ação de ocorre na degradação de proteínas presentes em todo o sistema conjuntivo. Autores afirmaram a eficiência de proteases de origem vegetal sobre as miofibrilas e o sarcômero carne de frango e de bacteriana de carne bovina. Para a produção de queijos as proteases são peças fundamentais na etapa de coagulação do leite para que ocorra normalmente o processo de fabricação. Na panificação o uso de proteases é bastante voltado para a degradação do glúten proteína que concede dureza a massa, foi constatado que seu uso aumenta a viscosidade da massa, diminui a dureza, melhora a textura e o sabor do produto. Já na indústria cervejeira as enzimas com atividade proteolítica são utilizadas para deixar o produto menos turvo, ou seja, na clarificação, na maturação do sabor e até mesmo na quantidade de espumas formadas pela bebida. Pesquisadores também testaram o uso de proteases na gradação do glúten presente na cerveja e constataram que a enzima foi capaz de diminuir o teor de glúten. Os dados observados demonstram que as proteases são bastante eficazes quando aplicadas em alimentos, suas propriedades podem agir em vários aspectos do produto levando a inovações, mudanças, melhoramentos e agregação de valores.
\end{abstract}

Palavras-chave: Peptidases, Biotecnologia, Indústrias de alimentos e bebidas.

\section{RESUMEN}

Las enzimas son proteinas capaces de acelerar reacciones químicas, según su acción durante estas reacciones, las enzimas se organizan en seis clases. En la Clase 3 se encuentran las proteasas, enzimas capaces que poseen características que les permiten ser útiles en diversos eventos como la coagulación, digestión de alimentos e incluso la mejora de productos industrializados, como detergentes, medicamentos y cuero por ejemplo. Al actuar en muchas reacciones, las proteasas se convierten en un gran aliado de las industrias alimentarias que utilizan estas enzimas para optimizar sus productos, cambiando su sabor, color, forma, textura o incluso funcionalidad nutricional. Algunos de los principales sectores de la industria alimentaria que utilizan proteasas durante el proceso de fabricación de sus

\footnotetext{
1 Bacharelado em Ciências Biológicas, Universidade Federal Rural de Pernambuco, mclaranaascimento@hotmail.com

${ }^{2}$ Mestra em Ciências da Saúde, Universidade Federal de Pernambuco, viviane.ntosilva@gmail.com

${ }^{3}$ Doutor em Biologia Aplicada a Saúde, Universidade Federal de Pernambuco, thiago_pajeu@ hotmail.com

${ }^{4}$ Doutora em Biociência Animal, Universidade Federal Rural de Pernambuco, juanizematias@ yahoo.com.br

${ }^{5}$ Professora Titular, Universidade Federal Rural de Pernambuco, analuporto@ yahoo.coom.br
} 
productos son los lácteos, carnes, cervezas y en panadería. El propósito de esta revisión es describir las características de las proteasas y cómo se aplican en algunas ramas de la industria alimentaria. En el sector cárnico, las proteasas se utilizan a menudo en el ablandamiento de la carne, su acción se produce en la degradación de las proteínas presentes en todo el sistema conjuntivo. Los autores afirman la eficacia de las proteasas de origen vegetal sobre las miofibrillas y la carne de pollo sarcómera y de las bacterias de la carne bovina. Para la producción de queso, las proteasas son partes esenciales en la etapa de coagulación de la leche para que el proceso de fabricación ocurra normalmente. En horneado, el uso de proteasas está muy enfocado a la degradación de la proteína del gluten que le da a la masa su dureza, se encontró que su uso aumenta la viscosidad de la masa, disminuye la dureza, mejora la textura y sabor del producto. En la industria cervecera se utilizan enzimas con actividad proteolítica para hacer el producto menos turbio, es decir, en la clarificación, en la maduración del sabor e incluso en la cantidad de espumas formadas por la bebida. Los investigadores también probaron el uso de proteasas en la clasificación del gluten presente en la cerveza y encontraron que la enzima podía disminuir el contenido de gluten. Los datos observados demuestran que las proteasas son bastante efectivas cuando se aplican a los alimentos, sus propiedades pueden actuar en varios aspectos del producto dando lugar a innovaciones, cambios, mejoras y agregación de valores.

Palabras Clave: Peptidasas, Biotecnología, Industrias de alimentos y bebidas.

\begin{abstract}
Enzymes are proteins capable of accelerating chemical reactions, according to their action during these reactions, enzymes are organized into six classes. In Class 3 are proteases, capable enzymes that have characteristics that allow them to be useful in various events such as coagulation, food digestion and even the improvement of industrialized products, such as detergents, medicines and leather for example. By acting in many reactions, proteases become a great ally of the food industries that use these enzymes to optimize their products, changing their taste, color, shape, texture or even nutritional functionality. Some of the main sectors of the food industry that use proteases during the manufacturing process of their products are dairy products, meats, beers and in bakery. The purpose of this review is to describe characteristics of proteases and how they are applied in some branches of the food industry. In the meat sector, proteases are often used in meat tenderization, their action occurs in the degradation of proteins present in the entire conjunctive system. Authors affirmed the efficiency of proteases of vegetal origin on the myofibrils and the sarcomere chicken meat and of bacterial of bovine meat. For cheese production, proteases are essential parts in the milk coagulation stage so that the manufacturing process normally occurs. In baking, the use of proteases is very focused on the degradation of the gluten protein that gives the dough its hardness, it was found that its use increases the viscosity of the dough, decreases the hardness, improves the texture and flavor of the product. In the brewing industry, enzymes with proteolytic activity are used to make the product less cloudy, that is, in clarification, in the maturation of the flavor and even in the amount of foams formed by the drink. Researchers also tested the use of proteases in the grading of gluten present in beer and found that the enzyme was able to decrease the gluten content. The observed data demonstrate that proteases are quite effective when applied to foods, their properties can act in several aspects of the product leading to innovations, changes, improvements and aggregation of values.
\end{abstract}

Keywords: Peptidases, Biotechnology, Food and beverage industries.

\title{
INTRODUÇÃO
}

Enzimas são proteínas especializadas cuja função é principalmente a catálise de reações. As enzimas podem ser proteínas específicas, nas quais uma das suas funções é a catálise de reações, portanto, essa propriedade torna as enzimas alvo de diversos estudos para sua aplicação em indústrias de diferentes setores. Dentre as enzimas de maior interesse comercial, as proteases, também chamadas de peptidases ou proteinases que tem como principal função de 
catálise em reações de clivagem de proteínas, atuando nas suas ligações peptídicas e agindo por meio da hidrólise. Essas enzimas no organismo estão envolvidas em vários processos como a digestão de alimentos, ativação de outras enzimas, coagulação sanguínea e também o transporte de proteínas através da membrana. Algumas características das proteases podem as classificálas em diferentes grupos, essas características incluem: sob qual $\mathrm{pH}$ a atividade da protease se expressa melhor, as substâncias presentes em seu sítio ativo, em quais tipos de ligações químicas ou em qual local da ligação irão ocorrer as clivagens realizadas por cada protease. Por estarem presentes em vários eventos biológicos, as proteases podem ser encontradas em inúmeros organismos (KERMASHA \& ESKIN, 2021).

As fontes das proteases podem ser diversas, como, plantas, animais e microrganismos. Em plantas geralmente essas enzimas se encontram no látex e nas sementes dos vegetais. Che et al., (2021) detectou a presença as proteases do tipo endopeptidases aspárticas e serina carboxipeptidases na semente de Sesamum indicum, o gergelim e sua ação na degradação das proteínas presentes na soja, amendoim, leite bovino e até mesmo do próprio gergelim. Em animais podem ser encontradas dentro do seu organismo ou no caso de animais peçonhentos elas estão presentes em suas peçonhas. A víbora Echis pyramidum endêmica no nordeste da África e na Península Arábica possui um veneno que pode desencadear diversas problemáticas na saúde de um indivíduo como, a desregulação na coagulação sanguínea, a formação de edemas e a perda excessiva de sangue que pode levar a morte, todos esses efeitos são potencialmente estimulados devido a presença de proteases no veneno, isso levou El-Yamany e colaboradores (2020) a investigarem a desintoxicação do veneno através da aplicação de raios gama sobre as metaloproteases presentes na peçonha, ao final da pesquisa os autores constataram grande sucesso no uso das metaloproteases produzidas pela víbora como antídoto contra o veneno de Echis pyramidum. A produção de proteases por microrganismos é bem diferente das demais, a produção acontece a partir de biotransformações realizadas durante o bioprocesso. Um estudo recentemente publicado pelos autores Mukhia, Kumar, A. e Kumar, R. (2021) demonstrou que as proteases extracelulares produzidas pela bactéria gram-negativa Chryseobacterium polytrichastri conseguiram hidrolisar as proteínas presentes soja levando a obtenção de peptídeos com grande ação antioxidantes que quando integrados na dieta proporcionam diversos benefícios a saúde além daqueles proporcionados por seus valores nutricionais.

Comparando as três fontes de proteases, a microbiana se torna a mais interessante por ser mais vantajosa por apresentar uma produção rápida, numerosa e de baixo custo (HARISH \& UPPULURI, 2018; RAZZAQ et al., 2019; TAVANO et al., 2018). Essa propriedade 
biológica permitiu que estudiosos utilizassem as peptidases em vários setores industriais como

em fármacos, formulação de detergentes, indústrias de couro, cervejaria e alimentos. $\mathrm{Na}$ indústria alimentícia, as proteases possuem uma gama de utilidades devido a sua capacidade de alterar diversas propriedades dos alimentos como a solubilidade, teor de emulsificação, interações peptídicas, formação de espuma, sabor e textura, logo, por esses motivos as indústrias alimentícias são as maiores consumidoras de enzimas comerciais (GRAND VIEW RESEARCH, 2019; TAVANO et al., 2018).

Portanto, com a expansão do conhecimento sobre as propriedades das proteases ocorre um crescimento no número de estudos sobre suas aplicações em laboratórios visando sua aplicação em escala industrial, gerando diferentes pesquisas nos mais variados setores alimentícios. Dessa forma, o objetivo desta revisão é descrever algumas propriedades das proteases, como ocorre a sua ação nos alimentos em que estão presentes e a discussão de algumas pesquisas correlacionadas ao assunto.

\section{FUNDAMENTAÇÃO TEÓRICA}

\section{Enzimas}

Enzimas são moléculas orgânicas que realizam reações de catalização ocorrendo alteração na velocidade de uma reação química. Elas são essenciais ao funcionamento dos organismos vivos, estão envolvidas em atividades que mantêm o equilíbrio do indivíduo tais como a digestão, produção e gasto de energia, crescimento celular, equilíbrio hormonal e outros. As enzimas são constituídas por proteínas o que as fazem ter uma estrutura rica e complexa, mas mesmo sendo tão completa em alguns momentos as enzimas necessitam do auxílio de outras substâncias para poderem realizar suas ações, essas são conhecidas como coenzimas (componentes químicos) e cofatores (componentes orgânicos). A quantidade de enzimas já descobertas é enorme o que como várias outras substâncias levou a necessidade de uma classificação, apesar de terem em suas estruturas proteínas e aminoácidos as enzimas foram classificadas de acordo com sua ação, o que levou a criação de seis classes de enzimas, sendo elas: Classe 1 (oxidorredutases), Classe 2 (transferases), Classe 3 (hidrolases), Classe 4 (liases), Classe 5 (isomerases) e Classe 6 (ligases). Na nomenclatura das enzimas ocorre muito a ambiguidade pelo fato de enzimas diferentes serem capazes de executar as mesmas ações, isso levou a uma nomenclatura mais detalhada onde a enzima deve ter um número "EC" determinado pela Enzyme Commission, ao total o nome da enzima terá quatro números: o 
número de sua classe, o número de sua subclasse, o número de sua sub-sub-classe e seu número

específico, e ao final a nomenclatura da enzima ficará "EC A.B.C.D” (ENZYME, 2021; NELSON E COX, 2018).

\section{Proteases}

Como supracitado na Classe 3 das enzimas estão as hidrolases (EC 3.b.c.d), seu prefixo "hidro" foi definido por enzimas atuarem através de hidrólise, onde a presença de uma ou mais moléculas de água $\left(\mathrm{H}_{2} \mathrm{O}\right)$ irão desencadear a quebra de outras moléculas. Elas estão presentes em vários eventos biológicos, como por exemplo na produção de glicose, onde durante a glicogênese uma enzima que catalisa a hidrólise de ésteres de fosfato (glicose-6-fosfatase) realiza a desfosforilação da Glicose-6-fosfato convertendo-a em uma molécula de fosfato e outra de glicose (Figura 01) (RODWELL et al., 2021). Por sua vez as hidrolases são separadas em subclasses, a classificação ocorre de acordo sobre qual ligação química sua ação irá ocorrer, essa separação levou a origem de doze subclasses de hidrolases, como pode ser visto na Tabela 01 (ENZYME, 2021).

Figura 01: Mecanismo de ação de uma hidrolase onde ocorre a conversão da Glicose-6-fosfato em moléculas distintas de Fosfato inorgânico e Glicose.

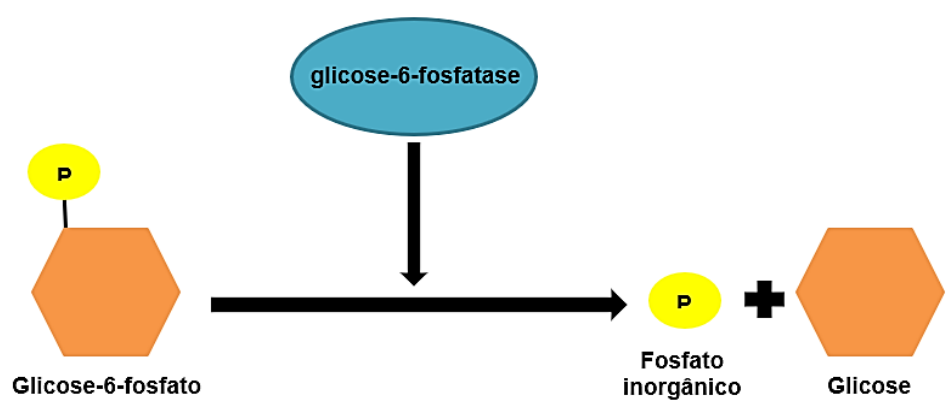

Fonte: Própria (2021). 


\begin{tabular}{cc}
\hline Subclasse & Local de atuação \\
\hline 3.1 & Ligações éster \\
\hline 3.2 & Glicosilases \\
\hline 3.3 & Ligações éter \\
\hline $\mathbf{3 . 4}$ & Ligações peptídicas \\
\hline 3.5 & Ligações carbono-nitrogênio \\
\hline 3.6 & Anidridos ácidos \\
\hline 3.7 & Ligações carbono-carbono \\
\hline 3.8 & Ligações halogenadas \\
\hline 3.9 & Ligações fósforo-nitrogênio \\
\hline 3.10 & Ligações enxofre-nitrogênio \\
\hline 3.11 & Ligações carbono-fósforo \\
\hline 3.12 & Ligações enxofre-enxofre \\
\hline 3.13 & Ligações carbono-enxofre \\
\hline
\end{tabular}

Fonte: Adaptado de Enzyme, apenas para fins ilustrativos (2020).

$\mathrm{Na}$ subclasse 3.4 das hidrolases estão presentes enzimas que atuam sobre ligações peptídicas, dentro desse grupo estão as proteases (EC 3.4.---) enzimas que capazes de hidrolisar as ligações peptídicas entre os aminoácidos presentes nas proteínas (Figura 02a). Essas são subdivididas em dois grandes grupos de acordo com o local de sua ação, quando a quebra da ligação entre os aminoácidos ocorre na extremidade N-terminal (aminopeptidases) ou Cterminal (carboxipeptidases) (Figura 02c) as proteases são classificadas como exopeptidases (EC 3.4.11.- até EC 3.4.19.-), quando a ação ocorre sobre ligações peptídicas internas (Figura 02b) as proteases são denominadas endopeptidases (EC 3.4.21.- até EC 3.4.99.-) (ÂNGELO, 2010). Outra classificação dentro do grupo das proteases é realizada de acordo com as substâncias presentes em seu sítio ativo (local onde ocorre a reação enzimática), levando essa característica em consideração, o banco de dados exclusivo de proteases MEROPS, classifica as proteases entre as famílias: aspártico $(\mathrm{A})$, cisteína $(\mathrm{C})$, glutâmico $(\mathrm{G})$, metalo $(\mathrm{M})$, asparagina (N), misto (P), serina (S), treonina (T) e desconhecido (U) (MEROPS, 2019; MURI, 2014). Além dessas classificações as proteases podem ainda serem divididas de com o seu pH ótimo, onde teremos as proteases ácidas, neutras e alcalinas. 
Figura 02: A - Representação de uma molécula de glúten; B - Hidrólise do glúten realizada por endopeptidases; C - Clivagem do glúten realizada por exopeptidases.
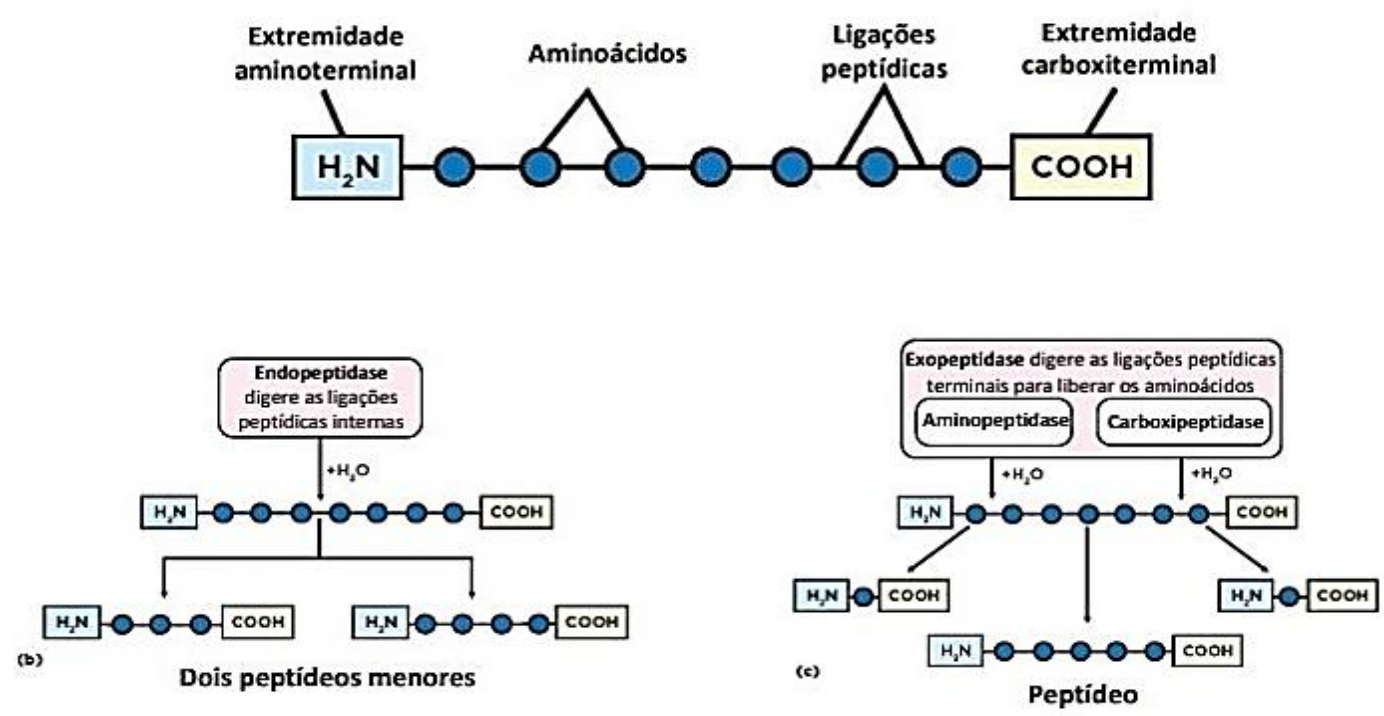

Fonte: Boa fórmula, 2020.

As proteases são enzimas que estão presentes em diversos seres vivos, elas podem ser produzidas por animais, vegetais e até mesmo por microrganismos. Como as proteases estão presentes em vários eventos biológicos, as proteases de origem animal e vegetal geralmente se encontram nos organismos dos indivíduos ou em produtos gerados por eles. Nos animais, podemos encontrar proteases nas peçonhas de serpentes, no corpo de crustáceos e no trato digestivo de peixes (LIU et al., 2019; NEUMANN et al., 2020; OLIVEIRA et al., 2020).

A utilização de animais como fontes de proteases pode sofrer desvantagens caso seja necessário o sacrifício do animal e consequentemente a necessidade do aval de comitês de éticas para obtenção da enzima, porém essa fonte pode ser a solução para o uso de resíduos sólidos gerados por algumas indústrias como o mercado da pesca, já que a estudos demonstram o uso das vísceras de peixes como fonte de proteases (SILVA et al., 2021). Várias proteases já foram encontradas, extraídas e utilizadas a partir do sistema digestivo de animais, entre elas a pepsina, a tripsina e a quimiotripsina (GURUMALLESH et al., 2019).

Em plantas, as proteases geralmente são detectadas em seus "produtos" como as sementes e o látex. Para a extração dessas enzimas em plantas é necessário mão de obra específica para o manejo e também a dependência de fatores ambientais como o clima, umidade, temperatura e sazonalidade temporal o que leva a processos de extração mais longos, trabalhosos e dependentes (MUSIDLAK et al., 2020; SILVA et al., 2020).

Diante dessas características sobre a obtenção de proteases a partir de animais e plantas, os microrganismos demonstram ser a fonte mais econômica e rápida. A produção de compostos 
bioativos, como as proteases, por microrganismos se dá através de processos fermentativos em

que geralmente há apenas a necessidade de um substrato e condições favoráveis ao crescimento do organismo e a produção de biomoléculas, o que pode facilmente ser controlado durante a fermentação. Ao realizar uma breve pesquisa em bancos de dados científicos, foi observado que cientistas já produziram proteases a partir de fungos, bactérias e cianobactérias (ELLEUCH et al., 2021; OSMOLOVSKIY et al., 2021; SHAFIQUE et al., 2021). Alguns organismos produtores de proteases pertencentes as três fontes supracitadas, estão descritas na Tabela 02.

Tabela 02: Organismos já utilizados como fontes de proteases.

\begin{tabular}{|c|c|c|c|}
\hline Fonte & Produtores & Classificação & Referências \\
\hline \multirow{6}{*}{ Microrganismos } & Arthrospira sp. & Cisteíno Protease & ELLEUCH et al., 2021 \\
\hline & Aspergillus sp. & Protease Ácida & $\begin{array}{c}\text { CHIMBEKUJWO, } \\
\text { JA'AFARU \& ADEYEMO, } \\
2021\end{array}$ \\
\hline & Bacillus sp. & Serina protease & YANG et al., 2021 \\
\hline & Penicillium sp. & Protease aspártica & GUO et al., 2021 \\
\hline & Pseudomonas sp. & Serina protease & IQBAL et al., 2018 \\
\hline & Streptomyces sp. & Protease alcalina & $\begin{array}{c}\text { SARKAR \& } \\
\text { SUTHINDHIRAN, } 2020\end{array}$ \\
\hline \multirow{6}{*}{ Animais } & Bothrops sp. & Serina protease & KUNIYOSHI et al., 2019 \\
\hline & Centropomus sp. & $\begin{array}{l}\text { Serina protease e } \\
\text { Metaloprotease }\end{array}$ & LÓPEZ et al, 2021 \\
\hline & Cupiennius sp. & Serina protease & $\begin{array}{l}\text { LANGENEGGER } \text { et al., } \\
2018\end{array}$ \\
\hline & Echis sp. & Metaloprotease & EL-YAMANY et al., 2021 \\
\hline & $\begin{array}{l}\text { Macrobrachium } \\
\text { sp. }\end{array}$ & Exopeptidase & SILVA et al., 2020 \\
\hline & Cichla sp. & Serina protease & OLIVEIRA et al., 2020 \\
\hline \multirow{5}{*}{ Plantas } & Calotropis sp. & Cisteíno protease & SILVA et al., 2020 \\
\hline & Gliricidia sp. & Cisteíno protease & SILVA et al., 2020 \\
\hline & Euphorbia sp. & Serina protease & URS et al., 2021 \\
\hline & Moringa sp. & $\begin{array}{c}\text { Serina e Cisteíno } \\
\text { protease }\end{array}$ & WANG et al., 2020 \\
\hline & Solanum sp. & Protease aspártica & IBAÑNZZ et al., 2021 \\
\hline
\end{tabular}

\section{Aplicações biotecnológicas das proteases}

Devido a suas atividades e propriedades, as proteases ou peptidases, como também podem ser definidas, foram as primeiras enzimas a serem exploradas economicamente. A empresa americana especialista em consultoria e pesquisa de mercado, Grand View Research, publicou um relatório em 2019 no qual estimou-se que o mercado mundial de enzimas atingiu 
a partir de 2020, e com previsão para até 2027 de US\$14,9 bilhões. As enzimas chegam atingir

até $60 \%$ de uso entre as indústrias, são utilizadas nos mais diversos setores, as proteases por sua vez estão presentes nos mais variados ramos industriais, como: na indústrias de alimentos durante o amaciamento de carnes; em indústria farmacêutica no desenvolvimento de medicamentos; na indústria de produtos limpeza como na potencialização de detergentes; na indústria de couros durante de remoção de pelos; no ramo da estética como no procedimento peeling (PATYSHAKULIYEVA, 2021).

O relatório da Grand View Research, que estudou a aplicação de enzimas em vários ramos industriais, também demonstrou que entre tais indústrias, as que mais fazem uso de enzimas são as indústrias bebidas e alimentos (Figura 03).

Figura 03: Gráfico representando a utilização de enzimas por diversas indústrias.

\section{U.S. industrial enzymes market size, by application, 2016 - 2027 (USD Billion)}

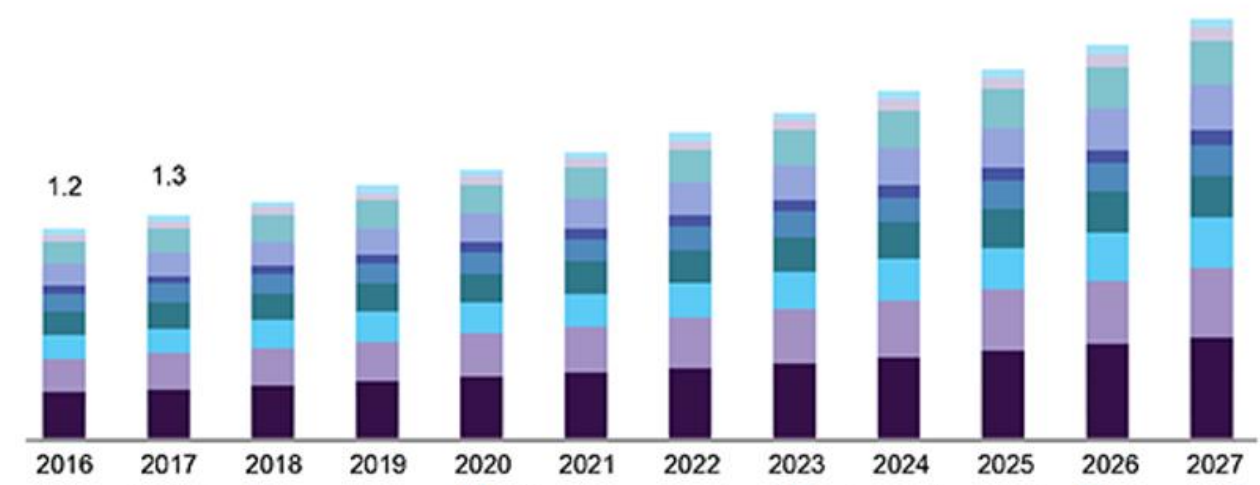

- Alimentos e bebidas Detergentes Alimentação animal Biocombustíveis Têxteis Papel de celulose Nutrição e farmácia cosméticos e cuidados pessoais Esgoto Outros

Fonte: Adaptado de Grand View Research, 2019.

A indústria alimentícia protagoniza uma incessante, e até mesmo necessária, busca por inovações e melhorias em seus produtos. Muitas das soluções biotecnológicas alcançadas, como a melhoria do sabor e aspectos de produtos nos setores de carnes e queijos, envolvem a aplicação de proteases que são utilizadas em diversas funções a fim de melhorar aroma, o sabor, a funcionalidade do produto, a textura e a sua qualidade nutricional. Entre os mais diversos produtos das indústrias alimentícias as proteases são aplicadas em laticínios, bebidas alcoólicas, molhos, sementes, massas, rações animais e outros (SILVA et al., 2017). 
Para a construção dessa revisão descritiva foram realizadas pesquisas nos bancos de dados científicos Scienc Direct e Scielo. Para o desenvolvimento do trabalho foram feitas pesquisas distintas dos descritores: enzymes, enzyme application, proteases, protease application, food industry and food biotechnology. A procura de artigos foi realizada fazendo combinações de descritores, sendo eles: [protease] and [cheese], [protease] and [beef], [protease] and [bread making], [protease and beer] e [protease] and [application] and [food or drink]. As obras publicadas de 2010 a 2021 e que mais se encaixavam com a temática da revisão foram selecionadas e descritas.

\section{RESULTADOS E DISCUSSÃO}

\section{Carnes}

No mercado de carnes a aplicação de proteases se torna comum quando o objetivo é a modificação da textura e sabor da carne, principalmente pelo interesse de agregar valores às peças de carnes que possuem pequenos valores no comércio. A classe das cisteína-proteases é a mais frequentemente utilizadas para o amaciamento de vários tipos de carnes, no sítio ativo dessas proteases estão presentes os aminoácidos cisteína, ácido aspártico e histidina que irão atuar nas extremidades ou no meio interno das ligações peptídicas. As cisteínas de origem vegetal são as mais preferidas, entre elas estão a papaína (EC3.4.22.2), actinidina (EC3.4.22.14), bromelaína (EC3.4.22.32), zingiberina, (EC3.4.22.67) e ficain (EC3.4.22.3) (BOTINESTEAN et al., 2021; CRUZ et al., 2020; GAGAOUA et al., 2020; JUN-HUI et al., 2020; LI et al., 2021; ZHU et al., 2018).

Para que ocorra a modificação na estrutura da carne essas enzimas irão desestruturar, principalmente, as proteínas miofibrilares e as sarcoplasmáticas (GAGAOUA et al., 2020). O uso de proteases vegetais em carne de aves de corte foi o objetivo da pesquisa realizada por Cruz et al. (2019) a fim de determinar a maciez, fragmentação miofibrilar e rendimento póscozimento do peito de frango. As proteases foram extraídas do rizoma de Zingiber officinale Roscoe (gengibre) oriundos da Região Sudeste do Brasil, local também de onde foram obtidos os cortes de peito de frango (espécie não informada). Com o extrato bruto foi realizada a atividade proteolítica da enzima através de método colorimétrico. Para avaliação da ação de degradação da protease uma concentração de $5 \%$ do extrato foi injetada na carne de frango, e 
com isso foram determinados o índice de fragmentação miofibrilar (MFI), o comprimento dos fragmentos miofibrilares (MFL) e o comprimento do sarcômero. A maciez foi avaliada por método de força de cisalhamento mecânico e a perda de peso foi calculada comparando o peso inicial e o final. Como resultados a pesquisa demonstrou, 76.05 de MFI, $4.54 \mu \mathrm{m}$ de MFL e 1.35 de comprimento do sarcômero $(\mu \mathrm{m})$. Isso demonstra que a aplicação de proteases obtidas do gengibre foi capaz de degradar as miofibrilas (Figura 04), o que levou a redução da força de cisalhamento e não houve redução significativa no rendimento do peito de frango após o cozimento.

Figura 04: Fragmentação da miofibrila e redução do MFL.
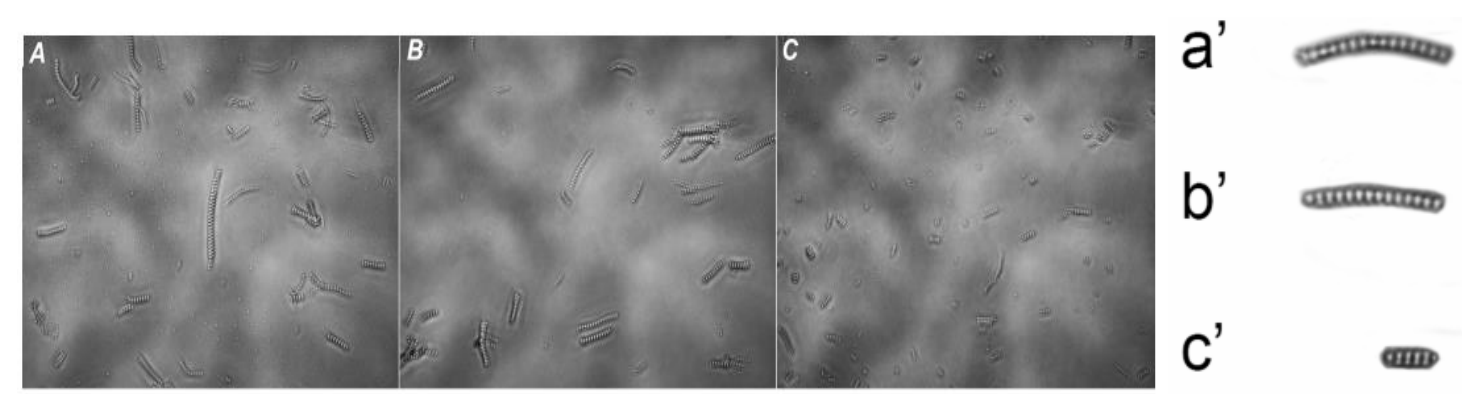

Fonte: Adaptado de Cruz et al. (2019).

Em alguns processos a aplicação de proteases para fins de amaciamento de carnes ocorre sobre uma proteína presente no tecido conjuntivo, o colágeno. Formado por uma tripla hélice de proteínas, o colágeno é uma proteína fibrosa que proporciona sustentação, elasticidade e resistência a várias estruturas, principalmente aos músculos o que caracteriza uma rigidez maior a carne que pode ser desfeita a partir da ação de clivagem de proteases colagenolíticas (EC 3.4.21.-) sobre o colágeno (RODRÍGUEZ et al., 2018). Sorapukdee et al. (2020) realizou um estudo sobre a capacidade de microrganismos proteases com potencial na degradação do colágeno. Na pesquisa os autores realizaram uma triagem sobre a capacidade de 400 espécies de Bacillus sp. produzirem proteases com atividade colagenolítica. Entre essas espécies estudadas apenas 20 foram capazes de produzir protease com atividade colagenolítica acima de 0,5 U/mL. As espécies Bacillus subtilis e B. siamensis foram as escolhidas para terem a capacidade colagenolítica de suas enzimas testadas sobre o tendão de Aquiles, o colágeno intramuscular e a proteína miofibrilar de carne bovina. As metodologias realizadas demonstraram que as proteases colagenolíticas produzidas por B. subtilis e B. siamensis foram capazes de degradar tanto o colágeno como a elastina de todas as estruturas utilizadas, comprovando o sucesso na aplicação de proteases produzidas por essas bactérias no amaciamento de carnes. Oliveira et al., (2016) realizaram um levantamento sobre a presença de 
proteases em várias espécies de peixes, crustáceos, poríferos e equinodermos. As proteases observadas pelos autores eram do tipo metalo e serinocolagenases. As metalocolagenases são capazes de degradar a matriz extracelular do colágeno sendo elas, as colagenases verdadeiras que clivam a tripla hélice do colágeno e as gelatinases hidrolisam os colágenos desnaturados e as gelatinas. Já as serinocolagenases são capazes de degradar os tipos I, II e III da tripla hélice do colágeno. Pelo autor foram citados os gêneros Novoden sp., Pagrus sp., Rhopaloeides sp., Raja sp., Gadus sp., Carcinus sp., Pseudopleuronectes sp., Thunnus sp., Macrobrachium sp., Scomber sp., Chionoecetes sp. Nesses indivíduos e vários outros oriundos do pescado normalmente as proteases são encontradas em suas vísceras digestivas, nos músculos, na cabeça, nas barbatanas, na cauda e vísceras reprodutivas. Os autores também perceberam que no ramo alimentício essas proteases são empregadas na musculatura de peixes auxiliando nas etapas de remoção da pele e extração do colágeno.

\section{Panificação}

No setor de panificação as proteases mais utilizadas são de fonte vegetal e microbiológicas. As ações dessas proteases consistem na degradação, por hidrólise, da proteína glúten, ele está presente em vários grãos e sua finalidade de uso na panificação visa a obtenção de uma massa consistente e viscosamente elástica que proporcione a retenção de ar (DAHIYA et al., 2020). O glúten é constituído pela junção de outras duas proteínas: a glutelina e a gliadina, a rede formada pelas ligações de dissulfeto e caso o número dessas ligações for superior ao ideal ocorre uma dificuldade da manipulação da massa devido à alta rigidez. Uma alternativa para a solução desse problema é o emprego de proteases durante a fermentação da massa, onde as enzimas irão hidrolisar as ligações peptídicas do glúten, dando mais maciez e menos densidade a massa o que facilita seu manuseio e melhora sua aparência (JAYAWARDANA et al., 2021). A liberação dos grupos carboxila (COOH) e amina $\left(\mathrm{NH}_{2}\right)$ pelas hidrólises realizadas nas extremidades $\mathrm{C}$ - e N-terminal acaba agregando ao sabor da massa a partir do momento em que tais compostos irão reagir com açúcar presente no meio, um efeito resultante da Reação de Maillard, onde sob calor os aminoácidos e o açúcar interagem dando cor e sabor a massa (FRANCISQUINI et al., 2017).

Sarabhai et al. (2021) estudou a aplicação de enzimas, entre elas as proteases, sobre as características de pão feito a partir de milho. Os pães foram preparados com Setaria parviflora (milho rabo de raposa), 0,05 e 0,1g / 100g de cada enzima (inclusive proteases) e outros ingredientes. Após assados, os pães foram triturados e liofilizados para serem submetidos a 
estudos de propriedades reológicas, colagem da farinha no pão, as características da massa, textura e outros. Os autores em seus resultados demonstraram que, a adição de proteases diminuiu a viscosidade da massa de $404 \mathrm{~Pa} \cdot \mathrm{s}$ para $154 \mathrm{~Pa} \cdot \mathrm{s}$, o que gerou uma maior elasticidade a massa; a matriz proteica que envolve os grânulos de amido foi degradada pela ação de proteases; o ângulo de fase $(\delta)$ foi diminuído pela protease; a adição de proteases também melhorou a aceitabilidade do produto, seu aroma e sabor. Após o estudo foi concluído que, entre as enzimas protease, glicose oxidase e xilanase as de atividade proteolíticas foram eleitas as melhores para o melhoramento do pão de forma feio com milho rabo de raposa (Figura 05).

Figura 05: Pão de milho rabo de raposa sem glúten com diferentes concentrações de enzimas. A controle, B - glicose oxidase $(0,05 \mathrm{~g} / 100 \mathrm{~g}), \mathrm{C}$ - glicose oxidase $(0,1 \mathrm{~g} / 100 \mathrm{~g}), \mathrm{D}$ - xilanase $(0,05 \mathrm{~g} / 100 \mathrm{~g}), \mathrm{E}$ - xilanase $(0,1 \mathrm{~g} / 100 \mathrm{~g}), \mathrm{F}$ - proteases $(0,05 \mathrm{~g} / 100 \mathrm{~g}), \mathrm{G}$ - protease $(0,1 \mathrm{~g} / 100 \mathrm{~g})$ com base no peso da farinha.

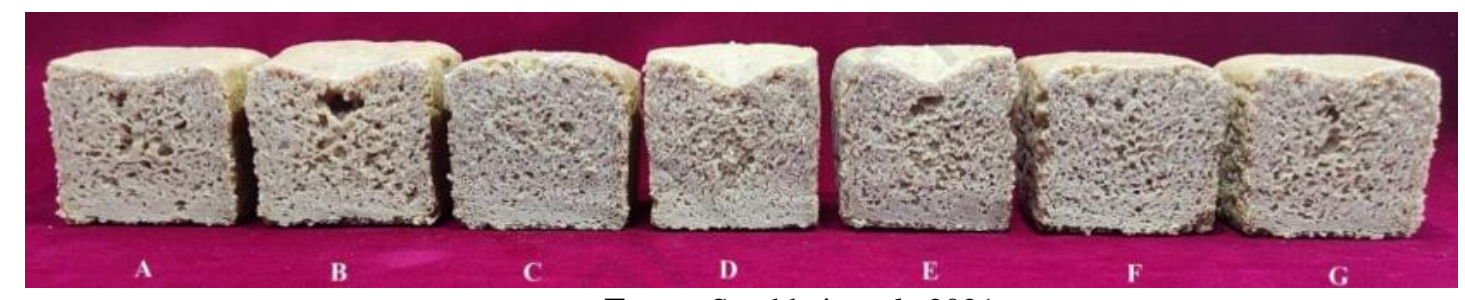

Fonte: Sarabhai et al., 2021.

\section{Laticínios}

No setor de fabricação dos mais variados tipos de queijos a proteases protagonizam alguns eventos do processo como a coagulação e a maturação do queijo. O objetivo da coagulação no processamento de queijos é a concentração do leite e a retenção de gorduras, frequentemente para esses processos é utilizado um composto denominado coalho, que tem como componentes as proteases, quimosina e pepsina (ARBITA et al., 2020).

Antigamente conhecida como "renina (EC 3.4.4.3.)" a quimosina (EC 3.4.23.4) pode ser extraída da secreção estomacal de ovinos, plantas ou microrganismos. Assim que extraída a quimosina encontra-se em seu estado inativo (quando em $\mathrm{pH}$ neutro) e posteriormente (em meio ácido) se transforma na quimosina que tem atividade proteolítica ativa. A quimosina age no processo de coagulação do leite, sua ação é sobre a caseína desestabilizando suas micelas a fim de romper a $\kappa$-caseína, mais precisamente onde estão os aminoácidos fenilalanina o metionina (Figura 06). A pepsina, por sua vez, possui uma atividade menos específica, clivando qualquer ligação que apresente resíduos de valina, fenilalanina, leucina ou tirosina. Após a coagulação existem várias outras etapas no processo de fabricação do queijo, uma delas é a etapa de maturação onde ocorre várias reações químicas sobre o coágulo, entre elas a proteólise, 

ALURU \& SUKUMARAN, 2021).

Figura 06: Ação das proteases sobre a caseína para coagular o leite durante a fabricação de queijos.

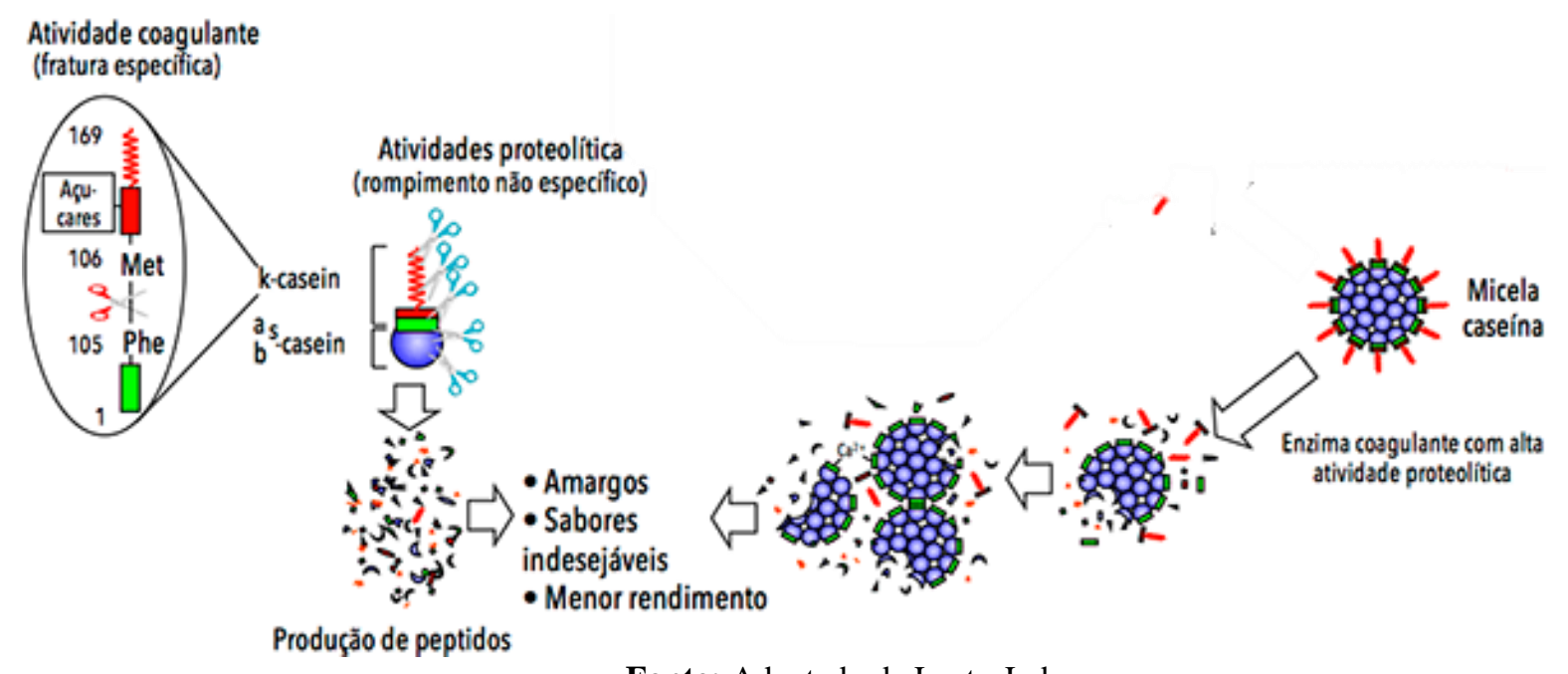

Fonte: Adaptado de Lacto-Lab.

Paludetti et al. (2020) avaliou os efeitos da aplicação de proteases fúngicas na produção de queijo do tipo cheddar. No leite foram adicionadas respectivas quantidades de 0,15 e 0,60 U/L de proteases produzida por Pseudomonas fluorescens. Após $48 \mathrm{~h}$ de armazenamento do leite a $4^{\circ} \mathrm{C}$ o queijo foi fabricado. Foi constatada alta atividade proteásica durante todo o processo de armazenamento, porém durante a fabricação do queijo a atividade diminuiu, o que pode ter sido influenciado pela diferença de $\mathrm{pH}$ entre os dois processos. A enzima degradou duas proteínas a $\beta$-caseína e a $\kappa$-caseína, porém não foram afetados o rendimento do queijo e a recuperação de gordura e proteínas. Comparados com o queijo controle (sem adição de proteases), os queijos com ambas as concentrações supracitadas demonstraram altos níveis de aminoácidos livres. Com isso, a pesquisa comprovou que as proteases podem modificar os aspectos do queijo e também podem aumentar seus valores nutricionais.

\section{Cervejas}

A produção de cervejas data aproximadamente 2100 a.C, acredita-se que a produção da bebida foi um acidente, mas que deixava o povo Sumério feliz. Ao passar de geração em geração e entre várias etnias, a cerveja hoje é uma das bebidas mais consumidas no mundo (SILVA \& PINHEIRO, 2018). O processo de cerveja inclui cerca de doze etapas no qual durante um deles ocorre a aplicação de proteases, na maturação. Logo após a etapa de 
fermentação ocorre a maturação, a etapa visa o armazenamento do produto sob baixas temperaturas. É um momento que pode demorar dias ou semanas dependendo do tipo de cerveja, visando a clarificação e a maturação do sabor. A presença de um grande quantitativo de leveduras faz com que o líquido fique muito turvo. Só uma filtração não é o suficiente para a diminuição da turbidez, e a partir disso são aplicadas as proteases. As enzimas com atividade proteolítica irão na hidrólise de peptídeos impedindo que eles se insolubilizem e formem a turvação (PIMENTA et al., 2020). Apesar de ser uma das bebidas mais consumidas no mundo, algumas pessoas evitam consumi-las devido ao seu teor de glúten. Assim como na panificação na indústria cervejeira, as proteases também podem ser aplicadas com o intuito de degradação do glúten (ROTOLO, 2019). Benucci et al. (2019) testou o uso da prolil endopeptidase de origem microbiana na redução do teor de glúten de cervejas. Proteases produzidas pelo fungo filamentoso Aspergillus niger foram imobilizadas em grânulos a quitosana e adicionadas a cerveja com malte de cevada. A imobilização aumentou a estabilidade térmica da protease, a quantidade de $728 \mathrm{~mL} / \mathrm{min}$ foi o suficiente para diminuir o teor de glúten de $65 \mathrm{mg} / \mathrm{kg}$ para 19 $\mathrm{mg} / \mathrm{kg}$ após 9 horas de vazão e para $15 \mathrm{mg} / \mathrm{kg}$ após 10h de tratamento. Demonstrando assim o sucesso da aplicação de proteases também na redução da quantidade de glúten na cerveja.

\section{CONCLUSÕES}

De fato, é notório o tão quanto a ação de clivagem através de hidrólise faz das proteases as enzimas mais exploradas comercialmente. Entre os inúmeros setores industriais existentes, os setores de bebidas e alimentos são os que mais utilizam essas enzimas durante seus processos de fabricação, e essa posição não só segue a mesma durante os últimos cinco anos como está prevista para seguir intacta nos próximos seis anos. Buscando a melhoria de seus produtos, as indústrias de carnes utilizam as proteases principalmente no seu amaciamento o que consequentemente leva a mudanças do aspecto, sabor e na consistência das carnes, sendo essas mudanças cobiçadas a agregar valores a certos tipos de carnes que geralmente não são tão valorizadas devido a suas características. Sem as proteases os processos de fabricação de laticínios seriam incompletos já que as etapas de coagulação e a maturação do queijo, por exemplo, é totalmente depende da ação de determinadas enzimas proteolíticas. Mas também, o setor de laticínios faz uso das proteases afim de aumentar os valores nutricionais de seus produtos. As industriais de panificação e cervejas utilizam as proteases com um foco comum, a diminuição ou até mesmo zerar a quantidade da proteína glúten nos produtos, visto que tal proteína pode causar algumas problemáticas a saúde humana como o excesso de peso e males 
ao intestino delgado. Todas essas aplicações biotecnológicas das proteases ressaltam ainda mais

o seu recorrente uso industrial visando a produção e melhoramento de bebidas e alimentos, confirmando também a importância das inúmeras pesquisas científicas que comprovam as ações biotecnológicas das proteases e claro a necessidade de mais pesquisas descrevendo novas fontes de peptidases, suas características e seus potenciais nos mais variados setores industriais.

\section{REFER̂̂ENCIAS}

ARBITA, A. A. et al. Extraction, partial purification and characterization of proteases from the red seaweed Gracilaria edulis with similar cleavage sites on $\kappa$-casein as calf rennet. Food chemistry, v. 330, p. 127324, 2020.

ALUDETTI, L. F. et al. Effect of Pseudomonas fluorescens proteases on the quality of Cheddar cheese. Journal of Dairy Science, v. 103, n. 9, p. 7865-7878, 2020.

AQUINO, C. M. Efeito das enzimas naturais e artificiais no amaciamento da carne ovina. 2017. 111 f. Dissertação (Mestrado em Tecnologia de Alimentos) - Instituto Federal de Educação, Ciência e Tecnologia do Ceará, Limoeiro do Norte.

BENUCCI, I. et al. Prolyl endopeptidase from Aspergillus niger immobilized on a food-grade carrier for the production of gluten-reduced beer. Food Control, v. 110, p. 106987, 2020.

BOTINESTEAN, C. et al. The influence of the interaction of sous-vide cooking time and papain concentration on tenderness and technological characteristics of meat products. Meat Science, p. 108491, 2021.

CHEN, Y. et al. Sesame water-soluble proteins fraction contains endopeptidases and exopeptidases with high activity: a natural source for plant proteases. Food Chemistry, p. 129519, 2021.

CHIMBEKUJWO, K. I; JA'AFARU, M. I.; ADEYEMO, O. M. Purification, characterization and optimization conditions of protease produced by Aspergillus brasiliensis strain BCW2. Scientific African, v. 8, p. e00398, 2020.

CRUZ, P. L. et al. Effect of proteases from ginger rhizome on the fragmentation of myofibrils and tenderness of chicken breast. LWT, v. 120, p. 108921, 2020.

DA SILVA, R. R. Bacterial and fungal proteolytic enzymes: production, catalysis and potential applications. Applied Biochemistry and Biotechnology, v. 183, n. 1, p. 1-19, 2017.

DAHIYA, S. et al. A review on biotechnological potential of multifarious enzymes in bread making. Process Biochemistry, 2020.

ELLEUCH, J. et al. Extracellular neutral protease from Arthrospira platensis: Production, optimization and partial characterization. International Journal of Biological Macromolecules, v. 167, p. 1491-1498, 2021. 
EL-YAMANY, M. F. et al. Gamma irradiated protease from Echis pyramidum venom: A promising immunogen to improve viper bites treatment. Toxicon, v. 188, p. 108-116, 2020.

ENZYME. Search by enzyme class. Disponível em: (https://enzyme.expasy.org/cgibin/enzyme/enzyme-search-cl?2). Acesso em 20 mar. 2021.

FRANCISQUINI, J. A. et al. Reação de maillard: uma revisão. Revista do Instituto de Laticínios Cândido Tostes, v. 72, n. 1, p. 48-57, 2017.

GAGAOUA, M. et al. Artificial meat tenderization using plant cysteine proteases. Current Opinion in Food Science, 2020.

GRAND VIEW RESEARCH. Enzymes Market Size, Share \& Trends Analysis Report By Application (Industrial Enzymes, Specialty Enzymes), By Product (Carbohydrase, Proteases, Lipases), By Source, By Region, And Segment Forecasts, 2020 - 2027. 2019. Disponível em: https://www.grandviewresearch.com/industry-analysis/enzymes-industry. Acesso em 21 mar. 2021.

GUO, Y. et al. Characterization of an intracellular aspartic protease (PsAPA) from Penicillium sp. XT7 and its application in collagen extraction. Food Chemistry, v. 345, p. 128834, 2021

HOSPITAL ISRAELITA ALBERT EINSTEIN. Intolerância à lactose: cuidados com a alimentação. Disponível em: https://vidasaudavel.einstein.br/intolerancia-a-lactose-cuidadoscom-a-alimentacao/. Acesso: 23 mar 2021.

IBAÑEZ, I. L. et al. In vivo tumor growth inhibition by Solanum tuberosum aspartic protease 3 (StAP3) treatment. Bioorganic \& Medicinal Chemistry Letters, p. 127959, 2021.

IQBAL, A. et al. Partial purification and characterization of serine protease produced through fermentation of organic municipal solid wastes by Serratia marcescens A3 and Pseudomonas putida A2. Journal of Genetic Engineering and Biotechnology, v. 16, n. 1, p. 29-37, 2018.

JAYAWARDANA, I.A. et al. The kiwifruit enzyme actinidin enhances the hydrolysis of gluten proteins during simulated gastrointestinal digestion. Food Chemistry, v. 341, p. 128239, 2021.

JUN-HUI, X. et al. The mechanistic effect of bromelain and papain on tenderization in jumbo squid (Dosidicus gigas) muscle. Food Research International, v. 131, p. 108991, 2020.

KERMASHA, S.; ESKIN, M. N. Enzymes. In: KERMASHA, S.; ESKIN, M. N. Enzymes Novel Biotechnological Approaches for the Food Industry. 1 ed. Cambridge: Academic Press, 2021. cap 2, 2021, páginas 15-44.

KUNIYOSHI, A. K. et al. Experimental antivenom against serine proteases from the Bothrops jararaca venom obtained in mice, and its comparison with the antibothropic serum from the Butantan Institute. Toxicon, v. 169, p. 59-67, 2019.

LACTO-LAB. Coagulante Liquido Ultra. Disponível em: http://www.lactolab.com/coagulante-liquido-ultra.html. Acesso em 23 mar. 2021. 
LANGENEGGER, N. et al. Identification of a precursor processing protease from the spider Cupiennius salei essential for venom neurotoxin maturation. Journal of Biological Chemistry, v. 293, n. 6, p. 2079-2090, 2018.

LI, D. et al. Effects of ficin, high pressure and their combination on quality attributes of postrigor tan mutton. LWT, v. 137, p. 110407, 2021.

LIU, H. et al. Functional characterization of two clip-domain serine proteases in the swimming crab Portunus trituberculatus. Fish \& shellfish immunology, v. 89, p. 98-107, 2019.

LÓPEZ, I. A. H. et al. Characterization of digestive enzymes during early ontogeny of white Snook (Centropomus viridis). Aquaculture, v. 535, p. 736399, 2021.

MEROPS. Families of Proteolytic Enzymes. Disponível em: https://www.ebi.ac.uk/merops/cgi-bin/family_index?type=P. Acesso em 20 mar. 2021.

MUKHIA, S.; KUMAR, A.; KUMAR, R. Generation of antioxidant peptides from soy protein isolate through psychrotrophic Chryseobacterium sp. derived alkaline broad temperature active protease. LWT, v. 143, p. 111152, 2021.

MUSIDLAK, O. Plant latex proteins and their functions. In: NAWROT, R. Advances in Botanical Research.: Látex, laticíferos e seus componentes moleculares de funções a possíveis aplicativos. Vol. 93. Amsterdã: Elsevier, 2020. Cap. 3, pag. 55-97.

MURI, E. M. F. Proteases virais: importantes alvos terapêuticos de compostos peptideomiméticos. Química Nova, v. 37, n. 2, p. 308-316, 2014.E

NELSON, D. L.; COX, M. M. Princípios de Bioquímica de Lehninger. 7ed. Artmed Editora, 2018.

NEUMANN, C. et al. Development of a generic high-throughput screening assay for profiling snake venom protease activity after high-resolution chromatographic fractionation. Toxicon, $\mathrm{v}$. 178, p. 61-68, 2020.

OLIVEIRA, V. et al. Colagenases do pescado e suas aplicações industriais. Pubvet, v. 11, p. 207-312, 2016.

OLIVEIRA, V. M. et al. Separation and partial purification of collagenolytic protease from peacock bass (Cichla ocellaris) using different protocol: Precipitation and partitioning approaches. Biocatalysis and Agricultural Biotechnology, v. 24, p. 101509, 2020.

OSMOLOVSKIY, A. A. et al. Vermiculite as a new carrier for extracellular protease production by Aspergillus spp. under solid-state fermentation. Biotechnology Reports, v. 29, p. e00576, 2021.

PATYSHAKULIYEVA. Fungal Proteases: Current and Potential Industrial Applications. Reference Module in Life Sciences. 2021.

PIMENTA, L. B. et al. A história e o processo da produção da cerveja: uma revisão. Cadernos de Ciência \& Tecnologia, v. 37, n. 3, p. 26715, 2020. 
RAJAGOPALAN, A.; ALURU, V.; SUKUMARAN, B. O. Characterisation of hydrolysate for identifying initial peptide cleavage site of $\kappa$-casein by milk coagulating Wrightia tinctoria serine proteases. International Dairy Journal, v. 115, p. 104934, 2021.

RODRÍGUEZ, M. I. A.; RODRIGUEZ, L. G. B.; SÁNCHEZ, M. L. Collagen: A review on its sources and potential cosmetic applications. Journal of Cosmetic Dermatology, v. 17, n. 1, p. 20-26, 2018.

RODWELL, V. W. et al. Bioquímica Ilustrada de Harper-31. McGraw Hill Brasil, 2021.

ROTOLO, T. Cultura cervejeira: breve história da cerveja artesanal no Brasil. Revista Ingesta, v. 1, n. 2, p. 141-142, 2019.

SAINTBIER. A história da cerveja. Disponível em: http://www.saintbier.com/historiacerveja. Acesso em 24 mar. 2021.

SARABHAI, S.; TAMILSELVAN, T.; PRABHASANKAR, P. Role of enzymes to improve gluten-free foxtail corn bread: It has an effect on the properties of quality, texture, rheology and collage. LWT, v. 137, p. 110365, 2021.

SARKAR, G.; SUTHINDHIRAN, K. Extraction and characterization of alkaline protease from Streptomyces sp. GS-1 and its application as dehairing agent. Biocatalysis and Agricultural Biotechnology, v. 25, p. 101590, 2020.

SHAFIQUE, T. et al. Screening, selection and development of Bacillus subtilis apr-IBL04 for hyper production of macromolecule alkaline protease. Saudi Journal of Biological Sciences, v. 28, n. 2, p. 1494-1501, 2021.

SILVA, A. V. et al. Partial purification of fibrinolytic and fibrinogenolytic protease from Gliricidia sepium seeds by aqueous two-phase system. Biocatalysis and Agricultural Biotechnology, v. 27, p. 101669, 2020.

SILVA, J. C. et al. Extraction of collagenolytic enzyme from fish viscera by phase partitioning (PEG/citrate) and its potential for industrial application. Boletim do Instituto de Pesca, v. 46, n. 4, 2021.

SILVA, L. H.; PINHEIRO, B. C. S. Produções científicas do antigo Egito: um diálogo sobre Química, cerveja, negritude e outras coisas mais. Revista Debates em Ensino de Química, v. 4, n. 1, p. 5-28, 2018.

SILVA, M. A. et al. Digestive enzymes profile of the midgut gland of juvenile painted river prawn (Macrobrachium carcinus). Aquaculture Reports, v. 18, p. 100507, 2020.

SILVA, M. Z. R. et al. Biotechnological potential of a cysteine protease (CpCP3) from Calotropis procera latex for cheesemaking. Food chemistry, v. 307, p. 125574, 2020.

SORAPUKDEE, S. et al. Collagenolytic proteases from Bacillus subtilis B13 and B. siamensis S6 and their specificity toward collagen with low hydrolysis of myofibrils. LWT, v. 126, p. 109307, 2020. 
URS, A. P. et al. Thrombin-like serine protease, antiquorin from Euphorbia antiquorum latex induces platelet aggregation via PAR1-Akt/p38 signaling axis. Biochimica et Biophysica Acta (BBA)-Molecular Cell Research, v. 1868, n. 3, p. 118925, 2021.

VIA FARMA. Literatura técnica: Zoomzyme Glu10 blend de enzimas para o glúten. Disponível em: https://viafarmanet.com.br/zoomzyme/\#: :text=Zoomzyme\%20Glu10\%C2\%AE\%20\%C3\%A 9\%20uma,\%C3\%A0s\%20existentes\%20hoje\%20no\%20mercado. Acesso em 22 mar 2021.

YANG, X. et al. Assessment of the production of Bacillus cereus protease and its effect on the quality of ultra-high temperature-sterilized whole milk. Journal of Dairy Science, 2021.

ZHU, X. et al. Actinidin pretreatment and sous vide cooking of beef brisket: Effects on meat microstructure, texture and in vitro protein digestibility. Meat science 2018, 145: 256-65.

WANG, X. et al. Comparative proteome analysis of matured dry and germinating Moringa oleifera seeds provides insights into protease activity during germination. Food Research International, v. 136, p. 109332, 2020. 


\author{
CAPÍTULO 06: USO DE POLÍMERO HIDRORRETENTOR AZOSPIRILLUM \\ BRASILIENSE EN LA PRODUCCIÓN DE MAÍZ SAFRINHA EN TANGARÁ DA \\ SERRA-MT
}

\author{
CHAPTER 06: USE OF POLYMER WATERRETENTAND AZOSPIRILLUM \\ BRASILIENSE IN THE PRODUCTION OF SAFRINHA CORN IN TANGARÁ DA \\ SERRA-MT
} Tulio Martinez-Santos ${ }^{1}$; João Felipe Barbosa da Silva ${ }^{2}$; Adrielle da Conceição Dias; ${ }^{3}$ Ilio
Fealho de Carvalho ${ }^{4}$ :Roberto Antonio Savelli Martinez ${ }^{5}$

DOI: $\underline{\text { https://doi.org/10.31692/978-65-88970-19-5.83-97 }}$

\begin{abstract}
RESUMO
A utilização de técnicas visa a diminuição de custos associados a adubação e de danos associados ao déficit hídrico no milho safrinha na região central do Brasil, vem ganhando importância cada vez maior no cenário da produção atual, visto a irregularidade frequente de chuvas nesse período e do valor de fertilizantes, assim como o valor agregado que o milho adquiriu. Nesse sentido, o presente estudo teve como objetivo, avaliar a influência do uso de hidrogel e da inoculação da bactéria Azospirillum brasiliense na cultura do milho na região de Tangará da Serra- MT. O presente estudo foi realizado em delineamento com blocos casualizados, com quatro tratamentos e cinco repetições, totalizando 20 parcelas experimentais sendo: T1 - testemunha (condições normais de plantio); T2 - Azospirillum + Hidrogel; T3 - Azospirillum + condições normais de plantio; T4 - Hidrogel + condições normais de plantio. As avaliações das características agronômicas foram realizadas nas áreas uteis de cada parcela, sendo aferida a altura de planta, comprimento da espiga, peso de mil grãos, rendimento de grãos e acamamento. Foi observado que a utilização do Azospirillum e hidrogel, combinadas ou individualmente obtiveram resultados satisfatórios na altura de planta e rendimento dos grãos, na cultura do milho. Os dados foram submetidos à análise de variância através do teste $\mathrm{F}$ e as diferenças significativas dos dados foram submetidas ao teste de Scott-Knott para verificar a diferença entre as medias das cultivares estudadas. Foi possível concluir que a utilização do Azospirillum e hidrogel, combinadas ou individualmente alteraram significativamente a altura de planta e rendimento dos grãos, na cultura do milho.
\end{abstract}

Palavras-Chave: Hidrogel, Bactérias inoculantes, Zea mays.

\title{
RESUMEN
}

El uso de técnicas destinadas a reducir los costos asociados a la fertilización y los daños asociados al déficit hídrico en el maíz safrinha en la región central de Brasil está adquiriendo una importancia creciente en el escenario productivo actual, dada la frecuente irregularidad de las lluvias en este período y el valor de los fertilizantes, así como el valor agregado que está adquiriendo el maíz. En este sentido, el presente estudio tuvo como objetivo evaluar la influencia del uso del hidrogel y la inoculación de la bacteria Azospirillum brasiliense en el cultivo de maíz en la región de Tangará da Serra- MT. Este estudio se llevó a cabo en un diseño de bloques al azar, con cuatro tratamientos y cinco repeticiones, con un total de 20 parcelas experimentales: T1 - control (condiciones normales de plantación); T2 Azospirillum + Hidrogel; T3 - Azospirillum + condiciones normales de plantación; T4 - Hidrogel + condiciones normales de plantación. Las evaluaciones de las características agronómicas se realizaron en las zonas útiles de cada parcela, midiéndose la altura de la planta, la longitud de la mazorca, el peso de los mil granos, el rendimiento del grano y el encamado. Se observó que el uso de Azospirillum e hidrogel, combinados o individualmente obtuvieron resultados satisfactorios en la altura de la planta y el rendimiento del grano, en el cultivo del maíz. Los datos se sometieron a un análisis de la varianza mediante la prueba F y las diferencias significativas de los datos se sometieron a la prueba de Scott- 
Knott para verificar la diferencia entre las medias de los cultivares estudiados. Se pudo concluir que el uso de Azospirillum e hidrogel, combinados o individualmente, alteraron significativamente la altura de la planta y el rendimiento del grano, en el cultivo de maíz.

Palabras Clave: Hidrogel, Bacterias inoculantes, Zea mays.

\begin{abstract}
The use of techniques aimed at reducing costs associated with fertilization and damage associated with water deficit in safrinha corn in the central region of Brazil is gaining increasing importance in the current production scenario, given the frequent irregularity of rainfall in this period and the value of fertilizers, as well as the added value that corn is gaining. In this sense, the present study aimed to evaluate the influence of the use of hydrogel and inoculation of Azospirillum brasiliense bacteria in corn culture in the region of Tangará da Serra- MT. This study was conducted in randomized block design, with four treatments and five repetitions, totaling 20 experimental plots, being: $\mathrm{T} 1$ - control (normal planting conditions); T2 - Azospirillum + Hydrogel; T3 - Azospirillum + normal planting conditions; T4 - Hydrogel + normal planting conditions. Evaluations of agronomic characteristics were performed in the usable areas of each plot, measuring plant height, ear length, thousand-grain weight, grain yield and lodging. It was observed that the use of Azospirillum and hydrogel, combined or individually, obtained satisfactory results in plant height and grain yield, in corn culture. The data were submitted to variance analysis through $\mathrm{F}$ test and the significant differences of the data were submitted to Scott-Knott test to verify the difference between the means of the studied cultivars. It was possible to conclude that the use of Azospirillum and hydrogel, combined or individually, significantly altered the plant height and grain yield, in corn culture.
\end{abstract}

Keywords: Hydrogel, Inoculating bacteria, Zea mays.

\title{
INTRODUÇÃO
}

A safra brasileira 2018/2019 de milho, alcançou mais de 100 milhões de toneladas de produção e produtividade média de $5,7 \mathrm{t} \mathrm{ha}^{-1}$ do grão, com projeção de 200 milhões de toneladas para a safra 20/21 (CONAB,2019). Segundo o levantamento realizado pelo USDA (United States Department of Agriculture), os três maiores produtores mundiais de milho são Estados Unidos, China e Brasil respectivamente, tendo o país norte americano colhido na última safra cerca de 364,3 milhões de toneladas (FIESP, 2019).

Mais de $90 \%$ do milho produzido no estado de Mato Grosso, maior produtor brasileiro do grão, é cultivado em segunda safra, ou seja, entre os meses de fevereiro e julho. Se a semeadura não é realizada logo nos primeiros meses do ano, o desenvolvimento da cultura pode ser comprometido devido a ocorrência de veranicos, principalmente em estágios críticos entre o $3^{\circ}$ e o $5^{\circ}$ estádio vegetativo e durante o florescimento até o enchimento de grãos (DALLACORT et al., 2011; BARBIERI et al., 2015).

Dentre os estresses abióticos que ocorrem na cultura, o déficit hídrico é o evento de maior relevância (SIONIT e KRAMER, 1977). A falta de agua além de interferir diretamente no processo de geração de energia, causa a abscisão das flores, impede a antese, afeta a massa de grãos e consequentemente a produção (FAGERIA et al., 2014; JÚNIOR el al., 2018; DA SILVA et al;. 2021). Como alternativas para amenizar esse déficit e principalmente a 
irregularidade da distribuição de água, moléculas hidrotentoras estão sendo estudadas desde a década de 70 (SAMPAT, 1973; KRAISIG et al., 2018).

Com a evolução de alguns trabalhos, foi possível verificar efeitos benéficos desses produtos principalmente em solos com textura média e ou arenosos, visto que em solos argilosos, pode ocorrer a obstrução de poros diminuindo a porosidade total para até $10 \%$ (SAAD et al., 2009 NARJARY et al. 2012).

Custos com adubação principalmente de nitrogênio na cultura do milho, sofrem muita alteração ao decorrer dos anos, principalmente em função da cotação do dólar, podendo encarecer muito os custos de produção (SOUZA et al., 2012). Visando principalmente diminuir custos e possivelmente perdas de N por lixiviação e ou volatilização, a utilização de bactérias promotoras de crescimento de plantas (BPCP) vem sendo estudadas (HUNGRIA, 2011; DUARTE et al., 2020).

Dentro desse complexo de bactérias, as do gênero Azospirillum, são conhecidas por estimular o crescimento das plantas e interagir de forma benéfica na rizosfera das plantas e por consequência podendo garantir maior absorção de nutrientes e também possível resistência a estresse hídrico (BASHAN et al., 2006; QUADROS et al., 2014).

Nesse sentido, o presente estudo teve como objetivo avaliar a influência do uso de hidrogel e da inoculação da bactéria Azospirillum brasiliense na cultura do milho na região de Tangará da Serra- MT.

\section{FUNDAMENTAÇÃO TEÓRICA}

Para a realização de atividades metabólicas é crucial que nutrientes e água estejam disponíveis (FAGERIA et al., 2014), a água é considerada um fator limitante e que influencia diretamente nas atividades e no desenvolvimento. As plantas respondem ao défit hídrico com o intuito de resistir ao estresse, todavia estas ações afetam no crescimento e produtividade (JÚNIOR et al., 2018).A planta de milho é sensivel a deficiencia hídrica, sendo o florescimento o estádio mais sensível, reduzindo a fertilidade da planta e dessa forma reduzindo a produção (AMARAL et al., 2016).

Como existem regiões que passam por períodos de estiagem a utilização do biopolimero pode ser uma possibilidade de reduzir os efeitos do período mais crítico, colaborando para manter umidade no solo, pois os biopolimeros são eficazes na retenção de água (KRAISIG et al., 2018). 
O hidrogél é um produto que tem a capacidade de reter água e de proporcionar a planta,

o solo também é um beneficiado com a possibilidade de elevar a capacidade de armazenamento de água no solo (AZEVEDO et al., 2002). O polímero tem a capacidade de reter água contribui para a redução da frequência de irrigação. Dessa forma, os polímeros hidrorretentores atuam como opção para disponibilidade de água quando há situações de estiagem ou déficit hrídrico (MENDONÇA et al., 2013).

De acordo com Coelho et al. (2017), sementes inoculadas com Azospirillum podem ter resultados de varios fatores que favorecem o desenvolvimento das plantas, como a influencia no sistema radicular, a bactéria também pode contribuir na produção de hormônios e substancias que regulam o crescimento da planta. Quadros et al. (2014) ressalta que a bactéria proporciona melhoria no solo quanto a disponibilidade de nitrogênio e maior rendimento de matéria seca da parte aérea da planta, mas para que tenha sua atividade realizada depende de fatores ambientais e propriedades do solo.

Considerando que um dos limitantes para a produção do milho, está correlacionado a fatores nutricionais em especial ao manejo da adubação nitrogenada, estratégias como a utilização de microrganismos como os do genero Azospirillum que em uma relação benéfica com as plantas promevem o crescimento dessas, estudos vem sendo realizados para avaliar a sua eficácia tanto de maneira isolada, como de forma associada com outros produtos disponíveis no mercado, visando aumentar o potencial produtivo das plantas. (DARTORA et al., 2013; REPEK et al.,2013)

\section{METODOLOGIA}

O presente estudo foi conduzido no município de Tangará da Serra - MT, latitude $-14^{\circ}$ 37' 40”, longitude $-57^{\circ} 30^{\prime} 25^{\prime \prime}$ com altitude de 440m (INMET, 2018), entre os meses de março a junho de 2019. De acordo com Alvares et al., (2013), na classificação de koppen, o estado de Mato Grosso caracteriza-se por dois tipos climáticos: regiões ao norte do estado identificado com Am (clima tropical úmido ou sub úmido) e a região central do estado (Pantanal MatoGrossense) caracterizada com Aw (clima tropical, com inverno seco). O solo da área de estudo é caracterizado como Latossolo Vermelho distrófico

O experimento foi regido por delineamento em blocos casualizados com quatro tratamentos e cinco repetições, totalizando 20 parcelas experimentais, sendo T1: Testemunha (condições normais de plantio) T2 :Azospirillum + Hidrogel; T3: Azospirillum + Condições normais de semenadura T4: Hidrogel + Condições normais de semeadura. 
A semeadura foi realizada no dia 03/03/2019, em uma área experimental de $200 \mathrm{~m}^{2}$, foi utilizado a cultivar de milho MG $580 \mathrm{PW}$, o qual possui um alto potencial produtivo, tanto no verão, quanto, para a safrinha podendo chegar a uma população de 75 mil plantas por hectare na safra de verão, dependendo da região de semeadura. Foi utilizado 4 plantas por metro linear, espaçadas por $0,50 \mathrm{~m}$ entre linhas, totalizando 80.000 plantas por hectare.

As parcelas foram constituídas de quatro fileiras, com 5 metros de comprimento e espaçamento de 0,5 metros entre linhas e foi colocado $1 \mathrm{~g} \mathrm{~m}^{-1}$ de hidrogel no sulco de plantio (FIDELIS et al., 2018; ). A área útil experimental foi considerada as duas linhas centrais para efeito de coleta de dados e observações. Foram eliminadas as duas fileiras externas assim com $50 \mathrm{~cm}$ no final de cada extremo das linhas do bloco experimental

A análise de solo da área, coletado na camada de 0-0,2 m de profundidade, foi classificado como Latossolo vermelho distrófico (EMBRAPA, 2017; SOIL SURVEY STAFF, 2014). A caracterização química e granulométrica, seguiu a metodologia preconizada pela EMBRAPA (1997), apresentando as seguintes características, $\mathrm{pH}\left(\mathrm{CaCl}_{2}\right)=5.1 \mathrm{MO}=40.8 \mathrm{~g}$ $\mathrm{Kg}^{-1} ; \mathrm{P}=1.2 \mathrm{mg} \mathrm{dm}^{-3}\left(\mathrm{Mehlich}^{-1}\right) ; \mathrm{K}=0,1 \mathrm{mg} \bullet \mathrm{dm}^{-3} ; \mathrm{Ca}=0.8 \mathrm{cmolc} \mathrm{dm}^{-3} ; \mathrm{Mg}=0.6 \mathrm{cmolc}^{-3}$ $\mathrm{dm}^{-3} ; \mathrm{Al}=0$ cmolc dm${ }^{-3} ; \mathrm{H}+\mathrm{Al}=5 \mathrm{cmolc} \mathrm{dm}^{-3}, 580 \mathrm{~g} \mathrm{~kg}^{-1}$ areia, $140 \mathrm{~g} \mathrm{~kg}^{-1}$ silte e $280 \mathrm{~g} \mathrm{~kg}^{-}$ 1 argila.

Com base nesses dados, antes da semeadura foi realizada a correção da acidez do solo, para se elevar a saturação por bases para $60 \%$ e as demais necessidades nutricionais seguiram as recomendações preconizadas por (SOUZA, 2004; BRITO et al., 2019), utilizando-se do preparo convencional da área, para realizar a semeadura.

O inoculante contendo a bactéria promotora de crescimento, foi utilizado na forma líquida, possuía a estirpes Ab-V5 e Ab-V6 na concentração $1 \times 10^{9}$ UFC.mL $^{-1}$. A dose de 350 $\mathrm{ml}$ para $50 \mathrm{~kg}$ de sementes, foi aplicado no dia da semeadura da cultura como preconiza Hungria (2011). Os tratos culturais posteriores seguiram o recomendado de acordo com a necessidade da cultura.

Não foram realizadas quaisquer suplementações hídricas durante a realização do experimento que teve duração de 180 dias durante o ano de 2018. A precipitação pluviométrica apresentou os seguintes volumes em mm entre os meses de fevereiro e julho como pode ser observado na (Figura 01). Os dados foram coletados da estação meteorológica GEOCLIMAMT, localizada a 200m da área experimental. 


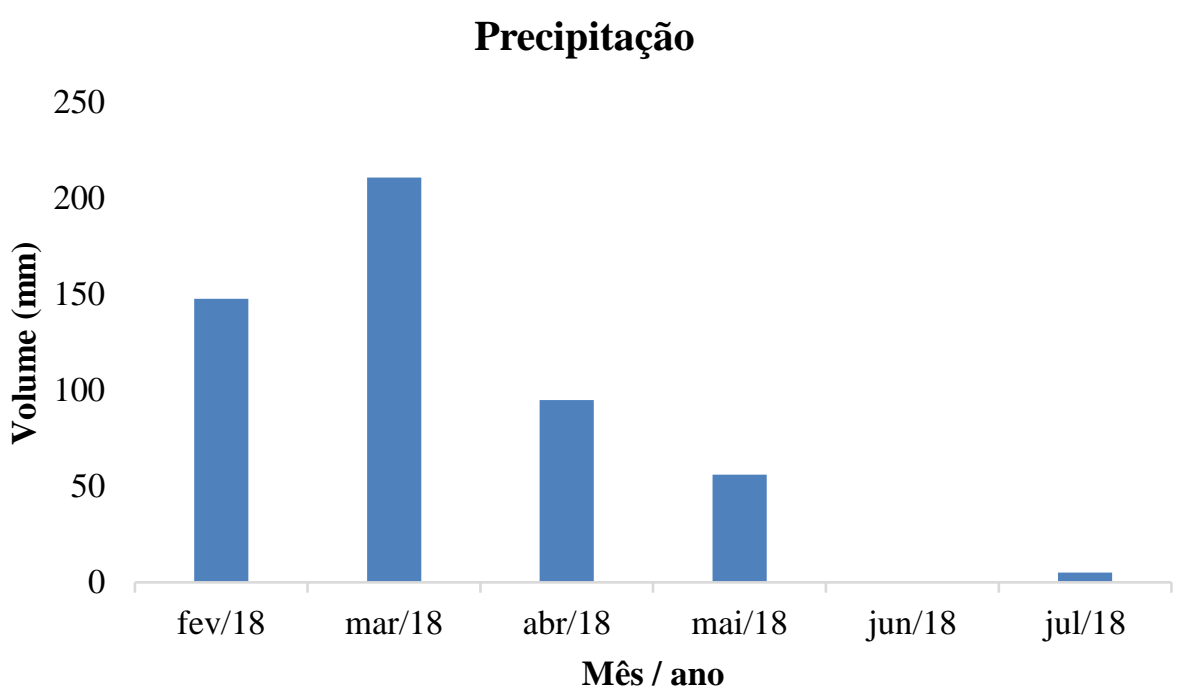

Fonte: Própria (2018).

No momento da colheita foram avaliados a altura de 10 plantas aleatórias dentro da área útil. Foi aferida com auxílio de uma trena medindo-se a distância do solo até a última folha completamente expandida da planta, Farinelli et al. (2012). O tamanho das espigas, foi aferido com auxílio de uma fita métrica graduada longitudinalmente. Os componentes de produtividade como PMG (Peso de mil grãos) e rendimento de grãos, foram aferidos logo após a debulha das espigas e a devida correção da umidade dos grãos a $13 \%$.

Após a obtenção e tabulação dos dados, foi utilizada análise de variância e as médias foram comparadas pelo teste Scott-Knott a 5\%, utilizando-se o programa estatístico SISVAR (FERREIRA, 2011).

\section{RESULTADOS E DISCUSSÃO}

Com base na análise de variância (Tabela 01) é possível observar que as variáveis resposta rendimento (REND) e altura de planta (AP), foram influenciados pelos tratamentos a 5 e $1 \%$ de probabilidade respectivamente. Por outro lado, o PMG (peso de mil grãos) e o CE (comprimento das espigas), não sofreram influência significativa dos tratamentos testados. 
Tabela 01: Quadrados médios e respectiva significância da análise de variância das características PMG, CE, AP e REND, Tangará da Serra 2019.

\begin{tabular}{llllll}
\hline FV & Gl & PMG $(\mathbf{g})$ & CE $(\mathbf{c m})$ & AP $(\mathbf{c m})$ & REND $(\mathbf{k g})$ \\
\hline Bloco & 4 & 97,50 & 1,038 & 0.029 & 3123139,20 \\
Tratamento & 3 & 453,42 & 1,560 & $0.030^{* *}$ & $1425419,73^{*}$ \\
& & & & & \\
Erro & 12 & 327,36 & 0,70 & 0,006 & 503265,07 \\
& & & & & \\
\hline CV \% & & 6,86 & 4,61 & 4,17 & 9,17 \\
Média & & $263,85 \mathrm{~g}$ & $13.18 \mathrm{~cm}$ & $1,88 \mathrm{~m}$ & $7740,4 \mathrm{~kg}$ \\
\hline
\end{tabular}

PMG: Peso de mil grãos; CE: Comprimento de espiga; AP: Altura de planta; REND: Rendimento ** e * significativos a 1 e $5 \%$ de probabilidade; respectivamente.

Fonte: Própria (2018).

Os coeficientes de variação (CV \%) observados no experimento estão dentro dos parâmetros aceitáveis para este tipo de experimento. A influência dos tratamentos nas características estudadas podem ser verificadas na Tabela 02.

Tabela 02: Resumo das médias dos tratamentos relativos à altura das plantas (AP), comprimento da espiga (CE), peso de mil grãos (PMG) e rendimento (REND.), obtidos no experimento sobre a influência do hidrogel e do Azospirillum brasiliense nas características agronômicas na cultura do milho.

\begin{tabular}{lcccc}
\hline TRATAMENTO & AP & CE & PMG & REND. \\
\hline T1 & $1,78 \mathrm{~b}$ & $12,50 \mathrm{a}$ & $249,92 \mathrm{a}$ & $6958,4 \mathrm{~b}$ \\
$\mathrm{~T} 2$ & $1,95 \mathrm{a}$ & $13,08 \mathrm{a}$ & $265,80 \mathrm{a}$ & $7896,0 \mathrm{a}$ \\
T3 & $1,93 \mathrm{a}$ & $13,29 \mathrm{a}$ & $268,80 \mathrm{a}$ & $7945,6 \mathrm{a}$ \\
T4 & $1,88 \mathrm{a}$ & $13,85 \mathrm{a}$ & $270,90 \mathrm{a}$ & $8161,6 \mathrm{a}$ \\
\hline T1: Testemunha (condições normais de & plantio) T2 :Azospirillum + Hidrogel; T3: Azospirillum + \\
Condições normais de semenadura T4: Hidrogel + Condições normais de semeadura. \\
\multicolumn{4}{l}{ Medias seguidas pela mesma letra não diferem entre si pelo teste de Scott Knott a 5\% de probabilidade. } \\
\hline
\end{tabular}

Fonte: Própria (2018).

Esperava-se que os comprimentos da espiga e o peso de mil grão fossem alterados com os tratamentos aqui aplicados. Afirma-se que uma alta população de plantas e ou um crescimento exacerbado atrelado ao excesso de N, podem acarretar competição intraespecífica de água, nutrientes e luminosidade, dessa forma podendo ocorrer uma redução do comprimento de espiga (PINOTTI, et al., 2014; THOMAZINNI, et al., 2019) e do peso de mil grãos (FUMAGALLI, 2017) 
Neste experimento os o uso do hidrogel e ou do A. brasiliense não tiveram efeito nessas

variáveis como foi mencionado anteriormente. Assim foram encontrados comprimentos de espiga variando entre $12,5 \mathrm{~cm}$ a $13,85 \mathrm{~cm}$, e para a variável peso de mil grãos os valores foram de 249,92 g a 270,9 g (Tabela 02).

Por outro lado com base nos resultados obtidos, é possível inferir que a associação do hidroretentor e o A brasiliense, podem ter estimulado a absorção de $\mathrm{N}$ e a produção de hormônios em maiores quantidades nas plantas, assim como, a melhora na absorção e disponibilidade de água às plantas, desse modo, deixado as plantas tratadas com maiores alturas e sendo mais produtivas (DIDONET et al., 2000; NUNES et al., 2015).

Apesar de que houve diferença entre os tratamentos para essa característica, as plantas não sofreram nenhum acamamento, dentro das parcelas estudadas (dados não apresentados). Todos os tratamentos estudados aqui foram superiores à testemunha Tabela 2. Para o tratamento T2 (Azospirillum + Hidrogel) houve um aumento na altura das plantas de 9,5\% em relação a testemunha. Já o tratamento T3 (Azospirillum + Condições normais de semeadura) obteve um crescimento de 8,4\% em comparação a testemunha. E por fim o tratamento T4 (Hidrogel + Condições normais de plantio) resultou-se em um aumento de 5,6\% em confrontação à testemunha.

A altura de planta, apesar de não ser um componente ligado diretamente a produção das plantas, influencia indiretamente algumas características produtivas, principalmente, quanto à perspectiva de maior número de folhas e ou maior comprimento dessas, potencializando a produção de fotoasimilados nas plantas, possibilitando assim maior produção. O metabolismo C4 da cultura do milho, proporciona alcançar máxima fotossíntese, perante situações de alta disponibilidade de radiação solar (BERGAMASCHI et al., 2004). Assim a interceptação da radiação solar de uma cultura pode ser potencializada com uma maior densidade de plantas, podendo proporcionar aumento ao potencial produtivo da cultura (SANGOI et al., 2013; DE ASSIS OLIVEIRA et al., 2020).

De acordo com Cacciari et al. (1989) a bactéria diazotróficas A brasiliense apresenta a capacidade de produção de hormônios principalmente giberelinas e citocininas. As giberelinas em combinação com a absorção de nitrogênio aumentam a força do dreno através do aumento do comprimento e da taxa de crescimento da célula, assim ocorre um aumento na altura da planta através do estímulo do crescimento de gemas, indução de divisão mitótica nas folhas promovendo assim o aumento da altura de plantas (HAFEEZ et al., 2018; GHODRAT et al., 2012; SÃO JOSE et al., 2014)). Além dos hormônios mencionados o AIA é produzido pela rizobactéria sendo este especialmente promotor do crescimento de plantas, podendo 
permanecer durante longos períodos após a inoculação bacteriana na muda vegetal (BASHAN; BASHAN, 2010).

Outro efeito induzido pelas bactérias é o de interação com diversos nutrientes. Assim D’Angioli et al. (2017), mensurando os efeitos da exsudação de carboxilato radicular na interação com Azospirillum brasilense, verificaram que o comprimento de raiz das plantas inoculadas foi positivamente correlacionado com o suprimento de $\mathrm{P}$, indicando que o suprimento de $\mathrm{P}$ afeta a comunidade microbiana, consequentemente a produção das plantas, visto que o P é um elemento essencial para a geração foto assimilados e reserva da planta.

Oliveira et al. (2018) avaliando combinações de aplicação de N e de A. braziliensis, identificaram que a inoculação com Azospirillum na semeadura $+\mathrm{N}$ mineral na cobertura proporcionou produtividade semelhante à do $\mathrm{N}$ mineral na semeadura e cobertura para ambas as cultivares de milho. Sendo assim, a utilização da bactéria é uma boa alternativa para suprir a demanda de $\mathrm{N}$ na cultura.

A utilização do hidrogel provavelmente permitiu que a água absorvida pela planta durante o seu ciclo pode ter sido melhor distribuída o que permitiu, por sua vez, melhorar a eficiência de absorção de nutrientes. O uso do hidrogel como uma nova ferramenta nos cultivos agrícolas tem como função fornecer disponibilidade de água do solo regularmente o que favoreceria a eficiência de absorção de nutrientes e, por consequência, o aumento da produtividade (MENDONÇA et al., 2013).

Levando em consideração a altura de plantas, este componente está diretamente relacionado com o rendimento de grãos. Os tratamentos afetaram da mesma forma essa característica pelo hidrogel e o Azospirillum (Tabela 2). Verificou-se incrementos na produtividade em relação ao tratamento controle na ordem de, 13.5, 14.2 e 17.3\%, para os tratamentos T2 (Azospirillum + Hidrogel), T3 (Azospirillum + Condições normais de plantio), T4 (Hidrogel + Condições normais de plantio), respectivamente.

Este efeito pode ser observado em estudos conduzidos com hidrogel + Nitrogênio na cultura do trigo, demonstrando resultados que comprovam que, o hidrogel melhora a eficiência de absorção de nutrientes (MAMANN et al., 2016). Scremin (2017), identificou que ao utilizar o polímero, verificou aumentou na eficiência do aproveitamento de nitrogênio na produtividade da aveia. Ou seja, o hidrogel demonstrou eficiência em gramíneas de interesse econômico e provavelmente, este mesmo efeito pode ser observado no milho.

No que se tange a utilização dessa BPCP (bactéria promotora de crescimento de plantas), estudo realizado por Souza et al. (2020) demonstrou que inoculação com B. japonicum e A. brasilense de forma isolada ou combinada pode amenizar os efeitos adversos da deficiência 
hídrica na cultura da soja, mantendo o crescimento e o acúmulo de matéria seca de plantas

quando expostas à restrição hídrica, principalmente pelo estímulo ao crescimento radicular das plantas.

A utilização do hidrogel provavelmente permitiu que a água absorvida pela planta durante o seu ciclo ter sido melhor distribuída o que comportou, por sua vez, melhorar a eficiência de absorção de nutrientes.

Scremin et al. (2017) avaliando a utilização de polímero hidrotentor no aproveitamento de $\mathrm{N}$ pela cultura da aveia, verificaram que a utilização do hidrogel colaborou para o aproveitamento do nutrientes em doses entre 30 e 60 kg.ha ${ }^{1}$, entretanto, esse aproveitamento é extremamente dependente do sistema de cultivo adotado e também de condições meteorológicas.

Quando utilizado em solos argilosos e em condições de homogeneidade da disponibilidade hídrica, não são observadas diferenças significativas quanto a utilização do hidrogel (SANTANA et al., 2007; PELEGRIN et al., 2017; KRAISIG et al., 2018). Pode até mesmo, causar a morte de raízes quando utilizado em solos pouco aerados ou quando submetidos a taxas de precipitação que prejudiquem a sua aeração (SAAD et al., 2009).

Narjary et al. (2012) avaliando em laboratório a aplicação de hidrogel em diferentes tipos de solo, verificaram que a aplicação de hidrogel em solos argilisos, reduziu para $10 \%$ a porosidade total do solo, ficando próximo a níveis críticos, entretanto, em solos arenosos, aumentou em até 4 vezes a retenção de água.

O solo da área de estudo, foi classificado texturalmente como franco argilo-arenoso, sendo mais propenso a melhorias da utilização do hidrogel pois, quando se considera que durante o período de execução do experimento, mais de $70 \%$ das precipitações correram nos dois primeiros meses de condução experimental pode ser verificado o efeito desse polímero no sistema. O hidrogel pôde proporcionar assim, boa aeração e promoveu maior retenção de água dentro do perfil do solo, assim como, condições adequadas para o desenvolvimento da bactéria em estudo.

\section{CONCLUSÕES}

Com base nos resultados elucidados na presente pesquisa é possível concluir que a utilização de A. braziliensis assim como a de hidrogel seja de forma individual ou combinadas, interferiram significativamente o rendimento de grãos e a altura de plantas de milho produzidos na entressafra na região de Tangará da Serra - MT, demonstrando assim que o uso do produto 
pode ser uma alternativa viável para os produtores de milho da região.

\section{REFERÊNCIAS}

ALVARES, Clayton Alcarde et al. Köppen's climate classification map for Brazil. Meteorologische Zeitschrift, v. 22, n. 6, p. 711-728, 2013.

AMARAL, T.A. et al. Resposta de Cultivares de Milho ao Estresse Hídrico. Embrapa milho e sorgo, Sete Lagoas, 2016 . Disponível em: <https://ainfo.cnptia.embrapa.br/digital/bitstream/item/161052/1/doc-207-1.pdf >. Acesso em: 17 mar. 2020.

AZEVEDO, T.L.F; BERTONHA, A.; GONÇALVES, A.C.A. Uso de hidrogel na agricultura. Revista do Programa de Ciências Agro-Ambientais, v.1, n.1, p.23-31, 2002.

BARBIERI, J. D.; DALLACORT, R.; SANTI, A.; ROCHA, R. P.; CARVALHO, M. A. C. Zoneamento agroclimático de amendoinzeiro para a Bacia do Alto Paraguai (MT). Pesquisa Agropecuária Tropical, v. 45, n. 2, p.231-240, 2015.

BASHAN, Y. e BASHAN, L. E. de. How the plant growth-promoting bacterium Azospirillum promotes plant growth - a critical assessment. Advances in Agronomy, v. 108, p. 77 - 136, 2010. ISSN 0065-2113.

BASHAN, Y.; BUSTILLOS, J.J.; LEYVA, L.A.; HERNANDEZ, J.-P.; BACILIO, M. Increase in auxiliary photoprotective photosynthetic pigments in wheat seedlings induced by Azospirillum brasilense. Biology and Fertility of Soils, v.42, p.279-285, 2006.

BERGAMASCHI, H. et al. Distribuição hídrica no período crítico do milho e produção de grãos. Pesquisa Agropecuária Brasileira, v.39, n.9, p.831-839, 2004.

BRITO, A. R.; PEREIRA, H. S. ; BRACHTVOGEL, E. Luiz. Saturação por bases na integração lavoura-pecuária com cultivo de milho nos dois primeiros anos. Colloquium Agrariae. 2019. p. $58-68$.

CACCIARI, I; LIPPI, D; PIETROSANTI, T; PIETROSANTI, W. phytohormone-like substances produced by single and mixed diazotrophic cultures of Azospirillum and Arthrobacter. Plant and Soil,v.115, p. 151-153, 1989.

COELHO, A.E. et al. Inoculação de sementes com Azospirillum brasilense em plantas de milho submetidas à restrição hídrica. Scientia Agraria Paranaensis, v. 16, n. 2, p. 186-192, 2017.

CONAB. Companhia Nacional de Abastecimento. Série histórica das safras (2019). Disponível em: https://www.conab.gov.br/info-agro/safras/serie-historica-das-safras?start=20. Acesso em: 17 mar. 2020.

D'ANGIOLI, M. A. et al. Inoculation with Azospirillum brasilense (Ab-V4, Ab-V5) increases Zea mays root carboxylate-exudation rates, dependent on soil phosphorus supply. Plant and soil, v. 410, n. 1-2, p. 499-507, 2017. 
DALLACORT, R.; MARTINS, J. A.; INOUE, M. H.; FREITAS, P. S. L.; COLETTI, A. J.

Distribuição das chuvas no município de Tangará da Serra, médio norte do Estado de Mato Grosso, Brasil. Acta Scientiarum. Agronomy, v. 33, n. 2, p.193-200, 2011.

DARTORA, J. et al. Adubação nitrogenada associada à inoculação com Azospirillum brasilense e Herbaspirillum seropedicae na cultura do milho. Revista Brasileira de Engenharia Agrícola e Ambiental, v. 17, n. 10, p. 1023-1029, 2013.

DA SILVA, T. R. G. et al. Fatores abióticos no crescimento e florescimento das plantas. Research, Society and Development, v. 10, n. 4, 2021.

DE ASSIS OLIVEIRA, Felipe et al. Níveis crescentes de irrigação e maior densidade de plantas aumentam a produtividade do milho verde. Brazilian Journal of Development, v. 6, n. 7, p. 43371-43381, 2020.

DIDONET, A. D. et al. Realocação de nitrogênio e de biomassa para os grãos, em trigo submetido a inoculação de Azospirillum. Pesquisa Agropecuária Brasileira, v. 35, n. 2, p. 401-411, 2000.

DUARTE, C. F. D. et al. Inoculação de bactérias promotoras do crescimento vegetal em Urochloa Ruziziensis. Research, Society and Development, v. 9, n. 8, 2020.

EMBRAPA. Empresa Brasileira de Pesquisa Agropecuária, Manual de Métodos de Análise de Solo, ed. 2, Rio de Janeiro, 212p, 1997.

EMBRAPA. Empresa Brasileira de Pesquisa Agropecuária, Sistema Brasileiro de classificação de solos, 3 ed. Brasília, 353p. 2013.

FAGERIA, N. K.; CARVALHO, M. C. S.; DOS SANTOS, F. C. Root growth of upland rice genotypes as influenced by nitrogen fertilization. Journal of Plant Nutrition, v. 37, n. 1, p. 95-106, 2014.

FARINELLI, R. et al. Características agronômicas e produtividade de cultivares de milho em diferentes espaçamentos entre linhas e densidades populacionais. Científica, v. 40, n.1, 2012.

FERREIRA, D. F. SISVAR: A computer analysis system to fixed effects split plot type designs. Revista Brasileira de Biometria, v. 37, n. 4, p. 529-535, 2019. Disponível em: < https://biometria.ufla.br/index.php/BBJ/article/view/450> Acesso em: 17 mar. 2020.

FIDELIS, R.R. et al. Influence of hydrogel use on soybean cultivation hydrical stress. Bioscice Journal,.v.34, n.5, p.1219-1224, 2018.

FIESP - Federação das Indústrias do Estado de São Paulo. Safra Mundial de Milho(2019). São Paulo: Fiesp. Disponível em: 〈https://www.fiesp.com.br>Acesso em: 17 mar. 2020.

FUMAGALLI, MAURÍCIO et al. Desempenho produtivo do milho híbrido simples em função de espaçamentos entre fileiras e populações de plantas. Revista Brasileira de Milho e Sorgo16, p. 426-439, 2017. 
GHODRAT, V. E M. J. ROUSTA. Effect of priming with gibberellic acid (GA3) on germination and growth of corn (Zea mays L.) under saline conditions. Int. J. Agric. Crop Sci., v.4, n.1, p. 882-885, 2012.

HAFEEZ, U. R; SAJJAD, A; LAIQ, Z; ZAID, K; MUHAMMAD, A. K. Yield and Growth Response of Maize Crop to Urea and Gibberellic 0038 Acid Potash Salt (Ga-K Salt) in Calcarious Soil. JOJ Hortic Arboric. v.1, n.2, 2018.

HUNGRIA, M. Inoculação com Azospirillum brasiliense: inovação em rendimento a baixo custo. Embrapa Soja, Londrina, 2011. Disponível em: https://ainfo.cnptia.embrapa.br/digital/bitstream/item/29560/1/DOC325.2011.p. Acesso em: 17 mar. 2020.

INMET. Estações automáticas. Ministério da Agricultura, Pecuária e Abastecimento, 2018. Disponível em: http://www.inmet.gov.br/portal/index.php?r=estacoes/estacoesautomaticas> Acesso em: 17 mar. 2020.

JÚNIOR, G. do N. A. et al. Estresse hídrico em plantas forrageiras: Uma revisão. Pubvet, v. 13, p. 148, 2018.

KRAISIG, A. R. et al. Análise da superfície de resposta sobre o uso do biopolímero hidrogel no sistema soja/aveia. Proceeding Series of the Brazilian Society of Computational and Applied Mathematics, v. 6, n. 1, 2018.

MAMANN, A. T. W., DA SILVA, J. A. G., SCREMIN, O. B., MANTAI, R. D., SCREMIN, A. H., e DORNELLES, E. F. Nitrogen efficiency in wheat yield through the biopolymer hydrogel. Revista Brasileira De Engenharia Agricola e Ambiental, v.21, n.10, p. 697-702, 2017.

MENDONÇA, T. G. et al. Hidrogel como alternativa no aumento da capacidade de armazenamento de água no solo. Instituto Nacional do Semiárido, Campina Grande, v.2, p. 87-92, 2013.

NARJARY, B.; AGGARWAL, P.; SINGH, A.; CHAKRABORTY, D., SINGH, R. Water availability in different soils in relation to hydrogel application. Geoderma, n.187 e 188, p.94$101,2012$.

NUNES, P. H. M. P. et al. Produtividade do trigo irrigado submetido à aplicação de nitrogênio e à inoculação com Azospirillum brasilense. Revista Brasileira de Ciência do Solo, v. 39, n. 1, p. 174-182, 2015.

OLIVEIRA, I.J., FONTES, J.R.A., PEREIRA, B.F.F. Inoculation with Azospirillum brasiliense increases maize yield. Chem. Biol. Technol. Agric. v.5, n.6, 2018. https://doi.org/10.1186/s40538-018-0118-z.

PELEGRIN, A.J., NARDINO, M., FERRARI, M., CARVALHO, I.R., SZARESKI, V.J., BELLE, R., CARON, B.O., SOUZA, V.Q. Polímeros hidroretentores na cultura da soja em condições de solo argiloso na região norte do Rio Grande do Sul. Rev Cienc Agra (Lisboa). v.40, n.1, p. 175-182, 2017. 
PINOTTI, E. B. et al. Características agronômicas de cultivares de milho em função de populações de plantas e épocas de semeadura. Revista Científica Eletrônica de Agronomia, v. 25, p. 17-33, 2014.

QUADROS, P.D. et al. Desempenho agronômico a campo de híbridos de milho inoculados com Azospirillum. Revista Ceres, v.61, n.2, p.209-218, 2014.

REPKE, R. A. et al. Eficiência da Azospirillum brasilense combinada com doses de nitrogênio no desenvolvimento de plantas de milho. Revista Brasileira de Milho e Sorgo, p. 214-226, 2013.

SAAD, J. C. C.; LOPES, J. L. W.; SANTOS, T. A. dos Manejo hídrico em viveiro e uso de hidrogel na sobrevivência pós-plantio de Eucalyptus urograndis em dois solos diferentes. Eng. Agríc., v.29, n.3, p.404-411, 2009.

SAMPAT, A. G. Física de suelos; principios y aplicaciones. México: Limusa-Wiley, 1973. $351 \mathrm{p}$.

SANGOI, L. et al. Senescência foliar e resposta de híbridos de milho liberados comercialmente para cultivo em diferentes épocas ao adensamento. Revista Brasileira de Milho e Sorgo, v. 12, n. 1, p. 21-32, 2013.

SANTANA, B. H.; MARTÍNEZ, A. P.; EMÉSTICA, O. A. S.; REYES, G. G. Efecto del hidrogel sobre el rendimiento de semilla en tres cultivares de Brachiaria spp en el valle de Iguala, México. REDVET. Revista electrónica de Veterinaria. v.8, n.9, 2007.

SÃO JOSÉ, ABEL REBOUÇAS et al. Marcha de absorção de nutrientes em anonáceas. Revista Brasileira de Fruticultura, v. 36, n. SPE1, p. 176-183, 2014.

SCREMIN, O. B. et al. Eficiência do nitrogênio na produtividade da aveia pelo biopolímero hidrogel. Revista Brasileira de Engenharia Agrícola e Ambiental, Campina Grande, v. 21, n. 6, p. 379-385, 2017.

SIONIT, N.; KRAMER, J.P. Effect of water stress during different stages of growth of soybeans. Agron. J. Madison, v.69, p.274-8, 1977.

SOIL SURVEY Staff. Keys to Soil Taxonomy. Washington, DC: USDA, Natural Resources Conservation Service. (2014).

SOUSA, F. G. et al. 2020. Inoculation and co-inoculation of bradyrhizobium japonicum and azospirillum brasilense in soybean culture. Research, Society and Development, v. 9, n. 6, 2020. Disponível em: < https://rsdjournal.org/index.php/rsd/article/view/3553/3898>. Acesso em: 17 mar. 2020.

SOUZA, D. M. G. Cerrado: correção do solo e adubação. Embrapa, Cerrados, ed. 2, Brasília, 2004. 


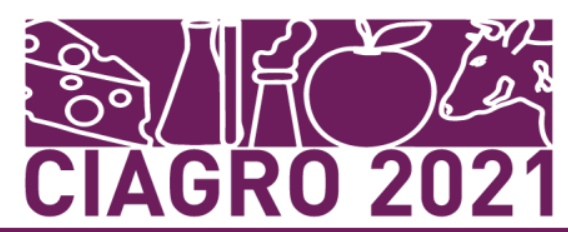

SOUZA, J. A., BUZETTI, S., TARSITANO, M. A. A., VALDERRAMA, M. Lucratividade do milho em razão das fontes, doses e épocas de aplicação de nitrogênio. Revista Ceres, v.59, n.3 p.321-329, 2012.

Disponível em: https://www.scielo.br/j/rceres/a/4SCwncVBrWhYDZSpsDfFmbq/?format=pdf\&lang=pt $>$.

THOMAZINI, GABRIELA et al. Inoculação de sementes com Azospirillum brasilense e doses de nitrogênio mineral em milho cultivado em sistema plantio direto. Revista Brasileira de Milho e Sorgo, v. 18, n. 3, p. 396-407, 2019. 


\title{
CAPÍTULO 07: FERMENTAÇÃO EM ESTADO SÓLIDO E SUBMERSO PARA PRODUÇÃO DE CELULASE: REVISÃO BIBLIOGRÁFICA
}

\author{
CAPÍTULO 07: FERMENTACIÓN SÓLIDA Y SUMERGIDA PARA LA \\ PRODUCCIÓN DE CELULASAS: REVISIÓN BIBLIOGRÁFICA
}

\section{CHAPTER 07: SOLID AND SUBMERGED FERMENTATION FOR CELLULASE PRODUCTION: BIBLIOGRAPHIC REVIEW}

\author{
Letícia Souza Silva $^{1}$; Adryelen Cassiano Martins ${ }^{2}$; Larine Kupski³; Juliana Bueno Ruiz ${ }^{4}$
}

DOI: https://doi.org/10.31692/978-65-88970-19-5.98-112

\begin{abstract}
RESUMO
Os processos fermentativos em estado sólido (FES) e submerso (FS) consistem na degradação de glicose ou de nutrientes por meio de microrganismos, como fungos, bactérias e leveduras. Estes tipos de fermentação são amplamente aplicados para a produção de enzimas, como a celulase. A alta eficiência do processo fermentativo para a produção de celulase está diretamente ligada as condições adequadas de cultivo. O presente trabalho teve como objetivo realizar uma revisão para identificar as condições de fermentação utilizadas na Fermentação em Estado Sólido (FES) e Fermentação Submersa (FS) para a produção da celulase. Foram selecionados um total de 21 artigos, todos entre os anos de 2018 a 2020, onde foram analisados fatores: microrganismos, substratos, $\mathrm{pH}$, umidade, temperatura e agitação. As seguintes ferramentas de dados bibliográficas foram utilizadas: Scielo, Science Direct, Scopus e Web of Science. Além disso as referências foram gerenciadas pelo software de banco de dados "EndNote" para a exclusão por duplicidade. A pesquisa dos artigos foi realizada com base nas palavras-chave: cellulase OR cellulolytic, Solid-State fermentation, Submerged fermentation e Production OR Synthesis. Os microrganismos que mais se destacaram foram Aspergillus nigger e Trichoderma reesei para as FES e FS, respectivamente. Os substratos mais empregados foram os resíduos agroindustriais, evidenciandose o farelo do trigo. As condições de umidade, temperatura, $\mathrm{pH}$ e agitação tiveram diferenças tanto para FES quanto para FS, isso justifica pela diversidade de microrsganismo utilizados. Os dados demonstraram que existe uma grande quantidade de condições a serem trabalhadas e que muitas vezes as mesmas condições podem ser utilizadas para os dois tipos de fermentação para a produção de celulase. Palavras-Chave: Enzima; Fermentação; Substrato; Microrganismos.
\end{abstract}

\section{RESUMEN}

Los procesos de fermentación en estado sólido (FES) y sumergido (FS) consisten en la degradación de glucosa o nutrientes por medio de microorganismos, como hongos, bacterias y levaduras. Estos tipos de fermentación se aplican ampliamente para la producción de enzimas, como la celulasa. La alta eficiencia del proceso de fermentación para la producción de celulasa está directamente relacionada con las condiciones adecuadas de cultivo. El presente trabajo tuvo como objetivo realizar una revisión para identificar las condiciones de fermentación utilizadas en la fermentación en estado sólido (FES) y la fermentación sumergida (FS) para la producción de celulasa. Se seleccionaron un total de 21 artículos, todos entre los años 2018 a 2020, donde se analizaron factores: microorganismos, sustratos, pH, humedad, temperatura y agitación. Se utilizaron las siguientes herramientas de datos bibliográficos: Scielo, Science Direct, Scopus y Web of Science. Además, las referencias fueron gestionadas por el software de base de datos "EndNote" para su exclusión por duplicación. La búsqueda de los artículos se realizó en base a las palabras clave: cellulase OR cellulolytic, Solid-State fermentation, Submerged fermentation y Production OR Synthesis. Los microorganismos que más destacaron fueron Aspergillus nigger y Trichoderma reesei para la FES y FS, respectivamente. Los sustratos más utilizados fueron los residuos agroindustriales, evidenciando el salvado de trigo. Las condiciones de humedad, temperatura,

\footnotetext{
${ }^{1}$ Graduanda em Engenharia de Alimentos, Universidade Estadual de Maringá, lesouzasilva1995@gmail.com

${ }^{2}$ Graduanda em Engenharia de Alimentos, Universidade Estadual de Maringá,, adryelencassiano15@gmail.com

${ }^{3}$ Doutora em Engenharia e Ciências de Alimentos, Universidade Estadual de Maringá, lkupski@uem.br

${ }^{4}$ Doutora em Genética e Melhoramento, Universidade Estadual de Maringá, jbrrebecca2@uem.br
} 
pH y agitación presentaron diferencias tanto para FES como para FS, esto se justifica por la diversidad de microorganismos utilizados. Los datos demostraron que hay un gran número de condiciones en las que trabajar y que a menudo se pueden utilizar las mismas condiciones para ambos tipos de fermentación para la producción de celulasa.

Palabras Clave: Enzima; Fermentación; Sustrato; Microorganismos.

\begin{abstract}
The fermentation processes in solid state (FES) and submerged (FS) consist of the degradation of glucose or nutrients by means of microorganisms, such as fungi, bacteria and yeasts. These types of fermentation are widely applied for the production of enzymes, such as cellulase. The high efficiency of the fermentation process for the production of cellulase is directly linked to the appropriate conditions of cultivation. The present work aimed to carry out a review to identify the fermentation conditions used in Solid State Fermentation (FES) and Submerged Fermentation (FS) for the production of cellulase. A total of 21 articles were selected, all between the years 2018 to 2020, where factors were analyzed: microorganisms, substrates, $\mathrm{pH}$, humidity, temperature and agitation. The following bibliographic data tools were used: Scielo, Science Direct, Scopus and Web of Science. In addition, the references were managed by the database software "EndNote" for exclusion due to duplication. The search for the articles was carried out based on the keywords: cellulase OR cellulolytic, Solid-State fermentation, Submerged fermentation and Production OR Synthesis. The microorganisms that stood out the most were Aspergillus nigger and Trichoderma reesei for the FES and FS, respectively. The most used substrates were the agro-industrial residues, evidencing the wheat bran. The conditions of humidity, temperature, $\mathrm{pH}$ and agitation had differences for both FES and FS, this justifies by the diversity of microorganisms used. The data demonstrated that there are a great number of conditions to be worked on and that the same conditions can often be used for both types of fermentation for the production of cellulase.
\end{abstract}

Keywords: Enzyme; Fermentation; Substrate; Microorganisms.

\title{
INTRODUÇÃO
}

As celulases são empregadas em inúmeros processos nas indústrias, como extração de óleos vegetais, extração de suco de frutas, agente de coloração alimentar, redução de deterioração de alimentos, pré-tratamento de chá fermentado, extração de café e açúcar, biocombustível, indústria têxtil, biogás, fabricação de papel, fármacos, tratamento de resíduos, entre outros (BAHRAMIAN et al., 2010; BEHERA et al., 2016; BEHERA et al., 2017; HU et al., 2018; SILVA, et al., 2019).

A produção de celulases microbianas é realizada a partir de processos fermentativos, onde destacam-se a Fermentação Submersa (FS) e Fermentação em Estado Sólido (FES) (CUNHA et al., 2014). O custo de produção de enzimas microbianas é fortemente ligado à sua produtividade (SHELDO e PELT, 2013; FLORENCIO et al., 2017). O custo dos substratos e as variações de rendimento enzimático, são problemas economicamente determinantes para produção de celulase, prejudicando seu potencial para aplicação em escala industrial (LIMAYEM e RICKE, 2012). Assim, para que o processo se torne viável é necessário que os parâmetros de otimização do processo como a seleção do microrganismo ideal para a enzima de interesse, o meio de cultivo, $\mathrm{pH}$, temperatura, aeração e agitação sejam definidos para se 
O tipo de microrganismos estudado, bem como o substrato para essa produção tornamse importante, pois a enzima celulase é indutiva, portanto, a sua produtividade enzimática está diretamente ligada a quantidade de celulose presente nos substratos e quais os microrganismos conseguem produzir a máxima atividade a partir dos mesmos (SUTO e TOMITA, 2001).

Portanto, pelas vantagens e desvantagens da produção de celulase pelas fermentações sólida e submersa, o objetivo desta revisão é avaliar as condições ótimas (substrato, microrganismo, umidade, temperatura, $\mathrm{pH}$, agitação) utilizadas em ambos processos.

\section{FUNDAMENTAÇÃO TEÓRICA}

As enzimas são substâncias orgânicas de polímeros de aminoácidos que atuam como catalizadores biológicos, ou seja, acelerando velocidade das reações (SOARES et al., 2010). A produção de enzimas é uma área amplamente promissora, estima-se que em 2023 o mercado global movimentará cerca de US\$ 7 bilhões, uma taxa de crescimento anual de 4,9\% no período de 2018-2023 (ARUN, 2017). Isto em virtudes das suas novas tecnologias para agregar valor em síntese de compostos (ROVEDA et al., 2010), além de serem consideradas ambientalmente corretas pela substituição de catalisadores químicos, economia de energia pela utilização de temperaturas, pH e pressão brandas (THOMAS et al., 2013; YAZID et al., 2017).

As enzimas podem ser obtidas de fontes vegetais, animais e microbianas. As enzimas microbianas podem ser produzidas através de processos fermentativos (submerso e estado sólido) (CUNHA et al., 2014) e apresentam vantagens frente as vegetais e animais, como baixos custos de produção, viabilidade de larga escala em fermentadores industriais, distintas características físico-químicas, são diretamente ligadas ao hábitat e fisiologia do microrganismo produtor, altamente sensíveis a modificações genética e são um recurso renovável (KASANA e GULATI, 2011). Dentre as enzimas microbianas produzidas destacam-se as celulases (ABREU et al., 2015).

As celulases constituem um complexo enzimático formado por endo- $\beta$-1,4-glicanases (EC 3.2.1.4), exo- $\beta$-1,4-glicanases (EC 3.2.1.91) e $\beta$-1,4-glicanases (EC 3.2.1.21) que atuam sinergisticamente na conversão da celulose cristalina a glicose (GOMES et al., 2016). A atividade enzimática de cada componente do complexo enzimático pode ser determinada suas atividades separadamente, ou a ação sinérgica pode ser determinada, empregando o ensaio de hidrólise no papel filtro e expressando a atividade de FPase (RAWAT et al., 2014).

A produção dessas enzimas é realizada a partir de processos fermentativos (CUNHA 
et al., 2014). A FS é a mais utilizada, devido ao fácil controle de processos e possibilita a sua

utilização em escalas industriais (LIU et al., 2020), para este tipo de fermentação utiliza-se água, que permite minimizar os gradientes de temperatura, concentrar os nutrientes (SILVA et al, 2019), além de ser possível a realização de aeração, agitação e controle do pH (RAMAMOORTHY et al., 2019). A FES, no entanto, é um processo de crescimento microbiano em um substrato sólido com pouca ou nenhuma água livre aparente (SOCCOL et al., 2017), de biorreatores simples, baixo custo de matéria-prima e de produção, requisitos de energia reduzidos, mínima produção de águas residuais, alta produtividade e alta eficiência recuperação do produto (SADH et al., 2018). Para que isso seja possível existem uma gama de microrganismos capazes de degradar materiais celulósicos como fungos ou bactérias SILVA et al., 2019).

Segundo Kuhad et al. (2016), a produção de celulase por meio processos fermentativos envolve uma diversidade de microrganismos, dentre eles são amplamente utilizados fungos e bactérias (SALAZAR et al., 2019). Alguns microrganismos, como as bactérias, necessitam de um alto teor de umidade para seu crescimento e são mais indicadas a FS (IRFAN et al., 2019). Por outro lado, a fermentação por fungos embora seja amplamente recomendada aos dois tipos de processo, sólido e submerso (SUBSAMRAN et al., 2019), é mais adequado para FES, por oferecer menor teor de umidade e sustentar o crescimento de fungos em materiais lignocelulósicos (YOON et al., 2014).

\section{METODOLOGIA}

A pesquisa é de abordagem quali e quantitativa e quanto aos procedimentos técnicos utilizou-se de revisão bibliográfica. As seguintes ferramentas de dados bibliográficas foram utilizadas: Scielo, Science Direct, Scopus e Web of Science. Para todas as buscas foram utilizadas base de dados apenas para artigos de pesquisa publicados em 2018, 2019 e 2020. Além disso, as referências foram gerenciadas pelo software de banco de dados "EndNote" para a exclusão por duplicidade.

A pesquisa dos artigos foi realizada com base nas palavras-chave: cellulase $O R$ cellulolytic, Solid-State fermentation, Submerged fermentation e Production OR Synthesis. Os dados selecionados englobaram tipo de fermentação, condições ótimas de fermentação (substrato, microrganismo, umidade, temperatura, $\mathrm{pH}$, agitação). 
Todos os artigos incluídos na pesquisa tiveram suas publicações de 2018 a 2020 e avaliaram a produção de celulase (expressão com atividade de FPase) por meio de processos fermentativos com planejamentos experimentais de otimização. Dentre eles 13 [1, 6, 8, 10, 11, $12,13,14,15,17,19,20,21]$ foram conduzidos por meio de fermentação sólida e 8 [2, 3, 4, 5 , $7,9,16,18]$ por meio de fermentação submersa.

A maior quantidade de artigos encontrados para fermentação em estado solido (n=13), frente a submersa $(n=8)$ pode estar associado ao fato que na FS há melhor controle de fatores ambientais como temperatura, gradiente de nutrientes e $\mathrm{pH}$, sendo tradicionalmente utilizada para produzir enzimas em escalas industriais (SINGHANIA et al., 2010). Controlar esses parâmetros ainda é considerado um desafio da FES (ABDULLAH et al., 2018), embora tenha um bom rendimento enzimático, e forneça um ambiente de crescimento em condições adequadas para que os microrganismos se desenvolverem naturalmente (CUNHA et al., 2012), portanto, mais estudos são conduzidos com este modo de cultivo a fim de contribuir com novas estratégias para produção enzimática.

$\mathrm{Na}$ Tabela 01 estão descritas as informações sobre as características gerais abordadas pelos os artigos selecionados.

Tabela 01: Condições da fermentação em estado sólida (FES) e submersa (FS) dos estudos selecionados para revisão da produçao de celulase, entre os anos de 2018 a $2020(n=21)$

\begin{tabular}{|c|c|c|c|c|c|c|c|c|}
\hline \multirow{2}{*}{$\begin{array}{l}\text { Código } \\
\text { do } \\
\text { artigo }\end{array}$} & \multirow{2}{*}{ Processo } & \multicolumn{6}{|c|}{ Condições ótimas de fermentação } & \multirow[b]{2}{*}{ Referêncas } \\
\hline & & Substrato & Microrganismo & $\begin{array}{l}\text { Umidade } \\
(\%)\end{array}$ & $\begin{array}{c}\mathrm{T} \\
\left({ }^{\circ} \mathrm{C}\right)\end{array}$ & $\mathrm{pH}$ & $\begin{array}{l}\text { Agitação } \\
\text { (rpm) }\end{array}$ & \\
\hline 1 & FES & $\begin{array}{c}\text { Bagaço de cana- } \\
\text { de -açúcar }\end{array}$ & Aspergillus niger & 80 & 35 & 3,50 & - & $\begin{array}{l}\text { Abdullah et al. } \\
\text { (2018) }\end{array}$ \\
\hline 2 & FS & $\begin{array}{l}\text { Mesocarpo de } \\
\text { coco }\end{array}$ & Trichoderma reesei & 100 & 30 & 5,50 & 150 & Dey et al. (2018) \\
\hline 3 & FS & Farelo de trigo & Schizophyllum commune & 100 & 25 & 5,00 & 100 & $\begin{array}{l}\text { Kumar et al. } \\
\text { (2018) }\end{array}$ \\
\hline 4 & FS & $\begin{array}{c}\text { Resíduos de } \\
\text { papel de } \\
\text { escritório }\end{array}$ & Bacillus velezensis & 100 & 30 & 4,70 & 100 & Nair et al. (2018) \\
\hline 5 & FS & - & Aspergillus $s p$ & 100 & 30 & 5,50 & 100 & $\begin{array}{l}\text { Shawky et al. } \\
\text { (2018) }\end{array}$ \\
\hline 6 & FES & $\begin{array}{l}\text { Resíduo têxtil } \\
\text { cottón/poliéster }\end{array}$ & Aspergillus niger & 78 & 28 & 7,29 & - & $\begin{array}{l}\text { Hu et al. } \\
(2018)\end{array}$ \\
\hline 7 & FS & Palha de arroz & Thermoascus aurantiacus & 100 & 50 & 5,00 & 120 & $\begin{array}{c}\text { Singh e Bajar } \\
\text { (2019) }\end{array}$ \\
\hline 8 & FES & Casca de soja & Penicillium sp. & 70 & 50 & 4,90 & - & $\begin{array}{l}\text { Salazar et al. } \\
\text { (2019) }\end{array}$ \\
\hline
\end{tabular}




\begin{tabular}{|c|c|c|c|c|c|c|c|c|}
\hline 9 & FS & $\begin{array}{c}\text { Casaca de } \\
\text { ervilha }\end{array}$ & Trichoderma reesei & 100 & 30 & 5,00 & 110 & $\begin{array}{l}\text { Sirohi et al. } \\
(2019)\end{array}$ \\
\hline 10 & FES & $\begin{array}{c}\text { Folhas de } \\
\text { plantação de } \\
\text { óleo de palma }\end{array}$ & Aspergillus niger & 75 & 30 & 4,50 & - & Tai et al. (2019) \\
\hline 11 & FES & Grama Vetiver & Aspergillus tubingensis & 80 & 30 & 7,00 & - & $\begin{array}{c}\text { Subsamran et al. } \\
\text { (2019) }\end{array}$ \\
\hline 12 & FES & $\begin{array}{c}\text { Farelo de } \\
\text { arroz, casca de } \\
\text { arroz e palha } \\
\text { de arroz }\end{array}$ & Trichoderma reesei & 75 & 35 & - & - & $\begin{array}{l}\text { Darabzadeh et } \\
\text { al. (2019) }\end{array}$ \\
\hline 13 & FES & $\begin{array}{c}\text { Vagens de } \\
\text { sementes de } \\
\text { Bombyx ceiba }\end{array}$ & Trichoderma viride & - & 35 & - & - & $\begin{array}{l}\text { Nazir et al } \\
\text { (2019) }\end{array}$ \\
\hline 14 & FES & $\begin{array}{l}\text { Bagaço de } \\
\text { sorgo doce e } \\
\text { farelo trigo }\end{array}$ & Aspergillus terreus & 80 & 45 & 5,80 & - & $\begin{array}{l}\text { Sharma et al } \\
\text { (2019) }\end{array}$ \\
\hline 15 & FES & Farelo de trigo & Aspergillus niger & 76 & 30 & 5,00 & - & $\begin{array}{l}\text { Verma e Kumar } \\
\text { (2019) }\end{array}$ \\
\hline 16 & FS & $\begin{array}{c}\text { Casca de } \\
\text { amendoim }\end{array}$ & Bacillus paralichniformis & 100 & 35 & - & - & $\begin{array}{c}\text { Irfan et al } \\
(2020)\end{array}$ \\
\hline 17 & FES & Palha de arroz & Myceliophthora thermophila & 80 & 45 & 5,00 & - & $\begin{array}{l}\text { Kumar et al } \\
\quad(2020)\end{array}$ \\
\hline 18 & FS & $\begin{array}{l}\text { Dreche } \\
\text { (residuos } \\
\text { cereais } \\
\text { cervejeira) }\end{array}$ & Trichoderma reesei & 100 & 30 & 5,00 & 180 & $\begin{array}{c}\text { Cekmecelioglu } \\
\text { e Demirci } \\
(2020)\end{array}$ \\
\hline \multirow{2}{*}{19} & \multirow{2}{*}{ FES } & \multirow{2}{*}{ Farelo de trigo } & Trichoderma reesei & 61 & 30 & 5,00 & \multirow{2}{*}{ - } & \multirow[t]{2}{*}{$\begin{array}{l}\text { Verma e Kumar } \\
\quad(2020)\end{array}$} \\
\hline & & & Neurospora crassa & 66 & 30 & 6,00 & & \\
\hline 20 & FES & Farelo de trigo & Pestalotiopsis microspora & 80 & 32 & 4,75 & - & $\begin{array}{c}\text { Joukanapalle et } \\
\text { al (2020) }\end{array}$ \\
\hline 21 & FES & $\begin{array}{c}\text { Casca de } \\
\text { laranja, bagaço } \\
\text { de cana e } \\
\text { farelo de trigo }\end{array}$ & Aspergillus fumigatus & 65 & 31 & 7,00 & - & $\begin{array}{l}\text { Mondal et al } \\
\qquad(2020)\end{array}$ \\
\hline
\end{tabular}

Fonte: Própria (2020).

De acordo com a Tabela 01, as condições ótimas de fermentação para a umidade na fermentação em estado sólido ficaram entre 61-80\% dependendo das diferentes condições. Quanto a temperatura, observou-se que a maioria dos artigos estudados estabeleceram a temperatura entre $30-35^{\circ} \mathrm{C}(\mathrm{n}=9)$ para FS e para FES $(\mathrm{n}=7)$. Pode-se notar que a solução nutriente apresentou uma grande diversidade para ambos os tipos de fermentação, o que está relacionado com o tipo de substrato e microrganismo utilizado que também apresentaram uma grande variedade. Para o valor de $\mathrm{pH}$, somente três estudos não mencionaram o valor e a maioria $(\mathrm{n}=10)$ utilizaram valores próximos de $\mathrm{pH} 5,0$, não apresentando grandes diferenças entre a FS e FES.

Essas variáveis se destacam, pois, um dos grandes desafios dos processos fermentativos em estado sólido é o controle de fatores ambientais, como temperatura, $\mathrm{pH}$ e umidade durante a fermentação (DEY et al., 2018), e seleção do microrganismo adequado está diretamente ligada a eficiência na produtividade enzimática (SUBSAMRA et al. 2019). Na fermentação submersa por sua vez a concentração de solução nutriente e substratos também se torna importante, pois o fato de operar em meio submerso ocasiona a diluição dos componentes presentes, sendo 
necessária a garantia das quantidades adequadas para o metabolismo microbiano e desenvolvimento do produto (DEY eet al., 2018; IRFAN et al., 2019).

Além das variáveis descritas anteriormente, o tipo de microrganismos estudado, bem como o substrato para essa produção tornam-se importante, pois a enzima celulase é indutiva, portanto, a sua produtividade enzimática está diretamente ligada a quantidade de celulose presente nos substratos e quais os microrganismos conseguem produzir a máxima atividade a partir dos mesmos (SUTO e TOMITA, 2001). Portanto, o efeito dessas variáveis serão discutidas isoladamente, bem como as produtividades obtidas.

Na Figura 01 estão descritos os diferentes microrganismos utilizados nos processos fermentativos (estado sólido e submerso) para produção de celulase.

Figura 01: Microrganismos utilizados para produção de celulase nas fermentações em estado sólido e submerso nos artigos selecionados com período de publicação entre os anos de 2018 a 2020.

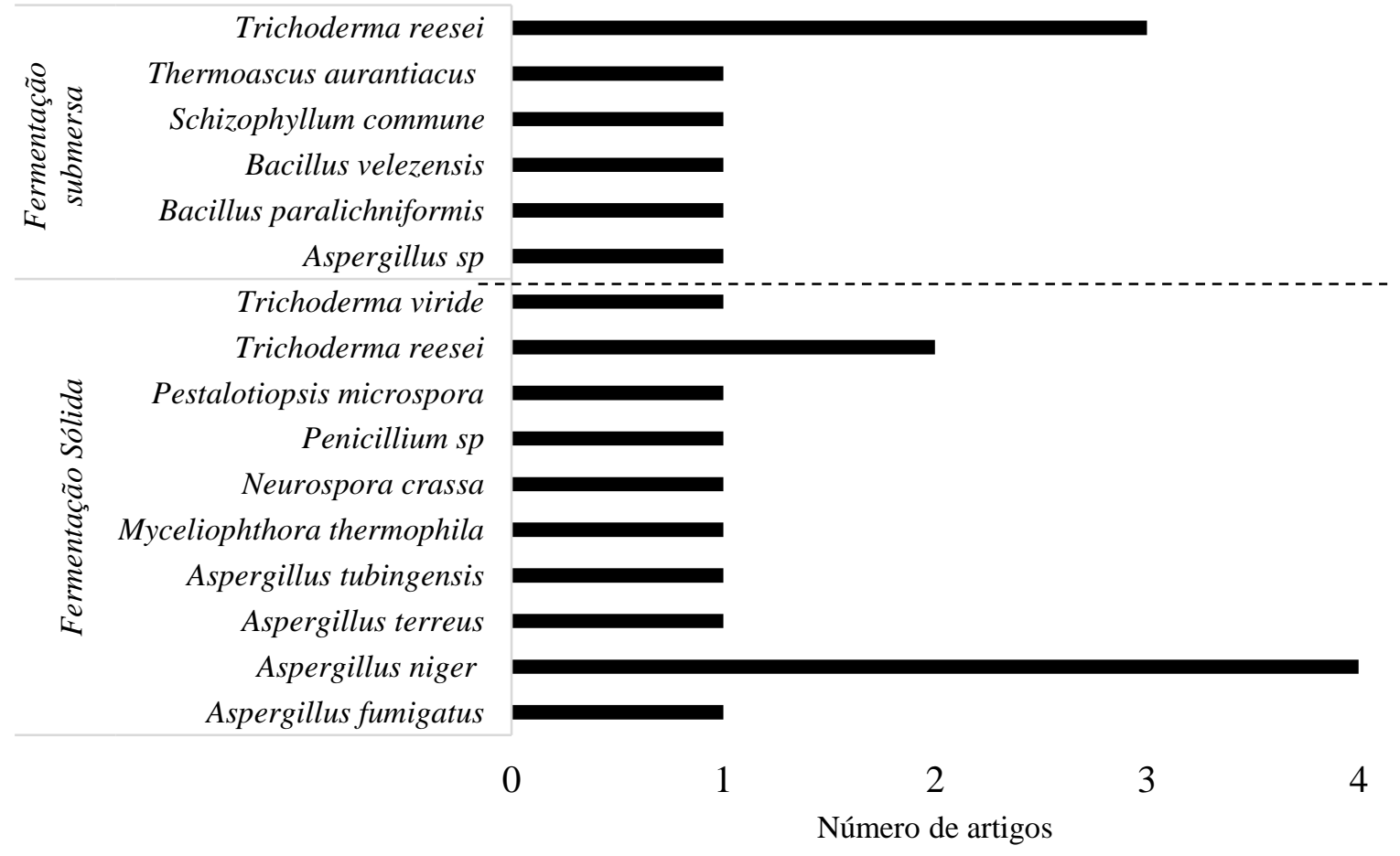

Fonte: Própria (2020).

No que se refere a utilização de microrganismos para processos fermentativos sólidos (FES) e submersos (FS), há uma notável variedade de espécies microbianas, como indicado na Figura 02.

Nos artigos selecionados na presente revisão ambos os processos apresentam maior número $(\mathrm{n}=19)$ de estudos utilizando fungos filamentosos, enquanto o uso de bactérias foi observado somente para a fermentação submersa $(n=2)$. Nos estudos de fermentação em estado 
sólido houve uma maior utilização do microrganismo A. niger $(\mathrm{n}=4)$, enquanto no processo de fermentação submersa o microrganismo mais utilizado foi o T. reesei $(\mathrm{n}=3)$

As cepas fúngicas A. niger e T. ressei tem-se mostrado importantes produtores de celulase, pela sua alta produtividade e aplicabilidade segura (ZNAMEROSKI et al. 2012). Alguns estudos apontam que fermentação submersa tem sido tradicionalmente bem-sucedida para a produção de celulase por meio de T. reesei em substratos lignocelulósicos (SATEESH et al., 2012; RANA et al., 2014; LI et al., 2016), assim como a fermentação em estado sólido com A. niger empregando substratos celulósicos (SANTOS et al., 2018), pelo seu rápido desenvolvimento e multiplicação farta de esporos (BLASZCZYK et al., 2014).

Os substratos selecionados pelos estudos são resíduos lignocelulósicos, como pode-se observar pela Figura 02:

Figura 02: Substratos utilizados para produção de celulase nas fermentações em estado sólido e submerso nos artigos selecionados com período de publicação entre os anos de 2018 a 2020.

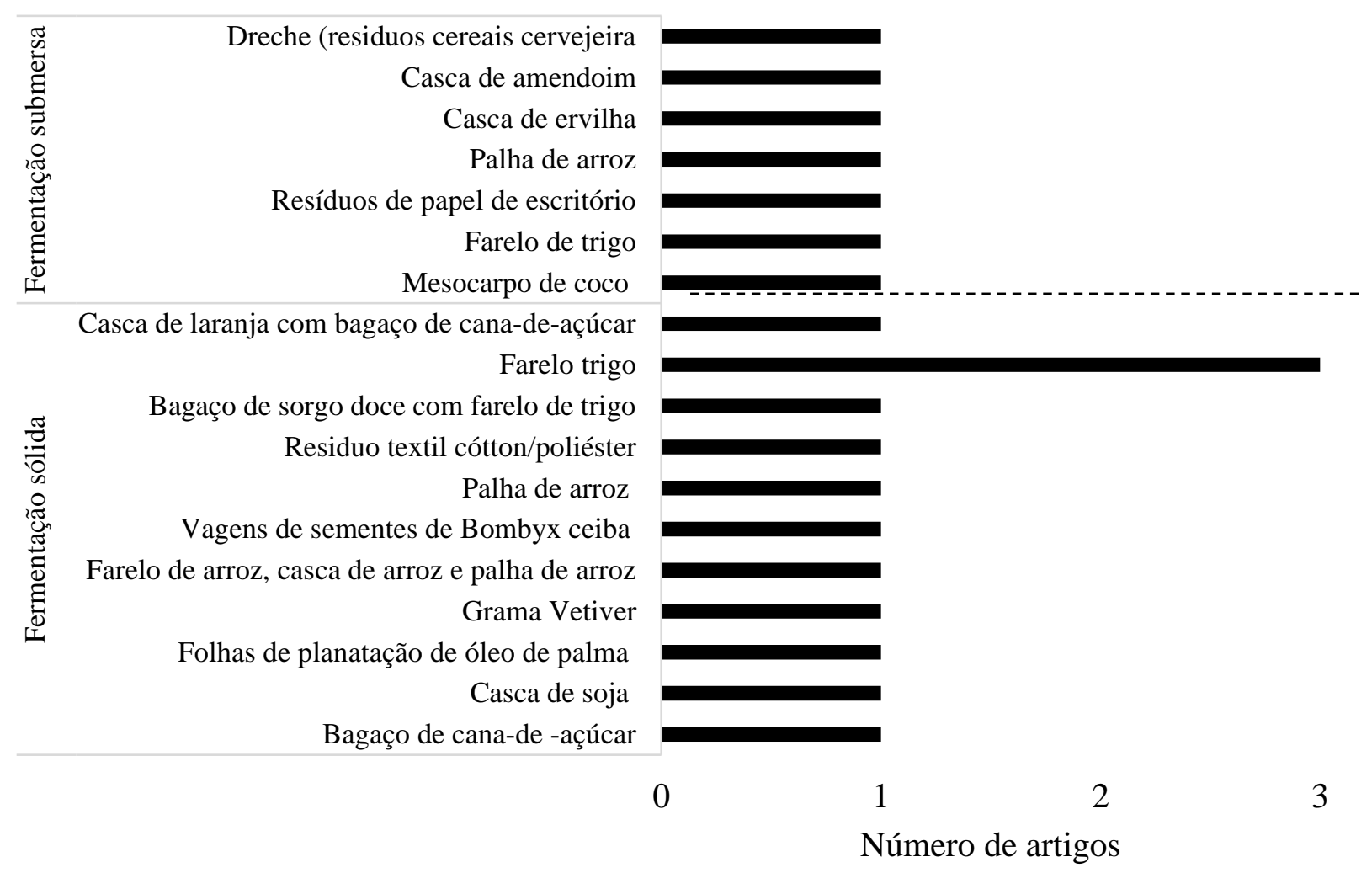

Fonte: Própria (2020).

Sabendo que a celulase é uma enzima indutiva, os substratos escolhidos para a fermentação são de extrema importância para a produção enzimática. Embora os resíduos sólidos sejam mais utilizados para a fermentação em estado sólido, nota-se que nos estudos 
selecionados para a revisão tanto para a FES quanto para a FS foram executadas a partir dos mesmos, como demonstrado na Figura 02.

Resíduos são uma alternativa promissora para redução de custos e aumento da sustentabilidade nos processos fermentativos para produção de enzimas celulase (SALAZAR et al., 2019). Estes resíduos são compostos pela chamada biomassa lignocelulósica, que apresentam, por sua vez, uma composição de aproximadamente 40-50\% de celulose, 25-30\% de hemicelulose e 15-20\% de lignina (ZHOU et al., 2017). Neste contexto, devido ao seu rico conteúdo orgânico, baixo custo e alta disponibilidade, os resíduos agrícolas podem ser substratos ideais para a fermentação microbiana (FALKOSKI et al., 2013; EL-BAKRY et al., 2015).

A FS (n=7) exibe, de acordo com a Figura 2, distintos tipos de resíduos, sendo eles resíduos agroindustriais $(n=6)$ e resíduos industrial $(n=1)$, resíduo de papel de escritório $(n=1)$. O artigo 5 de FS não foi incluído para esta análise, pois não apresentou o substrato usado em seu estudo. Para a FES (n=13), também é possível notar que uma maior parte dos substratos são resíduos agroindustriais $(n=12)$ e apenas um é resíduo industrial, resíduo têxtil de cótton/poliéster. Porém o resíduo de farelo de trigo é utilizado em maior quantidade, tanto individualmente $(n=3)$ quanto para misturas $(n=1)$, este mesmo acontecimento é verificado para o bagaço de cana-de-açúcar $(\mathrm{n}=2)$.

Ainda que a FS utilize resíduos agrícolas sólidos na sua composição do meio, para a disponibilidade de celulose (CEKMECELIOGLU e DEMIRCI, 2020), sua proporção será sempre reduzida, levando em consideração que este terá que ser combinado com um outro meio líquido (IRFAN et al., 2019). Já a FES os resíduos serão utilizados sem esta diluição, portanto a disponibilidade de celulose para a produção de celulase será maior (NAZIR et al., 2019).

Dentre os resíduos, o mais utilizado foi o farelo de trigo, que possui características em sua composição que o fazem um excelente indutor para produção de celulase, como os elevados níveis de proteínas (13-19\%) e hemicelulose (3-6\%), celulose (11\%) juntamente a um baixo teor de lignina (3-6\%) (FALKOSKI et al., 2013; CERDA et al., 2017; VERMA e KUMAR 2019). Ainda é possível notar que todos os 21 estudos foram combinados os substratos a uma solução nutriente que também auxiliarão na disposição de nutrientes para os microrganismos, sendo a mais utilizada pelos estudos a de Mendel $\left(\mathrm{KH}_{2} \mathrm{PO}_{4},\left(\mathrm{NH}_{4}\right)_{2} \mathrm{SO}_{4}, \mathrm{CO}\left(\mathrm{NH}_{2}\right)_{2}\right.$, $\mathrm{MgSO}_{4} .7 \mathrm{H}_{2} \mathrm{O}, \mathrm{CaCl}_{2}, \mathrm{FeSO}_{4} .7 \mathrm{H}_{2} \mathrm{O}, \mathrm{MnSO}_{4} \cdot \mathrm{H}_{2} \mathrm{O}, \mathrm{CoCl}_{2}, \mathrm{ZnSO}_{4} .7 \mathrm{H}_{2} \mathrm{O}$ ), alguns estudos a pontam alta utilização dessa solução nutriente pela sua alta eficiência na produção de celulase (MARTINS et al., 2007; SUN et al., 2018; CAMASSOLA et al., 2010). 
Diante dos artigos selecionados observou-se uma grande variação no tipo de microrganismo e substrato utilizado para a produção de celulase. Os microrganismos que mais se destacaram foram Aspergillus niger e Trichoderma reesei para as FES e FS, respectivamente. Os substratos mais empregados foram os resíduos agroindustriais, evidenciando-se o farelo do trigo. Quanto a temperatura, observou-se que a maioria dos artigos estudados estabeleceram a temperatura entre $30-35^{\circ} \mathrm{C}(\mathrm{n}=9)$ para FS e para FES $(\mathrm{n}=7)$. Os valores de $\mathrm{pH}$ utilizados nos estudos foram próximos de $\mathrm{pH}$ 5,0, não apresentando grandes diferenças entre a FS e FES.

Importante destacar que tanto para a FES quanto para a FS, o microrganismo Trichoderma reesei foi utilizado demonstrando que ele tem facilidade no crescimento em ambos os tipos de condução de fermentação. A utilização de substrato também apresentou uma grande variedade podendo estar relacionada com o tipo do microrganismo e as condições de fermentação utilizadas, o que demonstra uma grande diversidade de subprodutos agroindustriais que podem ser reutilizados para produção de celulase.

\section{REFERENCIAS}

ABDULLAH, Abdullah et al. Optimization of cellulase production by Aspergillus niger ITBCC L74 with bagasse as substrate using response surface methodology. HAYATI Journal of Biosciences, v. 25, n. 3, p. 115-115, 2018.

ABU YAZID, NORAZIAH et al. Solid-state fermentation as a novel paradigm for organic waste valorization: a review. Sustainability, v. 9, n. 2, p. 224, 2017.

ARUN, H. K. Global Markets for Enzymes in Industrial Applications (Report Highlights. BCC Research. Disponível em: < https://www.bccresearch.com/marketresearch/biotechnology/global-markets-for-enzymes-inindustrial-applications.html>.Acesso em: 28 outubro 2020. (2017) 1-184.

BAHRAMIAN, SAMIRA et al. Optimization of enzymatic extraction of sugars from Kabkab date fruit. Middle East J. Sci. Res., v. 7, p. 211-216, 2011.

BEHERA, SUDHANSHU S.; RAY, RAMESH C. Solid state fermentation for production of microbial cellulases: recent advances and improvement strategies. International journal of biological macromolecules, v. 86, p. 656-669, 2016.

BLASZCZYK, LMSKS et al. Trichoderma spp.-application and prospects for use in organic farming and industry. Journal of plant protection research, v. 54, n. 4, 2014.

CAMASSOLA, MARLI; DILLON, ALDO JP. Cellulases and xylanases production by Penicillium echinulatum grown on sugar cane bagasse in solid-state fermentation. Applied biochemistry and biotechnology, v. 162, n. 7, p. 1889-1900, 2010. 
CEKMECELIOGLU, DENIZ; DEMIRCI, ALI. Production of cellulase and xylanase enzymes using distillers dried grains with solubles (DDGS) by Trichoderma reesei at shake-flask scale and the validation in the benchtop scale bioreactor. Waste and Biomass Valorization, p. 1-10, 2020.

CERDA, ALEJANDRA et al. Cellulase and xylanase production at pilot scale by solid-state fermentation from coffee husk using specialized consortia: The consistency of the process and the microbial communities involved. Bioresource technology, v. 243, p. 1059-1068, 2017.

CUNHA, F. M. et al. Liquefaction of sugarcane bagasse for enzyme production. Bioresource technology, v. 172, p. 249-252, 2014.

CUNHA, F. M. et al. Sequential solid-state and submerged cultivation of Aspergillus niger on sugarcane bagasse for the production of cellulase. Bioresource technology, v. 112, p. 270-274, 2012.

DA SILVA, ISADORA FERREIRA et al. High-yield cellulase and LiP production after SSF of agricultural wastes by Pleurotus ostreatus using different surfactants. Biocatalysis and Agricultural Biotechnology, v. 22, p. 101428, 2019.

DARABZADEH, NAZANIN; HAMIDI-ESFAHANI, ZOHREH; HEJAZI, PARISA. Optimization of cellulase production under solid-state fermentation by a new mutant strain of Trichoderma reesei. Food science \& nutrition, v. 7, n. 2, p. 572-578, 2019.

DE ABREU, JÉSSICA ALINE SOARES; ROVIDA, AMANDA FLÁVIA DA SILVA; PAMPHILE, JOÃO ALENCAR. Fungos de interesse: aplicações biotecnológicas. Revista UNINGÁ Review, v. 21, n. 1, 2015.

DEY, PINAKI et al. Improved production of cellulase by Trichoderma reesei (MTCC 164) from coconut mesocarp-based lignocellulosic wastes under response surface-optimized condition. 3 Biotech, v. 8, n. 9, p. 1-13, 2018.

EL-BAKRY, MAMDOUH et al. From wastes to high value added products: novel aspects of SSF in the production of enzymes. Critical Reviews in Environmental Science and Technology, v. 45, n. 18, p. 1999-2042, 2015.

FALKOSKI, DANIEL LUCIANO et al. Chrysoporthe cubensis: a new source of cellulases and hemicellulases to application in biomass saccharification processes. Bioresource technology, v. 130, p. 296-305, 2013.

FLORENCIO, CAMILA et al. Desafios relacionados à produção e aplicação das enzimas celulolíticas na hidrólise da biomassa lignocelulósica. Química Nova, v. 40, n. 9, 2017.

GOMES, ARTHUR FILIPE SOUSA et al. Substract and temperature effect on xylanase production by Aspergillus fumigatus using low cost agricultural wastes. Bioscience Journal, v. 32, n. 4, 2016.

GOUKANAPALLE, PRAVEEN KUMAR REDDY et al. Optimization of cellulase production by a novel endophytic fungus Pestalotiopsis microspora TKBRR isolated from Thalakona forest. Cellulose, v. 27, p. 6299-6316, 2020. 
HU, YUNZI et al. Optimisation of fungal cellulase production from textile waste using experimental design. Process Safety and Environmental Protection, v. 118, p. 133-142, 2018.

IRFAN, M. et al. Utilization of peanut shells as substrate for cellulase production in submerged fermentation through Box-Behnken Design. International Journal of Biology and Chemistry, v. 12, n. 2, p. 28-39, 2020.

KASANA, RAMESH C.; GULATI, ARVIND. Cellulases from psychrophilic microorganisms: a review. Journal of basic microbiology, v. 51, n. 6, p. 572-579, 2011.

KUHAD, RAMESH CHANDER et al. Revisiting cellulase production and redefining current strategies based on major challenges. Renewable and Sustainable Energy Reviews, v. 55, p. 249-272, 2016.

KUMAR, ANIL et al. Production of cellulolytic enzymes by Myceliophthora thermophila and their applicability in saccharification of rice straw. Biomass Conversion and Biorefinery, $p$. $1-14,2020$.

KUMAR, BIKASH et al. Production, purification and characterization of an acid/alkali and thermo tolerant cellulase from Schizophyllum commune NAIMCC-F-03379 and its application in hydrolysis of lignocellulosic wastes. AMB Express, v. 8, n. 1, p. 1-16, 2018.

LI, YONGHAO et al. Overproduction of cellulase by Trichoderma reesei RUT C30 through batch-feeding of synthesized low-cost sugar mixture. Bioresource technology, v. 216, p. 503$510,2016$.

LIMAYEM, ALYA, and STEVEN C. RICKE. "Lignocellulosic biomass for bioethanol production: current perspectives, potential issues and future prospects." Progress in Energy and Combustion Science 38.4 (2012): 449-467.

LIU, JIAWEN et al. Comparative characterization of extracellular enzymes secreted by Phanerochaete chrysosporium during solid-state and submerged fermentation. International journal of biological macromolecules, v. 152, p. 288-294, 2020.

MARTINS, LEONARDO FARIA et al. Comparison of Penicillium echinulatum and Trichoderma reesei cellulases in relation to their activity against various cellulosic substrates. Bioresource technology, v. 99, n. 5, p. 1417-1424, 2008.

MONDAL, Subhadeep et al. Contemporaneous synthesis of multiple carbohydrate debranching enzymes from newly isolated Aspergillus fumigatus SKF-2 under solid state fermentation: A unique enzyme mixture for proficient saccharification of plant bioresources. Industrial Crops and Products, v. 150, p. 112409, 2020.

MONTEIRO, VALDIRENE NEVES; DO NASCIMENTO SILVA, ROBERTO. Aplicações industriais da biotecnologia enzimática. Revista processos químicos, v. 3, n. 5, p. 9-23, 2009.

NAIR, ANU SADASIVAN et al. Waste office paper: a potential feedstock for cellulase production by a novel strain Bacillus velezensis ASN1. Waste management, v. 79, p. 491-500, 2018. 
NAZIR, SOBIA et al. Utilization of Bombyx ceiba Seed Pods: A novel substrate for cellulase production through solid state fermentation using response surface methodology. Punjab University Journal of Zoology, v. 34, n. 2, p. 213-219, 2019.

RAMAMOORTHY, NAVNIT KUMAR; SAMBAVI, T. R.; RENGANATHAN, SAHADEVAN. A study on cellulase production from a mixture of lignocellulosic wastes. Process Biochemistry, v. 83, p. 148-158, 2019.

RANA, VANDANA et al. On-site enzymes produced from Trichoderma reesei RUT-C30 and Aspergillus saccharolyticus for hydrolysis of wet exploded corn stover and loblolly pine. Bioresource technology, v. 154, p. 282-289, 2014.

RAWAT, REKHA et al. Generating fermentable sugars from rice straw using functionally active cellulolytic enzymes from Aspergillus niger HO. Energy \& Fuels, v. 28, n. 8, p. 50675075, 2014.

ROVEDA, MIRELA; HEMKEMEIER, MARCELO; COLLA, LUCIANE MARIA. Avaliação da produção de lipases por diferentes cepas de microrganismos isolados em efluentes de laticínios por fermentação submersa. Food Science and Technology, v. 30, n. 1, p. 126-131, 2010.

SADH, PARDEEP KUMAR; DUHAN, SUREKHA; DUHAN, JOGINDER SINGH. Agroindustrial wastes and their utilization using solid state fermentation: a review. Bioresources and Bioprocessing, v. 5, n. 1, p. 1-15, 2018.

SALAZAR, LUDMILA NOSKOSKI et al. Production, Partial Characterization and Application of Cellulases by Newly Isolated Penicillium sp. Using Agro-Industrial Substrate Solid-State Fermentation. Industrial Biotechnology, v. 15, n. 2, p. 79-88, 2019.

SANTOS, PRISCILA SOUZA DOS et al. Fermentação em estado sólido em resíduos agroindustriais para a produção de enzimas: uma revisão sistemática. The Journal of Engineering and Exact Sciences - JCEC, V. 4, N. 2, p. 1-12, 2018.

SATEESH, LANKA et al. Simultaneous cellulase production, saccharification and detoxification using dilute acid hydrolysate of S. spontaneum with Trichoderma reesei NCIM 992 and Aspergillus niger. Indian Journal of Microbiology, v. 52, n. 2, p. 258-262, 2012.

SHARMA, REETIKA et al. Improved Production of Multi-component Cellulolytic Enzymes Using Sweet Sorghum Bagasse and Thermophilic Aspergillus terreus RWY Through Statistical Process Optimization. Waste and Biomass Valorization, p. 1-15, 2019.

SHAWKY, BAHAA T. et al. Optimization of Cellulolytic enzymes production from local potent fungi using full factorial design for bioethanol production from MFEX-treated rice straw using Klebsiella oxytoca P2. BIOSCIENCE RESEARCH, v. 15, n. 1, p. 250-261, 2018.

SHELDON, ROGER A.; VAN PELT, SANDER. Enzyme immobilisation in biocatalysis: why, what and how. Chemical Society Reviews, v. 42, n. 15, p. 6223-6235, 2013.

SILVA, A. F. V. et al. Cellulase production to obtain biogas from passion fruit (Passiflora edulis) peel waste hydrolysate. Journal of Environmental Chemical Engineering, v. 7, n. 6, p. 103510, 2019. 
SINGH, ANITA et al. Optimization of cellulolytic enzyme production by thermophilic fungus Thermoascus aurantiacus using response surface methodology. Indian Journal of Biochemistry and Biophysics (IJBB), v. 56, n. 5, p. 399-403, 2019.

SINGHANIA, REETA RANI et al. Advancement and comparative profiles in the production technologies using solid-state and submerged fermentation for microbial cellulases. Enzyme and Microbial Technology, v. 46, n. 7, p. 541-549, 2010.

SIROHI, RANJNA et al. Cellulase production from pre-treated pea hulls using Trichoderma reesei under submerged fermentation. Waste and Biomass Valorization, v. 10, n. 9, p. 2651$2659,2019$.

SOARES, IZABEL APARECIDA et al. Identificação do potencial amilolítico de linhagens mutantes do fungo filamentoso Aspergillus nidulans. Food Science and Technology, v. 30, n. 3, p. 700-705, 2010.

SOCCOL, CARLOS RICARDO et al. Recent developments and innovations in solid state fermentation. Biotechnology Research and Innovation, v. 1, n. 1, p. 52-71, 2017.

SUBSAMRAN, KHAJEEWAN et al. Potential use of vetiver grass for cellulolytic enzyme production and bioethanol production. Biocatalysis and Agricultural Biotechnology, v. 17, p. 261-268, 2019.

SUN, WEI-CHENG; CHENG, CHUNG-HSIEN; LEE, WEN-CHIEN. Protein expression and enzymatic activity of cellulases produced by Trichoderma reesei Rut C-30 on rice straw. Process Biochemistry, v. 43, n. 10, p. 1083-1087, 2008.

SUTO, MANABU; TOMITA, FUSAO. Induction and catabolite repression mechanisms of cellulase in fungi. Journal of bioscience and bioengineering, v. 92, n. 4, p. 305-311, 2001.

TAI, WAN YI et al. Comprehensive studies on optimization of cellulase and xylanase production by a local indigenous fungus strain via solid state fermentation using oil palm frond as substrate. Biotechnology progress, v. 35, n. 3, p. e2781, 2019.

THOMAS, LEYA; LARROCHE, CHRISTIAN; PANDEY, ASHOK. Current developments in solid-state fermentation. Biochemical Engineering Journal, v. 81, p. 146-161, 2013.

VERMA, NITIN; KUMAR, VIVEK. Application of Box-Behnken design for the optimization of cellulase production under solid-state fermentation. SN Applied Sciences, v. 1, n. 12, p. 1$10,2019$.

VERMA, NITIN; KUMAR, VIVEK. Impact of process parameters and plant polysaccharide hydrolysates in cellulase production by Trichoderma reesei and Neurospora crassa under wheat bran based solid state fermentation. Biotechnology Reports, v. 25, p. e00416, 2020.

YOON, LI WAN et al. Fungal solid-state fermentation and various methods of enhancement in cellulase production. Biomass and bioenergy, v. 67, p. 319-338, 2014.

ZHOU, WENTING et al. Feasibility of lipid production from waste paper by the oleaginous yeast Cryptococcus curvatus. BioResources, v. 12, n. 3, p. 5249-5263, 2017. 
ZNAMEROSKI, ELIZABETH A. et al. Induction of lignocellulose-degrading enzymes in

Neurospora crassa by cellodextrins. Proceedings of the National Academy of Sciences, v. 109, n. 16, p. 6012-6017, 2012. 


\title{
CAPÍTULO 08: CERVEJA ARTESANAL: COMPONENTES E PROCESSOS PRODUTIVOS
}

\section{CAPÍTULO 08: CERVEZA ARTESANAL: COMPONENTS Y PROCESOS DE PRODUCCIÓN}

\section{CHAPTER 08: CRAFT BEER: COMPONENTS AND PRODUCTION PROCESSES}

\author{
Higo Moreira de Assis ${ }^{1}$; Mônica Tejo Cavalcanti²; Mônica Correia Gonçalves ${ }^{3}$; Thamirys Lorranne Santos \\ Lima $^{4}$; Inês Maria Barbosa Nunes Queiroga ${ }^{5}$
}

DOI: https://doi.org/10.31692/978-65-88970-19-5.113-132

\begin{abstract}
RESUMO
A cerveja está presente em diversas culturas de diferentes países movimentando milhões anualmente e é uma bebida obtida a partir da fermentação alcoólica do mosto cervejeiro oriundo do malte de cevada, água potável e adição de lúpulo, por ação de leveduras, adicionados ou não de adjuntos, podendo ser produzida em diversos sabores e de formas variadas. Portanto, objetivou-se com esta pesquisa, realizar um levantamento bibliográfico à cerca da cerveja artesanal, como forma de compreender o processo de elaboração e seus respectivos constituintes. Esta pesquisa é de caráter exploratório e bibliográfico, onde realizou-se uma busca relacionada ao tema nos buscadores de maior facilidade de acesso. Este estudo foi estruturado em tópicos específicos, onde foi abordado desde a origem da cerveja até os componentes necessários para elaboração. Ademais, constatou-se neste estudo que geralmente, as cervejas artesanais possuem uma qualidade sensorial diferenciada quando comparadas as cervejas tradicionais. As cervejas populares têm o intuito de agradar à grande maioria dos consumidores de maneira mais barata possível, e conseguir manter um nível e padrão de qualidade invejável por qualquer empresa, devido ao controle que têm dos processos de produção, distribuição, etc. Enquanto as artesanais, têm o intuito de agradar um público restrito, no qual estão à procura de cervejas com características sensoriais diferenciadas das demais. Por fim, torna-se viável o conhecimento das questões que envolvem as principais características da cerveja artesanal, bem como do processo produtivo, como forma de promover o amplo acesso ao público consumidor de informações desta natureza, já que as cervejas são produtos altamente consumidos pela população em geral.
\end{abstract}

Palavras-Chave: Bebidas, Fermentação, Lúpulo, Mosto.

\section{RESUMEN}

La cerveza está presente en varias culturas en diferentes países, moviendo millones anualmente y es una bebida que se obtiene de la fermentación alcohólica del mosto cervecero a partir de malta de cebada, agua de bebida y la adición de lúpulo, mediante la acción de levaduras, agregadas o no con adyuvantes se puede producir en diferentes sabores y de diferentes formas. Por tanto, el objetivo de esta investigación fue realizar un relevamiento bibliográfico sobre la cerveza artesanal, como una forma de entender el proceso de elaboración y sus respectivos constituyentes. Esta investigación es de carácter exploratorio y bibliográfico, donde se realizó una búsqueda relacionada con la temática en buscadores de más fácil acceso. Este estudio se estructuró en temas específicos, donde se abordó desde el origen de la cerveza hasta los componentes necesarios para su elaboración. Además, en este estudio se encontró que las cervezas artesanales generalmente tienen una calidad sensorial diferenciada en comparación con las cervezas tradicionales. Las cervezas populares están destinadas a complacer a la gran mayoría de los consumidores de la manera más barata posible, y mantener un nivel y estándar de calidad envidiable para cualquier empresa, debido al control que tienen de los procesos de producción, distribución, etc. Si bien son artesanales, están destinadas a complacer a un público restringido, en el que buscan cervezas

\footnotetext{
${ }^{1}$ Bacharel em Química Industrial, UEPB-Campina Grande, higomoreira.assis@ gmail.com

${ }^{2}$ Doutora em Engenharia de Processos, UFCG-Pombal, monicatejoc@yahoo.com.br

${ }^{3}$ Doutora em Ciência e Tecnologia dos Alimentos, UFCG-Pombal, mnygoncalvez@gmail.com

${ }^{4}$ Docente do Curso Técnico Integrado em Alimentos, IFRN-Pau dos Ferros, thamirys.lorranne@ifrn.edu.br

${ }^{5}$ Doutora em Ciência e Tecnologia dos Alimentos, UFCG-Pombal, inesmaria@leaosampaio.edu.br
} 
con características sensoriales diferenciadas de las demás. Finalmente, se vuelve viable conocer los temas que rodean las principales características de la cerveza artesanal, así como el proceso de producción, como una forma de promover un amplio acceso al público que consume información de esta naturaleza, ya que las cervezas son productos altamente consumidos por población general.

Palabras Clave: Bebidas, Fermentación, Lúpulo, Mosto.

\begin{abstract}
Beer is present in several cultures in different countries, moving millions annually and is a drink obtained from the alcoholic fermentation of the brewing must from barley malt, drinking water and the addition of hops, through the action of yeasts, whether or not added with adjuncts, It can be produced in different flavors and in different ways. Therefore, the objective of this research was to carry out a bibliographic survey about craft beer, as a way to understand the process of elaboration and its respective constituents. This research is exploratory and bibliographic in nature, where a search related to the theme was carried out in search engines that are easier to access. This study was structured in specific topics, where it was addressed from the origin of the beer to the components necessary for elaboration. Furthermore, it was found in this study that artisanal beers generally have a differentiated sensory quality when compared to traditional beers. Popular beers are intended to please the vast majority of consumers in the cheapest way possible, and to maintain an enviable level and standard of quality for any company, due to the control they have of the production, distribution, etc. processes. While handcrafted, they are intended to please a restricted audience, in which they are looking for beers with differentiated sensory characteristics from the others. Finally, it becomes viable to know the issues surrounding the main characteristics of craft beer, as well as the production process, as a way of promoting wide access to the public that consumes information of this nature, since beers are products that are highly consumed by general population.
\end{abstract}

Keywords: Drinks, Fermentation, Hops, Must.

\title{
INTRODUÇÃO
}

De acordo com Decreto $n^{0}$ 6.871, de 4 de Junho de 2009, o Art. 36 define cerveja como "a bebida obtida pela fermentação alcoólica do mosto cervejeiro oriundo do malte de cevada e água potável, por ação da levedura, com adição de lúpulo" (BRASIL, 2009). A cerveja é vista como sendo a bebida alcoólica mais antiga (ARNOLD, 2005) e mais consumida (PATTINSON, 2006) no mundo. A mesma é produzida em diversos sabores e de formas variadas, obtida a partir da fermentação alcoólica do mosto cervejeiro oriundo do malte de cevada, água potável e adição de lúpulo, por ação de leveduras, podendo ainda ser adicionada de adjuntos (DINSLAKEN, 2016).

Produzindo cerca de 138,6 Mi hl/ano, o Brasil é atualmente o $3^{\circ}$ maior produtor de cerveja no mundo. A produção de cervejas artesanais vem crescendo com o passar dos anos, em 2017 cerca de $20 \%$ da produção nacional foi oriunda de cervejarias artesanais, situando o Brasil como um dos maiores fabricantes do mundo (SEBRAE, 2017; ASSIS et al., 2020). O mercado consumidor tem-se manifestado cada vez mais exigente no que diz respeito a requalificação e a reorganização na produção de bens de consumo, esse comportamento reflete diretamente sobre a produção recursos na busca or atender a demanda elucidada (MELO; SILVA, 2020). Tais preocupações são enfrentadas pelo setor de produção de cerveja, visto que as oportunidades demandam a constante busca por aperfeiçoamento dos produtos ofertados. dos requisitos nos projetos de produto. 
Segundo Ferreira et al. (2018) a produção e o consumo de cervejas artesanais no Brasil são singularizados a consumidores mais exigentes em termos de qualidade sensorial, entretanto, o produto entregue é diferenciado e o investimento na otimização dos processos de obtenção tem-se demonstrado menos oneroso. O sucesso é garantido por fatores como inovação, criatividade, tipicidade e autenticidade que caracterizam a cerveja artesanal como uma experiência que oferece prazer, senso de identidade e pertencimento, e reconhecimento social, além de cores, aromas, sons e sabores diferenciados (FERREIRA et a., 2019; KOCK \& SAUERBRONN; 2018).

Para a obtenção da cerveja, a matéria-prima utilizada é processada através da malteação e submetida à ambientes artificiais de germinação, passando pelos estágios de limpeza, maceração, germinação e secagem. Com o malte seco e limpo está pronto para utilizar no processo de fabricação da cerveja (PORTO, 2011). O Humulus lupulus, conhecido vulgarmente como Lúpulo, planta trepadeira pertencente à família da morácea e originária de zonas temperadas é utilizado para atribuir o sabor amargo da produção de cerveja. Inserido pela primeira vez na idade média, o Lúpulo, atualmente é considerado em nível mundial, como matéria-prima primordial para a fabricação de cerveja. Segundo o mesmo autor, no Brasil, o mercado cervejeiro é basicamente dividido entre as microcervejarias e as cervejarias de produção em massa, apesar de se discutir a inclusão de novas divisões visando diferenciar as cervejarias de porte intermediário (MARCUSSO, 2015).

Em seu processo de produção são utilizados não apenas ingredientes básicos de fabricação (água, malte, lúpulo e levedura), como também iguarias como café, pimenta, banana, gengibre, entre outros condimentos, gerando um valor agregado à cerveja (ALMEIDA \& BELO, 2017). As cervejarias artesanais, além de terem sua importância econômica, social e cultural, têm se mostrado uma excelente opção de negócio no atual cenário econômico brasileiro e apesar de representarem uma fatia de mercado relativamente pequena quando comparado aos grandes líderes, esse setor de cervejas especiais artesanais, oriundas desse nicho de mercado vem crescendo mais do que o setor das cervejas voltadas para as grandes massas populacionais (ASSIS et al., 2020).

Diante deste contexto, objetivou-se com esta pesquisa, realizar um levantamento bibliográfico à cerca da cerveja artesanal, como forma de compreender o processo de elaboração e seus respectivos constituintes.

\section{METODOLOGIA}

O delineamento desta pesquisa caracterizou-se como uma revisão sistemática, baseando-se em pesquisas por artigos científicos atuais em periódicos científicos indexados ao Portal de Periódicos da Coordenação de Aperfeiçoamento de Pessoal de Nível Superior (CAPES), no Google Acadêmico, na Scientific Electronic Library Online (SciELO), e na Science Direct. Os critérios de inclusão foram trabalhos publicados em português ou inglês, 
artigos na íntegra indexados nos referidos bancos de dados entre 2010 e 2020, utilizando os descritores: “origem da cerveja artesanal”, "situação mercadológica da cerveja artesanal”, “produção de cerveja artesanal". Foi utilizado como critério de exclusão artigos que não contemplassem a temática.

\section{RESULTADOS E DISCUSSÃO}

\section{Origem da Cerveja e Cerveja Artesanal}

Cerevisia ou cervisia é a denominação mais próxima da atualmente conhecida cerveja.Éo nome latino dado pelos gauleses à bebida feita de cevada e de cereais, em homenagem à Ceres, deusa da colheita e da fertilidade (MORADO, 2009). A cerveja é uma das bebidas alcoólicas mais populares do mundo por causa da sua disponibilidade, capacidade nutricional, refrescância, baixa potência de embriaguez e baixo custo (MORADO, 2015).

O mais antigo código referente à produção de cerveja é a Lei da Pureza (Reinheitsgebot), onde relatava que a cerveja devesse ser produzida somente com água, malte, lúpulo e levedura, instituída por Guilherme IV, Duque da Baviera, no dia 23 de abril de 1516. Hoje, é empregado o uso de outros ingredientes e também alguns aditivos alimentares (KUCK, 2008).

Segundo Dragone, Almeida e Silva (2010), a técnica de fabricação de cerveja é tida como tradição milenar, ocupando espaço na história da humanidade e toda sua evolução. Não se sabe ao certo a origem das primeiras cervejas, porém segundo Kunze (1997) acredita que a prática da cervejaria seja oriunda da região da Mesopotâmia, em que a cevada cresce em estado selvagem. Há registros que evidenciam que a cerveja maltada já era produzida na Babilônia em6000 a.C, embora foram os sumérios considerados como a primeira civilização a fabricar a cerveja. E, após a queda do império sumério, os babilônios aprimoraram a tecnologia de fabricação da cerveja.

Dragone, Almeida e Silva (2010) ressaltam que a prática de tomar cerveja no Brasil foi trazida por D. João VI, no início do século XIX, durante a permanência da Família Real Portuguesa em território brasileiro, época em que a cerveja era importada da Europa. Foi fundada em 1888, na cidade do Rio de Janeiro, a "Manufatura de Cerveja Brahma Villigier e Cia" e, poucos anos depois, em 1891, na cidade de São Paulo, a "Companhia Antarctica Paulista".

No processo de fabricação da cerveja, são utilizados grãos de cevada que passam pelo processo de malteação com a finalidade de produzir as enzimas diastásicas responsável pela 


\section{So/NR' 5
CIAGRO 2021}

conversão do amido (não fermentável) em açúcar (fermentável), nessas circunstâncias o grão de cevada passa a ser chamado de malte (SANTOS; DINHAM, 2006; MATSUBARA et al., 2014).

O sabor da cerveja é determinado pela matéria-prima, pelo tipo de processo e pela levedura utilizada, além dos compostos produzidos durante a fermentação e maturação, que exercem maior impacto nas características sensoriais da bebida (CARVALHO et al., 2007).

A cerveja do tipo Ale é considerado o processo mais antigo de produção de cerveja e passa por alta fermentação. Entre os estilos do tipo Ale, se destacam a Porte, Stout, Brow, Mild e Bitter, em que, geralmente, as cervejas têm cores claras, apresentam sabor de lúpulo acentuado e teor alcoólico entre $4 \%$ e $8 \%$. O tipo Lager é caracterizado pelo sabor suave, coloração clara e teor alcoólico entre 3\% e 4\%, sendo mais comuns e mais consumidas no mundo, inclusive no Brasil, cujas características da bebida são mais adequadas ao nosso clima. As principais variedades do tipo Lager são a Pilsen e a Bock (SIQUEIRA, 2007).

Até o ano de 2015, o Brasil ocupava o terceiro lugar no ranking mundial de produção de cerveja. O Investimento do setor cervejeiro contribuiu fortemente para o desenvolvimento econômico do Brasil, sendo visto como um dos mais relevantes da economia com investimento próximo aos R $\$ 20$ bilhões entre 2010 e 2014. Como possui um importante efeito multiplicador na economia, pode ser visto uma movimentação extensa da cadeia produtiva que foi responsável por 1,6\% do PIB e 14\% da indústria de transformação nacional, além de, gerar mais de 2,2 milhões de pessoas empregadas ao longo da cadeia produtiva (CERVBRASIL, 2015).

O Decreto $\mathrm{n}^{\circ} 6.871$ de 4 de junho de 2009 , que regulamenta a Lei $\mathrm{n}^{\circ} 8.918$ de 14 de julho de 1994, dispõe sobre a padronização, a classificação, o registro, a inspeção e a fiscalização da produção e do comércio de bebidas (BRASIL, 2009).

Ainda em análise, há o Projeto de Lei ${ }^{\circ}$ 5.191/13 proposto pelo Deputado Rogério Peninha Mendonça de Santa Catarina, com o objetivo de regulamentar a produção de cerveja artesanal que objetiva segregar o conceito de cerveja artesanal e definir as instituições que produzem adaptando a legislação para permitir o avanço regulamentado deste setor.

A cervejaria artesanal permite a produção de cerveja em pequena escala para consumo no local ou envasamento do excedente para venda ou consumo em outros locais. O envasamento pode ser feito em barris de aço inoxidável, latas ou garrafas de vidro. As capacidades de produção variam geralmente entre 1000 a 2000 litros por cozimento e o número de cozimentos por semana oscila entre um e cinco (CARVALHO, 2007). 
Água

A água é vista como elemento essencial para a produção da cerveja, representa $90 \%$ da constituição do peso da cerveja, suas características físicas e químicas são de fundamental importância para se obtiver uma cerveja de boa qualidade (MADRID et al., 1996). No Art. 13 do Decreto 6.871 , determina no $\S 7^{\circ}$ que a água destinada à produção de bebida deverá atender ao padrão oficial de potabilidade.

Portanto, antes de sua utilização a mesma deve ser submetida a análises físico-química destacando os parâmetros: de $\mathrm{pH}$, dureza, turbidez, cor, temperatura dentre outras, não importando a fonte que se obteve esse recurso hídrico (BRIGIDO; NETTO, 2006).

Broderick et al. (1977) consideram que a água cervejeira não deve satisfazer somente os requisitos gerais de água potável, mas também os requisitos básicos para assegurar o $\mathrm{pH}$ da massa, a extração do lúpulo, uma boa coagulação na cocção e na fermentação e o devido desenvolvimento da cor, do aroma e do sabor.

Atualmente, a tecnologia permite "calibrar" as propriedades da água conforme as necessidades e a formulação, podendo acentuar sabores maltados e de amargor pela alta concentração de sais de cálcio, magnésio e sulfato (MORADO, 2009). Suas características físico-químicas podem viabilizar ou inviabilizar a produção de determinado estilo de cerveja.

Uma água que precisa de muitas correções de qualidade requer um tratamento mais minucioso, o que irá resultar em um aumento no custo do produto final. Atualmente, as cervejarias tratam a água por osmose reversa para depois acrescentar sais minerais de acordo com o estilo de cerveja a ser fabricado (SANTOS, DINBAM e ADAMES, 2013; EUWA, 2006). É necessário que a fábrica esteja instalada próxima a uma fonte de água de boa qualidade, pois a indústria cervejeira consome grandes volumes de água e também é importante que a fonte utilizada possua água em abundância. Em média, uma indústria cervejeira consome 10 litros de água, para cada litro de cerveja produzido. Os principais parâmetros analisados na água estão dispostos na Tabela 01. 
Tabela 01: Especificações físico-químicas da água para a produção de cerveja

\begin{tabular}{|c|c|c|}
\hline Parâmetro & Umidade & Especificação \\
\hline Aparência & - & Límpida e clara \\
\hline Sabor & - & Insipida \\
\hline Odor & - & Inodoro \\
\hline $\mathrm{pH}$ & $\mathrm{pH}$ & $6,5-8,0$ \\
\hline Cor & $\mathrm{mg} \mathrm{Pt} / \mathrm{L}$ & $0-5$ \\
\hline Turbidez & NTU & Menor que 0,4 \\
\hline Matéria orgânica & $\mathrm{mg} \mathrm{O}_{2}$ cons./L & $0-0,8$ \\
\hline Sólidos dissolvidos totais & $\mathrm{mg} / \mathrm{L}$ & $50-150$ \\
\hline Dureza total & $\mathrm{mg} \mathrm{CaCO}_{3} / \mathrm{L}$ & $18,0-79,0$ \\
\hline Alcalinidade & $\mathrm{mg} \mathrm{CaCO}_{3} / \mathrm{L}$ & $0,8-25,0$ \\
\hline Sulfatos & $\mathrm{mg} \mathrm{SO}_{4} / \mathrm{L}$ & $1-30$ \\
\hline Cloretos & $\mathrm{mg} \mathrm{Cl} / \mathrm{L}$ & $1-20$ \\
\hline Nitratos & $\mathrm{mg} \mathrm{NO}_{3} / \mathrm{L}$ & Ausência \\
\hline Nitritos & $\mathrm{mg} \mathrm{NO}_{2} / \mathrm{L}$ & Ausência \\
\hline Sílica & $\mathrm{mg} \mathrm{SiO}_{2} / \mathrm{L}$ & $1-15$ \\
\hline Cálcio & $\mathrm{mg} \mathrm{Ca}{ }^{2+} / \mathrm{L}$ & $5-22,0$ \\
\hline Magnésio & $\mathrm{mg} \mathrm{Mg}^{2+} / \mathrm{L}$ & $1-6$ \\
\hline Ferro & $\mathrm{mg} \mathrm{Fe} / \mathrm{L}$ & Ausência \\
\hline Alumínio & $\mathrm{mg} \mathrm{Al} / \mathrm{L}$ & Máx. 0,05 \\
\hline Amoníaco & $\mathrm{mg} \mathrm{N} / \mathrm{L}$ & Ausência \\
\hline $\mathrm{CO}_{2}$ livre & $\mathrm{mg} \mathrm{CO}_{2} / \mathrm{L}$ & $0,5-5$ \\
\hline
\end{tabular}

Fonte: REINOLD (2008).

\section{Malte de cevada}

A produção brasileira de cevada para fins cervejeiros está concentrada em três estados da Região Sul do Brasil (MINELLA, 2013). De acordo com Andrade, Mega e Neves (2011), a cevada é uma planta da família das gramíneas e é nativa de climas temperados. Após a colheita, os grãos de cevada são enviados para as maltarias, onde são submetidos à germinação controlada. O malte é a própria cevada germinada. Maltear significa quebrar a dormência do grão (REBELLO, 2009), sendo considerado um processo no qual se obtém a degradação do endosperma dos grãos de cevada, além da acumulação de enzimas ativas nestes grãos (BRIGIDO; NETTO, 2006).

Os principais tipos de cevada utilizados na fabricação de cerveja se diferem pelo número de fileiras de grãos: a de duas e a de seis fileiras. A cevada de duas fileiras contém duas fileiras de grãos na mesma espiga, esta é a mais utilizada, pois é composta de grãos maiores e mais uniformes. Essa mesma se subdivide em dois subgrupos principais: a cevada de haste ereta (Hordeum distichum erectum) e a cevada de haste curta (Hordeum distichum nutans) (CARVALHO, 2007). Somente 15\% dos grãos de cevada se destinam a produção da cerveja, o 
Mundialmente, a cevada é considerada como o quinto grão mais empregado na produção da cerveja, superando outros tipos que também podem ser utilizados, tais como: arroz, milho, trigo e soja. Abaixo são descritas algumas características que explicam a preferência desse cereal que a torna mais adequada para a produção de cerveja do que outros cereais.

Segundo Oliveira (2011): possui alto teor de amido, o que a torna atrativa em termos de custo por ser mais barata e mais fácil de maltear que outros cereais; quando maltada, possui um teor elevado de enzimas que ajudam no processo de fabricação do mosto, principalmente na quebra do amido em açúcares; contém outras proteínas que proporcionam equilíbrio nos efeitos em relação à espuma, ao corpo e a sua estabilidade coloidal; possui teor de lipídios relativamente baixo, o que é vantajoso para a estabilidade de sabor da bebida; processo de malteação inicia a partir da etapa de umidificação dos grãos de cevada, denominada maceração, seguido da etapa de germinação, onde o sistema enzimático do grão que irá agir sobre a reserva de amido do mesmo irá fornecer carbono e energia para o desenvolvimento do embrião. Após isso, o processo atinge um ponto de germinação, então o processo é cessado através de secagem (BOULTON, 2006; PORTO, 2011).

\section{Lúpulo}

O Humulus lupulus, conhecido vulgarmente como Lúpulo, planta trepadeira pertencente à família da morácea e originária de zonas temperadas. É uma planta dióica, que quer dizer que produz flores masculinas e femininas. Na produção de cerveja utilizam-se apenas das flores femininas, que contêm a substância lupulina quando fecundadas, que confere o amargor, aroma e algumas propriedades medicinais (JÚNIOR, VIEIRA e FERREIRA, 2009).

Os compostos ativos de aroma de lúpulo estão presentes nas glândulas das flores fêmeas da planta (Figura 01) e estas, geralmente, apresentam de 4 a $5 \mathrm{~cm}$ de comprimento. O lúpulo constitui-sede óleos essenciais (0,2-3\%), $\beta$-ácidos também chamados lupulonas (1,5-9,5\%) e de $\propto$-ácidos (2,0-16,0\%) (NOONAN, 1996; SILVA; FARIA, 2008), também chamados humulonas. As proporções de cada composto dependem da variedade da planta. 


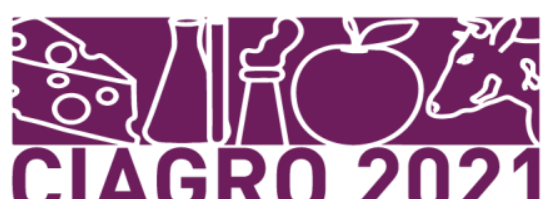

Figura 01: Corte longitudinal das Flores Fêmeas de Lúpulo

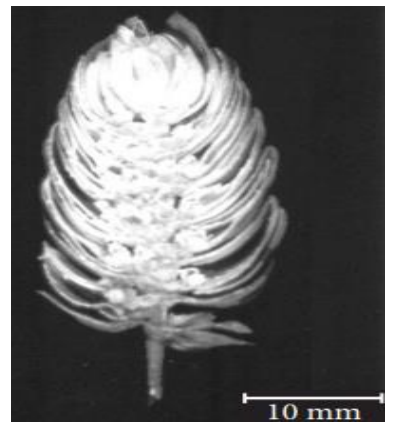

Fonte: SILVA E FARIA (2008).

Os lúpulos podem ser classificados em lúpulo aroma e de amargor. Os óleos essenciais do lúpulo possuem composição bastante complexa, apresentando mais de 200 compostos (SHARP; LAWS, 1981).

Os $\beta$-ácidos contribuem para uma menor intensidade para o amargor. A ação bactericida age no transporte de metabólitos na membrana celular e altera o $\mathrm{pH}$ intracelular, enquanto que os $\alpha$-ácidos são isomerizados através de calor produzindo os iso- $\alpha$-ácidos, que são constituídos principalmente por isohumulona, isocohumulona e isoadhumulona. Com isso, são considerados mais amargos que os ácidos originais não isomerizados, sendo responsáveis por mais de 70\% do amargor detectado sensorialmente em cerveja (SILVA; FARIA,2008). A Tabela 02 apresenta a porcentagem de cada um dos compostos amargos no lúpulo.

Tabela 02: Especificações físico-químicas da água para a produção de cerveja

\begin{tabular}{cccc}
\hline$\propto$-ácidos & Quantidade & $\beta$-ácidos & Quantidade \\
humulona & $35-70 \%$ & humulona & $30-55 \%$ \\
cohumulona & $20-55 \%$ & cohumulona & $20-55 \%$ \\
adhumulona & $10-15 \%$ & adhumulona & $5-10 \%$ \\
prehumulona & $1-10 \%$ & prehumulona & $1-3 \%$ \\
posthumulona & $1-5 \%$ & posthumulona & Valor não identificado \\
\hline
\end{tabular}

Fonte: VARNAM;SUTHERLAND (1997).

O lúpulo é utilizado em pequena quantidade, sendo necessários de 40 a 300 gramas de lúpulo para produzir 100 litros do produto final. Ao contrário do malte, o lúpulo não altera o teor alcoólico nem o corpo da cerveja (MORADO, 2009). Os principais países produtores são Alemanha, Estados Unidos, República Checa, Inglaterra e Nova Zelândia, que produzem mais de $80 \%$ do lúpulo mundial (CARVALHO, 2007).

A Tabela 03 indica a composição química do lúpulo com relação aos principais componentes e as respectivas quantidades. 
Tabela 03: Composição química do lúpulo

\begin{tabular}{cc}
\hline Componente & Quantidade \\
Água & $8-14 \%$ \\
Proteínas & $12-24 \%$ \\
Resinas Totais & $12-21 \%$ \\
Ácidos - alfa & $4-10 \%$ \\
Ácidos - beta & $3-6 \%$ \\
Taninos & $2-6 \%$ \\
Celulose & $10-17 \%$ \\
Cinzas & $7-10 \%$ \\
Óleos essenciais & $0,5-2,0 \%$ \\
\hline
\end{tabular}

Fonte: MORADO (2009).

\section{Levedura}

O fermento é o ingrediente utilizado para realizar o processo fermentativo dos açúcares no mosto cervejeiro. O fermento cervejeiro comumente utilizado para a produção de cervejas é a levedura Saccharomyces, com cepas de alta e baixa fermentação - Ale e Lager, respectivamente (CARVALHO, 2007).

As leveduras são microrganismos eucarióticos, predominantemente unicelulares, pertencentes ao Reino Fungi. Possui habilidade de metabolizar eficientemente os constituintes do mosto, que é um caldo resultante da mistura fervida de malte e água, rico em açúcares fermentáveis. Esse caldo é filtrado, para receber o lúpulo e o fermento ser transformado em álcool e gás carbônico a fim de produzir uma cerveja com qualidade e estabilidade sensorial satisfatória (CARVALHO et al., 2007).

As leveduras mais utilizadas em cervejaria são de duas espécies do gênero Saccharomyces: Saccharomyces cerevisiae (alta fermentação) e Saccharomyces uvarum (baixa fermentação) (EMBRAPA, 2010 apud OLIVEIRA, 2011).

Morado (2009) destaca que por ser fundamental na formação de aromas na cerveja, é de grande importância que a cultura de leveduras seja a mais pura possível, isenta de leveduras "mutantes" e de microrganismos contaminantes (bactérias e leveduras selvagens), sendo indispensável à assepsia das cervejarias durante a produção.

Para Dragone, Almeida e Silva (2010) o tipo de levedura está intrinsecamente ligado às características de sabor e aroma de qualquer cerveja em que é utilizada. Como principal produto da fermentação das leveduras é o álcool e o $\mathrm{CO}_{2}$, no entanto, inúmeros compostos são produzidos em menor proporção, e estes, são de grande importância no sabor da cerveja. A cepa da levedura, a temperatura e o $\mathrm{pH}$ da fermentação, o tipo e a proporção do adjunto quando utilizado e até mesmo o modelo do fermentador e a concentração do mosto são fatores que 
influenciam o sabor da cerveja na etapa de fermentação (KUCK, 2008).

Houg classificou as leveduras de acordo o seu comportamento durante o processo fermentativo, sendo leveduras tipo Lager (ou de baixa fermentação) as que decantam no fundo do fermentador e levedura do tipo Ale (ou alta fermentação) as que tendem a flutuar sobre a superfície do mosto.

\section{Aditivos}

\section{Antioxidantes}

Tem como função evitar a ação do oxigênio, que é o principal fator da deterioração das gorduras dos alimentos. Ao sofrerem transformações, essas gorduras alteram o sabor e odor dos alimentos, tornando-os impróprios para o consumo. A incorporação do oxigênio na bebida faz com que acelere a deterioração do produto (MENDA, 2011).

\section{Acidulantes}

Os acidulantes têm um papel importante, pois colaboram no realce do sabor da bebida, regula a doçura do açúcar, acentuam o sabor ácido, regulam o pH e colaboram na inibição dos microrganismos (MENDA, 2011). Atuam como adjunto de aroma e sabor, largamente encontrados na natureza e disponíveis comercialmente na forma de soluções aquosas que são incolores, inodoras, viscosas e não voláteis (CARVALHO, 2007).

\section{Estabilizantes}

Os estabilizantes mantêm as características físicas das emulsões e suspensões com a finalidade de aumentar a viscosidade. São adicionados às cervejas destinadas ao engarrafamento como ao embarrilamento, ambas são à base de alginatos (MENDES, 2004). Exemplos de estabilizantes são a polivinilpirrolidona (PVP) e a carboximetilcelulose (CMC, um polímero derivado da celulose), ambas solúveis em água (ROSA e AFONSO, 2015).

\section{Antiespumantes}

Agentes antiespumantes, livres de Ferro, Cobalto ou Níquel, atuam regulando a formação de espumas, minimizando a incidência de formação de espuma e também atuando 
como desespumante de ação imediata no processo de fermentação alcoólica. Os fermentadores

de aço comum têm de ser adequadamente revestidos para evitar a contaminação com íons metálicos (FOOD INGREDIENTS BRASIL, 2014).

\section{Processo para a fabricação da cerveja}

O processo de produção de cerveja artesanal está delineado no fluxograma da Figura 03, embora as cervejas de mesma classificação sejam produzidas utilizando basicamente o mesmo processo, elas podem apresentar algumas variações de um tipo para outro (OLIVEIRA, 2011). As etapas do desenvolvimento da cerveja estão descritas a seguir:

\section{Malteação}

O malte, cevada maltada é a principal fonte de substâncias químicas com atividade sensorial (gustativa ou olfativa), encontradas na cerveja, seja por via direta, seja através das transformações que ocorrem durante a produção do mosto e a fermentação (GALVÃO, 1997). O processo de malteação é constituído de três etapas: maceração, germinação e secagem. $\mathrm{Na}$ maceração, a cevada é colocada em tanque cilíndrico para ser macerada com água. A água deve estar na temperatura entre 5 e $18^{\circ} \mathrm{C}$ e é trocada a cada 6 a 8 horas.O oxigênio necessário à respiração do embrião da cevada é fornecido através da injeção de ar nos tanques. O processo termina em dois dias, quando a cevada atinge 42 a $48 \%$ de umidade, nesse ponto há o aparecimento da radícula (AQUARONE, 2011 LORENA, 2015).

\section{Preparo do Mosto}

O tipo de mosturação depende do tipo e da composição da cerveja que se deseja obter, agregando conhecimentos da quantidade desejada de açúcares, substâncias protéicas, consistência da espuma, dentre outras (DRAGONE; ALMEIDA e SILVA, 2010). Nesta etapa ocorre a moagem do malte que tem como objetivo quebrar o grão e expor o amido contido em seu interior. É um processo puramente físico em que o malte é colocado no interior de um moinho, que ao cortar/danificar a casca das sementes promove a exposição do amido do endosperma (MATOS, 2011).

A moagem promove a diminuição do tamanho da partícula do amido, aumentando assim, a velocidade de hidrólise do amido (OLIVEIRA, 2011). É considerável que a moagem 
não seja muito severa para que a fase filtração não seja prejudicada, porém se a moagem for muito grosseira, não atingirá o seu objetivo, que é aumentar a superfície de contato do substrato amiláceo com as enzimas do malte, facilitando sua hidrólise (OETTERER; REGITANOD'ARCE; SPOTO, 2006).

Na mosturação ou brassagem ocorre a mistura do malte moído com água, submetendoo a diferentes temperaturas por períodos de tempo determinados para que o amido venha a se solubilizar e também ativar enzimas proteolíticas e de sacarificação, formando uma solução chamada de "mosto" (MORADO, 2009). O objetivo deste procedimento consiste em promover a gomificação e posterior hidrólise do amido a açúcares. $\mathrm{O}$ pH e a temperatura interagem para controlar a degradação do amido e das proteínas (VENTURINI, 2005).

A filtração da mostura é extremamente importante para a qualidade da cerveja, onde é realizada em um recipiente denominado tina de filtração, com a finalidade de separar o mosto líquido do bagaço de malte. Durante a filtração, o mosto flui por gravidade através de uma superfície filtrante constituída pelas próprias cascas do malte. Este processo é seguido por sucessivas lavagens do elemento filtrante com água a $76^{\circ} \mathrm{C}$, a fim de recuperar a maior parte do extrato líquido que fica retido no bagaço (OETTERER; REGITANO-D’ARCE; SPOTO, 2006), pois nessa temperatura a viscosidade do mosto diminui, diluindo os açúcares, que terão mais facilidade para se livrarem dos sólidos do bagaço, diminuindo dessa forma as perdas. As enzimas serão então inativas, sendo bloqueado o desenvolvimento bacteriano (REITENBACH, 2010).

Na primeira filtragem, o líquido passa através da camada de cascas do malte depositadas no fundo da tina, formando assim, uma camada filtrante, constituindo o mosto primário. Já na segunda filtragem a camada de cascas que se encontra na tina de mosturação é então lavada com água por uma ou mais vezes, para recuperar a maior parte do extrato líquido que fica retido no bagaço após a filtração (KUCK, 2008).

Piccini, Moresco e Munhos (2002) destacamque a turbidezdo mosto que sai do processo de filtragem deve ser a mínima possível, devido ao fato da cerveja ter um número bastante grande de sólidos que precipitam ao longo do processo, tendo uma quantidade definida de sólidos que devem ser retirados nos três processos de filtração.

Após a filtração, o mosto é encaminhado para uma tina de fervura, iniciando assim a sua fervura a aproximadamente $100^{\circ} \mathrm{C}$, o qual permitirá a inativação enzimática e a evaporação da água. O bagaço que ficou na tina, denominado torta, deve ter menos de $1 \%$ de extratos solúveis e pode ser utilizado na fabricação de rações para animais. (OETTERER; REGITANOD’ARCE; SPOTO, 2006). 
Além destas transformações, o lúpulo deve ser adicionado junto com os componentes

do mosto, em altas temperaturas. A fervura do mosto tem que ser intensa, pois é responsável pela esterilização do mosto e também exerce função importante favorecendo a obtenção de aroma, sabor, cor e esterilidade microbiológica da cerveja, devido à ação da caramelização e reação de Maillard (JAY, 2005). A adição de lúpulo ou lupulagem, normalmente ocorre em duas etapas, à primeira visando conferir amargores e a segunda prestando-se à adição de aromas florais, herbais e mesmo condimentados, acrescentados no mosto durante a cocção (MORADO, 2009).

\section{Fervura do mosto}

De acordo com Garcia-Cruz, Foggetti e da Silva (2008) e Matos (2011), os principais objetivos da fervura são: estabilização biológica, o mosto é um meio ótimo para o desenvolvimento de microrganismos que possa vir a contaminar a produção nas operações precedentes, por isso na fervura é visada a esterilização; estabilização bioquímica onde as enzimas que se mantiverem ativas são inativadas; estabilizações físico-químicas que as proteínas de maior cadeia são desnaturadas, floculando, precipitando e, com elas, acabam decantando, também, polifenóis, taninos e outras substâncias que serão retiradas posteriormente.

Extração e transformação dos componentes do lúpulo, que pela fervura o amargor e aromas do lúpulo são extraídos; concentração do mosto, que na filtração é usada água para extrair o extrato residual do bagaço; com a fervura faz-se a evaporação do excesso de água usada, deixando o mosto na densidade desejada; e outras transformações, como a formação de melanoidinas (combinação de açúcares simples com aminoácidos). Estas substâncias contribuem para o aroma e para a cor da cerveja.

Conforme Morado (2009), após a fervura do mosto sucede a separação do trub aglutinado protéico - por um processo chamado whirlpool, o qual utiliza a força centrípeta para fazer o trub se acumular no centro do tanque e logo pode ser feito o resfriamento, fundamental para que o mosto atinja a temperatura adequada para a fermentação. Se não ocorresse a separação do trub, a cerveja absorveria características desagradáveis a seu aspecto sensorial e assim adquirir um amargor não esperado, com coloração escura, além da desestabilização da espuma (BAMFORTH, 2005). 


\section{Fermentação}

No resfriamento e na aeração do mosto o principal intuito é a inoculação das leveduras, que irão fermentar o extrato para a elaboração da cerveja. A temperatura depende do tipo de cerveja que se deseja obter, que deve estar diretamente ligada ao tipo de fermentação. A aeração é um processo fundamental para a fabricação de cerveja, pois trazem consequências diretas nos processos finais da cerveja. Em função disso, deve-se fazer uma aeração adequada de modo a facilitar a ação das leveduras e a retirada de compostos do mosto que provocariam turbidez na cerveja (VENTURINI, 2005).

Os carboidratos fermentescíveis presentes como a maltose, maltotriose, glicose, entre outros, são metabolizados pelas leveduras. Subprodutos podem desenvolver-se durante o processo de fermentação e componentes do mosto são assimilados pela levedura, sendo denominados produtos secundários da fermentação (DRAGONE; ALMEIDA; SILVA, 2010).

A levedura empregada deve ser inoculada a uma solução de $100 \mathrm{~mL}$ do mosto, depois de certo tempo fermentando, este passa para um recipiente de $1000 \mathrm{~mL}$ de mosto (inoculo). Depois de ter passado o tempo de crescimento da levedura, o mesmo é inoculado ao mosto principal nos tanques de fermentação. Tal processo serve tanto para as leveduras de fermentação alta, quanto para as de fermentação baixa (JACKSON, 2007).

Depois de realizado este processo o produto deve ser maturado, finalizando o processo fermentativo, além de melhorar as características da qualidade da cerveja como sua carbonatação e formação de ésteres responsáveis pelo aroma e sabor (FERREIRA e BENKA, 2014). A fermentação confere à bebida seu teor alcoólico, além de uma parte da carbonatação e espumação. Normalmente, é feita à proporção de $1 \%(\mathrm{v} / \mathrm{v})$ de fermento em relação ao mosto e o tempo de fermentação pode variar de acordo com a cervejaria e o tipo de cerveja que se pretende (OETTERER, REGITANO-D'ARCE e SPOTO, 2006).

O cuidado para que se tenha uma boa cerveja é indispensável, tais como: a seleção de uma boa cepa de levedura (a levedura boa deve flocular e decantar no fundo do tanque fermentador ao final do processo); se a cerveja será de baixa ou de alta fermentação; concentração celular a ser utilizada; dados de crescimento e morte celular do microrganismo; tempo e como determinar o término da fermentação (GARCIA-CRUZ, FOGGETTI E DA SILVA, 2008 apud MATOS, 2011).

As cervejas do tipo Lager são produzidas por leveduras de alta fermentação, a temperatura inicial do mosto deve ficar entre a faixa de 14 a $20^{\circ} \mathrm{C}$. Após 36 horas de fermentação, a temperatura do mosto é elevada para 20 a $25^{\circ} \mathrm{C}$ e depois de 72 horas diminui-se para $17^{\circ} \mathrm{C}$. Nas 
últimas 10 horas de fermentação as leveduras tendem a subir para a superfície do mosto. Para

as cervejas do tipo Ale produzidas a partir de leveduras de baixa fermentação, a temperatura do mosto deve estar entre 6 a $12^{\circ} \mathrm{C}$ e depois elevada para 10 a $15^{\circ} \mathrm{C}$ nos primeiros 3 a 5 dias da fermentação. No final, a temperatura é diminuída e a levedura passa a decantar (OETTERER; REGITANO-D'ARCE; SPOTO, 2006).

\section{Maturação}

O produto resultante da fermentação principal é a cerveja "verde", onde ainda existem leveduras em suspensão e certa quantidade de material fermentescível e passará por uma fermentação secundária, conhecida como maturação.Os objetivos principais da maturação são: arredondamento do paladar e aroma, clarificação da cerveja, amadurecimento e eliminação de substâncias sulfonadas que são arrastadas pelo gás carbônico (ALVISI, 2011).

Segundo Morado (2009), dado início a maturação grande parte dos açucares terá sido metabolizado e transformado em álcool etílico, dióxido de carbono, glicerol ácido cético, álcoois superiores e ésteres. Cerca de $10 \%$ do total de ésteres da cerveja são formados durante a maturação. Ocorrem além da redução dos teores de compostos sulfídricos, como o diacetil, acetaldeído e ácido sulfídrico, também uma atenuação no amargor do lúpulo onde é estabelecido o sabor final da cerveja (VENTURINI, 2005). A cerveja tipo Ale passa por um período de maturação de poucos dias, geralmente menos de um mês. A Ale forte pode precisar de um período de maturação de até um ano (EVANGELISTA, 2012).

\section{Tratamento e Armazenamento}

A cerveja pode ser armazenada em garrafas ou latas de alumínio e deve passar pelo processo de pasteurização. A pasteurização é feita com objetivo de proporcionar estabilidade biológica à cerveja, através da destruição de microrganismos pelo calor (CARVALHO et al., 2006). Por fim, a pasteurização que consiste em diminuir a carga microbiana que, se presentes, podem prejudicar as características da cerveja. Assim, a pasteurização costuma ser realizada a temperaturas por volta de $70^{\circ} \mathrm{C}$ (KUCK, 2008), porém críticos alegam que esta operação prejudica o paladar, conferindo adstringência adicional e até mesmo sabores de "queimado" à bebida (MORADO, 2009). 
Torna-se possível comprovar que produzir cerveja, hoje, com toda a informação e tecnologia disponíveis, é fácil. No entanto, produzir cerveja de alta qualidade com formulação e protocolos originais, inovando e compreendendo o que se está fazendo, é algo um tanto quanto mais complexo, devido à quantidade de variações possíveis nos processos, exigindo do fabricante conhecimento científico para que se alcance o resultado desejado. As cervejas artesanais geralmente têm uma qualidade sensorial diferenciadas quando comparadas as cervejas tradicionais. As cervejas populares têm o intuito de agradar à grande maioria dos consumidores da maneira mais barata possível, e conseguem manter um nível e padrão de qualidade invejável por qualquer empresa, devido ao controle que têm dos processos de produção, distribuição, etc. Ademais, conclui-se também que as cervejas artesanais, por sua vez, têm o intuito de agradar um público restrito, no qual estão a procura de cervejas com características sensoriais diferenciadas das demais.

\section{REFERÊNCIAS}

ALVISI, F. Manual de Treinamento Técnico Cervejeiro. AmBev, 2011.

ASSIS, G.P.; LIMA, B.M.B.; DOS SANTOS, L.M.R. Physical and chemical analysis of ipa beer of the southern fluminese region. Análises físico-químicas de cerveja tipo IPA da Região Sul Fluminense. Revista Teccen. 2020 Jul./Dez.; 13 (2): 47-51.

ANDRADE C. J.; MEGA F. J.; NEVES E. A Produção da Cerveja no Brasil. Ciência, Tecnologia, Inovação e Oportunidade, vol 1, nº 1. Barra do Bugres 2011.

ARNOLD, JOHN P. Origin and History of Beer and Brewing: From Prehistoric Times to the Beginning of Brewing Science and Technology. Reprint Edition by BeerBooks, Cleveland, OH, 2005.

BAMFORTH, C. W. Food, fermentation and micro-organisms. Blackewell Science Ltda Blackwell Publishing company. 2005. .

BRASIL. MINISTÉRIO DA AGRICULTURA. SECRETARIA NACIONAL DE DEFESA AGROPECUÁRIA. Decreto $\mathbf{n}^{\mathbf{0}} \mathbf{6 . 8 7 1}$, de 04 de junho de 2009. Regulamentação da Lei $\mathrm{N}^{\circ}$ 8.918, de 14 de julho de 1994, sobre a padronização, a classificação, o registro, a inspeção e a fiscalização da produção e do comércio de bebidas. Diário Oficial da União, Brasília, 04 de junho de 2009.

BRIGIDO R. V.; NETTO M. S. Produção de Cerveja. Trabalho apresentado à disciplina de Engenharia Bioquímica da Universidade Federal de Santa Catarina. Florianópolis, 2006. 
manual para la industria cervecera. 2.ed. Peru: Associacón de Maestros Cerveceros de las Américas, 1977. 550p.

CARVALHO, GBM; DRAGONE, G; BENTO, CV; SANTOS, DT; SARROUH, BF; FELIPE, MGA; ALMEIDA E SILVA, JB. Utilização da banana como adjunto na obtenção de mosto cervejeiro de alta densidade: um estudo para fim biotecnológico clássico inédito. In: Congresso Mineiro de Propriedade Intelectual, Agosto 9-11, UFJF, Juiz de Fora - MG, 2006.

CARVALHO, G.B.M., ROSSI, A.A., ALMEIDA e SILVA, J.B. Elementos biotecnológicos fundamentais no processo cervejeiro: $2^{\mathrm{a}}$. parte, A fermentação. Revista Analytica, v.26, p.46 54, 2007.

CARVAlHO, L. G. Dossiê Técnico. Produção de cerveja. Rede de Tecnologia do Rio de Janeiro, Rio de Janeiro, mar. 2007.

CERVBRASIL. Anuário 2015. Disponível em: http://www.cervbrasil.org.br/arquivos/ANUARIO_CB_2015_WEB.pdf. Acesso em: 07 março 2018.

DINSLAKEN, D. Manual do Cervejeiro Caseiro. $1^{\text {o }}$ edição. V.1. Edição virtual, 2016.

DRAGONE, G. ALMEIDA e SILVA, J.B. Bebidas Alcoólicas: Ciências e tecnologia. V.1. São Paulo: Edgard Blücher, 2010.

EUWA, M. EUMANN. Water in brewing. In: Brewing New technology. Published in North America, 2006.

EVANGELISTA, R. R. Análise do processo de fabricação industrial de cerveja. São Paulo: Fatec Araçatuba, 2012, 50 p.

FERREIRA, A. de S.; BENKA, C.L. Produção de Cerveja Artesanal a Partir de Malte Germinado Pelo Método Convencional e Tempo Reduzido de Germinação. Trabalho de Conclusão de Curso (Tecnólogo em Alimentos, no Curso Superior de Tecnologia em Alimentos) - Universidade Tecnológica Federal do Paraná. 2014.

FERREIRA, J. Fermentação. Salvador, BA, 2007.

FERREIRA, A. C., PEREIRA, M. M. O., REZENDE, D. C. E VIEIRA, A. S. Simbolismo e Construção da Identidade por meio do Consumo de Cerveja Artesanal. Revista de Negócios, 23(3), 19-35, 2018.

FERREIRA, A. C., PEREIRA, M. M. O., REZENDE, D. C. E VIEIRA, A. S. Motivações de compra e hábitos de consumo: um estudo com apreciadores de cerveja artesanal. Revista da Micro e Pequena Empresa, 13(1), 12-31, 2019.

JACKSON, M. Cerveja. 2 ed. Rio de Janeiro: Editora Zahar. 2007.

JAY, J. M. Microbiologia de alimentos. 6 ed. Porto Alegre: Artmed. 2005. 
JÚNIOR, A. A. D.; VIEIRA, A. G.; FERREIRA, T. P. Processos de produção de cerveja.

Revista Processos químicos. p. 61-71, jul./dez. 2009.

KENNING, DAVID. Beers Of the Word. London: Parragon Books Ltd., 2010.

KUCK, L. S. Cerveja: Sabor e Aroma. 2008. 47 f. Trabalho acadêmico do Curso de Bacharelado em Química de Alimentos - Universidade Federal de Pelotas, RS.

KUNZE, W. Technology brewing and malting. Berlim: VLB, 1997. p. 433-435.

MADRID, A. Manual de indústrias de alimentos. 1.ed. São Paulo: Varela, 1996. p. 599.

MARCUSSO, E. F. AS MICROCERVEJARIAS NO BRASIL ATUAL: Sustentabilidade e Territorialidade. 171 f. Dissertação. Mestrado em Sustentabilidade na Gestão Ambiental.Universidade Federal de São Carlos (UFSC). Sorocaba - SP. 2015

MARCONI, M. A; LAKATOS, E. M. Técnicas de Pesquisa: planejamento e execução de pesquisas, amostragens e técnicas de pesquisa, elaboração, análise e interpretação de dados. 7 ed. São Paulo: Atlas, 2010.

MATSUBARA, AMANDA KAORI; PLATH, ARIANE R. Desenvolvimento de Cerveja Artesanal de Trigo adicionada de Gengibre (ZingiberofficinaleRoscoe). 51f. Trabalho de Conclusão de Curso (Curso Superior de Tecnologia em Alimentos). Universidade Tecnológica Federal do Paraná. Londrina, 2014.

MATOS, RICARDO AUGUSTO GRASEL. Cerveja: Panorama do Mercado, Produção Artesanal, e Avaliação de Aceitação e Preferência. 2011. Trabalho de Conclusão de Curso. Florianópolis - SC.

MENDA, M. Refrigerantes. Rio de Janeiro: Conselho Regional de Química 4ª Região, 2011.

MELLO, J. A V. B.; SILVA, JK. L. M. Requisitos de produto para um projeto de cerveja artesanal. Innovar, vol. 30, núm. 77, 2020.

MENDES, DIAS, A. Processamento de cerveja. Universidade Federal de Santa Catarina, Florianópolis, SC), 2004.

MINELLA E. Reunião Nacional de Pesquisa de cevada (29: 2013: Passo Fundo, RS). Indicações técnicas para a produção de cevada cervejeira nas safras 2013 e 2014. Editado por Euclydes Minella. Passo Fundo: Embrapa Trigo,105 p, 2013.

MORADO, R. Larousse da Cerveja, $1^{\text {a }}$ edição. São Paulo, SP: Larousse do Brasil, 2009. 357p.

MORADO, RONALDO. A rivalidade deixada de lado para dar lugar ao prazer de degustar bebidas de qualidade. SP, 2015.

OLIVEIRA, N. A. M. Leveduras utilizadas no processo de fabricação da cerveja. 2011. 45f. Monografia (Pós-graduação em Microbiologia) - Instituto de Ciências Biológicas, UFMG, Belo Horizonte, 2011. 44p. 
e Tecnologia de Alimentos. Barueri, SP: Manole, 612p, 2006.

PATTINSON, RON. European Beer Statistics: Volume of World Beer Production, 2006.

PICCINI A. R., MORESCO, C. e MUNHOS, L. Cerveja. 2002. Acessado em: http://www.ufrgs.br/alimentus1/feira/prcerea/cerveja/defini.htm.

PORTO, PAULA DE D. Tecnologia de fabricação de malte: uma revisão. 2011. 58 f. Trabalho de Conclusão de Curso (Graduação) - Universidade Federal do Rio Grande do Sul, Porto Alegre, 2011.

REBELlO, F. D. F. P. Produção de cerveja. Revista Agro geo ambiental. Inconfidentes. Dezembro 2009.

REINOLD, M. R. Fatores importantes para a elaboração de uma cerveja de qualidade. Revista Indústria de Bebidas: Fc Santos, 2008, Ano 07, № 41.

REITENBACH, A. F. Desenvolvimento de cerveja funcional com adição de probiótico: Saccharomyces boulardii. Não paginado. Dissertação (Mestrado) - Universidade Federal de Santa Catarina, Centro Tecnológico, Programa de Pós-Graduação em Engenharia de Alimentos, Florianópolis, 2010.

ROSA, N. A.; AFONSO, J. C. A. Química da Cerveja. Química Nova, v. 37, N² 2, p. 98-105, 2015.

SEBRAE - Serviço Brasileiro de Apoio às Micro e Pequenas Empresas - Potencial de Consumo de Cervejas no Brasil, 2014.

SILVA, PAULO HENRIQUE ALVES DA; FARIA, FERNANDA CAROLINA DE. Avaliação da intensidade de amargor e do seu princípio ativo em cervejas de diferentes características e marcas comerciais. Ciência e Tecnologia de Alimentos. p. 902-906, out.-dez. 2008

SHARP, F. R.; LAWS, D. R. J. The essential oil of hops - a review. Journal of the Institut of Brewing, v. 87, p. 96-107, 1981.

SIQUEIRA, P. B. Estudo da cinética bioquímica e sensorial de diferentes tipos de cervejas brasileira. 2007. 125f. Dissertação (Mestrado em Ciência de Alimentos) - Faculdade de Engenharia de Alimentos, Universidade Estadual de Campinas, Campinas, 2007.

VARNAM, A. H.; SUTHERLAND, J. P. Bebidas alcohólicas: I. Cerveza. In: Bebidas: Tecnologia, Química y Microbiologia. Zaragoza: Acribia, S.A., 1997. 487p.

VENTURINI, W. G. Cerveja. In: Tecnologia de Bebidas. 1.ed. São Paulo: Edgard Blücher, 2005. p. 550. 


\title{
CAPÍTULO 09: PRODUCCIÓN DE COMPUESTOS FENÓLICOS POR FERMENTACIÓN EN ESTADO SÓLIDO CON EL USO DE RESIDUOS AGROINDUSTRIALES: REVISIÓN BIBLIOGRÁFICA
}

\section{CHAPTER 09: PRODUCTION OF PHENOLIC COMPOUNDS BY FERMENTATION IN SOLID STATE WITH THE USE OF AGRO-INDUSTRIAL WASTE: BIBLIOGRAPHIC REVIEW}

\author{
Adryelen Cassiano Martins ${ }^{1}$; Letícia Souza Silva ${ }^{2}$, Juliana Bueno Ruiz ${ }^{3}$; Larine Kupski ${ }^{4}$
}

DOI: https://doi.org/10.31692/978-65-88970-19-5.133-145

\begin{abstract}
RESUMO
Os compostos fenólicos são encontrados em diversas matrizes, como nos resíduos agroindustriais. No entanto, podem estar associados a macromoléculas, reduzindo sua disponibilidade. Desta maneira, a fermentação em estado sólido (FES) torna-se uma alternativa promissora para a disponibilização destes compostos em resíduos agroindustriais. O objetivo desta revisão bibliográfica foi identificar na literatura identificar na literatura disponível o uso de resíduos agroindustriais de cereais e leguminosas na fermentação em estado sólido para produção de compostos fenólicos. Como referências de base de dados eletrônicas foram utilizadas as plataformas SCIELO, WEB OF SCIENCE, SCOPUS e SCIENCE DIRECT, analisando estudos publicados nos anos de 2015, 2016, 2017, 2018 e 2020; usando as seguintes palavras chaves: Compostos fenólicos (Phenolic Compounds), Fermentação em estado sólido (Solidstate fermentation), Resíduos agroindustriais (Agro-industrial wastes), Resíduos agroindustriais cereais (Agro-industrial wastes cereals), Resíduos agroindustriais leguminosas (Agro-industrial wastes leguminous), Produção (Production), Síntese Synthesis), flavonóides (Flavonoids), Ácidos fenólicos (Phenolic acids) e Disponibilidade (Availability). Foram selecionados 23 artigos, entre os anos de 2015 a 2020, para avaliar as condições de fermentação mais empregadas para disponibilizacao de compostos fenólicos. Destes estudos 19 referem-se à fermentação de resíduos de cereais e o restante (4), a fermentação de resíduos de leguminosas. O microrganismo mais utilizado foi o fungo filamentoso Aspergillus oryzae. De modo geral, a utilização de resíduos agroindustriais como substratos em fermentação em estado sólido para aumentar a disponibilização de compostos bioativos representa mais uma rota tecnológica em experimentação e que está em grande evolução, o que pode futuramente, diminuir substancialmente os custos de produção, reduzir o acúmulo destes materiais no meio ambiente e agregar valor nestes materiais que antes eram desvalorizados.
\end{abstract}

Palavras-Chave: Antioxidante natuais; Substratos; Fermentação.

\section{RESUMEN}

Los compuestos fenólicos se encuentran en varias matrices, como en los residuos agroindustriales. Sin embargo, pueden asociarse con macromoléculas, reduciendo su disponibilidad. De esta manera, la fermentación en estado sólido (FES) se convierte en una alternativa prometedora para hacer que estos compuestos estén disponibles en residuos agroindustriales. El propósito de esta revisión de la literatura fue identificar en la literatura para identificar en la literatura disponible el uso de residuos agroindustriales de cereales y legumbres en fermentación en estado sólido para la producción de compuestos fenólicos. Se utilizaron las plataformas SCIELO, WEB OF SCIENCE, SCOPUS y SCIENCE DIRECT como referencias de la base de datos electrónica, analizando los estudios publicados en los años 2015, 2016, 2017, 2018 y 2020; utilizando las siguientes palabras clave: Compuestos

\footnotetext{
${ }^{1}$ Graduanda em Engenharia de Alimentos, Universidade Estadual de Maringá, adryelencassiano15@gmail.com

${ }^{2}$ Graduanda em Engenharia de Alimentos, Universidade Estadual de Maringá, lesouzasilva1995@gmail.com

${ }^{3}$ Doutora em Genética e Melhoramento, Universidade Estadual de Maringá, jbrrebecca2@uem.br

${ }^{4}$ Doutora em Engenharia e Ciências de Alimentos, Universidade Estadual de Maringá, lkupski@uem.br
} 

agroindustriales (Agro-industrial wastes), Cereales agroindustriales (Agro-industrial wastes cereals), Residuos agroindustriales leguminosos (Agro-industrial wastes leguminous), Producción (Production), Síntesis (Synthesis), flavonoides (Flavonoids), ácidos fenólicos (Phenolic acids) y disponibilidad (Availability). Se seleccionaron 23 artículos, entre los años 2015 a 2020, para evaluar las condiciones de fermentación más utilizadas para la disponibilidad de compuestos fenólicos. De estos estudios 19 se refieren a la fermentación de residuos de cereales y el resto (4), a la fermentación de residuos de leguminosas. El microorganismo más utilizado fue el hongo filamentoso Aspergillus oryzae. En general, el uso de residuos agroindustriales como sustratos en la fermentación en estado sólido para aumentar la disponibilidad de compuestos bioactivos representa una vía más tecnológica en experimentación, que está experimentando una gran evolución, que puede, en el futuro, disminuir sustancialmente los costos de producción, reducir la acumulación de estos materiales en el medio ambiente y agregan valor a estos materiales que antes estaban devaluados.

Palabras Clave: Antioxidantes naturales; Sustratos; Fermentación.

\begin{abstract}
Phenolic compounds are found in several matrices, such as in agro-industrial residues. However, they can be associated with macromolecules, reducing their availability. In this way, solid state fermentation (FES) becomes a promising alternative for making these compounds available in agro-industrial residues. The purpose of this literature review was to identify in the literature to identify in the available literature the use of agro-industrial residues from cereals and legumes in solid state fermentation for the production of phenolic compounds. As electronic database references, the SCIELO, WEB OF SCIENCE, SCOPUS and SCIENCE DIRECT platforms were used, analyzing studies published in the years 2015, 2016, 2017, 2018 and 2020; using the following keywords: Phenolic Compounds, Solidstate fermentation, Agro-industrial wastes, Agro-industrial cereals (Agro-industrial wastes cereals), Leguminous agro-industrial residues industrial wastes leguminous), Production (Production), Synthesis Synthesis), flavonoids (Flavonoids), Phenolic acids (Phenolic acids) and Availability (Availability). Twenty three articles were selected, between the years 2015 to 2020, to evaluate the fermentation conditions most used for making available phenolic compounds. Of these studies, 19 refer to the fermentation of cereal residues and the remainder (4), the fermentation of leguminous residues. The most used microorganism was the filamentous fungus Aspergillus oryzae. In general, the use of agroindustrial residues as substrates in solid state fermentation to increase the availability of bioactive compounds represents yet another technological route under experimentation, which is undergoing great evolution, which may, in the future, substantially decrease production costs, reduce the accumulation of these materials in the environment and add value to these materials that were previously devalued.
\end{abstract}

Keywords: Natural antioxidants; Substrates; Fermentation.

\title{
INTRODUÇÃO
}

A extensão do território brasileiro possibilita a realização de diversas atividades econômicas, sendo a atividade agrícola a maior responsável pelos valores da balança comercial do País. Entretanto, como consequência dessa produção agroindustrial tem-se uma enorme geração de resíduos (Palomino García \& Del Bianchi, 2015b). A exposição direta dos resíduos agroindustriais ao meio ambiente caracteriza uma das principais causas da poluição ambiental, além de significar a perda de material com alto potencial de utilização na produção ou recuperação de diversos compostos com valor comercial (Palomino García \& Del Bianchi, 2015a). Dentre estes compostos destacam-se os compostos fenólicos, que fazem parte de uma das principais classes de antioxidantes naturais. Além de apresentarem atividade antioxidante, 
tem sido atribuído aos compostos fenólicos benefícios à saúde humana, atuando de maneira a retardar ou prevenir o desenvolvimento de doenças (Palomino García \& Del Bianchi, 2015b).

A fermentação em estado sólido (FES) é uma técnica antiga e vem sendo empregada como alternativa para a produção ou aumento do conteúdo fenólico (Machado et al., 2012). Direcionado pelo contexto atual, no qual se observa uma grande produção de resíduos agroindustriais, utilizá-los como substrato alternativos na fermentação em estado sólido para a produção de compostos antioxidantes é interessante do ponto de vista ambiental e econômico. Desta maneira, o objetivo desta revisão é identificar na literatura disponível o uso de resíduos agroindustriais de cereais e leguminosas na fermentação em estado sólido para produção de compostos fenólicos.

\section{FUNDAMENTAÇÃO TEÓRICA}

Os compostos fenólicos são metabólitos secundários das plantas e são subdivididos em 3 grupos que mais se destacam, como os: ácidos fenólicos, flavonoides e cumarinas (Angelo \& Jorge, 2007). Os ácidos fenólicos por sua vez, são os primeiros na via de síntese, pois são sintetizados a partir da estrutura fenólica mais simples. Estes, possuem um grupo carboxílico ligado ao seu anel aromático que serve como precursor de outros compostos fenólicos mais complexos, como é o caso dos flavonoides (da Silva, 2016). Além disso, os compostos fenólicos podem ser encontrados na sua forma livre, ligados e/ou conjugados e insolúveis (Mira et al., 2008).

Os ácidos fenólicos são subdivididos em duas classes, sendo elas: os ácidos hidroxibenzoicos e os hidroxicinâmicos. Os hidroxibenzoicos são menos abundantes em vegetais de consumo humano, diferente dos hidroxicinâmicos que estão presentes em vários alimentos e bebidas de origem vegetal. Pertencem a este grupo, os ácidos: ácido caféico, $\rho$ cumárico, ferúlico e sinápico que, na maior parte dos alimentos, se encontram esterificados ao ácido quínico, ácido tartárico ou carboidratos e derivados (De Oliveira \& Bastos, 2011).

Em específico, os resíduos proveniente de cereais são ricos em ácidos fenólicos como os ácidos ferúlico, vanílico e $p$ - cumárico e flavonoides (Dey et al., 2016). Já os oriundos de leguminosas são ricos em ácidos fenólicos como ferúlico, siringico, cumárico, vanilina, flavonoides, como por exemplo as isoflavonas daidzeína, genisteína e gliciteína (da Silva, Kupski \& Badiale-Furlong, 2018). A diferença encontrada nos resíduos, deve-se ao fato dos compostos fenólicos serem metabólitos secundários de plantas, e sua produção é influenciada por fatores bióticos e abióticos (Furlong et al.,2020). Entretanto, a insolubilidade de compostos 
fenólicos predominantemente ligados e conjugados reduzem suas biodisponibilidade em cereais

e leguminosas. Desta maneira, são estudadas técnicas para melhorar a biodisponibilidade e as propriedades antioxidantes destes compostos, como por exemplo a fermentação em estado sólido (Dey et al., 2016).

A fermentação em estado sólido (FES) trata-se de um processo microbiológico que ocorre na superfície de um sólido - fonte de carbono e energia (Orlandelli et al., 2012), simulando as condições ideais de vida dos fungos filamentosos, que produzem enzimas para degradá-lo, utilizando seus próprios nutrientes para sobreviver. Os fungos são considerados ideais para a FES, pois, se desenvolvem em meios com baixa atividade de água (Ferreira et al., 2011). As variáveis do processo, incluindo pré-tratamento e tamanho de partícula dos substratos, suplementação do meio de crescimento, teor de umidade, concentração do inóculo, temperatura, $\mathrm{pH}$, agitação e aeração, têm um efeito significativo sobre a eficiência dos processos fermentativos em estado solido (Martins et al., 2011) e consequentemente na disponibilização dos compostos bioativos.

\section{METODOLOGIA}

A pesquisa é de abordagem quali e quantitativa e quanto aos procedimentos técnicos utilizou-se de revisão bibliográfica. Como referências de base de dados eletrônicas foram utilizadas as plataformas SCIELO, WEB OF SCIENCE, SCOPUS e SCIENCE DIRECT, analisando estudos publicados nos anos de 2015, 2016, 2017, 2018 e 2020; usando as seguintes palavras chaves: Compostos fenólicos (Phenolic Compounds), Fermentação em estado sólido (Solid-state fermentation), Resíduos agroindustriais (Agro-industrial wastes), Resíduos agroindustriais cereais (Agro-industrial wastes cereals), Resíduos agroindustriais leguminosas (Agro-industrial wastes leguminous), Produção (Production), Síntese Synthesis), flavonóides (Flavonoids), Ácidos fenólicos (Phenolic acids) e Disponibilidade (Availability).

As combinações de busca que foram utilizadas são: "Phenolic acids" AND "Solid state fermentation" AND "Agro industrial wastes" AND "Production OR Availability", "Flavonoids" AND "Solid state fermentation" AND "Agro industrial wastes" AND "Production or availability", "Phenolic compounds" AND "Solid state fermentation", "Synthesis" AND "Phenolic compounds" AND "Solid state fermentation", "Solid state fermentation" AND "Production OR Synthesis OR Availability" AND "Phenolic compounds", "Solid fermentation" AND "Phenolic compounds" AND "Agro industrial wastes cereals OR Agro industrial wastes leguminous" e "Solid state fermentation" AND "Phenolic compounds" 


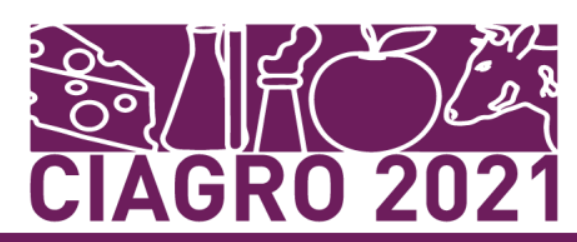

AND "Agro industrial wastes". As listas de referências foram exportadas das plataformas

eletrônicas e contabilizadas pelo software (EndNote, Thomson Reuters). Foi utilizado o mesmo software para remover as referências duplicadas.

\section{RESULTADOS E DISCUSSÃO}

Como resultado, foram obtidos 23 artigos, 19 estudos referem-se à fermentação de resíduos de cereais (Acosta-Estrada et al.,2019; Călinoiu, Cătoi, \& Vodnar, 2019; De Souza et al.,2019; Janarny \& Gunathilake, 2020; Liu et al., 2016; Maia et al., 2020; Mao et al., 2020; Rashid et al., 2019; Rashid et al., 2015; Razak et al., 2015; Razak et al., 2016; Razak et al., 2017; Razak et al., 2019a; Razak et al., 2019b; Shin et al., 2019; Spaggiari et al., 2020; Tišma et al., 2018; Tu et al., 2020; Yin et al., 2017), e o restante (4), a fermentação de resíduos de leguminosas (Beniwal et al., 2015; Karakurt et al., 2019; Santos et al., 2018; Shi et al.,2020). A quantidade de estudos selecionados para o subprodutos de leguminosas, pode estar associado ao fato de que a maioria dos artigos emprega a fermentação em estado sólido diretamente na leguminosa, sendo excluídos da revisão. Na Figura 01 é possível observar, dentre o conjunto de estudos selecionados, quais são os resíduos agroindustriais de cereais e de leguminosas que mais foram utilizados pelos autores na realização da fermentação em estado sólido como alternativa a produção de compostos fenólicos, ácidos fenólicos e flavonoides.

Figura 01: Substratos utilizados para produção de compostos fenólicos, ácidos fenólicos e flavonoides na fermentação em estado sólido para as publicações de 2015 a 2020

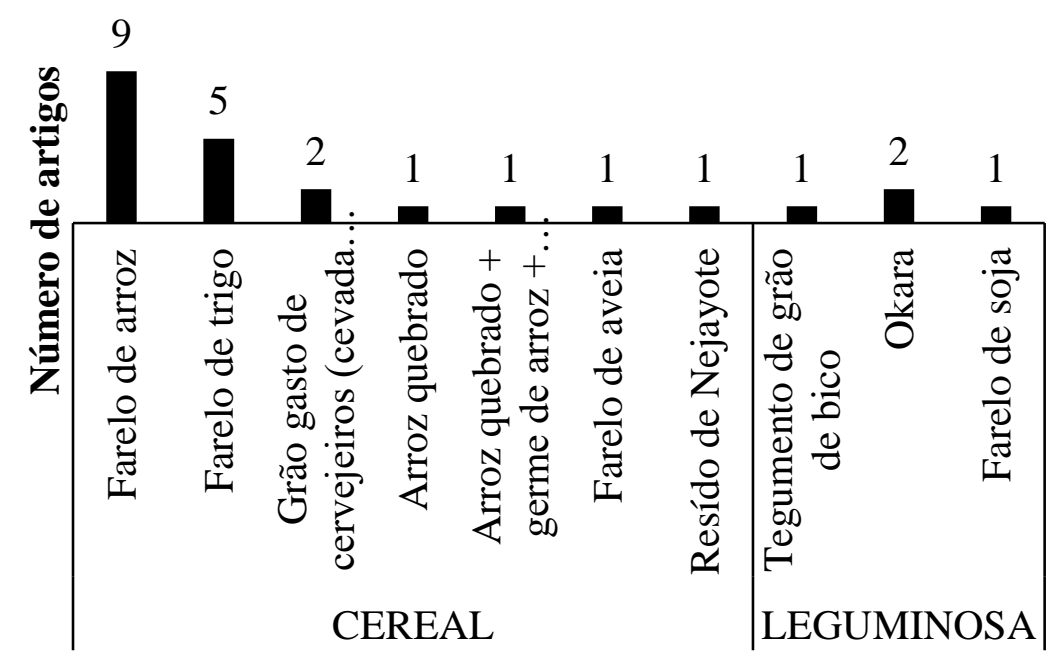

Fonte: Própria (2020). 
Para a fermentação em estado sólido de subprodutos de cereais os resíduos que mais

se destacaram, foram: o farelo de $\operatorname{arroz}(\mathrm{N}: 9)$ e farelo de trigo (N:5). Esta escolha justifica-se pelo fato de serem cereais que apresentam alta produtividade, um número considerável de exportação e devido sua composição físico-química, em específico por serem materiais lignocelulósicos (composto por celulose, hemicelulose e lignina).

A degradação microbiana de resíduos agroindustriais está se tornando um caminho mais aplicável para recuperação e produção de compostos bioativos, entre eles, estão os compostos fenólicos e flavonoides. A hidrólise do material lignocelulósico pelas enzimas produzidas pelo fungo durante a fermentação têm grande influência na atividade biológica e biodisponibilidade de compostos bioativos (Mao et al., 2020).

Segundo Statista (2020) estima-se que a produção mundial de arroz na safra de 2019/2020 seja de 495,78 milhões de toneladas métricas e a produção de trigo seja de 764,49 milhões de toneladas métricas. Devido sua alta demanda o processamento industrial destes cereais gera uma grande quantidade de subproduto. O farelo de trigo representa cerca de $15 \%$ da massa total do grão, além disso, é constituído por $23,7 \%$ de hemicelulose, $11 \%$ de celulose e 3,6\% de lignina e composto por proteína bruta $(17,4 \%)$, extrato etéreo $(2,1 \%)$, fibra bruta $(7,2 \%)$ e cinzas (4,2\%) (Kupski et al., 2018). O farelo de arroz representa cerca de 8,5-14,8\% da massa do grão (Walter, Marchezan, \& de Avila, 2008) cerca de 180.000 toneladas métricas de farelo de arroz são geradas por ano (Rashid et al., 2015). É constituído por 2,6\% de celulose, 17,3\% de hemicelulose e 20,9\% de lignina (Lacerda et al., 2010). Além disso, o farelo de arroz é considerado uma boa fonte de nutrientes, rico em fibra alimentar, proteínas, vitaminas e fitoquímicos (Rashid et al., 2015).

Já para a fermentação em estado sólido de leguminosas o resíduo agroindustrial que se mais se destacou foi o Okara, que é um subproduto de soja proveniente do processo de fabricação do leite (tonyu), do queijo (tofu), entre outros produtos relacionados a soja. Assim como o arroz e o trigo, a soja também apresenta alta produtividade e grande parte da sua produção é destinada à exportação. A produção mundial estimada de soja para safra de 2019/2020 é de 336.209 milhões de toneladas métricas (Statista, 2020). Como consequência do aumento do consumo de produtos à base de soja, tem-se uma maior produção de okara.

Segundo Shi et al. (2020), este resíduo é constituído por cerca de $34,7 \%$ de hemicelulose, 43,3\% de celulose e 4,9\% de lignina (Freitas, Natalino, \& Palmiro, 2015) e apresenta alto teor de fibra bruta, proteínas, minerais e compostos fenólicos, além de serem pobres em carboidratos e lipídios. 


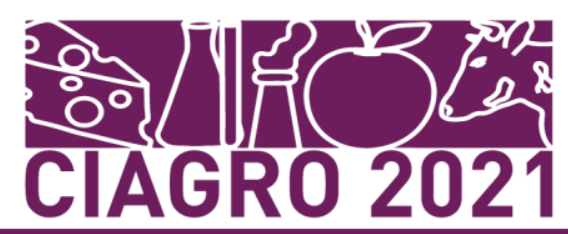

Considerando que o microrganismo empregado desempenha um grande papel durante

a fermentação em estado sólido, na Figura 02 encontra-se a relação dos microrganismos empregados durante os estudos selecionados.

Figura 02: Microrganismos utilizados para produção de compostos fenólicos, ácidos fenólicos e flavonoides na fermentação em estado sólido para as publicações de 2015 a 2020

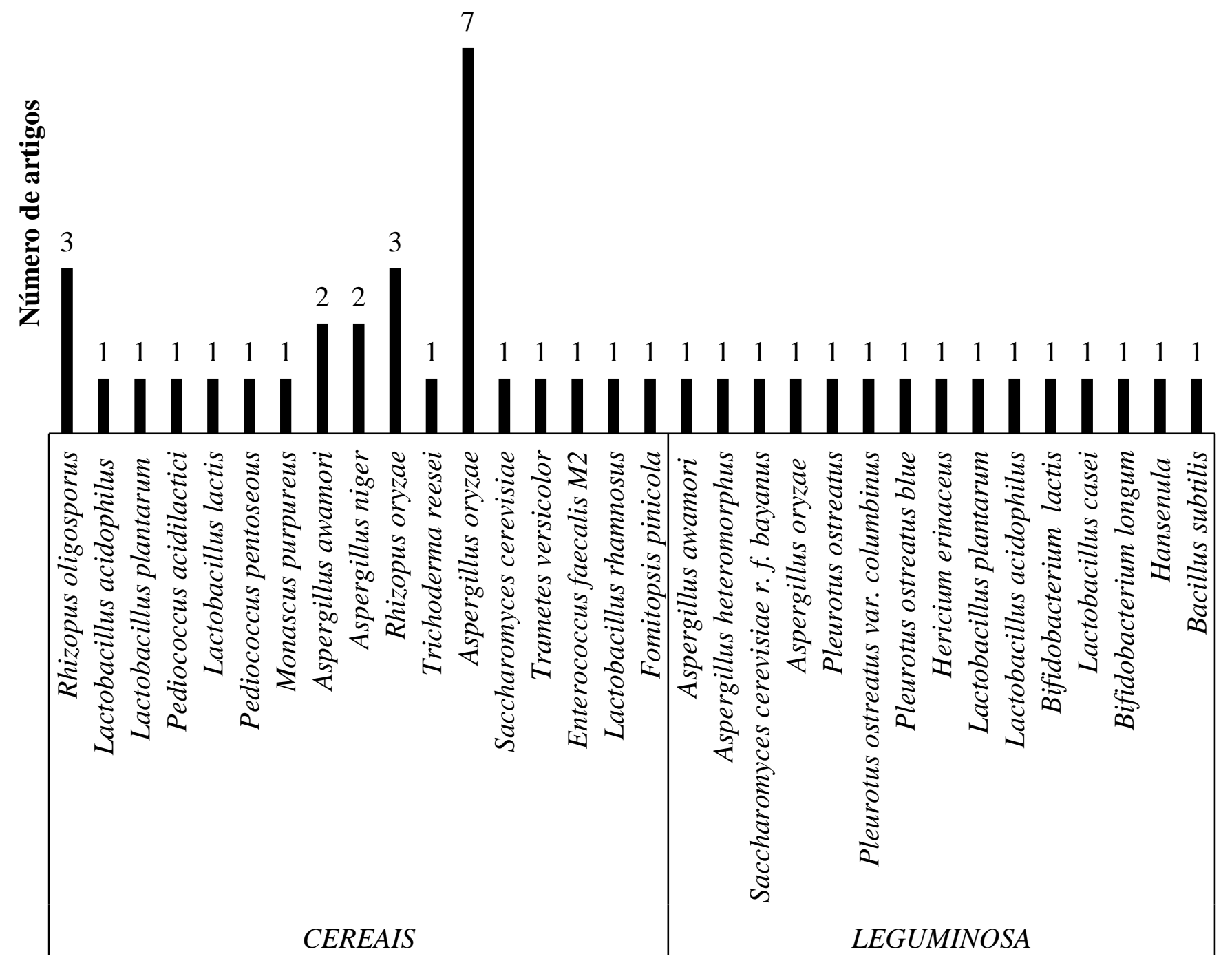

Fonte: Própria (2020).

Dos microrganismos empregados na fermentação de subprodutos provenientes de cereais, os que se destacaram por serem mais utilizados pelos autores, foram: Aspergillus oryzae (N:7), Rhizopus oligosporus (N:3) e Rhizopus oryzae (N:3), diferente da fermentação utilizando subprodutos de leguminosas, no qual nenhum microrganismo foi utilizado em mais de um artigo. 
Vale ressaltar, que diversas espécies microbianas estão sendo cultivadas sob

fermentação em estado sólido em resíduos agroindustriais, porém os fungos filamentosos, como é o caso de Aspergillus oryzae, Rhizopus oligosporus e Rhizopus oryzae, têm merecido uma atenção especial. Os fungos filamentosos podem se reproduzir tanto de maneira sexuada quanto de maneira assexuada, sendo que a reprodução assexuada ocorre pela fragmentação de suas hifas, as quais são responsáveis por colonizar a matriz sólida do substrato. Ambas reproduções (sexuada e assexuada) ocorrem pela formação de esporos, e logo após o fungo filamentoso formar um esporo, o mesmo se separa da célula parental e germina dando origem a novo fungo filamentoso (Pereira, 2016). Portanto, devido suas propriedades fisiológicas, bioquímicas e enzimáticas, os fungos filamentosos conseguem se adaptar em meios com baixa umidade, o que não acontece com as bactérias, consequentemente crescem com mais facilidade sobre substratos sólidos, o que explica a preferência dos autores pelo Aspergillus oryzae, que faz parte do gênero considerado como degradante primário de celulose e lignina (dos Santos et al., 2018).

Por meio da leitura dos estudos selecionados, foi possível identificar na metodologia empregada pelos autores, as análises empregadas e verificar quais foram as mais realizadas para ambos os tipos de substratos (cereal e leguminosa), conforme ilustrado na Figura 03.

Figura 03: Análises empregadas para determinação de compostos fenólicos, ácidos fenólicos e flavonoides na fermentação em estado sólido para as publicações de 2015 a 2020

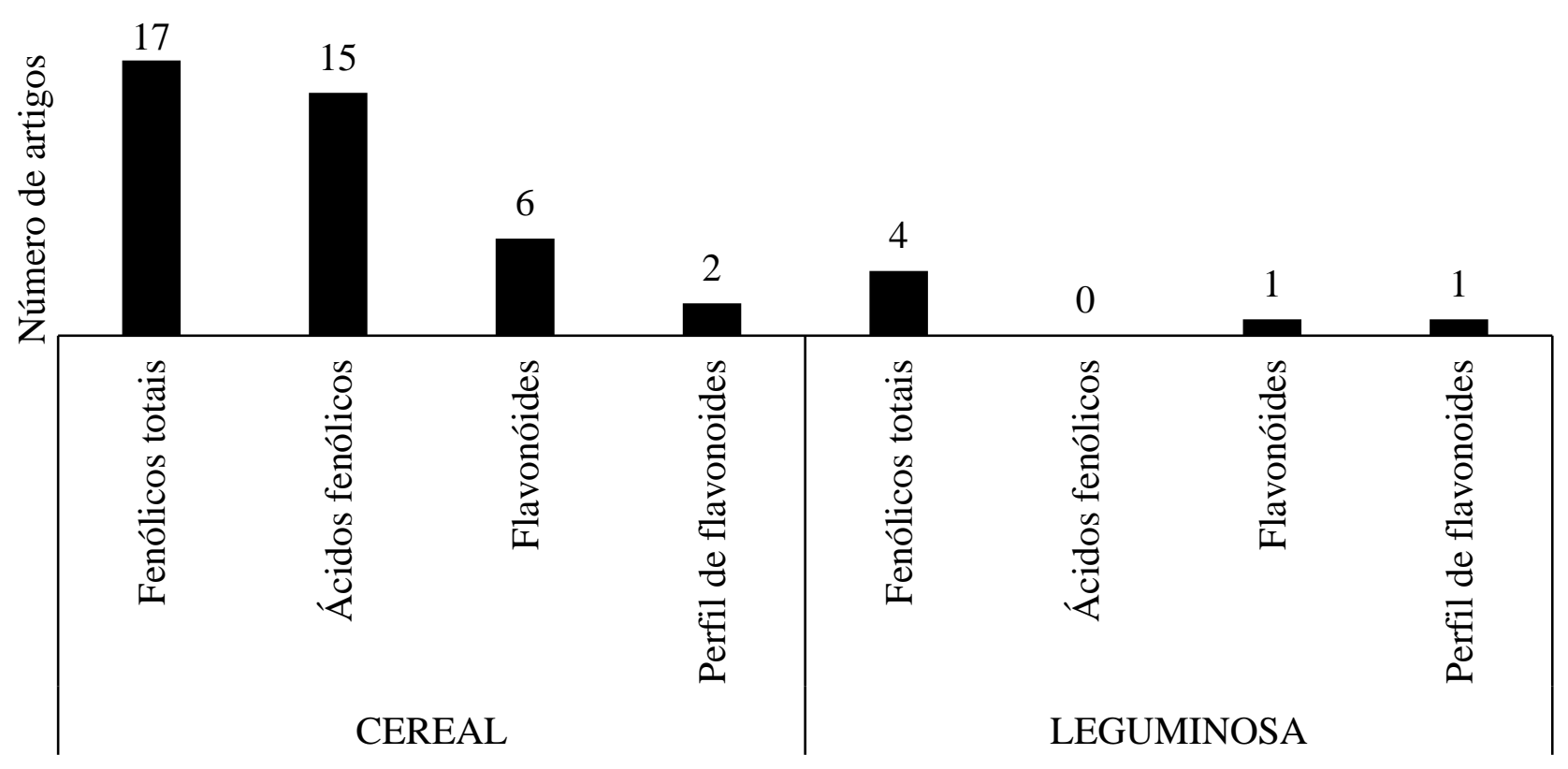

Fonte: Própria (2020).

Nota-se por meio da Figura 03, que a maior parte dos estudos (N: 21) avaliaram a produção e/ou aumento dos fenólicos totais por meio da fermentação em estado sólido. O que 
se justifica pelo fato de os compostos fenólicos serem metabólitos secundários de plantas, que são subdivididos em três grupos, os: ácidos fenólicos (ácidos benzoicos, cinâmico e seus derivados), os flavonoides (antocianinas, flavonóis e seus derivados) e cumarinas (Angelo \& Jorge, 2007). Portanto, ao determinarem os compostos fenólicos totais estão determinando toda uma classe. No entanto, as pesquisas indicam que a decisão de determinar o perfil de ácidos fenólicos e flavonoides está associada ao subproduto escolhido para estudo.

Nos estudos em que se utilizaram subprodutos provenientes de cereais, 17 avaliaram os compostos fenólicos totais, 15 os perfis de ácidos fenólicos, 6 os flavonoides totais e 2 determinaram o perfil de flavonoides. De acordo com Martins et al. (2011), materiais como cereais, vegetais, resíduos de palhas, bagaço, espigas, cascas, etc., são materiais lignocelulósicos, que apresentam em sua fração de lignina numerosos componentes fenólicos, principalmente os ácidos, como os: ferúlico, p-cumárico, seringico, vanílico e p- hidroxibenzoico. Desta maneira, se o subproduto é composto por uma parcela considerável de lignina, portanto a determinação do perfil de ácidos fenólicos pode ser considerada.

Nos estudos em que se empregaram os subprodutos de leguminosas como substrato na fermentação, 4 avaliaram os compostos fenólicos totais e apenas 1 determinou os flavonoides totais e o perfil de flavonoides. Dentre as classes de flavonoides analisadas, as isoflavonas se destacaram, como: Daidzeína, Gliciteínas e a Genisteína. As isoflavonas são encontradas em diversas quantidades em leguminosas e estão presentes, principalmente, como glicosídeos (daidzina e genistina) e agliconas (daidzeína e genisteína) (Angelo \& Jorge, 2007). Os ácidos fenólicos são os primeiros na via de síntese, pois são sintetizados a partir da estrutura fenólica mais simples. Estes ácidos possuem um grupo carboxílico em uma posição do anel aromático que servem como percussores para outros compostos fenólicos mais complexos, como por exemplo os flavonoides (da Silva, 2016).

\section{CONCLUSÕES}

Considerando a revisão realizada neste estudo, a qual considerou como conjunto de amostras diversos estudos em que foi utilizada a fermentação em estado sólido em substratos de cereais e leguminosas para disponibilização de compostos bioativos, foi possível concluir que, poucos estudos foram conduzidos utilizando substratos de leguminosas (N:4), consequentemente a maior parte das amostras foram de estudos conduzidos por meio da utilização de subprodutos de cereais (N:19). 
De modo geral, a utilização de resíduos agroindustriais como substratos em

fermentação em estado sólido para aumentar a disponibilização de compostos bioativos representa mais uma rota tecnológica em experimentação e que está em grande evolução, o que pode futuramente, diminuir substancialmente os custos de produção, reduzir o acúmulo destes materiais no meio ambiente e agregar valor nestes materiais que antes eram desvalorizados.

\section{REFERÊNCIAS}

ACOSTA-ESTRADA, ET AL. (2019). Effects of solid-state fungi fermentation on phenolic content, antioxidant properties and fiber composition of lime cooked maize by-product (nejayote). Journal of Cereal Science, 90(September), 102837.

ANGELO, P. M., \& JORGE, N. (2007). Compostos fenólicos em alimentos - Uma breve revisão. Revista Do Instituto Adolfo Lutz, 66(1), 1-9.

BENIWAL, V., ET AL. (2015). Use of chickpea (Cicer arietinum L.) milling agrowaste for the production of tannase using co-cultures of Aspergillus awamori MTCC 9299 and Aspergillus heteromorphus MTCC 8818. Annals of Microbiology, 65(3), 1277-1286.

CĂLINOIU, L. F., CĂTOI, A. F., \& VODNAR, D. C. (2019). Solid-state yeast fermented wheat and oat bran as a route for delivery of antioxidants. Antioxidants, 8(9).

DA SILVA, (2016) B. Soja: compostos funcionais e contaminantes. 101 f. Dissertação (Mestrado em Engenharia e Ciência de Alimentos) - Universidade Federal do Rio Grande, Programa de pós-graduação em Engenharia e Ciência de Alimentos, Rio Grande.

DA SILVA, B., KUPSKI, L., \& BADIALE-FURLONG, E. Central Composite DesignDesirability Function Approach for Optimum Ultrasound-Assisted Extraction of Daidzein and Genistein from Soybean and Their Antimycotoxigenic Potential. Food Analytical Methods, v. 12, p. 258-270, 2018.

DE SOUZA, T. D., ET AL. (2019). Profile of phenolic compounds released from rice bran by Rhizopus oryzae and Trichoderma reesei: their relation with hydrolases activity. Journal of Food Science, 84. https: //doi:10.1111/1750-3841.14646

DE OLIVEIRA, D. M., \& BASTOS, D. H. M. (2011). Biodisponibilidade de Ácidos fenólicos. Quimica Nova, 34(6), 1051-1056. https://doi.org/10.1590/S0100-40422011000600023.

DEY, T.B., ET AL., Antioxidant fenólicos e sua produção microbiana por processo de fermentação submersa e em estado sólido: uma revisão, Trends in Food Science \& Technology (2016), doi: 10.1016 / j.tifs.2016.04.007.

DOS SANTOS, ET AL. (2018). Fermentação em estado sólido em resíduos agroindustriais para a produção de enzimas: uma revisão sistemática. The Journal of Engineering and Exact Sciences, 04(02), 181-188. 
FERREIRA, A. N., ET AL. (2011). Aplicação da fermentação em estado sólido na biotransformação do resíduo do cajá. Revista Acadêmica: Ciência Animal, 9(2), 207.

FREITAS, M. M., NATAlinO, M. T., \& PALMIRO, R. A. D. (2015). 55 ${ }^{\circ} \mathbf{C B Q}$ - Casca de soja_Extração e caracterização da polpa celulósica e obtenção de carboximetilcelulose. Obtido em: $\quad$ http://www.abq.org.br/cbq/2015/trabalhos/13/810319026.html\#: :text=A\%20composi\%C3\% A7\%C3\%A3o\%20qu\%C3\%ADmica\%20da\%20CS ,et\%20al.\%2C\%202011). Acessado em 02 de novembro de 2020.

FURLONG, E. B., ET AL. (2020). Use of natural resources from Southern Brazil as a strategy to mitigate fungal contamination. Critical Reviews in Food Science and Nutrition, 1-8.

JANARNY, G., \& GUNATHILAKE, K. D. P. P. (2020). Changes in rice bran bioactives, their bioactivity, bioaccessibility and bioavailability with solid-state fermentation by Rhizopus oryzae. Biocatalysis and Agricultural Biotechnology, 23, (December) 101510.

KARAKURT, Y., ET AL. (2019). Chemical, enzymatic, and antioxidant enrichments of fullfat soybean and sunflower meal by Bacillus subtilis (ATCC® 6633TM) fermentation using a solid-state bioreactor. Turkish Journal of Veterinary and Animal Sciences, 43(1), 82-93.

KUPSKI, L., ET AL. (2018). Recovery of functional compounds from lignocellulosic material: An innovative enzymatic approach. Food Bioscience, 22(April 2017), 26-31.

LACERDA, D. B. C. L., ET AL. (2010). Qualidade De Farelos De Arroz Cru, Extrusado E Parboilizado. Pesquisa Agropecuária Tropical, 40(4), 521-530.

LIU, L., ET AL. (2016). Fermentation and complex enzyme hydrolysis enhance total phenolics and antioxidant activity of aqueous solution from rice bran pretreated by steaming with $\alpha$ amylase. Food Chemistry, 221, 636-643.

MACHADO, E. M. S., ET AL. (2012). Growth of fungal strains on coffee industry residues with removal of polyphenolic compounds. Biochemical Engineering Journal, 60, 87-90.

MAIA, I. DA C., ET AL. (2020). Effect of solid-state fermentation over the release of phenolic compounds from brewer's spent grain revealed by UPLC-MSE. Lwt, 133(August). https://doi.org/10.1016/j.lwt.2020.110136

MAO, M., ET AL. (2020). Effect of solid state fermentation by Enterococcus faecalis M2 on antioxidant and nutritional properties of wheat bran. Journal of Cereal Science, 94(April), 102997.

MARTINS, S. ET AL. (2011). Bioactive phenolic compounds: production and extraction by solid-state fermentation. A review. Biotechnology advances, 29(3).

MIRA, N. V. M. DE, ET AL. (2008). Extração, análise e distribuição dos ácidos fenólicos em genótipos pigmentados e não pigmentados de arroz (Oryza sativa L.). Ciência e Tecnologia de Alimentos, 28(4), 994-1002.

ORLANDELLI, R., ET AL. (2012). Enzimas de interesse industrial: produção por fungos e aplicações. SaBios-Revista de Saúde e Biologia, 7(3), 97-109. 
PALOMINO GARCÍA, L. R., \& DEL BIANCHI, V. L. (2015a). Capacidade antioxidante em resíduos da indústria cafeeira. Brazilian Journal of Food Technology, 18(4), 307-313.

PALOMINO GARCÍA, L. R., \& DEL BIANCHI, V. L. (2015b). Efeito da fermentação fúngica no teor de compostos fenólicos em casca de café robusta. Semina:Ciencias Agrarias, 36(2), 777-786.

PEREIRA, C. B. (2016). Avaliação da produção de enzimas celulolíticas e hemicelulolíticas por fungos isolados do cerrado, costa marinha brasileira e da Antártica, utilizando casca de soja como substrato. 117 f. il., Dissertação (Mestrado em Ciências Farmacêuticas) Faculdade de Ciências de Saúde, Universidade de Brasília, Brasília.

RASHID, N. Y. A., ET AL. (2019). Quantification of phenolic compounds changes by Aspergillus oryzae on rice bran fermentation. Food Research, 3(2), 133-137.

RASHID, N. Y. A., ET AL. (2015). Bioactive compounds and antioxidant activity of rice bran fermented with lactic acid bacteria. Malaysian Journal of Microbiology, 11(Specialissue2), $156-162$.

RAZAK, D. L. A, ET AL. (2015). Enhancement of phenolic acid content and antioxidant activity of rice bran fermented with Rhizopus oligosporus and Monascus purpureus. Biocatalysis and Agricultural Biotechnology, 4(1), 33-38.

RAZAK, D. L. A., ET AL. (2016). Comparative study of antioxidant activities, cosmeceutical properties and phenolic acids composition of fermented rice bran and coconut testa. Jurnal Teknologi. 2, 29-34.

RAZAK, D. L. A., ET AL. (2017). Cosmeceutical potentials and bioactive compounds of rice bran fermented with single and mix culture of Aspergillus oryzae and Rhizopus oryzae. Journal of the Saudi Society of Agricultural Sciences, 16(2), 127-134.

RAZAK, D. L. A, ET AL. (2019a). Assessment of fermented broken rice extracts for their potential as functional ingredients in cosmeceutical products. Annals od Agricultural Sciences, 64, 176-182.

RAZAK, D. L. A., ET AL. (2019b). Brewer's rice-A potential substrate for cosmeceutical bioingredient production by solid state fermentation using Aspergillus oryzae. Malaysian Journal of Microbiology, 15(SpecialIssue4), 260-266.

SANTOS, V. A. Q, ET AL. (2018). Solid-state fermentation of soybean okara: Isoflavones biotransformation, antioxidant activity and enhancement of nutritional quality. Lwt, 92, 509515.

SHI, H., ET AL. (2020). Solid-state fermentation with probiotics and mixed yeast on properties of okara. Food Bioscience, 36(April), 100610.

SHIN, H. Y., ET AL. (2019). Solid-state fermentation of black rice bran with Aspergillus awamori and Aspergillus oryzae: Effects on phenolic acid composition and antioxidant activity of bran extracts. Food Chemistry, 272, 235-241. 
SPAGGIARI, M., ET AL. (2020). Solid state lactic acid fermentation: A strategy to improve wheat bran functionality. Lwt, 118, 108668.

STATISTA (2020). Grain production worldwide 2019/20. Obtido em: https://www.statista.com/statistics/263977/world-grain-production-by-type/. Acessado em 02 novembro de 2020.

TIŠMA, M., ET AL. (2018) Biovalorization of brewers' spent grain for the production of laccase and polyphenols. Journal Institute of Brewing \& Distilling, 124, 182-186.

TU, J., ET AL. (2020). Solid state fermentation by Fomitopsis pinicola improves physicochemical and functional properties of wheat bran and the bran-containing products. Food Chemistry, 328, 127046.

WALTER, M., MARCHEZAN, E., \& DE AVILA, L. A. (2008). Arroz: composição e características nutricionais. Ciência Rural, 38(4), 1184-1192.

YIN, Z., ET AL (2017). Comparison of releasing bound phenolic acids from wheat bran by fermentation of three Aspergillus species. International Journal of Food Science and Technology, 53(5), 1120-1130. 


\section{CAPÍTULO 10: AVALIAÇÃO DA TOXICIDADE IN VITRO DO EXTRATO ENZIMÁTICO DO LÁTEX DA EUPHORBIA MILII PARA PROCESSAMENTO DE ALIMENTOS}

\section{CAPÍTULO 10: EVALUACIÓN DE LA TOXICIDAD IN VITRO DEL EXTRACTO ENZIMÁTICO DE EUPHORBIA MILII LATEX PARA EL PROCESAMIENTO DE} ALIMENTOS

\section{CHAPTER 10: IN VITRO TOXICITY ASSESSMENT OF EUPHORBIA MILII' LATEX ENZYMATIC EXTRACT FOR FOOD PROCESSING} Iris Barbosa de Souza ${ }^{1}$; Graziela Domingues Almeida Lima²; Erika Valente de Medeiros ${ }^{3}$; Keila Aparecida Moreira
Ana Lucia Porto Figueiredo

DOI: $\underline{\text { https://doi.org/10.31692/978-65-88970-19-5.146-158 }}$

\section{RESUMO}

A importância das plantas tóxicas não está somente nos riscos que possam causar, mas também dos benefícios que podem proporcionar. Entre essas, o látex de E. milii que apresenta atividade moluscicida, mas também potencial para uso farmacológico e no processamento de alimentos. Incentivando assim a avaliação da sua toxicidade através de ensaios que são necessários principalmente quando se trata de investigações toxicológicas preliminares em atendimento aos princípios éticos e econômicos. Nesse sentido, o presente estudo objetivou avaliar a toxicidade in vitro do látex de E. milii usando como modelo a Artemia salina e a avaliação de citotoxicidade com eritrócitos humanos, linhagem Vero e macrófagos. O látex de E. milii foi extraído e diluído (1/1) em solução tampão fosfato de sódio $1 \mathrm{M}, \mathrm{pH} 7,0$ foi centrifugado $\left(5000 \mathrm{~g}, 4{ }^{\circ} \mathrm{C}\right.$ por $30 \mathrm{~min}$.) e o produto final passou por processo de liofilização. No ensaio de toxicidade frente a A. salina foram testadas o látex liofilizado nas concentrações de 3,$5 ; 7,0 ; 10,5 ; 14 ; 21 ; 28$ e $35 \mathrm{mg} / \mathrm{mL}$ de água do mar esterilizada. No teste de citotoxicidade o látex foi dialisado antes da liofilização e diluído nas mesmas concentrações em soro fisiológico. A toxicidade do látex no ensaio com $A$. salina foi estimada pela $\mathrm{CL}_{50}$ usando o Probit e o percentual de viabilidade celular foi determinado para os resultados de citotoxicidade e avaliado pelo teste de Dunnett. Após 24 horas de exposição ao látex, a $\mathrm{CL}_{50}$ das larvas de $A$. salina foi estimada em $64,22 \mathrm{mg} / \mathrm{mL}$. O látex de E. milii manteve a viabilidade das células sem causar hemólise dos eritrócitos, teve ligeira diminuição das células da linhagem Vero (10,33\%) na concentração de $35 \mathrm{mg} / \mathrm{mL}$ e reduziu a viabilidade de macrófagos (26,34 - 45,53\%) nas concentrações usadas no ensaio. Os testes preliminares in vitro revelaram que o látex de E. mili não apresenta risco de toxicidade, mas investigações complementares são necessárias principalmente para uso na área da saúde e em alimentos.

\footnotetext{
${ }^{1}$ Engenharia de Alimentos, Universidade Federal do Agreste de Pernambuco (UFAPE), iris.barbosa@ufape.edu.br

${ }^{2}$ Entomologia, Universidade Federal de Viçosa (UFV), graziela.gdal@gmail.com

${ }^{3}$ Agronomia, Universidade Federal do Agreste de Pernambuco (UFAPE), erika.valente@ufape.edu.br

${ }^{4}$ Veterinária, Universidade Federal do Agreste de Pernambuco (UFAPE), keila.moreira@ufape.edu.br

${ }^{5}$ Pós Doutora, Universidade Federal Rural de Pernambuco (UFRPE), analuporto@yahoo.com.br
} 
Palavras-Chave: citotoxidade, toxicidade, viabilidade celular, Euphorbia milii, Artemia salina. RESUMEN

La importancia de las plantas tóxicas no está solamente en los riesgos que éstas pueden ocasionar, sino también en los beneficios que pueden brindar. Entre estos, el látex de E. milii que presenta actividad molusquicida, además de potencial para el uso farmacológico y en el procesamiento de alimentos. Incentivando, por lo tanto, la evaluación de su toxicidad a través de ensayos que son necesarios principalmente cuando se trata de investigaciones toxicológicas preliminares en cumplimiento de principios éticos y económicos. En este sentido, el presente estudio tuvo como objetivo evaluar la toxicidad in vitro del látex de E. milii utilizando Artemia salina como modelo, y la evaluación de la citotoxicidad con eritrocitos humanos, linaje Vero y macrófagos. Se extrajo látex de E. milii y se diluyó $(1 / 1)$ en una solución tampón de fosfato de sodio $1 \mathrm{M}$, se centrifugó a $\mathrm{pH}$ 7,0 $\left(5000 \mathrm{~g}, 4^{\circ} \mathrm{C}\right.$ durante $30 \mathrm{~min}$ ) y el producto final se sometió a un proceso de liofilización. En el ensayo de toxicidad ante A. salina, se probó látex liofilizado a concentraciones de 3,$5 ; 7,0 ; 10,5 ; 14 ; 21 ; 28$ y $35 \mathrm{mg} / \mathrm{mL}$ de agua marina estéril. En la prueba de citotoxicidad, el látex se dializó antes de la liofilización y se diluyó a las mismas concentraciones en suero fisiológico. La toxicidad del látex en el ensayo con $A$. salina se estimó mediante la CL50 usando Probit y el porcentaje de viabilidad celular se determinó para los resultados de citotoxicidad y se evaluó mediante la prueba de Dunnett. Después de 24 horas de exposición al látex, la CL50 de las larvas de A. salina se estimó en 64,22 mg / ml. El látex de $E$. milii mantuvo la viabilidad celular sin causar hemólisis de eritrocitos, presentó una ligera disminución

en las células del linaje Vero (10,33\%) en la concentración de $35 \mathrm{mg} / \mathrm{mL}$ y redujo la viabilidad de los macrófagos $(26,34-45,53 \%)$ en las concentraciones utilizadas en el ensayo. Las pruebas preliminares in vitro revelaron que el látex de E. mili no presenta riesgo de toxicidad, pero se necesitan investigaciones complementares principalmente para su uso en las áreas de la salud y de los alimentos.

Palabras Clave: citotoxicidad, toxicidad, viabilidad celular, Euphorbia milii, Artemia salina.

\section{ABSTRACT}

The importance of toxic plants is not only on the risks they can cause, but also on the benefits they can provide. Among these, the latex of E. milii has molluscicidal activity, but also potential for pharmacological use and in food processing. Thus encouraging the assessment of its toxicity through essays that are necessary mainly when it comes to preliminary toxicological investigations in compliance with ethical and economic principles. In this sense, the present study aimed to evaluate the in vitro toxicity of $E$. milii' latex using Artemia salina as a model, and the evaluation of cytotoxicity with human erythrocytes, Vero lineage and macrophages. E. milii' latex was extracted and diluted (1/1) in $1 \mathrm{M}$ sodium phosphate buffer solution, pH 7.0 was centrifuged $\left(5000 \mathrm{~g}, 4^{\circ} \mathrm{C}\right.$ for $30 \mathrm{~min}$.) and the final product underwent a freeze-drying process. In the toxicity essay against $A$. salina, lyophilized latex was tested at concentrations of $3.5 ; 7.0 ; 10.5 ; 14 ; 21 ; 28$ and $35 \mathrm{mg} / \mathrm{mL}$ of sterile seawater. In the cytotoxicity test, the latex was dialysed before lyophilization and diluted to the same concentrations in saline. The toxicity of the latex in the assay with A. salina was estimated by the LC50 using Probit and the percentage of cell viability was determined for the results of cytotoxicity and evaluated by the Dunnett test. After 24 hours of exposure to latex, the LC50 of A. salina larvae was estimated at 64.22 $\mathrm{mg} / \mathrm{mL}$. The latex of E. milii maintained the viability of the cells without causing hemolysis of the erythrocytes, and presented a slight decrease in the cells of the Vero lineage $(10.33 \%)$ at a concentration of $35 \mathrm{mg} / \mathrm{mL}$ and reduced the viability of macrophages $(26.34-45,53 \%)$ at the concentrations used in the essay. Preliminary in vitro tests revealed that $E$. mili' latex does not present a risk of toxicity, but further investigations are needed mainly for its use in the health and food fields.

Keywords: cytotoxicity, toxicity, cell viability, Euphorbia milii, Artemia salina. 


\section{INTRODUÇÃO}

O látex de Euphorbia milii, assim como outros compostos considerados "naturais", vêm sendo estudado quanto a sua composição química e toxicidade ( LYNN; CLEVETTE-RADFORD, 1988; SOUZA et al., 1997; OLIVEIRA-FILHO; PAUMGARTTEN, 2000; OLIVEIRA-FILHO et al., 2012; SHAH; PARAY, 2014; PRINSLOO; STREET, 2018). Esse interesse visa atender a expectativa de buscar na natureza e nos conhecimentos populares tradicionais uma maior aplicabilidade para o uso de extratos de plantas e seus princípios ativo devido a sua disponibilidade e aceitabilidade (BERLINCK et al., 2017; FARNSWORTH et al., 1985; KAUR et al., 2005; DUTRA et al., 2016; KHALIL et al., 2014; OMOYENI et al., 2016; LIMA JUNIOR; ABREU, 2018).

E. milii também conhecida como "Coroa-de-Cristo" ou "Coroa-de-Espinhos" é facilmente cultivada em estacas, bem adaptada a solos pobres em nutrientes e resistente à escassez de água. A planta é nativa de Madagascar e seu látex é usado no controle de moluscos e na medicina tradicional no tratamento de fígado e esquistossomose em animais, (GONZÁLEZ-RÁBADE et al., 2011; KHALIL et al., 2014), mas na China foi usado para tratamento de hepatite e edema abdominal (SOUZA et al., 1997; YADAV; PANDE; JAGANNADHAM, 2006). No Brasil há relatos do uso de seu látex no peeling de pele (DELGADO et al., 2003; MORO et al., 2008).

Dentre os testes in vitro, a Artemia salina é usada como referência e mantém uma boa correlação com ensaios de toxicidade em geral e anti-tumorais (MEYER et al., 1982; OLIVEIRA-FILHO; PAUMGARTTEN, 2000; SANTOS et al., 2010; ARCANJO et al., 2012; RAUF, KHAN; UDDIN, 2013). Nesse sentido, o presente estudo objetivou avaliar a toxicidade in vitro do látex de E. milii, utilizando para tal modelos de estudos de referência e alternativos.

\section{FUNDAMENTAÇÃO TEÓRICA}

A E. milii é identificada na natureza como um arbusto perene com ramos contorcidos e 
numerosos espinhos, mas rico em látex. Este látex é um líquido que contém uma mistura de soro, borracha, materiais de baixa densidade (LYNN; CLEVETTE-RADFORD, 1988) e várias enzimas, dentre as quais três: miliin (serino protease), milin e eumiliim (cisteína protease) que já foram caracterizadas, quanto aos efeitos do $\mathrm{pH}$, temperatura e sua atividade proteolítica (YADAV; PANDE; JAGANNADHAM, 2006; MORO et al., 2008; FONSECA et al., 2010). Devido a estabilidade dessas macromoléculas, elas podem despertar o interesse da indústria farmacêutica, biotecnológica e alimentícia (YADAV; PANDE; JAGANNADHAM, 2006).

Nessa potencial aplicação industrial, se faz necessária pesquisar o látex de E. milii e suas enzimas para o desenvolvimento de novos produtos e emprego nos diferentes segmentos industriais.

Sufiate et al. (2017) mostraram a eficiência das proteases do látex de E. milii in vitro na mortalidade de larvas de nematoides (Panagrellus redivivus).

Recentes estudos apresentado por Okonkwo e Ohaeri (2018) utilizaram os óleos essenciais obtidos das folhas de E. milii, para testes em larvas de insetos e encontraram fortes evidências para mostrar que os extratos podem exercer ação como inseticida classificado como organoclorados em função da sua ação fisiológica

Em camundongos fêmeas, Sreenika et al. (2015) induziram linhagens de células cancerígenas, trataram os animais com o extrato da flor de E. milii em acetato de etila e depois avaliaram parâmetros bioquímicos, parâmetros específicos de câncer (antígeno embrionário Ferritina e Carcino - CEA) e laudos histopatológicos para revelar a sua ação eficaz como antioxidante e quimiopreventivo.

Assim como relevantes pesquisas envolvendo a toxicidade das enzimas sobre moluscos e embriões de Biomphalaria glabrata no sentido de combater os caramujos vetores da esquistossomose. (VASCONCELLOS et al., 1986; MENDES et al., 1997; OLIVEIRA-FILHO et al., 2010; SANTOS et al., 2010; OLIVEIRA-FILHO et al., 2012; AUGUSTO et al., 2017). E. milii é considerada o recurso natural mais promissor apresentado pela Organização Mundial de Saúde (OMS) como estratégia de controle da esquistossomose (FARNSWORTH et al., 1985; AUGUSTO et al., 2017; AUGUSTO; MELO SILVA, 2018).

No trabalho desenvolvido por Fonseca et al. (2010) uma dessas enzimas, cisteína protease (eumiliin) induziu edema, mionecrose com leucócitos infiltrados e danificou as fibras musculares na pata do camundongo após injeção intraplantar. Delgado et al. (2003) estudaram 
compostos fitoquímicos de E. milli e identificaram a presença de $\beta$-sitosterol, cicloartenol, acetato de $\beta$-amirina, lupeol, eufol, triterpenos e flavonóides.

Por outro lado, Venkatesha e Vishwanath (2016) relataram que não tem sido observado nenhum efeito tóxico para serino proteases isoladas de látex de plantas e que esses efeitos são principalmente devidos a outras substâncias presentes nos mesmos. Entre essas, os diterpenos, que causam efeitos adversos como irritação da pele com formação de bolhas, inflamação e alterações carcinogênicas. (MOREIRA et al., 2014; PRINSLOO; NOGEMANE; STREET, 2018).

Diante do exposto, fica claro a necessidade de conhecer não somente os potenciais usos industriais, mas em princípio, os possíveis efeitos tóxicos do látex de E. milli. Considerando as razões éticas e econômicas o uso de animais deve ser evitado quando se trata de investigações toxicológicas preliminares, dando assim ênfase à utilização de modelos experimentais in vitro de referência ou alternativos. O uso de células humanas e de animais é um sistema alternativo para testes toxicológicos de diferentes classes de produtos sintéticos e naturais (KRISTEN, 1997; LIMA et al., 2018).

Os testes in vitro podem ser realizados com bactérias, fungos, algas e crustáceos, além de frações subcelulares presentes no sistema biológico como suspensões celulares, cultivo de tecidos, cultivos celulares, enzimas e proteínas. Contudo, os estudos com cultura de células vêm se destacando dentre os demais (FRAZIER, 1992; BEDNARCZUK et al, 2010).

\section{METODOLOGIA}

A pesquisa é quantitativa com ensaio experimental no campo das ciências biológicas envolvendo material coletado da flora do Brasil e seguindo protocolos de testes in vitro de toxicidade.

\section{Coleta do material vegetal}

As plantas de Euphorbia milii Des Moulins foram localizadas em Garanhuns Pernambuco (GPS $08^{\circ} 53^{\prime} 26^{\prime \prime} \mathrm{S}$ e 36²9'47’W) para a coleta do látex no período de maio a julho de 2017. Amostra representativa da planta foi encaminhada para classificação e depositado no herbário Dárdano de Andrade Lima, sob o número 91595, do Instituto Pernambucano de Agronomia (IPA). 
A coleta do látex de E. mili foi realizada higienicamente protegido com luvas descartáveis e material cortante em inox e pinça para remoção das sujidades. A coleta foi realizada diretamente em tubos plásticos tipo Falcon de $15 \mathrm{~mL}$ com identificação de volume até atingir $4 \mathrm{~mL}$ e em seguida completados com $4 \mathrm{~mL}$ de solução tampão fosfato de sódio $1 \mathrm{M}, \mathrm{pH} 7,0$. O látex adicionado do tampão foi homogeneizado e acondicionado em caixa isotérmica mantendo a temperatura de $8{ }^{\circ} \mathrm{C}$ para transporte até o laboratório. Os tubos com o látex homogeneizados foram identificados e congelados em freezer da $\operatorname{Bosch}^{\circledR}$ a temperatura de $\left(-20^{\circ} \mathrm{C}\right)$ até o desenvolvimento do experimento.

\section{Preparação do látex de Euphorbia milii}

O látex homogeneizado passou por duas etapas de centrifugação a 5000 . g e $4{ }^{\circ} \mathrm{C}$ por 30 minutos para remover partículas maiores e concentrar as enzimas. Em seguida, o líquido sobrenadante límpido contendo as enzimas foi separado e transportado para um novo tubo de plástico tipo Falcon de $15 \mathrm{~mL}$ e repetida a mesma centrifugação e as partículas sedimentadas foram removidas e descartadas. Em seguida, o látex de E. mili foi pipetado (1mL), distribuído em microtubos eppendorf e armazenados em ultra-congelador Eletrolux ${ }^{\circledR}\left(-70{ }^{\circ} \mathrm{C}\right)$ por 24 horas para liofilização.

No teste de toxicidade in vitro com A. salina foi utilizado o látex liofilizado e no ensaio de citotoxicidade o látex passou também pelo processo de diálise em água pdeionizada por 24 horas sob refrigeração na geladeira da $\operatorname{Bosch}^{\circledR}\left(8^{\circ} \mathrm{C}\right)$ antes da etapa de liofilização realizada em Liofilizador Terroni ${ }^{\circledR}$. Após essa etapa as amostras liofilizados/dialisadas foram armazenadas sob congelamento em freezer da $\operatorname{Bosch}^{\circledR}\left(-20^{\circ} \mathrm{C}\right)$ para posterior realização dos ensaios.

\section{Toxicidade do látex de Euphorbia milii in vitro}

Nos testes de toxicidade in vitro, incialmente foi preparada uma solução padrão resuspendendo $70 \mathrm{mg}$ de látex liofilizado/dialisado em $1 \mathrm{~mL}$ de água do mar esterilizada para exposição das $A$. salina ou $1 \mathrm{~mL}$ de soro fisiológico para avaliação de viabilidade dos eritrócitos humanos e das células de linhagens Vero e de macrófagos. Na realização dos ensaios a solução foi preparada nas concentrações de 3,5 mg/mL (5\%); $7 \mathrm{mg} / \mathrm{mL}$ (10\%); 10,5 $\mathrm{mg} / \mathrm{mL}(15 \%), 14 \mathrm{mg} / \mathrm{mL}(20 \%) ; 21 \mathrm{mg} / \mathrm{mL}(30 \%) ; 28 \mathrm{mg} / \mathrm{mL}(40 \%)$ e $35 \mathrm{mg} / \mathrm{mL}(50 \%)$ para os testes com A. salina e citotoxicidade. 


\section{Primeiro teste: Obtenção e ensaio de sobrevivência da Artemia salina}

A. salina em forma de cistos (embalagem de $5 \mathrm{~g}$ ) foi adquirida em casa de alimentação animal e ativada na proporção de $25 \mathrm{mg}$ em $500 \mathrm{~mL}$ de água do mar com $\mathrm{pH}$ 8,44 e temperatura de $25-30{ }^{\circ} \mathrm{C}$. A água do mar foi coletada no litoral de Recife-Pernambuco e esterilizada a $\left(121 / 15^{\circ} \mathrm{C}\right)$. A eclosão da $A$. salina ocorreu com aeração por 48 horas e em ambiente adaptado com foto-controle.

Após a eclosão, as larvas viáveis foram divididas em microplaca para cultura celular em nove grupos, sendo sete para testar as concentrações do látex de E. milii, um controle positivo que foi feito com um sal de dicromato de potássio $\left(\mathrm{K}_{2} \mathrm{Cr}_{2} \mathrm{O}_{7}\right)$ diluído a $20 \mathrm{ppm}$ em água do mar e um controle negativo apenas água marinha. Em cada grupo continha 24 a 37 unidades de $A$. salina para exposição nas concentrações do ensaio. (MEYER, et al, 1982). As larvas foram expostas ao látex de E. milii nas concentrações de $3,5 \mathrm{mg} / \mathrm{mL}$ até $35 \mathrm{mg} / \mathrm{mL}$ $(50 \%)$.

$\mathrm{Na}$ avaliação de sobrevivência e mortalidade os animais vivos ou em óbitos foram contados e os resultados analisados no programa Probit usando o software SPSS ${ }^{\circledR} 19.0$ (IBM ${ }^{\circledR}$ Corp., NY, EUA), obtendo-se o valor de $\mathrm{CL}_{50}$ com um intervalo de confiança de $95 \%$ (SANTOS et al., 2010)

\section{Segundo teste: Ensaio de hemólise}

Este ensaio foi realizado para determinar a compatibilidade de eritrócitos humanos com o látex de E. milii. O sangue humano fresco foi coletado, centrifugado a 700. g por 10 min., lavado três vezes com tampão fosfato-salino (PBS 10 mM; NaCl 137 mM, KCl 2,7 mM, $\left.\mathrm{Na}_{2} \mathrm{HPO}_{4} 10 \mathrm{mM}, \mathrm{KH}_{2} \mathrm{PO}_{4} 2 \mathrm{mM}, \mathrm{pH} 7,4\right)$ e ressuspenso no mesmo tampão para preparar a suspensão de glóbulos vermelhos a 2\% (XU et al., 2017). Posteriormente, 3,5 até $35 \mathrm{mg} / \mathrm{mL}$ $(50 \%)$ do látex foram incubadas com a suspensão de hemácias a $37^{\circ} \mathrm{C}$.

As hemácias também foram incubadas com tampão fosfato-salino e Triton X-100 (1\% $\mathrm{v} / \mathrm{v}$ ) como controle negativo e positivo, respectivamente. Após $24 \mathrm{~h}$, as amostras foram centrifugadas por $10 \mathrm{~min}$ a $700 \mathrm{~g}$ (XU et al., 2017) e determinou-se a liberação de hemoglobina com auxílio de um leitor de microplaca (SpectraMax M5, Molecular Devices) a $540 \mathrm{~nm}$.

O percentual de hemólise foi determinado pela seguinte equação: 
Os procedimentos descritos acima estão de acordo com os princípios éticos de pesquisa (protocolo número 108/2012/CEPH/wmt).

\section{Terceiro teste: Viabilidade celular em dois tipos de linhagens celulares e cultivo celular}

Células das linhagens Vero (rim de macaco) e de macrófago (RAW 264.7) foram gentilmente cedidas pela Prof ${ }^{\text {a }}$ Dra. Juliana Lopes Rangel Fietto (Departamento de Bioquímica e Biologia Molecular, UFV, Viçosa, Minas Gerais, Brasil), as mesmas foram cultivadas, mantidas em meio RPMI 1640, pH 7,2 (Gibco, Invitrogen, CA, USA) e suplementadas com $10 \%$ de soro fetal bovino (10\% SFB), penicilina (1\%), estreptomicina (1\%) a $37{ }^{\circ} \mathrm{C}$, sob tensão de $5 \%$ de $\mathrm{CO}_{2}$. Antes de cada experimento, as células foram removidas das garrafas de cultivo com auxílio de tripsina (0,25\%), centrifugadas (1500 rpm; 5 minutos) e ressuspensas em meio RPMI 1640, sendo suplementadas com SFB. Em seguida, essas células foram contadas em câmara de Neubauer e semeadas em placas de 96 poços, respeitando-se as concentrações celulares adequadas para cada ensaio (LIMA et al., 2018).

A viabilidade celular de duas linhagens celulares frente ao látex de E. milii foi determinada pelo ensaio de MTT (brometo de (3- (4,5 dimetiltiazol-2-il)-2,5-difeniltetrazólio; Sigma) previamente descrito (PIETRASZEK et al., 2013). As linhagens Vero $\left(3 \times 10^{4}\right.$ células/poço) e macrófago $\left(5 \times 10^{4}\right.$ células/poço) foram incubadas em placas de 96 poços, por 24 horas a $37^{\circ} \mathrm{C}$ e $5 \%$ de $\mathrm{CO}_{2}$. Cada poço continha $100 \mu \mathrm{L}$ de meio RPMI completo e $100 \mu \mathrm{L}$ do látex de E. milii nas concentrações de 3,5 mg/mL (5\%) até $35 \mathrm{mg} / \mathrm{mL}$ (50\%) diluídos em meio RPMI com $10 \%$ de SFB.

Após 48 de incubação, MTT (5 mg/mL, Sigma) foi adicionado em cada poço. Após 4h a $37^{\circ} \mathrm{C}$, a solução de MTT foi removida e $100 \mu \mathrm{l}$ de DMSO foi adicionado um cada poço para solubilizar os cristais de formazan. A absorbância foi lida a $540 \mathrm{~nm}$ em um leitor de microplaca (SpectraMax M5, Molecular Devices).

Os resultados foram normalizados considerando os poços tratados com meio RPMI (controle). Para os cálculos da viabilidade celular foi utilizada a seguinte equação: \% de viabilidade $=($ absorbância da amostra x 100)/absorbância do controle (RPMI) $)$. 


\section{RESULTADOS E DISCUSSÃO}

O ensaio com $A$. salina foi realisado como triagem para medir o gráu de toxicidade do látex de E. mili e serviu de parâmetro na busca dos testes de citotoxicidade para dar continuidade na avaliaçao da sua segurança. Os resultados do bioensaio com A. salina, um microcrustáceo usado no teste de toxicidade do látex liofilizado de E. milii estão apresentados na Tabela 1.

Tabela 1. Dados de sobrevivência de Artemia salina expostas ao látex liofilizado de Euphorbia milii após 24 h de exposição.

\begin{tabular}{ccccc}
\hline Látex & Artemia & \multicolumn{3}{c}{ Sobrevivência após 24 horas } \\
{$[\mathbf{m g} / \mathbf{m L}]$} & Salina $\mathbf{( n )}$ & Vivos & Mortos & Sobrevivência (\%) \\
\hline 3,5 & 37 & 35 & 2 & 94,60 \\
7,0 & 28 & 26 & 2 & 92,86 \\
10,5 & 30 & 27 & 3 & 90,00 \\
14,0 & 33 & 29 & 4 & 87,88 \\
21,0 & 33 & 28 & 5 & 84,84 \\
28,0 & 30 & 20 & 10 & 66,66 \\
35,0 & 30 & 17 & 13 & 56,66 \\
Controle + & 24 & 2 & 22 & 8,33 \\
Controle - & 24 & 24 & 0 & 100 \\
\hline
\end{tabular}

Fonte: Própria (2019)

Após 24 horas de exposição da A. salina ao látex de E. mili nas concentrações de 3,5 até $21 \mathrm{mg} / \mathrm{mL}$ as larvas sobreviveram com leve redução de 94,60\% até 84,84\%, respectivamente. Mas nas concentrações maiores $28 \mathrm{mg} / \mathrm{mL}$ (40\%) e $35 \mathrm{mg} / \mathrm{mL}$ (50\%) o meio ficou turvo com formação de uma pequena película na superfície e foram observadas as maiores reduções na sobrevivência das larvas de 66,66\% e 56,66\%, respectivamente. Esse resultado encontrado pode ser interpretado pela exposição das larvas a alta concentração do látex, ou outros compostos ativos presentes no látex ou até mesmo resíduos das larvas mortas que não sobreviveram e que permaneceram no mesmo local. $\mathrm{O}$ índice de mortalidade das larvas após 24 horas no bioensaio de toxicidade do látex de E. milii sobre A. salina foi estimado por meio do cálculo da $\mathrm{CL}_{50}$, obtendo-se o valor de $64,22 \mathrm{mg} / \mathrm{mL}$ ou $64220 \mu \mathrm{g} / \mathrm{mL}$. Esse resultado pode considerar o látex de E. milii como composto não tóxico segundo Meyer et al. (1982). Na metodologia proposta (MEYER et al., 1982) foi estabelecido uma relação entre o grau de toxicidade e a dose letal média, $\mathrm{CL}_{50}$, de extratos de plantas sobre microcrustáceos A. salina, considerando que quando verificados valores acima de 1000 
$\mu \mathrm{g} / \mathrm{mL}$ e não havendo morte acima de $50 \%$, estes, são considerados atóxicos.

$\mathrm{O}$ resultado encontrado nesse trabalho de $\mathrm{CL}_{50}=64,22 \mathrm{mg} / \mathrm{mL}$ difere dos dados encontrados por Oliveira-Filho e Paumgartten, (2000), que analisaram o látex bruto de E. milii e encontraram $\mathrm{CL}_{50}=24,23 \mathrm{mg} / \mathrm{L}(0,024 \mathrm{mg} / \mathrm{mL})$ em 24 horas para o tempo de exposição de larvas de Artemia sp nauplii. A diferença nos resultados pode estar na forma de preparo do látex para realizar os ensaios. Nesse trabalho o látex foi coletado e misturado na mesma proporção com solução tampão fosfato de sódio $1 \mathrm{M}, \mathrm{pH} 7,0$ e após duplo processo de centrifugação foi usado somente a parte aquosa sobrenadante com descarte de todo material tipo borracha decantado no tubo de plástico. No processo de centrifugação e diálise, segundo Ramos et al. (2006) as principais proteínas solúveis são facilmente separadas da borracha e compostos de baixo peso molecular que podem causar maior toxicidade. No caso de Oliveira-Filho e Paumgartten, (2000) foi utilizado o látex bruto, da forma que foi coletado e liofilizado para uso no ensaio.

No ensaio de citotoxicidade o látex de E. milii foi dialisado seguindo metodologia de Fonseca et al., (2010) antes de ser liofilizado. Inicialmente foi realizado o ensaio do látex de E. milii frente a eritrócitos primários humanos (Figura 1) e duas diferentes linhagens de células de mamífero (Figura 2 e 3).

Figura 1- Gráfico representativo do teste de hemólise do efeito do extrato enzimático de Euphorbia milii sobre eritrócitos primários. Valores expressos como média \pm S.E.M. ${ }^{*} P<0,05$ pelo teste de Dunnett. n.s: não significativo. Controle positivo $(\mathrm{C}+)$ : Triton $\mathrm{X}-100$, indicando hemólise total. Controle negativo (C-): tampão fosfato-salino, hemólise basal.

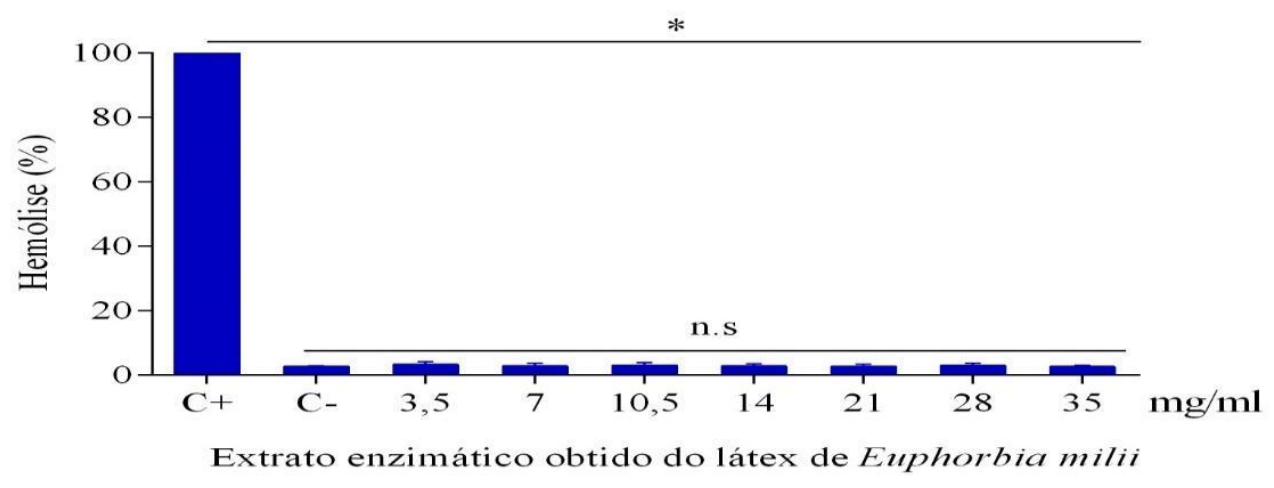

Fonte: Própria (2019)

O ensaio de hemólise mostrou que o látex de E. milii nas concentrações e condições experimentais utilizadas não causou hemólise, visto que não houve diferença significativa entre as concentrações do látex e o controle negativo. 
Figura 2- Gráfico representativo do teste de MTT do efeito do extrato enzimático de Euphorbia milii sobre a linhagem Vero. Dados expressos como média \pm S.E.M. ${ }^{*} P<0,05$ : concentrações do látex versus controle (RPMI) pelo teste de Dunnett.

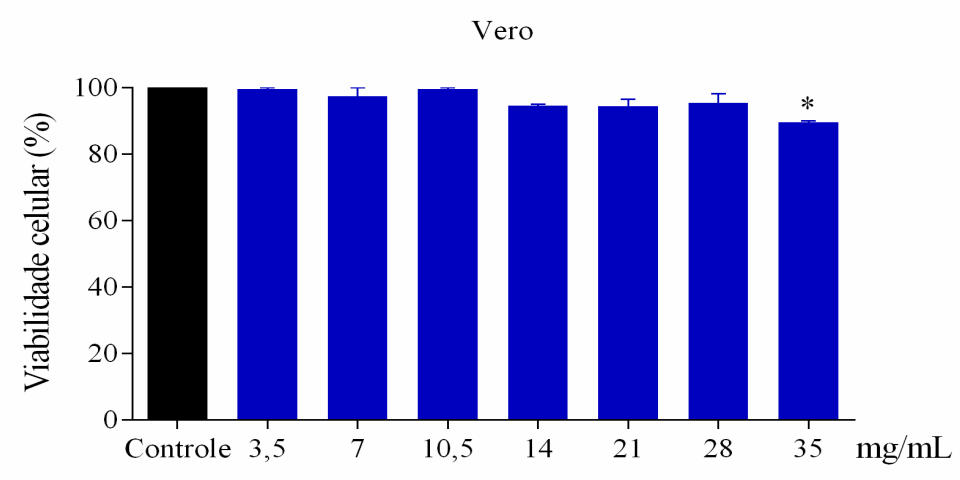

Extrato enzimático obtido do látex de Euphorbia milii

Fonte: Própria (2019)

No que se refere à viabilidade celular, a linhagem Vero foi ligeiramente sensível ao látex de E. milii apenas na concentração de $35 \mathrm{mg} / \mathrm{mL}$ (10,33\%; Figura 2). Esse resultado pode indicar que o látex de E. milii não cause resposta direta sobre linhagens celulares menos reativas (i.e., menos sensíveis ou suceptíveis).

Figura 3- Gráfico representativo do teste de MTT do efeito do extrato enzimático de Euphorbia milii sobre macrófagos. Gráfico representativo do teste de MTT. Dados expressos como média \pm S.E.M. ${ }^{*} P<0,05$ : concentrações do látex versus controle (RPMI) pelo teste de Dunnett.

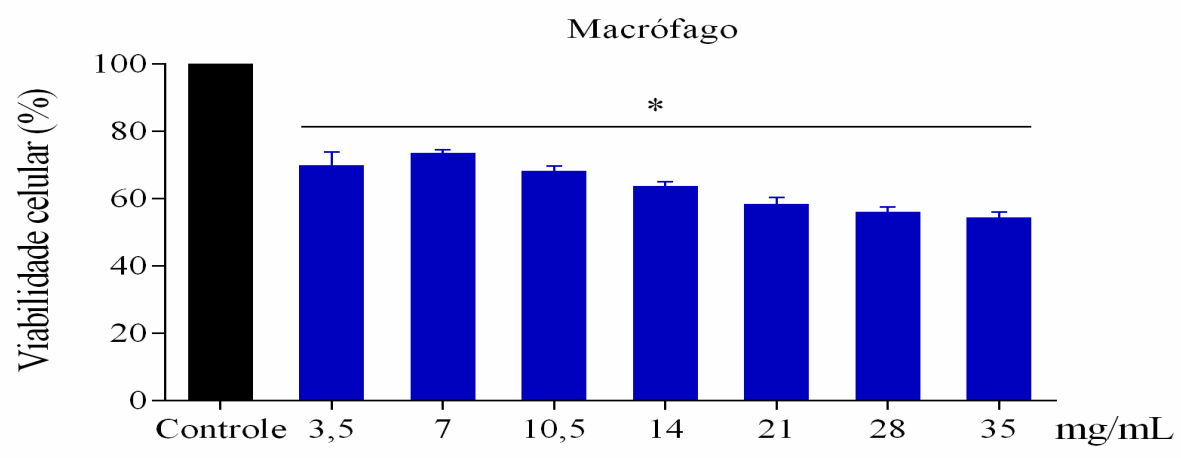

Extrato enzimático obtido do látex de Euphorbia milii

Fonte: Própria (2019)

No entanto é importante notar que o látex de E. milii pode causar significativa resposta em células mais reativas (i.e., relacionados à resposta inflamatória) como macrófagos (Figura 3). Todas as concentrações do látex foram capazes de reduzir a viabilidade celular da linhagem de macrófago de 26,34\% na concentração de $7 \mathrm{mg} / \mathrm{mL}$ mas atingindo o máximo de 
45,53\% na concentração de $35 \mathrm{mg} / \mathrm{mL}$. Esse resultado indica que componentes presentes no látex de E. milii podem modular respostas fisiológicas relacionada com a sensibilidade. Resposta similar observada por Fonseca et al., (2010), que em estudo in vivo usaram o látex de E. milii liofilizado e também dialisado para extrair a eumiliin (cisteína protease) para avaliar e caracterizar os efeitos da enzima ao aplicarem injeção intraplantar na pata de camundongos. Eles realizaram análises histopatológicas e observaram a formação de edema com infiltrado leucocitário visível e a alta presença de macrófagos sugerindo que a eumiliin presente no látex de E. milii pode causar perturbações teciduais em camundongos, mas não sem evidências de lesões vasculares ou hemorrágicas. Estes autores também ressaltaram que existe pouca informação disponível sobre as atividades bioquímicas presentes no látex de $E$. milii, mostrando a importância de pesquisar esses efeitos, tanto pelo seu uso na medicina tradicional como possíveis aplicação na indústria farmacêutica e de alimentos. No resultado de citotoxicidade em relação aos macrófagos evidencia a presença da eumiliin como uma das proteases presentes no látex de E. milii e com atividade sobre a caseína, evidenciada na patente de processo de obtenção de um novo coagulante de leite a partir do látex da "Coroa de Cristo" para processamento de queijos (Souza et al., 2018).

\section{CONCLUSÕES}

O látex de E. milii analisado in vitro mantem a viabilidade das larvas de $A$. salina $\mathrm{e}$ das células nas concentrações e condições experimentais utilizadas nos ensaios. As larvas de A. salina apresentam baixa mortalidade após 24 horas de exposição ao látex de E. milii e o índice de mortalidade das larvas no bioensaio de toxicidade é estimado em $\mathrm{CL}_{50}=64,22$ $\mathrm{mg} / \mathrm{mL}$. O látex de E. milii não causa hemólise frente a eritrócitos primários humanos, a linhagem Vero apresenta ser ligeiramente sensível apenas na concentração de $35 \mathrm{mg} / \mathrm{mL}$ $(10,33 \%)$ e na linhagem de macrófago a viabilidade é reduzida em todas as concentrações usadas no ensaio atingindo o máximo de $45,53 \%$ na maior concentração de $35 \mathrm{mg} / \mathrm{mL}$. Os testes preliminares in vitro revelam que o látex de E. mili não apresenta risco de toxicidade mas são recomendados dados farmacocinéticos para substâncias isoladas ou concentradas cujo metabolismo não é conhecido. 


\section{REFERÊNCIAS}

ARCANJO, D.D.R., et al. Bioactivity evaluation against Artemia salina Leach of medicinal plants used in Brazilian Northeastern folk medicine. Brazilian Journal Biology, v. 72, n. 3, p. $505-509,2012$.

ANVISA. Guia para Comprovação da Segurança de Alimentos e Ingredientes. Brasil Anvisa, p. 45, 2013. Disponível em: <http://nutrimialimentos.com.br/guia.pdf $>$.

AUGUSTO, R.C. et al. Double impact: natural molluscicide for schistosomiasis vector control also impedes development of Schistosoma mansoni cercariae into adult parasites. PLOS Neglected Tropical Diseases, v. 11, n. 7, p. 1-19, 2017.

AUGUSTO, R. C. \& MELLO SILVA, C. C. Phytochemical molluscicides and schistosomiasis: What We Know and What We Still Need to Learn. Veterinary Sciences, v. 5, n. 4, p. 94-102, 2018.

BEDNARCZUK, V.O. et al. Testes in vitro e in vivo utilizados na triagem toxicológica de produtos naturais. Visão Acadêmica, v.11, n.2, p.43-50, 2010.

BERLINCK, R. G. S. et al. A química de produtos naturais do Brasil do Século XXI. Quimica Nova, v. 40, n. 6, p. 706-710, 2017.

DELGADO, I. F. et al. Absence of tumor promoting activity of Euphorbia milii latex on the mouse back skin. Toxicology Letters, v. 145, n. 2, p. 175-180, 2003.

DUTRA, R. C. et al. Medicinal plants in Brazil: Pharmacological studies, drug discovery, challenges and perspectives. Pharmacological Research, v. 112, p. 4-29, 2016.

FARNSWORTH, N. R. et al. Medicinal plants in therapy. Bulletin of the World Health Organization, v. 63, n. 6, p. 965-981, 1985.

FONSECA, K. C. et al. Purification and biochemical characterization of eumiliin from Euphorbia milii var. hislopii latex. Phytochemistry, v. 71, n. 7, p. 708-715, 2010.

FRAZIER, J. M. In vitro toxicity testing. Applications to safety evaluation. New York, Marcel Dekker, Inc., 1992. p. 300.

GONZÁLEZ-RÁBADE, N. et al. Production of plant proteases in vivo and in vitro - A review. Biotechnology Advances, v. 29, n. 6, p. 983-996, 2011.

LIMA JUNIOR, R.N.; ABREU, F.O.M.S. Produtos naturais utilizados como coagulantes e floculantes para tratamento de águas: uma revisão sobre benefícios e potencialidades. Revista Virtual de Química, v. 10, n. 3, p.1-27, 2018.

KAUR, S. et al. The in vitro cytotoxic and apoptotic activity of Triphala - An Indian herbal drug. Journal of Ethnopharmacology, v. 97, n. 1, p. 15-20, 2005.

KHALIL, A. T. et al. Phyto-therapeutic claims about Euphorbeaceous plants belonging to Pakistan; an ethnomedicinal review. Pakistan Journal of Botany, v. 46, n. 3, p. 1137-1144, 2014. 
KRISTEN, U. Use of higher plants as screens for toxicity assessment. Toxicology in vitro, United Kingdom, v.11, p.181-191, 1997.

LIMA et al. Synthesis and antimetastatic activity evaluation of cinnamic acid derivatives containing 1,2,3-triazolic portions. Toxicology in Vitro, v. 53, p 1-9, 2018.

LYNN, K. R.; CLEVETTE-RADFORD, N. A. Proteases of euphorbiaceae. Phytochemistry, v. 27, n. 1, p. 45-50, 1988.

MENDES, N. M. et al. Evaluation of the molluscicidal properties of Euphorbia splendens var. hislopii (N.E.B.) Latex: Experimental test in an endemic area in the state of Minas Gerais, Brazil. Instituto Oswaldo Cruz, v. 92, n. 5, p. 719-724, 1997.

MEYER, B. N. et al. Convenient general biossay for active plant constituents. Medicinal Plant Research, v.45p.31-34, 1982.

MOREIRA, D. D. L. et al. Traditional use and safety of herbal medicines. Brazilian Journal of Pharmacognosy, v. 24, n. 2, p. 248-257, 2014.

MORO, L. P. et al. Purification, biochemical and functional characterization of miliin, a new Thiol-Dependent serine protease isolated from the latex of Euphorbia milii.. Protein \& Peptide Letters, v. 15, n. 7, p. 724-730, 2008.

OKONKWO, C. O.; OHAERI, O. C. Essential oils from the leaves of Euphorbia Milieu exert insecticidal activity through disruption in ionic composition. Journal of Pharmacy and Biological Sciences, v. 13, n. 4, p. 46-53, 2018.

OLIVEIRA-FILHO, E. C. et al. Absence of antimicrobial activity of Euphorbia milii molluscicidal latex. Journal of Pharmaceutical Negative Results, v. 3, n. 1, p. 13, 2012.

OLIVEIRA-FILHO, E. C. et al. Chemosphere comparative toxicity of Euphorbia milii latex and synthetic molluscicides to Biomphalaria glabrata embryos. Chemosphere, v. 81, n. 2, p. 218-227, 2010.

OLIVEIRA-FILHO, E. C.; PAUMGARTTEN, F. J. R. Toxicity of Euphorbia milii latex and niclosamide to snails and nontarget aquatic species. Ecotoxicology and Environmental Safety, v. 46, n. 3, p. 342-350, 2000.

OMOYENI, O. A. et al. A review of the ethnomedicinal uses, phytochemistry and pharmacology of the Pleiocarpa genus. Phytochemistry Reviews, v. 6, n. 1, p. 1-19, 2016.

PIETRASZEK et al. Lumican - Derived peptides inhibit melanoma cell growth and migration. Plos One, v.8, n.13, p.1-11, 2013.

PRINSLOO, G.; NOGEMANE, N.; STREET, R. The use of plants containing genotoxic carcinogens as foods and medicine. Food and Chemical Toxicology, v. 116, n. March, p. 27-39, 2018.

RAUF, A.; KHAN, A.; UDDIN, N. Cytotoxic study of aerial parts of Euphorbia Milli and Euphorbia pulcherrima. Topclass Journal of Herbal Medicine, v.2, n. 12, p. 266-269, 2013.

SANTOS, A. F. DOS et al. Toxicity of some glucose/mannose-binding lectins to Biomphalaria glabrata and Artemia salina. Bioresource Technology, v. 101, n. 2, p. 794-798, 2010 . 
SCHALL, V.T. et al. Evaluation of the genotoxic activity and acute toxicity of Euphorbia splendens lates, a molluscicide for the control of schistosomiasis. Brazilian Journal Medician Biology, n.24, p.573-582, 1991.

SHAH, M. A.; MIR, S. A.; PARAY, M. A. Plant proteases as milk-clotting enzymes in cheesemaking: A review. Dairy Science and Technology, v. 94, n. 1, p. 5-16, 2014.

SOUZA, C. A. M. et al. Study of the embryofeto-toxicity of Crown-of-Thorns (Euphorbia milii) latex, a natural molluscicide. Brazilian Journal of Medical and Biological Research, v. 30, n. 11, p. 1325-1332, 1997.

REENIKA, G. et al. Antioxidant and antitumor activity of Euphorbia milii flower extract against in vivo breast cancer and colon cancer in mice. Journal of Pharmacy and Pharmaceutical Sciences, v. 4, n. 06, p. 912-934, 2015.

SUFIATE, B. L. et al. Nematicidal activity of proteases from Euphorbia milii. Biocatalysis and Agricultural Biotechnology, v. 10, n. 12, p. 239-241, 2017.

VASCONCELLOS, M, C. \& S. Latex of "Coroa de Cristo" (Euphorbia splendens) an effective moluuscicide. Mem. Insti. Osvaldo Cuz, v. 81, n. 4, p. 475-476, 1986.

VENKATESHA, S. H.; VISHWANATH, R. R.; BANNIKUPPE, S. V. Hemostatic interference of plant latex. Journal of Clinical Pathology, v. 1, n. 1, p. 1-7, 2016.

XU, T. et al. Novel electrochemical immune sensor based on Hep-PGA-PPy nanoparticles for detection of $\alpha$-Fetoprotein in whole blood. Manuscripty. Analytica Chimica Acta, p. 1-40, 2017.

YADAV, S. C.; PANDE, M.; JAGANNADHAM, M. V. Highly stable glycosylated serine protease from the medicinal plant Euphorbia milii. Phytochemistry, v. 67, n. 14, p. 1414-1426, 2006.

ZAMITH, H. P.S.; PAUMGARTTEN, F. J. R.; SPEIT, G. Evaluation of the mutagenicity of the molluscicidal latex of Christ's Crown (Euphorbia milii var. hislopii) in mammalian cells in vitro and in vivo. Mutation Research, v. 368, p.15-20, 1996. 


\title{
CAPÍTULO 11: UNA MINI REVISIÓN SOBRE LA PESCA INTEGRAL COMO ALTERNATIVA AL DESCARGA
}

\section{CHAPTER 11: A MINI REVIEW ON INTEGRAL FISHING AS AN ALTERNATIVE TO DISCHARGE}

\author{
Nilson Fernando Barbosa da Silva; Quesia Jemima da Silva; Julyanne Victória Dos Santos \\ Ferreira;Ana Lúcia Figueiredo Porto; Vagne Melo Oliveira.
}

DOI: https://doi.org/10.31692/978-65-88970-19-5.159-177

\begin{abstract}
RESUMO
Tendo em vista o crescimento da atividade pesqueira em todo o mundo, sobretudo da pesca artesanal, e a maior produção de resíduos sólidos oriundos desta atividade, medidas de reaproveitamento devem ser adotadas como forma de amenizar os danos causados devido ao mal descarte. Uma forma eficaz de evitar o descarte de resíduos é encontrar um uso alternativo deste insumo, de modo a aproveitá-lo completamente. Processos biotecnológicos dos mais simples como cortumização e decomposição aos mais complexos e caros como extração de proteínas, enzimas e lipídeos pode garantir ao subproduto uma qualidade de coproduto, ou seja, um novo material com valor comercial. Assim, essa mini revisão objetivou relatar sobre o estado atual da pesca de apaiari no Brasil e diferentes modos de reaproveitamento dos resíduos gerados pelo seu processamento. Dentre os tópicos abordados nesse estudo, a ecologia e dados referentes a pesca de apaiari no norte e nordeste do Brasil, mostraram a importância dessa espécie em diversas culturas. Foi evidenciado a predileção dos consumidores de peixes pelo seu filé, que percentualmente falando não ultrapassa $30 \%$ do todo. Tópicos seguintes descreveram estudos referentes aos subprodutos oriundos do processamento de diferentes tipos de peixes e seus potenciais bioativos, como teor proteico, enzimático e lipídico, mostrando também processos biotecnológicos que visaram aplicar esses resíduos em diferentes setores da indústria, como na produção de silagem, compostagem, fonte alternativa de proteínas em ração, entre outros. Ao deste estudo, atenta-se aos diversos modos de reaproveitamento de resíduos e como todos esses podem se aplicar ao apaiari, podendo garantir maior fonte de renda e abranger mais setores industrial ao quesito de pescado.
\end{abstract}

Palavras-Chave: Pesca artesanal, Apaiari, Resíduos.

\section{RESUMEN}

Ante el crecimiento de la actividad pesquera a nivel mundial, especialmente la pesca artesanal, y la mayor producción de residuos sólidos derivados de esta actividad, se deben adoptar medidas de reutilización como forma de mitigar los daños ocasionados por la mala disposición. Una forma eficaz de evitar la eliminación de residuos es encontrar un uso alternativo de este insumo para aprovecharlo al máximo. Los procesos biotecnológicos desde los más simples, como la cortumización y descomposición hasta los más complejos y costosos, como la extracción de proteínas, enzimas y lípidos, pueden garantizar al subproducto una calidad de coproducto, es decir, un nuevo material con valor comercial. Así, esta mini-revisión tuvo como objetivo informar sobre el estado actual de la pesca de apaiari en Brasil y las diferentes formas de reutilización de los residuos generados por su procesamiento. Entre los temas tratados en este estudio, la ecología y los datos relacionados con la pesca de apaiari en el norte y noreste de Brasil, mostraron la importancia de esta especie en varias culturas. Se evidenció la predilección de los consumidores de pescado por su filete, cuyo porcentaje hablando no supera el $30 \%$ del total. A continuación, se describieron los estudios referentes a los subproductos del procesamiento de diferentes tipos de pescado 
y sus potenciales bioactivos, como el contenido de proteínas, enzimas y lípidos, mostrando también los procesos biotecnológicos que tenían como objetivo aplicar estos residuos en diferentes sectores de la industria, tales como producción de ensilaje, compostaje, fuente alternativa de proteína en los piensos, entre otros. En este estudio se presta atención a las diversas formas de reutilización de los residuos y cómo todas ellas se pueden aplicar al apaiari, lo que puede garantizar una mayor fuente de ingresos y abarcar más sectores industriales en materia de pescado.

Palabras Clave: Pesca artesanal, Apaiari, Residuos.

\section{ABSTRACT}

In view of the growth of fishing activity worldwide, especially artisanal fishing, and the greater production of solid waste arising from this activity, reuse measures must be adopted as a way to mitigate the damage caused due to poor disposal. An effective way to avoid waste disposal is to find an alternative use of this input, in order to take full advantage of it. Biotechnological processes from the simplest, such as cortumization and decomposition to the most complex and expensive, such as the extraction of proteins, enzymes and lipids, can guarantee the byproduct a co-product quality, that is, a new material with commercial value. Thus, this minireview aimed to report on the current state of apaiari fishing in Brazil and different ways of reusing the waste generated by its processing. Among the topics covered in this study, the ecology and data referring to apaiari fishing in the north and northeast of Brazil, showed the importance of this species in several cultures. The predilection of fish consumers for their fillet was evidenced, which percentage speaking does not exceed $30 \%$ of the whole. Following topics described studies referring to by-products from the processing of different types of fish and their bioactive potentials, such as protein, enzyme and lipid content, also showing biotechnological processes that aimed to apply these residues in different sectors of the industry, such as silage production, composting, alternative source of protein in feed, among others. In this study, attention is paid to the various ways of reusing waste and how all of these can be applied to the apaiari, which can guarantee a greater source of income and cover more industrial sectors in terms of fish.

Keywords: Artisanal fishing, Apaiari, Waste.

\section{INTRODUÇÃO}

A pesca artesanal é um dos meios de trabalho informal mais enraizados no Brasil. Segundo dados da Organização das Nações Unidas para Alimentação e Agricultura (FAO, 2021), há cerca de 1 milhão de trabalhadores informais envolvidos diretamente com a pesca e há mais de 3 milhões que são envolvidos indiretamente. A maioria dos pescadores artesanais vive em comunidades ribeirinhas próximas a baías, aumentando ainda mais sua relação com o meio aquático e os insumos que este meio provém. A pesca realizada por essa parcela da população serve principalmente para sua própria alimentação, entretanto, eles também comercializam o material pescado e tiram dali a sua renda mensal.

Dentre as espécies de peixes comerciais, o apaiari ou Oscar (Astronotus ocellatus) é uma das mais significativas no mercado ornamental, um tipo de peixe pertencente à família cichlidae e que vive em águas interiores, sendo esta uma 

de apaiari é durante o verão, onde devido a estiagem, os níveis dos berços caem e sobra poucos lugares com um nível de profundidade elevado, o que garantirá uma maior concentração dessa espécie. A pesca de apaiari se dá utilizando embarcações de pequeno porte e utilizando apetrechos como linhas de mão, redes e tarrafas. Este ciclídio é conservado e vendido in natura em feiras próximas (BRAGA; MUNDURUKU, 2020).

Do peixe inteiro, apenas o seu filé serve para consumo nas mesas brasileiras, isso em percentagem, equivale a apenas $30 \%$ do peso bruto da espécie. O restante do pescado obtido é considerado subproduto, resíduo. Infelizmente os resíduos de pescados ainda não são acolhidos dentro das políticas de reaproveitamento, sobrando como destino para esses materiais apenas aterro sanitário. Acontece que esses resíduos possuem um alto potencial proteico e enzimático, e a partir de processos biotecnológicos, podem ser transformados em coprodutos de grande interesse comercial (SILVA, 2020).

Assim, esta presente revisão teve como principal objetivo trazer informações sobre a pesca artesanal de apaiari no Brasil e estudos referentes ao seu aproveitamento integral como alternativa ao descarte de seus resíduos.

\section{FUNDAMENTAÇÃO TEÓRICA}

\section{Pesca artesanal no Brasil}

A pesca é, numa definição mais abrangente, uma atividade extrativista que tem como objetivo a utilização de organismos aquáticos, marinhos, de águas interiores ou estuarinas para alimentação/comercialização. A partir desse ponto, a pesca subdividese em dois ramos, com base no grau de extração e das tecnologias adotadas. A pesca industrial é uma atividade mais formal, realizadas por grandes corporações e empresas pesqueiras e que utiliza embarcações grandes e tecnologias mais avançadas, tendo como resultado uma maior extração, geralmente em milhares de toneladas. A pesca artesanal, por sua vez, é uma atividade exponencialmente menor, executada por comunidades ribeirinhas ou por povos que vivem próximos a praias, mangues ou estuários (ZACARDI et al., 2021). Esse tipo de atividade pesqueira conta com a atualização de embarcações menores e uma tecnologia de captura mais 


\section{5. \\ CIAGRO 2021}

arcaica como por exemplo, de redes de arrastos, armadilhas rudimentares, varas e anzóis, tarrafas e algumas outras mais (ALARCON et al., 2018). Diferente da pesca industrial, atividade artesanal gera quantidades menores de insumos extraídos, servindo apenas para consumo próprio ou para comércio em pequena escala. A figura 01 abaixo relata pescadores artesanais realizando a extração de peixes por redes em canoas.

Figura 01: Pescadores artesanais em uma despesca utilizando canoas e redes

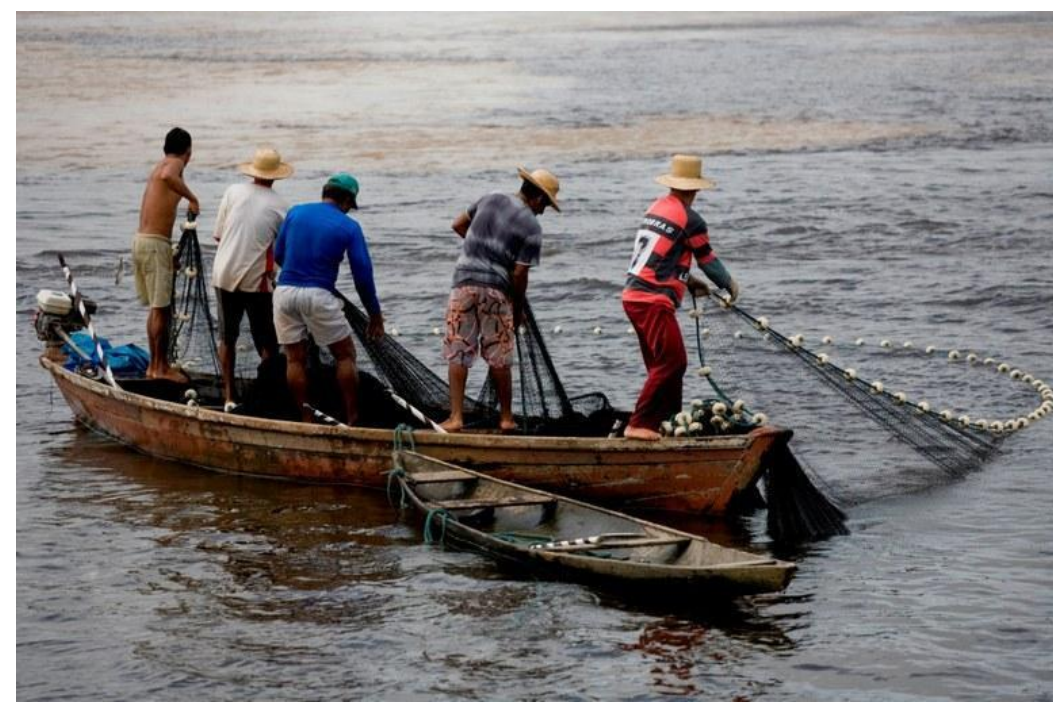

Fonte: Ministério da agricultora, pecuária e abastecimento. 2013

A Organização das Nações Unidas para a Alimentação e a Agricultura (FAO) em seu estudo mais recente, observou que no Brasil mais de 1 milhão dos trabalhadores brasileiros vivem diretamente da pesca artesanal. Desse número, $99,2 \%$ vive da pesca artesanal. Indiretamente, cerca de 3 milhões de trabalhadores brasileiros estão envolvidos nas atividades pesqueiras. A FAO ainda mostra que em território nacional há cerca de 650 unidades de pesca identificadas, estando essas próximas a estuários, baías ou em regiões ribeirinhas (FAO, 2021).

A pesca artesanal é responsável por cerca de $60 \%$ da produção total por meio da pesca de captura (FAO, 2021). Segundo dados da secretaria de agricultura, 0 consumo per capita de peixes no Brasil chega a 10kg/ano. Esse valor médio sofre de picos e declives se considerarmos valores estaduais, já que, no rio grande do Sul o consumo per capita beira cerca de $4 \mathrm{~kg} / \mathrm{ano}$ enquanto que o amazonas possui mais de 10x esse valor, como uma média de 50kg/ano (GREGOLIN, 2019). 
Os peixes equivalem a cerca de $70 \%$ do total do pescado extraído a partir da pesca de captura no Brasil (FAO, 2021). Esses insumos aquícolas podem ser subdivididos quanto à naturalidade e quanto ao intuito da sua despesca (EMBRAPA, 2021). Peixes naturais do nosso ecossistema são os denominados peixes nativos, enquanto os peixes que são trazidos de fora e adaptados ao nosso ambiente, como a tilápia ou algumas espécies de carpas, por exemplo, são denominados peixes exóticos (AGOSTINHO, 1996). Além de nativos ou exóticos, os peixes comerciais podem ser consumíveis e ornamentais. Os peixes consumíveis são os que são comercializados mortos, inteiros ou processados. Já os peixes ornamentais são os peixes cujo seu comércio é vivo, destinado maioritariamente ao aquarismo, são os "peixes domésticos". As tabelas 01 e 02 abaixo mostram as mais importantes espécies comerciais de peixes ornamentais e consumíveis, respectivamente, no Brasil.

Tabela 01: Lista de peixes ornamentais nativos

\begin{tabular}{ll} 
Nome popular & Nome científico \\
\hline Acará-bandeira & Phyterophyllum scalare \\
\hline Paulistinha & Danio rerio \\
\hline Tetras & Tetra-serpae \\
Matogrosso & Hyphessobrycom eques \\
Guaru & Paracheirodon axelrodi \\
Neon & Poecilia reticulata \\
\hline Acará-disco & Symphysodon aequifasciatus \\
\hline \multicolumn{2}{c}{ Fonte: Adaptada a partir de dados presentes no site veterinária Da vinci } \\
\hline
\end{tabular}

Tabela 02: Lista de peixes consumíveis nativos

\begin{tabular}{lll} 
Nome Popular & Nome científico & $\begin{array}{l}\text { Ecossistema } \\
\text { residente }\end{array}$ \\
\hline Beijupirá & Rachycentron canadum & Água salgada \\
Carpa comum & Cyprinus carpio & Água doce \\
\hline Tambaqui & Colossoma macropomum & Água doce \\
Pacu & Piaractus mesopotamicus & Água doce \\
Robalo & Centropomus undecimalis & Água salgada \\
Dourado & Coryphaena hippurus & Água salgada \\
Garoupa & Ephinepelus marginalus & Água salgada \\
Pirarucu & Arapaima gigas & Água doce \\
\hline Pirapitinga & Piaractus brachypomus & Água doce \\
Linguado & Paralichthys orbignyanus & Água salgada \\
\hline Paraíba & Brachyplatystoma & Água doce \\
& filamentosum & \\
\hline
\end{tabular}


Apesar de possuir um grande berço hidrográfico (Cerca de $8.000 \mathrm{~km}$ de faixa costeira, além de um percentual de $13 \%$ de toda a água doce do planeta) que abriga uma enorme variedade de espécies de animais aquáticos, o Brasil ainda não abrange toda sua grandeza, acarretando numa "predominância de espécies" (RIBEIRO et al., 2018). O principal produto é a Tilápia (Oreochromis niloticus), espécie mais comercializada internamente, exportada e importada pelo país (XIMENES; VIDAL, 2018). Os estados do Norte são os maiores consumidores e exportadores de Tambaqui (Colossoma macropomum) e Pirarucu (Arapaima gigas) (PEREIRA, 2020), mas também são fortes consumidores de curimatã (Prochilodus lineatus), Jaraqui (Semaprochilodus taeniurus) e matrinxã (Brycon) (RAPOSO; FERREIRA, 2020; SILVA et al., 2020).

Em casos isolados, como no Estado de Tocantins, há uma predileção peixes ciclídeos, e algumas espécies de tucunaré (Cichla ocellaris) e surubim (Pseudoplatystoma corruscans), enquanto que no Macapá, as maiores espécies consumidas são a dourada (Coryphaena hippurus) e a pescada-branca (Cynoscion leiarchus) (FORNARI et al., 2017). No Nordeste, sobretudo na região de Alagoas, ARAÚJO et al. (2020) evidenciaram que a maioria dos alagoanos têm predileção:ö̉icurimatãs-pacu (Prochilodus lineatus), piau (Leporinus obtusidens), tambaquis (Colossoma macropomum) e tilápias (Oreochromis niloticus). Apesar da variedade de espécies descritas acima, ainda há uma sobreposição da tilápia-do-nilo (Oreochromis niloticus) como espécie predominante, sendo esta a mais consumida, importada e exportada (PEIXE BR, 2020).

\section{Ecologia do apaiari (Astronotus ocellatus)}

O apaiari (Astronotus ocellatus) é uma espécie de peixe da família cichlidae, os chamados peixes redondos (SMITH et al., 2020). A família ciclídia é uma família com 227 gêneros e pouco mais de 27 mil espécies (CAREAGA et al., 2020), todas pertencentes à classe dos Actinopterygii, cuja a maior característica são as nadadeiras suportadas por raios, nadadeiras lepidotríquias (HUGHES et al., 2018).

O apaiari é bentopelágico, ou seja, vive em ambientes logo acima do fundo. É mais comumente encontrado em águas doces ou estuarinas, com uma faixa de $\mathrm{pH}$ 
mais neutra, com poucas variações, mas especificamente entre 6,0 - 8,0. Sua temperatura ótima é entre $22^{\circ}$ - 25ํㅡㄹ sendo este um peixe tropical (AGOSTINHO, 1997). Têm maior ocorrência na América do Sul, sobretudo em países como o Peru, Colômbia, Brasil, Guiana francesa e Argentina (PELICICE et al., 2005).

O apaiari costuma viver em águas rasas, geralmente canais de rios, ou lagos de fundo arenoso. Por ser uma espécie bentopelágica, o apaiari alimenta-se de espécies menores presentes no substrato como microcrustáceos, peixes ou larvas de insetos (PELICICE et al., 2005). Esta espécie de peixe é uma das únicas com cuidado parental, ou seja, ambos os pais cuidam dos ovos até o momento de eclosão, quando movem os alevinos eclodidos para covas nas areias, onde os alevinos permanecem por dias até adquirir estruturas que garantam a sua sobrevivência (MONTEIRO; NETO, 2017). A figura 02 abaixo mostra um apaiari retirado da despesca e sujeito a choque térmico

Figura 02: Apaiari retirado da despesca

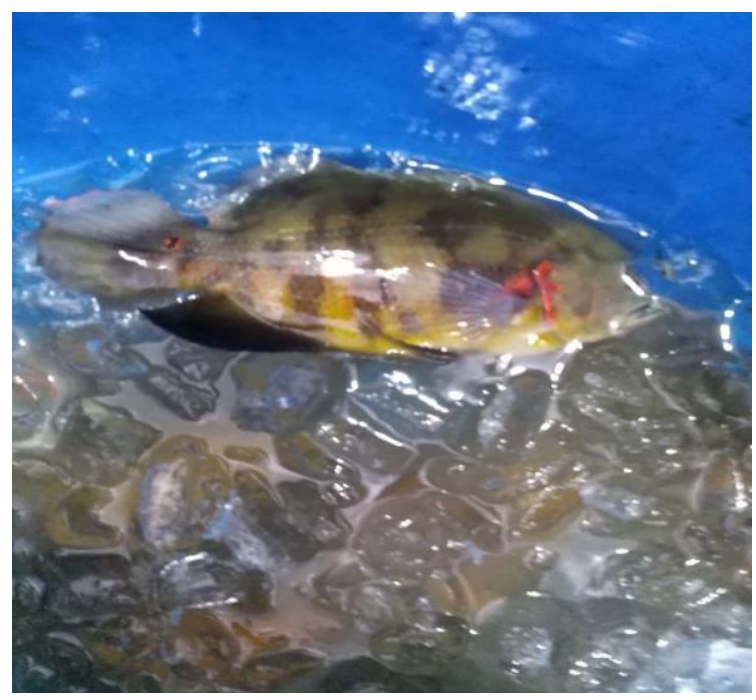

Fonte: Acervo pessoal

\section{Pesca do apaiari no Brasil}

A pesca artesanal de apaiari ocorre com maior frequência nos estados do Norte e Nordeste, em regiões lacustres, como leitos de rios e lagos (ALVES; BARTHEM, 2008). Esta atividade pode ser feita utilizando apetrechos simples como anzóis, linhas de mão ou redes de pesca, sendo essa última a mais utilizada por entre os pescadores (BRAGA; MUNDURUKU, 2020). As embarcações utilizadas são embarcações pequenas como canoas, canoas a motor ou barcos de pequeno porte. 
A maioria dos pescadores artesanais buscam os peixes para seu próprio meio de alimentação, ou tentam tirar do peixe extraído a sua renda, vendendo-os em pequenos comércios (BRAGA; MUNDURUKU, 2020). Há uma necessidade de se saber qual a melhor "época" para a pesca de determinada espécie. O apaiari ( $A$. ocellatus) é uma espécie bentônica, portanto, o melhor período para a sua captura é o verão, devido à estiagem que atinge os berços hídricos (BRELAZ et al., 2018). Nessa época do ano há poucos pontos onde o nível água dos leitos não reduziu totalmente, garantindo uma maior concentração da espécie. Segundo um estudo realizado por DAADY et al., (2016) com pescadores artesanais da região do Amazonas, durante o verão, os pescadores conseguem um total de captura que ultrapassa os $50 \mathrm{Kg}$ da espécie (DAADY et al., 2016).

Eles conservam a espécie utilizando métodos de resfriamento e salga em caixas térmicas. Ainda no mesmo estudo, DAADY et al., (2016) chegou a fazer estimativas sobre o preço da venda do apaiari em feiras locas, chegando ao valor médio de RS\$3,15 por espécie in natura.

\section{O problema do mal descarte de resíduos sólidos provenientes do Pescado}

A pesca artesanal é um dos meios de trabalho informal mais importante e forte que temos no Brasil. Essa atividade é responsável pela sobrevivência de milhares de pessoas que vivem em comunidades ribeirinhas ou próximas a elas. Entretanto, há uma problemática que permeia essa atividade agropecuária. Mesmo que o peixe comercializado in natura, ou seja, por extenso, antes que ele chega às mesas é necessário que haja uma etapa de processamento, já que a única parte do peixe que serve para alimentação é o seu músculo, o que equivale a apenas $30 \%$ do todo (OLIVEIRA et al., 2019).

A cabeça ainda é usada em algumas culturas, mas é uma exceção quando se olha de um modo geral. O percentual restante (cerca de 70\%) equivalente a escamas, pele, nadadeiras, notocorda e vísceras, não têm a mesma importância, portanto sendo descartado ao fim da etapa de processamento (SILVA et al., 2020). Esse material, apesar de não possuir um grau de toxicidade, é chamado de resíduo sólido e quando descartado de maneira errada podem causar sérios danos ambientais e a saúde pública indiretamente (PACHECO et al., 2019). Ricos em macromoléculas orgânicas, quando descartado no ambiente esses resíduos podem ser decompostos e 0 
resultante dessa decomposição irá eutrofizar a região na qual foi descartado (NASCIMENTO et al., 2018).

O problema de uma eutrofização é que espécies competitivas que se nutrem das macromoléculas presentes nos resíduos (geralmente plantas) irão se sobrepuser em números em relação às outras espécies e isso desbalanceará toda uma cadeia biológica (GUREVITCH et al., 2009). O aumento de uma espécie produtora por sua vez fomentará no aumento de consumidores, que em áreas urbanas são caracterizados por ratos, rãs, escorpiões e outras espécies prejudiciais a saúde direta ou indiretamente. Além disso, esse resíduo quando descartado em esgotos, aumentam ainda mais o grau de poluição e isso pode causar danos á saúde pública uma vez que esses esgotos são desaguados ilegalmente nos berços hídricos (BEGON et al., 2007). As figuras 03 e 04 abaixo relatam problemas com poluição e com excesso de nutrientes, acarretando em blooms de microalgas, respectivamente.

Figura 03: Poluição de um lago

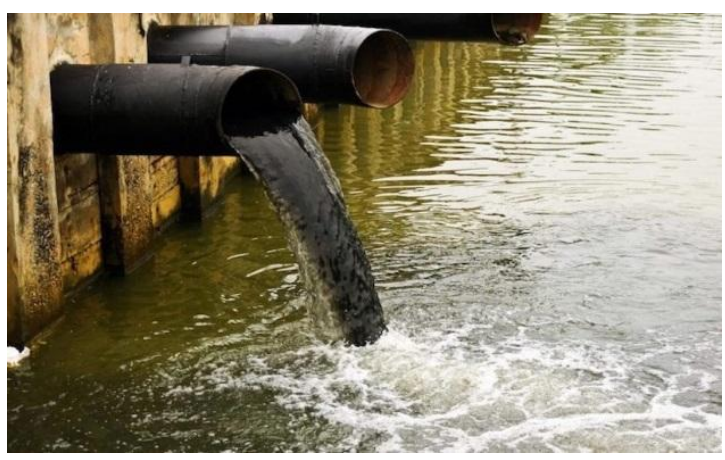

Fonte: Aquablog
Figura 04: Eutrofização de um lago

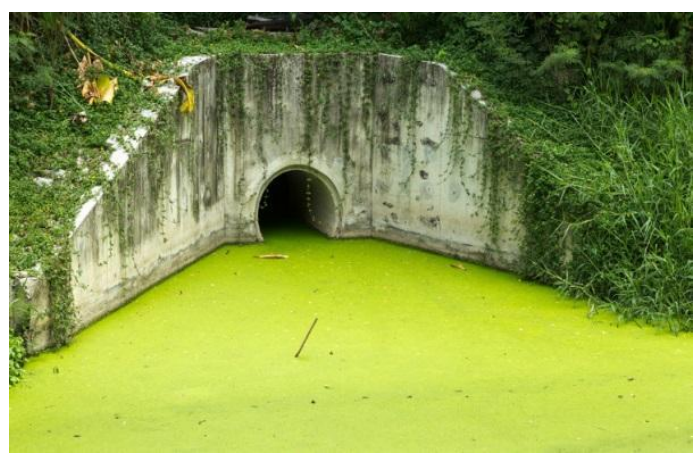

Fonte: Biologia Net

Tendo em vista a problemática que permeia o mal descarte de resíduos provenientes do pescado, esta revisão teve como objetivo apresentar estudos referentes a aproveitamento integral de pescado, com o intuito de combater o descarte de resíduo de apaiari.

\section{METODOLOGIA}

Esta mini-revisão foi desenvolvida a partir de levantamento bibliográfico, fazendo uso de plataformas eletrônicas científicas, como: ScienceDirect (https://www.sciencedirect.com/), Elsevier (https://www.elsevier.com/), TandFonline (https://www.tandfonline.com/), Scopus (https://www.scopus.com/), Google Scholar (https://scholar.google.com.br/), Springer (https://www.springer.com/), PubMed 
(https://pubmed.ncbi.nlm.nih.gov/) e Wiley Online Library PAGE (https://onlinelibrary.wiley.com/), utilizando como descritores as palavras-chave: Pesca artesanal, Apaiari e resíduos de pescado. Realizou-se a leitura dos títulos e resumos para seleção dos artigos, livros, capítulos de livro, notas científicas, entre outros, excluindo os que não estavam dentro do escopo da proposta ou mesmo que não detinham informações relevantes para nossa investigação. Foram incluídas publicações em inglês e português que atenderam aos critérios de busca.

\section{RESULTADOS E DISCUSSÃO}

\section{Formulação de artesanatos a partir de pele e escama de peixe}

Peles e escamas de peixes são amplamente utilizadas na confecção de artesanatos devido à sua alta resistência. Antes do processo artístico, é necessária que haja uma etapa de cortumização, visando adequar tanto a pele quanto a escama a partir de um processo de retirada os materiais interfibrilares, separando as fibras existentes. Um estudo de VIDAL-CAMPELLO et al., (2021) mostraram a efetividade da pele de tilápia (Oreochromis spp.) após uma etapa de curtimento, utilizando curtume vegetal, na produção de brincos e pulseiras de couro. Outro estudo como o de PRAIA et al., (2020) utilizaram a efetividade da produção de biojóias a partir de escamas doadas de Tambaqui (C. macropomum), produzindo brincos, colares e pulseiras a partir de resíduos de escama. A tabela 03 apresenta outros mais tipos de artesanatos produzidos a partir de resíduos oriundos da pesca.

Tabela 03: Artesanatos produzidos a partir de diferentes resíduos

\begin{tabular}{|c|c|c|c|c|}
\hline $\begin{array}{l}\text { NOME POPULAR } \\
\text { DA ESPÉCIE }\end{array}$ & $\begin{array}{c}\text { NOME } \\
\text { CIENTÍFICO }\end{array}$ & $\begin{array}{l}\text { RESÍDUO } \\
\text { UTILIZADO }\end{array}$ & $\begin{array}{c}\text { ARTESANATO } \\
\text { CONFECCIONADO }\end{array}$ & AUTOR \\
\hline Linguado & $\begin{array}{c}\text { Pleuronectesli } \\
\text { neatus }\end{array}$ & Pele & Couro & $\begin{array}{l}\text { SCHWARZ et } \\
\text { al., (2018) }\end{array}$ \\
\hline Robalo flecha & $\begin{array}{l}\text { Centropomus } \\
\text { undecimalis }\end{array}$ & Pele & Couro & $\begin{array}{l}\text { SCHWARZ et } \\
\text { al., (2018) }\end{array}$ \\
\hline Tilápia & $\begin{array}{l}\text { Oreochromis } \\
\text { niloticus }\end{array}$ & Pele & Couro & $\begin{array}{l}\text { SCHWARZ et } \\
\text { al., (2018) }\end{array}$ \\
\hline Pacu & $\begin{array}{l}\text { Chaetodipterus } \\
\text { faber }\end{array}$ & Pele & Couro & $\begin{array}{l}\text { SCHWARZ et } \\
\text { al., (2018) }\end{array}$ \\
\hline Camurupim & $\begin{array}{l}\text { Megalopus } \\
\text { antlaticus }\end{array}$ & Escama & Flor artesanal & $\begin{array}{c}\text { COSTA et al., } \\
(2016)\end{array}$ \\
\hline Cioba & Lutjanus analis & Escama & Flor artesanal & $\begin{array}{c}\text { COSTA et al., } \\
(2016)\end{array}$ \\
\hline Pescada & Cynoscion spp. & Escama & Flor artesanal & $\begin{array}{c}\text { COSTA et al., } \\
(2016)\end{array}$ \\
\hline
\end{tabular}




\begin{tabular}{cclll} 
Corvina & $\begin{array}{c}\text { Micropogonias } \\
\text { furnieri } \\
\text { Pomatomus } \\
\text { saltator }\end{array}$ & Escama & Flor artesanal & \multicolumn{2}{c}{ VEIGA et al., PAGE } \\
$(2015)$ & Escama & Flor artesanal & VEIGA et al., \\
Pescada amarela & Mcteroperca \\
spp. & Escama & Flor artesanal & $\begin{array}{c}\text { VEIGA et al., } \\
(2015)\end{array}$
\end{tabular}

\section{Potencial proteico de Peles e escamas de peixes}

Além da aplicação em artesanatos, peles e escamas possuem outro ponto forte devido as suas estruturas fibrilares. As estruturas fibrilares presentes em peles e escamas de peixes são proteínas, mas especificamente colágeno. O colágeno é a proteína estrutural mais abundante em seres vivos. Essa proteína consiste em três cadeias polipeptídicas ligadas entre si por pontes de hidrogênio numa conformação helicoidal que formam as microfibrilas de colágeno (NELSON; COX, 2014). A figura 05 abaixo representa a estrutura de uma fibra de colágeno

Figura 05: Estrura da fibra do colágeno

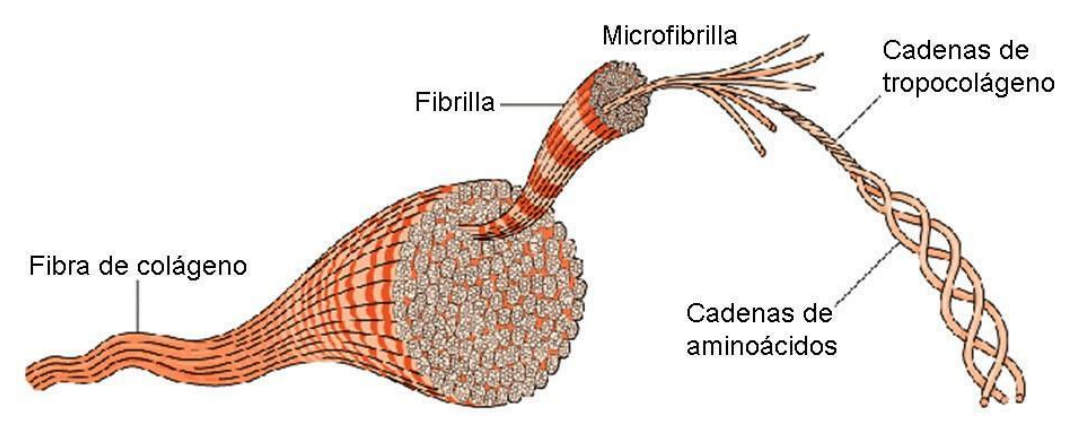

Fonte: Central Nutrition

Existem pelo menos 29 subtipos de moléculas da família do colágeno catalogados atualmente, todos distintos quanto à localização no organismo e a sua função biológica. Dentre os tipos de colágeno, o tipo I é o mais comumente encontrado nos tecidos e o que possui maior interesse comercial, devido seu alto grau de biodegradabilidade, biocompatibilidade, alta elasticidade, potencial antioxidante, antiinflamatório além de muitos outros. Essa proteína estrutural possui muitas aplicações no mercado, desde a sua aplicação na confecção de fármacos quanto na produção de biofilme, gelatina, suplementos alimentares, cosméticos e outros mais produtos (OLIVEIRA et al., 2019).

Atualmente, o mercado supre a necessidade de colágeno a partir do colágeno bovino, porém a demanda tem aumentado muito mais nos últimos anos, e isso acaba por exigir novas fontes de colágeno para o mercado. Assim, pesquisadores têm se 
dedicado a mostrar o potencial dos resíduos de pescado para extração de colágeno e

o potencial biológico desse colágeno para sua aplicação na indústria. Estudos como os de GOVINDHARAJ et al., (2019) mostram que hidrogéis feitos a partir do colágeno de pele de enguia possuem uma alta atividade metabólica e isso pode permitir seu uso em impressoras 3D. Já WANG et al., (2017) percebeu em seu estudo uma boa integração de manchas de colágeno extraídas a partir de escamas de peixe com tecidos e vasos sanguíneos, salientando então o potencial do colágeno na indústria biomédica em seu estudo. APODACA et al., (2020) observou a capacidade antioxidante e o alto teor de emulsificação do colágeno extraído a partir de diferentes subprodutos de peixes, e a partir daí caracterizou o colágeno e o colocou como um forte potencial alternativo biotecnológico para a indústria. Todos esses estudos sinalizam o quão promissor é o colágeno de subprodutos de peixes e o quanto vale a pena investir nessa tecnologia.

\section{Potencial enzimático das vísceras de peixe}

Assim como a pele possui um alto potencial proteico, as vísceras internas de peixes possuem um alto potencial enzimático. Essas enzimas em sua maioria são proteases que catalisam reações de hidrólise de proteínas. Essa capacidade torna as proteases alvo de vários estudos referente à aplicação na indústria. Estudos já demonstraram a efetividade de proteases oriundas do trato digestivo de peixes na hidrólise de colágeno nativo. Essa informação já abre um leque de possibilidades como a utilização dessas enzimas na formulação de detergente e fármacos (GOMEZ et al., 2018).

O estudo de CHAVES-POZO et al., (2019) mostrou ser possível extrair e caracterizar diversos tipos de granzimas (serinoproteases) a partir do trato digestivo de Dourado e Robalo, esse estudo também constatou que a granzima triptase possui uma alta atividade funcional e que também pode atuar conta o nodavírus, vírus que acomete várias espécies de peixes. Um outro estudo, dessa vez realizado por AZEVEDO et al., (2018) se mostrou efetivo na extração de tripsina a partir das vísceras de tilápia e testar sua atividade na inibição de antinutrientes para sua aplicação na detecção de fatores antinutricionais que reduzem a capacidade digestiva animal. Em um estudo um pouco diferente, BANG et al., (2018) conseguiu detectar a presença de tripsina de salmão em filtros de ar de indústrias de processamento a partir 
da eletroforese em gel, utilizando tripsina suína para comparação. A tripsina é uma

enzima que possui inúmeras funções biológicas e essas funções podem ter aplicações na indústria. A presença de tripsina em indústrias de processamento mostra que peixes são fontes promissoras dessas enzimas, salientando ainda mais o seu estudo. SARANYA et al., (2018) conseguiu extrair proteases alcalinas a partir de resíduos de processamento de peixe, purificando-as e as caracterizando quanto ao peso molecular e função biológica. Os autores conseguiram também evidenciar o potencial dessas enzimas como biocatalisadoras e alertou em seu estudo sobre seu potencial na indústria.

\section{Utilização dos resíduos de processamento na fabricação de silagem e compostagem}

No setor agropecuário, subprodutos provenientes do pescado também pode utilidade a partir de processos biotecnológicos. Silagem e compostagem são compostos resultados do processo de decomposição de matéria orgânica, tornandoas fontes de nutrientes para plantas e animais, respectivamente. Nesse quesito, resíduos de pescado devido seu alto teor de micromoléculas nutricionais como Nitrogênio, fósforo e potássio, podem ser utilizados na fabricação desses biomateriais (CORADANI et al., 2020).

O estudo de COUTINHO et al., (2020) conseguiu produzir silagem orgânica a partir de resíduos (Vísceras, cabeça, espinhas e nadadeiras) de processamento de filé de pescada. Ainda nesse estudo o autor utiliza ácido acético para melhor manutenção da qualidade da silagem e afirma que aquele composto quando em $\mathrm{pH}$ ácido (entre 5 e 6) pode servir como fertilizante na agricultura. NASCIMENTO et al., (2018) evidenciou que resíduos de pescado (cabeça, vísceras, carcaças e escamas) provindos da feira de Manaus - AM, se mostraram eficazes na produção de compostagem orgânica, após isolamento sob temperatura controlada. RIBEIRO, 2019 utilizando resíduos de Dourada, Piramutaba e Pescada amarela, conseguiu produzir e caracterizar silagem ácida em seu mais recente estudo.

\section{Produção de farinha de peixes a partir de resíduos da pesca}

Um outro meio de reaproveitamento de resíduos é a sua transformação em uma fonte alternativa de proteína animal, podendo usá-la em dietas de engorda. $A$ 


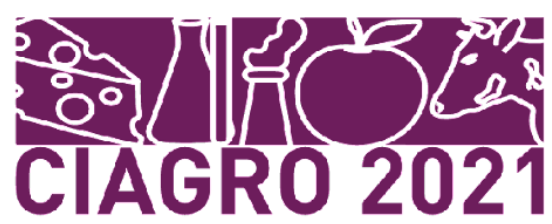

farinha de peixe é um composto que, diferente das rações atuais, apresenta maior concentração de proteína ao invés de carboidratos, isso garante à dieta de uma espécie um maior valor nutricional e mais acessibilidade aos aminoácidos essenciais que não são sintetizados naturalmente pelo organismo (CORADINI et al., 2020).

O estudo de ROSSATO et al., (2018) utilizou diversos tipos de fontes de proteínas na dieta de juvenis de Jundiá e observou que a farinha de resíduo de carcaça e vísceras de Jundiá garantiu um melhor crescimento da espécie, com resultados mais promissores do que outros tipos de fontes como a farinha de carne e ossos suínos. No final do experimento, ROSSATO et al., (2018) concluiu que as espécies alimentadas com farinha de resíduo de carcaça e vísceras tiveram uma melhor conversão alimentar (1,3:1), taxa de crescimento (3,9-dia-1), peso final $(50,5$ kg) e disposição de proteína $(6,3 \mathrm{~g})$.

A tabela 04 mostra diferentes tipos de farinhas de peixes, resíduos e seus valores nutricionais.

Tabela 04: Farinhas de peixes produzidas a partir de deferentes resíduos

\begin{tabular}{|c|c|c|c|}
\hline $\begin{array}{l}\text { RESÍDUO } \\
\text { UTILIZADO }\end{array}$ & ESPÉCIE & $\begin{array}{c}\text { TEOR DE PROTEÍNA } \\
(\%) \\
\end{array}$ & AUTOR \\
\hline Carcaça & Oreochromis niloticus & 77 & $\begin{array}{l}\text { MACEDO, } \\
(2019)\end{array}$ \\
\hline Filé & $\begin{array}{l}\text { Colossoma } \\
\text { macropomum }\end{array}$ & 4,17 & $\begin{array}{l}\text { COSTA et al., } \\
\text { (2019) }\end{array}$ \\
\hline Cabeça & Oreochromis niloticus & 41,40 & $\begin{array}{l}\text { LIMA et al., } \\
\text { (2019) }\end{array}$ \\
\hline Cabeça & $\begin{array}{c}\text { Labotes } \\
\text { Surinamensis }\end{array}$ & 55,40 & $\begin{array}{c}\text { SOUZA et al., } \\
(2020)\end{array}$ \\
\hline Cabeça & Prochilodus lineatus & 33,95 & $\begin{array}{l}\text { SOUZA et al., } \\
(2020)\end{array}$ \\
\hline Completo & Chyprocharax voga & 55,39 & $\begin{array}{l}\text { ENKE et al., } \\
(2019)\end{array}$ \\
\hline Ossos & --- & --- & $\begin{array}{l}\text { GOMES et al., } \\
(2018)\end{array}$ \\
\hline
\end{tabular}

Fonte: adaptada a partir de estudos

\section{CONCLUSÕES}

Esta revisão conseguiu apresentar um panorama geral da pesca artesanal no Brasil, sobretudo da pesca artesanal de Apaiari. Evidenciou-se a partir desse panorama, a problemática do consumo de Apaiari em relação a produção de subprodutos. Alternativas que mostram a produção de coprodutos a partir dos subprodutos de pescados devem ser adotadas em uma escala de comércio para que haja um melhor 


\section{REFERÊNCIAS}

AGOSTINHO, A. A.; JÚLIO JÚNIOR, H. F.; GOMES, L. C.; BINI, L. M.; AGOSTINHO, C. S.; Composição, abundância e distribuição espaço-temporal da ictiofauna. In: VAZZOLER, Anna Emília Amato de Moraes; AGOSTINHO, Angelo Antonio; HAHN, Norma Segatti (Ed.). A Planície de inundação do alto rio Paraná: aspectos físicos, biológicos e socioeconômicos. Maringá: EDUEM, 1997. cap.II.4, p.179-208.

AGOSTINHO, A. A.; O lado oculto da introdução de peixes. Boletim Informativo da Abrapoa no9, p.9-11, 1996.

ALARCON, D. T.; COSTA DÂMASO, R. C. S.; SCHIAVETTI, A. Ethnoecological approach to fishery and the bycath of non-target species in Itacaré, Bahia (Brazil). Boletim do estatuto da pesca, v.35 no4, p.675-686, 2018.

APODACA, J. C. Z.; SIFUENTES, C. O. G.; MILLÁN, E. C.; ACEVEDO, S. M. S.; SÁNCHEZ, M. E. L.; Biological and functional properties of peptide fractions obtained from mixed by-products of different fish species. Food Chemistry. v.331, 2020.

ARAÚJO, D. M.; TAMANO, L. T. O.; NASCIMENTO, C. W. S.; TAVARES K. A. S.; LINS, J. L. F.; SILVA, J.; Curimatã-pacu como espécie preferida pelos consumidores em feiras livres do baixo rio são Francisco, Alagoas - Brasil. Holos v.36, 2020.

AZEVEDO, R. D. S.; AMARAL, I. P. G.; FERREIRA, A. C. M.; ESPÓSITO, T. S.; BEZERRA, R. S.; Use of fish trypsin immobilized onto magnetic-chitosan composite as a new tool to detect antinutrients in aquafeeds. Food Chemistry. v.257, p. 302309, 2018.

BANG, B. E.; MALLA, N.; BHAGWAT, S. S.; AASMOE, L.; WINBERG J. O.; A sensitive assay for proteases in bioaerosol samples: characterization and quantification of airbone proteases in salmon industry work environments. Annals of Work Wxposures and Health. v.XX, p.1-11, 2018.

BEGON, M.; TOWSEND, C. R.; HARPER, J. L.; Ecologia: De indivíduos a ecossistema. $4^{\mathrm{a}}$ ed. Artmed, 2007.

BRAGA, T. M. P.; MUNDURUKU, D. K.; A pesca e o uso de recursos naturais na comunidade indígena São Lourenço, Jacareacanga, Pará, Brasil. Ciência e Tecnologia do Pescado: Uma análise Pluralista, 2020.

BRELAZ, R.L.; FARIA-JUNIOR, C.H..; RIBEIRO, F.R.V. Caracterização da atividade pesqueira na comunidade Vila Flexal do município de Óbidos, Pará, Brasil: subsídios para gestão dos recursos pesqueiros. Scientia Amazônia, v. 7, n.1, 134-155. 2018.

CAREAGA, M.; MALDONADO, M.; CARVAJAL-VALLEJOS, F. M.; Invetario de la 
família cichlidae (Teleostei: Cichliformes) en Bolivia. Hidrobiologia Neotropical y Conservacíon Acuática v.1(2), p. 225-232, 2020.

CHAVES-POZO, E.; VALERO, Y.; LOZANO, M. T.; CEREZO, P. R.; MIAO, L.; CAMPO, V.; ESTEBAN, M. A.; CUESTA, A.; Fish granzyme a shows a greater role than granzyme $B$ in fish innate cell-mediated cytotoxicity. Fronties in Immunology. V10, 2019.

CORADINI, M. F.; CAVICCHIOLI, N.; CHAMBO, A. P. S.; BRACCINI, G. L.; SOUZA, M. L. R.; Inclusão de farinha de peixes de diferentes espécies em massa de esfirra aberta. Anais do Congresso Internacional de agroindústria, 2020.

COSTA, L. M F.; LAGES, A. C. V.; NASCIMENTO, J. F.; SILVA, A. S. S.; JÚNIOR, A. C. S. S.; Desenvolvimento, avaliação físico-química e microbiológica da farinha de Tambaqui Colossoma macropomum (Cuvier, 1818). Pubvet. v.13, p.1-7, 2019.

COSTA, W. M.; VIDAL, J. M. A.; VEIGA, M. C. M.; RODRIGUES, J. M.; SANTOS, J. F.; Aproveitamento dos resíduos do pescado: Artesanato com escamas de peixe. Revista Ciência em Extensão. v.12, p. 8-17, 2016.

COUTINHO, K.; TOMITA, R. T.; CARVALHO, C. R. L.; FURLAN, E. F.; Aproveitamento de resíduos do pescado: Aspectos nutricional e sanitário. Ciência e Tecnologia do Pescado: Uma análise pluralista. 2020.

DAADDY, M. D. V.; SANTOS, C.; BRANDÃO, R. M. L.; AMANAJÁS, R. D.; RIBEIRO, A. B. N. Pesca do apaiari, Astronotus ocellatus (Agassiz, 1831), e perfil socioeconômico dos pescadores artesanais de uma região da Amazônia brasileira. Boletim do Museu Paraense Emílio Goeldi. Ciências Humanas, v. 11, n. 2, p. 363378, maio-ago. 2016.

ENKE, D. B. S.; LOPES, P. R. S.; ROCHA, C. B.; POUEY, J. L. O. F.; Produção e caracterização de farinha de silagem de pescado, destinado a piscicultura. Pubvet. v.13, no08, 2019.

FAO. The State of World Fisheries and Aquiculture. 2021 Disponível em: $<$ http://www.fao.org $>$.

FORNARI, C. A. C.; COSTA, R. P. B.; PIRES, C. R. F.; KATO, H. C. A.; SOUSA, D. N.; Estudo sobre os hábitos alimentares e de consumo de pescado da população de Palmas (TO). Revista Desafios v.04 no04, 2017.

GOMES, R. L. M.; RODRIGUES, R. B.; SILVA, T. C.; MOREIRA, P. O.; ROCHA, J. D. M.; BITTENCOURT, F.; BOSCOLO, W. R.; Farinha de ossos de peixe como fonte de cálcio e fósforo em rações para pós-larvas de tilápia do Nilo. Acta. Iguazu. v.7, p. 7483, 2018.

GOMEZ, A. V. A.; GOMEZ, G.; CHAMORRO, E.; BUSTILLO, S.; LEIVA, L. C.; Digestive aspartic proteases from sábalo (Prochilodus lineatus): characterization and application for collagen extraction. Food Chemistry. v.269, p.610-617, 2018. 
GOVINDHARAJ, M.; ROOPAVATH, U.K.; RATH, S.N.; Valorization of discarded marine Eel fish skin for collagen extraction as a 3D printable blue biomaterial for tissue engineering. Journal of Cleaner Production v.230, 2019.

GREGOLIN, A. Consumo per capita de peixes no Brasil praticamente dobrou nos últimos 10 anos, mas ainda está abaixo da média mundial. [Entrevista concedida a] Alexander Horta e Andressa Simão. Notícias Agrícolas. 2019.

GUREVITCH, J.; SCHEINER, S. M.; FOX, G. A.; Ecologia Vegetal. $2^{\mathrm{a}}$ ed. Artmed, 2009.

HUGHES, L. C.; ORTÍ, G.; HUANG, Y.; SUN, Y.; BALDWIN, C. C.; THOMPSON, A. W.; ARCILA, D.; BENTACUR, R.; LI, C.; BECKER, L.; BELLORA, N.; ZHAO, X.; LI, X.; WANG, M.; FANG, C.; XIE, B.; ZHOU, Z.; HUANG, H.; CHEN, S.; VENTAKATESH, B.; SHI, Q.; Comprehensive phylogeny of ray-finned fishes (Actinopterygii) based on transcriptomic and genomic data. PNAS v.115, p. 6249-6254, 2018.

LIMA, D. P.; WILLY, K. A.; SANTOS, D. A.; Elaboração do perfil fisico-químico e microbiológico de farinha de cabeça de tilápia-do-nilo (Oreochromis niloticus). Ciência e Tecnologia dos Alimentos. Cap 3, v.4, 2019.

MACEDO, A. B. N.; Produção e caracterização de farinha de Tilápia (Oreochromis niloticus) submetida a diferentes tratamentos térmicos. 2019. 50 fl. (Trabalho de Conclusão de Curso - Monografia), Curso de Licenciatura em Ciências Biológicas, Centro de Educação e Saúde, Universidade Federal de Campina Grande, Cuité Paraíba - Brasil, 2019.

NASCIMENTO, M. S.; PEREIRA, S. J. B.; SANTOS, R. F.; VIEIRA, A. M.; Avaliação e caracterização do processo de compostagem de resíduos de peixe. Pubvet. v.12 no11, p.1-7, 2018.

OLIVEIRA, V.M.; SILVA, J.C; SILVA, Q.J, PORTO, A.L.F. Purificação parcial de biomoléculas extraídas dos resíduos sólidos do pescado beneficiado em PetrolândiaPE. In: EL-DEIR, S.G.; PINHEIRO, S.M.G.; AGUIAR, W.J. (Org.) Resíduos sólidos: impactos ambientais e inovações tecnológicas. EDUFRPE, $1^{\text {a }}$ ed. Recife: EDUFRPE, 2019, p. $128-139$.

PACHECO, M. G. F.; GONZAGA, L. F.; ELIOMAR, J. J. S.; NETO, O. J. A. G.; GOMES, W. C.; Avaliação da qualidade do adubo orgânico produzido pelo processo de compostagem, a partir dos resíduos de pescado gerados no mercado do peixe em São Luís - MA. Revista Geama. v.5 no.2, 2019.

PELICICE, F. M.; AGOSTINHO, A. A.; GOMES, L. C.; Biodiversidade e conservação de peixes na planície de inundação do alto rio Paraná. Cadernos da Biodiversidade v.5 no1, p.34-44, 2005.

PEREIRA, R. G. A.; Produção da piscicultura de espécies nativas da Amazônia em Rondônia. Caderno de ciências agrárias v.12, p.1-4, 2020.

PRAIA, M. N.; SILVA, O. L. L.; OLIVEIRA, L. C.; QUADROS, L. A.; FREITAS, L.; SILVA, F. N. L.; Mercado de breves, Marajó, Pará: perfil socioeconômico, ambiental e 


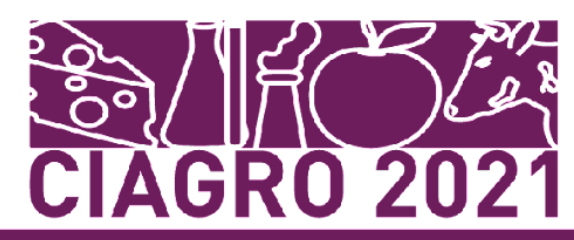

aproveitamento de resíduos de tambaqui para biojóias. Pubvet. v.14, p. 1-12, 2020.

RAPOSO, B. R.; FERREIRA, D. S. F.; Diagnóstico do consumo de peixe na comunidade do contão, município de Pacaraima $(R R)$. Brazilian Journal of Development v.6 no2, p.6156-6169, 2020.

RIBEIRO, I. A.; Caracterização de silagens produzidas a partir do resíduo de beneficiamento da indústria de pesca. Orientador: Rodrigo Taka. 2019. $63 \mathrm{f}$. Dissertação (Mestrado em Aquicultura e Recursos Aquáticos Tropicais) Universidade Federal Rural da Amazônia, Campus Belém, PA, 2019.

ROSSATO, S.; MASCHIO, D.; MARTINELLI, S. G.; NUNES, L. M. C.; NETO, J. R.; LAZZARI, R.; Fish meal obtained from the processing of Rhamdia quelen: an alternative protein source. Boletim do instituto de Pesca. v.44 no4, 2018.

SARANYA, R.; JAYAPRIYA, J.; TAMI, S. A.; Purification, characterization, molecular modeling and docking study of fish waste protease. International Journal of Biological Macromolecules. v.118, p.569-583, 2018.

SCHAWRZ, K. K.; MENDONÇA, K. S.; WAKIUCHI, S. S.; SASSAMORI, J. C.; REBULI, G. C. J. P.; Metodologias para a transformação das peles de linguado, robalo, paru e tilápia em couro. Pubvet. v,12, p. 1-8, 2018.

SILVA, N. F. B.; FERREIRA, J. S.; COSTA, B. A. M.; PORTO, A. L. F.; OLIVEIRA, V. M.; Aproveitamento de pele e escamas de saramunete (Pseudopeneus maculatus) como fonte de proteína colagenosa para uso comercial. Transversalidade da Engenharia de Pesca. 1를: Latin american publicações, v., p.175-181, 2020.

SILVA, R. S.; FRANÇA, S. M. A.; YAMAGUCHI, K. K. L.; Identificação das espécies de peixes mais comercializadas em um município no interior do Amazonas. Brazilian Journal of Development v.6 no04, p. 20483-20498, 2020.

SMITH, W. S.; STEFANI, M. S.; ESPINDOLA, E. L. G.; ROCHA, O.; Mudanças na composição de espécies no médio e baixo rio tietê (São Paulo, Brasil) através dos séculos, enfatizando espécies reofílicas e introduzidas. Acta Limnologia Brasiliensia v.30, 2018.

SOUZA, A. C. S.; SILVA, R. G.; ZIMMER, F. C.; FUZINATTO, M. M.; Produção e caracterização de farinha e óleo de resíduo de curimba (prochilodus lineatus) / production and characterization of curimba flour and oil residue (prochilodus lineatus).

Brazilian Journal of Development. v.6, 2020.

SOUZA, F. C. P.; SASSI, K. K. B.; GUSMÃO, T. A. S.; MOREIRA, R. T.; Obtenção de farinha de subproduto do beneficiamento do peixe cará-açu (lobotes surinamensis)/obtaining flour by-products from the processing of the cará-açu fish (lobotes surinamensis). Brazilian Journal of Development. v.6, 2020.

VEIGA, M. C. M.; MOURA, J. R.; VIDAL, J. M. A.; ROCHA, M. A. V.; COSTA, W. M.; Tingimento natural: Alternativa ecológica no aproveitamento de escamas de peixes. IX Congresso Brasileiro de Agroecologia. V.10, 2015. 
VIDAL-CAMPELLO, J. M. A.; LIRA, E. B. S.; JUNIOR, C. A. F. M.; VEIGA, M. C. M.; COSTA, W. M.; Curtimento de pele de peixe utilizando tanino vegetal extraído de eucalipto. Brazilian Journal of Animal and Evironmental Research. v.4, p.392-401, 2021.

WANG, J. K.; YEO, K. P.; CHUN, Y. Y.; TAN, T. T. Y.; TAN, N. S.; ANGELI, V.; CHOONG, C.; Fish scale-derived collagen patch promotes growth of blood and lymphatic vessels in vivo. Acta Biomaterialia. v.63, p. 246-260, 2017.

XIMENES, L. F.; VIDAL, M. F.; Pescado no Brasil: produzir bem e vender melhor. Banco do nordeste do Brasil ano 3 no49, 2018.

ZACARDI, D. M.; PASSOS, L. S.; SILVA, T. C.; A pesca artesanal na região dos lagos: casos do município de paracuuba, Amapá. Revista Desafios. v.8 no01, 2021. 


\title{
CAPÍTULO 12: MONITORAMENTO TECNOLÓGICO DE PATENTES ENVOLVENDO PREBIÓTICOS NO CENÁRIO GLOBAL E BRASILEIRO
}

\author{
CAPÍTULO 12: SEGUIMIENTO DE PATENTES TECNOLÓGICAS CON \\ PREBIÓTICOS EN EL ESCENARIO GLOBAL Y BRASILEÑO
}

\section{CHAPTER 12: TECHNOLOGICAL PATENT MONITORING INVOLVING PREBIOTICS IN THE GLOBAL AND BRAZILIAN SCENARIO}

\author{
Wanessa Braz da Silva ${ }^{1}$; Maria Eduarda Menezes Rocha ${ }^{2}$; Nathan Gabriel Barbosa Moura ${ }^{3}$; Rodrigo Lira de \\ Oliveira ${ }^{4}$ Tatiana Souza Porto ${ }^{5}$
}

DOI: $\underline{\text { https://doi.org/10.31692/978-65-88970-19-5.178-197 }}$

\begin{abstract}
RESUMO
Diante da crescente preocupação com uma vida mais saudável, tem-se observado uma maior procura por alimentos que apresentem efeitos positivos na saúde. Dentre os alimentos funcionais, os prebióticos se destacam como componentes não digeríveis que afetam beneficamente o hospedeiro pelo estímulo seletivo da proliferação ou atividade de populações de bactérias desejáveis no cólon. Este trabalho objetivou-se em realizar uma prospecção tecnológica sobre o desenvolvimento e aplicação nacional e internacional de patentes sobre prebióticos tendo como base para essa análise as plataformas Derwent, Espacenet, Lens, INPI, Patentscope e USPTO. A plataforma Lens obteve o maior número de patentes (5241 documentos) e por isto foi a base de dados selecionada para a realização do monitoramento tecnológico sobre prebióticos. Em relação aos registros, 75\% correspondiam à pedidos de patente e $15 \%$ as patentes que foram concedidas. O país que lidera o número de depósitos é a China com aproximadamente $38 \%$ do total. No que diz respeito as organizações requerentes, a Nestec $S A$ foi a organização que mais realizou depósitos de patentes, um total de 175 registros. Também foram analisados os dados de Classificação Internacional de Patentes (IPC), no qual $30 \%$ se referem a seção A23L que compreendem alimentos, produtos alimentícios ou bebidas não alcoólicas, indicando ser uma excelente aplicação para a indústria de alimentos. No Brasil, a base de dados nacional INPI apresentou 122 pedidos de patentes sobre prebióticos, onde o Brasil é o principal depositante com $48 \%$ do total. Com relação ao depositante, $54 \%$ dos pedidos de patente são de empresas privadas, seguidos por $37 \%$ de instituições públicas e $9 \%$ por pessoas físicas. No geral, os resultados mostram que os avanços nas pesquisas sobre prebióticos são promissores e esse estudo pode contribuir no planejamento e tomada de decisões para o desenvolvimento dessa área.
\end{abstract}

Palavras-Chave: Prebióticos, Prospeção tecnológica, Patentes, Panorama global.

\section{RESUMEN}

\footnotetext{
${ }^{1}$ Engenharia de Alimentos, Universidade Federal do Agreste de Pernambuco, wanessa.braz09@gmail.com

${ }^{2}$ Engenharia de Alimentos, Universidade Federal do Agreste de Pernambuco, eduardamenezes32@gmail.com

${ }^{3}$ Engenharia de Alimentos, Universidade Federal do Agreste de Pernambuco, nathangabriel1515@gmail.com

${ }^{4}$ Bolsista de pós-doutorado, Universidade Federal do Agreste de Pernambuco, rodrigolira1@outlook.com

${ }^{5}$ Doutora em tecnologia Bioquímico-Farmacêutica, Universidade Federal do Agreste de Pernambuco, portots@yahoo.com
} 
Ante la creciente preocupación por una vida más sana, ha habido una mayor demanda de alimentos que tienen efectos positivos en la salud. Entre los alimentos emitidos, los prebióticos se destacan como componentes no digeribles que afectan beneficiosamente al huésped al estimular activamente la proliferación o actividad de poblaciones bacterianas deseables en el colon. Este trabajo tuvo como objetivo realizar un relevamiento tecnológico sobre el desarrollo y aplicación nacional e internacional de patentes de prebióticos a partir de este análisis como plataformas Derwent, Espacenet, Lens, INPI, Patentscope y USPTO. La plataforma Lens obtuvo el mayor número de patentes (5241 documentos) y por ello fue la base de datos facilitada para realizar el seguimiento de prebióticos. En cuanto a los registros, el $75 \%$ corresponde a solicitudes de patentes y el $15 \%$ a patentes otorgadas. El país que lidera el número de depósitos es China con aproximadamente el $38 \%$ del total. En cuanto a las asociaciones solicitantes, Nestec $S A$ fue la organización que presentó más solicitudes de patente, un total de 175 registros. También se disiparon los datos de la Clasificación Internacional de Patentes (IPC), no del cual el $30 \%$ se refirió a la sección A23L que comprende alimentos, productos alimenticios o bebidas no alcohólicas, lo que indica que es una excelente aplicación para la industria alimentaria. En Brasil, una base de datos nacional del INPI presentó 122 solicitudes de patente sobre prebióticos, donde Brasil es el principal depositante con el $48 \%$ del total. En cuanto al depositante, el $54 \%$ de las solicitudes de patentes son de empresas privadas, seguido del $37 \%$ de instituciones públicas y el $9 \%$ de particulares. En general, los resultados muestran que los avances en la investigación sobre prebióticos son prometedores y este estudio puede contribuir a la planificación y toma de decisiones para el desarrollo de esta área.

Palabras Clave: Prebióticos, Prospección tecnológica, Patentes, Perspectiva global.

\section{ABSTRACT}

In view of the growing concern with a healthier life, there has been a greater demand for foods that have positive effects on health. Among the foods emitted, prebiotics stand out as non-digestible components that beneficially affect the host by actively stimulating the proliferation or activity of desirable bacterial populations in the colon. This work aimed to carry out a technological research on the development and national and international application of patents on prebiotics based on this analysis as Derwent, Espacenet, Lens, INPI, Patentscope and USPTO platforms. The Lens platform obtained the highest number of patents (5241 documents) and for this reason it was the database provided for monitoring prebiotics. Regarding registrations, $75 \%$ correspond to patent applications and $15 \%$ to patents that have been granted. The country that leads the number of deposits is China with approximately $38 \%$ of the total. With regard to the applicant associations, Nestec SA was the organization that filed more patent applications, a total of 175 registrations. The International Patent Classification (IPC) data was also dissipated, not which $30 \%$ referred to section A23L which comprise food, food products or non-alcoholic beverages, indicating that it is an excellent application for the food industry. In Brazil, a national INPI database submitted 122 patent applications on prebiotics, where Brazil is the main depositor with $48 \%$ of the total. Regarding the depositor, $54 \%$ of patent applications are from private companies, followed by $37 \%$ from public institutions and $9 \%$ from individuals. Overall, the results show that advances in research on prebiotics are promising and this study can contribute to planning and decision-making for the development of this area.

Keywords: Prebiotics, Technological prospecting, Patents, Global landscape.

\section{INTRODUÇÃO}

A crescente preocupação com a saúde e o bem-estar têm proporcionado um aumento na procura por alimentos funcionais. Estes, apresentam um efeito positivo na saúde, além de suas funções nutricionais básicas (NITHYABALASUNDARI et al., 2020). Os alimentos 
funcionais compreendem: (i) alimentos tradicionais com substâncias bioativas de ocorrência natural como a fibra alimentar, (ii) alimentos suplementados com substâncias bioativas como probióticos e antioxidantes e (iii) ingredientes alimentares introduzidos em alimentos convencionais como os prebióticos (AL-SHERAJIA et al.,2013). A legislação brasileira não determina o que são alimentos funcionais, mas a Resolução no 19, de 30 de abril de 1999 apresenta uma definição para alegação de propriedade funcional que "é aquela relativa ao papel metabólico ou fisiológico que o nutriente ou não nutriente tem no crescimento, desenvolvimento, manutenção e outras funções normas do organismo humano" (BRASIL, 1999).

Dentre esses alimentos, se destacam os prebióticos que são substratos que estimulam o crescimento e/ou ativam o metabolismo de algum grupo de bactérias benéficas (ROSA et al., 2021). Estimasse que o mercado global de prebióticos deve crescer cerca de 12,7\% em 2025 com um lucro de aproximadamente U\$ 10,55 bilhões, desta forma, esforços significativos de pesquisas estão se concentrando na busca, na produção ou síntese de ingredientes com potencial prebiótico (MANO et al., 2017).

$\mathrm{O}$ aperfeiçoamento de novas tecnologias é proveniente do êxito na relação entre as organizações como, indústria, empresas e instituições de pesquisa. Assim, o desenvolvimento de estudos relacionados a prospecção tecnológica tem crescido em ritmo cada vez mais acelerado, possibilitando verificar quais os nichos de mercado estão em ascensão, tecnologias mais relevantes, parceiros envolvidos e concorrência, através da coleta, análise e autenticação de dados sobre os avanços tecnológicos e científicos da área de interesse por meio da busca de informações a partir de documentos como as patentes, por exemplo (LEE; JEON; PARK, 2011).

Diante disso, o presente trabalho teve como objetivo realizar um levantamento do cenário nacional e internacional de patentes relacionadas aos prebióticos, analisando alguns parâmetros como quantidade de publicações e pedidos de patentes por ano, países de origem, tipo de documento, organizações requerentes, principais Classificações Internacionais de Patentes (IPC), entre outros.

\section{FUNDAMENTAÇÃO TEÓRICA}

Prebióticos

O termo prebiótico foi definido pela primeira vez como "um ingrediente alimentar não 
digerível que afeta beneficamente o hospedeiro ao estimular seletivamente o crescimento e/ou a atividade de uma ou de um número limitado de bactérias no cólon, e assim melhora a saúde do hospedeiro" (GIBSON; ROBERFROID, 1995). Porém, devido ao avanço nas pesquisas, a Associação Científica Internacional de Probióticos e Prebióticos (ISAPP) redefiniu o conceito para "um substrato que é utilizado seletivamente por microorganismos hospedeiros, conferindo um benefício à saúde" (GIBSON et al., 2017).

Para que um ingrediente seja considerado um prebiótico, alguns critérios devem ser levados em consideração, como: i) apresentar resistência à degradação por ácidos e enzimas através do sistema gastrointestinal e resistência à absorção gastrointestinal; ii) manter a fermentação sustentada pelas células probióticas do cólon e iii) estimular seletivamente o crescimento e/ou atividade das bactérias do cólon associados à saúde e ao bem-estar. A maioria desses efeitos estão associados ao funcionamento e metabolismo do cólon, as mudanças na microbiota, seus produtos metabólicos e efeitos na bioquímica do hospedeiro, no qual constituem a base do fundamento lógico da associação entre prebióticos e benefícios à saúde (ILLANES; GUERRERO, 2016).

Além da importância para manter o equilíbrio da microbiota intestinal, entretanto, apenas alguns compostos de carboidratos são considerados prebióticos e alguns deles podem ser produzidos industrialmente com o uso de enzimas como os frutooligossacarídeos (FOS), obitidos pela ação das enzimas frutosiltransferases, $\beta$-frutofuranosidase e inulinases; galacto-oligossacarídeos (GOS) e lactulose ambos obtidos pelas reações catalisadas pela enzima $\beta$-galactosidase, e inulina, os quais favorecem o crescimento de Lactobacillus spp. e/ou Bifidobacterium spp. (AZAD et al., 2020).

Existem muitos tipos de prebióticos dietéticos, a maioria deles à base de carboidratos, mas evidências recentes demonstraram que outras substâncias, como compostos fenólicos, fitoquímicos e ácidos graxos conjugados, também podem se enquadrar nessa definição (FARIAS et al., 2019). Os polifenóis são compostos bioativos presentes em várias fontes alimentares, incluindo chá verde, vinho tinto, mirtilo, semente de uva, aloé vera, agave, pêssegos, alho e quando atingem o cólon, entram em contato direto com os micróbios intestinais, resultando em uma interação complexa e multidirecional, que mostra potente atividade prebiótica. Além disso, algumas substâncias como proteínas, ácidos graxos poliinsaturadas, ácidos orgânicos e metabólitos bacterianos foram propostos como substâncias prebióticas porque podem ser usados para potencializar o efeito dos probióticos (GIBSON et 
Para os prebióticos servirem como ingredientes alimentares funcionais, eles não devem afetar negativamente as propriedades organolépticas do produto e devem ser quimicamente estáveis em tratamentos de processamento de alimentos, como calor, baixo $\mathrm{pH}$ e condições de reação de Maillard. Se houver uma alteração química e/ou degradação dos prebióticos em seus componentes mono e dissacarídeos, eles não estarão disponíveis para metabolismo bacteriano, nem fornecer estimulação seletiva de microrganismos, ou exercer seus mecanismos para melhorar a saúde (NERI-NUMA; PASTORE, 2020).

Leguminosas, frutas e legumes, como trigo, aveia, cevada, feijão marinho, feijão branco, feijão preto, lentilhas, grão-de-bico, tomates, cebola, alho, chicória, verduras, alho-poró, cebolinha, espinafre, alcachofras de Jerusalém, bananas são ricos em fibras prebióticas. Geralmente, os agentes prebióticos benéficos são classificados como polióis (álcoois de açúcar), oligossacarídeos e fibras solúveis (MOHANTY et al., 2018). Os prebióticos são empregados em diversas formulações de alimentos, como bebidas, panificação, carnes e laticínios, com o intuito de aumentar seu potencial saudável ou para melhorar suas propriedades tecnológicas. Além disso, melhoram recursos sensoriais, como frescor e fornecem uma composição nutricional mais equilibrada porque são frequentemente usados como fibra dietética e adicionados como um ingrediente de volume de baixo valor energético (HURTADO-ROMERO et al., 2020).

\section{Prospecção tecnológica}

Uma das formas de acompanhar as informações tecnológicas em nicho específico é através da prospecção tecnológica de patentes. A prospecção tecnológica é um método que visa realizar um levantamento de tecnologias existentes, determinar o estágio de maturidade da tecnologia em questão e como ela se insere na sociedade. Além disso, são identificados aspectos de tecnologias concorrentes e lacunas a serem preenchidas, onde é possível que determinada tecnologia ou suas variações sejam competitivas. As tecnologias afins também são buscadas e podem ser incorporadas à tecnologia que está sendo mapeada, formando parcerias com alto potencial de sucesso, podendo aumentar seu impacto sinérgico (QUINTELLA et al., 2011; PROCACI et al., 2016).

A prospecção tecnológica através de patentes constitui uma poderosa ferramenta de apoio à decisão, considerando a riqueza de informações contidas neste tipo de documento, 
permitindo a identificação de tecnologias relevantes, parceiros envolvidos, nichos de mercado para desempenho, inovações e movimentos da concorrência, além disso, cerca de $2 / 3$ da informação tecnológica está disponibilizada somente em documentos de patentes (DEORSOLA et al., 2011). A patente compreende uma fonte de informação mais formal, constituída por dados técnicos e jurídicos de invenção. Assim, é fundamental que os pesquisadores utilizem as informações encontradas em documentos de patentes por se constituírem como a principal fonte de conhecimento técnico existente, caso contrário, desperdiçam uma importante fonte sobre o desenvolvimento tecnológico de determinado setor (MARQUES et al., 2016).

A metodologia que envolve a prospecção tecnológica deve ser desmistificada, tornando-se ferramenta rotineira e contribuindo para facilitar a apropriação com qualidade da Propriedade Intelectual (PI) e desta forma melhorar a gestão da inovação, ao aumentar o senso crítico e ampliar a visão dos gargalos tecnológicos e das oportunidades (QUINTELLA et al., 2011).

\section{METODOLOGIA}

A pesquisa de patentes foi realizada entre os dias 16 e 23 de abril de 2021 nas seguintes bases de dados: Derwent, Espacenet, INPI, Lens, Patentscope e USPTO. A realização das buscas sobre prebióticos ocorreram nos intervalos de tempo disponíveis em cada base de dados e utilizando os procedimentos metodológicos descritos nos tópicos posteriores.

\section{Derwent}

O Derwent Innovations Index é uma ferramenta que oferece acesso a mais de 30 milhões de invenções descritas em mais de 65 milhões de documentos de patentes. Esta base de dados permite a pesquisa de patentes a todos os níveis de uma organização por meio de pesquisas simples. A cobertura inclui registros de patentes de Derwent World Patents Index e informações de citação de patentes de Derwent Patents Citation Index. No Brasil, o Derwent possui acesso livre através de universidades, institutos federais e P\&D, pelo portal da CAPES. A metodologia utilizada compreende as etapas abaixo.

- Acesse:https://www-periodicos-capes-gov-br.ez19.periodicos.capes.gov.br/

- Na página inicial: Buscar $\rightarrow$ Buscar base $\rightarrow$ Digite "Web of Science" $\rightarrow$ Clique em 
"Derwent Innovations Index - DII (Web of Science/ Clarivate Analytics)".

- Pesquisa básica: Tópico: "prebiotic” OU “prebiotics”.

- Entre em "Pesquisar".

\section{Espacenet}

O Espacenet é disponibilizado pelo Escritório Europeu de Patentes (European Patent Office, EPO), junto com a Comissão Europeia e vários escritórios nacionais e regionais de patentes. Trata-se de uma plataforma online, acessível para iniciantes e especialistas e que é atualizada diariamente. Contém dados sobre mais de 120 milhões de documentos de patentes em todo o mundo, desde 1782 até hoje. A metodologia utilizada compreende as etapas abaixo.

- Acesse: https://worldwide.espacenet.com/.

- Na página inicial: Acesso rápido $\rightarrow$ Espacenet clássico.

- Ir em "Busca avançada".

- No campo "Escolha a coleção que deseja pesquisar", selecione "No mundo todocoleção de pedidos publicados de mais de 100 países”.

- Item "Título ou resumo" preenchido com "prebiotic ou prebiotics".

- Clique em "Procurar".

INPI

O Instituto Nacional da Propriedade Industrial (INPI) é o órgão regulamentador responsável pelo aperfeiçoamento, disseminação e gestão do sistema brasileiro de concessão e garantia de direitos sobre uma invenção tecnológica, uma marca ou modelo industrial, entre outros, para a indústria. Seus serviços compreendem o registro e concessão de marcas, patentes, desenho industrial, transferência de tecnologia, indicação geográfica, programa de computador e topografia de circuitos integrados. A metodologia utilizada compreende as etapas abaixo.

- Acesse: https://www.gov.br/inpi/pt-br.

- Na página principal: clique em Patentes $\rightarrow$ Busca $\rightarrow$ Faça login.

- Acesse "Patentes". 
- Na pesquisa básica: selecione "todas as palavras" $\rightarrow$ (prebiótico ou prebióticos no título" e "prebiótico ou prebióticos no resumo").

- Entre em "Pesquisar".

Lens

O Lens é uma plataforma que foi lançada nos anos 2000 como uma iniciativa da Cambia, organização não governamental sediada em Camberra, Austrália, em parceria com a Queensland University of Technology. Os dados de patentes são oriundos do Escritório Europeu de Patentes, do Escritório Americano de Patentes, do Escritório Australiano de Patentes e dos documentos relacionados ao Tratado de Cooperação em termos de Patentes da WIPO, com informações bibliográficas a partir de 1907. Esse banco de dados possui mais de 127 milhões de registros de patentes de 105 jurisdições e 70,1 de famílias de patentes até o começo do primeiro semestre de 2021. A metodologia utilizada compreende as etapas abaixo.

- Acesse: https://www.lens.org/.

- Na página inicial: Patentes $\rightarrow$ Pesquisa estruturada de patentes.

- Campo de pesquisa: Título (prebiotic ou prebiotics) OU Resumo (prebiotic ou prebiotics).

- Entre em "Pesquisar".

Patentscope

O Patentscope é a base de dados da Organização Mundial da Propriedade Intelectual (OMPI ou WIPO em inglês). Ela proporciona acesso de forma gratuita a documentos de vários países, incluindo os depósitos via PCT (Tratado de Cooperação em matéria de Patentes). Permite fazer pesquisas em 93 milhões de documentos de patentes, além de 4,0 milhões de pedidos de patentes internacionais (PCT) que são publicados desde 1978. A metodologia utilizada compreende as etapas abaixo.

- Acesse: https://www.wipo.int/portal/en//.

- Na página inicial: Recursos $\rightarrow$ Base de dados IP (PATENTSCOPE) $\rightarrow$ Clique em "Acesse a base de dados PATENTSCOPE".

- Pesquisa simples: Campo "página de cobertura" $\rightarrow$ Termo pesquisado 


\section{응

"FP:((EN_TI:("prebiotic" ou "prebiotics") OU EN_AB:("prebiotic" ou "prebiotics")))".

- Clique em $\mathrm{Q}$.

\section{USPTO}

O United States Patent and Trademark Office é o escritório americano que concede patentes para a proteção de invenções e registra marcas. Possui uma das mais completas bases, com busca altamente refinada. As patentes referentes aos anos de 1790 a 1975 apresentam informações restritas e a partir de 1976 está disponível o texto completo das patentes. A metodologia utilizada compreende as etapas abaixo.

- Acesse: https://www.uspto.gov/.

- Na página inicial: Encontre rápido $\rightarrow$ Patentes $\rightarrow$ Clique em "PatFT".

- Campo de pesquisa preenchido com: Termo 1 (prebiotic OU prebiotics) no campo 1 (Título) OU Termo 2 (prebiotic OU prebiotics) no campo 2 (Resumo).

- Selecione anos: “1976 para exibir [texto completo]”.

- Entre em "Pesquisar".

Análise de dados

A partir das bases de dados selecionadas, a primeira etapa do estudo consistiu em identificar qual plataforma apresenta um banco de dados mais abrangente quanto ao número de invenções de patentes. Em seguida as patentes selecionadas da base de dados mais completa determinada na etapa anterior, tiveram a análise dos seguintes dados: Frequência de publicação de documentos e pedidos de patentes ao longo dos anos, status de depósito, país de prioridade, organizações requerentes e Classificação Internacional de Patentes (IPC). Os resultados foram apresentados na forma de gráficos, permitindo conhecer a distribuição temporal dos depósitos, o número de registros relacionados a utilização de celulases, a distribuição dos depósitos a nível mundial, quais instituições de pesquisa, indivíduos e empresas privadas que são detentoras tecnologia e a quantidade de documentos dispostos, entre outras informações. Para a análise das patentes depositadas no Brasil, utilizou-se a metodologia descrita anteriormente do INPI. 


\section{RESULTADOS E DISCUSSÃO}

Após a realização da pesquisa nas bases de dados, foi possível determinar a quantidade de patentes sobre prebióticos em cada plataforma (Tabela 01). A partir dessa busca, observou-se que o banco de dados Lens apresentou o maior número de documentos de patentes (5241) em comparação com as outras bases. Desta forma, o Lens foi selecionado para a realização do monitoramento tecnológico sobre os prebióticos.

Tabela 01: Número de registros de patentes em cada banco de dados.

$\begin{array}{cc}\text { Base de dados } & \text { Quantidade de patentes } \\ \text { Lens } & 5241 \\ \text { Derwent } & 4479 \\ \text { Espacenet } & 4289 \\ \text { Patentscope } & 4228 \\ \text { USPTO } & 226 \\ \text { INPI } & 122\end{array}$

Fonte: O Autor, por pesquisa direta nos bancos de dados Lens, DERWENT, Patentscope, Espacenet, USPTO e INPI (2021).

A Figura 01, apresenta o comportamento quantitativo de patentes no período de 1996 a 2020. Observou-se um aumento gradativo, com pequenas oscilações de crescimento e decréscimo até o ano de 2013. Em 2014, no entanto, houve um aumento significativo da quantidade de patentes em comparação aos anos anteriores, com recorde no número de depósitos de patentes, totalizando 537 registros. Com base nos resultados para a análise das patentes quanto ao tipo de documento, $75 \%$ correspondem a pedido de patente, $15 \%$ referem-se a patentes que atenderam aos critérios e foram concedidas e os $10 \%$ restantes compreendem a documentos identificados desconhecidos, ambíguos, relatórios de pesquisa, patente limitada e alterada (Figura 02).

Figura 01: Distribuição de publicação e pedidos de patentes ao longo dos anos. 


\section{B.

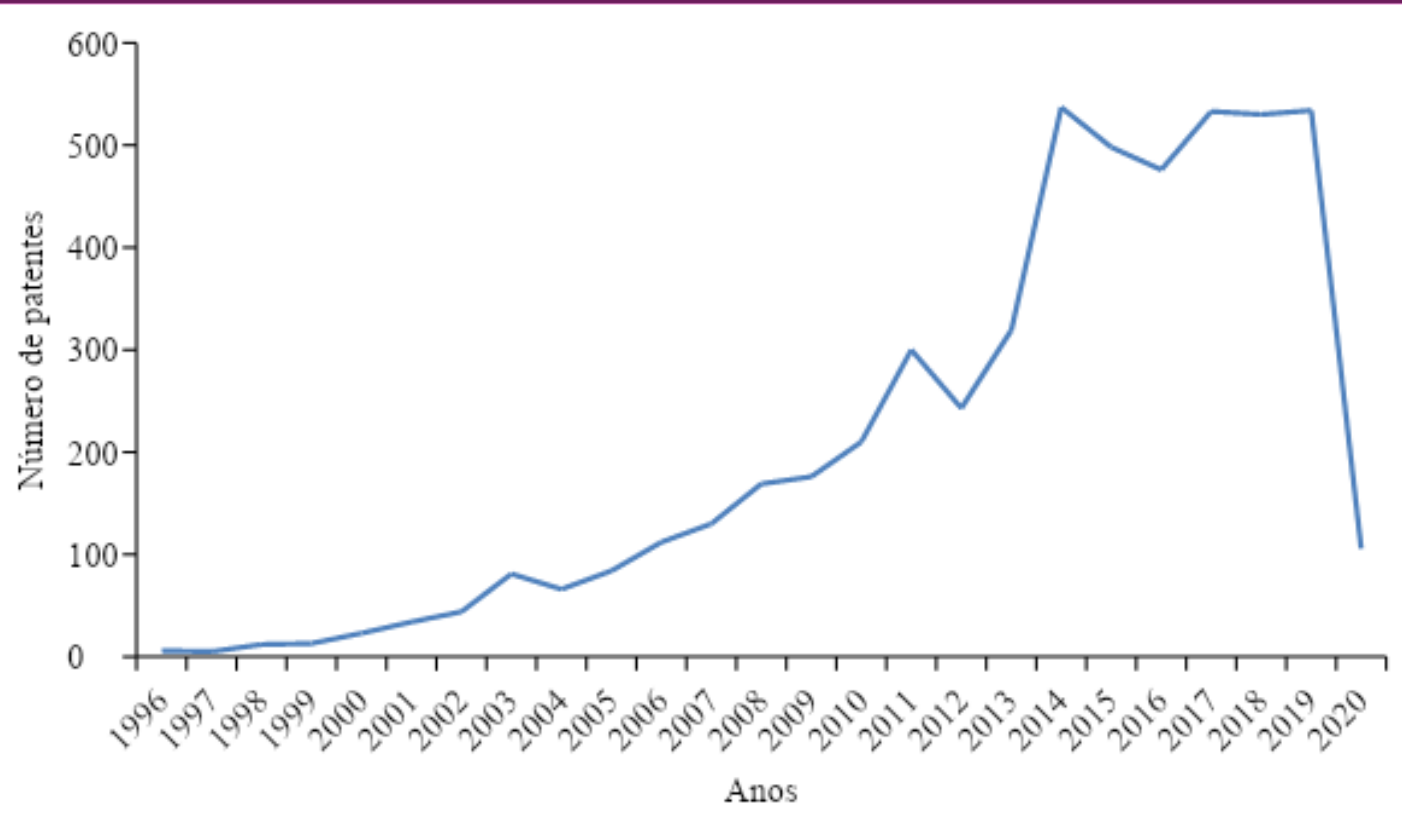

PICDED

Fonte: O Autor, por pesquisa direta no banco de dados de patentes Lens (2021).

Figura 02: Tipo de documento das patentes.

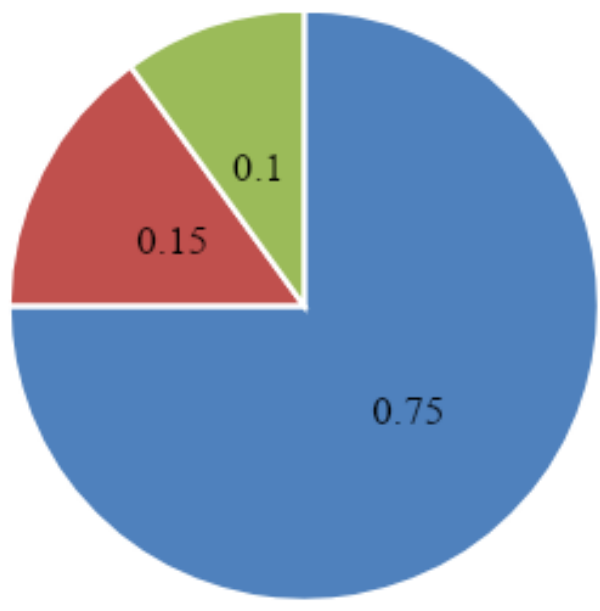

= Pedido de patente

- Patente concedida

autros

Fonte: O Autor, por pesquisa direta no banco de dados de patentes Lens (2021).

Dentre as 10 principais jurisdições, a China lidera como a principal jurisdição depositante de patentes sobre prebióticos com 1980 registros, equivalendo a aproximadamente $38 \%$ do total de registros (Figura 03). De acordo com o relatório de Indicadores Mundiais de Propriedade Intelectual 2020, a China se destacou como a principal fonte de pedidos internacionais de patentes, seguido dos Estados Unidos e Japão (WIPO, 
2020).

Figura 03: Principais jurisdições depositantes de patentes.

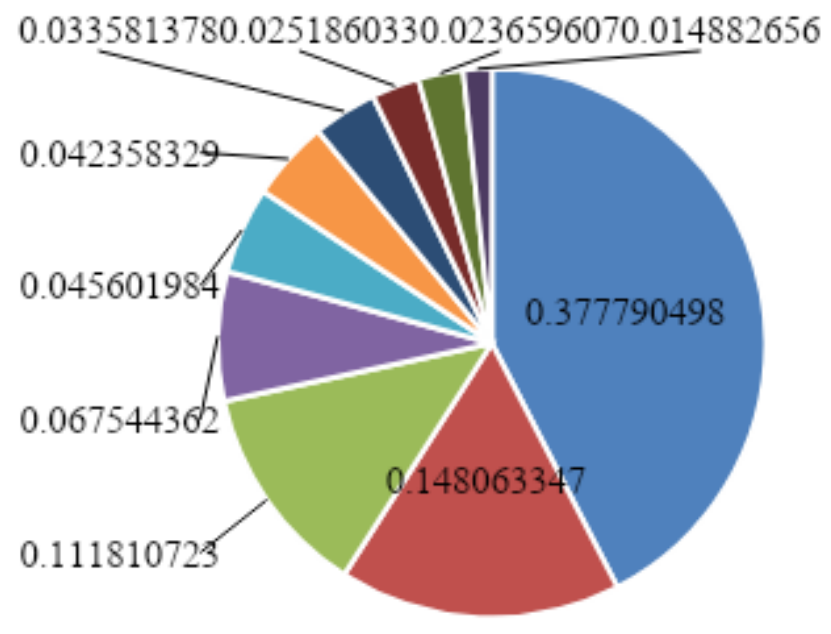

- China

- Estados Unidos

= Wo-Wipo

- Patentes européias

- Canadá

" Austrália

- Rússia

- México

- República da Coréia

- Japão

Fonte: O Autor, por pesquisa direta no banco de dados de patentes Lens (2021).

Com relação as principais organizações requerentes de documentos de patentes, verificou-se que a Nestec $S A$ foi a organização que mais realizou depósitos de patentes (175 registros) e é responsável por oferecer pesquisa comercial e serviços de consultoria para a Nestlé S.A. e suas subsidiárias, os resultados das 10 principais organizações pode ser observado na Figura 04. A empresa também presta serviços de pesquisa científica e desenvolvimento tecnológico além disso, opera como subsidiária do The Nestlé Group, que é a empresa líder mundial em nutrição, saúde e bem-estar.

Figura 04: Principais organizações requerentes de patentes (Critério Top 10). 


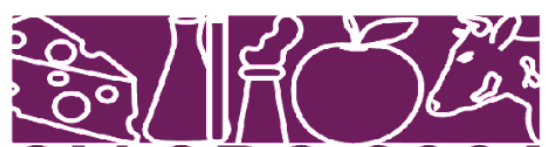

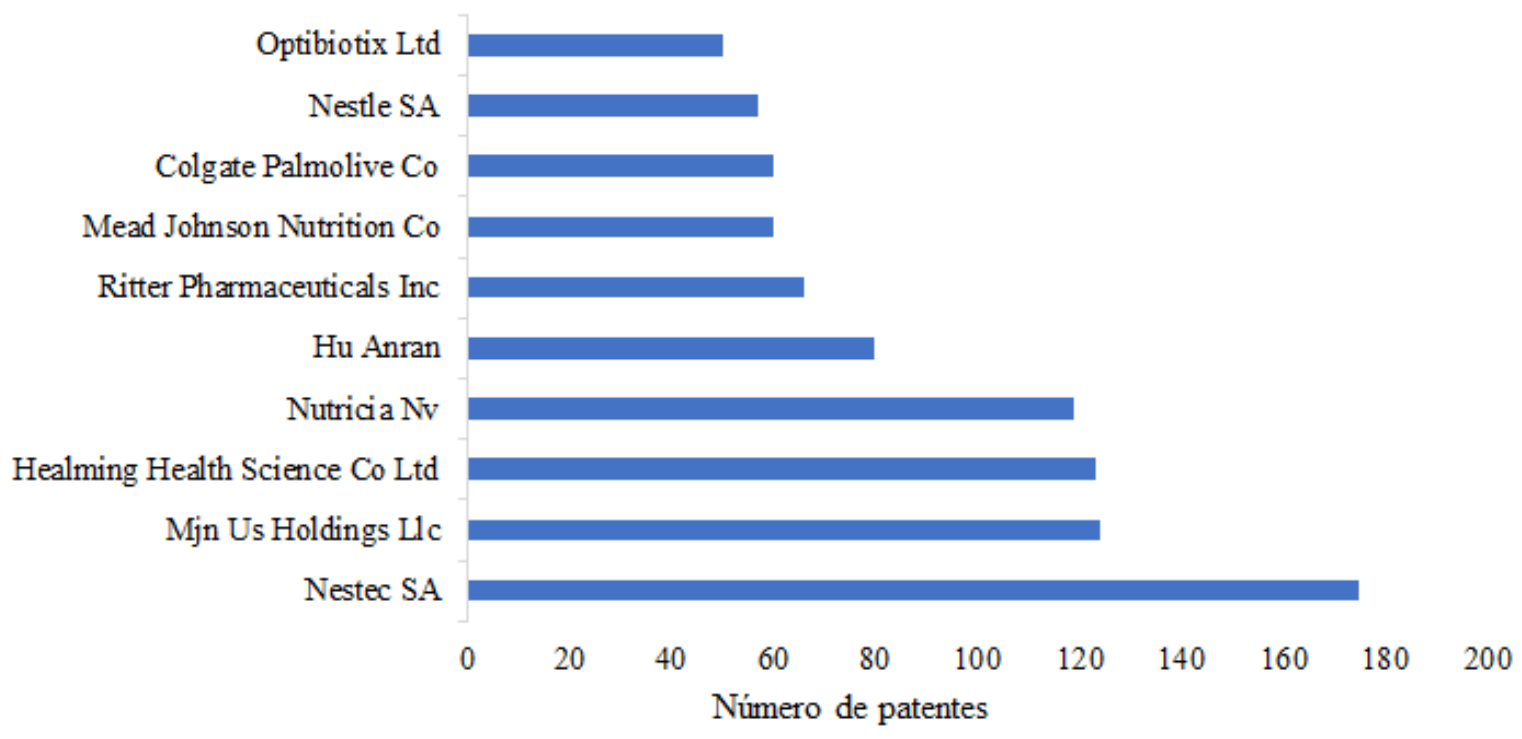

Fonte: O Autor, por pesquisa direta no banco de dados de patentes Lens (2021).

Dentre as patentes de titularidade da Nestec $S A$, pode-se citar:

i) No da patente MX 2011012955 A (publicada em 2012): refere-se a uma composição nutricional prebiótica, em particular dirigida a bebês e/ou crianças desmamadas que melhora o desempenho cognitivo, em particular a aprendizagem e a memória da criança.

ii) $\mathrm{N}^{\mathrm{o}}$ da patente US 2017/0273997 A1 (publicada em 2017): propõe uma composição nutricional composta por oligossacarídeos selecionados que reduz a abundância de bactérias estreptococos no intestino de bebês ou mamíferos jovens. A redução do estreptococo e do equilíbrio da microbiota relacionada afeta e reduz o risco de adiposidade ou obesidade futuramente.

O eixo microbiota-intestino-cérebro se refere à extensa rede de comunicação entre a microbiota que reside no intestino, o intestino e o cérebro. A microbiota e o cérebro se comunicam por diferentes vias, como a inervação vagal, metabólitos microbianos e neurotransmissores derivados de micróbios (Ácido gama-aminobutírico (GABA), serotonina, catecolaminas e acetilcolina). A microbiota é necessária para a estrutura, desenvolvimento e função do cérebro, pois já foi demonstrado que o sistema serotonérgico não se desenvolve adequadamente sem micróbios e a atividade do hipocampo também foi associada à presença de micróbios (ROMO-ARAIZA; IBARRA; 2020).

De acordo com Kallus e Brandt (2012), o mecanismo que relaciona a microbiota intestinal e a obesidade não é bem compreendido, mas o que está bem estabelecido é que a 


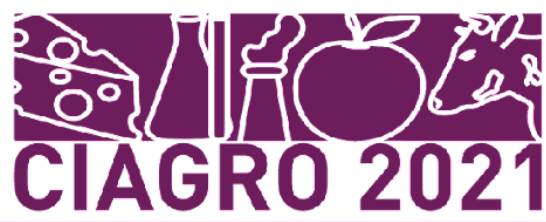

microbiota intestinal pode aumentar a energia da dieta e regular a composição de ácidos graxos. Alguns ensaios clínicos demonstraram que a ingestão de prebióticos foi associado a PIuma melhora significativa na saciedade, glicose pós-prandial e concentrações de insulina em indivíduos adultos. O consumo de uma mistura de inulina/oligofrutose também demonstrou aumentar Bifidobacterium spp. e Fae calibacterium prausnitzii, que se correlacionaram negativamente com lipopolissacarídeos e Bifidobacterium spp. que se correlacionam negativamente com porcentagem de massa gorda e colesterol LDL. Esses resultados promissores em adultos justificam a avaliação de prebióticos como uma intervenção dietética para modular a microbiota intestinal e os resultados metabólicos na obesidade pediátrica (NICOLUCCI et al., 2017).

Os documentos de patentes também foram analisados em relação a Classificação Internacional de Patentes (IPC) que serve para classificar o conteúdo técnico de um documento de patente (ou outra invenção) (Tabela 02). Foram identificadas 90 classificações diferentes, no qual 30\% se referem a seção A23L que compreendem alimentos, produtos alimentícios ou bebidas não alcoólicas, não abrangidos pelas subclasses A21D ou A23B-A23J; sua preparação ou tratamento, por exemplo, cozinha, modificação de qualidades nutritivas, tratamento físico (modelagem ou trabalho, não totalmente abrangidos por esta subclasse, A23P); preservação de alimentos ou alimentos, em geral. Vale ressaltar que um mesmo documento pode abranger diferentes IPC's.

Tabela 02: Principais subclasses dos IPC's nos registros de patentes sobre prebióticos.

IPC

\section{Descrição}

Modificação das qualidades

A23L33/00 nutritivas dos alimentos, produtos dietéticos, preparação ou tratamento dos mesmos.

A23L1/30 Não encontrado

Carboidratos, Açúcares derivados do mesmo sorbitol;

Oligossacarídeos, ou seja, com três a cinco radicais sacáridos ligados um ao outro por ligações glicosídicas.

A23L33/135 Bactérias ou seus derivados, ex. Probióticos.

A61K35/747 Lactobacilos, ex. L. acidophilus ou

\section{Contagem de} registros

1178 22,48

681

662

558

10,64

519 


\begin{tabular}{|c|c|c|c|}
\hline A61P1/00 & $\begin{array}{l}\text { L. brevis } \\
\text { Medicamentos para distúrbios do } \\
\text { trato alimentar ou do sistema } \\
\text { digestivo }\end{array}$ & 479 & 9,14 \\
\hline A61K35/74 & $\begin{array}{l}\text { Bactérias (uso terapêutico de uma } \\
\text { proteína bacteriana). }\end{array}$ & 475 & 9,06 \\
\hline A23L33/21 & $\begin{array}{l}\text { Adição de substâncias } \\
\text { substancialmente indigeríveis, ex. } \\
\text { fibras dietéticas (adição de agentes } \\
\text { gelificantes ou espessantes). }\end{array}$ & 404 & 7,71 \\
\hline A23L33/125 & $\begin{array}{l}\text { Uso de aditivos sem precedência; } \\
\text { contendo xaropes de carboidratos } \\
\text { contendo açúcares } \\
\text { álcoois de açúcar } \\
\text { hidrolisados de amido substâncias } \\
\text { indigestas. }\end{array}$ & 391 & 7,46 \\
\hline A61K31/715 & $\begin{array}{l}\text { Polissacarídeos, isto é, tendo mais } \\
\text { de cinco radicais sacarídeos ligados } \\
\text { uns aos outros por ligações } \\
\text { glicosídicas; seus derivados, e. } \\
\text { éteres, ésteres. }\end{array}$ & 388 & 7,40 \\
\hline
\end{tabular}

O desenvolvimento desse setor no mercado está relacionado a diversos fatores, inclusive o interesse dos consumidores por alimentos que proporcionem benefícios à saúde. A utilização de prebióticos como componentes alimentares apresenta múltiplas vantagens, uma vez que melhoram as características sensoriais e fornecem uma composição nutricional mais bem balanceada. Quando os prebióticos são empregados em produtos de panificação e cereais matinais, isso representa um grande progresso em comparação com a fibra dietética clássica. Prebióticos fornecem mais frescor em salgadinhos e cereais e prolongam a prateleira vida. Eles também mantêm pães e bolos úmidos e frescos por um muito tempo. Sua solubilidade permite a incorporação da fibra em sistemas líquidos como bebidas, laticínios e produtos para barrar. Os prébióticos também são frequentemente utilizados como fibra alimentar em comprimidos e em alimentos funcionais, particularmente em gamas inteiras de produtos lácteos e pães, pois os ingredientes prebióticos aumentam a viabilidade de bactérias intestinais saudáveis (AL-SHERAJIA et al., 2013).

Partindo das combinações de palavras-chaves descritas sobre a plataforma brasileira, também foi possível realizar uma triagem de diversos indicadores relacionados aos registros de patentes depositados na autarquia federal brasileira INPI. A busca nessa base de dados 


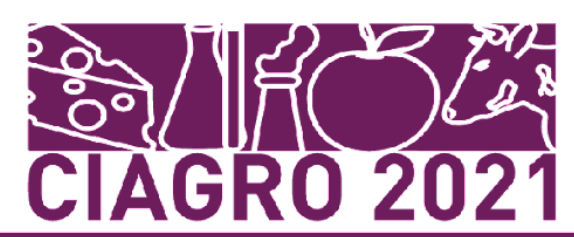

recuperou 122 pedidos de patentes, a distribuição das patentes de acordo com o ano de publicação (Figura 5), sendo 2017 seu ápice com 13 depósitos. No entanto, é importante

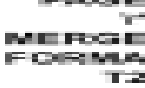
ressaltar que o processo de publicação do relatório de inovação só será concluído caso o documento atenda a todas exigências do sistema de patente e no Brasil, tal procedimento pode durar até um ano e meio após realização do pedido de patente.

Figura 05: Distribuição de publicação e pedidos de patentes ao longo dos anos no Brasil.

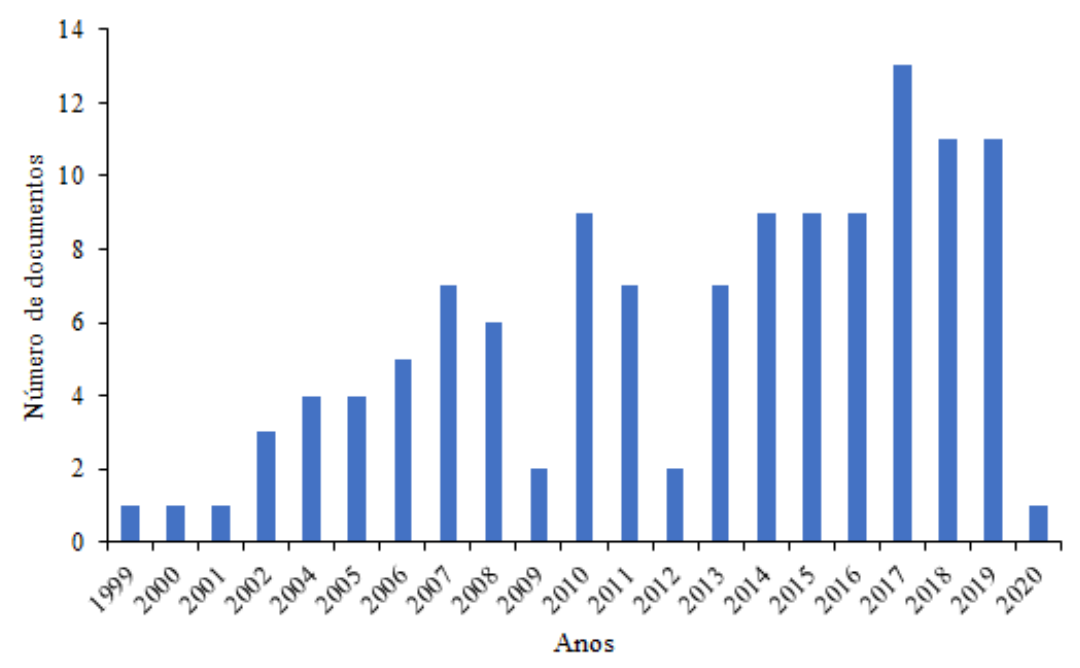

Fonte: O Autor, por pesquisa direta no banco de dados de patentes INPI (2021).

Com relação aos países de origem dos pedidos de patentes residentes no Brasil (Figura 06), o Brasil é o principal depositante com 59 documentos, equivalente a $48 \%$ do total de registros, em seguida tem o Estados Unidos com 19\% e os 33\% restante são provenientes de outros países como Suíça, Alemanha, Dinamarca, Holanda, Itália, Rússia, França, México, Bélgica, Índia, China, Espanha, Panamá, Singapura e Suécia.

Figura 06: Países dos pedidos de patentes no INPI. 


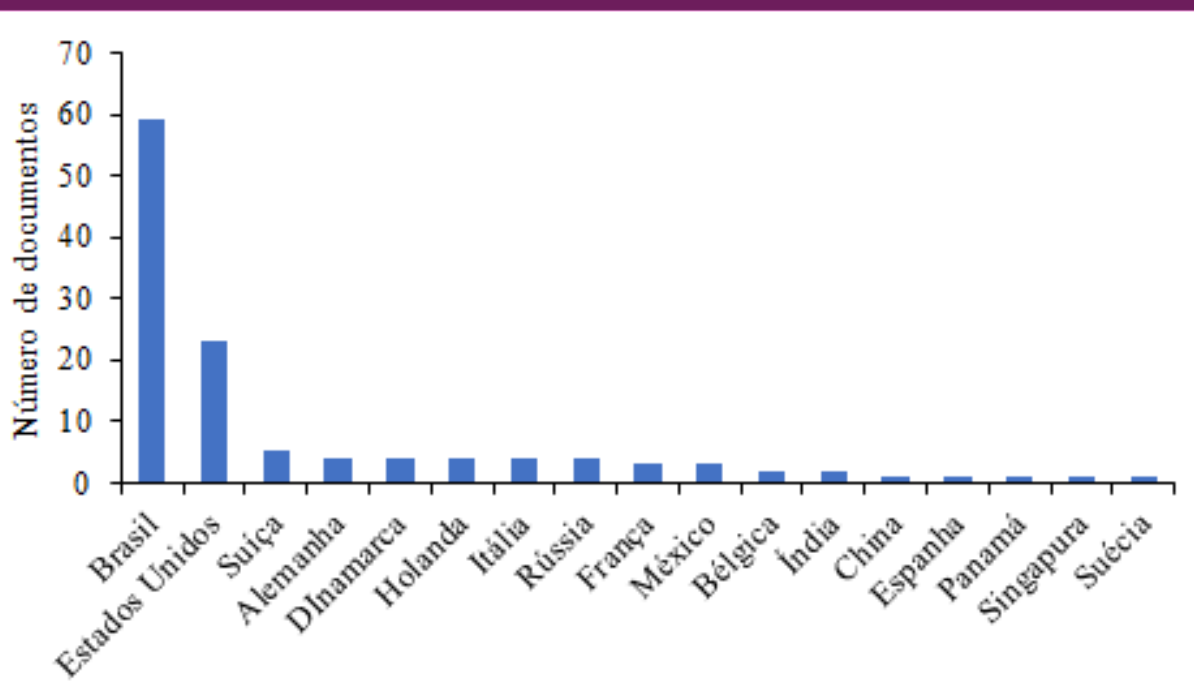

Paises

Fonte: O Autor, por pesquisa direta no banco de dados de patentes INPI (2021).

Em relação ao status do documento, a patente pode ser classificadas como depositada ou concedida. Neste estudo, $88 \%$ compreendem as patentes depositadas e apenas $12 \%$ do total correspondem a patentes concedidas. De acordo com informações dispostas no guia básico do endereço eletrônico do Instituto Nacional da Propriedade Industrial (INPI), as patentes no Brasil podem ser de dois tipos: Patente de invenção (PI) para produtos ou processos que apresentem uma nova tecnologia e Patente de Modelo de Utilidade (MU) quando confere apenas melhorias e aperfeiçoamento no uso ou na fabricação de metodologias e objetos já existentes. Neste monitoramento tecnológico, $66 \%$ dos documentos correspondem patentes do tipo MU e as demais são do tipo PI. Dentre as patentes concedidas, apenas $19 \%$ são classificadas como patente de invenção (PI) (Figura 07).

Figura 07: Distribuição do tipo de documento e situação dos pedidos de patentes no INPI. Onde: MU - Modelo de utilidade; PI - Patente de Invenção. 


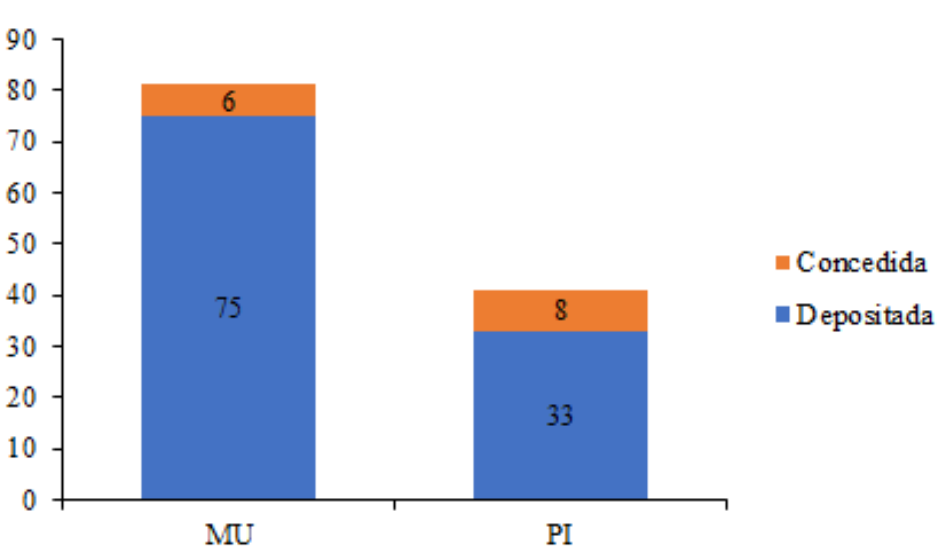

Fonte: O Autor, por pesquisa direta no banco de dados de patentes INPI (2021)

Com base no boletim mensal de propriedade industrial disponibilizado no INPI, até o mês de outubro de 2020, 78 países solicitaram proteção de patentes, entre os países que mais depositaram pedidos de patentes de invenção, sendo os principais os Estados Unidos (30\%), Brasil (21\%), Alemanha (7\%), Japão (7\%) e China (5\%). Entre os depósitos de modelo de utilidade, depositantes residentes do Brasil foram responsáveis por 99\% dos pedidos (INPI, 2020).

Com relação ao depositante, verificou-se que assim como foi apresentado na seção anterior no estudo de patentes a nível global, a maior parte das patentes também são de empresas privadas com $54 \%$ pedidos de patentes, em seguida por $37 \%$ pedidos de patentes de instituições públicas sendo elas universidades e institutos federais, e 9\% por pessoas físicas, conforme apresentado na Figura 8.

Figura 08: Distribuição por depositante dos documentos nos pedidos patentes envolvendo prebióticos no Brasil.

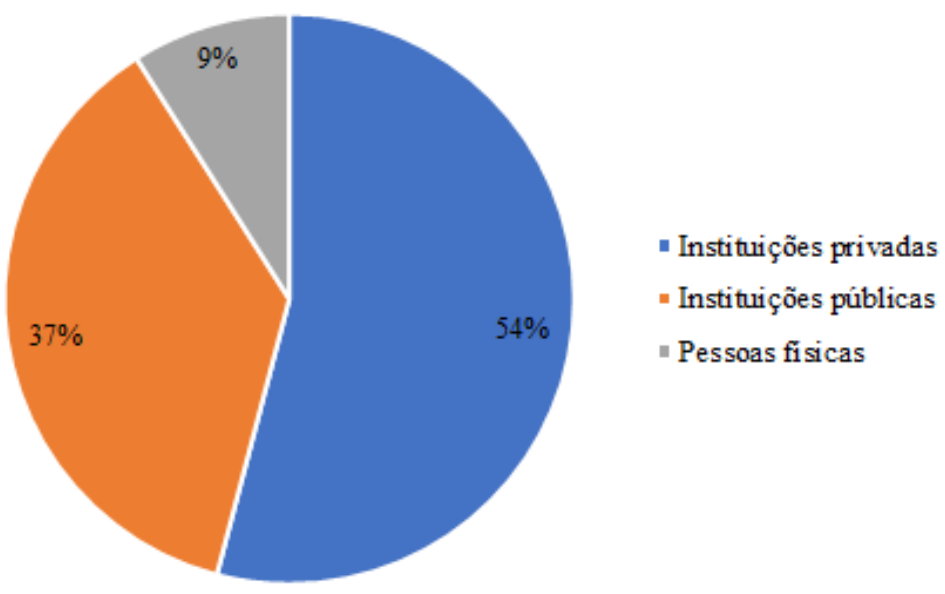

Fonte: O Autor, por pesquisa direta no banco de dados de patentes INPI (2021). 
Em relação ao período janeiro-outubro de 2020, entre os depósitos de residentes, a categoria de pessoas físicas foi responsável por $42 \%$ do total de patentes de invenção, seguido das instituições de pesquisa e ensino e governo (27\%) e empresas de médio e grande porte (18\%). Analisando as patentes classificadas como modelo de utilidade, a categoria de pessoas físicas também se destacou como a principal depositante de patentes (60\%), seguido das MEI, ME e EPP (22\%) (INPI, 2020).

Segundo um ranking liberado pelo Instituto Nacional de Propriedade Intelectual (INPI) em setembro de 2020, a Universidade Federal da Paraíba se destacou, pelo segundo ano consecutivo, como a instituição mais depositante no ano de 2019, com 100 pedidos de patentes enquanto que a Universidade de São Paulo (USP) ocupa a $8^{\text {a }}$ colocação, com 45 registros (INPI, 2019), demonstrando o potencial do ensino público superior para contribuição científica tanto à indústria como para a sociedade.

Contudo, os esforços existentes para gerar inovações tecnológicas no Brasil são bastante baixos. Segundo o Relatório patrocinado pelo Banco Interamericano de Desenvolvimento (BID) de avaliação das políticas recentes de incentivos à pesquisa, desenvolvimento e inovação no Brasil, afirmam que para superar esse atraso relativo é necessária uma alteração pronunciada nos gastos privados em PD\&I (Pesquisa, Desenvolvimento e Inovação) a exemplo dos países desenvolvidos. Mas é fundamental reconhecer que também são necessárias políticas sociais e educacionais adequadas para enfrentar dificuldades de "eficiência" internos e atingir um estágio caracterizado por um sistema nacional de inovação de qualidade (LIMA; RAMALHO, 2016).

\section{CONCLUSÕES}

Após a busca nas bases de dados, constatou-se que o Lens apresentou um escopo mais amplo de patentes sobre prebióticos. Analisando os resultados dessa plataforma, houve um aumento significativo de registros de patentes ao longo dos anos, sendo em 2014 o ano que apresentou número recorde de depósitos. Entre as jurisdições, a China foi o país que mais realizou depósitos de patentes (38\%). Quanto ao tipo de documento, apenas $15 \%$ dos documentos foram concedidos e a Nestec $S A$ foi a principal organização requerente de patentes sobre prebióticos.

Com relação ao INPI, o Brasil se destacou como o principal país depositante e entre as instituições, as empresas privadas são responsáveis pela maior parte dos registros de patentes. 
Porém ainda se faz necessário maiores investimentos para promoção da ciência, tecnologia e inovação. A partir dos resultados obtidos, é possível constatar que o cenário global de patentes relacionadas a prebióticos é promissor e esse estudo pode contribuir para organizações na tomada de decisões e definição de estratégias afim de estabelecer uma posição competitiva no mercado.

\section{REFERÊNCIAS}

AL-SHERAJIA, S.H.; ISMAILA, A.; MANAP, M. Y.; MUSTAFAC, S.; YUSOFA, R. M.; HASSANA, F. A. Prebiotics as functional foods: A review. Journal of fuctional foods, v. 5, n.4, p.1542-1553, 2013.

BRASIL. Ministério da Saúde. Agência Nacional de Vigilância Sanitária. Resolução n. 19, de 30 de abril de 1999. Aprova o Regulamento Técnico de Procedimentos para Registro de Alimento com Alegação de Propriedades Funcionais e ou de Saúde em sua Rotulagem. Brasília, 1999.

Acesso

em: https://www.gov.br/agricultura/pt-br/assuntos/inspecao/produtos-vegetal/legislacao-1/bibliote ca-de-normas-vinhos-e-bebidas/resolucao-no-19-de-30-de-abril-de-1999.pdf/view. Acesso em: 22 de mai. 2021.

AZAD, M. A. K.; GAO, J.; MA, J.; LI, T.; TAN, B.; HUANG, X.; YIN, J. Opportunities of prebiotics for the intestinal health of monogastric animals. Animal Nutrition, v. 6, p. 379-388, 2020.

DEORSOLA, A. C.; MOTHE, C. G.; OLIVIEIRA, L. G.; DEORSOLA, A. B. Technological monitoring of cyclodextrin e World panorama. World Patent Information, v. 39, p 41-49, 2014.

FARIAS, D. P.; ARAÚJO, F. F.; NERI-NUMA, I. A.; PASTORE, G. M. Prebiotics: Trends in food, health and technological applications. Trends in Food Science \& Technology, v. 93, p. 23-35, 2019.

GIBSON, G. R.; ROBERFROID, M. B. Dietary modulation of the human colonie microbiota: Introducing the concept of prebiotics. The Journal of nutrition, v. 125, ed. 6, p. 1401-1412, 1995.

GIBSON, G. R.; HUTKINS, R.; SANDERS, M. E.; PRESCOTT, S. L.; REIMER, R. A.; SALMINEN, S. J.; SCOTT, K.; STANTON, C.; SWANSON, K. S., CANI, P. D., VERBEKE, K.; REID, G. Expert consensus document: The International Scientific Association for Probiotics and Prebiotics (ISAPP) consensus statement on the definition and scope of prebiotics. Nature Reviews Gastroenterology \& Hepatology, 2017.

HURTADO-ROMERO, A.; TORO-BARBOSA, M. D.; GARCIA-AMEZQUITA, L. E.; GARCÍA-CAYUELA, T. Innovative technologies for the production of food ingredients with prebiotic potential: Modifications, applications, and validation methods. Trends in Food Science \& Technology, v. 104, p. 117-131, 2020.

ILLANES, A.; GUERRERO, C. Functional Foods and Feeds. Lactose-Derived Prebiotics, 
cap. 2, p. 35-86, 2016.

INPI- Instituto Nacional da Propriedade Industrial. RANKINGS DOS DEPOSITANTES RESIDENTES EM 2019. Disponível em: https://cct.ufcg.edu.br/wp-content/uploads/2020/09/Ranking-dos-Depositantes-Residentes-em -2019-INPI.pdf. Acesso em: 27 de abr. 2021.

INPI- Instituto Nacional da Propriedade Industrial. Indicadores de Propriedade Industrial. Boletim mensal de Propriedade Industrial, Rio de Janeiro, v.5, n.11 p. 1-20, nov. 2020.

KALLUS, S.J.; BRANDT, L. J. The intestinal microbiota and obesity. Journal of Clinic Gastroenterology, v. 46, n. 1, 2012.

LEE, C.; JEON, J.; PARK, Y. Monitoring trends of technological changes based on the dynamic patent lattice: A modified formal concept analysis approach. Technological Forecasting and Social Change, v. 78, ed. 4, p. 690-702, 2011.

LIMA, M. G.; RAMALHO, W. Avaliação de patentes: Modelos e estudo de um caso de propriedade de uma IFES. In: IV Simpósio Internacional de Gestão de Projetos, Inovação e Sustentabilidade, 2016. Anais do V SINGEP. São Paulo, 2016.

MANO, M. C. R.; NERI-NUMA, I. A.; SILVA, J. B. DA, PAULINO, B. N.; PESSOA, M. G.; PASTORE, G. M. Oligosaccharide biotechnology: An approach of prebiotic revolution on the industry. Applied Microbiology and Biotechnology, v. 102, n. 1, p. 17-37, 2017.

MARQUES, H. R.; PEREIRA, R. M.; GARCIA, M. O.; GAVA, R. Monitoramento tecnológico: um estudo de uma patente da Universidade Federal de Viçosa. Revista Gestão \& Tecnologia, Pedro Leopoldo, v. 16, n. 3, p. 110-137, 2016.

MOHANTYA, D.; MISRAB, S.; MOHAPATRAC, S.; SAHUD, P. S. Prebiotics and synbiotics: Recent concepts in nutrition. Food Bioscience, v. 28, p. 152-160, 2018.

NERI-NUMA, I. A., PASTORE, G. M. Novel insights into prebiotic properties on human health: A review. Food Research International, v. 131, 2020.

NICOLUCCI, A. C.; HUME, M. P.; MARTÍNEZ, I.; MAYENGBAM, S.; WALTER, J.; REIMER, R. A. Prebiotics Reduce Body Fat and Alter Intestinal Microbiota in Children Who Are Overweight or With Obesity. Gastroenterology, v. 153, n. 3, p. 711-722, 2017.

NITHYABALASUNDARI, S.; NIVEDITA, V.; CHAKRAVARTHY, M.; SRISOWMEYA, G.; USHA ANTONY; NANDHINI DEV, G. Characterization of microbial polysaccharides and prebiotic enrichment of wheat bread with pullulan. LWT - Food Science and Technology, v. $112,2020$.

PAVANELLI, M. A.; OLIVEIRA, E. F. T. Registro de patentes das universidades brasileiras em bases internacionais; In: XVII Encontro Nacional de Pesquisa em Ciência da Informação (XVII ENANCIB), Bahia, 2016.

PROCACI, T. B.; ARAUJO, R.; SIQUEIRA, S.; NUNES, B. P. Prospecção Tecnológica: Levantamento de Patentes, Atuação da Academia e Potenciais Inovações em Ambientes de Aprendizagem no Brasil de 2000 a 2015. Revista Brasileira de Sistemas de Informação, 


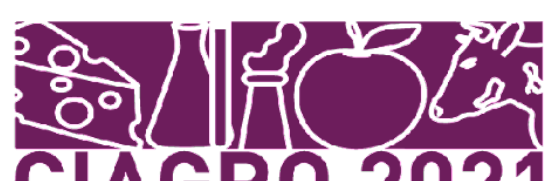

Rio de Janeiro, vol. 9, No. 3, pp. 69-88, 2016.

QUINTELLA, C. M.; MEIRA, M.; GUIMARÃES, A. K.; TANAJURA, A. S.; DA SILVA, H. R. G. Prospecção Tecnológica como uma Ferramenta Aplicada em Ciência e Tecnologia para se Chegar à Inovação. Revista Virtual de Química, v. 3, n. 5, 2011.

ROMO-ARAIZA, A.; IBARRA, A.; Prebiotics and probiotics as potential therapy for cognitive impairment. Medical Hypotheses, v. 134, 2020.

ROSA, M. C.; CARMO, M. R. S.; BALTHAZAR, C. F., GUIMARAES, J. T.; ESMERINO, E. A.; FREITAS, M. Q.; SILVA, M. C.; PIMENTEL, T. C.; CRUZ, A. G. Dairy products with prebiotics: An overview of the health benefits, technological and sensory properties. International Dairy Journal, v. 117, 2021.

\section{WIPO - World Intellectual Property Organization. Indicadores Mundiais de Propriedade Intelectual 2020. Disponível em: https://www.wipo.int/edocs/pubdocs/en/wipo_pub_941_2020.pdf. Acesso em: 24 de abr. 2021.}




\author{
CAPÍTULO 13: COMPORTAMIENTO DE LA ACTIVIDAD ENZIMÁTICA DE LA \\ POLIFENOLOXIDASA (PPO), LA PEROXIDASA (PO) Y LA \\ PECTINAMETILESTERASA (PME) EN LOS ENSAYOS DE FERMENTACIÓN DEL \\ CACAO (THEOBROMA CACAO L).
}

\begin{abstract}
CHAPTER 13: BEHAVIOR OF POLYPHENOLOXIDASE (PPO), PEROXIDASE (PO), PECTINAMETHYLESTERASE (PME) ENZYME ACTIVITY IN COCOA (THEOBROMA CACAO L) FERMENTATION TRIALS.
\end{abstract}

\title{
RESUMO
}

DOI: $\underline{\text { https://doi.org/10.31692/978-65-88970-19-5.198-211 }}$

O presente artigo apresenta o comportamento das enzimas polifenoloxidase (PPO), peroxidase (PO) e pectinametilesterase (PME) extraída de sementes de cacau durante o processo de fermentação convencional $\left(f_{1}\right)$ com duração de sete dias, equivalente a 168 horas e uma projeção deste comportamento no teste da fermentação com inóculo start $\left(\mathrm{f}_{2}\right)$. As amostras de sementes retiradas da fermentação foram monitoradas através dos parâmetros como: temperatura $\left({ }^{\circ} \mathrm{C}\right), \mathrm{pH}$ e Sólidos Solúveis Totais ( ${ }^{\circ}$ Brix), os dados das análises foram plotados no programa R. A partir da prospecção da atividade enzimática na fermentação $\left(\mathrm{f}_{2}\right)$, pode-se inferir que ao atingir o pico de máxima temperatura para todas as enzimas, estas atividades permanecem constantes, no gráfico de absorbância e sólidos solúveis é possível observar uma projeção de uma área maior desta atividade para a enzima (PO), no gráfico para o $\mathrm{pH}$ e a ABS há um intervalo maior antes de iniciar o declínio da atividade para todas as enzimas analisadas.

Palavras-Chave: Cacau, Fermentação, Enzimas.

\section{RESUMEN}

En este trabajo se presenta el comportamiento de las enzimas polifenoloxidasa (PPO), peroxidasa (PO) y pectinametilesterasa (PME) extraídas de los granos de cacao durante el proceso de fermentación convencional (f1) de siete días de duración, equivalente a 168 horas y una proyección de este comportamiento en el ensayo de fermentación con inicio de inóculo (f2). Las muestras de semillas tomadas de la fermentación fueron monitoreadas a través de los parámetros como: temperatura $\left({ }^{\circ} \mathrm{C}\right)$, $\mathrm{pH}$ y Sólidos Solubles Totales ( ${ }^{\circ}$ Brix), los datos de los análisis fueron graficados en el programa R. De la prospección de la actividad enzimática en la fermentación (f2), se puede inferir que al alcanzar el pico de temperatura máxima para todas las enzimas, estas actividades se mantienen constantes, en la gráfica de absorbancia y sólidos solubles se puede observar una proyección de un área mayor de esta actividad para la enzima (PO), en la gráfica de $\mathrm{pH}$ y ABS hay un intervalo más largo antes de iniciar el descenso de la actividad para todas las enzimas analizadas.

Clave: Cacao, Fermentación, Enzimas

\begin{abstract}
This paper presents the behavior of the enzymes polyphenoloxidase (PPO), peroxidase (PO) and pectinamethylesterase (PME) extracted from cocoa beans during the process of conventional fermentation (f1) with a duration of seven days, equivalent to 168 hours and a projection of this behavior in the fermentation test with inoculum start (f2). The seed samples taken from the fermentation were monitored through parameters such as: temperature $\left({ }^{\circ} \mathrm{C}\right), \mathrm{pH}$ and Total Soluble Solids ( ${ }^{\circ}$ Brix), the analysis data were plotted in the R program. From the prospection of the enzymatic
\end{abstract}


activity in fermentation (f2), it can be inferred that when reaching the peak of maximum temperature for all enzymes, these activities remain constant, in the graph of absorbance and soluble solids it is possible to observe a projection of a larger area of this activity for the enzyme (PO), in the graph for $\mathrm{pH}$ and ABS there is a longer interval before starting the decline of activity for all enzymes analyzed.

Keywords: Cocoa, Fermentation, Enzymes.

\section{INTRODUÇÃO}

Enzimas são também intituladas biocatalisadores, estes por sua vez, estão constituídos de unidades formadas por diversos aminoácidos interligados via cadeia longa, contendo um grupo amino básico e um grupo carboxílico ácido, o complexo enzimático (regenera) formando produto, a partir do substrato envolvido na reação, das ligações enzimáticas, as;; reações podem ser inibidas por ácido que possui estrutura semelhante ao substrato para competir pelo mesmo sítio ativo.

Essas enzimas são moléculas protéicas, entretanto, nem todas as matrizes protéicas são enzimas, são encontradas nos vegetais e microrganismos vivos e, possuem alta massa molecular uma vez que catalisam reações em sistemas biológicos, aumentando a velocidade de uma reação química, estão associadas a biomoléculas por conter elevado poder catalítico, atuando também como reagentes altamente especializadas, ou seja, participam da digestão, respiração, metabolismo e manutenção dos tecidos (BRASIL, 2011), (LIMA et al., 2001).

Dentre as aplicações industriais, envolvendo as enzimas, estas podem ser utilizadas na otimização de processos fermentativos, na modificação de alimentos e em outros processos industriais, possibilitando a obtenção de produtos com diferentes características físico-químicas e sensoriais (LIMA et al., 2001).

Nos alimentos, as enzimas poligalacturonase, ou desmetoxilação e pectinametilesterase (PME) catalisam reações que reduzem a consistência da polpa do cacau por despolimerização, as enzimas oxidativas, polifenoloxidase e peroxidase, degradam vitaminas e minerais que reduzem as propriedades vitamínicas das substâncias; A enzima ascórbico oxidase, atua quando o teor de vitamina $\mathrm{C}$ tende a diminuir durante o processo de estocagem de frutas e hortaliças minimamente processadas, devido ação das enzimas oxidantes (SKOOG et al., 2007).

O trabalho objetiva acompanhar o comportamento da atividade das enzimas concomitante avaliação dos parâmetros de $\mathrm{pH}$, sólidos solúveis e temperatura durante a fermentação do cacau convencional $\left(f_{1}\right)$ e realizar uma projeção para a atividade enzimática 
na fermentação com inóculo prévio de leveduras $\left(\mathrm{f}_{2}\right)$ e com isso, identificar a existência de parâmetros ou melhores condições que contribuem para com uma ótima atividade enzimática.

\section{REFERENCIAL TEÓRICO}

As formas químicas de certos pigmentos são demasiadamente alteradas em condições que afetam a integridade estrutural do tecido destes antioxidantes naturais devido a fatores como: Exposição à luz, pH, Temperatura, Reações de oxidação (GAIO, 2016), (ANDRADE et al., 2018), (PALUDO; KRÜGER, 2011), (SANTI; BERGER; SILVA, 2014), (DOMINGUES, 2010).

“A produção de cacau do Pará é de 132 mil t/ano e atualmente é o maior produtor do Brasil” ("Líder nacional na produção de cacau, Pará ainda não é reconhecido pelo chocolate que produz | Pará | G1”, [s.d.]). “O termo Theo (Deus) broma (alimento) advém da lenda asteca que se refere ao fruto como um alimento dos deuses" (OETTERER; REGITANO-D'ARCE; SPOTO, 2006).

Os frutos de cacau fornecem a matéria prima para a elaboração do chocolate, produto altamente energético e mundialmente consumido Leite (2012); Cavalcante (2010); Maki (2006) o que faz deste fruto um dos mais ricos, dentre as inúmeras riquezas naturais da Amazônia.

O processo fermentativo aplicado nas sementes de cacau é antigo e tradicionalmente efetuado para produzir, conservar e/ou modificar o flavor desagradável, adstringente e amargo das amêndoas, característico da transformação tecnológica do cacau em chocolate e dos diversos outros produtos análogos do cacau (AMORIM, 2005), (PRADO et al., 2015), (SANTOS, 2010); (JUNIOR, 2016), (SERRA; MOUCHRECK; DARNET, 2016).

A degradação dos carboidratos que circunda a polpa mucilaginosa, inicialmente ocorre em anaerobiose, com a conversão da glicose em outros compostos orgânicos, expelindo subprodutos como álcool e $\mathrm{CO}_{2}$, pela ação incessante de microrganismos como leveduras, bactérias acéticas e bactérias lácticas DIAZ (2016); LLERENA, 2016) (2016); (RAMÔA JÚNIOR (2011) acarretando inúmeras transformações bioquímicas, com o propósito de obtenção de energia na forma de ATP.

Entre os parâmetros que compõem e contribuem para o processo fermentativo está à temperatura, a acidez em que se encontram as sementes, o intervalo de tempo que desencadeia todo o processo e principalmente a capacidade de degradação das leveduras, juntamente com 
a microflora que constitui o ambiente em que o fruto é submetido (CRUZ, 2012).

$\mathrm{O}$ ambiente que favorece a fermentação está relacionado à presença de substratos formados pela contaminação com microrganismos endofíticos Maki (2006) contaminantes naturais da planta e fungos não causadores de danos ao hospedeiro (Colletotrichum spp). Algumas espécies de microrganismos crescem e se proliferam, outras são mortas por conta da disputa por nutrientes, das condições ambientais do sistema o qual estão dispostas, do tipo de fermentação, e outros fatores como pH, temperatura, carboidratos, aeração, etc (MIGLIARI, 2001).

Durante todo o processo de beneficiamento das sementes, acontecem reações desejáveis para que ao final, as amêndoas desenvolvam o flavor convencional e peculiar do chocolate. Nas últimas etapas do processo estão a secagem e a torração, onde ocorre a reação de Maillard desencadeada pelas altas temperaturas.

A reação de Maillard é uma reação química de escurecimento não enzimático que envolvem várias etapas, e que tem início com a reação do amino grupo de aminoácidos, peptídeos ou proteínas com o grupo hidroxila envolvido na ligação glicosídica de açúcares redutores como glicose, maltose e lactose, e termina com a formação de pigmentos marrons chamados de melanoidinas. As melanoidinas são polímeros nitrogenados marrons de baixo peso molecular responsáveis pelo gosto, cor e aroma dos alimentos (NESPOLO et al., 2015).

Os efeitos do monitoramento preferencial na atividade enzimática com este estudo para as enzimas (PME), (PPO) e (PO) foram testados após leitura no espectrofotômetro onde, os resultados finais estiveram associados a certa atenuação para com os parâmetro ótimos das enzimas, nos ensaios da fermentação sem $\left(\mathrm{f}_{1}\right)$ e a projeção no ensaio com inóculo start $\left(\mathrm{f}_{2}\right)$, através da comparação das temperaturas, $\mathrm{pH}$ e SST durante o tempo medido nos dois ensaios, objetivando identificar na etapa do processo de fermentação do cacau quando as condições são mais favoráveis à atividade das enzimas.

\section{METODOLOGIA}

O trabalho apresenta análises quantitativas para a atividade enzimática quando monitorada em amostras de cacau. As sementes de cacau que serviram de amostras foram coletadas durante o intervalo do tempo de 7 dias, totalizando 168 horas de ensaio para a fermentação com inóculo $\left(\mathrm{f}_{2}\right)$ e sem inóculo start $\left(\mathrm{f}_{1}\right)$. As enzimas analisadas foram: polifenoloxidase (PPO), pectinametilesterase (PME) e peroxidase (PO). O experimento e as 
análises foram realizadas no laboratório de Químicas na Universidade do Estado do Pará (UEPA).

Seleção dos frutos do cacau

Os frutos foram obtidos no mercado aberto, ver-o-peso, para seguir posteriormente com a higienização desses e dar início a fermentação e posterior preparo das soluções extratoras para seguir com as análises da atividade enzimática do cacau.

\section{Caracterização da atividade enzimática}

A atividade enzimática foi quantificada a partir dos extratos obtidos de amostras (polpa e sementes de cacau), anteriormente cominuídas, filtradas para iniciar o preparo das soluções analíticas extratoras, estas foram determinadas no início da fermentação (tempo zero), a cada $24 \mathrm{~h}$ ( $1^{\circ}$ dia $), 48$ h ( $2^{\circ}$ dia $), 72$ h ( $3^{\circ}$ dia $), 96$ h ( $4^{\circ}$ dia $), 120$ h ( $5^{\circ}$ dia $), 144$ h ( $6^{\circ}$ dia) e 168 h ( $7^{\circ}$ dia) e comparadas com os parâmetros como: $\mathrm{pH}$, realizado segundo método descritos por Lutz (2008) a concentração desses íons H + mensurada é expressa através da leitura direta em pHmetro digital (QUIMIX), SST Sólidos Solúveis Totais ( ${ }^{\mathrm{o}}$ Brix) efetuada em refratômetro de bancada Abbe, conforme normas da AOAC (2005) e temperatura mensurada com auxílio do (Digital Thermometer MINIPA MT - 450).

A extração prévia nas amostras das sementes de cacau ocorreram após filtração o vácuo, seguiram para a centrifugação dessa solução extratora e posteriormente as alíquotas desta solução são submetidas a leituras das absorbâncias requeridas por cada enzima específica em equipamento espectrofotômetro marca (METASH) (“ANÁLISES BIOQUÍMICAS Atividade Enzimática - Pectinmethylestearase (PME) Espectrofotometro", [s.d.]).

\section{Fermentações em fermentador sustentável}

A fermentação das sementes do cacau foi realizada em um fermentador, composto de material isolante, folha de compensado e que contém um compartimento central, removível, com orifícios, preparado mediante a técnica do filetador em garrafas PETs para captar o exsudado do cacau resultante do processo fermentativo das amêndoas para que este subproduto da fermentação seja reaproveitado. 
O processo fermentativo teve início com $1,835 \mathrm{~kg}$ de sementes, acondicionadas no fermentador, e essa etapa do beneficiamento do cacau seguiu sendo monitorado durante sete dias, realizando revolvimentos nos intervalos, seqüenciais: - 0 h, 24 h, 48 h, 72 h, 96 h, 120 h, 144 h e 168 horas em que ocorreu a etapa.

Diariamente foram realizadas análises para o monitoramento da atividade enzimática concomitante a aferição da temperatura $\left({ }^{\circ} \mathrm{C}\right), \mathrm{pH}$ e sólidos solúveis totais (SST).

\section{Enzima Pectina-Metilesterase (PME)}

Solução extratora

Foram necessárias $10 \mathrm{~g}$ das amostras (polpa e sementes de cacau), cominuídas e filtradas à vácuo e, submetê-las como solução em erlenmeyer contendo $50 \mathrm{~mL}$ de cloreto de sódio $\mathrm{NaCl}$ a 8,8 \%. Segue com a homogeneização desse extrato em agitador magnético, durante 1 hora em banho de gelo a temperatura mínima $4{ }^{\circ} \mathrm{C}$ (ANÁLISES BIOQUÍMICAS Atividade Enzimática - Pectin Methylesterase (PME) Espectrofotômetro, n.d.).

\section{Preparo do substrato - Ativar as enzimas}

A solução para ativar as enzimas Pectinametilesterase (PME) utilizada é o azul de Bromotimol a $0,01 \%$ e, a solução de $0,5 \mathrm{~g}$ de pectina em $100 \mathrm{~mL}$ de água destilada.

\section{Determinação da atividade da Pectina-Metilesterase (PME)}

Em triplicata, utilizando tubos de ensaios grandes foram adicionados $0,16 \mathrm{~mL}$ do extrato prévio (cacau e tampão), mais $1,0 \mathrm{~mL}$ de pectina cítrica a $0,5 \%$, mais $0,3 \mathrm{~mL}$ da solução de azul de bromotimol a $0,01 \%$ e $0,4 \mathrm{~mL}$ de $\mathrm{NaCl}$ (cloreto de sódio) a $1 \mathrm{M}$.

Em seguida realizou-se o aquecimento dos tubos com o substrato acondicionando estes em um Becker grande sob chapa aquecedora a temperatura $80^{\circ} \mathrm{C}$ durante o tempo $1 \mathrm{~min}$, os tubos seguiram para o repouso por 9 min e alíquotas foram direcionadas em cubetas para iniciar as leituras das absorbância no comprimento de onda em $620 \mathrm{~nm}$ (ANÁLISES BIOQUÍMICAS Atividade Enzimática - Pectinmethylestearase (PME) Espectrofotometro, n.d.).

\section{Polifenoloxidase (ppo) e Peroxidase (po)}

Solução extratora 
As enzimas foram extraídas de acordo com os métodos descritos por LIMA et al., (2001) com modificações, para isso foi preciso pesar $10 \mathrm{~g}$ das amostras e acondicioná-las em erlenmeyer contendo $40 \mathrm{~mL}$ de solução tampão fosfato de potássio $0,1 \mathrm{M}, \mathrm{pH} 6,0$.

O extrato preparado foi direcionado a centrífuga durante $40 \mathrm{~min}$, retira-se o suspenso para realizar a leitura no espectro OKTAY et al, e LIMA (1995, 1999 apoud (PAZ, 2010), (“ANÁLISES BIOQUÍMICAS Atividade Enzimática - Pectinmethylestearase (PME) Espectrofotometro", [s.d.]).

\section{Preparo do substrato (PPO) - Ativar as enzimas}

O método para o meio de reação que ocorre entre enzima/substrato $(\mathrm{E} / \mathrm{S})$ inicia após inserir nos tubos de ensaio, em triplicata, $1,7 \mathrm{~mL}$ de solução tampão fosfato de sódio a $0,1 \mathrm{M}$, $\mathrm{pH} 6$, mais $1,2 \mathrm{~mL}$ do catecol $0,4 \%$ e $0,1 \mathrm{~mL}$ de extrato contendo a enzima em volume final de máximo $3,0 \mathrm{~mL}$.

\section{Determinação da atividade da enzima polifenoloxidase (PPO)}

Os tubos de ensaio contendo o substrato para as enzimas são direcionados a um agitador magnético seguido da estabilização desses para iniciar a introdução desta solução nas cubetas para iniciar com a leitura no equipamento.

O branco é constituído por uma solução contendo $2,9 \mathrm{~mL}$ de tampão fosfato de sódio 0,2 M, pH 7,0, mais $0,1 \mathrm{~mL}$ do extrato. A atividade da enzima (PPO) foi determinada em espectrofotômetro (Biochrom Libra S50) medindo-se o aumento da absorbância a $420 \mathrm{~nm}$.

\section{Preparo do substrato (PO) - Ativar as enzimas}

Em um tubo de ensaio grande foi adicionado $1,5 \mathrm{~mL}$ de guaiacol a $1 \%$, mais $1,2 \mathrm{~mL}$ de solução tampão fosfato $0,1 \mathrm{M}$ com $\mathrm{pH} 6,0$, mais $0,1 \mathrm{~mL}$ do extrato previamente preparado e $0,4 \mathrm{~mL}$ de $\mathrm{H}_{2} \mathrm{O}_{2}$ (peróxido de hidrogênio) a $0,4 \%$.

\section{Determinação da atividade da enzima peroxidase (PO)}

A atividade enzimática para a (PO) foi medida com leituras espectrofotométricas de absorbâncias em $470 \mathrm{~nm}$. Uma unidade de atividade enzimática foi definida como a quantidade de enzima que causa um aumento de 0,001 de absorbância por minuto por grama 
de amostra (LIMA et al., 2001).

A solução branco utilizada nesta é constituída da mesma forma que o preparo do extrato, no entanto, não contém peróxido. A atividade da (PO) foi determinada medindo-se o aumento da absorbância a $470 \mathrm{~nm}$. O cálculo abaixo foi utilizado para a atividade enzimática.

$$
\frac{U}{m L}=A x F D x 1000 \div E x V e x T
$$

Onde A é a absorbância, FD o Fator de Diluição, E é a absorbância das enzimas (PPO = 26.9/ $\mathrm{PO}=26.6$ ), Ve é o volume utilizado e T o tempo de reação.

\section{RESULTADOS E DISCUSSÃO}

Atividades enzimáticas na Fermentação do cacau

As enzimas são consideradas moléculas biológicas, porque atuam na catálise de reações para digerir alimentos, enviar sinais nervosos ou contrair músculos que não ocorrem na velocidade adequada sem catálise enzimática (NELSON; COX, 2014).

As Tabelas 01 e 02 apresentam os resultados dos parâmetros para a temperatura, o pH e para os sólidos solúveis totais ${ }^{\circ}$ Brix monitorados durante as duas fermentações do cacau. Através destas tabelas pode-se inferir que na tabela 02 há um pico no aumento da temperatura logo com 24 horas de fermentação para a fermentação $\left(\mathrm{f}_{2}\right)$ com relação a tabela 01 que apresenta o pico de temperatura apenas após 48 horas.

Tabela 01: Parâmetros monitorados durante a fermentação $\left(\mathrm{f}_{1}\right)$.

\begin{tabular}{cccc}
\hline Tempo (dias) & Temperatura $\left({ }^{\circ} \mathrm{C}\right)$ & $\mathrm{pH}$ & $\mathrm{SST}^{*}\left({ }^{\circ}\right.$ Brix $)$ \\
0 & 29 & 4,2 & 20 \\
1 & 30 & 3,89 & 6 \\
2 & 39 & 4,56 & 3 \\
3 & 38 & 3,91 & 2 \\
4 & 38 & 4,11 & 2 \\
5 & 38 & 4,58 & 2 \\
6 & 31 & 4,66 & 2 \\
7 & 31 & 5,26 & 1 \\
\hline
\end{tabular}

Legenda: *Sólidos Solúveis Totais. Fonte: Própria (2021).

Ao final da fermentação as sementes alcançaram o valor de $\mathrm{pH}$ alto, entretanto, com relação aos resultados das tabelas, as sementes do ensaio $\left(\mathrm{f}_{2}\right)$ obteve o maior $\mathrm{pH}$. Quanto aos 
valores para sólidos solúveis totais, houve rápido consumo destes açúcares em ambos ensaios $\left(f_{1}\right)$ e $\left(f_{2}\right)$.

Tabela 02: Parâmetros monitorados durante a fermentação $\left(\mathrm{f}_{2}\right)$.

\begin{tabular}{cccc}
\hline Tempo (dias) & Temperatura $\left({ }^{\circ} \mathrm{C}\right)$ & $\mathrm{pH}$ & $\mathrm{SST}^{*}\left({ }^{\circ}\right.$ Brix $)$ \\
0 & 23 & 5,02 & 16 \\
1 & 29 & 4,71 & 10 \\
2 & 28 & 5,42 & 2,5 \\
3 & 27 & 4,70 & 1 \\
4 & 24 & 5,32 & 1 \\
5 & 30 & 5,30 & 0 \\
6 & 30 & 5,19 & 0 \\
7 & 29 & 6,30 & 0 \\
\hline
\end{tabular}

Legenda: *Sólidos Solúveis Totais. Fonte: Própria (2021).

A atividade enzimática foi determinada quantitativamente apenas no ensaio da fermentação $\left(f_{1}\right)$ as figuras que expressam os resultados para a atividade enzimática na fermentação $\left(\mathrm{f}_{2}\right)$ é apenas uma projeção a partir dos parâmetros monitorados durante o ensaio, de forma a simular o possível comportamento da atividade destas enzimas para a fermentação utilizando inóculo leveduriformes.

De acordo com os resultados descritos na figura 01 abaixo, a respeito do efeito da temperatura monitorada nos ensaios das fermentações sem inóculo $\left(\mathrm{f}_{1}\right)$, e com inóculo start $\left(\mathrm{f}_{2}\right)$, respectivamente, há atividade para todas as enzimas analisadas desde o estágio inicial da fermentação, onde o pico máximo foi no terceiro dia quando a temperatura atingiu $39^{\circ} \mathrm{C}$ no ensaio $\left(f_{1}\right)$ e no quinto dia quando a temperatura atingiu $30^{\circ} \mathrm{C}$ no ensaio $\left(f_{2}\right)$.

Figura 01 - Temperatura e ABS (absorbância) da atividade enzimática no ensaio monitorado da fermentação $\left(f_{l}\right)$ e $\left(f_{2}\right)$. 

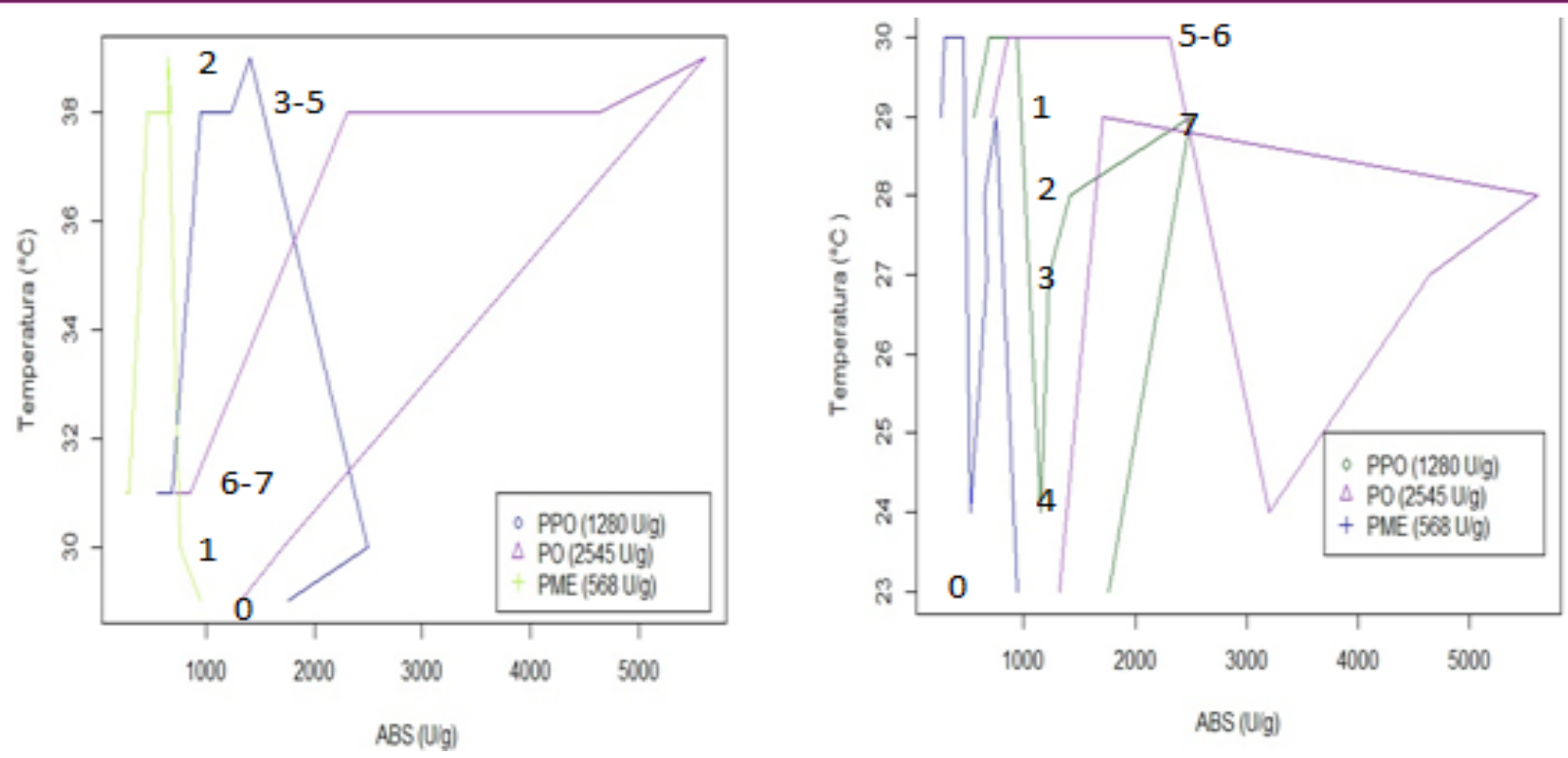

Fonte: Própria (2021).

A tabela 03 apresenta os resultados para a atividade das enzimas polifenoloxidase e peroxidase analisadas após extração das amostras coletadas durante os sete dias de fermentação, para a polifenoloxidase (PPO) a maior atividade $(2497 \mathrm{U} / \mathrm{g})$ ocorreu no primeiro dia, com a temperatura a $30^{\circ} \mathrm{C}$, a enzima (PO) alcançou absorbância máxima no segundo dia de fermentação, atingiu (5608 U/g), quando o pH das sementes estavam a 4.5 FLURKEY; JEN (1978) apresentou atividade polifenoloxidase (900 U/g) na semente de cacau SAKHAROV; ARDILA (1999) relataram que a amêndoa e a casca de cacau apresentaram atividade da Peroxidase de $(5.700 \mathrm{U} / \mathrm{g})$.

Tabela 03: Análise Quantitativa das Enzimas (PPO), (PO) e (PME) durante o ensaio da Fermentação $\left(f_{\mathcal{L}}\right)$

\begin{tabular}{cccccc} 
Tempo (dias) & Temperatura $\left({ }^{\circ} \mathrm{C}\right)$ & $\mathrm{pH}$ & $\mathrm{PPO}(\mathrm{Ug})$ & $\mathrm{PO}(\mathrm{U} / \mathrm{g})$ & $\mathrm{PME}(\mathrm{U} / \mathrm{g})$ \\
0 & 29 & 4,2 & 1765 & 1322 & 946 \\
1 & 30 & 3,8 & 2497 & 1708 & 756 \\
2 & 39 & 4,5 & 1412 & 5608 & 646 \\
3 & 38 & 3,9 & 1228 & 4639 & 673 \\
4 & 38 & 4,1 & 1151 & 3198 & 526 \\
5 & 38 & 4,5 & 945 & 2312 & 459 \\
6 & 31 & 4,6 & 692 & 860 & 287 \\
7 & 31 & 5,2 & 554 & 716 & 256 \\
\hline
\end{tabular}

Fonte: Própria (2021).

A figura 02 abaixo apresenta a relação da atividade enzimática e a quantidade de sólidos solúveis das sementes que iniciam com 20 e $16^{\circ}$ Brix, respectivamente, chegando ao final do processo com 1 e $0^{\circ}$ Brix, onde as enzimas pectinases hidrolisam ligações 
glicosídicas ao longo da cadeia de pectina, sendo este o principal carboidrato contido na polpa que possui características de mucilagem que envolve as sementes de cacau produzindo ácidos monogalacturônicos (DOMINGUES, 2010).

Figura 02 - Relação dos SST e a ABS da atividade enzimática no ensaio da fermentação $\left(f_{l}\right)$ e $\left(f_{2}\right)$.

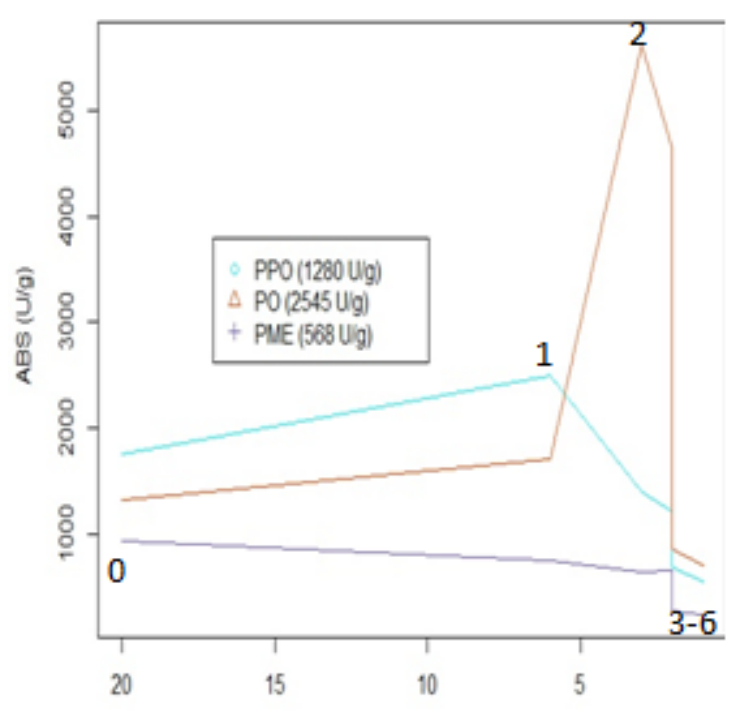

SST (das)

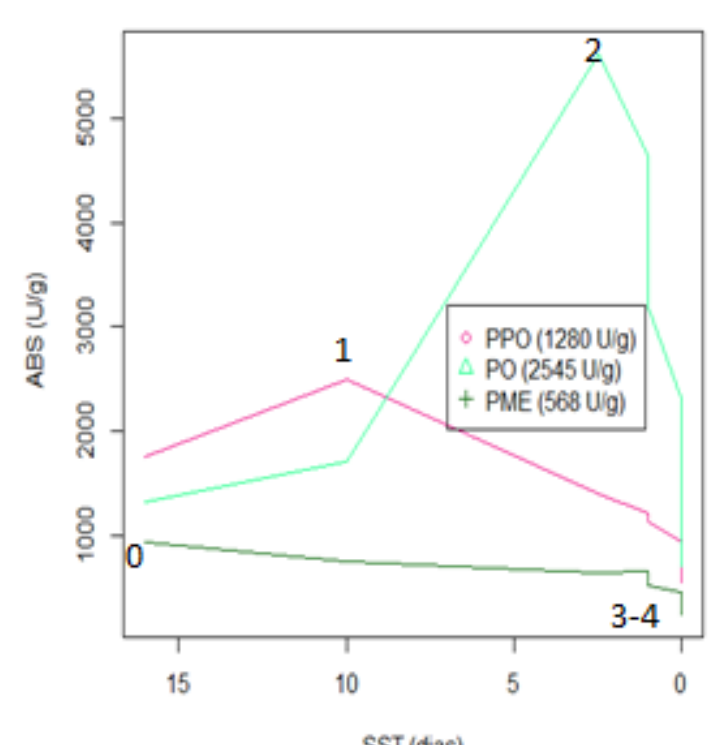

Fonte: Própria (2021).

A atividade máxima para pectina-metilesterase durante a etapa da fermentação, foi no primeiro dia $(946,0 \mathrm{U} / \mathrm{g})$, a partir do quarto dia, a atividade dessas enzimas reduziram pois estas enzimas atuam na desintegração desta massa de cacau, tornando-se pegajosa, por isso a atividade da enzima (PME) tende a decair logo após 48 horas de fermentação pois a consistência da massa das sementes já não é a mesma que iniciou o processo de degradação.

O resultado quantitativo apresentado para esta enzima foi maior que o exposto por PINTO et al., (2013) que encontrou o valor máximo para (PME) no $30^{\circ}$ dia de armazenamento para os mamões foi de $(365,42 \mathrm{U} / \mathrm{mL})$.

A enzima (PPO) está envolvida na descoloração das antocianinas (Aa), atuam na presença de O-difenol e $\mathrm{O}_{2}$ oxidando as antocianinas. Durante a fermentação do cacau as amêndoas de estão submetidas a esse efeito ocasionado pelas enzimas (PO) e (PPO), onde estas aceleram o processo de pigmentação das sementes, acentuando a coloração marrom das amêndoas e consequentemente havendo oscilação do $\mathrm{pH}$ das sementes como mostra a figura 03.

As sementes apresentaram oscilações no $\mathrm{pH}$ durante a fermentação $\left(\mathrm{f}_{1}\right)$, onde o menor valor de 3,8 foi encontrado no primeiro dia de fermentação e o maior 5,2 no último, na 


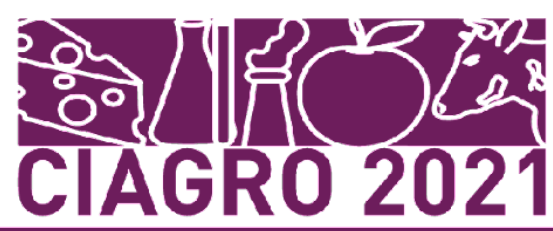

fermentação $\left(f_{2}\right)$ o menor valor para o $\mathrm{pH} 4,70$ foi no terceiro dia e o maior 6,30 no último dia.

Figura 3 - Relação do pH e a ABS das atividades enzimáticas no ensaio com a fermentação $\left(f_{l}\right)$ e $\left(f_{2}\right)$.
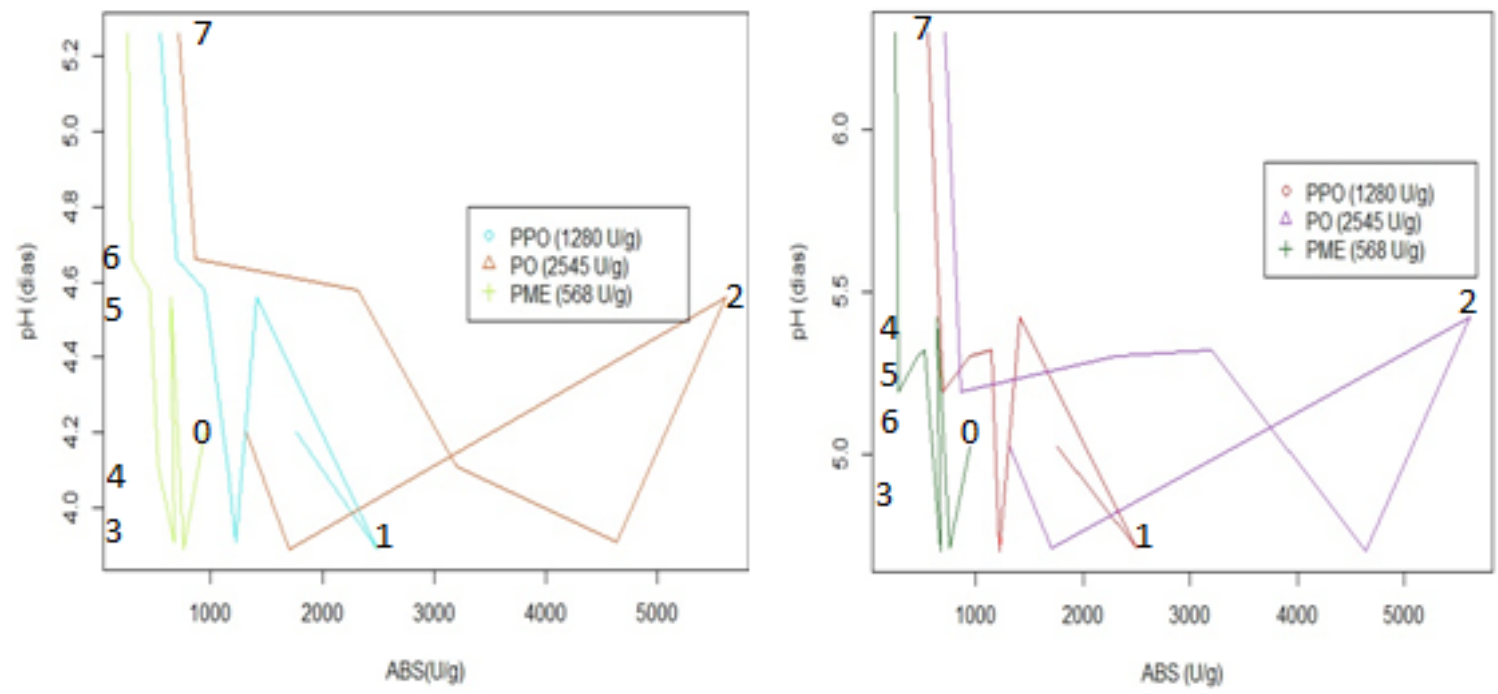

Fonte: Própria (2021).

A enzima peroxidase (PO) está relacionada com o aparecimento de sabores estranhos nos alimentos, sendo que a atividade ótima desta enzima se encontra em pH 4,5 (ARAÚJO, 1999). Após o terceiro dia a massa das sementes do cacau apresentam odor intenso de ácidos, resultante da decomposição dos carboidratos envolvidos na composição química da polpa das sementes e ação das enzimas (PPO) e (PO).

\section{CONSIDERAÇÕES FINAIS}

Os resultados para a temperatura na atividade enzimática durante a etapa de fermentação $\left(f_{1}\right)$ e $\left(f_{2}\right)$ indicam que as enzimas permanecem com sua atividade por mais tempo na $\left(\mathrm{f}_{2}\right)$ ao atingir o pico de máxima temperatura, portanto, pode-se inferir que a fase estacionária dessas enzimas na fermentação start $\left(\mathrm{f}_{2}\right)$ é maior que na fermentação convencional $\left(\mathrm{f}_{1}\right)$.

No gráfico para sólidos solúveis totais $\left({ }^{\circ} \mathrm{Brix}\right)$ percebe-se uma área mais pronunciada no ensaio para a fermentação $\left(f_{2}\right)$ para a atividade da enzima peroxidase e, não houve diferença perceptível para a atividade enzimática com relação ao $\mathrm{pH}$ nos dois ensaios para a fermentação do cacau.

A partir dos resultados apresentados com este estudo, sugere-se realizar a atividade enzimática em extratos provindos dos ensaios na fermentação com adição de inóculo start 
para confirmar que há o melhoramento no desempenho da atividade enzimática na fermentação melhorada com relação à fermentação convencional.

\section{REFERÊNCIAS}

AMORIM, H. V. DE. Fermentação Alcoólica: Ciência e Tecnologia. Piracicaba: [s.n.].

Análises BIOQUÍMICAS Atividade Enzimática - Pectinmethylestearase (PME) Espectrofotômetro, 2005.

ANDRADE, A. S. A. DE et al. Estudo Da Produção De Enzimas Pectinolíticas E Celulolíticas Por Fermentação Em Estado Sólido a Partir Do Study of Production of Pectinolytic and Cellulolytic Enzymes By Solid State Fermentation Using As Substrate Caja Bagasse. REVISTA SAÚDE \& CIÊNCIA ONLINE, v. 7, p. 457-472, 2018.

AOAC. Official Methods of Analysis of AOAC INTERNATIONAL. 18. ed. USA: [s.n.], 2005.

ARAÚJO, J. M. DE A. Química de alimentos: teoria e prática. 2. ed. Viçosa: [s.n.], 1999.

BRASIL, F. I. Enzimas: natureza e ação nos alimentos. www.revista-fi.com, v. 11, p. 26-37, 2011.

CAVAlCANTE, P. B. Frutas comestíveis na Amazônia. 7. ed. Belém, PA: Museu Paraense Emílio Goeldi: [s.n.].

CRUZ, J. Caracterização das sementes de variedades de cacau Theobroma cacao L . resistentes à vassoura de bruxa durante a fermentação e após a secagem. [s.1.] Universidade federal da bahia faculdade, 2012.

DIAZ, A. M. Sucessão microbiana durante a fermentação espontânea do cacau para caracterização e isolamento de linhagem starter. [s.1.] Universidade estadual de santa cruz, 2016.

DOMINGUES, E. S. Seleção de linhagens de leveduras pectinolíticas para fermentação de sementes de cacau (Theobroma cacao). [s.1.] Universidade de São Paulo, 2010.

FLURKEY, W. H.; JEN, J. J. Peroxidase and Polyphenol Oxidase Activities in Developing Peaches. Journal of Food Science, v. 43, n. 6, p. 1826-1828, 1978.

GAIO, I. Avaliação da atividade e estabilidade de pectinases comerciais imobilizadas e submetidas ao tratamento com gás liquefeito de petróleo. [s.1.] Universidade Federal de santa catarina, 2016.

JUNIOR, G. C. A. C. Isolamento e identificação molecular de populações de leveduras presentes na fermentação do cacau da Amazônia brasileira. [s.l.] Universidade Federal do Pará, 2016.

LEITE, P. B. Caracterização de chocolates provenientes de variedades de cacau Theobroma 
cacao L resistentes à vassoura de bruxa. [s.1.] Universidade Federal da Bahia, 2012.

Líder nacional na produção de cacau, Pará ainda não é reconhecido pelo chocolate que produz | Pará | G1. Disponível em: $<$ https://g1.globo.com/pa/para/noticia/2019/04/20/lider-nacional-na-producao-de-cacau-para-a inda-nao-e-reconhecido-pelo-chocolate-que-produz.ghtml>. Acesso em: 9 maio. 2021.

LIMA, E. D. P. D. A. et al. Obtenção e utilização da enzima polifenoloxidase extraída de polpa de pinha (Annona squamosa L.) Madura no melhoramento do sabor do cacau (Theobroma cacao L.). Revista Brasileira de Fruticultura, v. 23, n. 3, p. 709-713, 2001.

LLERENA, W. F. T. Mejoramiento del Proceso de Fermentación del Cacao: (Theobroma cacao L.) Variedad Nacional y Variedad CCN51. [s.1: s.n.], 2016.

LUTZ, I. A. Métodos físico-químicos para análise de Alimentos. IV Edição ed. São Paulo: [s.n.], 2008.

MAKI, C. S. Diversidade e potencial biotecnológico de fungos endofíticos de cacau (Theobroma cacao L .). [s.1.] Universidade de São Paulo Escola, 2006.

MIGLIARI, P. C. Classificação das cepas de leveduras dominantes de processos fermentativos utilizando parâmetros fermentativos e taxonomia numérica. [s.1.] Universidade estadual de campinas, 2001.

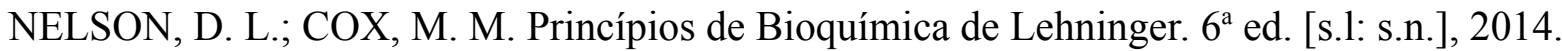

NESPOLO, C. R. et al. Práticas em Tecnologia de Alimentos. 1 ${ }^{\mathrm{a}}$ ed. Porto Alegre: [s.n.], 2015.

OETTERER, M.; REGITANO-D'ARCE, M. A. B.; SPOTO. Fundamentos de Ciências e Tecnologia de Alimentos. $1^{\circ}$ ed. [s.l: s.n.], 2006.

PAlUDO, M. C.; KRÜGER, R. L. Ação Da Enzima Pectinase Na Extração Do Suco De Jabuticaba. Arquivos de ciências da saúde da UNIPAR, v. 15, n. 3, p. 279-86, 2011.

PAZ, J. C. S. N. Caracterização bioquímica da polifenoloxidase e da peroxidase de ameixa rubimel, polpa de cacau e estudo do efeito de agentes anti-escurecimento. [s.1.] Universidade Estadual de Campinas, 2010.

PINTO, L. K. D. A. et al. Avaliação da atividade das enzimas pectina metilesterase e $\beta$-galactosidase em mamões cv. Golden armazenados sob diferentes concentrações de oxigênio 1 activity of pectin methylesterase and $\beta$-galactosidase enzymes in "golden" papaya stored under different. Revista Brasileira de Fruticultura, n. 1, p. 015-022, mar. 2013.

PRADO, F. C. et al. Development and evaluation of a fermented coconut water beverage with potential health benefits. Journal of Functional Foods, v. 12, p. 489-497, 1 jan. 2015.

RAMÔA JÚNIOR, A. G. A. Polifenólicos E Enzimas Oxidativas Na Fermentação. [s.1.] Universidade Federal do Pará, 2011. 
SAKHAROV, I. Y.; ARDILA, G. B. Variations of peroxidase activity in cocoa (Theobroma cacao L.) beans during their ripening, fermentation and drying. Food Chemistry, v. 65, p. 51-54, 1999.

SANTI, L.; BERGER, M.; SILVA, W. O. B. DA. Pectinases e pectina: aplicação comercial e potencial biotecnológico. Caderno pedagógico, n. 1, p. 130-139, 2014.

SANTOS, D. S. Inoculação de leveduras starters na fermentação do cacau para melhoria do flavor. [s.1.] Universidade estadual de santa cruz, 2010.

SERRA, J. L.; MOUCHRECK, A. N.; DARNET, S. Quantificação de leveduras associadas à fermentação de cacau no estado do Pará. XXV Congresso Brasileiro de Ciência e Tecnologia de Alimentos Alimentação: a árvore que sustenta a vida. X CIGR Section IV International Technical Symposium Food: the three that sustains life, p. 6, 2016.

SKOOG, D. et al. Fundamentos de Química Analitica. $8^{\circ}$ ed. Rio de Janeiro: [s.n.], 2007. 


\title{
CAPÍTULO 14: PURIFICAÇÃO DE PROTEASES DE Aspergillus heteromorphus URM 0269 POR SISTEMA DE DUAS FASES AQUOSAS PEG-Citrato
}

\section{CAPÍTULO 14: PURIFICACIÓN DE PROTEASAS DE Aspergillus heteromorphus URM 0269 MEDIANTE SISTEMA DE DOS FASES ACUOSAS PEG-Citrato}

\section{CHAPTER 14: PURIFICATION OF PROTEASES OF Aspergillus heteromorphus URM 0269 BY AQUEOUS TWO-PHASE SYSTEM PEG-Citrate}

\author{
Maria Eduarda Menezes Rocha ${ }^{1}$; Yuri Matheus Silva Amaral ${ }^{2}$; Rodrigo Lira de Oliveira ${ }^{3}$; Wanessa Braz da Silva \\ 4; Tatiana Souza Porto ${ }^{5}$
}

DOI: https://doi.org/10.31692/978-65-88970-19-5.212-230

\begin{abstract}
RESUMO
As proteases são enzimas capazes de catalisar a hidrólise de ligações peptídicas e apresentam diversas aplicações biotecnológicas, sendo uma das principais enzimas empregadas nos diferentes setores industriais, especialmente na indústria de alimentos. A produção dessas enzimas através de métodos fermentativos apresenta diversas vantagens como baixo custo, rendimento elevado e produção em larga escala, porém, a presença de impurezas nos extratos obtidos no final do processo pode ocasionar diminuição no potencial biotecnológico em termos de aplicações, sendo assim, necessário técnicas que proporcionem a viabilidade da função e estrutura das proteases. O Sistema de Duas Fases Aquosas (SDFA) é uma técnica simples, econômica e com elevando rendimento de extração. Diante disso, o SDFA PEG/Citrato foi utilizado para extrair e purificar parcialmente as proteases produzidas a partir do micro-organismo Aspergillus heteromorphus URM 0269 por fermentação submersa (FSm). Para essa finalidade, foi realizado um planejamento fatorial completo $2^{4}$ tendo como variáveis reposta $\mathrm{o}$ coeficiente de partição $(\mathrm{K})$, recuperação $(\mathrm{Y})$ e fator de purificação $(\mathrm{FP})$ e as variáveis independentes estudadas foram a massa molar de PEG $\left(\mathrm{M}_{\mathrm{PEG}}\right)$, concentração de $\mathrm{PEG}\left(\mathrm{C}_{\mathrm{PEG}}\right)$, concentração de citrato $\left(\mathrm{C}_{\text {CITRATO }}\right)$ e $\mathrm{pH}$. A protease apresentou maior preferência pela fase superior, rica em PEG, onde as variáveis $\mathrm{M}_{\mathrm{PEG}}$ e $\mathrm{C}_{\mathrm{CITRATO}}$, bem como a interação entre ambas, apresentaram efeitos significativos para todas as variáveis resposta. O ensaio $5\left(\mathrm{M}_{\mathrm{PEG}} 400 \mathrm{~g} / \mathrm{mol}, \mathrm{C}_{\mathrm{PEG}} 24 \% \mathrm{~m} / \mathrm{m}, \mathrm{C}_{\mathrm{CITRATO}} 20 \% \mathrm{~m} / \mathrm{m}\right.$, pH 6$)$ apresentou os melhores resultados K $(9,24)$, Y $(222,53 \%)$ e FP $(1,93)$. A utilização do SDFA se mostrou eficiente para extração e purificação parcial da protease obtida por Aspergillus heteromorphus URM 0269 apresentando elevadas recuperações, indicando a possibilidade de aplicação na extração de proteases com potencial de aplicação industrial, especialmente na indústria de alimentos.
\end{abstract}

Palavras-Chave: Aspergillus, Purificação, Proteases, SDFA.

\section{RESUMEN}

Las proteasas son enzimas capaces de catalizar la hidrólisis de enlaces peptídicos y tienen varias aplicaciones biotecnológicas, siendo una de las principales enzimas empleadas en diferentes sectores industriales, especialmente en la industria alimentaria. La producción de estas enzimas mediante

\footnotetext{
${ }^{1}$ Engenharia de Alimentos, Universidade Federal do Agreste de Pernambuco, eduardamenezes32@gmail.com

${ }^{2}$ Engenheiro de Alimentos, Universidade Federal Rural de Pernambuco, yuri.amaral17@gmail.com

${ }^{3}$ Bolsista de pós-doutorado, Universidade Federal do Agreste de Pernambuco, rodrigolira1@outlook.com

${ }^{4}$ Engenharia de Alimentos, Universidade Federal do Agreste de Pernambuco, wanessa.braz09@gmail.com

${ }^{5}$ Doutora em Tecnologia Bioquímico-Farmacêutica, Universidade Federal do Agreste de Pernambuco, portots@yahoo.com
} 
métodos fermentativos tiene varias ventajas como bajo costo, alto rendimiento y producción a gran escala, sin embargo, la presencia de impurezas en los extractos obtenidos al final del proceso puede provocar una disminución del potencial biotecnológico en términos de aplicaciones, por tanto, técnicas necesarias que proporcionen la viabilidad de la función y estructura de las proteasas. El sistema de dos fases acuoso (SDFA) es una técnica sencilla y económica con un alto rendimiento de extracción. Por tanto, se utilizó SDFA PEG/Citrato para extraer y purificar parcialmente las proteasas producidas a partir del microorganismo Aspergillus heteromorphus URM 0269 mediante fermentación sumergida (FSm). Para ello se realizó un diseño factorial completo $2^{4}$, con el coeficiente de partición $(\mathrm{K})$, recuperación (Y) y factor de purificación (FP) como variables, y las variables independientes estudiadas fueron la masa molar de PEG $\left(\mathrm{M}_{\mathrm{PEG}}\right)$, concentración de PEG $\left(\mathrm{C}_{\mathrm{PEG}}\right)$, concentración de citrato $\left(\mathrm{C}_{\text {CITRATO }}\right)$ y $\mathrm{pH}$. La proteasa mostró mayor preferencia por la fase superior, rica en PEG, donde las variables $\mathrm{M}_{\mathrm{PEG}}$ y $\mathrm{C}_{\mathrm{CITRATO}}$, así como la interacción entre ambas, mostraron los mayores efectos estadísticamente significativos para todas las variables de respuesta. El ensayo $5\left(\mathrm{M}_{\mathrm{PEG}} 400 \mathrm{~g} / \mathrm{mol}\right.$, $\mathrm{C}_{\mathrm{PEG}} 24 \% \mathrm{p} / \mathrm{p}, \mathrm{C}_{\text {CITRATO }} 20 \% \mathrm{p} / \mathrm{p}, \mathrm{pH}$ 6) mostró los mejores resultados $\mathrm{K}(9,24), \mathrm{Y}(222,53 \%)$ y FP $(1,93)$. El uso de SDFA demostró ser eficiente para la extracción y purificación parcial de la proteasa obtenida por Aspergillus heteromorphus URM 0269 mostrando altas recuperaciones, lo que indica la posibilidad de aplicación en la extracción de proteasas con potencial de aplicación industrial, especialmente en la industria alimentaria.

Palabras Clave: Aspergillus, Purificación, Proteasas, SDFA.

\section{ABSTRACT}

Proteases are enzymes capable of catalyzing the hydrolysis of peptide bonds and have several biotechnological applications, being one of the main enzymes used in different industrial sectors, especially in the food industry. The production of these enzymes through fermentative methods has several advantages such as low cost, high yield and large-scale production, however, the presence of impurities in the extracts obtained at the end of the process can cause a decrease in the biotechnological potential in terms of applications, thus, necessary techniques that provide the viability of the function and structure of the proteases. The Aqueous Two-Phase System (ATPS) is a simple, economical technique with high extraction yield. In view of this, the ATPS PEG/Citrate was used to extract and partially purify the proteases produced from the microorganism Aspergillus heteromorphus URM 0269 by submerged fermentation (FSm). For this purpose, a complete factorial design was carried out $2^{4}$, with the partition coefficient $(\mathrm{K})$, yield $(\mathrm{Y})$ and purification factor (FP) as variables, and the independent variables studied were the molar mass of PEG $\left(\mathrm{M}_{\mathrm{PEG}}\right)$, concentration of PEG $\left(\mathrm{C}_{\mathrm{PEG}}\right)$, citrate concentration $\left(\mathrm{C}_{\mathrm{CITRATE}}\right)$ and $\mathrm{pH}$. The protease showed greater preference for the upper phase, rich in $\mathrm{PEG}$, where the variables $\mathrm{M}_{\mathrm{PEG}}$ and $\mathrm{C}_{\mathrm{CITRATO}}$, as well as the interaction between both, showed the greatest statistically significant effects for all response variables. Assay $5\left(\mathrm{M}_{\mathrm{PEG}}\right.$ $\left.400 \mathrm{~g} / \mathrm{mol}, \mathrm{C}_{\mathrm{PEG}} 24 \% \mathrm{w} / \mathrm{w}, \mathrm{C}_{\text {CITRATE }} 20 \% \mathrm{w} / \mathrm{w}, \mathrm{pH} 6\right)$ showed the best results $\mathrm{K}(9.24), \mathrm{Y}(222.53 \%)$ and FP (1.93). The use of SDFA proved to be efficient for extraction and partial purification of the protease obtained by Aspergillus heteromorphus URM 0269 showing high recoveries, indicating the possibility of application in the extraction of proteases with potential for industrial application, especially in the food industry.

Keywords: Aspergillus, Purification, Proteases, ATPS.

\section{INTRODUÇÃO}

Proteases constituem um dos mais importantes grupos de enzimas e têm aplicações em diversos setores na indústria, como a têxtil, farmacêutica, de alimentos e detergentes (LADEIRA et al. 2012). Na indústria de alimentos apresenta diferentes aplicações, como na 
panificação proporcionando diminuição no tempo de mistura e facilitar a manipulação da massa, na produção de laticínios para modificar as propriedades funcionais das proteínas do ar

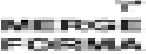
leite e reduzir o tempo global da cura do queijo, no amaciamento de carnes, assim como na diminuição da turbidez resultante das proteínas de sucos de frutas e bebidas alcoólicas, no preparo de hidrolisados de soja, de gelatina e caseína e recuperação de proteína de carne (ORLANDELLI et al. 2012; SOUZA, 2015).

A obtenção de enzimas proteolíticas, utilizando processos fermentativos apresenta certas vantagens quando em comparação a fontes animal e vegetal, pois proporciona um menor custo, altos rendimentos e produção em larga escala, porém, os extratos fermentados podem apresentar diversas outras biomoléculas como outras enzimas, ácidos orgânicos, pigmentos e compostos fenólicos (SOUZA, 2015; SOCCOL et al., 2017). O potencial biotecnológico das enzimas e consequentemente sua viabilidade econômica pode ser alterada pela presença destas impurezas, sendo necessária uma eficiente produção, atrelada as técnicas de extração e purificação capazes de preservar a estrutura e funcionalidade nativa da enzima (AMARAL et al., 2020).

Com o objetivo de garantir maior purificação de biomoléculas algumas técnicas de maior eficiência como os métodos cromatográficos são utilizadas, porém devido as grandes quantidades de contaminantes presentes nos extratos enzimáticos essas técnicas apresentam um baixo rendimento, pela desnaturação enzimática, além de serem processos com elevados custos, trabalhosos e complexos. Como alternativa o Sistemas de Duas Fases Aquosas (SDFA) atua como um processo de pré-purificação, uma vez que pode promover redução substancial de grande quantidade de contaminantes, auxiliando no aumento do rendimento em processos mais robustos de purificação (NASCIMENTO et al., 2016; PHONG et al. 2018; ABD SAMAD et al., 2017; DA SILVA et al., 2017).

Desta forma, este trabalho teve como objetivo produzir proteases de Aspergillus heteromorphus através da fermentação submersa e avaliar a extração e purificação destas enzimas através de Sistemas de Duas Fases Aquosas.

\section{FUNDAMENTAÇÃO TEÓRICA}

Proteases 
As proteases são biomoléculas capazes de catalisar a hidrólise de ligações peptídicas originando peptídeos de tamanhos variáveis ou aminoácidos livres e representam um dos principais grupos de enzimas comerciais e industriais. Estas apresentam um amplo campo de aplicações, sendo empregadas na indústria farmacêutica, cosméticos, de couro, no processamento de alimentos, na fabricação de detergentes, na produção de bebidas, entre outros (RAZZAQ et al., 2019; SANTOS, 2019).

Os microrganismos representam uma excelente fonte de proteases, sendo também a principal fonte de produção. Apesar das enzimas proteolíticas também serem obtidas de animais e plantas, os microrganismos são os principais produtores devido às suas vantagens econômicas e técnicas, além da diversidade bioquímica e da possibilidade de manipulação genética (LAXMAN et al., 2005). Essas enzimas microbianas possuem uma variedade de funções bioquímicas, fisiológicas e regulatórias. Ao longo dos séculos, as proteases microbianas desempenharam um papel fundamental na produção de alimentos fermentados tradicionais e agora o setor de enzimas industriais, dominado por produtos de protease microbiana, fornece ao mundo biocatalisadores para uso em muitas indústrias (AGUILLAR; SATO, 2018).

As proteases podem ser aplicadas em vários setores da indústria alimentícia como na produção e maturação de queijos, onde são empregadas na coagulação do leite por meio da hidrólise da ligação peptídica específica para gerar caseína e macropeptídeos (SANTOS, 2019). O amaciamento de carnes é outro processo que pode ser realizado com o uso de enzimas proteolíticas, podendo ocorrer por imersão, pulverização, adicionadas a condimentos, por injeção direta em animais vivos ou logo após o abate e também podem ser utilizadas para facilitar a separação mecânica da carne e dos ossos (DORNELLES, 2017). Na panificação, são usadas para modificar o glúten, que é uma proteína solúvel que determina as propriedades viscoelásticas e a capacidade de expansão de massa e além disso, contribuem na redução do tempo de mistura da massa e no custo da produção (AGUILAR; SATO, 2018). Além disso, as proteases podem atuar na melhoria do sabor e qualidade de hidrolisados proteicos. Geralmente, são formados a partir de caseína e proteínas do soro do leite e proteínas de soja e possuem diversas aplicações como constituintes de alimentos dietéticos e produtos naturais, formulações infantis, suplementos para nutrição clínica, além de serem usadas em alimentos para pessoas alérgicas às proteínas do leite (DORNELLES, 2017; SANTOS, 2019). 
O desenvolvimento de técnicas e métodos para a separação e purificação de enzimas tem sido um pré-requisito indispensável para muitos dos avanços feitos na indústria biotecnológica. O SDFA é bastante utilizado para purificação de biomoléculas com aplicação nos mais variados ramos da biotecnologia, tais como, enzimas, anticorpos e proteínas estruturais. Esses sistemas dividem-se em duas fases aquosas, quando são misturados dois polímeros (por exemplo, PEG e dextrana) ou um polímero e um sal apropriado (por exemplo: fosfato ou citrato) e certas condições termodinâmicas são determinadas (MARTIM et al., 2015).

Ainda assim, em muitos casos uma purificação com menor eficiência já é o suficiente, e sendo assim, o SDFA torna-se uma metodologia mais simples e econômica. Essa técnica de separação foi desenvolvida primeiramente pelo bioquímico sueco, P. A. Albertsson em 1986, e consiste na formação de duas fases entre polímeros como polietilenoglicol (PEG) e dextrana, ou entre um polímero e um sal PEG/fosfato de potássio, por exemplo, inicialmente solúveis, porém quando adicionados além das concentrações críticas de solubilidade, se tornam imiscíveis (PHONG et al. 2018). Outra característica importante desse método é a grande quantidade de água, o que garante condições não desnaturantes as biomoléculas alvo (DA SILVA et al., 2017). Essa técnica consiste no processo de purificação que engloba a integração de uma parte de extração como primeira fase de processo de retirada para sintetizar e recolher conjuntamente o bioproduto de relevância (SHOW et al., 2012).

Estudos envolvendo SDFA são fundamentais, principalmente pela incerteza em estimar o comportamento do particionamento das biomoléculas entre as fases, devido à presença de diversas interações relacionadas ao processo, como, ligações de hidrogênio, interação de cargas, força de Van der Waals, interações hidrofóbicas e efeito estérico (CHAVAN; AVHAD; RATHOD, 2015).

Sendo assim, a utilização do SDFA é uma alternativa para separação e purificação de diversos componentes biológicos e não biológicos, como proteínas recombinantes derivadas de plantas (BUYEL, TWYMAN e FISCHER, 2015), pigmentos (GÓMEZ-LOREDO, GONZÁLEZ-VALDEZ e RITO-PALOMARES, 2015), nano partículas (BENAVIDES et al., 2008) e ácidos (WANG et al., 2017), além de diversas enzimas, como lipases (RAMAKRISHNAN et al., 2016), poligalacturonase (SILVA, DE FRANÇA e PORTO, 2018), celulases (KUMAR et al., 2018), $\alpha$-amilase (SHAD et al., 2018) e proteases (AMARAL et al., 
2020). O sistema de duas fases aquosas PEG-Sal é preferido ao sistema PEG-dextrana, por apresentar maior seletividade, menor custo e um meio menos viscoso para o particionamento de proteínas, dentre os sais mais utilizados tem-se, fosfatos, sulfatos ou carbonatos de amônia, potássio ou sódio, porém o descarte de altas concentrações desses sais em águas residuais pode acarretarem problemas ao meio ambiente, como alternativa, pode se utilizar o sal citrato, que é biodegradável e atóxico (CHAVAN, AVHAD e RATHOD, 2015; DA SILVA et al., 2017; SILVA, DE FRANÇA e PORTO, 2018).

\section{METODOLOGIA}

\section{Micro-organismo}

Para a realização do trabalho foi utilizado o fungo filamentoso Aspergillus heteromorphus URM 0269 cedido pela coleção de culturas Micoteca URM da Universidade Federal de Pernambuco, mantido em tubos de ensaio inclinados contendo meio BDA (Batata Dextrose Agar) a $25 \pm 1^{\circ} \mathrm{C}$.

\section{Meio de manutenção e preparação do inóculo}

A inoculação do micro-organismo foi realizada em Erlenmeyers de $125 \mathrm{~mL}$ que continham meio de cultura BDA já esterilizados, onde foram incubados a $30^{\circ} \mathrm{C}$ em estufa por 7 dias, até que ocorresse a esporulação. Os esporos foram suspensos com a adição de solução de $\mathrm{NaCl}(0,9 \%)$ e Tween $80(0,01 \% \mathrm{v} / \mathrm{v})$ previamente esterilizados. Em seguida, foi realizada a contagem de esporos em câmara de Neubauer, até uma quantidade suficiente para concentração final $10^{5}$ esporos $/ \mathrm{mL}$, e foram inoculados nos Erlenmeyers contendo substratos para a produção de protease por fermentação submersa.

\section{Substrato para fermentação}

O substrato utilizado para fermentação submersa foi a farinha de soja, obtido do comércio local. A granulometria do substrato foi padronizada em $(<0,5 \mathrm{~mm})$ em peneiras de Tyler e em seguida seco em estufa a $65^{\circ} \mathrm{C}$ por 24 horas. Posteriormente, o substrato foi armazenamento em recipiente hermeticamente fechado à temperatura ambiente.

\section{Produção de proteases por fermentação submersa (FSm)}


A produção de proteases foi realizada em Erlenmeyers de $250 \mathrm{~mL}$ agitados a $150 \mathrm{rpm}$ e $30^{\circ} \mathrm{C}$ por $72 \mathrm{~h}$. O meio de cultura foi preparado com concentração de farinha de soja $(2 \%)$ e extrato de levedura $(0,1 \%)$. Filtrados de farinha de soja foram preparados em água destilada. O filtrado de soja foi autoclavado por 20 min a $121{ }^{\circ} \mathrm{C}$ para extração das proteínas da farinha. A mistura foi então filtrada para remover sólidos suspensos. Os sais - $0,7 \mathrm{mM}\left(\mathrm{NH}_{4}\right)_{2} \mathrm{SO}_{4}, 0,8$ $\mathrm{mM} \mathrm{MgSO}_{4} \cdot 7 \mathrm{H}_{2} \mathrm{O}$ e $5,0 \mathrm{mM} \mathrm{K} \mathrm{KPO}_{4}$ - extrato de levedura $0,5 \%$ e glicose $1 \%$ foram adicionados aos meios e foram esterilizados em autoclave sob as mesmas condições acima descritas. Após a preparação do meio de soja, foi seguida a inoculação de $10^{5}$ esporos $/ \mathrm{mL}$. Ao término da fermentação, foi realizada a filtração do extrato enzimático bruto em bomba à vácuo e as amostras foram mantidas congeladas a $-20^{\circ} \mathrm{C}$ para posterior análises.

\section{Determinação de atividade proteásica}

Para determinação da atividade proteásica foi utilizado o método descrito por Ginther (1979) em que o substrato utilizado foi a Azocaseína (1\%) com $\mathrm{CaCl}_{2} \mathrm{mM}$. A reação consistiu na adição de $0,15 \mathrm{~mL}$ do extrato enzimático e $0,25 \mathrm{~mL}$ do substrato Azocaseína $1 \%$. A mistura foi incubada por 1 hora sob o abrigo da luz a temperatura ambiente $25 \pm 1^{\circ} \mathrm{C}$. Em seguida, a reação foi interrompida com $1 \mathrm{~mL}$ de TCA $10 \%$. Foi realizada a centrifugação das amostras a $12000 \mathrm{rpm}$ por 20 minutos a $4^{\circ} \mathrm{C}$, o sobrenadante retirado e adicionado de $0,2 \mathrm{~mL}$ de $\mathrm{NaOH}$ 1,8 M. Uma unidade de atividade da protease representa a quantidade de enzima necessária para produzir uma variação de absorbância de 0,1 em 1 hora utilizando um comprimento de onda de 420nm. O resultado obtido foi expresso em $\mathrm{U} / \mathrm{mL}$.

\section{Quantificação de proteínas totais}

O teor de proteínas foi determinado através do método de Bradford (1976), utilizando-se albumina de soro bovino (BSA) como padrão.

\section{Purificação através do sistema de duas fases aquosas PEG-Citrato}

A extração por SDFA foi realizada em tubos cônicos graduados de $15 \mathrm{~mL}$ com forma cônica, contendo as quantidades desejadas de polietilenoglicol (PEG) e do sal citrato de sódio, foi adicionado o extrato bruto enzimático, que corresponde a $20 \%(\mathrm{~m} / \mathrm{m})$ da massa total do sistema. A água foi adicionada a um valor final de $5 \mathrm{~g}$. Após agitação por vórtex $1 \mathrm{~min}$, as fases foram separadas por decantação por $60 \mathrm{~min}$. Em seguida, os volumes das fases foram 
mensurados, alíquotas das fases foram retiradas separadamente com pipetas e analisadas para a concentração de proteína e atividade proteásica para os cálculos das variáveis respostas: coeficiente de partição (K), fator de purificação (FP) e recuperação (Y) calculadas de acordo com as Equações 1-3. Os parâmetros de extração estudados foram: massa molar do PEG, concentração do PEG, concentração do citrato e $\mathrm{pH}$, na extração da protease, utilizando um planejamento fatorial completo $2^{4}$. Os sistemas de suas fases aquosas foram preparados inicialmente através da mistura de PEG de diferentes massas molares em diferentes concentrações e sal citrato de sódio acrescida de ácido cítrico, para ajuste do $\mathrm{pH}$ em diferentes valores, a $25 \pm 1^{\circ} \mathrm{C}$, somando-se uma concentração final, a concentração de ácido cítrico representa $10 \%$ do total da concentração final como apresentado na Tabela 01 . Vale destacar que não é possível manter a amplitude entre o ponto $-1,0$ e +1 para a massa molar de PEG, uma vez que não é produzido solução com massa requerida (4200 g/mol), sendo o mais próximo o de $3350 \mathrm{~g} / \mathrm{mol}$. A análise estatística dos resultados foi realizada, com o auxílio do programa Statistica 7.0 (STATSOFT INC, 2008).

Tabela 01: Níveis dos fatores do Planejamento fatorial completo $2^{4}$ para purificação de proteases por Aspergillus heteromorphus URM 0269 por sistema de duas fases aquosas.

\begin{tabular}{lccc}
\hline \multicolumn{1}{c}{ Variável } & \multicolumn{3}{c}{ Nível } \\
\hline & $(-1)$ & $(0)$ & $(+1)$ \\
Massa Molar PEG $(\mathrm{g} / \mathrm{mol})$ & 400 & 3350 & 8000 \\
Concentração do PEG $(\% \mathrm{~m} / \mathrm{m})$ & 20 & 22 & 24 \\
Concentração de Citrato $(\% \mathrm{~m} / \mathrm{m})$ & 15 & 17,5 & 20 \\
$\mathrm{pH}$ & 6 & 7 & 8 \\
\hline
\end{tabular}

Fonte: O autor (2020).

\section{Definições das variáveis respostas}

O coeficiente de partição das proteases foi determinado como a razão entre atividade da protease $(U / m L)$ na fase superior rica em PEG $\left(A_{S}\right)$ e a fase inferior rica em sal $\left(A_{I}\right)$ : $K=\frac{A_{S}}{A_{I}}(1)$

O fator de purificação foi definido como a razão entre a atividade específica na fase superior ou inferior $\left(\mathrm{A}_{\mathrm{S}-\mathrm{I}} / \mathrm{C}_{\mathrm{S}-\mathrm{I}}\right)$ e seu valor inicial no extrato bruto antes da partição $\left(\mathrm{A}_{\mathrm{EB}} / \mathrm{C}_{\mathrm{EB}}\right)$ : 


\section{$F P=\frac{A S-I / C S-I}{A E B / C E B}$}

Onde, $\mathrm{C}_{\mathrm{S}-\mathrm{I}}$ e $\mathrm{C}_{\mathrm{EB}}$ são as concentrações totais de proteína $(\mathrm{mg} / \mathrm{mL})$ na fase superior ou inferior e no extrato bruto, respectivamente.

A recuperação foi determinada como a razão entre a atividade total na fase superior ou inferior $\left(\mathrm{A}_{\mathrm{S}-\mathrm{I}} \mathrm{V}_{\mathrm{S}-\mathrm{I}}\right)$ e a do extrato bruto $\left(\mathrm{A}_{\mathrm{EB}} \mathrm{V}_{\mathrm{EB}}\right)$ e expressa em porcentagem (\%):

$Y=\left(\frac{A S-I V S-I}{A E B V E B}\right) X 100$

Onde, $\mathrm{V}_{\mathrm{S}-\mathrm{I}}$ e $\mathrm{V}_{\mathrm{EB}}$ são os volumes da fase superior ou inferior e do extrato bruto, respectivamente.

\section{RESULTADOS E DISCUSSÃO}

A Tabela 02 apresenta a matriz do planejamento com os resultados obtidos para a extração e purificação da protease de Aspergillus heteromorphus URM 0269 produzida por fermentação submersa. Durante fermentação o micro-organismo apresentou uma produção de proteases $92,73 \mathrm{U} / \mathrm{mL}$. Os ensaios de extração 1, 3, 9 e 11 não formam fase, já que, as concentrações de PEG e citrato utilizadas estavam abaixo da curva binodal para o PEG de massa molar $400(\mathrm{~g} / \mathrm{mol})$ conforme reportado previamente por Porto et al. (2007).

Tabela 02: Planejamento experimental fatorial completo $2^{4}$ e resultados da purificação de proteases de Aspergillus heteromorphus URM 0269 por sistema de duas fases aquosas (SDFA) PEG/Citrato.

\begin{tabular}{cccccccc}
\hline ensaios & $\mathrm{M}_{\mathrm{PEG}}{ }^{\mathrm{a}}$ & $\mathrm{C}_{\mathrm{PEG}}{ }^{\mathrm{b}}$ & $\mathrm{C}_{\text {CITRATO }}{ }^{\mathrm{c}}$ & $\mathrm{pH}$ & $\mathrm{K}^{\mathrm{d}}$ & $\mathrm{Y}^{\mathrm{e}}(\%)$ & $\mathrm{FP}^{\mathrm{f}}$ \\
\hline 1 & 400 & 20 & 15 & 6 & - & - & - \\
2 & 8000 & 20 & 15 & 6 & 0,81 & 65,89 & 0,18 \\
3 & 400 & 24 & 15 & 6 & - & - & - \\
4 & 8000 & 24 & 15 & 6 & 0,84 & 62,18 & 0,73 \\
5 & 400 & 20 & 20 & 6 & 9,24 & 222,53 & 1,93 \\
6 & 8000 & 20 & 20 & 6 & 3,08 & 105,45 & 1,49 \\
7 & 400 & 24 & 20 & 6 & 4,43 & 199,83 & 1,35 \\
8 & 8000 & 24 & 20 & 6 & 2,61 & 133,42 & 0,66 \\
9 & 400 & 20 & 15 & 8 & - & - & - \\
10 & 8000 & 20 & 15 & 8 & 1,12 & 91,18 & 1,20 \\
11 & 400 & 24 & 15 & 8 & - & - & - \\
12 & 8000 & 24 & 15 & 8 & 0,52 & 59,94 & 0,79
\end{tabular}




\begin{tabular}{cccccccc}
13 & 400 & 20 & 20 & 8 & 2,51 & 136,26 & 0,99 \\
14 & 8000 & 20 & 20 & 8 & 0,74 & 65,20 & 0,99 \\
15 & 400 & 24 & 20 & 8 & 4,24 & 247,84 & 1,45 \\
16 & 8000 & 24 & 20 & 8 & 1,21 & 129,41 & 1,27 \\
$17(\mathrm{C})$ & 3350 & 22 & 17,5 & 7 & 0,94 & 105,01 & 0,95 \\
$18(\mathrm{C})$ & 3350 & 22 & 17,5 & 7 & 0,83 & 85,36 & 0,77 \\
$19(\mathrm{C})$ & 3350 & 22 & 17,5 & 7 & 0,93 & 90,52 & 0,83 \\
$20(\mathrm{C})$ & 3350 & 22 & 17,5 & 7 & 0,97 & 95,78 & 0,95 \\
\hline
\end{tabular}

-, Sistema que não forma fase. a - Massa molar do PEG. b - Concentração de PEG. c - Concentração de citrato. d - Coeficiente de partição. e - Recuperação de atividade na fase PEG. f - Fator de purificação na fase PEG.

Fonte: O Autor (2020).

A protease indicou a preferência pela fase superior rica em PEG, por apresentar o coeficiente de partição $\mathrm{K}>1$ para a grande maioria dos ensaios. Tanto os resultados apresentados na Tabela 02 para a Recuperação e Fator de purificação, quanto os efeitos estatísticos calculados para os mesmos parâmetros (Tabela 03) foram estipulados para fase superior rica em PEG, por ter apresentado resultados superiores para os parâmetros avaliados em relação a fase inferior (dados não mostrados).

Tabela 03: Efeitos estatísticos calculados para as respostas dos resultados de purificação de protease de Aspergillus heteromorphus URM 0269 por sistema de duas fases aquosa PEG/Citrato realizadas de acordo com o delineamento experimental $2^{4}$ da Tabela 02.

\begin{tabular}{lccc}
\hline Variável ou interação & $\mathrm{K}^{\mathrm{a}}$ & $\mathrm{Y}^{\mathrm{b}}(\%)$ & $\mathrm{FP}^{\mathrm{c}}$ \\
\hline$(1) \mathrm{M}_{\mathrm{PEG}}{ }^{\mathrm{d}}$ & $-36,56^{*}$ & $-2,76$ & $4,43^{*}$ \\
$(2) \mathrm{C}_{\mathrm{PEG}}{ }^{\mathrm{e}}$ & $-15,36^{*}$ & $4,35^{*}$ & $-1,47$ \\
$(3) \mathrm{C}_{\mathrm{CITRATO}}^{\mathrm{f}}$ & $104,02^{*}$ & $28,64^{*}$ & $20,65^{*}$ \\
$(4) \mathrm{pH}$ & $-44,88^{*}$ & $-1,77$ & 1,01 \\
$1 \times 2$ & $10,45^{*}$ & $-0,94$ & $-0,82$ \\
$1 \times 3$ & $-67,56^{*}$ & $-19,43^{*}$ & $-12,01^{*}$ \\
$1 \times 4$ & $13,26^{*}$ & $-0,51$ & $5,81^{*}$ \\
$2 \times 3$ & $-10,49^{*}$ & $6,44^{*}$ & $-2,29$ \\
$2 \times 4$ & $28,78^{*}$ & $4,26^{*}$ & $3,37^{*}$ \\
$3 \times 4$ & $-44,75^{*}$ & $-3,15^{*}$ & $-5,12^{*}$ \\
$1 \times 2 \times 3$ & $15,32^{*}$ & $-1,14$ & $-1,64$ \\
$1 \times 2 \times 4$ & $-26,15^{*}$ & $-3,74^{*}$ & $-2,58$ \\
$1 \times 3 \times 4$ & $13,39^{*}$ & $-0,87$ & 0,32 \\
$2 \times 3 \times 4$ & $34,09^{*}$ & $5,90^{*}$ & $8,87^{*}$ \\
\hline
\end{tabular}

a - Coeficiente de partição. b - Recuperação da atividade na fase PEG. c - Fator de purificação na fase PEG. d Massa molar do PEG. e - Concentração de PEG. f - Concentração de citrato. * Valores estatisticamente significativos (para $\mathrm{p}<0,05)$. 


\section{Efeitos no coeficiente de partição}

Todas as variáveis independentes assim como suas interações, apresentaram significância frente à variável resposta $\mathrm{K}$, coeficiente de partição. $\mathrm{O}$ efeito mais significante foi da variável independente $\mathrm{C}_{\text {CITRATO, }}$, sendo ele positivo, indicando que com o aumento dessa variável têm se os melhores resultados, de fato é possível observar essa influência, já que os ensaios 5, 7, e 15, onde a concentração de citrato foi superior $(20 \% \mathrm{~m} / \mathrm{m})$ os valores de K, estão acima dos demais ensaios. Em contrapartida outros ensaios que também apresentam a concentração superior de citrato, não resultaram em valores de $\mathrm{K}$ altos em relação aos ensaios 5, 7 e 15, isso ocorreu principalmente devido à massa molar do $\mathrm{PEG}$ e o $\mathrm{pH}$, tendo ambas as variáveis independentes apresentado um efeito estatístico negativo, indicando o aumento dos resultados a partir da diminuição dos níveis dessas variáveis.

Bem como o efeito antagônico entre a interação $\mathrm{C}_{\mathrm{CITRATO}}$ e $\mathrm{M}_{\mathrm{PEG}}(1 * 3)$ (Figura 01) e da interação $\mathrm{C}_{\text {CITRATo }}$ e $\mathrm{pH}(3 * 4)$, ou seja, o aumento de uma das variáveis e a diminuição da outra, resulta em maiores valores, neste caso, fica claro que o aumento da $\mathrm{C}_{\text {CITRATo }}$ e a diminuição da $\mathrm{M}_{\mathrm{PEG}}$ e do $\mathrm{pH}$ resultam nos maiores valores, todos esses efeitos explicam o maior valor encontrado no ensaio 5 de 9,24.

Figura 01: Diagrama de interpretação geométrica da interação entre $C_{\text {CITRATO }}$ e $M_{P E G}$ sobre coeficiente de partição $(\mathrm{K})$. 


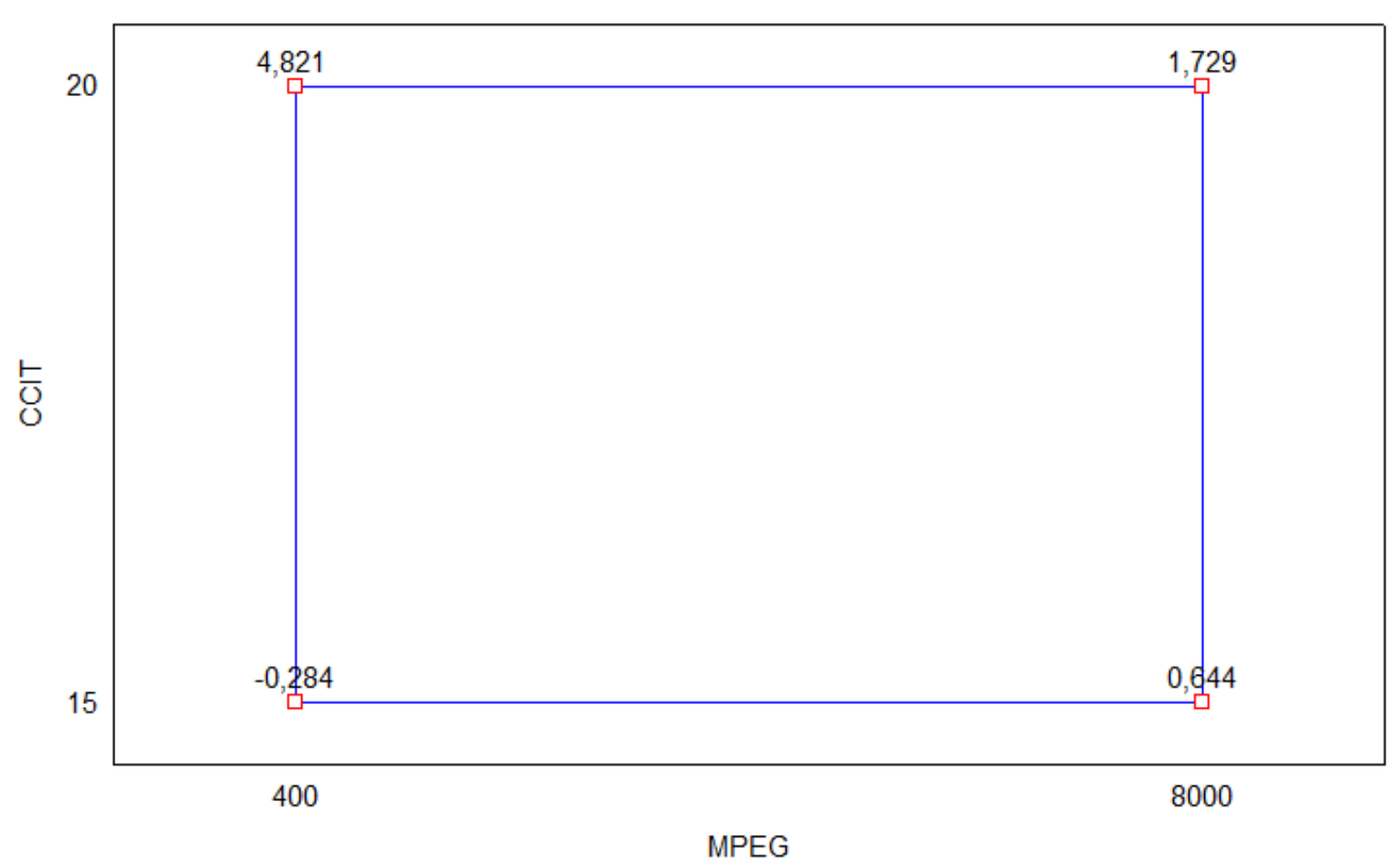

Panger $F=0$

Fonte: O autor (2020)

A razão pela tamanha importância da concentração de citrato no melhor particionamento das proteínas já é esperado, devido ao fenômeno "salting out" que comumente ocorre no caso de precipitação de proteínas, na qual grandes quantidades de sal diminuem a solubilidade das proteínas impedindo-as de se manterem na fase inferior rica em sal, e assim, direcionando-as para a fase superior rica no polímero. Por outro lado, a influência da massa molar do polímero também influencia a partição das biomoléculas, quanto menor sua massa molar do PEG, mais espaço e solvente disponível aumentando a solubilidade das proteínas (DA SILVA et al., 2017).

Outro importante efeito, foi o do $\mathrm{pH}$ que apresentou efeito significativo negativo, levando a acreditar que a enzima pode ter caráter mais alcalino, com superfície carregada positivamente no $\mathrm{pH}$ 6,0, a formação de carga pode ter contribuído para o deslocamento para a fase superior, devido justamente à intensificação de interações eletrostáticas entre o PEG e a enzima (HERCULANO et al., 2012). Neste trabalho, a protease de Aspergillus heteromorphus apresentou uma faixa de pH ótimo entre pH 7 e 8 (dados não mostrados), o que confirma a teoria de carga de superfície positiva.

Um estudo realizado por Fernandes et al. (2020) para purificar proteases de 
Aspergillus heteromorphus produzidas por fermentação em estado sólido apresentou pH ótimo 8, semelhante ao apresentado no presente trabalho. Semelhantemente os autores também observaram a partição preferencial da protease para fase PEG e observaram efeito positivo da concentração de citrato e negativo da massa molar do PEG para o K. Porém a massa molar do PEG maior $(8000 \mathrm{~g} / \mathrm{mol})$ foi melhor para purificação da enzima.

O efeito positivo da concentração de sal em resposta de maiores valores do coeficiente de partição na purificação de enzimas por sistema de duas fases aquosas também já foi relatado em diversos estudos (AMARAL et al., 2020; SILVA, DE FRANÇA e PORTO, 2018; NASCIMENTO et al., 2016; DA SILVA et al., 2017; LIMA et al., 2013). Amaral et al., (2020) durante purificação de protease de Aspergillus tamarii Kita UCP 1279 obteve efeito negativo para a interação concentração de citrato e massa molar de PEG, semelhantemente aos resultados obtidos no presente trabalho, porém verificou efeito estatístico positivo para o $\mathrm{pH}$, demonstrando as diferenças de particionamento para diferentes proteases a depender de sua carga elétrica em torno da estrutura proteica.

\section{Efeitos na Recuperação da Atividade da enzima}

Assim como o coeficiente de partição, a recuperação da atividade (Y) da protease teve efeito significativo positivo para concentração do citrato, e para a interação entre $\mathrm{C}_{\text {CITRATO }} \mathrm{e}$ $\mathrm{M}_{\mathrm{PEG}}\left(1^{*} 3\right)$ efeito negativo, como é possível observar pelos ensaios 5, 7 e $15(20 \% \mathrm{~m} / \mathrm{m}$ de citrato, massa molar do PEG $400 \mathrm{~g} / \mathrm{mol}$ ) que apresentaram recuperação na atividade da protease de $222,53 \%, 199,83 \%$ e $247,84 \%$ respectivamente, valores esses que demonstraram um alto aumento da atividade enzimática após a extração e remoção de possíveis inibidores. Além disso, altos valores de recuperação na atividade da enzima, quando o $\mathrm{K}>1$, indica que as biomoléculas não foram degradadas durante o processo, desta forma valores de Y maiores que $80 \%$ tornam viável a utilização da metodologia industrialmente (BARROS et al., 2014).

No entanto diferente do coeficiente de partição, apesar da interação $1 * 3$ significativa a massa molar de PEG $\left(\mathrm{M}_{\mathrm{PEG}}\right)$ não apresentou efeito significativo, o que demonstra que a simples diminuição da massa molar do PEG não é suficiente para a melhoria dos resultados, o mesmo ocorre para o pH. Em contrapartida a concentração de PEG apresentou efeito significativo positivo, uma vez que os melhores resultado são obtidos no nível mais alto desta variável. A concentração de $\mathrm{PEG}\left(\mathrm{C}_{\mathrm{PEG}}\right)$ foi ainda uma importante variável independente quando se tratando das interações de segunda ordem e de terceira ordem, como é o caso da 


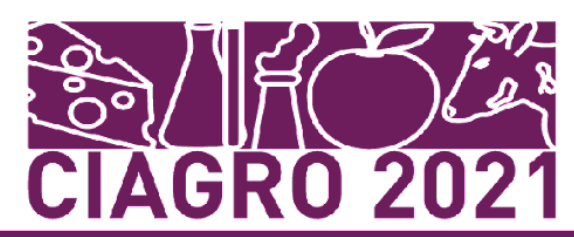

interação entre $\mathrm{C}_{\mathrm{PEG}}$ e $\mathrm{C}_{\text {CITRATO }}(2 * 3)$ (Figura 2) com efeito positivo, onde neste caso foi perceptível que o aumento das duas variáveis também promoveu um aumento em $\mathrm{Y}$, como foi nos casos dos ensaios 7 e 15 (24\% m/m de PEG e $20 \% \mathrm{~m} / \mathrm{m}$ de Citrato).

Figura 02: Diagrama de representação geométrica da interação entre $\mathrm{C}_{\mathrm{CITRATO}}$ e $\mathrm{C}_{\mathrm{PEG}}$ no rendimento $(\mathrm{Y})$ no SDFA.

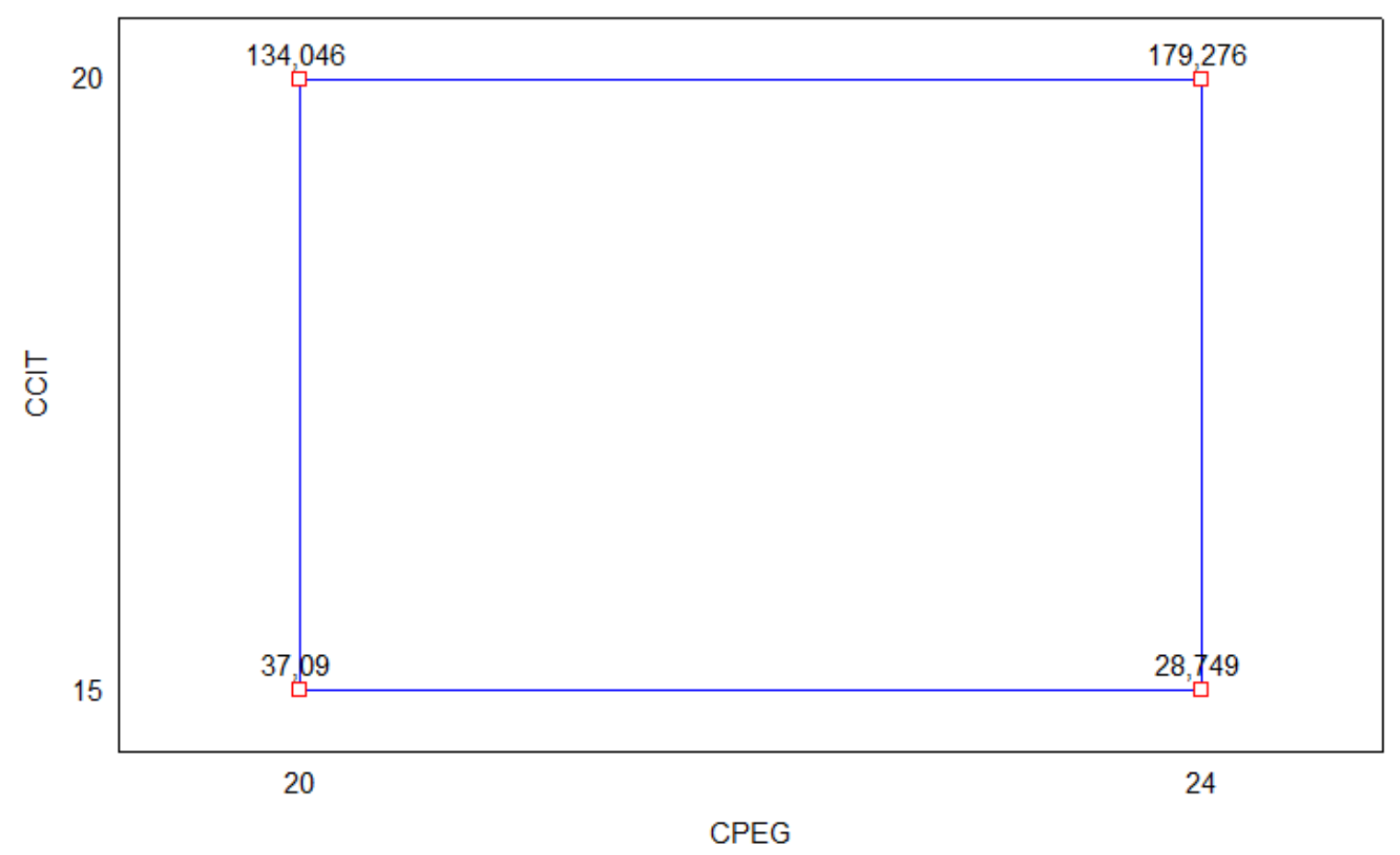

Fonte: O autor (2020).

A interação de terceira ordem entre a concentração de citrato, a concentração de PEG e o pH apresentou efeito estatístico positivo, indicando que o aumento nos níveis das três variáveis aumentou o valor da recuperação (Ensaio 15, 247,84\%). Os valores de recuperação de atividade encontrados neste trabalho e em outros artigos como Ketnawa et al., (2014) com recuperação máxima de $220 \%$ na purificação de proteases, demonstram a eficiência do SDFA em não somente apresentar baixar desnaturação enzimática, mas aumentar a atividade pela remoção de inibidores. Diferente de técnicas como a cromatografia de troca iônica que apresenta perdas por desnaturação muitas vezes acima de $80 \%$, como demonstrado por Yildirim et al., (2017).

\section{Efeitos no fator de purificação}


O fator de purificação deve ser considerado a variável mais importante no estudo da purificação de proteases de Aspergillus heteromorphus URM 0269 por SDFA, para viabilidade de aplicações industriais, pois quanto maior o fator de purificação maior a atividade especifica da protease em relação ao extrato bruto fermentado, ou seja, menor utilização de volume do extrato enzimático para o mesmo potencial catalítico.

Assim como as variáveis respostas anteriores, o fator de purificação sofreu maior

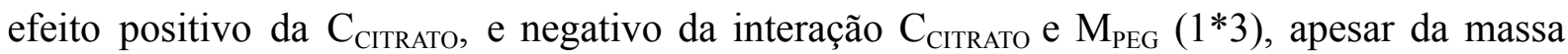
molar avaliada de forma isolada apresentar efeito positivo. De fato, a forte influência da $\mathrm{C}_{\text {CITRAto }}$ e da interação $1 * 3$ é bem evidente, dado que um aumento da concentração de $15 \%$ a $20 \%(\mathrm{~m} / \mathrm{m})$, atrelado a diferença de massa molar de PEG de 8000 para $400 \mathrm{~g} / \mathrm{mol}$ resultou em uma diferença no FP de 0,18 para 1,93 (ensaios 2 e 5 respectivamente).

Apesar da $\mathrm{C}_{\mathrm{PEG}}$ e do $\mathrm{pH}$ não apresentarem efeito estatístico significativo, a interação ternária entre $\mathrm{C}_{\mathrm{PEG}}, \mathrm{pH}$ e $\mathrm{C}_{\mathrm{CITRATO}}(2 * 3 * 4)$ foi estatisticamente significativa e apresentou interação sinérgica, indicando que o aumento das três variáveis resulta em melhoria das variáveis respostas, conforme pode ser visualizado no gráfico de representação geométrica cúbica (Figura 3), o que demonstra a importância da utilização de experimentos envolvendo planejamentos fatoriais, a fim de determinar condições de difícil observação em sistemas de purificação por SDFA.

Figura 03: Gráfico cubico dos efeitos de interação $\mathrm{C}_{\mathrm{CITRATO}}, \mathrm{C}_{\mathrm{PEG}}$, e $\mathrm{pH}$ na variável fator de purificação (FP) 


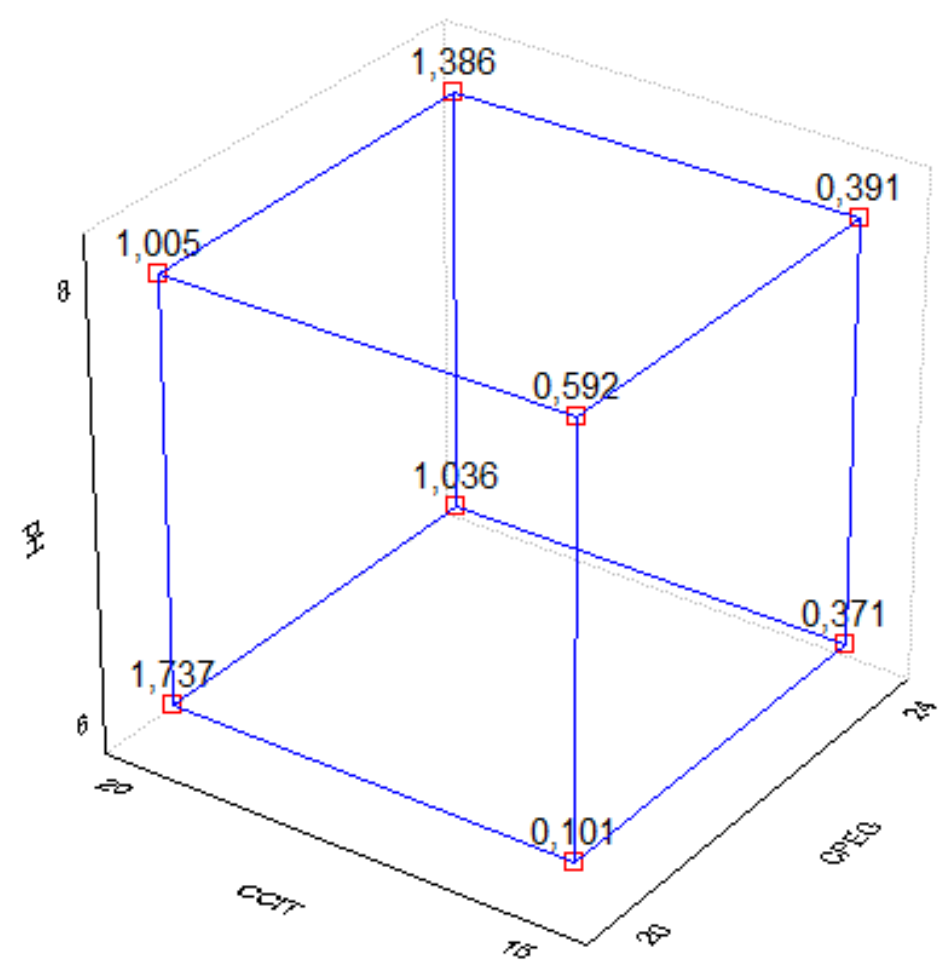

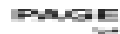
$=0$

Fonte: O autor (2020)

As variáveis respostas $\mathrm{K}$ e FP sofreram maior efeito significativo das variáveis $\mathrm{M}_{\mathrm{PEG}} \mathrm{e}$ $\mathrm{C}_{\text {CItRAto }}$ e da interação entre ambas $(1 * 3)$ e desta forma torna-se capaz a possibilidade de otimização de ambas as respostas simultaneamente, por exemplo, nas condições de $\mathrm{M}_{\mathrm{PEG}}$ $400 \mathrm{~g} / \mathrm{mol}, \mathrm{C}_{\mathrm{PEG}} 24 \% \mathrm{~m} / \mathrm{m}, \mathrm{C}_{\text {CITRATO }} 20 \% \mathrm{~m} / \mathrm{m}$, pH 6 obteve-se os melhores resultados no geral, sendo eles $\mathrm{K}=9,24, \mathrm{Y}=222,53 \%$ e $\mathrm{FP}=1,93$.

\section{CONCLUSÕES}

Os resultados obtidos no presente trabalho indicam uma extração eficiente com alta recuperação da protease produzida por Aspergillus heteromorphus URM 0269 pelo sistema de duas fases aquosas utilizando PEG/Citrato, o que promove a possibilidade de aplicação de uma metodologia simples, rápida, reprodutível e de baixo custo. A protease indicou a preferência pela fase superior rica em PEG, por apresentar o coeficiente de partição $\mathrm{K}>1$ para a grande maioria dos ensaios, sendo possível obter uma recuperação de atividade (Y) de até $247,84 \%$. De forma geral, os melhores resultados foram obtidos no ensaio 5 nas condições de $\mathrm{M}_{\text {PEG }} 400 \mathrm{~g} / \mathrm{mol}, \mathrm{C}_{\text {CITRATO }} 20 \% \mathrm{~m} / \mathrm{m}, \mathrm{C}_{\mathrm{PEG}} 20 \% \mathrm{~m} / \mathrm{m}$ e $\mathrm{pH} 6,0$, no qual $\mathrm{K}$, Y e $\mathrm{FP}$ 
corresponderam a 9,24, 222,53\% e 1,93, respectivamente. As variáveis respostas $\mathrm{K}$ e FP

sofreram maior efeito significativo da variável $\mathrm{C}_{\mathrm{CITRATO}}$ e da interação entre $\mathrm{C}_{\mathrm{CITRATO}}$ e $\mathrm{M}_{\mathrm{PEG}}$ (1*3), resultado de fenômenos como o "salting out" e maior disponibilidade de espaço e solvente, o que consequentemente promove maior solubilidade da protease pela menor massa molar do PEG. Com isso, o SDFA PEG-Citrato se apresenta como uma metodologia viável para extração de proteases que em futuros estudos poderão ser aplicadas em diversos setores, principalmente da indústria de alimentos.

\section{REFERÊNCIAS}

ABD SAMAD, N. S. A.; AMID, A.; JIMAT, D. N.; SHUKOR, N. A. A. Protease purification from Bacillus amyloliquefaciens B7 using aqueous two-phase system (ATPS). International Food Research Journal, v. 24, n. Suppl., 2017.

AGUILAR, J. G. S.; SATO, H. H. Microbial proteases: Production and application in obtaining protein hydrolysate. Food Research International, v. 103, p. 253-262, 2018.

ALBERTSSON, P. A. Partition of cell particles and macromolecules, Wiley-Interscience, New York, p.346, 1986.

AMARAL, Y. M. S.; DA SILVA, O. S.; DE OLIVEIRA, R. L.; PORTO, T. S. Production, extraction, and thermodynamics protease partitioning from Aspergillus tamarii Kita UCP1279 using PEG/sodium citrate aqueous two-phase systems. Preparative Biochemistry \& Biotechnology, 1-8, 2020.

BARROS, K. V. G.; SOUZA, P. M.; FREITAS, M. M.; FERREIRA FILHO, E. X.; JUNIOR, A. P., MAGALHÃES, P. O. PEG/NaPA aqueous two-phase systems for the purification of proteases expressed by Penicillium restrictum from Brazilian Savanna. Process Biochemistry, v. 49, n. 12, p. 2305-2312, 2014.

BENAVIDES, J.; AGUILAR, O.; LAPIZCO-ENCINAS, B. H.; RITO-PALOMARES, M. Extraction and purification of bioproducts and nanoparticles using aqueous two-phase systems strategies. Chemical Engineering \& Technology: Industrial Chemistry-Plant Equipment-Process Engineering-Biotechnology, v. 31, n. 6, p. 838-845, 2008.

BRADFORD, M.M. A rapid and sensitive method for the quantitation of microgram quantities of protein utilizing the principle of protein-dye binding. Anal. Biochem. v. 72, p. 248-254, 1976.

BUYEL, J. F.; TWYMAN, R. M.; FISCHER, R. Extraction and downstream processing of plant-derived recombinant proteins. Biotechnology advances, v. 33, n. 6, p. 902-913, 2015.

CHAVAN, R. S.; AVHAD, D. N.; RATHOD, V. K. Optimization of Aqueous Two-Phase Extraction of Protease Produced from Bacillus licheniformis NCIM 2042 Using Response Surface Methodology. Separation Science and Technology, v. 50, n. 1, p. 45-55, 2015.

DA SILVA, O. S.; GOMES, M. H. G.; DE OLIVEIRA, R. L.; PORTO, A. L. F.; CONVERTI, A.; PORTO, T. S. Partitioning and extraction protease from Aspergillus tamarii URM4634 
using PEG-citrate aqueous two-phase systems. Biocatalysis and Agricultural Biotechnology, v. 9, p. 168-173, 2017.

FERNANDES, L. M. G.; CARNEIRO-DA-CUNHA, M. N.; SILVA, J. C.; PORTO, A. L F.; PORTO, T. S. Purification and characterization of a novel Aspergillus heteromorphus URM 0269 protease extracted by aqueous two-phase systems PEG/citrate. Journal of Molecular Liquids, v. 317, 113957, 2020.

DORNELLES, L. P. Purificação, caracterização e utilização de protease de Mytella charruana (Bivalvia: Mytilidae) na obtenção de peptídeos antimicrobianos. Dissertação (mestrado em bioquímica e fisiologia) - Centro de Biociências. Bioquímica e Fisiologia, Universidade Federal de Pernambuco, 2017.

GINTHER, C. L. Sporulation and the production of serine protease and cephamycin C by Streptomyces lactamdurans. Antimicrobial Agents and Chemotherapy, 15, 522-526, 1979.

GÓMEZ-LOREDO, A.; GONZÁLEZ-VALDEZ, J.; RITO-PALOMARES, M. Insights on the downstream purification of fucoxanthin, a microalgal carotenoid, from an aqueous two-phase system stream exploiting ultrafiltration. Journal of applied phycology, v. 27, n. 4, p. 1517-1523, 2015.

HERCULANO, P. N.; PORTO, T. S.; MACIEL, M. H.; MOREIRA, K. A.; SOUZA-MOTTA, C. M.; PORTO, A. L. Partitioning and purification of the cellulolytic complex produced by Aspergillus japonicus URM5620 using PEG-citrate in an aqueous two-phase system. Fluid Phase Equilibria, v. 335, p. 8-13, 2012.

KETNAWA， S.; BENJAKUL， S.; MARTÍNEZ-ALVAREZ， O.; RAWDKUEN, S. Three-phase partitioning and proteins hydrolysis patterns of alkaline proteases derived from fish viscera. Separation and Purification Technology, 132, 174-181, 2014.

KUMAR, B.; BHARDWAJ, N.; ALAM, A.; AGRAWAL, K.; PRASAD, H.; VERMA, P. Production, purification and characterization of an acid/alkali and thermo tolerant cellulase from Schizophyllum commune NAIMCC-F-03379 and its application in hydrolysis of lignocellulosic wastes. AMB Express, v. 8, n. 1, p. 173, 2018.

LADEIRA, S. A.; DELATORRE, A. B.; ANDRADE, M. V. V.; MARTINS, M. L. L. Nota Científica: Utilização da pectina, proteínas do soro de queijo e água de maceração de milho para a produção de proteases por Bacillus sp. termofílico. Brazilian Journal of Food Technology, v. 15, n. 1, p. 92-98, 2012.

LAXMAN, R. S.; SONAWANE, A. P.; MORE, S. V.; RAO, B. S.; RELE, M. V.; JOGDAND, V. V.; DESHPANDE, V. V.; RAO, M. B. Optimization and scale up of production of alkaline protease from Conidiobolus coronatus. Process Biochemistry, v. 40, p. 3152-3158, 2005.

LIMA, C. A.; JÚNIOR, A. C. F.; LIMA FILHO, J. L.; CONVERTI, A.; MARQUES, D. A. V.; CARNEIRO-DA-CUNHA, M. G.; PORTO, A. L. F. Two-phase partitioning and partial characterization of a collagenase from Penicillium aurantiogriseum URM4622: Application to collagen hydrolysis. Biochemical engineering journal, v. 75, p. 64-71, 2013.

MARTIM, S. R.; SILVA, T. A.; TEIXEIRA, L. S.; CRUZ-FILHO, R. F.; FONSECA, T. R. B.; MARINHO, N. M. V.; SANTOS-EBINUMA, V. C.; TEIXEIRA, M. F. S. Produção e extração de proteases por fermentação extrativa. Diversidade Microbiana da Amazônia, p. 
NASCIMENTO, T. P.; SALES, A. E.; PORTO, C. S.; BRANDÃO, R. M. P.; DE CAMPOS-TAKAKI, G. M.; TEIXEIRA, J. A. C.; CONVERTI, A. Purification of a fibrinolytic protease from Mucor subtilissimus UCP 1262 by aqueous two-phase systems (PEG/sulfate). Journal of Chromatography B, v. 1025, p. 16-24, 2016.

ORLANDELLI, R. C.; SPECIAN, V.; FELBER, A. C.; PAMPHIL, J. A. Enzimas de interesse industrial: Produção por fungos e aplicações, SaBios: Rev. Saúde e Biol., v.7, n.3, p.97-109, 2012.

PHONG, W. N.; SHOW, P. L.; CHOW, Y. H.; LING, T. C. Recovery of biotechnological products using aqueous two-phase systems. Journal of bioscience and bioengineering, 2018.

RAMAKRISHNAN, V.; GOVEAS, L. C.; SURALIKERIMATH, N.; JAMPANI, C.; HALAMI, P. M.; NARAYAN, B. Extraction and purification of lipase from Enterococcus faecium MTCC5695 by PEG/phosphate aqueous-two phase system (ATPS) and its biochemical characterization. Biocatalysis and agricultural biotechnology, v. 6, p. 19-27, 2016.

RAZZAQ, A.; SHAMSI, S.; ALI, A.; ALI, Q.; SAJJAD, M.; MALIK, A.; ASHRAF, M. Microbial Proteases Applications. Frontiers in Bioengineering and Biotechnology, v. 7, 2019.

SANTOS, G. L. Produção, purificação e caracterização parcial de proteases de penicillium citrinum. Dissertação (mestrado em engenharia química) - Faculdade de Engenharia Química, Universidade Estadual de Campinas, 2019.

SHAD, Z.; MIRHOSSEINI, H.; HUSSIN, A. S. M.; FORGHANI, B.; MOTSHAKERI, M.; MANAP, M. Y. A. Aqueous two-phase purification of $\alpha$-Amylase from white pitaya (Hylocereus undatus) peel in polyethylene glycol/citrate system: Optimization by response surface methodology. Biocatalysis and agricultural biotechnology, v. 14, p. 305-313, 2018.

SHOW, P. L.; TAN, C. P.; SHAMSULANUAR M.; ARIFF, A.; YUSOF, Y. A.; CHEN, S. K.; LING, T. C.; Extractive fermentation for improved production and recovery of lipase derived from Burkholderia cepacia using a thermoseparating polymer in aqueous two-phase systems. BioresourTechnol , p. 116:226-233, 2012.

SILVA, J. C.; DE FRANÇA, P. R. L.; PORTO, T. S. Optimized extraction of polygalacturonase from Aspergillus aculeatus URM4953 by aqueous two-phase systems PEG/Citrate. Journal of Molecular Liquids, v. 263, p. 81-88, 2018.

SOCCOL, C. R.; DA COSTA, E. S. F.; LETTI, L. A. J.; KARP, S. G.; WOICIECHOWSKI, A. L.; DE SOUZA VANDENBERGHE, L. P. Recent developments and innovations in solid state fermentation. Biotechnology Research and Innovation, v. 1, n. 1, p. 52-71, 2017.

SOUZA, P. M. Produção de Proteases por Fungos Filamentosos Isolados do Cerrado do Centro-oeste Brasileiro. Tese (Doutorado) - USP, 2015. 
STASOFT, I. STATISTICA (Data Analysis Software Systems) Version 8.0, 2008.

WANG, T.; XU, W. J.; WANG, S. X.; KOU, P.; WANG, P.; WANG, X. Q.; FU, Y. J. meare Integrated and sustainable separation of chlorogenic acid from blueberry leaves by deep eutectic solvents coupled with aqueous two-phase system. Food and bioproducts processing, v. 105, p. 205-214, 2017.

YILDIRIM, V.; BALTACI, M. O.; OZGENCLI, I.; SISECIOGLU, M.; ADIGUZEL, A.; ADIGUZEL, G. Purification and biochemical characterization of a novel thermostable serine alkaline protease from Aeribacillus pallidus C10: a potential additive for detergents. Journal of enzyme inhibition and medicinal chemistry, 32(1), 468-477, 2017. 


\title{
CAPÍTULO 15: ACÚMULO E PARTIÇÃO DA MATÉRIA SECA NAS BRAQUIÁRIAS BRIZANTHA E DECUMBENS, NA REGIÃO DE CORURIPE, AL \\ CAPÍTULO 15: ACUMULACIÓN Y DIVISIÓN DE LA MATERIA SECA EN LAS BRACHIARIAS BRIZANTHA E DECUMBENS, EN LA REGIÓN DE CORURIPE,
} AL.

\section{CHAPTER 15: DRY MATTER ACCUMULATION AND PARTITIONING IN BRIZANTHA, DECUMBENS AND BRACHIARIES, IN THE CORURIPE REGION - AL}

\begin{abstract}
Dalmo de Freitas Santos ${ }^{1}$; Wesley Oliveira de Assis²; José Valdemir Ferreira Júnior ${ }^{3}$; Terezinha Bezerra Albino Oliveira $^{4}$; Mauro Wagner de Oliveira ${ }^{5}$
\end{abstract}

\section{DOI: https://doi.org/10.31692/978-65-88970-19-5.231-236}

\section{INTRODUÇÃO}

As pastagens constituem a principal fonte de alimentos volumosos para os ruminantes e, em Alagoas, extensas áreas são utilizadas para a pecuária de corte e para a pecuária de leite. Nas pastagens introduzidas, ou semeadas, há predominância do gênero Urochloa, anteriormente designado de Brachiaria. As plantas desse gênero têm sido as preferidas pelos pecuaristas devido à sua rusticidade, ampla adaptação a diferentes ambientes edafoclimáticos, associadas ao alto potencial produtivo e boa qualidade nutricional das plantas (BRAZ, 2003; PACHECO et al., 2013; OLIVEIRA et al., 2017). Estudos conduzidos por Souza (2010), em Arapiraca, mostraram que a Urochloa brizantha (braquiária brizantha) cultivares Marandú e Xaraés e, os Panicum maximum, cultivares Massai e Tanzânia foram as plantas de maior produtividade na região do agreste sub-úmido de Alagoas.

Ante ao exposto, o objetivo do presente estudo foi avaliar, no ambiente edafoclimático de Coruripe - AL, a taxa de acúmulo de matéria seca, a alocação da matéria seca nas folhas e no restante da planta, aos 30, 45 e 60 dias após a emergência, em condições de bom

\footnotetext{
${ }^{1}$ Agronomando, Campus de Engenharia e Ciências Agrarias, Universidade Federal de Alagoas (CECA/UFAL), dalmo.santos@ceca.ufal.br

${ }^{2}$ Engenheiro Agrônomo, Campus de Engenharia e Ciências Agrarias, Universidade Federal de Alagoas (CECA/UFAL), wesleyoliveiradeassis@hotmail.com

${ }^{3}$ Agronomando, Campus de Engenharia e Ciências Agrarias, Universidade Federal de Alagoas (CECA/UFAL), jose.valdemir@ceca.ufal.br

${ }^{4}$ Professora, Campus de Engenharia e Ciências Agrarias, Universidade Federal de Alagoas (CECA/UFAL), tbalbino@ceca.ufal.br

${ }^{5}$ Professor Associado, Campus de Engenharia e Ciências Agrarias, Universidade Federal de Alagoas

(CECA/UFAL), mwagner@ceca.ufal.br
} 


\section{suprimento de nutrientes no solo.}

\section{FUNDAMENTAÇÃO TEÓRICA}

A adaptação e o crescimento das plantas forrageiras podem ser avaliados por algumas variáveis, sendo a produtividade de matéria seca e sua distribuição na planta, ao longo do ciclo biológico, uma das mais usadas (OLIVEIRA et al., 2000; PORTES et al., 2000; OLIVEIRA et al., 2017). Portes et al. (2000) avaliaram o crescimento da braquiária brizantha, em área de recuperação de pastagem devido à degradação do solo, e verificaram que a biomassa seca da parte aérea foi de 19,6 $\mathrm{t} \mathrm{ha}^{-1}$ aos 117 dias após a emergência (D.A.E.).

Com o propósito de melhorar a baixa produtividade da terra e dos animais, vários produtores optam por substituir uma forrageira por outra, porém, esta opção não melhora a baixa produtividade da terra e dos animais, para tanto, é imprescindível reconstituir a fertilidade do solo por calagem, gessagem e adubações químicas, além de descompactar a camada superficial do solo, geralmente selada, pelo intenso pisoteio dos animais (PORTES et al., 2000; OLIVEIRA et al., 2018). Em solos depauperados, química e fisicamente, a forragem é de baixo valor nutritivo, caracterizada pelos altos teores de constituintes da parede celular e pelos baixos teores de proteína, cálcio e fósforo (OLIVEIRA et al., 2017).

\section{METODOLOGIA}

O estudo foi instalado em propriedade rural localizada no município de Coruripe, Alagoas, em área anteriormente utilizada para pastagem. Antes da semeadura foi realizada a aração e gradagem visando a melhoria das propriedades físicas do solo. Foram semeadas duas espécies de braquiárias: braquiária brizantha (Urochloa brizantha) e braquiária decumbens (Urochloa decumbens). A semeadura foi realizada em abril de 2020.

O delineamento experimental foi o de blocos ao acaso, com cinco repetições, sendo as parcelas constituídas de cinco sulcos de cinco metros de comprimento, espaçados de 0,60 metro. No fundo do sulco aberto para a semeadura foi aplicado fósforo, na dose equivalente a $50 \mathrm{~kg}$ de $\mathrm{P} \mathrm{ha}^{-1}$ (equivalente a 114,5 $\mathrm{kg}$ de $\mathrm{P}_{2} \mathrm{O}_{5}$ ) usando o superfosfato simples com fonte de $\mathrm{P}$, com o objetivo de aumentar a eficiência no metabolismo do nitrogênio e a síntese proteica, uma vez que há forte interação do N, P e do S em rotas bioquímicas (OLIVEIRA et al., 2018). $\mathrm{O}$ adubo fosfatado foi coberto com uma camada de terra oscilando em torno de $5 \mathrm{~cm}$. As sementes, em quantidades equivalentes a $15 \mathrm{~kg}$ por hectare, foram distribuídas manualmente no sulco e cobertas com fina camada de terra, em torno de $1 \mathrm{~cm}$. Não houve necessidade de 
controle de pragas e de plantas daninhas.

As adubações nitrogenada e potássica foram realizadas em cobertura, quando as plantas apresentaram cerca de $5 \mathrm{~cm}$ de altura. As adubações nitrogenada e potássica foram em doses equivalentes a $150 \mathrm{~kg}$ de $\mathrm{N}$ e $150 \mathrm{~kg}$ de $\mathrm{K} \mathrm{ha}^{-1}$, usando o sulfato de amônio e cloreto de potássio como fontes de nutrientes. $\mathrm{O}$ uso do sulfato de amônio visa eliminar as perdas de $\mathrm{N}$ por volatilização (OLIVEIRA et al., 2018) e aumentar a eficiência do metabolismo do N, conforme citado anteriormente. As quantidades de nutrientes aplicados foram com base nos trabalhos de Braz (2003); Pacheco et al. (2013) e Oliveira et al. (2017), com expectativa de alta produtividade de matéria seca na parte aérea das plantas.

As avaliações do acúmulo e partição da matéria seca foram realizadas aos 30, 45 e 60 dias após a emergência das plantas (D.A.E), amostrando-se nas linhas centrais das parcelas áreas de $1,0 \mathrm{~m}^{2}$. Essas épocas de amostragem foram definidas com base no estudo conduzido por Braz (2003), na EMBRAPA Arroz e Feijão. As braquiárias foram cortadas rentes ao solo, separando-se as folhas verdes do restante das plantas. Subamostras dessas partes das plantas foram secas em estufa de ventilação forçada a $50{ }^{\circ} \mathrm{C}$ até massa constante e pesadas. Os resultados obtidos foram submetidos à análise de variância e, as médias de cada braquiária, ajustada a modelos de regressão (FERREIRA, 2011; OLIVEIRA et al., 2000).

\section{RESULTADOS E DISCUSSÃO}

Na tabela 1 é apresentado o quadrado médio das análises de variância e o coeficiente de variação para acúmulo de matéria seca nas folhas, acúmulo de matéria seca nos caules + pecíolos e o acúmulo total de biomassa na parte aérea da planta, nas coletas realizadas aos 30, 45 e 60 dias D.A.E.

Tabela 01: Quadrados médios das análises de variância e coeficiente de variação (C.V.) do acúmulo de matéria seca nos caules + pecíolos (Ac. $\mathrm{C}+\mathrm{P}$ ), acúmulo de matéria seca nas folhas (Ac. Folhas), o acúmulo total de biomassa na parte aérea da planta (Ac. MS Td. Pl), nas coletas realizadas aos 30, 45 e 60 dias D.A.E., em duas braquiárias cultivadas na região de Coruripe, AL.

\section{Fonte de Variação}

Braquiária (B) Bloco Época (E)

B x E

Resíduo

\section{GL}

Ac. C + P

$\left(\mathrm{t} \mathrm{ha}^{-1}\right)$

4. $441,37^{* *}$

93,17

$20248,7^{* *}$

$354,9^{*}$

75,8

2,49

11,07

Quadrados médios

Ac. Folhas

$\left(\mathrm{t} \mathrm{ha}^{-1}\right)$

$2.218,1^{* *}$

108,4

$14.037,8^{* *}$

$47,8^{\text {ns }}$

14,3

2,81

13,47
Ac. MS Td. Pl.

$\left(\mathrm{t} \mathrm{ha}^{-1}\right)$

$12.936,6^{* *}$

344,2

$66.976,6^{* *}$

$151,1^{\text {ns }}$

349,7

5,30

11,16

C.V. (\%)

**, *, ns, , significativo a 1,0 ; a $5,0 \%$ ou, não significativo, respectivamente de probabilidade pelo teste $\mathrm{F}$. 


\section{Fonte:Autor (2021)}

Pela análise da tabela 1 constata-se que houve efeito de braquiária e de épocas de amostragens para todas as variáveis analisadas. Para a interação braquiária e época de amostragem observou-se efeito apenas para o acúmulo de matéria seca nos caules + pecíolos.

Na tabela 2 estão apresentadas as médias do acúmulo de matéria secas nos caules + pecíolos (Ac. $\mathrm{C}+\mathrm{P})$, acúmulo de matéria seca nas folhas (Ac. Folhas), o acúmulo de matéria seca na parte aérea da planta (Ac. MS Td. Pl), nas braquiárias brizantha e decumbens, nas coletas realizadas aos 30,45 e 60 dias D.A.E.

Tabela 02: Valores médios dos acúmulos de matéria seca nos caules + pecíolos (Ac. MS C+P), acúmulo de matéria seca nas folhas (Ac. Folhas) e o acúmulo de matéria seca na parte aérea de toda a planta (Ac. MS Td. Pl), na braquiária brizantha (brizantha) e na braquiária decumbens (decumbens), nas coletas realizadas aos 30, 45 e 60 dias após a emergência (D. A. E.), em estudo conduzido na região de Coruripe, AL
Ac. $\mathrm{MS} \mathrm{C}+\mathrm{P}$
Ac. MS Folhas
Ac. MS Td. Pl.

D. A. E

$\begin{array}{lcccccc} & \text { brizantha } & \text { decumbens } & \text { brizantha } & \text { decumbens } & \text { brizantha } & \text { decumbens } \\ 30 & 0,72 \mathrm{~A} \mathrm{a} & 11,1 \mathrm{~B} \mathrm{a} & 1,29 \mathrm{~A} \mathrm{a} & 1,99 \mathrm{~B} \mathrm{a} & 2,01 \mathrm{~A} \mathrm{a} & 3,10 \mathrm{~B} \mathrm{a} \\ 45 & 2,46 \mathrm{~A} \mathrm{~b} & 3,28 \mathrm{~B} \mathrm{~b} & 2,53 \mathrm{~A} \mathrm{~b} & 3,03 \mathrm{~A} \mathrm{~b} & 5,0 \mathrm{~A} \mathrm{~b} & 6,27 \mathrm{~B} \mathrm{~b} \\ 60 & 3,12 \mathrm{~A} \mathrm{c} & 4,26 \mathrm{~B} \mathrm{c} & 3,80 \mathrm{~A} \mathrm{c} & 4,23 \mathrm{~A} \mathrm{c} & 6,91 \mathrm{~A} \mathrm{c} & 8,48 \mathrm{~B} \mathrm{c}\end{array}$

Médias seguidas da mesma letra minúscula na coluna e maiúscula na linha não diferem entre si pelo teste de Scott-Knott a 5\% de probabilidade. Fonte: Autor (2021)

Nas três épocas analisadas, a braquiária decumbens acumulou maior quantidade de matéria seca que a braquiária brizantha, nos caules + pecíolos e, na biomassa aérea de toda planta. Somente para o acúmulo de matéria seca nas folhas houve semelhança entre as braquiárias nas avaliações realizadas aos 45 e aos 60 D. A. E. A taxa de crescimento e o acúmulo de matéria seca são influenciados por diversos fatores, destacando-se a disponibilidade hídrica e de nutrientes no solo, temperatura, luminosidade, potencial produtivo da planta e período considerado. No presente estudo a braquiária decumbens teve acúmulo de matéria seca em toda a parte aérea, de 54; 25 e 22\% maior que a braquiária brizantha, respectivamente aos 30, 45 e 60 dias. Na figura 1 é mostrada essas taxas de acúmulo de matéria seca em toda a parte aérea das duas braquiárias e as respectivas equações de regressão.

Em trabalhos conduzidos por Portes et al. (2000), um dos poucos encontrados pelos 
autores na revisão de literatura, com enfoque próximo a do presente estudo, foi relatado que, aos 60 dias após a emergência, a biomassa da parte aérea da braquiária brizantha era de 3,0 $\mathrm{t}$ por hectare. Contudo, aos 117 dias após a emergência, a biomassa seca da parte aérea foi de 19,6 t por hectare. Oliveira et al. (2017) também citam alta produção de matéria seca da braquiária ruziziensis, após a colheita do milho de primeira safra. No estudo de Portes et al. (2000), a maior taxa de crescimento foi observada aos 97 D.A.E: $372 \mathrm{~kg}$ de matéria seca por hectare por dia.

Um dos fatores que pode ter contribuído para o maior acúmulo de matéria seca no presente estudo, comparativamente ao de Portes et al. (2000) foi a disponibilidade de nutrientes, consequência da maior adubação empregada na semeadura e em cobertura. Portes et al. (2000) aplicaram $300 \mathrm{~kg}$ por hectare do 04-30-16, na semeadura e, $40 \mathrm{~kg}$ de $\mathrm{N}$ por hectare, aos 40 D.A.E. No presente estudo, foi aplicado no fundo do sulco aberto para a semeadura apenas o fósforo, na dose equivalente a $50 \mathrm{~kg}$ de $\mathrm{P}$ por hectare (equivalente a $114,5 \mathrm{~kg}$ de $\mathrm{P}_{2} \mathrm{O}_{5}$ ) usando o superfosfato simples com fonte de P. Quando as plantas apresentaram cerca de $5 \mathrm{~cm}$ de altura, foi aplicada a adubação nitrogenada e potássica em cobertura, em doses equivalentes a $150 \mathrm{~kg}$ de $\mathrm{N}$ e $150 \mathrm{~kg}$ de $\mathrm{K}$ por hectare, usando o sulfato de amônio e cloreto de potássio como fontes de nutrientes. Oliveira et al. (2018) citam que as gramíneas tem alta resposta à adubação, especialmente a adubação nitrogenada.

Figura 01: Taxas de acúmulo de matéria seca em toda a parte aérea da braquiária brizantha e da braquiária decumbens, aos 30; 45 e 60 dias após a emergência, em estudo conduzido em Pindorama, Coruripe - AL.

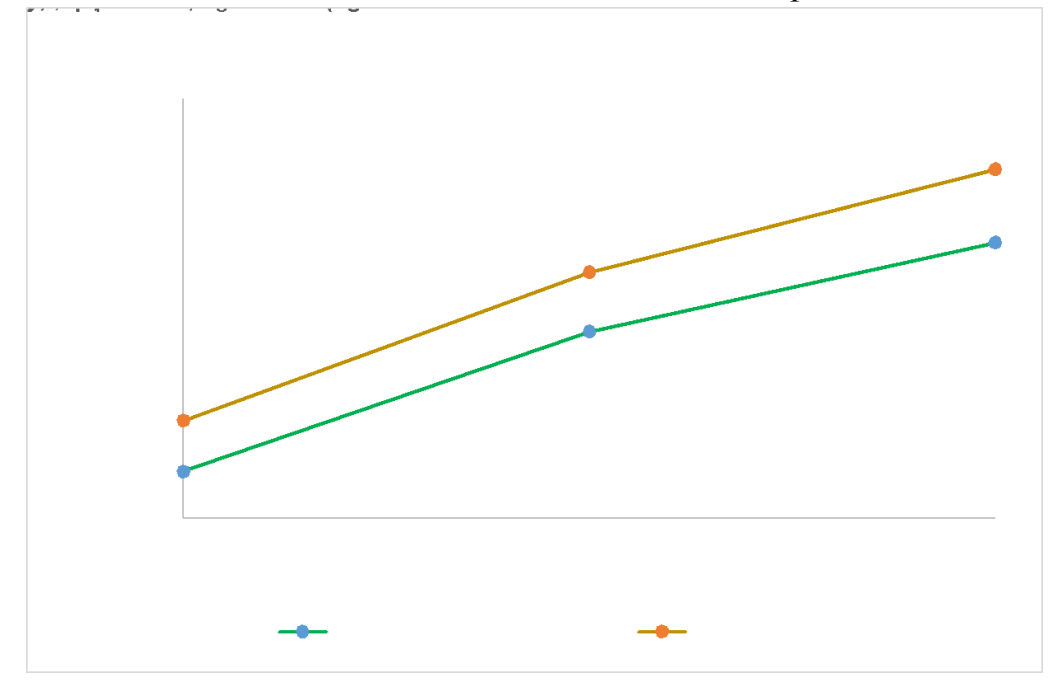

Fonte: Autor (2021)

\section{CONCLUSÕES}




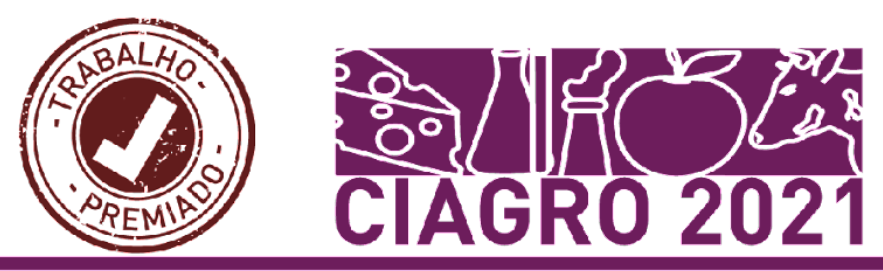

Nas condições em que foi conduzido o presente trabalho as braquiárias tiveram alta taxa de crescimento, mas a braquiária decumbens teve acúmulo de matéria seca em toda a parte aérea, de 54; 25 e 22\% maior que a braquiária brizantha, respectivamente aos 30, 45 e 60 dias.

\section{REFERÊNCIAS}

BRAZ, A. J. B. P. Fitomassa e decomposição de espécies de cobertura do solo e seus efeitos na resposta do feijoeiro e do trigo ao nitrogênio. 2003. 72p. Tese (Doutorado em Agronomia) - Escola de Agronomia e Engenharia de Alimentos, Universidade Federal de Goiás, Goiânia.

FERREIRA, D. F. Sisvar: a computer statistical analysis system. Ciência e Agrotecnologia, Lavras, v. 35, n. 6, p. 1039-1042, 2011.

OLIVEIRA, G. C. B. et al. Produção e composição química da braquiária ruziziensis cultivada após a colheita do milho de primeira safra. In: VI Simpósio Nacional de Bovinocultura de Leite. p 253 - 256. Universidade Federal de Viçosa. 2017.

OLIVEIRA, M. A. et al. Análise de crescimento do capim-bermuda 'Tifton 85' (Cynodon spp.) Revista Brasileira de Zootecnia, v. 29, n.6, p.:1930-1938, 2000 (Suplemento 1).

OLIVEIRA, M. W. et al. Mineral Nutrition and Fertilization of Sugarcane. In: Alexandre Bosco de Oliveira. (Org.). Sugarcane - Technology and Research. 1ed. Londres: INTECH Open Science, v. 1, p. 169-191, 2018.

PACHECO, L. P. et al. Ciclagem de nutrientes por plantas de cobertura e produtividade de soja e arroz em plantio direto. Pesquisa Agropecuária Brasileira, v.48, n.9, p.1228-1236. 2013.

PORTES, T. A. et al. Análise de crescimento de uma cultivar de braquiária em cultivo solteiro e consorciado com cereais. Pesquisa Agropecuária Brasileira, Brasília, DF, v.35, n.7., p. 1349-1358, 2000.

SOUZA, M. T. C. Seleção de cultivares de forrageiras para o agreste Alagoano. 2010. 53p. Dissertação (Mestrado em Zootecnia) - Centro de Ciências Agrárias, Universidade Federal de Alagoas, Rio Largo, Alagoas. 


\title{
CAPÍTULO 16: A INSERÇÃO DA MANTA DE CARNEIRO NA AGROINDÚSTRIA DE PEQUENO PORTE: UM RELATO DE EXPERIÊNCIA
}

\section{CAPÍTULO 16: EL INSERTO DE LA MANTA DE OVEJAS EN LA PEQUEÑA AGROINDUSTRIA: UN INFORME DE EXPERIENCIA}

\section{CHAPTER 16: THE INSERT OF THE SHEEP BLANKET IN THE SMALL AGROINDUSTRY: AN EXPERIENCE REPORT}

\begin{abstract}
Francisca Giselle da Cruz; ; João Paulo Arcelino do Rêgo²; Priscila Izidro de Figueirêdo ${ }^{3}$; Wagner Pessanha Tamy ${ }^{4}$; Alfredo Tavares Fernandez ${ }^{5}$
\end{abstract}

\section{INTRODUÇÃO}

\section{DOI: https://doi.org/10.31692/978-65-88970-19-5.237-241}

A manta de carneiro pode ser conceituada como um produto cárneo salgado, proveniente da desossa e manteação de carcaças ovinas e caprinas inteiras, submetida às etapas de salga seca e secagem. O sal e a carne são os únicos ingredientes utilizados para obtenção da manta. O que ocorre basicamente na secagem é a difusão da umidade do interior para o exterior da carne e a difusão do sal na carne, com consequente diminuição da umidade do produto (COSTA et al., 2010).

A discussão sobre a dificuldade de acesso de agricultoras(es) familiares, representantes da agroindústria rural de pequeno porte, ao mercado de produtos de origem animal não é nova (LOPES et al., 2017). A agroindustrialização e o acesso aos mercados fazem parte dos grandes desafios enfrentados pela agricultura familiar. As famílias que comercializam regularmente sua produção estão em sua maioria submetidas às cadeias produtivas dominadas pelas grandes agroindústrias (PREZZOTO, 2016).

Vale a pena ressaltar que, nos estabelecimentos da Agricultura Familiar, a população ocupada se reduziu em 2,166 milhões de pessoas. No entanto, nos estabelecimentos que não caracterizados dessa forma, a oferta de postos de trabalho seguiu um rumo oposto: de 2006 para 2017, a população ocupada nesse tipo de estabelecimentos ganhou mais 702,9 mil trabalhadores. No Censo Agropecuário de 2017, 3.897 .408 estabelecimentos atenderam aos critérios e foram classificados como agricultura familiar, o que representa $77 \%$ dos

\footnotetext{
${ }^{1}$ Aluna do curso de Especialização em Produção animal, higiene e tecnologia de POA, UFF, franciscagiselle@id.uff.br; ${ }^{2}$ Professor do IFCE campus Boa Viagem, joaopaulo.rego@gmail.com; ${ }^{3}$ Aluna do curso de Doutorado em Biociência Animal da UFRPE, priscila.izoot@gmail.com; ${ }^{4}$ Professor da UFF, Co-orientador, wagnertamy@id.uff.br; ${ }^{5}$ Professor da UFF, Orientador, afernandez@id.uff.br
} 


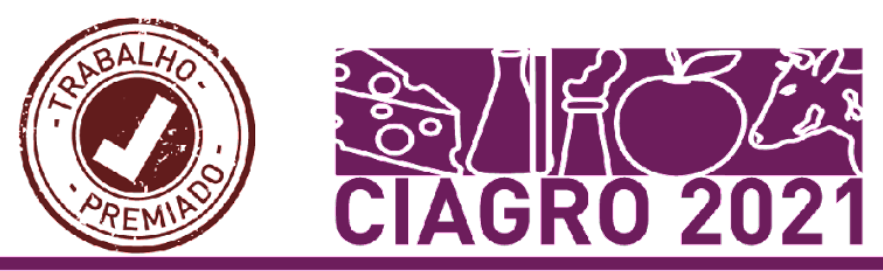

estabelecimentos agropecuários levantados pelo censo. Ocupavam uma área de 80,9 milhões de hectares, ou seja, $23 \%$ da área total dos estabelecimentos agropecuários brasileiros. Nos estabelecimentos classificados como de agricultura familiar o total de pessoas ocupadas em 30 de setembro de 2017 foi de 10,1 milhões de pessoas; 67\% do total, nestes estabelecimentos a média de pessoas ocupadas era de 2,6. A agricultura familiar foi responsável por 23\% do valor total da produção dos estabelecimentos (IBGE, 2019).

Diante do exposto, o presente trabalho objetivou relatar um relato de experiência, oriundo de uma oficina (4h/a) realizada no evento de extensão Agri \& Pec Cariri, em outubro de 2019, realizada na seção de agroindústria do Instituto de Educação, Ciência e Tecnologia do Ceará, campus Crato, sobre a obtenção da manta de carneiro e a inserção da mesma para agoindústria de pequeno porte.

\section{METODOLOGIA}

Uma oficina (4h/a) foi realizada sobre a obtenção da manta de carneiro, prática tradicional, cultural e bastante realizada na Região dos Inhamuns, CE e em Petrolina-PE. As seguintes problemáticas foram levantadas e discutidas: Como efetivar a inserção da manta de carneiro, na agroindústria de pequeno porte? Como a realização desta prática pode auxiliar na construção do conhecimento para o pequeno agricultor?

O presente estudo foi de natureza qualitativa e descritiva, seguindo a proposta de Marconi e Lakatos (2013). Vale elucidar que este trabalho foi fundamentado na elaboração do relato de experiência de uma oficina, proferida no evento de extensão Agri \& Pec Cariri, na seção de agroindústria do IFCE campus Crato-CE, em outubro de 2019, sobre a obtenção da manta de carneiro. Nesse sentido, a proposta deste estudo em repassar a prática de elaboração da manta de carneiro foi efetiva, envolvendo públicos-alvo interno e externo às atividades acadêmicas do IFCE campus Crato, totalizando em 20 participantes.

\section{RELATO DE EXPERIÊNCIA}

Os participanete tiveram a oportunidade em acompanhar a oficina, proferida pelo professor Dr. João Paulo. Na oportunidade, o rendimento tecnológico foi calculado, pela diferença de peso $(\mathrm{kg})$ da carcaça ovina in natura e resfriada $\left(4^{\circ} \mathrm{C} / 24 \mathrm{~h}\right.$ após o abate), com o peso $(\mathrm{kg})$ da carcaça manteada, posteriormente adicionada de tempero seco, composto de sal comum, alho desidratado em pó e pimenta do reino em pó, aplicados diretamente sobre a manta, à gosto, assim como o vinho tinto doce. Houve uma redução de $6 \mathrm{~kg}$, em relação ao 


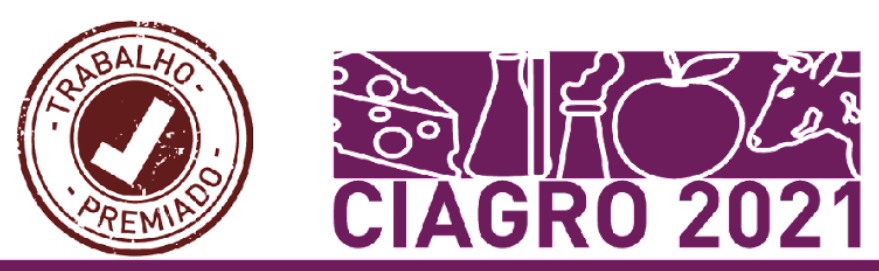

peso da carcaça in natura $(18 \mathrm{~kg})$ e da manta obtida desossada $(12 \mathrm{~kg})$. Cabe ressaltar, que a manta ovina é um produto típico da região Nordeste, amplamente consumido, sendo processado a partir da desossa, salga e secagem de carcaças inteiras de ovinos ou caprinos, recebendo esta denominação pela aparência final de uma manta ou lençol (FÉLIX et al., 2011).

De acordo com Costa et al. (2010) os rendimentos das mantas após a desossa inicial das carcaças de animais adultos (de 13 a 24 e de 25 a 36 meses de idade) são similares, com valores de 74,8 e $75,1 \%$, enquanto os das mantas provenientes de carcaças de animais mais jovens alcançam em média 71,5\%. Estes valores são atribuídos às maiores quantidades de tecidos musculares e adiposos nas carcaças de animais com maiores faixas etárias, representadas, em grande parte, por carcaças originadas de fêmeas adultas.

A figura 1 apresenta a obtenção da manta de carneiro.

Figura 01: Obtenção da manta de carneiro

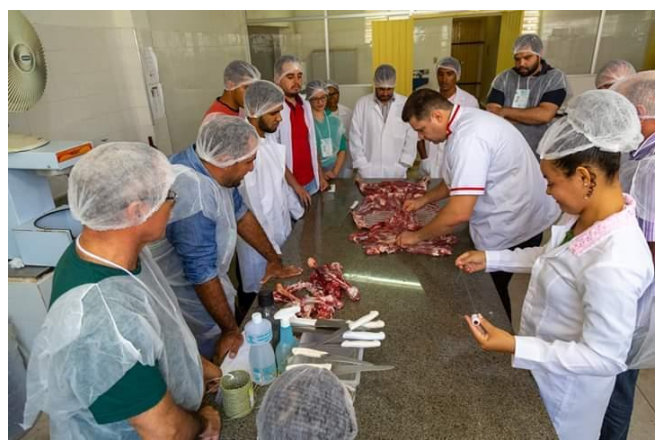

Fonte: Própria (2019).

Como efetivar a inserção da manta de carneiro, na agroindústria de pequeno porte? Como a realização desta prática pode auxiliar na construção do conhecimento para o pequeno agricultor? Então, para as pequenas agroindústrias, a importância da implantação do Sistema Unificado de Atenção à Sanidade Agropecuária, SUASA é a facilitação da inserção dos produtos no mercado formal (local, regional e nacional). Este é um importante aspecto, pois possibilita a comercialização dos produtos em todo o território nacional, quando inspecionados por qualquer uma das instâncias do SUASA pelos municípios, estados, Distrito Federal ou União. Vale destacar mesmo que, a agroindústria de pequeno porte solicite a adesão de estados e municípios ao Sistema Brasileiro de Inspeção de Produtos de Origem Animal, SISBI/SUASA, os agricultores e agricultoras familiares devem registrar a agroindústria em um dos serviços de inspeção municipal ou estadual, SIM ou SIE, por se tratar de um produto de origem animal, a manta de carneiro e consequentemente obter o selo 
ARTE (PREZZOTO, 2016).

Contudo, a recém publicada Instrução Normativa ${ }^{\circ} 61$, de 16 de novembro de 2020 do Ministério da Agricultura, Pecuária e Abastecimento, MAPA que entrou em vigor desde $1^{\circ}$ de dezembro de 2020, que resolve estabelecer, em todo o território nacional, o Regulamento para enquadramento dos produtos cárneos e artesanais, necessário à concessão do Selo ARTE, as exigências de Boas Práticas Agropecuárias e de Fabricação que são aquelas previstas nos programas de saúde animal e do Serviço de Inspeção Oficial (BRASIL, 2020).

Contudo, a implantação de pequenas agroindústrias é uma das alternativas econômicas para a permanência dos agricultores e agricultoras familiares no meio rural. Para eles, a industrialização dos produtos agropecuários é um grande desafio, mas não se constitui em uma novidade. Isto já faz parte da sua própria história e cultura, destinado ao consumo familiar e/ou a venda de excedentes (PREZZOTO, 2016). Nesse caso, cabe a nós, como corpo técnico difundir esta tecnologia de baixo custo e de fácil acesso, desde que, o manipulador de alimentos seja bem treinado, em Boas Práticas de Fabricação e elaboração da manta, além da instrução legal, por meio de certificação deste produto, perante a legislação sanitária vigente.

Houve uma excelente aceitação da oficina, por meio dos vinte participanetes, onde alguns deles já trabalham na área de cortes cárneos, da carne ovina, e também são agricultores familiares. Com isto, pode-se afirmar que a socialização e a troca dos conhecimentos colaboram para um movimento de contribuição para a vida profissional dos discentes e público externo, com o planejamento de atividades e com a reflexão na forma de registros que permitem a mobilização de saberes disciplinares, curriculares e pedagógicos, conforme destaca Tardif (2002), os quais podem fundamentar a formação do futuro profissional e contribuir significativamente na constituição de seus saberes.

\section{CONCLUSÕES}

A experiência de extensão vivenciada foi exitosa, estudos sobre rendimento da manta, obtenção dos cortes para esepeto poderão ser realizados em estudos futuros. A obtenção da manta ovina faz parte do cotidiano do nordestino, principalmente nos estados do Ceará e Pernambuco e, elucidar esta prática por meio da legalização da atividade, Inspeção sanitária e 
adessão ao selo ARTE é sem dúvidas, uma tarefa que se faz necessária ser conduzida por nós, técnicos da área, para que assim, a agroindústria de pequeno porte possa atuar com excelência, qualidade e segurança dos alimentos de origem animal elaborados.

\section{REFERÊNCIAS}

BRASIL, Ministério da Agricultura, Pecuária e Abastecimento. Instrução Normativa ${ }^{\circ} 61$, de 16 de novembro de 2020. Resolve estabelecer, em todo o território nacional, o Regulamento para enquadramento dos produtos cárneos e artesanais, necessário à concessão do selo ARTE, na forma desta Instrução Normativa. Diário Oficial [da] República Federativa do Brasil, Brasília, DF, p. 147, 18 nov. Seção 1. 2020.

COSTA, R. G.; MADRUGA, M. S.; MEDEIROS, G. R.; VOLTOLINI, T. V.; DUARTE, T. F.; PEDROSA, N. D. A. Manta de Petrolina: uma alternativa para agregar valor às carnes caprina e ovina. Petrolina: MCT/INSA, 2010. 109p.

FÉLIX, S. S. D. S.; FERNANDES, T. D.; ALVES, F. S. F., LÔBO, K. M.; GUERRA, I. C. D.; MADRUGA, M. S. Avaliação físico-química da manta ovina salgada do Tauá. $5^{\circ}$ Simpósio Internacional sobre Caprinos e Ovinos de Corte, $5^{\circ}$ SINCORTE. Feira Nacional do Agronegócio de Caprino-ovinocultura de corte - FENACORTE. João Pessoa-PB, 24 a 28 de outubro de 2011.

IBGE. Instituto Brasileiro de Geografia e Estatística. Censo Agro 2017: população ocupada nos estabelecimentos agropecuários cai 8,8\%. 2006. 25 de outubro de 2019. Disponível em:

https://agenciadenoticias.ibge.gov.br/agencia-sala-de-imprensa/2013-agencia-de-noticias/relea ses/25789-censo-agro-2017-populacao-ocupada-nos-estabelecimentos-agropecuarios-cai-8-8. Acesso em: 17 abr. 2021.

MARCONI, M. A; LAKATOS, E. M. Fundamentos de metodologia científica. $5^{\text {a }}$. ed. São Paulo: Editora Atlas, 2006.

PREZZOTO, L. L. Agroindústria da agricultura familiar: regularização e acesso ao mercado. Brasília, DF: CONTAG .60 p. 2016.

TARDIF, M. Saberes docentes e saberes docentes e formação profissional. Petrópolis:

Vozes, 2002. 


\title{
CAPÍTULO 17: PRODUÇÃO SUSTENTÁVEL DE ALIMENTOS UTILIZANDO ZEÓLITAS COMO FERTILIZANTES DE LIBERAÇÃO LENTA: UMA REVISÃO
}

\section{CAPÍTULO 17: PRODUCCIÓN DE ALIMENTOS SOSTENIBLE CON ZEOLIT COMO FERTILIZANTES DE LIBERACIÓN LENTA: UNA REVISIÓN}

\section{CHAPTER 17: SUSTAINABLE FOOD PRODUCTION USING ZEOLITE AS SLOW RELEASE FERTILIZERS: A REVIEW}

\begin{abstract}
Lisandro Simão ${ }^{1}$; Carlos Rafael Silva de Oliveira ${ }^{2}$; Luís Antonio Lourenço ${ }^{3}$; Afonso Henrique da Silva Júnior ${ }^{4}$; Éllen Francine Rodrigues ${ }^{5}$
\end{abstract}

DOI: https://doi.org/10.31692/978-65-88970-19-5.242-264

\section{RESUMO}

Os fertilizantes são intencionalmente adicionados no solo ou na superfície da planta com o objetivo de fornecer os nutrientes necessários durante sua vida e assim aumentar a produtividade. Os principais nutrientes utilizados na agricultura são nitrogênio, fósforo e potássio, sendo o conjunto destes macronutrientes chamados de N-P-K. O uso indiscriminado e de longo prazo de fertilizantes tem se tornado uma fonte relevante de poluição do solo, ar e água. O desequilíbrio entre as taxas de liberação dos nutrientes oriundos dos fertilizantes e as taxas de absorção pelas plantas, tornam o processo de fertilização do solo menos eficientes. Para resolver este problema, pode-se usar fertilizantes que tem em sua composição mecanismos que fazem com que os nutrientes adequados para as plantas sejam liberados de maneira compatível com suas demandas. Estes materiais são chamados de fertilizantes de liberação lenta. Uma revisão da literatura é realizada neste trabalho com o objetivo de avaliar as principais características dos fertilizantes de liberação lenta a base de materiais zeolíticos. As zeólitas são aluminosilicatos hidratados de metais alcalinos ou alcalinos terrosos e tem como principais aplicações o uso em tratamento de água e efluentes. As principais características das zeólitas são também abordadas buscando compreender suas propriedades potenciais para a aplicação proposta. Os benefícios em relação ao uso destes materiais na agricultura referem-se principalmente a sua notável seletividade catiônica e microporosidade. $\mathrm{O}$ uso de fertilizantes de liberação lenta a base de zeólitas se mostra uma possibilidade factível de utilização na agricultura, aumentando a eficiência e melhorando a sustentabilidade econômica, social e ambiental dos processos de produção agrícola.

Palavras-Chave: Fertilizantes, Liberação lenta, Zeólitas, Nutrientes, Produção sustentável.

\section{RESUMEN}

Los fertilizantes se agregan intencionalmente al suelo o a la superficie de la planta para proporcionar los nutrientes necesarios durante su vida y así aumentar la productividad. Los principales nutrientes

\footnotetext{
${ }^{1}$ Engenheiro Ambiental (Universidade do Extremo Sul Catarinense - UNESC), Doutor em Ciência e Engenharia de Materiais (Universidade Federal de Santa Catarina - UFSC), lisandrosimao@gmail.com;

${ }^{2}$ Engenheiro Têxtil (Universidade Estadual de Maringá - UEM), Doutor em Engenharia Química (UFSC), carlos.oliveira@ufsc.br;

${ }^{3}$ Curso de Engenharia Química, Instituto Latino-Americano de Tecnologia, Infraestrutura e Território (ILATIT), Universidade Federal da Integração Latino-Americana (UNILA), luis.lourenco@unila.edu.br;

${ }^{4}$ Engenheiro Agroindustrial-Agroquímico (Universidade Federal do Rio Grande - FURG), Estudante de mestrado em Engenharia Química (UFSC), afonso.silva@posgrad.ufsc.br;

${ }^{5}$ Engenheira de Alimentos (Universidade de Passo Fundo - UPF), Doutora em Engenharia Química

(UFSC), ellenfrodrigues@gmail.com;
} 


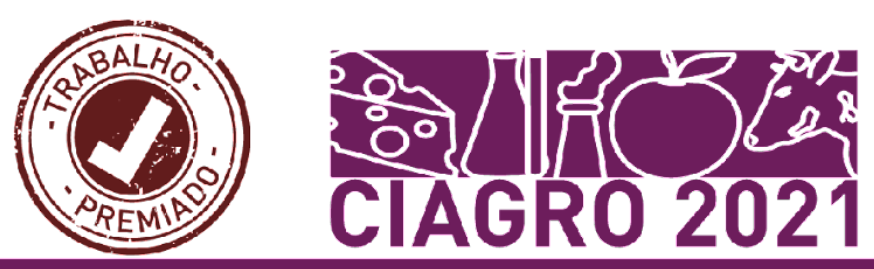

que se utilizan en la agricultura son el nitrógeno, el fósforo y el potasio, siendo el conjunto de estos macronutrientes el denominado N-P-K. El uso indiscriminado y prolongado de fertilizantes se ha convertido en una fuente importante de contaminación del suelo, el aire y el agua. El desequilibrio entre las tasas de liberación de nutrientes de los fertilizantes y las tasas de absorción por las plantas, hace que el proceso de fertilización del suelo sea menos eficiente. Para solucionar este problema, se pueden utilizar fertilizantes que tengan en su composición mecanismos que hagan que los nutrientes sean liberadas de forma compatible con las demandas de las plantas. Estos materiales se denominan fertilizantes de liberación lenta. En este trabajo se realiza una revisión de la literatura con el fin de evaluar las principales características de los fertilizantes de liberación lenta a base de materiales zeolíticos. Las zeolitas son aluminosilicatos hidratados de metales alcalinos o alcalinotérreos y tienen como aplicaciones principales el uso en el tratamiento de aguas y efluentes. Las principales características de las zeolitas también se abordan en un intento por comprender sus propiedades potenciales para la aplicación propuesta. Los beneficios en relación al uso de estos materiales en agricultura se refieren principalmente a su notable selectividad catiónica y microporosidad. El uso de fertilizantes de liberación lenta a base de zeolitas es una posibilidad factible de uso en agricultura, aumentando la eficiencia y mejorando la sostenibilidad económica, social y ambiental de los procesos productivos agrícolas.

Palabras Clave: Fertilizantes, Liberación lenta, Zeolitas, Nutrientes, Producción sustentable.

\begin{abstract}
Fertilizers are intentionally added to the soil or the surface of the plant to provide the necessary nutrients during its life and thus increase productivity. The main nutrients used in agriculture are nitrogen, phosphorus, and potassium, commonly called N-P-K. The indiscriminate and long-term use of fertilizers has become a relevant source of soil, air, and water pollution. The imbalance between the rates of release of nutrients from fertilizers and the absorption rates by plants makes the soil fertilization process less efficient. To solve this problem, you can use fertilizers that have in their composition mechanisms that make the nutrients suitable for the plant's demands. These materials are called slow-release fertilizers. A literature review is carried out in this work to evaluate the main characteristics of slow-release fertilizers based on zeolitic materials. Zeolites are hydrated aluminosilicates of alkaline or alkaline earth metals and have as main applications the use in water and effluent treatment. The main characteristics of zeolites are also addressed in an attempt to understand their potential properties for the proposed application. The benefits of the use of these materials in agriculture refer mainly to their remarkable cationic selectivity and microporosity. The use of slow-release fertilizers based on zeolites is a feasible possibility of use in agriculture, increasing efficiency and improving the economic, social, and environmental sustainability of agricultural production processes.
\end{abstract}

Keywords: Fertilizers, Slow release, Zeolites, Nutrients, Sustainable production. 


\section{FERTILIZANTES DE LIBERAÇÃO LENTA}

MATERIAIS ZEOLÍTICOS

USO DE MATERIAIS ZEOLÍTICOS COMO FERTILIZANTES

CONCLUSÕES

REFERÊNCIAS

\section{INTRODUÇÃO}

Com o crescimento da população ao longo dos anos, o setor agrícola está cada vez mais usando fertilizantes para aumentar a produtividade e consequente oferta de alimentos em todo o mundo (AZEEM et al., 2014). O uso excessivo de fertilizantes químicos na agricultura causa graves problemas ao meio ambiente pois apenas uma fração dos nutrientes é absorvida pelo solo e pelas plantas. O excesso de nutrientes presentes nos fertilizantes, tais como nitrogênio, fósforo e potássio, são normalmente lixiviados para os corpos d'água levando a eutrofização dos corpos hídricos. Em alguns casos, como do $\mathrm{N}$, pode-se ter perdas consideráveis pela volatilização para o ar (BANSIWAL et al., 2006; YUAN et al., 2017).

Sendo assim, há uma necessidade extrema de se mudar as práticas agronômicas, desenvolvendo fertilizantes amigáveis que facilitem a absorção máxima de nutrientes e consequentemente aumentem o rendimento das colheitas (LATEEF et al., 2016). Esta mudança de paradigma estaria coerente com as práticas de preservação ambiental, tornando o processo de produção de alimentos mais sustentável.

Neste cenário, a utilização de fertilizantes de liberação lenta tem sido estudada nos últimos anos para resolução dessa problemática econômica e ambiental do setor agrícola (LATEEF et al., 2016; PICKERING; MENZIES; HUNTER, 2002; SOUZA et al., 2018). Os fertilizantes de liberação lenta são materiais que em sua estrutura possuem mecanismos que retardam a liberação dos elementos nutricionais ao longo do tempo, melhorando a eficiência do fertilizante e da produção de alimentos, além de evitar a contaminação do solo, água e ar (YUAN et al., 2017).

As zeólitas são um grupo de minerais de ocorrência natural ou sintética que possuem estruturas cristalinas tridimensionais contendo em seu interior vazios e canais de tamanho molecular, sendo bastantes conhecidas por conta da sua alta capacidade de troca cationica (PICKERING; MENZIES; HUNTER, 2002) e utilização em diversos processos de remediação ambiental (LIU et al., 2016; VISA, 2016; ZHENG et al., 2019) e catálise (CHICA, 2013; HE et al., 2019; KHANDAN et al., 2015). 


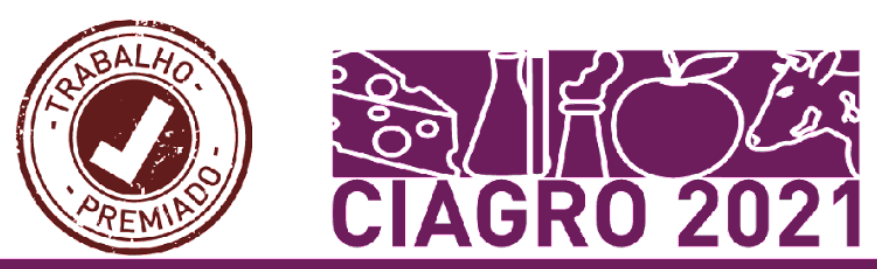

Muitos estudos tem sido realizados para aproveitar as características das zeólitas no desenvolvimento de fertilizantes com propriedades de liberação lenta (DWAIRI, 1998). Os benefícios em relação ao uso destes materiais na agricultura refere-se principalmente a sua notável seletividade catiônica e microporosidade (PARK et al., 2005), tornando-a ainda mais atrativa para a aplicação como fertilizantes. Em relação aos desafios, pode-se relatar a sua baixa capacidade de retenção de alguns nutrientes aniônicos, apesar de sua alta capacidade de troca iônica (BANSIWAL et al., 2006; PARK et al., 2005).

Neste trabalho, uma revisão da literatura é realizada para avaliar as principais características dos fertilizantes de liberação lenta a base de materiais zeolíticos. As principais características e propriedades das zeólitas são também abordadas buscando compreender suas propriedades potenciais para a aplicação proposta.

\section{FERTILIZANTES DE LIBERAÇÃO LENTA}

Os fertilizantes são um termo comum utilizado para os materiais que são intencionalmente adicionados no solo ou na superfície da planta com o objetivo de fornecer os nutrientes necessários no período de crescimento da cultura. São derivados de uma variedade de ingredientes naturais e materiais sintetizados, podendo estar na forma sólida ou líquida. Os fertilizantes comerciais usualmente utilizados na agricultura são nitrogênio $(\mathrm{N})$, fósforo $\left(\mathrm{P}_{2} \mathrm{O}_{5}\right)$ e potássio (K) (PURNOMO; SAPUTRA, 2021), sendo o conjuntos destes macronutrientes chamados de N-P-K. Estes fertilizantes podem ser adicionados no solo de maneira unitária utilizando apenas o nutriente de interesse, ou até mesmo de maneira conjunta, utilizando formulações mais complexas de fertilizantes contendo mais de um elemento na mistura (PURNOMO; SAPUTRA, 2021). A tabela 1 mostra os principais adubos simples utilizados para produção de outras formulações comerciais, sendo compostos principalmente pelos macronutrientes N-P-K.

Estes compostos nutricionais podem ser classificados de diferentes maneiras, podendo considerar o seu conteúdo nutricional, seu padrão de liberação e origem. Em relação a sua origem, podemos classificar os fertilizantes como orgânicos ou sintéticos. Os orgânicos são fabricados a partir de restos de organismos, enquanto que os sintéticos são fabricados a partir de gás natural ou minerais com processamentos específicos de acordo com o nutriente produzido (DIMKPA et al., 2020; PURNOMO; SAPUTRA, 2021).

Com o aumento das demandas por alimentos em todo o globo, é necessário o aumento 


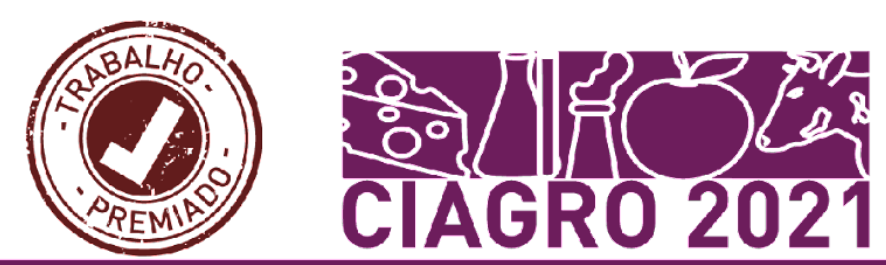

da produção agrícola para suprir as necessidades globais. Este aumento pode ser atingido minimizando as perdas por pragas e ervas daninhas ou utilizando agroquímicos e fertilizantes

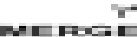

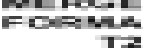
mais eficientes. Nesta linha de pensamento, os fertilizantes tem um papel importantíssimo no aumento da produção agrícola, mas aumentar o uso por si só pode não ser a melhor estratégia, já que durante a utilização há diversas perdas por processos como adsorção, degradação, escoamento e lixiviação. O desequilíbrio entre as taxas de liberação dos nutrientes oriundos dos fertilizantes e as taxas de absorção pelas raízes das plantas, tornam o processo de fertilização do solo menos eficientes, gerando custos para a produção de alimentos como um todo (BHARDWAJ et al., 2012; DIMKPA et al., 2020). Além disso, os autos índices de nutrientes desperdiçados aliado a sua alta solubilidade podem causar diversos problemas ao meio ambiente (BHARDWAJ et al., 2012; NOTARIO DEL PINO et al., 1995).

Tabela 01: Principais adubos simples utilizados em formulções comerciais

\begin{tabular}{ccc}
\hline Adubo & Nutriente & Teores minímos (\%) \\
Uréia & $\mathrm{N}$ & 44 \\
Nitrato de sódio & $\mathrm{N}$ & 15 \\
Nitrato de amônio & $\mathrm{N}$ & 32 \\
Sulfato de amônio & $\mathrm{N}$ & 20 \\
Nitrato de amônio e cálcio & $\mathrm{N}$ & 20 \\
& $\mathrm{Ca}$ & $2-8$ \\
& $\mathrm{Mg}$ & $1-5$ \\
Nitrato de cálcio & $\mathrm{N}$ & 14 \\
& $\mathrm{Ca}$ & $18-19$ \\
Superfosfato simples & $\mathrm{P}_{2} \mathrm{O}_{5}$ & 18 \\
& $\mathrm{~S}$ & $10-12$ \\
Superfosfato triplo & $\mathrm{P}_{2} \mathrm{O}_{5}$ & 41 \\
& $\mathrm{Ca}$ & $12-14$ \\
Monoamônio fosfato & $\mathrm{N}$ & 9 \\
& $\mathrm{P}_{2} \mathrm{O}_{5}$ & 48 \\
Diamônio fosfato & $\mathrm{N}$ & 16 \\
& $\mathrm{P}_{2} \mathrm{O}_{5}$ & 45 \\
Cloreto de potassio & $\mathrm{K}_{2} \mathrm{O}$ & 58 \\
Sulfato de potássio & $\mathrm{K}_{2} \mathrm{O}$ & 48 \\
Nitrato de potássio & $\mathrm{K}_{2} \mathrm{O}$ & 44 \\
& $\mathrm{~N}$ & 13 \\
\hline
\end{tabular}

Fonte: (BISSANI; MEURER; GIANELLO, 2021)

No caso do nitrogênio, um dos nutrientes mais importantes para o crescimento e desenvolvimento de diversas culturas agrícolas, seu uso está normalmente relacionado a grandes perdas após sua aplicação. Estas perdas resultam na maioria das vezes em impactos ao meio ambiente, tais como o aumento da produção de gases do efeito estufa devido a 


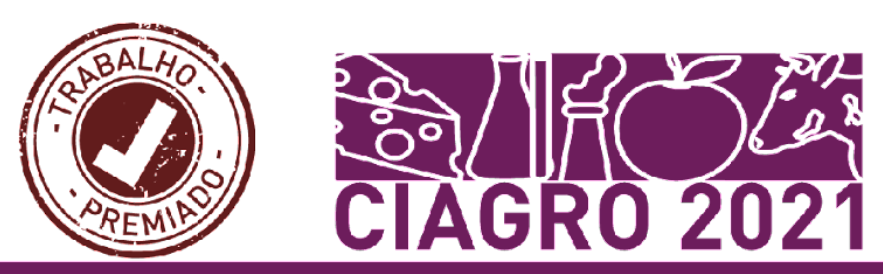

volatização de compostos como a amônia e óxido nitroso; e lixiviação de nitratos para o meio aquoso (DIMKPA et al., 2020). A contaminação das águas por nitratos é uma grande preocupação devido a sua toxicidade e efeitos nocivos no meio ambiente e saúde humana, tais como a síndrome do bebe azul, câncer, diabetes e danos ao fígado (BHARDWAJ et al., 2012). Para resolver este problema, pode-se usar fertilizantes que tem em sua composição mecanismos que fazem com que os nutrientes adequados para as plantas sejam liberados de maneira mais lenta e compatível com as demandas nutricionais das plantas (BHARDWAJ et al., 2012; LATEEF et al., 2016).

Alguns nutrientes são modificados quimicamente e estruturalmente buscando fornecer as plantas-alvo suprimentos constantes nos períodos mais necessários, ou seja, durante os picos de maior crescimento. Estes fertilizantes são comumente chamados de fertilizantes de liberação lenta (BHARDWAJ et al., 2012; LATEEF et al., 2016; PURNOMO; SAPUTRA, 2021).

Estes fertilizantes de liberação lenta possuem vantagens, tais como a capacidade de diminuir a taxa de perda, fornecendo nutrientes de forma sustentável, redução da frequência de aplicação e minimização dos potenciais efeitos negativos associados à sobre dosagem (PURNOMO; SAPUTRA, 2021) comentados anteriormente.

\section{MATERIAIS ZEOLÍTICOS}

As zeólitas são aluminosilicatos hidratados de metais alcalinos ou alcalinos terrosos (principalmente sódio, potássio, magnésio e cálcio) (LUZ, 1995; NOTARIO DEL PINO et al., 1995). Elas englobam variados minerais com características comuns e que podem ser naturais ou sintéticos. As zeólitas são normalmente estruturadas em redes cristalinas de tetraedros do tipo TO4, podendo o $\mathrm{T}$ ser $\mathrm{Si}, \mathrm{Al}, \mathrm{B}, \mathrm{Ge}, \mathrm{Fe}, \mathrm{P}, \mathrm{Co}$, dentre outros. Sua fórmula química é representada pela equação 1 , onde $\mathrm{M}$ é o cátion de valência $\mathrm{n}, \mathrm{m}$ é o número de moléculas de água e x+y é o número de tetraedros por célula unitária (LUZ, 1995).

$$
M_{\frac{x}{n}}\left[\left(\mathrm{AlO}_{2}\right)_{x}\left(\mathrm{SiO}_{2}\right)_{y}\right] \cdot \mathrm{mH}_{2} \mathrm{O} \text { (Equação 1) }
$$

A estrutura das zeólitas possui canais e cavidades interconectadas, onde encontra-se íons de compensação, moléculas de água ou outros sais (LUZ, 1995; NOTARIO DEL PINO 


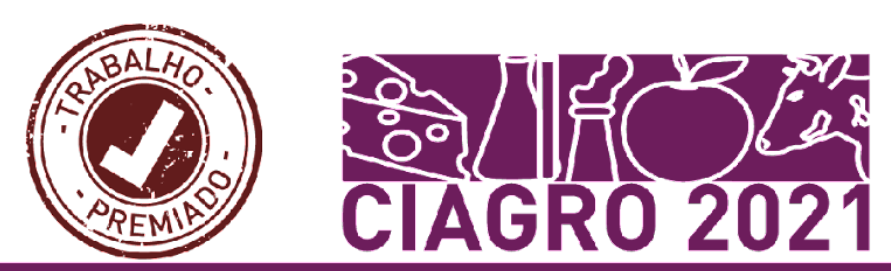

et al., 1995). Estas características de microporosidade fazem com que estes materiais possuam uma grande área de superfície específica interna quando comparado a sua superfície externa. Psere

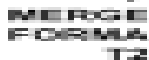
A porosidade desses materiais permitem ainda a transferência de matéria, limitado pelo tamanho dos poros (LUZ, 1995).

Estes materiais possuem como principais propriedades físico-químicas a superfície específica; volume de vazios; índice de refração; massa específica; capacidade de adsorção de gás (YAN et al., 2019), capacidade de troca catiônica; alto grau de hidratação; baixa densidade; condutividade elétrica; e propriedades catalíticas (CHICA, 2013; LUZ, 1995).

Os principais usos das zeólitas (Figura 1) são na construção civil: como blocos de rocha, pozolanas e agregados leves (LUZ, 1995; RAMEZANIANPOUR et al., 2015; TRAN et al., 2019); tratamento de água e efluentes (LIU et al., 2016); catálise (HU et al., 2021); Aplicações biomédicas (SERATI-NOURI et al., 2020), agentes microbianos (DUTTA; WANG, 2019), tratamento de resíduos radioativos (JIMÉNEZ-REYES; ALMAZÁN-SÁNCHEZ; SOLACHE-RÍOS, 2021), captura de $\mathrm{CO}_{2}$ (KUMAR; SRIVASTAVA; KOH, 2020), carga na indústria de papel; detergentes, nutrição animal e na agricultura (LUZ, 1995).

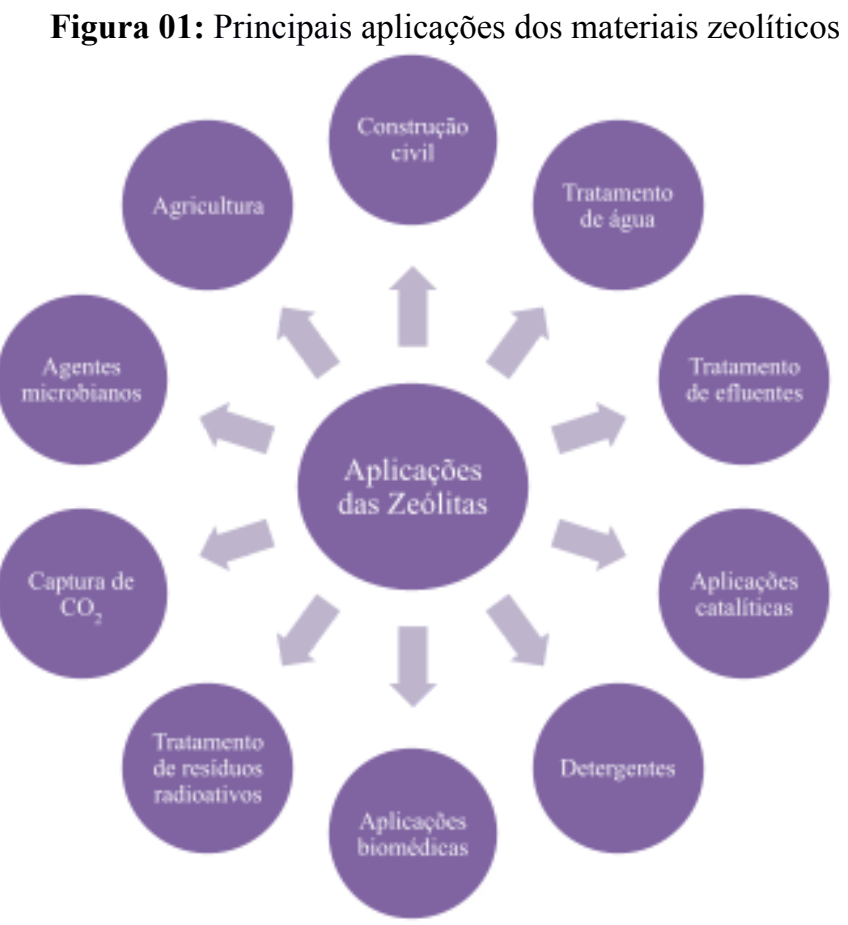

Fonte: Dos autores (2021).

$\mathrm{Na}$ agricultura, o Japão vem usando a clinoptilolita no melhoramento da qualidade do solo aproveitando a capacidade de troca catiônica desses materiais e favorecendo a retenção 


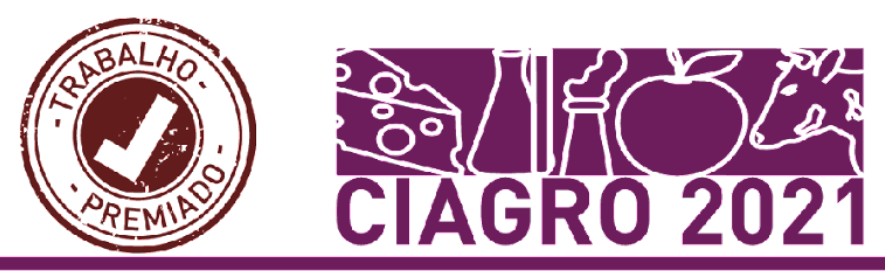

de nutrientes pelo solo, tais como potássio e nitrogênio. Sua alta capacidade de troca catiônica também faz das zeólitas bons suportes para herbicidas e fungicidas (LUZ, 1995). O uso de zeólitas na agricultura pode ter outras funções importantes, tais como boa capacidade de retenção de água, aumento da disponibilidade de nutrientes e melhora das propriedades físicas, químicas e biológicas do solo (KHAN et al., 2021).

Recentemente, estudos tem avaliado a sua utilização como fertilizantes de liberação lenta, assunto debatido com profundidade no tópico subsequente. Suas propriedades de alta área de superfície específica, capacidade de troca catiônica e microporosidade são algumas das motivações dos diversos estudos presentes na literatura.

\section{USO DE MATERIAIS ZEOLÍTICOS COMO FERTILIZANTES}

Neste tópico uma revisão da literatura sobre os principais trabalhos de fertilizantes de liberação lenta oriundos de materiais zeolíticos (Quadro 01) são relatados buscando compreender as potencialidades, desafios e principais vantagens do uso das zeólitas na agricultura.

O uso indiscriminado e de longo prazo de fertilizantes fosfatados tem se tornado uma fonte relevante de poluição do solo e água. A recuperação do fósforo em recursos hídricos pode, além de resolver o problema da eutrofização, gerar oportunidade de se obter novas fontes secundárias deste fertilizante. Da mesma forma, a liberação lenta de potássio em zeólitas, quando comparado aos fertilizantes tradicionais, evitam as perdas por lixiviação, além de permitir a retenção de outros nutrientes (principalmente nitrogênio) em sua estrutura porosa. Estes fatores aumentam a absorção das plantas e consequentemente aumentam a produtividade do solo, trazendo benefícios tanto ambientais quanto econômicos para o processo, já que reduzem as taxas de aplicação de fertilizantes químicos no solo. Neste sentido, a síntese de zeólitas de K contendo outros nutrientes essenciais (tais como fósforo) se torna um interesse chave para o agronegócio (HERMASSI et al., 2020). Nesta linha de pensamento, Hermassi et al. (2020) investigou a sorção de fosfato por K-zeólitas sintetizadas a partir de cinzas volantes por conversão hidrotérmica. Os resultados obtidos mostraram que as zeólitas sintetizadas são materiais promissores para a recuperação de íons de $\mathrm{P}$ de efluentes sanitários. Por conseguinte, as zeólitas contendo fósforo se tornam um potencial material fertilizante para ser utilizado na recuperação de áreas degradadas (HERMASSI et al., 2020). 


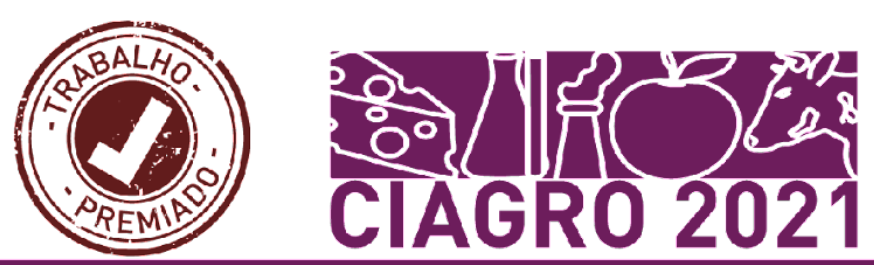

O uso de zeólitas $\mathrm{F}$ pode fornecer além do $\mathrm{K}$ ao solo, outras funções importantes, tais como correção de acidez, retenção de água e de outros nutrientes. Yuan et al. (2017) investigou a influência da concentração de $\mathrm{KOH}$ e do tempo de reação na síntese de zeólitas $\mathrm{F}$ a partir de feldspatos. Os resultados de DRX indicaram a presença de zeólita K-G $\left(\mathrm{K}_{2} \mathrm{Al}_{2} \mathrm{SiO}_{6} \cdot \mathrm{H}_{2} \mathrm{O}\right)$ com estrutura hexagonal quando utilizado concentrações de $2 \mathrm{~mol} / \mathrm{kg}$ de $\mathrm{KOH}$; e de zeólitas $\mathrm{F}\left(\mathrm{KAlSiO}_{4} \cdot 1,5 \mathrm{H}_{2} \mathrm{O}\right)$ com estrutura tetragonal quando utilizados concentrações de 4-5 mol $/ \mathrm{kg}$. Os resultados de liberação de nutrientes, demonstram que após 42 d houve uma liberação de $68,97 \%$ do potássio presente nas zeólitas formadas (YUAN et al., 2017).

Li et al. (2014) realizou uma síntese de zeólitas merlinoita usando cinzas volantes e $\mathrm{KOH}$ para uso como fertilizantes de liberação lenta em minas degradadas e plantações com alta demanda de nutrientes, como na cultura do girassol. Além dos benefícios da aplicação do material obtido, a valorização de um resíduo no processo, aumentou seu valor econômico e reduziu os custos ambientais e econômicos do envio destes resíduos para aterros. Os resultados obtidos mostraram que zeólitas merlinoita de alta qualidade (CEC de $160 \mathrm{cmol} / \mathrm{kg}$ ) foi produzida utilizando soluções de $\mathrm{KOH}$ de $5 \mathrm{M}$, temperatura de ativação de $150{ }^{\circ} \mathrm{C}$, tempo de ativação de $8 \mathrm{~h}$ e razão $\mathrm{KOH} /$ cinza volante de $2 \mathrm{~L} / \mathrm{kg}$. Além disso, as conclusões dos autores demonstraram que as zeólitas produzidas são fertilizantes de K com liberação lenta eficientes, podendo ser utilizado em plantações que requerem alto teor de reposição nutricional e solos pobres de áreas degradadas (LI et al., 2014).

Quadro 01: Principais zeólitas utilizadas como fertilizantes de liberação lenta.

\begin{tabular}{|c|c|c|}
\hline Zeólita utilizada & Nutrientes de interesse & Referência \\
\hline K-Zeólitas & $\mathrm{K} \mathrm{e} \mathrm{P}$ & Hermassi et al. (2020) \\
\hline Zeólita F & $\mathrm{K}$ & Yuan et al. (2017) \\
\hline zeólita K-G & $\mathrm{K}$ & Yuan et al. (2017) \\
\hline Merlinoita & $\mathrm{K}$ & Li et al. (2014) \\
\hline Filipsita & $\mathrm{K} \mathrm{e} \mathrm{P}$ & Notario Del Pino et al. (1995) \\
\hline Clinoptilolita & $\mathrm{N}$ & Souza et al. (2018) \\
\hline zeólitas Na-P & $\mathrm{N}$ & Park et al. (2005) \\
\hline Clinoptilolita & $\mathrm{N}$ & Bhardwaj et al. (2012) \\
\hline Zeólita A & $\mathrm{P}$ & Bansiwal et al. (2006) \\
\hline Clinoptilolita & $\mathrm{P}, \mathrm{N} \mathrm{e} \mathrm{K}$ & Pickering et al. (2002) \\
\hline
\end{tabular}

Fonte: Elaborado pelos autores a partir de várias fontes (2021).

Notario Del Pino et al. (1995) fez um estudo comparativo de liberação de P e K utilizando fertilizantes a base de zeólitas e $\mathrm{KH}_{2} \mathrm{PO}_{4}$ (fertilizante comercial) em um reator de percolação com fluxo de solução constante. A zeólita Filipsita de Tenerife foi utilizada como 


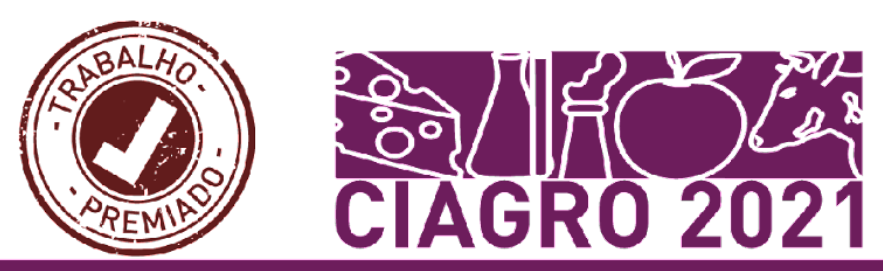

matriz para preparar os fertilizantes de $\mathrm{P}$ e K com liberação controlada. Os resultados mostraram que os fertilizantes a base de zeólitas fornecem $\mathrm{P}$ ao sistema após mais de 70 dias de percolação contínua, enquanto que o $\mathrm{P}$ do $\mathrm{KH}_{2} \mathrm{PO}_{4}$ se esgota após 50 dias. As conclusões dos autores foram que os fertilizantes de zeólitas filipsita se mostraram promissores para liberação controlada de potássio (NOTARIO DEL PINO et al., 1995).

O nitrogênio é um nutriente essencial e limitante para o crescimento das plantas, principalmente para a cultura do arroz. A ureia, fertilizante comumente utilizado para fornecimento de $\mathrm{N}$, é altamente solúvel e rapidamente convertida em amônio $\left(\mathrm{NH}_{4}^{+}\right)$, o qual pode ser perdido por escoamento, lixiviação e volatização (AZEEM et al., 2014; MAGHSOODI et al., 2020; SOUZA et al., 2018). Os métodos atuais de fertilização dos solos reduzem a eficiência do uso do nitrogênio pelas plantas, limitando seu crescimento e contribuindo para a poluição ambiental no que se refere as emissões de gases perigosos e eutrofização dos recursos hídricos (AZEEM et al., 2014). Uma alternativa para reduzir as perdas de nitrogênio é desenvolver os fertilizantes de liberação lenta, onde a ureia é revestida por espécies inertes e biodegradáveis, criando uma barreira física ao redor dos grânulos e controlando a liberação do nitrogênio pela difusão da ureia pelo carreador, aumentando o tempo de liberação de nutrientes quando comparado a ureia tradicional (AZEEM et al., 2014; COSTA et al., 2013; SOUZA et al., 2018).

Nesse sentido, Maghsoodi (2020) investigou a liberação de nitrogênio (N) utilizando diferentes matrizes de fertilizantes, tais como ureia biochar, hidrocarburante, zeólitas e nanohíbridos de ureia-hidroxiapatita. Os resultados mostraram que as zeólitas são fertilizantes de liberação lenta eficientes, reduzindo a liberação de ureia em 9 vezes quando comparado ao padrão utilizado (MAGHSOODI et al., 2020). Souza et al. (2018) desenvolveu um fertilizante a base de ureia e zeólita clinoptilolita em comprimidos para uso como fertilizantes de liberação lenta. A possibilidade de interação com íons amônia, aliado a alta troca catiônica das zeólitas clinoptilolita foram as motivações para desenvolver o estudo. Os resultados mostraram que não houve interações químicas entre os componentes da formulação, mas as formulações foram capazes de diminuir em até 53\% a quantidade de amônia volatilizada (SOUZA et al., 2018).

Os estudos sobre zeólitas como fertilizantes de liberação lenta são normalmente limitados aos nutrientes em formas catiônicas, a citar, $\mathrm{NH}_{4}^{+}$e $\mathrm{K}^{+}$. No caso de nutrientes aniônicos, tais como $\mathrm{NO}_{3}{ }^{-}$e $\mathrm{PO}_{4}{ }^{3-}$ o carregamento em materiais zeoliticos não modificados são insignificantes. Estudos e pesquisas que deixem estes materiais com afinidades por ânions se tornam importantes para uso como fertilizantes de liberação lenta (BANSIWAL et al., 2006; 


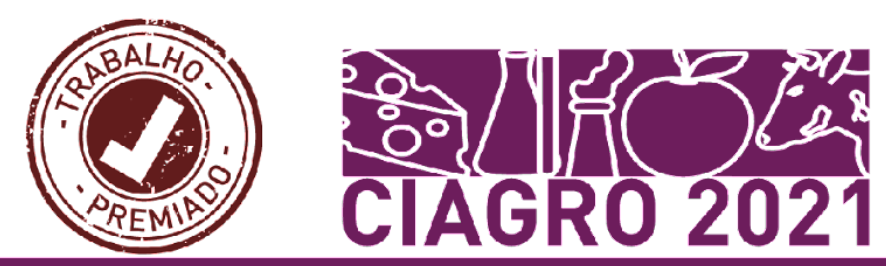

BHARDWAJ et al., 2012).

Alternativas para aumentar a proporção dos nutrientes nas zeólitas tem sido estudada, como por exemplo, a formação de sais estáveis nos poros da zeólita (oclusão de sal). Esta técnica pode inclusive exibir propriedades de liberação lenta dos nutrientes. Park et al. (2005) avaliou zeólitas Na-P ocluídas por sais de $\mathrm{NH}_{4} \mathrm{NO}_{3}(\mathrm{~N}-\mathrm{NaP})$ usando uma solução simulada de solo e água deionizada como soluções de lixiviação. A solução de solo afetou a liberação de $\mathrm{NH}_{4}^{+}$e $\mathrm{NO}_{3}^{-}$diferentemente, enquanto a água deionizada liberou quase os mesmos equivalentes desses íons. Isso indica claramente que a liberação de íons do zeólita ocluído por sal envolve duas reações diferentes, troca catiônica e dissolução. Os resultados apresentados indicam que as zeólitas ocluídos por $\mathrm{NH}_{4} \mathrm{NO}_{3}$ podem ser utilizadas como fertilizantes de liberação lenta e aumentar a sua eficiência de fertilização quando utilizadas no solo (PARK et al., 2005).

As propriedades aniônicas podem ser transmitidas para superfície zeolítica usando surfactantes. Bhardwaj et al. (2012) sintetizou zeólitas clinoptilolita e modificou sua estrutura utilizando o surfactante brometo de hexadeciltrimetilamônio (HDTMAB) e brometo de dioctadecildimetilamônio (DODMAB). Os produtos obtidos foram primeiramente utilizados para remoção de nitratos e posteriormente para uso como fertilizantes de liberação lenta. Os resultados mostraram uma capacidade de adsorção muito maior do que os materiais não modificados: $30,58 \mathrm{mg} / \mathrm{g}$ para clinoptilolita sem carregamento, $75,19 \mathrm{mg} / \mathrm{g}$ para clinoptilolita carregada com DODMAB e 125,00 mg/g para clinoptilolita carregada com HDTMAB. Por fim, os testes de liberação lenta mostraram que ainda há uma liberação de $\mathrm{NO}_{3}{ }^{-}$após 15-20 dias nos estudos de lixiviação (BHARDWAJ et al., 2012).

Bansiwal et al. (2006) investigou a viabilidade do uso de zeólitas modificadas com surfactante como fertilizantes de liberação lenta de P. A zeólita A foi modificada usando brometo de hexadeciltrimetilamónio, um tensoativo catiônico que aumenta a capacidade de reter ânions fosfatos. Os resultados mostraram que o P presente no surfactante ficou disponível após $1080 \mathrm{~h}$ de percolação contínua, enquanto que o $\mathrm{P}$ provindo do $\mathrm{KH}_{2} \mathrm{PO}_{4}$ ficou disponível até 264 h. Por fim, pôde-se concluir que o produto obtido é um bom sorvente para íons fosfatos, tendo uma liberação lenta de P durantes as condições testadas (BANSIWAL et al., 2006).

Neste estudo, Pickering et al. (2002), avaliou o uso de zeólitas clinoptilolita juntamente com rochas fosfáticas com objetivo de aumentar a absorção de P por girassóis. A combinação das zeólita e da rocha fosfática atuou como um fertilizante de troca, trocando $\mathrm{Ca}^{2+}$ nas zeólitas em resposta à absorção de nutrientes catiônicos pela planta $\left(\mathrm{NH}_{4}^{+}\right.$ou $\left.\mathrm{K}^{+}\right)$, 
aumentando assim a dissolução da rocha fosfática (PICKERING; MENZIES; HUNTER, 2002).

\section{CONCLUSÕES}

O aumento da população mundial e consequentemente, o aumento do consumo de alimentos faz com que as técnicas agrícolas se atualizem para suprir as demandas globais em relação a produção de alimentos.

O uso excessivo de fertilizantes tradicionais, tornam-se ineficazes para suprir estas demandas, já que as taxas de absorção das plantas não consomem as quantidades utilizadas, trazendo desperdícios e principalmente impactos ambientais ao solo, ar e água.

O uso de fertilizantes de liberação lenta a base de zeólitas se mostram uma possibilidade factível de utilização na agricultura com os objetivos de aumentar a eficiência e melhorar a sustentabilidade econômica, social e ambiental dos processos de produção agrícola.

\section{REFERÊNCIAS}

AZEEM, B.; KUSHAARI, K.; MAN, Z. B.; BASIT, A.; THANH, T. H. Review on materials \&amp; methods to produce controlled release coated urea fertilizer. Journal of Controlled Release, v. 181, p. 11-21, maio 2014.

BANSIWAL, A. K.; RAYALU, S. S.; LABHASETWAR, N. K.; JUWARKAR, A. A.; DEVOTTA, S. Surfactant-Modified Zeolite as a Slow Release Fertilizer for Phosphorus. Journal of Agricultural and Food Chemistry, v. 54, n. 13, p. 4773-4779, jun. 2006.

BHARDWAJ, D.; SHARMA, M.; SHARMA, P.; TOMAR, R. Synthesis and surfactant modification of clinoptilolite and montmorillonite for the removal of nitrate and preparation of slow release nitrogen fertilizer. Journal of Hazardous Materials, v. 227-228, p. 292-300, ago. 2012.

BISSANI, C. A.; MEURER, E. J.; GIANELLO, C. Fertilizantes e Formulações

Comerciais. Disponível em: $<$ https://www.ufrgs.br/agronomia/materiais/[000456916] p. 239-2490001.pdf>.

CHICA, A. Zeolites: Promised Materials for the Sustainable Production of Hydrogen. ISRN Chemical Engineering, v. 2013, p. 1-19, 31 jan. 2013.

COSTA, M. M. E.; CABRAL-ALBUQUERQUE, E. C. M.; ALVES, T. L. M.; PINTO, J. C.; FIALHO, R. L. Use of Polyhydroxybutyrate and Ethyl Cellulose for Coating of Urea 


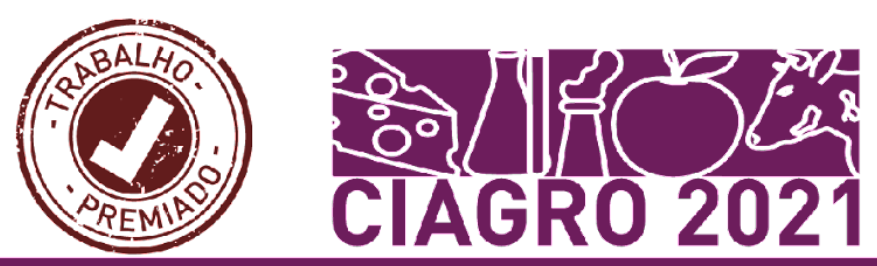

Granules. Journal of Agricultural and Food Chemistry, v. 61, n. 42, p. 9984-9991, 23 out. 2013.

DIMKPA, C. O.; FUGICE, J.; SINGH, U.; LEWIS, T. D. Development of fertilizers for enhanced nitrogen use efficiency - Trends and perspectives. Science of The Total Environment, v. 731, p. 139113, ago. 2020.

DUTTA, P.; WANG, B. Zeolite-supported silver as antimicrobial agents. Coordination Chemistry Reviews, v. 383, p. 1-29, mar. 2019.

DWAIRI, I. M. Evaluation of Jordanian zeolite tuff as a controlled slow-release fertilizer for NH 4 +. Environmental Geology, v. 34, n. 1, p. 1-4, 14 abr. 1998.

HE, P. Y.; ZHANG, Y. J.; CHEN, H.; HAN, Z. C.; LIU, L. C. Low-energy synthesis of kaliophilite catalyst from circulating fluidized bed fly ash for biodiesel production. Fuel, v. 257, p. 116041, dez. 2019.

HERMASSI, M.; VALDERRAMA, C.; FONT, O.; MORENO, N.; QUEROL, X.; BATIS, N. H.; CORTINA, J. L. Phosphate recovery from aqueous solution by K-zeolite synthesized from fly ash for subsequent valorisation as slow release fertilizer. Science of The Total

Environment, v. 731, p. 139002, ago. 2020.

HU, G.; YANG, J.; DUAN, X.; FARNOOD, R.; YANG, C.; YANG, J.; LIU, W.; LIU, Q. Recent developments and challenges in zeolite-based composite photocatalysts for environmental applications. Chemical Engineering Journal, v. 417, p. 129209, ago. 2021.

JIMÉNEZ-REYES, M.; ALMAZÁN-SÁNCHEZ, P. T.; SOLACHE-RÍOS, M. Radioactive waste treatments by using zeolites. A short review. Journal of Environmental Radioactivity, v. 233, p. 106610, jul. 2021.

KHAN, M. Z. H.; ISLAM, M. R.; NAHAR, N.; AL-MAMUN, M. R.; KHAN, M. A. S.; MATIN, M. A. Synthesis and characterization of nanozeolite based composite fertilizer for sustainable release and use efficiency of nutrients. Heliyon, v. 7, n. 1, p. e06091, jan. 2021.

KHANDAN, N.; ZIARATI, MAHMOUD; KARKEABADI, R.; GHAFOURI ROOZBAHANI, M. A. Hydrogen production via steam reforming of LPG on Ni/Zeolite catalysts. Iranian Journal of Hydrogen \& Fuel Cell, v. 1, n. 4, p. 233-238, 2015.

KUMAR, S.; SRIVASTAVA, R.; KOH, J. Utilization of zeolites as $\mathrm{CO} 2$ capturing agents: Advances and future perspectives. Journal of CO2 Utilization, v. 41, p. 101251, out. 2020.

LATEEF, A.; NAZIR, R.; JAMIL, N.; ALAM, S.; SHAH, R.; KHAN, M. N.; SALEEM, M. Synthesis and characterization of zeolite based nano-composite: An environment friendly slow release fertilizer. Microporous and Mesoporous Materials, v. 232, p. 174-183, set. 2016.

LI, J.; ZHUANG, X.; FONT, O.; MORENO, N.; VALLEJO, V. R.; QUEROL, X.; TOBIAS, A. Synthesis of merlinoite from Chinese coal fly ashes and its potential utilization as slow release K-fertilizer. Journal of Hazardous Materials, v. 265, p. 242-252, jan. 2014. 
LIU, Y.; YAN, C.; ZHANG, Z.; WANG, H.; ZHOU, S.; ZHOU, W. A comparative study on fly ash, geopolymer and faujasite block for $\mathrm{Pb}$ removal from aqueous solution. Fuel, v. 185, p. $181-189,2016$.

LUZ, A. B. DA. Zeólitas: propriedades e usos industriais. Rio de Janeiro: CETEM/CNPq, 1995.

MAGHSOODI, M. R.; NAJAFI, N.; REYHANITABAR, A.; OUSTAN, S. Hydroxyapatite nanorods, hydrochar, biochar, and zeolite for controlled-release urea fertilizers. Geoderma, v. 379, p. 114644, dez. 2020.

NOTARIO DEL PINO, J. S.; ARTEAGA PADRÓN, I. J.; GONZÁLEZ MARTIN, M. M.; GARCIA HERNÁNDEZ, J. E. Phosphorus and potassium release from phillipsite-based slow-release fertilizers. Journal of Controlled Release, v. 34, n. 1, p. 25-29, abr. 1995.

PARK, M.; KIM, J. S.; CHOI, C. L.; KIM, J.-E.; HEO, N. H.; KOMARNENI, S.; CHOI, J. Characteristics of nitrogen release from synthetic zeolite Na-P1 occluding NH4NO3. Journal of Controlled Release, v. 106, n. 1-2, p. 44-50, ago. 2005.

PICKERING, H. W.; MENZIES, N. W.; HUNTER, M. N. Zeolite/rock phosphate-a novel slow release phosphorus fertiliser for potted plant production. Scientia Horticulturae, v. 94, n. 3-4, p. 333-343, jun. 2002.

PURNOMO, C. W.; SAPUTRA, H. Manufacturing of slow and controlled release fertilizer. In: Controlled Release Fertilizers for Sustainable Agriculture. [s.1.] Elsevier, 2021.p. 95-110.

RAMEZANIANPOUR, A. A.; MOUSAVI, R.; KALHORI, M.; SOBHANI, J.; NAJIMI, M. Micro and macro level properties of natural zeolite contained concretes. Construction and Building Materials, v. 101, p. 347-358, dez. 2015.

SERATI-NOURI, H.; JAFARI, A.; ROSHANGAR, L.; DADASHPOUR, M.; PILEHVAR-SOLTANAHMADI, Y.; ZARGHAMI, N. Biomedical applications of zeolite-based materials: A review. Materials Science and Engineering: C, v. 116, p. 111225, nov. 2020.

SOUZA, I. M. S.; GURGEL, G. C. S.; MEDEIROS, A. M.; ZONTA, E.; RUIZ, J. A. C.; PASKOCIMAS, C. A.; MOTTA, F. V.; BOMIO, M. R. D. The use of clinoptilolite as carrier of nitrogened fertilizer with controlled release. Journal of Environmental Chemical Engineering, v. 6, n. 4, p. 4171-4177, ago. 2018.

TRAN, Y. T.; LEE, J.; KUMAR, P.; KIM, K.-H.; LEE, S. S. Natural zeolite and its application in concrete composite production. Composites Part B: Engineering, v. 165, p. 354-364, maio 2019.

VISA, M. Synthesis and characterization of new zeolite materials obtained from fly ash for heavy metals removal in advanced wastewater treatment. Powder Technology, v. 294, p. 338-347, jun. 2016.

YAN, B.; YU, S.; ZENG, C.; YU, L.; WANG, C.; ZHANG, L. Binderless zeolite NaX 


\section{microspheres with enhanced $\mathrm{CO} 2$ adsorption selectivity. Microporous and Mesoporous}

Materials, v. 278, p. 267-274, abr. 2019.

YUAN, J.; YANG, J.; MA, H.; CHANG, Q. Preparation of Zeolite F as Slow Release

Fertilizers from K-Feldspar Powder. ChemistrySelect, v. 2, n. 33, p. 10722-10726, 21 nov. 2017.

ZHENG, Z.; MA, X.; ZHANG, Z.; LI, Y. In-situ transition of amorphous gels to Na-P1 zeolite in geopolymer: Mechanical and adsorption properties. Construction and Building Materials, v. 202, p. 851-860, mar. 2019. 


\section{CAPÍTULO 18: APROVEITAMENTO ENERGÉTICO DE BAGAÇO DE LARANJA E CASCA DE MARACUJÁ IN NATURA DA AGROINDÚSTRIA DE SUCO PARA PRODUÇÃO METANO}

\section{CHAPTER 18: ENERGY USE OF ORANGE BAGASSE AND PASSION FRUIT PEEL IN NATURA THE OF JUICE AGROINDUSTRY FOR METANE PRODUCTION}

\section{CAPÍTULO 18:USO ENERGÉTICO DE ENVASES DE NARANJA Y PASION EN NATURA DE LA AGROINDUSTRIA DE JUGO PARA LA PRODUCCIÓN DE METANO}

Liliana Andréa dos Santos ${ }^{1}$; Carollinni Roberta de Melo Oliveira ${ }^{2}$; André Felipe de Melo Sales Santos ${ }^{3}$; José Fernando Thomé Jucá ${ }^{4}$

\section{RESUMO}

DOI : $\underline{\text { https://doi.org/10.31692/978-65-88970-19-5.265-279 }}$

$\mathrm{Na}$ produção de suco e polpas são gerados cerca de $50 \%$ de resíduos como cascas, sementes, caroços, os quais são subvalorizados ou descartados como forma de rejeito na maior parte do Brasil. Contudo, estes resíduos de frutas podem ser valorizados como fonte de recursos utilizando a biomassa para a produção de energia por tecnologias renováveis como a digestão anaeróbia. O trabalho teve como objetivo avaliar o potencial de geração de metano de bagaço de laranja e casca de maracujá in natura utilizando o lodo industrial como inóculo através de ensaio de potencial bioquímico de metano (BMP). Os resíduos de frutas e o lodo industrial foram caracterizados em termos de $\mid \mathrm{pH}$, sólidos voláteis, umidade, sólidos totais e condutividade elétrica. O Potencial Bioquímico de Metano (BMP) foi avaliado em reatores em batelada, de $250 \mathrm{~mL}$, em condições mesofílicas $\left(37 \pm 2{ }^{\circ} \mathrm{C}\right)$, sob agitação $(60$ rpm), durante 60 dias, utilizando inóculo anaeróbio (lodo industrial) e com adição de bicarbonato de sódio $\left(1 \mathrm{~g} \mathrm{NaHCO}_{3}\right)$. Em termos de resultados de caracterização, o bagaço de laranja e casca de maracujá apresentaram $\mathrm{pH}$ ácido, elevado teor de umidade e sólidos voláteis. O lodo industrial apresentou $\mathrm{pH}$ neutro, alta umidade e sólidos voláteis. Em termos de composição de biogás gerado apresentou concentrações médias de metano de 67 a $73 \%$ para substratos e inóculo. O potencial de

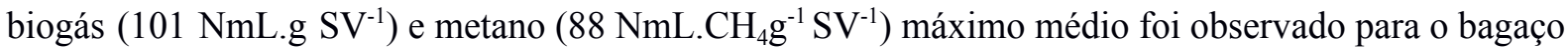
de laranja, com de biogás utilizando lodo anaeróbio industrial. A digestão anaeróbia de resíduos de frutas é uma alternativa viável para valorização e aproveitamento de seu potencial energético, proporcionando ganhos à cadeia produtiva.

Palavras-Chave: resíduos de frutas, digestão anaeróbia, biogás

\section{RESUMEN}

En la producción de jugos y pulpas, se genera alrededor del $50 \%$ de los residuos, como cáscaras, semillas, semillas, que son infravalorados o descartados como una forma de desperdicio en la mayor parte de Brasil. Sin embargo, estos residuos de frutas pueden valorarse como fuente de recursos utilizando biomasa para la producción de energía mediante tecnologías renovables como la digestión anaeróbica. El objetivo de este trabajo fue evaluar el potencial de generación de metano a partir de

\footnotetext{
${ }^{1}$ Profa.Doutora no Mestrado Profissional em Tecnologia Ambiental, ITEP, liliana.andrea.santos@gmail.com.br

${ }^{2}$ Bacharel em Ciências Biológicas e Ciências Ambientais, UFPE, rcarolinni@gmail.com

${ }^{3}$ Prof. Doutor do Departamento de Tecnologia Rural, UFRPE, andrefelipeufrpe@outlook.com

${ }^{4}$ Prof. Doutor do Departamento de Engenharia Civil, UFPE, jftjucah@gmail.com
} 
orujo de naranja y cáscara de maracuyá in natura utilizando lodos industriales como inóculo mediante una prueba de potencial bioquímico de metano (BMP). Los residuos de frutas y lodos industriales se caracterizaron en términos de $\mathrm{pH}$, sólidos volátiles, humedad, sólidos totales y conductividad eléctrica. El Potencial Bioquímico del Metano (BMP) se evaluó en reactores discontinuos, de $250 \mathrm{~mL}$, en condiciones mesofílicas $\left(37 \pm 2^{\circ} \mathrm{C}\right)$, bajo agitación $(60 \mathrm{rpm})$, durante 60 días, utilizando inóculo anaeróbico (lodo industrial) y con adición de bicarbonato de sodio $\left(1 \mathrm{~g} \mathrm{de} \mathrm{NaHCO}_{3}\right)$. En cuanto a los resultados de la caracterización, el orujo de naranja y la piel de maracuyá presentaron pH ácido, alto contenido de humedad y sólidos volátiles. La industria de lodos presentó pH neutro, alta humedad y sólidos volátiles. En cuanto a la composición del biogás generado, presentó concentraciones promedio de metano de 67 a $73 \%$ para sustratos e inóculo. Se observó el potencial máximo de biogás (101 NmL.g SV ${ }^{-1}$ ) y metano ( $88 \mathrm{NmL} . \mathrm{CH} 4 \mathrm{~g}^{-1} \mathrm{SV}^{-1}$ ) para el bagazo de naranja, con biogás utilizando lodos anaeróbicos industriales. La digestión anaeróbica de los residuos de frutas es una alternativa viable para la valorización y aprovechamiento de su potencial energético, aportando ganancias a la cadena productiva.

Palabras clave: residuos de frutas, digestión anaeróbica, biogás.

\begin{abstract}
In the production of juice and pulps, about $50 \%$ of residues are generated, such as peels, seeds, seeds, which are undervalued or discarded as a form of waste in most of Brazil. However, these fruit residues can be valued as a source of resources using biomass to produce energy by renewable technologies such as anaerobic digestion. The objective of this work was to evaluate the potential of methane generation from orange bagasse and passion fruit peel in natura using industrial sludge as an inoculum using a methane biochemical potential test (BMP). Fruit waste and industrial sludge were characterized in terms of $\mid \mathrm{pH}$, volatile solids, moisture, total solids, and electrical conductivity. The Biochemical Potential of Methane (BMP) was evaluated in batch reactors, of $250 \mathrm{~mL}$, under mesophilic conditions $\left(37 \pm 2^{\circ} \mathrm{C}\right)$, under agitation $(60 \mathrm{rpm})$, for 60 days, using anaerobic inoculum (industrial sludge) and with addition of sodium bicarbonate $\left(1 \mathrm{~g} \mathrm{NaHCO}_{3}\right)$. In terms of characterization results, orange bagasse and passion fruit peel showed acid $\mathrm{pH}$, high moisture content and volatile solids. The sludge industry presented neutral $\mathrm{pH}$, high moisture, and volatile solids. In terms of the composition of biogas generated, it presented average methane concentrations of 67 to $73 \%$ for substrates and inoculum. The maximum biogas (101 NmL.g SV $\left.{ }^{-1}\right)$ and methane $\left(88 \mathrm{NmL} \mathrm{CH}_{4} \mathrm{~g}^{-1} \mathrm{SV}^{-1}\right)$ potential was observed for orange bagasse, with biogas using industrial anaerobic sludge. The anaerobic digestion of fruit waste is a viable alternative for the valorization and use of its energy potential, providing gains to the production chain.
\end{abstract}

Keywords: fruit waste, anaerobic digestion, biogas.

\title{
1. INTRODUÇÃO
}

O Brasil ocupa a terceira colocação no ranking de produção de frutas, representando cerca de $6 \%$ da produção mundial, produzindo cerca de 41 milhões de toneladas de frutas frescas em 2019 (IBGE, 2019). No segmento de frutas processadas o Brasil se destaca na produção de néctares, drinques e polpas de frutas, sucos (SANTOS, 2019).

$\mathrm{Na}$ produção de suco e polpas são gerados cerca de 50\% de resíduos em base úmida (cascas, sementes, caroços), os quais são descartados ou subvalorizados na maior parte do país, mesmo sendo fonte de vitaminas e nutrientes essenciais (DO NASCIMENTO FILHO; 
FRANCO, 2015). Estes resíduos de frutas são destinado a aterros sanitários ou usados como alimentação animal. Devido aos altos custos de armazenamento estes resíduos podem se tornar um problema ambiental devido à elevada facilidade de fermentação e biodegradabilidade, essas características podem contribuir para problemas negativos em sistemas tradicionais de disposição de resíduos sólidos, como emissões de gases de efeito estufa e geração de lixiviado em aterros sanitários (EDWIGES et al., 2018). Entretanto, estes resíduos que antes eram descartados pela agroindústria de suco, podem ser valorizados como fonte de recursos utilizando a biomassa para a produção de energia por tecnologias renováveis como a digestão anaeróbia (SANTOS, 2019; SANTOS et al., 2020).

A digestão anaeróbia converte a biomassa em biogás $\left(\mathrm{CH}_{4}, \mathrm{CO}_{2}\right)$ que pode ser aproveitado para produção de energia elétrica, gás natural, combustível veicular, entre outros, além de produzir biofertilizante que pode ser utilizado na agricultura (SILVA; FRANCISCO, 2010; SANTOS, 2016).

Desta forma, o objetivo deste estudo foi avaliar o potencial de geração de metano de bagaço de laranja (BLI) e casca de maracujá (CMI) in natura utilizando o lodo industrial (LI) como inóculo através de ensaio de potencial bioquímico de metano (BMP).

\section{FUNDAMENTAÇÃO TEÓRICA}

A fruticultura é um dos setores da economia de maior destaque do agronegócio brasileiro, principalmente na produção de frutas frescas (in natura), industrialização de sucos e néctares (OCDE-FAO, 2015). A produção de frutas em 2017 foi mais de 865 milhões de toneladas de frutas no mundo (OCDE-FAO, 2015). O Brasil figura entre os principais produtores mundiais de frutas, com colheitas superiores a 40 milhões de toneladas em 2018, estando entre os três maiores produtores (China, Índia e Brasil) do mundo.

No Brasil, a laranja e o maracujá têm se destacado no setor de fritucultura para utilização na indústria de sucos (SANTOS, 2019).

Os citrus são as frutas mais produzidas e consumidas no mundo, principalmente laranjas, tangerinas, limas e limões (MEDEIROS, 2014). O Brasil é líder mundial na produção e exportação de laranjas, com aproximadamente 17.750 milhões de toneladas na safra de 2018/2019 (USDA, 2019). 85\% da produção de laranja in natura no Brasil é utilizada pela indústria de sucos, sendo o maior produtor e exportador de suco de laranja do 
mundo (SILVA, 2014).

Outra fruta com destaque no cenário brasileiro é o maracujá, sendo o Brasil o maior produtor e consumidor de maracujá do mundo, com $95 \%$ da produção nacional de maracujá sendo representado pelo maracujazeiro-azedo (Passiflora edulis Sims) (JANZANTTI; MONTEIRO, 2014; JESUS et al., 2016). Em 2017, o país produziu 554 mil toneladas, com destaque para região Nordeste que é a maior produtora nacional com mais de 337 mil toneladas (IBGE, 2019). Cerca de 60\% do maracujá é utilizado para consumo in natura, 40\% na indústria de suco, principalmente para extração de polpa para fabricação de suco. O suco de maracujá ocupa o terceiro lugar em escala nacional, perdendo apenas para o suco de laranja e caju representando $8,5 \%$ do volume de sucos prontos para beber consumidos no país (GRECO, 2014).

Grandes quantidades de resíduos são gerados a partir de atividades agrícolas, florestais e municipais, com destaque para a agroindustria que gera elevada quantidade de resíduos a partir do processamento de frutas para produção de sucos (SANTOS, 2019). Após a extração, cerca de 40\%-60\% da fruta (laranja, maracujá) é descartada na forma de bagaço, o resíduo resultante do processamento dessas frutas (casca, semente e polpa), podem ser prensados, desidratados e peletizados para facilitar o manuseio e transporte (CYPRIANO et al., 2017).

Os resíduos gerados após o processamento são destinados a aterros sanitários ou usados como ração animal, entretanto, devido aos altos custos de armazenamento e transporte muitas vezes doados ou tratados como rejeitos, descartando seus potenciais usos, contribuindo para a poluição ambiental INFANTE et al., 2013; SANTOS, 2019).

Ao mesmo tempo, os resíduos podem se tornar um problema ambiental decorrendo em custos para as agroindústrias, estes podem ser fontes de recursos, mediante processamento tecnológico adequado, com destaque para produção de biopolímeros, biocombustíveis (etanol, biogás), enzimas, produtos químicos e fertilizantes (KALYANI et al., 2013; CUI et al., 2015).

Além disso, esses resíduos podem ser utilizados como fonte de biomassa devido as suas características de elevada umidade, elevado teor de carboidratos (polímeros solúveis, insolúveis) e fácil biodegradação, ideal para conversão em biocombustíveis biológicos, como etanol e biogás (TAGHIZADEH-ALISARAEI et al., 2017).

A digestão anaeróbia, como alternativa de valorização energética de resíduos agroindustriais, vem ganhando interesse nos últimos anos visto representar uma fonte de 
energia com baixa emissão de carbono e de aproveitamento mais sustentável dos resíduos orgânicos (EBNER et al., 2015). Dentre os benefícios do uso destaca-se a aplicação em pequena e grande escala e a geração de combustível gasoso renovável (SILVA et al., 2021). Assim, a digestão anaeróbia representa uma solução alternativa para o tratamento de resíduos agroindustriais de frutas, gerando o biogás, que pode ser utilizado como fonte de energia alternativa, obtendo ainda biofertilizante com capacidade de aproveitamento agroindustrial (SANTOS et al., 2019).Vários pesquisadores têm investigado o potencial de fermentação de frutas e vegetais comuns para demonstrar as vantagens de usar o processo de digestão anaeróbica para produzir energia através do biogás (FORGACS et al., 2012; CALABRÒ et al., 2016; CARVALHO et al., 2017; SILVA et al., 2019; SANTOS et al., 2020). No entanto, existem poucos trabalhos com o uso do maracujá como fonte de biomassa para digestão anaeróbia, sendo o número de publicações ainda mínimo, embora essa fruta tenha elevada importância para o mercado brasileiro.

No entanto, as características especificas dos resíduos de frutas podem ser vistas como desvantagem e representar desafios para aplicação eficaz da digestão anaeróbia. Tais características incluem $\mathrm{pH}$ ácido (3-4), conteúdo orgânico de ST (10\%), sólidos voláteis (6-18\%), relação $\mathrm{C} / \mathrm{N}(20)$, umidade $>80 \%$ e alto teor de material lignocelulósico (RUIZ; FLOTATS, 2016) Entretanto, a utilização desses resíduos como fonte de biomassa na digestão anaeróbia é viável, desde que seja utilizado um inóculo anaeróbio eficiente, contribuindo de forma integral para o seu gerenciamento (RUIZ; FLOTATS, 2014).

\section{METODOLOGIA}

\subsection{Obtenção dos resíduos de frutas e lodo industrial}

As amostras de laranja (BLI) e maracujá (CMI) in natura foram obtidas de um mercado local localizado na cidade do Recife no Estado de Pernambuco.

A laranja e o maracujá in natura antes da realização dos ensaios, foram cortados manualmente em pedaços, em seguida, foi extraído o suco da laranja e retirada a polpa do maracujá, posteriormente as amostras foram trituradas em liquidificador para obtenção do bagaço de laranja e casca de maracujá.

O inóculo anaeróbio utilizado foi lodo industrial (LI) coletado de um reator UASB (upflow anaerobic sludge blanket) de $1000 \mathrm{~m}^{3}$ para produção de energia elétrica, a partir biogás, utilizando como biomassa a vinhaça bruta com adição de lodo granular industrial. 


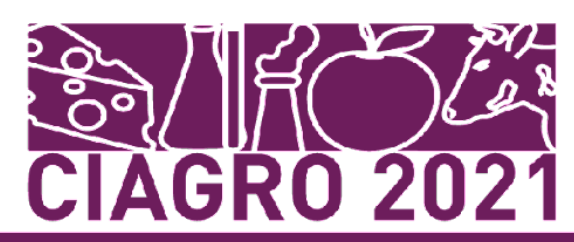

Foram coletadas amostras de 5 litros do lodo anaeróbio, armazenadas em bombonas de polietileno e conservadas a $19 \pm 1^{\circ} \mathrm{C}$ antes da realização dos ensaios.

\subsection{Caracterização do bagaço de laranja, casca de maracujá e inóculo anaeróbio}

Antes da realização dos ensaios físico-químicos, os resíduos BLI, CMI foram colocados em estufa a $65^{\circ} \mathrm{C}$ para secagem até a estabilização da umidade, em seguida, foram triturados em moinho de facas (tipo Willye, marca SPLabor), homogeneizados, peneirados e armazenados em temperatura ambiente $\left(26 \pm 2{ }^{\circ} \mathrm{C}\right)$.

Os substratos BLI, CMI e o lodo industrial (LI) foram caracterizados através das análises de o teor umidade, sólidos totais (ST) e sólidos totais voláteis (SV), conforme WHO (1978). O Potencial hidrogeniônico (pH) de acordo com a metodologia NBR 10006 (ABNT, 2004); as análises de pH e condutividade elétrica foram realizadas antes e após a finalização dos ensaios BMP. Todas as análises foram realizadas em triplicata.

\subsection{Ensaio do potencial bioquímico de metano (BMP)}

O teste de Potencial de Bioquimico de Metano (BMP) seguiu a metodologia de Santos et al. (2020).

Para o teste BMP (batelada), foram utilizados frascos de borossilicato, com volume total de $250 \mathrm{~mL}$, constituídos de tampa de nylon rosqueada, com anéis de vedação. A tampa do frasco continha acoplada duas válvulas-agulha, sendo uma para alívio da pressão do biogás gerado ou para a inserção de $\mathrm{N}_{2}$ (purga do $\mathrm{O}_{2}$, no início do ensaio), e outra, onde fica instalado um manômetro mecânico (100 kPa), para monitoramento da pressão do biogás no interior do reator.

A quantidade de BLI e CMI inseridos nos reatores foram de 13,5 g (2,16 g/seca), 11,2 $\mathrm{g}(2,45 \mathrm{~g} / \mathrm{seca})$ úmida, respectivamente, conforme a Tabela 1. A quantidade de inóculo anaeróbio (LI) adicionado em cada frasco foi de 26,5 g. A quantidade de bicarbonato de sódio utilizado foi de $1 \mathrm{~g}$ de acordo com Santos et al. (2020). Para manter a DQO de $2 \mathrm{~g}$. $\mathrm{L}^{-1} \mathrm{e}$ um volume útil de $200 \mathrm{~mL}$ para cada configuração, dentro do reator foi inserido água destilada. Em todos os reatores, foi mantido o headspace de $50 \mathrm{~mL}$, representando $20 \%$ do volume do reator. O experimento foi realizado em triplicata, considerando ainda um branco, no qual apenas foi adicionada água destilada e inóculo.

Tabela 1: Experimental configurations of BMP assays. 


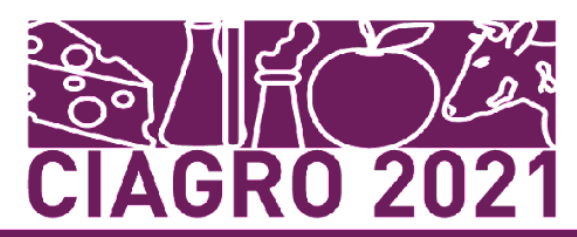

\begin{tabular}{lcccc} 
Configurações & $\begin{array}{c}\text { Substrato } \\
\text { (g/úmida) }\end{array}$ & Inóculo $(\mathbf{g})$ & Água $(\mathbf{m L})$ & Headspace $(\mathbf{m L})$ \\
\hline BLI+LI & 13,5 & 26,5 & 160 & 50 \\
CMI+LI & 11,2 & 26,5 & 160 & 50 \\
LI & - & 26,5 & 160 & 50 \\
\hline
\end{tabular}

Fonte: Própria (2021).

O preenchimento do reator foi de acordo com a metodologia de Santos et al. (2020), seguindo a sequência: adição do resíduo, adição do inóculo anaeróbio, complementação do volume com água destilada (calculada), adição do bicarbonato de sódio, aferição inicial da condutividade elétrica e $\mathrm{pH}$ do conteúdo do reator, fechamento do reator e válvulas, envolvimento do reator em papel alumínio. Depois que os reatores foram preenchidos e fechados, os manômetros foram retirados e realizado a introdução de $\mathrm{N}_{2}$ com as válvulas-agulha abertas (proporcionar condições anaeróbias ideais para degradação do substrato), por 2 minutos. Em seguida, as válvulas de saída e entrada de gás foram fechadas e os manômetros recolados aos reatores mantendo-se uma pressão em todos os frascos de 20 KPa (SANTOS et al., 2020). Em seguida, os reatores foram mantidos em mesa incubadora (TECNAL TE 424$)$ com controle de temperatura $\left(37 \pm 2^{\circ} \mathrm{C}\right)$ e com agitação orbital (60 rpm), por 60 dias. Os ensaios foram realizados em triplicata.

O volume de biogás acumulado foi analisado indiretamente através da medição da pressão acumulada de biogás obtida no monitoramento diário conforme a metodologia de Ivanova et al. (2008). O monitoramento da pressão dos reatores ocorreu durante 60 dias.

A composição do biogás foi avaliada a partir do $7^{\circ}$ dia do experimento, mantendo o headspace dos reatores nos dois últimos dias, antecedentes da medição, sem descarte, para aumentar o volume de biogás disponível para a injeção no cromatógrafo (triplicata) (SANTOS, 2019).

Para avaliar a composição do biogás $\left(\mathrm{CH}_{4}, \mathrm{CO}_{2}\right)$ foi utilizando um cromatógrafo gasoso (APPA GOLD), com detector de condutibilidade térmica (TCD), com uma coluna (Porapak “N”), que utiliza o $\mathrm{H}_{2}$ como gás de arraste, a uma temperatura do forno de $60^{\circ} \mathrm{C}$. Foi utilizado um gás padrão $\left(60 \%\right.$ de $\mathrm{CH}_{4}$ e $40 \%$ de $\mathrm{CO}_{2}$ ), para calibração do cromatógrafo. Para o tratamento dos dados foi utilizado o Sistema de Aquisição de Dados Cromatográficos N2000 Chromatostation. 


\subsubsection{Análise do potencial de biogás e $\mathrm{CH}_{4}$}

$\mathrm{O}$ potencial de biogás e metano $\left(\mathrm{Y}_{\mathrm{m}}\right)$ foi obtido através da subtração do volume acumulado de biogás/metano das configurações (substrato + inóculo) pelo volume acumulado do branco do inóculo respectivo, dividido pela massa (em grama sólidos voláteis) do substrato de acordo com a Equação 1.

$$
Y_{m}=\frac{V A_{s}-V A_{i}}{V S_{g}}
$$

$-\mathrm{Y}_{\mathrm{m}}=$ Potencial de biogás ou metano $\left(\mathrm{NmL} \cdot \mathrm{g}^{-1} \mathrm{SV}\right)$

- $V A_{s}=$ Volume acumulado de biogás/metano da configuração estudada (NmL)

- $V A_{i}$ V Volume acumulado de biogás/metano do branco do inóculo (NmL)

$-\mathrm{VS}_{\mathrm{g}}=$ Concentração inicial de VS do substrato seco $\left(\mathrm{g}^{-1} \mathrm{SV}\right)$

\section{RESULTADOS E DISCUSSÃO}

\subsection{Caracterização dos substratos in natura, inóculo anaeróbio e conteúdo inicial e final}

\section{do Teste BMP}

A Tabela 2 apresenta os resultados da caracterização em termos de $\mathrm{pH}$, umidade, ST, $\mathrm{SV}$, dos substratos in natura (BLI, CMI) e inóculo (LI).

Tabela 2: Caracterização de substratos in natura e inóculo utilizados

$\begin{array}{lccc}\text { Parâmetro } & \text { BLI } & \text { CMI } & \text { LI } \\ \text { pH } & 3,4 & 3,5 & 7,0 \\ \text { Umidade (\%) } & 87 & 90 & 89 \\ \text { ST (\%) } & 13 & 10 & 10 \\ \text { SV (\%) } & 94 & 90 & 76\end{array}$


Os substratos (BLI, CMI) e o inóculo (LI) apresentaram elevado teor de umidade, sendo favorável para facilitar o contato dos micro-organismos com substrato e o transporte de nutrientes durante a digestão anaeróbia (Santos et al., 2020). O BLI apresentou sólidos totais (13\%) superior em comparação a CMI (10\%) e LI (10\%). Resultados similares de teor de umidade (85 a 88\%) foram encontrados na literatura para bagaço de laranja e casca de maracujá (DEUS et al., 2014, ZHAO et al., 2016; SANTOS et al. 2020).

Os sólidos voláteis de BLI e CMI variaram de 90 a 94\%, cujos valores estão próximos aos encontrados na literatura para estes tipos de substratos. Valores superiores foram encontrados por Santos et al. (2020) que obtiveram valores de sólidos voláteis de 94\% e 95\% para casca de maracujá e bagaço de laranja secos, respectivamente. Resíduos de frutas e vegetais normalmente possuem elevado teor de sólidos voláteis, devido à elevada fração orgânica presente, sendo benéfico a digestão anaeróbia (CALABRÒ et al., 2015, RUIZ e FLOTATS, 2016). O inóculo LI obteve SV de 76\%, considerado elevado para lodos anaeróbios.

$\mathrm{O} \mathrm{pH}$ dos substratos estudado apresentaram valores na faixa ácida $(3,4$ a 3,5), típicos para resíduos de bagaço de laranja e casca de maracujá in natura. Valores semelhantes de $\mathrm{pH}(3,0$ a 4,2) foram encontrados por outros autores para estes tipos de substratos (DEUS et al., 2014; CARVALHO et al., 2017; SANTOS et al., 2020). O inóculo LI obteve pH neutro $(7,0)$, normalmente relatado para inóculos anaeróbios em equilibrio.

Diversos autores ao estudarem inóculos anaeróbios encontaram $\mathrm{pH}$ na faixa neutra (6,6-8,0) (STEINMETZ et al., 2016; CARVALHO et al., 2017; SANTOS et al., 2020).

Na Tabela 3 são apresentadas as características das configurações dos ensaios BMPs, antes e após os testes.

Tabela 3: Caracterização inicial e fina dos conteúdos dos teste BMP das configurações estudadas

Parâmetro

$\mathrm{pH}$ inicial

$\mathrm{pH}$ final

Condutividade inicial $\left(\mu \mathrm{s} . \mathrm{cm}^{-1}\right)$

Condutividade final $\left(\mu \mathrm{s} . \mathrm{cm}^{-1}\right)$
BLI+LI

8,3

7,6

474

6953

\section{CMI+LI}

6,8

7,7

1495

6796 . 
Legenda: BLI (Bagaço de laranja in natura); CMI (Casca de maracujá in natura); LI (Lodo industrial).

Fonte: Própria (2021).

Os valores iniciais $(8,3,6,8)$ e finais $(7,6,7,0)$ médios de $\mathrm{pH}$, antes e após a digestão anaeróbia das configurações estudadas encontram-se próxima a faixa de $\mathrm{pH}(6,4$ a 7,5$)$ recomendada para produção de metano (CHERNICHARO, 1997).

Valores similares de $\mathrm{pH}$ final $(7,6)$ foram obtidos por outros autores ao estudaram a digestão de bagaço de laranja in natura com adição de digestivo líquido em reatores em batelada (1,1 litros) em condição mesofilica (CALABRÓ; PANZERA, 2018). O BLI+LI apresentou $\mathrm{pH}(8,3)$ final elevado, valores de $\mathrm{pH}$ acima de 8,3 devem ser evitados, pois podem inibir a fase metanogênica durante a digestão anaeróbia (CHERNICHARO, 1997).

Em termos de condutividade elétrica, em todas houve aumento da condição inicial para final em todas as configurações estudadas nos testes BMP, indicando que o substrato está sendo degradado pelos micro-organismos anaeróbios (ROCHA, 2009; SANTOS, 2020).

A condutividade elétrica final (6953 a $\left.6953 \mu \mathrm{s} . \mathrm{cm}^{-1}\right)$ de BLI e CMI com adição de LI

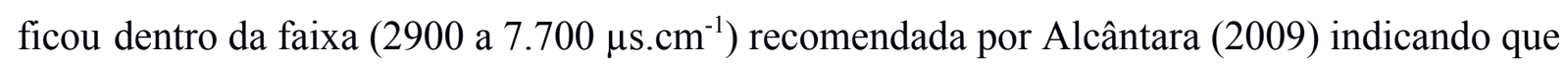
digestão anaeróbia na última fase (metanogênese).

Santos et al. (2020) obtiveram condutividade elétrica de 5358 e $7402 \mu \mathrm{s} . \mathrm{cm}^{-1}$ para bagaço de laranja e casca de maracujá com adição de lodo anaeróbio, respectivamente.

\subsection{Avaliação da produção, potencial e percentagem de biogás e metano de bagaço de laranja e casca de maracujá in natura}

Em termos de produção de biogás acumulado, considerando o valor médio das configurações de resíduos de frutas in natura, a configuração BLI+LI, apresentou volume acumulado de biogás (654 NmL) superior em relação combinação CMI+LI (415 NmL) (Figura 1).

Figura 1. Volume de biogás acumulado $(\mathrm{NmL})$ das configurações testadas 


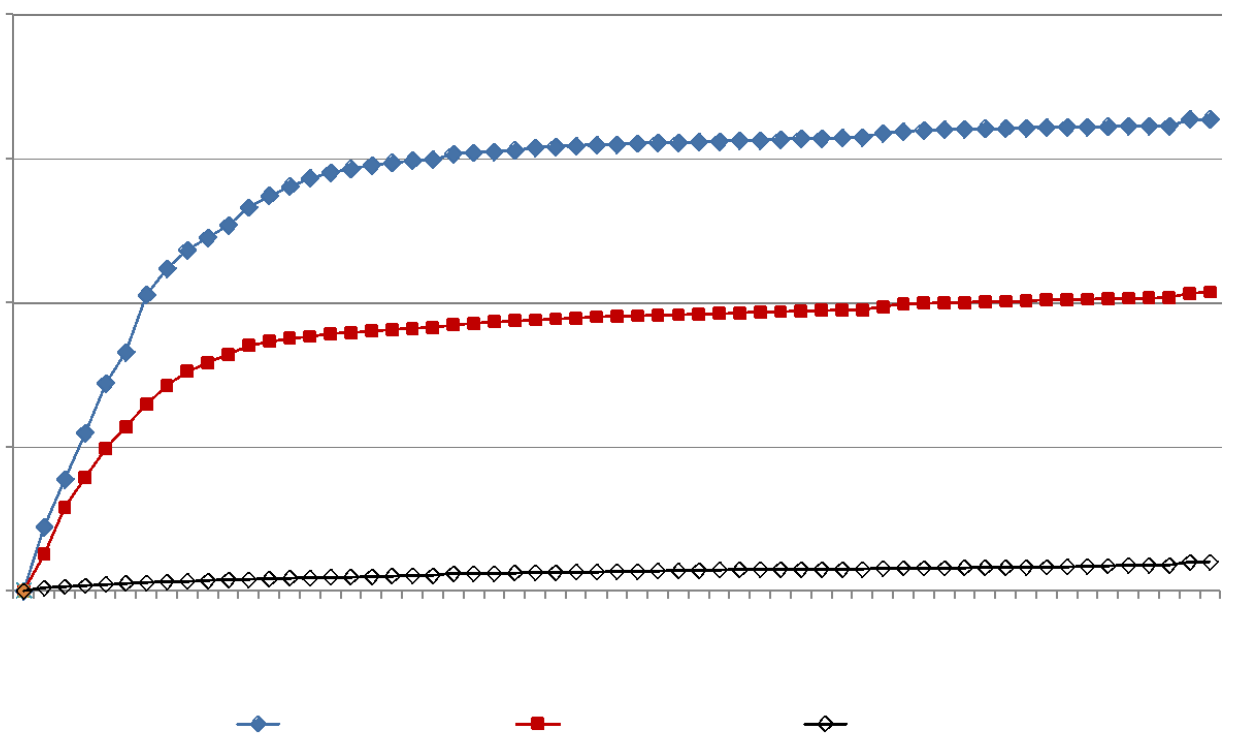

Legenda: BLI (Bagaço de laranja in natura); CMI (Casca de maracujá in natura); LI (Lodo industrial).

Fonte: Própria (2021).

Em relação ao volume acumulado de $\mathrm{CH}_{4}$ a configuração BLI+LI (181 NmL) apresentou o melhor resultado em comparação a CMI+LI que apresentou o menor volume acumulado de $\mathrm{CH}_{4}(111 \mathrm{NmL})$ (Figura 2).

Por volta do $25^{\circ}$ dia de realização do experimento, mais de $80 \%$ do total do biogás acumulado havia sido produzido em todas as configurações.

$\mathrm{O}$ volume acumulado de biogás e $\mathrm{CH}_{4}$ do inóculo (LI) sem adição de substrato foi de 41 NmL, $21 \mathrm{NmL}$, respectivamente.

Figura 2: Volume de metano $(\mathrm{NmL})$ das configurações estudadas

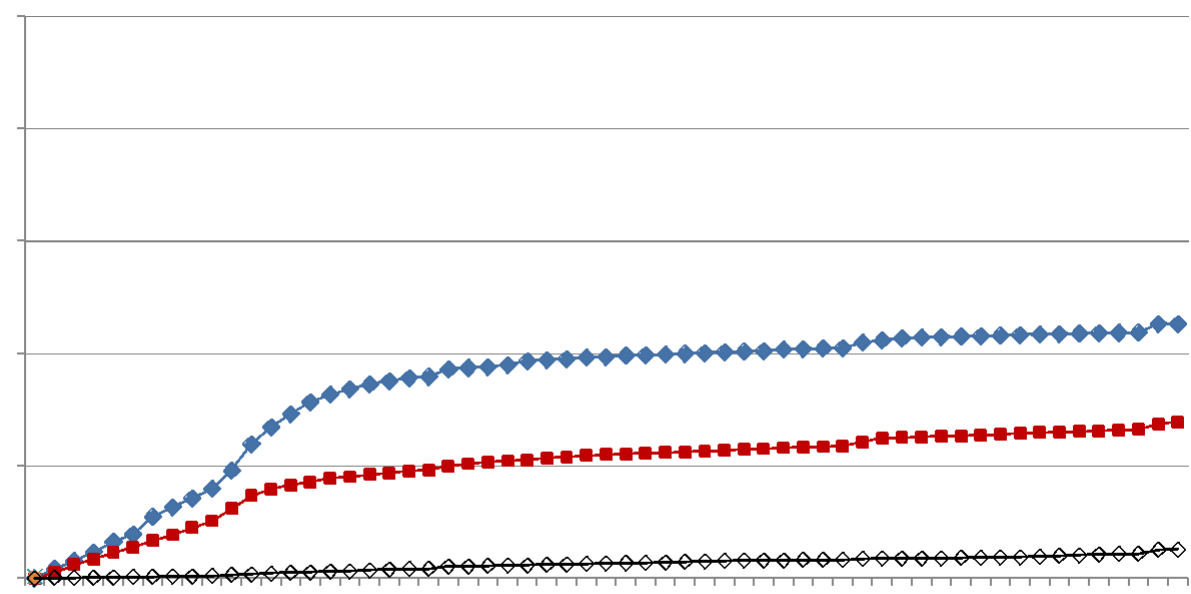

Legenda: BLI (Bagaço de laranja in natura); CMI (Casca de maracujá in natura); LI (Lodo de industrial). 


\section{Fonte: Própria (2021).}

Pode-se observar que em níveis de produção de volume de metano na digestão com bagaço de laranja in natura, o inóculo LI acelerou a etapa de hidrólise, consequentemente houve maior produção de metano em comparação a CMI+LI (Figura 2).

Na Figura 3 estão apresentados o potencial de geração e metano das configurações estudadas.

O melhor potencial de geração de biogás $\left(298 \mathrm{NmL} \cdot \mathrm{g}^{-1} \mathrm{SV}\right)$ e metano $\left(88 \mathrm{NmL} \cdot \mathrm{CH}_{4} \mathrm{~g}^{-1}\right.$ $\mathrm{SV}$ ) foi da combinação do bagaço de laranja in natura com lodo industrial (BLI+LI).

Resultados similares de potencial de metano $\left(86 \mathrm{NmL} \mathrm{CH}_{4} \cdot \mathrm{g}^{-1} \mathrm{SV}\right)$ foram encontrados por Santos et al. (2018) ao estudarem a digestão anaeróbia de bagaço de laranja seco com adição de lodo industrial utilizando reatores em batelada sob temperatura de $37^{\circ} \mathrm{C}$ por 47 dias. Entretanto, outros autores obtiveram potencial de geração de metano $\left(360 \mathrm{NmL}\right.$. $\left.\mathrm{CH}_{4} \mathrm{~g}^{-1} \mathrm{SV}\right)$ superior ao avaliarem a digestão anaeróbia de bagaço de laranja in natura com adição de inóculo anaeróbio (digestato líquido) em reatores batelada em condições mesófilas durante 30 dias (CALABRÓ; PANZERA, 2018). A configuração CMI+LI obteve o menor potencial de biogás (162 NmL.g $\left.{ }^{-1} \mathrm{SV}\right)$ e metano (48 $\left.\mathrm{NmL} \mathrm{CH}_{4} \mathrm{~g}^{-1} \mathrm{SV}\right)$ em comparação a BLI+LI. Resultados superiores foram encontrados por outros autores na literatura. Santos et al. (2020) obtiveram potencial de geração de metano (115 NmL. $\left.\mathrm{CH}_{4} \mathrm{~g}^{-1} \mathrm{SV}\right)$ superior ao estudarem a digestão anaeróbia de casca de maracujá seca com adição de lodo industrial em condições mesófilas $\left(37^{\circ} \mathrm{C}\right)$. Zhao et al. (2016) avaliaram a digestão de casca de maracujá com lodo de esgoto em reatores em batelada a temperatura de $37^{\circ} \mathrm{C}$ obtiveram potencial superior de metano de $195 \mathrm{NmL} \mathrm{CH}_{4} \cdot \mathrm{g}^{-1} \mathrm{SV}$.

Figura 3: Potencial de geração de biogás e metano $\left(\mathrm{NmL} \cdot \mathrm{g}^{-1} \mathrm{SV}\right)$ das configurações estudadas

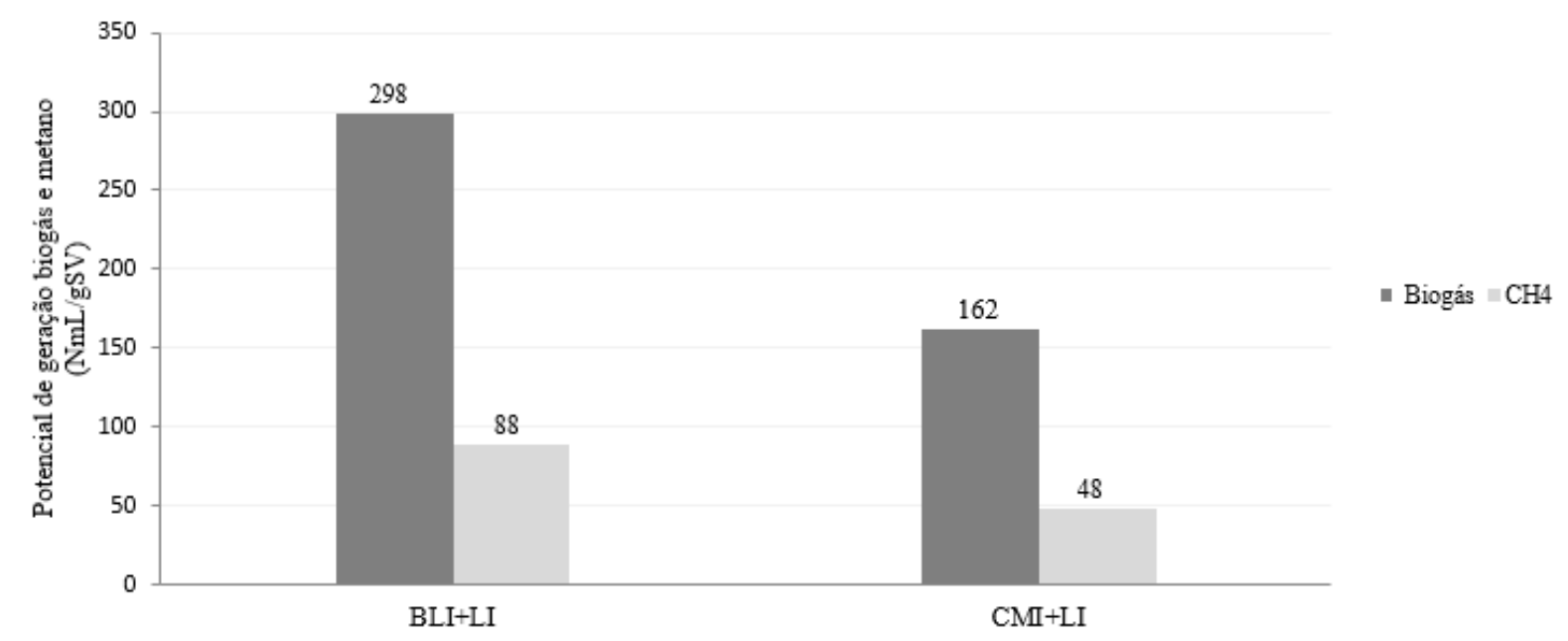

Legenda: BLI (Bagaço de laranja in natura); CMI (Casca de maracujá in natura); LI (Lodo de industrial). Fonte: Própria (2019). 
Em termos composição do biogás, as configurações (BLI+LI, CMI+LI) estudadas apresentaram percentagem de $\mathrm{CH}_{4}$ elevada, variando de 64 a $71 \%$, atestando a eficiência da digestão anaeróbia desses resíduos (Figura 4) (SANTOS, 2019). A configuração CMI+LI apresentou percentagem de metano (71\%) superior em comparação a BLI+LI (64\%). Os valores de percentagem de metano foram semelhantes aos encontrados na literatura, variando 58 a 73\% de para resíduos de laranja e maracujá (EDWIGES et al., 2018; SILVA et al., 2019; SANTOS et al., 2020). O lodo industrial apresentou elevada percentagem de metano (73\%) típico para inóculos anaeróbios que possui micro-organismos produtores de metano como as Arqueas metanogênicas.

Figura 4: Porcentagem média de metano, em volume, presente em cada configuração estudada

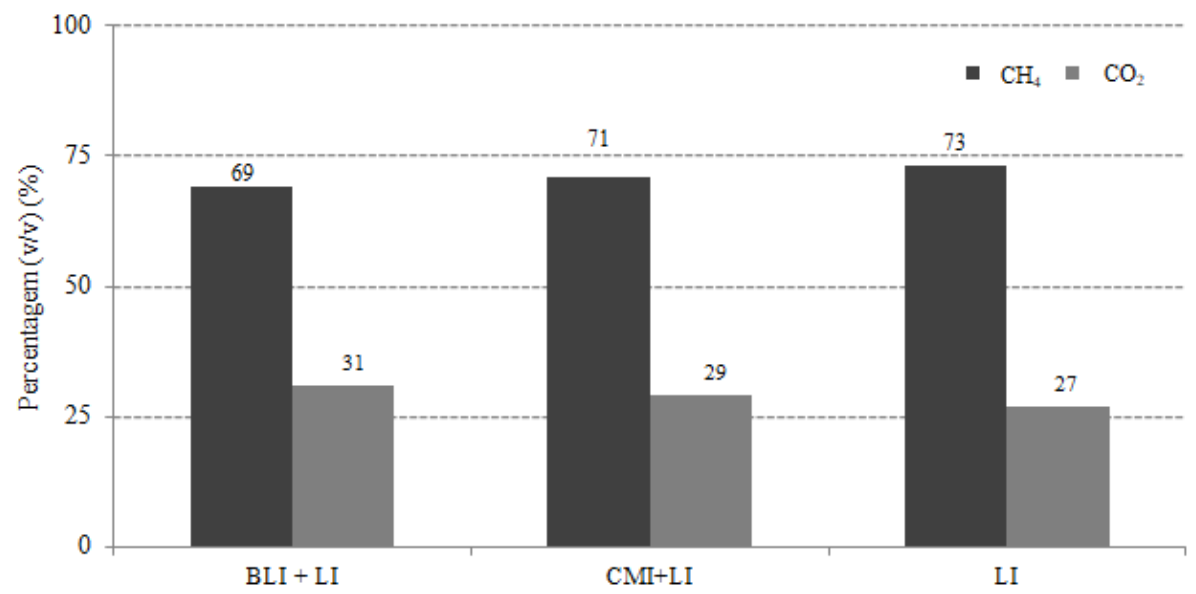

Legenda: BLI (Bagaço de laranja in natura); CMI (Casca de maracujá in natura); LI (Lodo de industrial). Fonte: Própria (2021).

\section{CONSIDERAÇÕES FINAIS}

O potencial máximo de geração de biogás $\left(298 \mathrm{NmL} \cdot \mathrm{g}^{-1} \mathrm{SV}\right)$ e metano $\left(88 \mathrm{NmL} \cdot \mathrm{g}^{-1}\right.$ SV) foi observado para o bagaço de laranja in natura com adição lodo industrial. O bagaço de laranja e casca de maracujá apresentaram elevada percetagem de metano (67-71\%), indicando que o resíduo pode ser utilizado como biomassa para fins energéticos. Destaca-se que os ganhos com a valorização energética desses resíduos para o setor agroindustrial contribui para sua competitividade e sustentabilidade dessa importante cadeia produtiva.

\section{REFERÊNCIAS}


ABNT. NBR 10.006. Procedimento para obtenção de extrato solubilizado de resíduos sólidos.

Rio de Janeiro. 2004.

ALCÂNTARA, P. B. Avaliação da influência da composição dos resíduos sólidos urbanos no comportamento de aterros simulados. 2007. 366 f. Tese (Doutorado em Engenharia Civil) - Universidade Federal de Pernambuco, Recife.

CHERNICHARO, C. A. L. Princípios do Tratamento Biológico de Águas Residuárias Reatores Anaeróbios, v. 5.2 ed. Belo Horizonte: Segrac, DESA, UFMG, 1997, 246 p.

CUI, Y.; DONG, X.; TONG, J.; LIU, S. Degradation of Lignocellulosic Components in Un-pretreated Vinegar Residue Using an Artificially Constructed Fungal Consortium. BioResources, [s.l], v.10, n. 2, p. 3434-3450, 2015.

CALABRÒ, P. S.; PONTONI, L.; PORQUEDDU, I.; GRECO, R.; PIROZZI, F.; MALPEI, F. Effect of the concentration of essential oil on orange peel waste biomethanization: Preliminary batch results, Waste Management, Oxford, v. 48, p. 440- 447, 2015.

CALABRÒ, P.S.; PANZERA, M. F. Biomethane production tests on ensiled orange peel waste. Thermal Science and Engineering Progress, [s.l], v. 35, n. 1, p.130-136, 2017.

CARVALHO, A.; R. FRAGOSO, R.; J. GOMINHO, J.; E. DUARTE, E.; Effect of Minimizing d-Limonene Compound on Anaerobic Codigestion Feeding Mixtures to Improve Methane Yield. Waste Biomass Valor, [s.l], p. 1-9, 2017.

CYPRIANO, D. Z.; DA SILVA, L. L.; MARIÑO, M. A.; TASIC, L. A Biomassa da Laranja e seus Subprodutos. Revista Virtual Quimica, [s.l], v. 9, n. 1, p. 176-191, 2017.

DO NASCIMENTO FILHO, W. B.; FRANCO, C. R. Avaliação do Potencial dos Resíduos Produzidos através do Processamento agroindustrial no Brasil. Revista Virtual de Quimica, [s.l], v. 7, n. 6, p. 1968-1987, 2015.

EBNER, J. H.; LABATUT, R. A.; RANKIN, M. J.; PRONTO, J. L.; GOOCH, C. A.; WILLIAMSON, A. A.; TRABOLD, T.A. Lifecycle Greenhouse Gas Analysis of an Anaerobic Codigestion Facility Processing Dairy Manure and Industrial Food Waste. Environmental Science \& Technology, [s.l], v. 47, n. 18, p. 11199-11208, 2015.

EDWIGES, T.; FRARE, L.; MAYER, B.; LINS, TRIOLO, L.; J. M.; FLOTATS, X.; COSTA, M. S. S. M. Influence of chemical composition on biochemical methane potential of fruit and vegetable waste. Waste Management, Oxford, v. 71, p. 618-625, 2018.

FORGACS, G.; MOHAMMAD POURBAFRANI, M.; NIKLASSON, C.; TAHERZADEHA, M. J.; HOV'ATHA, I. S. A. Methane production from citrus wastes: process development and cost estimation. Journal of Chemical Technology Biotechnology, [s.l], v. 87, n.250-255, 2012.

GRECO, S. M. L. Caracterização físico-química e molecular de genótipos de maracujá 
azedo cultivados no Distrito Federal. 2014. 149 f. Tese (Doutorado em Agronomia) Faculdade de Agronomia e Medicina Veterinária, Brasília.

IBGE-INSTITUTO BRASILEIRO DE GEOGRAFIA E ESTATÍSTICA. Levantamento sistêmico de produção agrícola. Rio de Janeiro, 2017. Disponível em: $<$ http://www.sidra.ibge.gov.br>. Acesso em: 12 out. 2019.

INFANTE, J.; SELANI, M. M.; TOLEDO, N. M. V.; SILVEIRA-DINIZ, M. F.; ALENCAR, S. M.; SPOTO, M. H. F. Atividade antioxidante de resíduos agroindustriais de frutas tropicais. Brazilian Journal of Food Nutrition., Araraquara, v. 24, n. 1, 2013.

IVANOVA, L.K., RICHARDS, D.J., SMALLMAN, D.J. The long-term settlement of landfill waste. Waste and Resource Management. Proceedings of the Institution of Civil Engineers, [s.l], p. 121-133, 2008.

JANZANTTI N. S.; MONTEIRO M. Changes in the aroma of organic passion fruit (Passiflora edulis Sims f. flavicarpa Deg.) during ripeness. Lwt-Food Science Technology, [s.l], v. 59, p. 612-624, 2014.

KALYANI, D.; LEE, K. M.; KIM, T. S.; LI, J.; DHIMAN, S. S.; KANG, Y. C.; LEE, J. K. Microbial consortia for saccharification of woody biomass and ethanol Fermentation. Fuel, [s.l], v. 107, p. 815-822, 2013.

JESUS, O. N.; SOARES, T. L.; GIRARDI, E. A.; ROSA, R. C. R.; OLIVEIRA, E. J.; NETO, A. J. C.; SANTOS, V. T.; OLIVEIRA, J. R. P. Evaluation of intraspecific hybrids of yellow passion fruit in organic farming. African Journal of Agricultural Research, [s.l], v. 11. n. 24, p. 2129-2138, 2016.

MEDEIROS, O. M. Enriquecimento nutricional por bioconversão de resíduos agroindustriais para utilização na alimentação animal. 2007. $121 \mathrm{f}$. Tese (Doutorado em Engenharia de processos) - Universidade Federal de Campina Grande, Campina Grande.

OCDE-Organização das Nações Unidas para Agricultura e Alimentação (FAO). Agricultura brasileira: Perspectivas e Desafios. 54 p, 2015.

ROCHA, L. SOATES, T do C, ARAUJO. Avaliação de Biodigestor para uso domiciliar na reciclagem de resíduos semi-sólidos orgânicos. Encontro de Ensino, Pesquisa e Extensão, Presidente Prudente, 5 a 8 de outubro, 2009.

RUIZ, B.; FLOTATS, X.; Citrus essential oils and their influence on the anaerobic digestion process: An overview. Waste Management, Oxford, v. 34, n. 11, p. 2063-2079, 2014.

RUIZ, B.; FLOTATS, X. Effect of limonene on batch anaerobic digestion of citrus peel waste. Journal Biochemical Engineering, [s.l], v. 109, p. 9-18, 2016.

SANTOS, L. A.; SANTOS, A. F. M. S.; VALENÇA, R. B.; JUCÁ, J. F. T.; OLIVEIRA, C. R. M. Produção de biogás a partir de bagaço de laranja. Revista GEAMA, Recife, v. 4, n. 3, p. 022-027, 2018. 
SANTOS, I. V. V. S. Biodigestão anaeróbia dos resíduos da agroindústria de citrus. 2016. 47 f. Dissertação (Mestrado Profissional em Energia da Biomassa) - Universidade Federal de Alagoas, Rio Largo.

SANTOS, L. A. Potencial de geração de biogás a partir de resíduos agroindustriais de frutas. 2019. 185 f. Tese (Doutorado em Engenharia Civil) - Universidade Federal de Pernambuco, Recife.

SANTOS, L. A.; VALE NÇ A, R. B.; SILVA, L. C. S.; HOLAND A, S. H. B.; SILV A, A.F.V.; JUCÁ, J. F. T.; SANTOS, A. F. M. S. Methane generation potential through an aerobic digestion of fruit waste. Journal of Cleaner Production, [s.l], v. 256, p. 120389, 2020.

SILVA, N. P.; FRANCISCO, A. C. Geração de energia elétrica a partir de dejetos suínos: um estudo de caso em uma propriedade rural na região oeste do estado do Paraná. Nucleus, [s.l], v. 7, n. 2 , p. $65-82,2010$.

SILVA, C. E. F. Avaliação do potencial de uso de resíduos do processamento de frutas na produção de etanol 2G. 2014. 101 f. Dissertação (Mestrado Engenharia Química) Universidade Federal de Alagoas, Maceió.

SILVA, A. F. V.; SANTOS, L. A.; VALENÇA, R. B.; PORTO, T. S.; MOTTA, M. A. S.; GOMES, G. J. C.; JUCÁ, J.F.T.; SANTOS, A. F. M. S. Cellulase production to obtain biogas from passion fruit (Passiflora edulis) peel waste hydrolysate. Journal of Environmental Chemical Engineering, [s.l], v. 7, n. 6, p. 103510, 2019.

SILVA, T. H. L.; SANTOS, L. A.; CAROLINNI ROBERTA DE MELO OLIVEIRA, C. R. M.; PORTO, T. S.; JUCÁ, J. F. T.; SANTOS, A. F. M. S. Determination of methane generation potential and evaluation of kinetic models in poultry wastes. Biocatalysis and Agricultural Biotechnology, [s.l], v. 32, p. 101936, 2021.

STEINMETZ, R. L. R.; MEZZARI, M. P.; SILVA, M. L. B.; KUNZ, A.; AMARAL, A. C.; TÁPPARO, D. C.; SOARES, H. M. Enrichment and acclimation of an anaerobic mesophilic microrganism's inoculum for standardization of BMP assays. Bioresource Technology, Essex, Essex, v. 219, p. 21-28, 2016.

TAGHIZADEH-ALISARAEIA, A.; HOSSEINIA, S. H.; GHOBADIANB, B.; MOTEVALIC, A. Biofuel production from citrus wastes: A feasibility study in Iran. Renewable and Sustainable Energy, [s.l], v. 69, p. 1100-1112, 2017.

USDA- United States Department of Agriculture. Agricultural Statistics Annual 2013. Washington, 2019.

WHO - International Reference Center for Waste Disposal. Methods of analysis of sewage sludge solid wastes and compost. Suíça. 1978.

ZHAO, C.; YAN, H.; LIU, Y.; HUANG, Y.; ZHANG, R.; CHEN, C.; LIU, G. Bio-energy conversion performance, biodegradability, and kinetic analysis of different fruit residues during discontinuous anaerobic digestion. Waste Management, Oxford, v. 52, p. 295-301, 2016. 


\title{
CAPÍTULO 19: LOS ALIMENTOS COMO FUENTES NATURALES PARA EL CONTROL BIODIN MICO DE INSECTOS Y PLAGAS
}

\section{CHAPTER 19: FOODS AS NATURAL SOURCES FOR BIODYNAMIC CONTROL OF INSECTS AND PESTS}

\author{
Juliana Dias Maia
}

\author{
DOI:https://doi.org/10.31692/978-65-88970-19-5.280-297
}

\begin{abstract}
RESUMO
Os agrotóxicos sintéticos estão cada vez mais em defasagem internacionalmente, menos no Brasil. Concomitantemente o surgimento e/ou migração de propriedades rurais para o sistema sustentável é crescente. Isso por causa da preocupação intensa com os malefícios que os defensivos sintéticos ocasionam à saúde do consumidor, de quem aplica e ao meio ambiente (solo, água e vegetais), além de promover a seleção de artrópodes resistentes e atingir organismos não-alvo. Os alimentos são fontes naturais de compostos efetivos contra insetos e pragas. Especiarias que são utilizadas como condimentos na culinária como tomilho, pimenta ou outros ingredientes como alho, jambu, também podem ser utilizadas no combate ecológico de insetos. As plantas produzem metabólitos com capacidade de atrair insetos polinizadores e de repelir insetos predadores. É preciso identificar tais substâncias, isolá-las e aplicá-las frente aos insetos para verificar sua eficácia em relação ao número de insetos. O ambiente para o controle da quantidade dos artrópodes pode ser no campo, nas lavouras, em fazendas, em relação à saúde dos animais ou em cidades, em relação a saúde do homem. A agroecologia prevê a utilização de caldos, pastas ou extratos diluídos dos alimentos/plantas para aplicação direta sob as pragas. Porém, estes nem sempre são tão eficazes ao comparar com pesticidas sintéticos. Para potencializar os efeitos dos defensivos naturais, convém-se concentrá-los antes do seu uso. Além disso, pode-se utilizar outra técnica para aperfeiçoar sua aplicação em campo: a microencapsulação do óleo essencial ou extrato natural. Dependendo da escolha do material de recobrimento (de preferência biodegradável) e do método (barato e sustentável), a microencapsulação é uma excelente alternativa, pois tem os seguintes objetivos: proteger o composto ativo, controlar a sua liberação e diminuir a concentração necessária para obter a atividade biológica desejada.
\end{abstract}

Palavras-Chave: Agroecologia, Defensivos alternativos, Extratos naturais, Microencapsulação, Óleos essenciais.

\begin{abstract}
Synthetic pesticides are increasingly lagging internationally, less in Brazil. Concomitantly, the emergence and / or migration of rural properties to the sustainable system is growing. This is due to the intense concern with the harms that synthetic pesticides cause to the health of the consumer, to those who apply it and to the environment (soil, water, and vegetables), in addition to promoting the selection of resistant arthropods and reaching non-target organisms. Food is a natural source of compounds effective against insects and pests. Spices that are used as condiments in cooking such as thyme, pepper, or other ingredients such as garlic, jambu, can also be used in the ecological fight against insects. Plants produce metabolites capable of attracting pollinating insects and repelling predatory insects. It is necessary to identify such substances, isolate them and apply them to insects to
\end{abstract}

\footnotetext{
${ }^{1}$ Doutora em Engenharia de Alimentos, Universidade Estadual de Campinas, juliana_dias_maia@hotmail.com
} 
verify their effectiveness about the number of insects. The environment for controlling the number of arthropods can be in the field, in crops, on farms, about the health of animals, or in cities, about the human health. Agroecology provides for the use of broths, pastes, or diluted extracts from food / plants for direct application under pests. However, these are not always as effective when compared to synthetic pesticides. To enhance the effects of natural pesticides, it is advisable to concentrate them before their use. In addition, another technique can be used to improve its application in the field: microencapsulation of essential oil or natural extract. Depending on the choice of covering material (preferably biodegradable) and the method (cheap and sustainable), microencapsulation is an excellent alternative, as it has the following objectives: protecting the active compound, controlling its release, and decreasing the concentration necessary to obtain the desired biological activity.

Keywords: Agroecology, Alternative pesticides, Essential oils, Microencapsulation, Natural extracts.

\section{INTRODUÇÃO}

Esta revisão bibliográfica aborda sobre os seguintes conteúdos: prejuízos de insetos à agricultura e à saúde do homem e dos animais; agrotóxicos sintéticos no controle de pragas; alimentos que são utilizados como controle natural de insetos; como potencializar os efeitos biológicos dos pesticidas naturais; microencapsulação de defensivos naturais; um estudo de caso sobre aplicação de partículas contendo óleo essencial contra larvas de mosquito.

Ao longo do texto são feitos questionamentos pertinentes que a sociedade, seja ela acadêmica ou não, se faz corriqueiramente, como: "é menos pior comer veneno ou comer inseto?"; "porque pagar mais caro pelo extrato concentrado se é possível utilizar o extrato diluído em forma de caldo?", “por quanto tempo após exposição no ambiente a atividade biológica do defensivo natural será mantida?", "porque aplicar a microencapsulação se vai encarecer meu produto?”, “o sistema particulado desenvolvido será eficaz no meio de aplicação?”.

Desta forma, serão abordados diversos assuntos dentro da grande área das ciências agrárias, mas que se interrelacionam, pois assim é a construção da ciência, que visa sempre a aplicação pela sociedade. O objetivo é elencar como os alimentos podem ser utilizados como substitutos de pesticidas sintéticos, de forma sustentável e ecologicamente correta.

\section{FUNDAMENTAÇÃO TEÓRICA}

Os insetos de um modo geral estão presentes em quase todas as culturas agrícolas, exemplo: lagartas em grãos e sementes; moscas em frutas, pulgão em hortaliças folhosas; formigas, percevejos, mariposas, ácaros, cupins, larvas, gorgulhos, besouros, traças que 
atacam folhas, sementes e raízes em geral, entre muitos outros (GUIMARÃES; MICHEREFF FILHO; LIZ, 2011).

Entretanto, a presença dos insetos não deve ser considerada apenas como um aspecto negativo, pois eles indicam que naquele ecossistema há um equilíbrio natural, que há vida. $\mathrm{O}$ grande problema é quando os insetos estão presentes em quantidade demasiada, se tornando uma infestação ou praga, descaracterizando o equilíbrio inicial. Só para citar, o caso mais recente foi a nuvem de gafanhotos que devastou lavouras no Sul da América do Sul e ameaçou chegar ao Brasil (G1 NOTÍCIAS, 2020).

Consequentemente, as perdas começam a surgir: são os famosos danos pós-colheita. As pragas podem causar desde pequenas manchas ou perfurações na superfície do vegetal até a perda total por causa de podridões ocasionadas por microrganismos (fungos, bactérias) ou até mesmo a saída de larvas do seu interior, o que é extremamente rejeitado pelo consumidor. É preciso salientar dois pontos importantes: 1) a qualidade inicial da matéria-prima é primordial para a obtenção de um produto de origem vegetal de qualidade; 2) junto aos danos pós-colheita, somam-se ainda os prejuízos econômicos do produtor.

Sob outro ponto de vista, os insetos em quantidade desequilibrada são um transtorno também para a saúde do homem, pois são veículos (vetores) para a transmissão dos agentes causadores de doenças (agentes etiológicos). A título de exemplo, uma única espécie de mosquito, o Aedes aegypti, pode transmitir vírus de enfermidades graves, e muitas vezes letais, como: dengue, zika, chikungunya e febre amarela; o barbeiro transmite o protozoário responsável por causar a doença de Chagas. Alguns outros insetos são mais preocupantes no caso de transmissão de patologias aos animais, especialmente ao gado produtor de leite, como berne, carrapato etc., mas que também precisam ter sua população controlada no ambiente.

Um agrave maior e que não pode deixar de ser comentado é que ainda não existe vacina contra as doenças que o Aedes transmite assim como existe para outras doenças virais cujo próprio homem é o vetor de transmissão. Por isso que mesmo em tempo de pandemia causada pelo coronavírus (SARS-CoV-2) é preciso controlar a população de mosquito e não pode haver descuido dos casos de dengue, zika, chikungunya e febre amarela. Na Figura 01 é possível verificar uma comparação do número de casos registrados e mortes de doenças promovidas por vírus acometidas nos brasileiros no ano de 2019, dentre elas as que são transmitidas pelo mosquito. Infelizmente, a taxa de letalidade da covid-19 mostrada na Figura 01 foi alterada devido ao aumento do número de casos e de mortes no Brasil, mas a vacinação 
da população já foi iniciada.

PISETE

Figura 01: Comparação de doenças virais ao longo dos anos no Brasil

\section{Panorama de doenças virais no Brasil em 2019}

$\begin{array}{lccc}\text { Doença } & \text { Casos } & \text { Mortes } & \text { Letalidade (\%) } \\ \text { Dengue } & 1.544 .987 & 782 & 0,05 \\ \text { Chikungunya } & 132.205 & 92 & 0,07 \\ \text { Zika } & 10.768 & 3 & 0,03 \\ \text { Sarampo } & 18.203 & 15 & 0,08 \\ \text { H1 } 1 \text { 1 } & 3.430 & 796 & 23,2 \\ \text { Total } & \mathbf{1 . 7 0 9 . 5 9 3} & \mathbf{1 . 6 8 8} & \end{array}$

\section{Covid-19}

Números relativos ao período de 26 de fevereiro a $\mathbf{2 7}$ de abril de 2020

$\begin{array}{ccc}\text { Casos } & \text { Mortes } & \text { Letalidade (\%) } \\ 66.501 & 4.5743 & 6,8\end{array}$

Fonte: Jornal do Comércio (2020).

A Figura 02 resume onde os insetos e pragas quando em quantidade acima do normal são um problema para a sociedade.

Figura 02: Locais onde insetos e pragas são um problema para a sociedade quando em quantidade acima do normal e o que/quem são os mais afetados

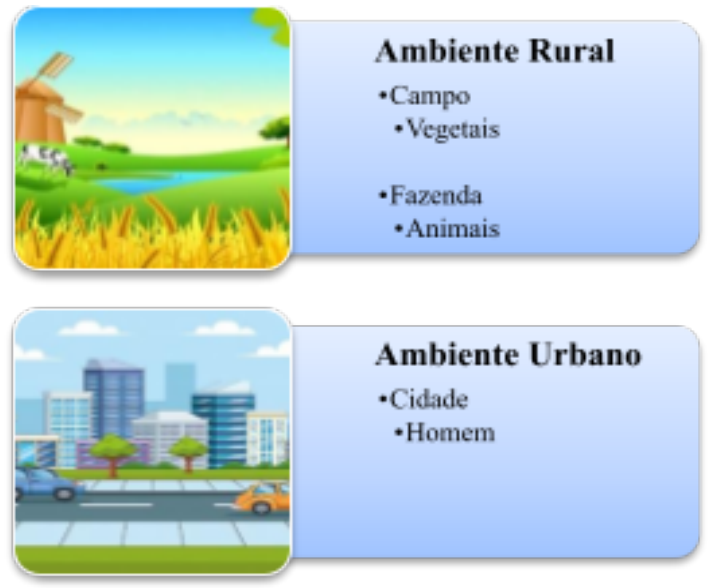

Fonte: Própria (2021). 
Desta maneira, uma forma de contornar os problemas ocasionados pela presença de pragas e insetos é utilizar substâncias químicas com capacidade de atuar sob eles. Tais substâncias têm diferentes denominações, tais como: pesticida, praguicida, defensivo, biocida, produto fitossanitário. Porém, o nome mais popular dentre eles é agrotóxico, indicando a sua alta toxicidade. Tal denominação reflete o quão nociva a substância química pode ser, principalmente são produtos de origem sintética, visto que, são triplamente prejudiciais: à saúde do consumidor e de quem aplica e ao meio ambiente. Os principais malefícios dos pesticidas sintéticos são: riscos de desenvolvimento de câncer, contaminação de solo, água e vegetais, inclusive frutas e hortaliças que serão consumidas frescas (Figura 03), toxicidade a organismos não-alvo e desenvolvimento de resistência ao princípio ativo por parte do inseto, havendo necessidade de reaplicação e em dose maior, iniciando um ciclo vicioso.

Figura 03: Ranking de vegetais que apresentam irregularidades quanto ao uso de agrotóxicos no Brasil em 2018 conforme o Programa de Análise de Resíduos de Agrotóxicos de Alimentos (PARA) da Agência Nacional de

Vigilância Sanitária (Anvisa) vinculada ao Ministério da Saúde

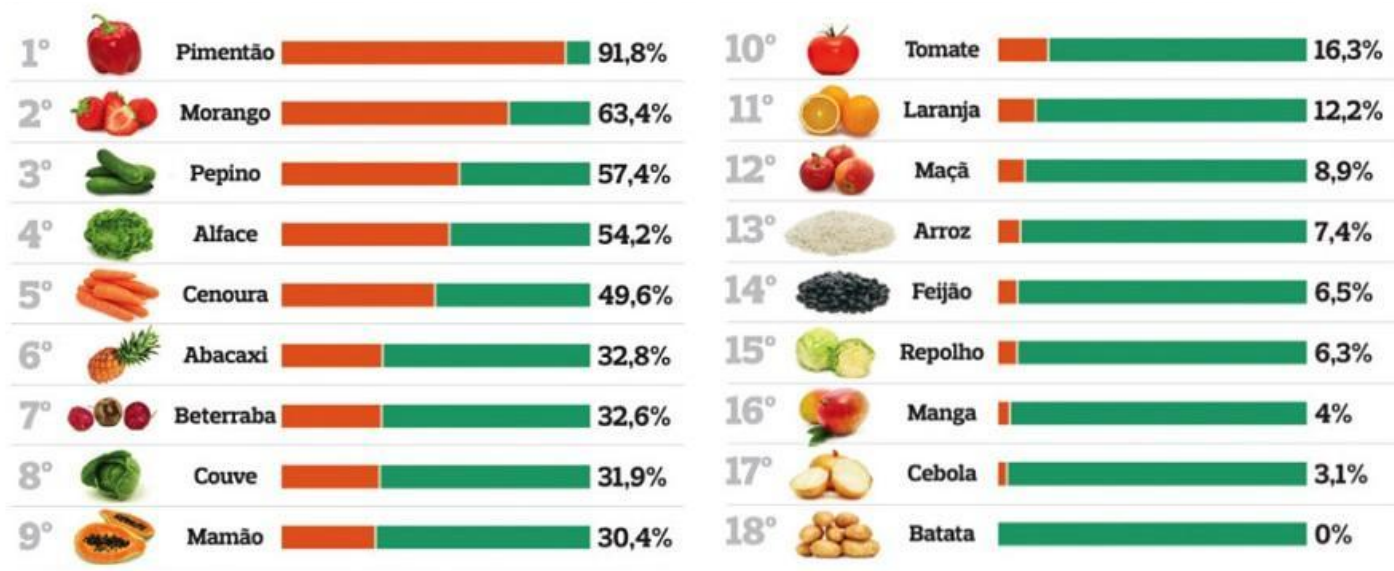

Fonte: Borges (2018).

Isto significa que em relação à segurança e inocuidade, os agrotóxicos são considerados perigos químicos para os alimentos de origem vegetal. Os agrotóxicos dividem-se basicamente em dois grupos de transmissão: por contato ou sistêmicos - os agrotóxicos sistêmicos, mais usados atualmente penetram no fruto pela raiz e incorporam-se ao DNA do vegetal (DAEMON, 2017). Se a contaminação do agrotóxico for sistêmica, isto é, através da raiz do vegetal, ele será incorporado ao seu DNA, não podendo ser removido pela sanitização, processamento térmico, ou qualquer outro método de conservação. Por isso é 
importante utilizar matéria-prima de qualidade, de preferência, isenta de agrotóxico sintético. Outras possibilidades são: utilizar a menor quantidade possível para atingir o efeito desejado, respeitar o limite estabelecido por lei e considerar os estudos das evidências dos riscos de seus usos e realmente banir aqueles que foram excluídos da lista de agrotóxicos não permitidos.

Pelo discutido até aqui, o consumidor, leigo no assunto, pergunta-se: “é menos pior comer veneno ou comer inseto?". Não é uma questão fácil de se fazer, tampouco de ser respondida pelo profissional da área de alimentos. Porém, é preciso analisar a questão como um todo e verificar quais as possíveis soluções não extremistas.

Apesar da comprovação dos malefícios dos defensivos sintéticos, o Brasil desde 2016 vem liberando cada vez mais agrotóxicos como mostra a Figura 04 e em 2020 bateu o recorde de registro de agrotóxicos. Desta forma, apesar do Ministério da Saúde fazer o controle com o Programa de Análise de Resíduos de Agrotóxicos de Alimentos (PARA) em todos as unidades federativas desde 2001, o Ministério da Agricultura, Pecuária e Abastecimento parece não estar considerando tais dados, deliberando o registro de novos agrotóxicos, muitos deles banidos na União Europeia. É preciso repensar estes fatos e verificar quais posicionamentos são mais relevantes neste momento: alavancar a produção, comercialização e uso de defensivos agrícolas ou repensar o seu uso excessivo, resíduos em alimentos e população brasileira doente.

Figura 04: Número de registros de agrotóxicos aprovados pelo Governo Federal a cada ano no Brasil de acordo com o Ministério da Agricultura, Pecuária e Abastecimento (MAPA)

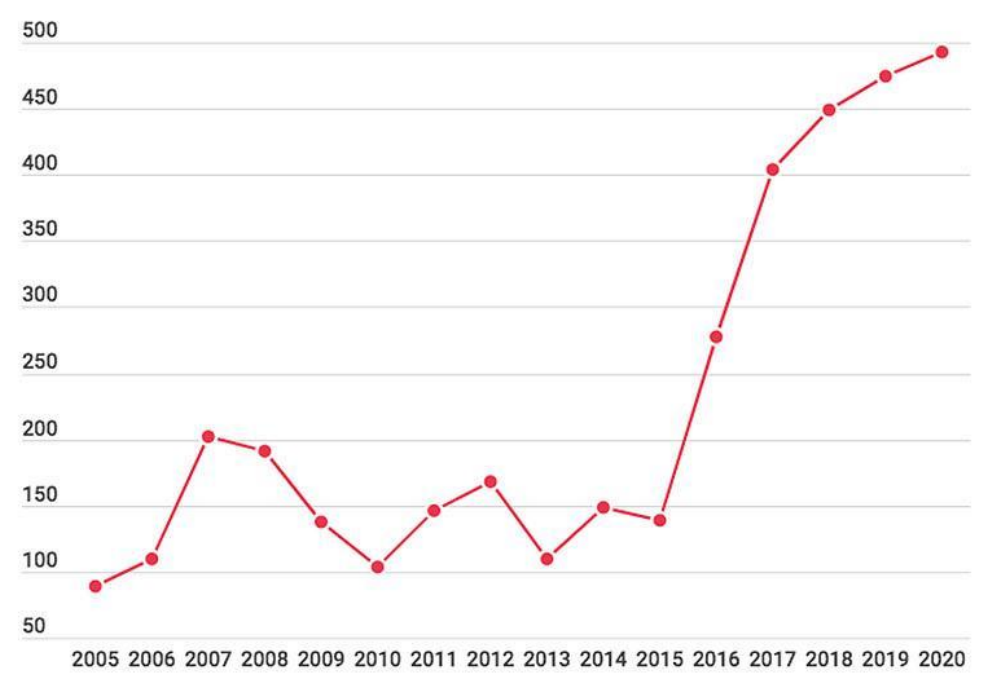

Fonte: Grigori (2021).

Assim, utilizar defensivos sintéticos é uma solução que está em defasagem e vem 
sendo substituída recentemente pela produção sustentável no ambiente rural. Este é um termo atual para indicar a produção em propriedades que vislumbram um equilíbrio maior com o ecossistema. A pecuária e agricultura são orgânicas, ou seja, as pastagens para alimentação dos animais e as culturas agrícolas não recebem defensivos agrícolas ou, quando recebem, eles são de origem natural. Sim, alimentos são utilizados como fontes naturais para controlar insetos e pragas durante o cultivo de outros alimentos. Mais adiante vamos detalhar como isto é possível. Complementando a afirmativa anterior, os alimentos de origem vegetal e animal chegam à mesa do consumidor isentos de resíduos químicos.

Um dos princípios da produção sustentável é a regeneração do solo, que inclui melhorar a relação entre os insetos e seu habitat, não excluindo-os totalmente. Especialmente porque aqui o conceito de "praga" não é mais adequado, pois os insetos são organismos que ocupam diferentes posição nos ecossistemas: as suas populações se regulam conforme a abundância de alimentos e a existência de inimigos naturais (predadores). Um aumento de uma dessas populações é uma resposta da natureza a algum desequilíbrio no ecossistema (FUNDAÇÃO KONRAD ADENAUER, 2010). Algumas propostas para controlar a população de insetos na lavoura é fazer a rotação de culturas, fazer cultivos intercalados (espécies diferentes), cercas vivas etc.

Assim, a produção orgânica de alimentos não é só uma alternativa, mas uma necessidade para desenvolver modelos de agricultura sustentáveis para as gerações futuras e corrigir os impactos da agricultura convencional. É preciso a partir de agora focar no manejo ecológico, a partir da manutenção da biodiversidade, integrando objetivos ambientais, econômicos, sociais, propondo estratégias para o desenvolvimento rural sustentável (FUNDAÇÃO KONRAD ADENAUER, 2010).

A maior desvantagem dos agrossistemas é que eles ainda são pouco utilizados quando comparados às grandes comodities, sendo mais aplicados em pequenas propriedades, mas muitas já se encontram em transição agroecológica no Brasil. Além disso, o mercado de produtos orgânicos tem crescido muito nos últimos anos (Figura 05) e tem ainda um grande potencial. Tudo isso por causa do aumento da consciência do consumidor por alimentos saudáveis, necessidade de satisfazer o cliente, responsabilidade ambiental e zelo pelo bem-estar dos animais na fazenda.

Figura 05: Mercado de produtos orgânicos no Brasil: número de produtores (a) e número de unidade de produção (b) ao longo dos anos. 


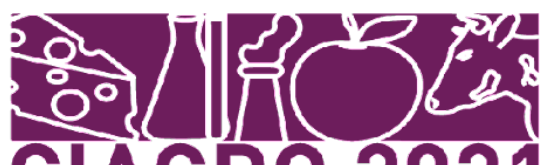

$\mathbf{a}$
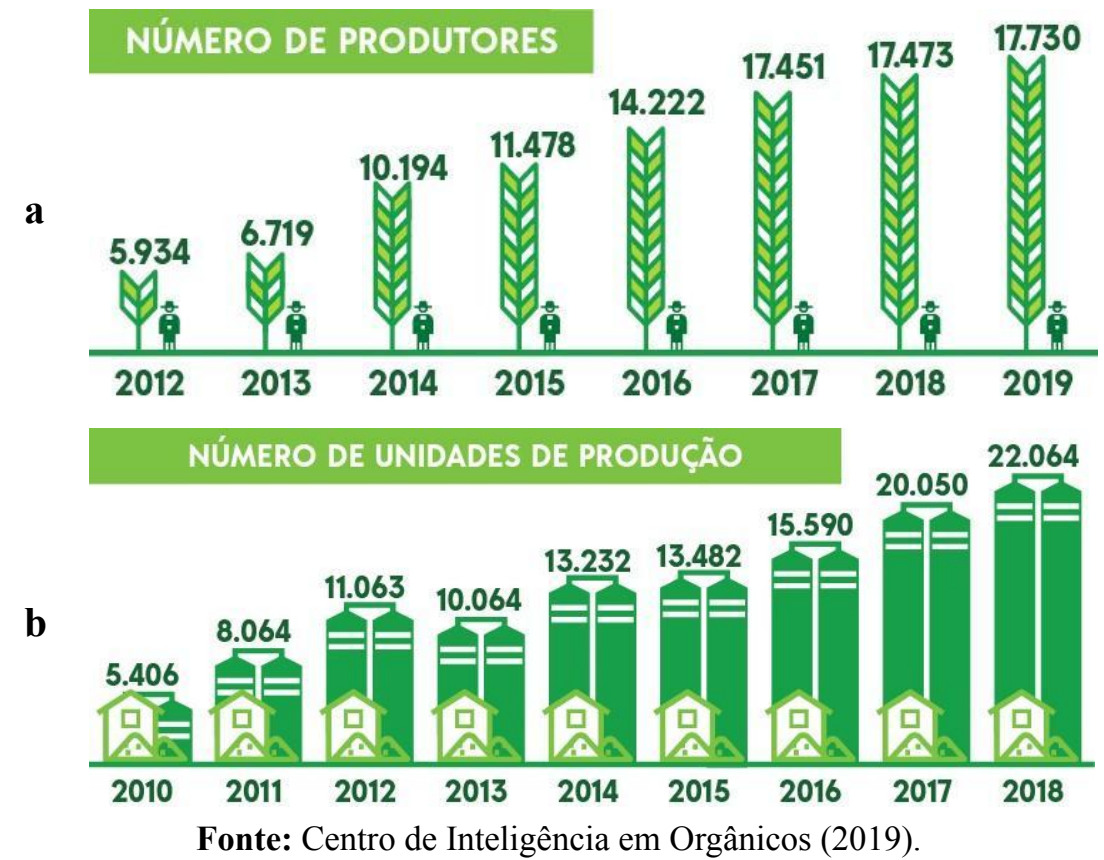

Entendido como controlar os insetos de forma mais amigável no campo, como fazê-lo em relação a insetos e pragas que ameaçam a saúde dos animais na fazenda e do homem na cidade? Tais medidas são muito difíceis, pois dependem de inúmeros fatores: poder público (existência de vacina contra a patologia), saúde do animal, infraestrutura da fazenda (zona de separação de animais sadios e doentes), saneamento ambiental (coleta de resíduos, limpeza do ambiente), conscientização do consumidor em relação ao descarte correto de resíduos, impedindo a propagação dos insetos etc.

Retomando o assunto citado anteriormente, os alimentos podem ser a solução para o controle da população de insetos e pragas que ameaçam a saúde dos animais e do homem. Mais especificamente, muitas plantas produzem substâncias em resposta a um ataque patogênico e algumas delas têm a capacidade de atrair insetos (polinizadores) ou repelir insetos (predadores). O homem faz uso então dessas plantas como pesticidas naturais para o controle de insetos.

Os defensivos alternativos apresentam como características: sustentabilidade, pois são recursos renováveis e rapidamente degradáveis; baixa ou nenhuma toxicidade ao homem e ao meio ambiente (animais, plantas, solo e água); grande disponibilidade; custo reduzido de aquisição e de utilização; simplicidade de manejo e aplicação (PEREIRA, 2020); não favorecem o desenvolvimento de resistência por parte dos insetos, pois extratos naturais e óleos essenciais são constituídos por associações complexas de princípios ativos (PROPHIRO et al., 2008) e não simplesmente por moléculas puras como os agrotóxicos sintéticos são. 
Os defensivos alternativos podem ser caldos, extratos diluído e/ou pastas de plantas, tendo como principais matérias-primas: alho, tomilho, camomila, cravo, jambu, pimenta, citronela, nim (ou neem), mamona, moringa, aroeira, entre outras variedades (ANDRADE; NUNES, 2001; COHIDRO, 2016; FUNDAÇÃO KONRAD ADENAUER, 2010; PEREIRA, 2020). A quantidade de defensivos naturais possíveis de serem obtidos é proporcional à diversidade de plantas do bioma brasileiro, ou seja, com oportunidades infinitas, muitas ainda inexploradas.

Observa-se aqui uma coincidência: especiarias que são utilizadas como condimentos na culinária, que são fontes de óleos essenciais, também podem ser utilizadas no combate ecológico de insetos. A engenharia de alimentos busca então agregar valor à matéria-prima a partir da aplicação de uma tecnologia adequada para extrair o composto ativo de interesse e, se possível, concentrá-lo para poder potencializar seu efeito biológico. Desta maneira, o defensivo natural estará cada vez mais competitivo no mercado comercial em relação ao defensivo sintético. Convém destacar que não apenas ervas aromáticas são fontes de substâncias com atividades biológicas (fitoquímicos), mas sementes, frutas, hortaliças, como já foram mencionados anteriormente diferentes exemplos. A questão principal está voltada então para o método de extração que será aplicado para a obtenção do óleo essencial ou extrato natural. Ele envolve inúmeras variáveis e está totalmente relacionado à qualidade do produto, bem como a sua pureza, consequentemente, a sua eficácia biológica.

Uma observação é que ao se fazer a análise do perfil químico do extrato/óleo, não é mandatório que o composto majoritário seja o composto ativo, isto é, aquele que confere a atividade biológica, por isso que a concentração do princípio ativo às vezes é necessária. Além disso, é importante conhecer os dados de solubilidade e difusão do composto ativo no meio onde será aplicado para ter sua atividade biológica (areia, água, ar, planta).

Geralmente, esta atividade é expressa em termos de concentração letal para eliminar uma parte da população de insetos: 50,90 ou $99 \%$, ou seja, a $\mathrm{CL}_{50}, \mathrm{CL}_{90}$ ou $\mathrm{CL}_{99}$ respectivamente. $\mathrm{A} \mathrm{CL}_{50}$ dos agrotóxicos sintéticos é muito pequena, mostrando sua eficiência, mas apresentam muitas desvantagens já discutidas. Para equilibrar a comparação com os defensivos naturais, o que se tem feito é a testagem da atividade biológica do composto ativo do óleo/extrato isolado quimicamente. Consequentemente, a $\mathrm{CL}_{50}$ do composto ativo isolado pode ser menor do que a $\mathrm{CL}_{50}$ do óleo/extrato, porém é preferível o uso do óleo/extrato bruto por causa da sua composição de mistura de substâncias complexas, 
que atuam nos artrópodes sob efeito sinergístico. Para exemplificar, a Tabela 01 traz alguns dados da literatura para o tomilho e seu composto ativo referente sua atividade biológica contra larvas de mosquito.

Tabela 01: Concentração letal para eliminar 50\% $\left(\mathrm{CL}_{50}\right)$ de larvas de diferentes vetores após $24 \mathrm{~h}$ de exposição do óleo essencial de tomilho (Thymus vulgaris) em comparação com seu metabólito isolado

\begin{tabular}{|c|c|c|c|c|}
\hline $\begin{array}{l}\text { Parte da planta } \\
\text { usada }\end{array}$ & Método de extração & $\begin{array}{l}\text { Espécie do } \\
\text { mosquito }\end{array}$ & $\begin{array}{l}\mathrm{CL}_{50} \\
(\mathrm{ppm})\end{array}$ & Referência \\
\hline $\begin{array}{l}\text { Biomassa da } \\
\text { matéria vegetal }\end{array}$ & Hidrodestilação & $\begin{array}{l}\text { Anopheles } \\
\text { labranchiae }\end{array}$ & 352,63 & El-Akhal et al. (2016) \\
\hline Folhas secas & Hidrodestilação & $\begin{array}{l}\text { Culex } \\
\text { quinquefasciatus }\end{array}$ & $14-117$ & $\begin{array}{l}\text { Pavela; Vrchotová, } \\
\text { Tríska (2009) }\end{array}$ \\
\hline Folhas & Hidrodestilação & Aedes aegypti & 17,3 & Massebo et al. (2009) \\
\hline NI & Hidrodestilação & Aedes aegypti & $\begin{array}{l}2,14- \\
25,37\end{array}$ & López et al. (2015) \\
\hline NI & $\begin{array}{l}\text { Hidrodestilação assistida } \\
\text { por microondas }\end{array}$ & Aedes aegypti & 45,73 & $\begin{array}{l}\text { Ríos; Stashenko; } \\
\text { Duque (2017) }\end{array}$ \\
\hline \multicolumn{5}{|c|}{ Metabólito isolado } \\
\hline Timol & & Culex pipiens & 52,3 & $\begin{array}{l}\text { Zahran; Abdelgaleil } \\
\text { (2011) }\end{array}$ \\
\hline
\end{tabular}

NI - Não informado; ppm - partes por milhão

Dentre os fatores que influenciam no processo de obtenção do fitoquímico de interesse, os principais são: a área superficial de contato, isto é, é necessário moer/triturar a matéria-prima para expor o produto para a ação do solvente e verificar a granulometria ideal para o processo; o tempo de contato para extração; o tipo de solvente - polaridade, viscosidade, solubilidade, lembrando que estas duas últimas propriedades podem ser moduladas pelas condições operacionais de pressão e temperatura; técnica - maceração, destilação, ultrassom, micro-ondas, extração a alta pressão (supercrítica, com líquido pressurizado). As possibilidades de métodos de extração são infinitas, contudo, as mais utilizadas são: solventes polares a baixa pressão - maceração com etanol e hidrodestilação; extração com dióxido de carbono supercrítico.

Atenta-se para o fato de tecnologias não térmicas como a extração supercrítica estarem cada vez mais em ascensão, justamente por causa da sensibilidade dos compostos de interesse ao aquecimento intenso, mas que em sua maioria encarecem o produto. É preciso sempre avaliar todo o contexto, pois o cliente pode se perguntar: "porque vou pagar mais caro pelo extrato concentrado se eu poderia utilizar o extrato diluído?" e ofertar a proposta de valor que o mercado consumidor necessita.

Apesar da possibilidade de degradação durante o aquecimento, como foi dito, a 
hidrodestilação é um dos métodos de obtenção de óleo essencial mais antigo e utilizado, justamente porque os compostos ativos são moléculas pequenas, consequentemente, voláteis, sendo facilmente extraídas por tal. Contudo, tais características trazem consigo outras particularidades: facilidade de degradação pela ação do oxigênio e da luz. Sendo assim, por quanto tempo após exposição no ambiente a atividade biológica do defensivo natural será mantida? Lembrar que a reaplicação é um dos fatores para o desenvolvimento da resistência por parte dos insetos, mesmo que seja um processo de menor incidência para os defensivos naturais, mas ele pode ocorrer. Obviamente que o desenvolvimento da ciência não parou por aí e a engenharia de alimentos trouxe mais uma alternativa tecnológica.

A microencapsulação é um processo que coloca pequenas partículas de sólido ou líquido (material de recheio) dentro de uma camada de recobrimento (matriz polimérica). É uma técnica bastante utilizada por dois motivos: 1) conferir a proteção necessária ao composto ativo frente à degradação pela ação do oxigênio e da luz; 2) controlar a liberação do composto ativo no momento e lugar mais adequado. Este segundo implica em dois outros aspectos positivos da aplicação da microencapsulação, são eles: 3) pode diminuir a concentração necessária para obter a atividade biológica desejada; 4) pode prolongar a vida útil do composto ativo (SOBEL; VERSIC; GAONKAR, 2014; TACKENBERG; KLEINEBUDDE, 2015).

Existem diferentes técnicas, como atomização, extrusão, gelificação, coacervação complexa etc. Tratando-se de microencapsulação de óleos essenciais e extratos naturais, a técnica de microencapsulação mais utilizada é a formação da emulsão com o material de recobrimento seguida por secagem em atomizador spray dryer de um modo geral.

De acordo com o processo selecionado, as partículas variam: de forma (esferas, irregulares), de estrutura (porosa, compacta) e estado físico (amorfo ou sólido cristalino desidratado, elástico ou vítreo). Tudo isso afeta as propriedades de difusão ou a estabilidade durante o armazenamento. Outros parâmetros importantes na hora da escolha da melhor técnica de microencapsulação são: custo, rendimento e adaptação à produção em escala industrial (GUEVARA-BRÉTON; JIMÉNEZ-MUNGUÍA, 2008).

As partículas produzidas podem ser classificadas quanto ao seu tamanho em: macro ( $>$ $5000 \mu \mathrm{m})$, micro $(0,2$ a $5000 \mu \mathrm{m})$ e nano $(<0,2 \mu \mathrm{m})$. Outra classificação está relacionada à distribuição do ativo no material de parede: sistema do tipo reservatório ("verdadeiras" microcápsulas, o núcleo é concentrado na região central e está circundado pelo material de 
parede) e sistema matricial (microesferas, o núcleo se encontra totalmente disperso na matriz). (AZEREDO, 2005).

Os materiais de recobrimento podem ser polímeros sintéticos ou naturais, dando-se preferência, é claro, sempre para os naturais, por serem biodegradáveis, de origem animal ou vegetal, principalmente carboidratos ou proteínas. Alguns exemplos: amidos (de milho, batata, mandioca, modificado), gomas (arábica, xantana, de cajueiro), maltodextrina, pectina, gelatina etc.

O foco é saber se o sistema particulado produzido/idealizado irá ser eficiente, seja no ambiente rural ou no ambiente urbano (Figura 02). Para ter uma noção disso, a Tabela 02 apresenta uma compilação dos fatores que podem influenciam na liberação do composto ativo.

Tabela 02: Fatores que afetam a liberação do composto ativo Solubilidade no meio de liberação

$\begin{array}{cl}\begin{array}{c}\text { Propriedades do } \\ \text { ativo }\end{array} & \begin{array}{l}\text { Solubilidade no polímero } \\ \text { Características de dissolução/difusão } \\ \text { Solubilidade no meio de liberação } \\ \text { Propriedades térmicas }\end{array} \\ \begin{array}{c}\text { Propriedades do } \\ \text { polímero }\end{array} & \begin{array}{l}\text { Grau de cristalinidade } \\ \text { Solubilidade no meio de liberação } \\ \text { Velocidade de absorção do meio de liberação }\end{array} \\ \begin{array}{c}\text { Propriedades do } \\ \text { meio de liberação }\end{array} & \begin{array}{l}\text { Velocidade de agitação } \\ \text { Temperatura }\end{array}\end{array}$




$\begin{array}{cl} & \text { Íons } \\ & \text { pH } \\ & \text { Viscosidade } \\ & \text { Enzimas } \\ & \text { Pressão } \\ & \text { Seleção do método de encapsulação } \\ \text { Propriedades do } & \text { Temperatura, pressão, tensão de cisalhamento } \\ \text { processo } & \text { Diagrama de fases do solvente com o ativo } \\ & \text { Umidade final } \\ & \text { Proporção entre polímero e ativo } \\ & \text { Composição e espessura da camada de polímero } \\ \text { Projeto do } & \text { Carga inicial de ativo e distribuição no polímero } \\ \text { processo } & \text { Microestrutura da partícula } \\ & \text { Quantidade de ativo na superfície e eficiência de encapsulação } \\ & \text { Geometria do sistema } \\ & \text { Rendimento } \\ & \text { Custo } \\ & \text { Fonte: Adaptado de Raval; Parikh; Enginner (2010). }\end{array}$

Pensando em tudo isso, Maia et al. (2019) desenvolveram um sistema particulado muito interessante para combater o mosquito Aedes aegypti. Este trabalho será utilizado como um estudo de caso de alimentos como fontes naturais para o controle biodinâmico de insetos e pragas no ambiente urbano.

A metamorfose completa do Aedes aegypti é: fase ovo, fase larva (4 estádios: L1, L2, L3 e L4), fase pupa e fase adulto, as quais podem ser observadas na Figura 06.

Figura 06: Fases de desenvolvimento do mosquito Aedes aegypti em função da duração e do ambiente. 


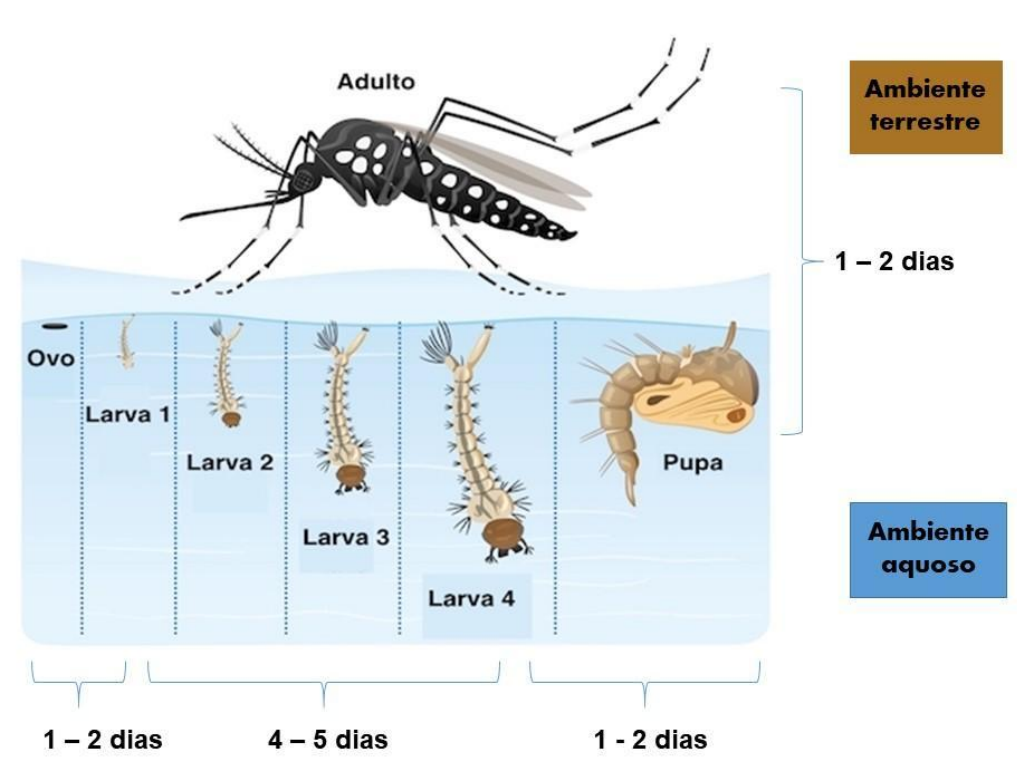

Fonte: Adaptado de Shutterstock (2019)

De acordo com Pavela (2015), a proteção química contra o mosquito é baseada em três métodos: 1) matar o mosquito adulto utilizando inseticidas do tipo aerossóis, mas nesta fase o mosquito pode estar contaminado com o vírus da doença e o ambiente de aplicação é muito grande se for um ambiente aberto e ventilado, havendo a necessidade de reaplicação constante; 2) prevenir a alimentação de sangue pelo mosquito adulto utilizando repelentes, mas é necessário aplicar corriqueiramente para continuar tendo seu efeito; 3) reduzir a população de mosquito, evitando a eclosão dos ovos ou matando as larvas, com o uso de larvicidas naturais ou sintéticos, preferindo-se os naturais por razões já comentadas.

Sendo assim, as ações para controlar a população do mosquito são realizadas principalmente na fase de larva (ambiente aquoso conforme a Figura 06), quando o inseto se encontra mais vulnerável, ainda não é um vetor em potencial (GUARDA et al., 2016) e tem menor mobilidade do que em ambiente terrestre.

Muitos anos atrás, era comum encontrar mosquito apenas na zona rural, mas ele migrou para a zona urbana por encontrar condições favoráveis para sua multiplicação. De acordo uma pesquisa realizada em Goiânia (GO, Brasil) os focos mais comuns de larvas de Aedes aegypti são vaso de plantas, garrafas abertas, latas e utensílios domésticos, representando 65\% dos locais de reprodução do mosquito (SANTOS et al., 1999). A alta prevalência de criadouros domésticos é a razão pela qual o controle de mosquitos é intensamente promovido pelos governos e nas mídias sociais; a mensagem é eliminar os focos 
de água parada e proteger os reservatórios de água do acesso por mosquitos, para evitar a proliferação do vetor. No entanto, este método depende da adesão da população à política de descarte de utensílios não utilizados e cobertura dos reservatórios. Lembrando do agrave que ainda não existe vacina para as doenças transmitidas por este artrópode.

Destarte, Maia et al. (2019) desenvolveram um sistema particulado (Figura 06) para ser aplicado em reservatórios de água, com potencial para criadouros do mosquito, como vasos de plantas, pneus velhos descartados de forma errada etc. O material de recheio utilizado foi o óleo essencial de tomilho comercial, contendo $53,2 \%$ de timol como composto ativo e majoritário, o material de recobrimento foi o amido de milho, que é barato, abundante e biodegrável (YILMAZ et al., 2001), fazendo-se uma mistura de amidos para obter $15 \%$ de teor de amilose. O método de microencapsulação aplicado foi a extrusão termoplástica, que é rápido, aplicável em escala industrial, com baixo custo e elevado rendimento, não utiliza solventes durante seu funcionamento (GUEVARA-BRÉTON; JIMÉNEZ-MUNGUÍA, 2008), tendo como princípios básicos de funcionamento o aquecimento, cisalhamento e compressão. As condições operacionais de pressão e temperatura aplicadas visaram promover danos mínimos ao óleo essencial e pouca expansão do extrusado (MAIA et al., 2017).

Figura 06: Aparência do sistema particulado produzido por extrusão termoplástica com óleo essencial de tomilho.

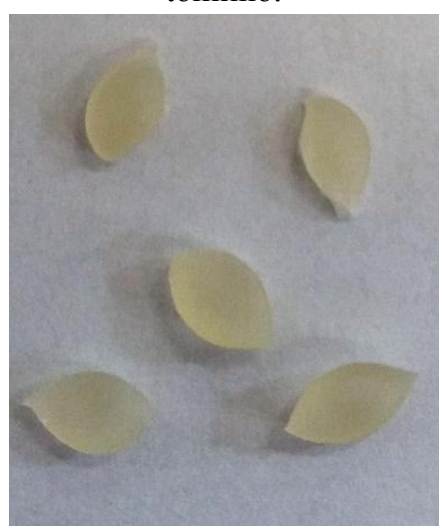

Fonte: Maia et al. (2019)

A hipótese dos mecanismos envolvidos para a liberação do composto ativo do sistema particulado para atuar sob as larvas é representado na Figura 07. Após determinado tempo em contato com a água, ocorre absorção de umidade (inchamento do amido), consequentemente um aumento dos poros que facilitam a difusão do óleo essencial de tomilho incorporado ao material polimérico e ocorre a lixiviação de sólidos do material polimérico, indicado pela 
descoloração do sistema.

Figura 07: Imersão do sistema particulado em água contendo larvas de Aedes aegypti e os mecanismos envolvidos na liberação do composto ativo.

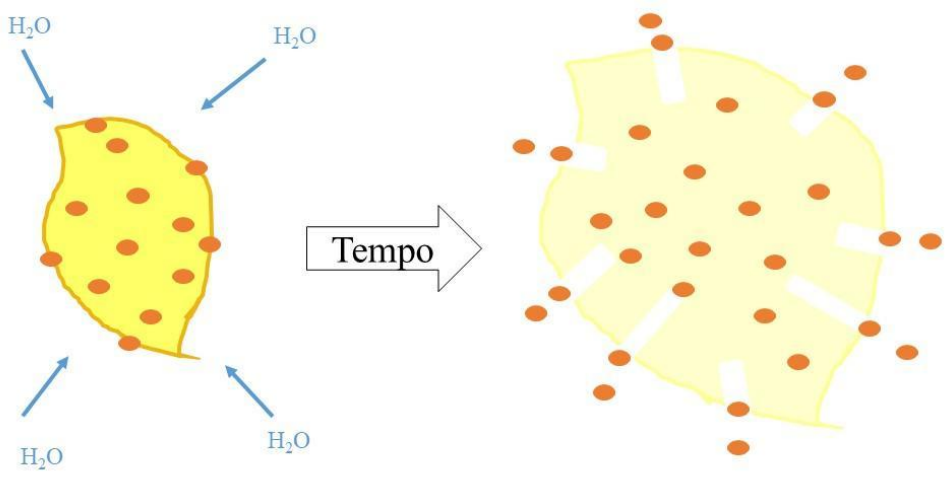

Fonte: Maia et al. (2017).

Os inúmeros efeitos positivos da microencapsulação em comparação com o óleo essencial livre (não encapsulado) obtidos por Maia et al. (2019) são apresentados na Tabela 03. Além disso, o teste de efeito residual demonstrou que o óleo essencial de tomilho livre no $3^{\circ}$ dia de exposição já tinha sua eficácia reduzida $(<20 \%$ de mortalidade larval), enquanto o sistema particulado manteve $100 \%$ de mortalidade até o $11^{\circ}$ dia e inferior a $50 \%$ apenas no $17^{\circ}$ dia. Os autores ressaltam que o sistema particulado pode ter outras aplicações mais amplas contra outros organismos (microrganismos, insetos, larvas de mosquitos de outras espécies), podendo ser aplicado com herbicidas ou nutrientes em lavouras, com fármacos em viveiros de pescado (MAIA et al., 2017, 2019).

Tabela 03: Atividade larvicida do sistema particulado e do óleo essencial de tomilho não encapsulado

\begin{tabular}{|c|c|c|c|c|}
\hline \multirow{3}{*}{$\begin{array}{l}\text { População / Fase } \\
\text { Tempo de contato }\end{array}$} & \multicolumn{3}{|c|}{ Sistema particulado } & \multirow{3}{*}{$\begin{array}{c}\text { Óleo essencial livre } \\
\mathrm{CL}_{50}\left(\mu \mathrm{g} \mathrm{mL}^{-1}\right) \\
24 \mathrm{~h}\end{array}$} \\
\hline & \multicolumn{2}{|c|}{ Mortalidade (\%) } & $\mathrm{CL}_{50}\left(\mu \mathrm{g} \mathrm{mL}^{-1}\right)$ & \\
\hline & $24 \mathrm{~h}$ & $48 \mathrm{~h}$ & $48 \mathrm{~h}$ & \\
\hline Susceptível a / L3 & $79,0 \pm 14,0$ & $99,0 \pm 1,0$ & 31 & 94 \\
\hline Susceptível ${ }^{\mathrm{a}} / \mathrm{L} 1^{\mathrm{b}}$ & - & $99,8 \pm 0,3$ & - & - \\
\hline Resistente ${ }^{c / L 3}$ & $86,0 \pm 13,0$ & $100 \pm 0.6$ & - & - \\
\hline
\end{tabular}

Fonte: Maia et al. (2019)

\section{CONSIDERAÇÕES FINAIS}

Os insetos não são vilões. Eles precisam apenas estar em número equilibrado no ecossistema, seja ele um ambiente rural ou urbano. $\mathrm{O}$ homem precisa aprender com a própria 
natureza a controlar de forma mais amigável possível a regular os predadores, a alimentação, reduzir os focos de reprodução, entre outras medidas. O mais importante é mudar o ponto de vista sobre os insetos, revendo então o conceito de pragas, o qual não existe dentro da agroecologia, visto que caracteriza apenas um desequilíbrio no habitat.

Dentre as alternativas apresentadas nesta revisão bibliográfica, a que mais tem repercussão é o uso de pesticidas naturais, que utilizam alimentos como fontes naturais de metabólitos com atividades biológicas. Tais alimentos, principalmente plantas, ervas aromáticas, sementes, podem ser utilizadas em formas de pastas, caldos ou extratos diluídos com aplicação, mas que apresentam uma curta vida útil de aplicação e baixo eficácia em comparação com pesticidas sintéticos.

Para potencializar os efeitos dos defensivos naturais, eles podem ser concentrados e, idealmente, microencapsulados, pois esta técnica visa proteger óleos essenciais e extratos, prolongando seus efeitos desejados e reduzindo a quantidade de composto ativo necessário. Quando o desenvolvimento de sistemas que apresentam eficiência comprovada, rentabilidade e custo rentável de produção, vale muito a pena aplicar a técnica de microencapsulação.

\section{REFERÊNCIAS}

ANDRADE, L. N. T.; NUNES, M. U. C. Produtos alternativos para controle de doenças e pragas em agricultura orgânica. Documentos ed. Aracaju: Embrapa Tabuleiros Costeiros, 2001. Disponível em: <www.cpatc.embrapa.br>. Acesso em: 28 abr. 2021.

AZEREDO, H. M. C. Encapsulação: aplicação à tecnologia de alimentos. Alimentos e Nutrição, [s. 1.], p. 89-97, 2005.

BORGES, L. Brasileiros consomem 7 litros de agrotóxicos por ano. 2018. Disponível em: $<$ https://autossustentavel.com/2018/04/brasileiros-7-litros-de-agrotoxicos.html $>$. Acesso em: 28 abr. 2021.

CENTRO DE INTELIGÊNCIA EM ORGÂNICOS. Interesse por alimentos saudáveis triplica número de produtores de orgânicos no País. 2019. Disponível em: $<$ https://ciorganicos.com.br/noticia/interesse-por-alimentos-saudaveis-triplica-numero-de-pro dutores-de-organicos-no-pais/>. Acesso em: 28 abr. 2021.

COHIDRO. Produtos alternativos para o controle de pragas e doenças na agricultura. $2^{\mathrm{a}}$ ed. Aracaju: Governo de Sergipe, 2016. Disponível em: $<$ https://cohidro.se.gov.br/wp-content/uploads/2017/11/produtos_alternativos_para_o_control 
e_de_pragas_e_doencas_na_agricultura.pdf $>$

DAEMON, C. É impossível remover agrotóxicos dos alimentos. 2017. Disponível em: $<$ https://www.funverde.org.br/blog/e-impossivel-remover-agrotoxicos-dos-alimentos/>. Acesso em: 28 abr. 2021.

EL-AKHAL, F. et al. Larvicidal activity of essential oils of Thymus vulgaris and Origanum majorana (Lamiaceae) against of the malaria vector Anopheles labranchiae (Diptera: Culicidae). International Journal of Pharmacy and Pharmaceutical Sciences, [s. 1.], v. 8, n. 3, p. 372-376, 2016.

FUNDAÇÃO KONRAD ADENAUER. Cartilha Agroecologia - Manejo de "pragas" e doenças. Agricultura Familiar, Agroecologia e Mercado, [s. 1.], v. no 6, p. 1-44, 2010. Disponível em: $<$ https://issuu.com/mobilizadorescoep/docs/cartilha_agroecologia_-_manejo_de_p $>$. Acesso em: 28 abr. 2021.

G1 NOTÍCIAS. Nuvem de gafanhotos chega à Argentina e se aproxima do Brasil. 2020. Disponível

em: $<$ https://g1.globo.com/economia/agronegocios/noticia/2020/06/23/nuvem-de-gafanhotos-cheg a-a-argentina-e-se-aproxima-do-brasil.ghtml>. Acesso em: 28 abr. 2021.

GRIGORI, P. 2020 é o ano com maior aprovação de agrotóxicos da história. 2021. Disponível

em:

$<$ https://ciclovivo.com.br/vida-sustentavel/alimentacao/2020-e-o-ano-com-maior-aprovacao-d e-agrotoxicos-da-historia/>. Acesso em: 28 abr. 2021.

GUARDA, C. et al. Atividade larvicida de produtos naturais e avaliação da susceptibilidade ao inseticida temefós no controle do Aedes aegypti (Diptera: Culicidae). Interciencia, [s. 1.], v. 41, n. 4, p. 243-247, 2016.

GUEVARA-BRÉTON, N. A.; JIMÉNEZ-MUNGUÍA, T. Encapsulación: técnicas y aplicaciones en la industria alimentaria. Temas Selectos de Ingeniería de Alimentos, [s. 1.], v. 2, p. $36-49,2008$.

GUIMARÃES, J. A.; MICHEREFF FILHO, M.; LIZ, R. S. Manejo de pragas em campos de produção de sementes de hortaliças. Circular Técnica no 94 Embrapa, [s. 1.], p. 1-21, 2011. Disponível em: <https://core.ac.uk/download/pdf/15445298.pdf>. Acesso em: 28 abr. 2021.

JORNAL DO COMÉRCIO. Covid-19 mata mais que zika, dengue, chikungunya, H1N1 e sarampo somados. 2020. Disponível em: $<$ https://www.jornaldocomercio.com/_conteudo/especiais/coronavirus/2020/04/736010-covid19-mata-mais-que-zika-dengue-chikungunya-h1n1-e-sarampo-somados.html >. Acesso em: 29 abr. 2021.

LÓPEZ, L. A. P. et al. Essential oils from Zanthoxylum fagara Wild Lime, Ruta chalepensis L. and Thymus vulgaris L.: composition and activity against Aedes aegypti larvae. Pakistan journal of pharmaceutical sciences, [s. 1.], v. 28, n. 5, p. 1911-1915, 2015. 
MAIA, J. D. et al. Partícula biodegradável e uso, BR 102017026411 4, 2017.

MAIA, J. D. et al. Improved activity of thyme essential oil (Thymus vulgaris) against Aedes aegypti larvae using a biodegradable controlled release system. Industrial Crops \& Products, [s. 1.], v. 136, p. 110-120, 2019. Disponível em: $<$ https://doi.org/10.1016/j.indcrop.2019.03.040>

MASSEBO, F. et al. Evaluation on larvicidal effects of essential oils of some local plants against Anopheles arabiensis Patton and Aedes aegypti Linnaeus (Diptera, Culicidae) in Ethiopia. African Journal of Biotechnology, [s. 1.], v. 8, n. 17, p. 4183-4188, 2009.

PAVELA, R. Essential oils for the development of eco-friendly mosquito larvicides: A review. Industrial Crops \& Products, [s. 1.], v. 76, p. 174-187, 2015.

PAVELA, R.; VRCHOTOVÁ, N.; TŘÍSKA, J. Mosquitocidal activities of thyme oils (Thymus vulgaris L.) against Culex quinquefasciatus (Diptera: Culicidae). Parasitology Research, [s. 1.], v. 105, n. 5, p. 1365-1370, 2009.

PEREIRA, W. H. Práticas alternativas para a produção agropecuária. [s.1.] : EMATER MG, $2020 . \quad$ Disponível em: $<$ https://ciorganicos.com.br/wp-content/uploads/2020/07/Manual_de_Praticas_Agroecológica s-Emater1.pdf>. Acesso em: 28 abr. 2021.

PROPHIRO, J. S. et al. Estudo comparativo do efeito larvicida de extratos de frutos verdes e maduros de Melia azedarach L. (Sapindales: Meliaceae) em Aedes aegypti L. (Diptera: Culicidae). BioAssay, [s. 1.], v. 3, n. 2, p. 1-5, 2008.

RAVAL, A.; PARIKH, J.; ENGINEER, C. Mechanism of controlled release kinetics from medical devices. Brazilian Journal of Chemical Engineering, [s. 1.], v. 27, n. 2, p. 211-225, 2010.

RÍOS, N.; STASHENKO, E. E.; DUQUE, J. E. Evaluation of the insecticidal activity of essential oils and their mixtures against Aedes aegypti (Diptera: Culicidae). Revista Brasileira de Entomologia, [s. 1.], v. 61, n. 4, p. 307-311, 2017.

SANTOS, A. H. et al. Controle de criadouros dos vetores de dengue e da febre amarela urbana na cidade de Goiânia, com participação popular. Revista de Patologia Tropical, [s. 1.], v. 28, n. 2, p. 231-241, 1999.

SHUTTERSTOCK. Google pictures for life cycle of mosquito Aedes aegypti. 2019. Disponível

$<$ https://www.shutterstock.com/image-vector/nature-aedes-aegypti-mosquito-stilt-life-369343 772>. Acesso em: 1 fev. 2019.

SOBEL, R.; VERSIC, R.; GAONKAR, A. G. Introduction to microencapsulation and controlled delivery in foods. In: GAONKAR, A. et al. (Eds.). Microencapsulation in the food industry - a practical implementation guide. San Diego: Academic Press, 2014. p. 590. 
TACKENBERG, M. W.; KLEINEBUDDE, P. Encapsulation of liquids via extrusion - A review. Current Pharmaceutical Design, [s. 1.], v. 21, n. 40, p. 5815-5828, 2015.

YILMAZ, G. et al. Encapsulation of sunflower oil in starch matrices via extrusion: effect of the interfacial properties and processing conditions on the formation of dispersed phase morphologies. Carbohydrate Polymers, [s. 1.], v. 45, p. 403-410, 2001.

ZAHRAN, H. E. M.; ABDELGALEIL, S. A. M. Insecticidal and developmental inhibitory properties of monoterpenes on Culex pipiens L. (Diptera: Culicidae). Journal of Asia-Pacific Entomology, [s. 1.], v. 14, p. 46-51, 2011. 


\title{
CAPÍTULO 20: ESTIMATIVA DA PRODUÇÃO DE BIOGÁS PARA GERAÇÃO DE ENERGIA ELÉTRICA ATRAVÉS DE DEJETOS DE ANIMAIS DA PECUÁRIA NO BRASIL
}

\section{CAPÍTULO 20: PRODUCCIÓN ESTIMADA DE BIOGÁS PARA GENERACIÓN DE ELECTRICIDAD A TRAVÉS DE RESIDUOS ANIMALES GANADEROS EN BRASIL}

\author{
CHAPTER 20: ESTIMATED BIOGAS PRODUCTION FOR ELECTRICITY \\ GENERATION THROUGH LIVESTOCK ANIMAL WASTE IN BRAZIL
}

Fábio Ferreira Batista ${ }^{1}$; Milla Gomes Albuquerque ${ }^{2}$; Valmir Cristiano de Arruda Marques ${ }^{3}$; André Felipe de melo Sales Santos ${ }^{4}$

\section{RESUMO}

DOI: https://doi.org/10.31692/978-65-88970-19-5.298-316

O Brasil possui um grande potencial de incrementar e diversificar sua matriz elétrica mesmo esta já sendo de base significativa de energias renováveis. A participação da valorização energética de biomassas ainda é incipiente no país, mas as políticas de valorização energética e desenvolvimento de novas tecnologias estão mudando este cenário. Este trabalho objetivou avaliar o potencial de geração de energia elétrica a partir da valorização de dejetos da pecuária (bovinos, suinos, equinos e aves) através do uso do biogás gerado em sistemas anaeróbios. Foram utilizados dados secundários do tamanho dos rebanhos nacionais e literatura técnica para o cálculo dos potenciais. $\mathrm{O}$ cálculo do potencial teórico ainda considerou fatores relativos aos processos anaeróbios mais comuns e perdas do processo. Observou-se que o potencial de energia teórico seria de cerca de 36,3 TWh/ano, correspondendo 5,6\% do montante gerado pela matriz energética no ano avaliado (2019) e suficiente para atender de cerca de 18.658 .858 residências por um ano, equivalente à $25,7 \%$ das residências no Brasil, impactando diretamente na vida de cerca de 54,11 milhões de pessoas. Esse tipo de avaliação contribui para quebra de paradigmas neste tema em comparação a estudos em escala real. As contribuições reais seriam majoritariamente para a produção de energia distribuída com caráter de aumento da competitividade dos produtores locais e apelo sustentável aos seus empreendimentos.

Palavras-Chave: Dejetos da pecuária; Biogás; Energia Elétrica; Estimativa teórica.

\section{RESUMEN}

Brasil tiene un gran potencial para incrementar y diversificar su matriz eléctrica, aunque ya se basa en energías renovables. La participación en la recuperación energética de biomasa es aún incipiente en el país, pero a medida que las políticas de recuperación energética y el desarrollo de nuevas tecnologías están cambiando este escenario. Este trabajo tuvo como objetivo evaluar el potencial de generación de energía eléctrica a partir de la valorización de los desechos pecuarios (bovinos, porcinos, equinos y aves) mediante el uso de biogás generado en sistemas anaeróbicos. Se utilizaron datos secundarios sobre el tamaño de los rebaños nacionales y literatura técnica para calcular los potenciales. El cálculo del potencial teórico aún considera factores relacionados con los procesos anaeróbicos más comunes y las pérdidas del proceso. Se observó que el potencial energético teórico rondaría los 36,3 TWh/año, correspondiente al 5,6\% de la cantidad generada por la matriz energética en el año evaluado (2019) y

\footnotetext{
${ }^{1}$ Engenharia Ambiental, Universidade Federal Rural de Pernambuco, fabio19ferreira@gmail.com

${ }^{2}$ Engenharia Ambiental, Universidade Federal Rural de Pernambuco, engmillag@gmail.com

${ }^{3}$ Professor Doutor, Universidade Federal Rural de Pernambuco, valmir.arruda@ufrpe.br

${ }^{4}$ Professor Doutor, Universidade Federal Rural de Pernambuco, andrefelipe.santos@ufrpe.br
} 
suficiente para atender alrededor de 18.658 .858 residencias durante un año, equivalente al $25,7 \%$ de las residencias en Brasil, impactando directamente la vida de alrededor de 54,11 millones de personas. Este tipo de evaluación contribuye a romper paradigmas en este tema en comparación con estudios a escala real. Los aportes reales son principalmente para la producción de energía distribuida con el carácter de aumento de la producción local y atractivo sostenible para sus empresas.

Palabras clave: Residuos de ganado; Biogás; Energia electrica; Estimación teórica.

\begin{abstract}
Brazil has great potential to increase and diversify its electrical matrix, even though it is already based on renewable energies. The participation of the energy recovery of biomass is still incipient in the country, but as policies for energy recovery and the development of new technologies are changing this scenario. This work aimed to evaluate the potential of electric power generation from the valorization of livestock waste (cattle, swine, horses and birds) through the use of biogas generated in anaerobic systems. Secondary data on the size of national herds and technical literature were used to calculate the potentials. The calculation of the theoretical potential still considers factors related to the most common anaerobic processes and process losses. It was observed that the theoretical energy potential would be about $36.3 \mathrm{TWh} /$ year, corresponding to $5.6 \%$ of the amount generated by the energy matrix in the year evaluated (2019) and sufficient to serve around to $18,658,858$ residences for a year, equivalent to $25.7 \%$ of residences in Brazil, directly impacting the lives of approximately 54.11 million people. This evaluation contributes to breaking paradigms in this theme in comparison to studies on a real scale. The real contributions are mainly for the production of distributed energy with the character of increasing local production and sustainable appeal to its enterprises.
\end{abstract}

Key words: Livestock manure; Biogas; Electricity; Theoretical estimation.

\title{
INTRODUÇÃO
}

As atividades agropecuárias no Brasil têm sido ampliadas e com isso todas as atividades dos seus sistemas de produção. Assim, paralelamente a isso, tem-se aumentado significadamente a geração de dejetos dos animais envolvidos nessas atividades, que podem trazer prejuízos ambientais quando não conduzidos de forma adequada, como mau cheiro e contaminação da água, gerando um mal-estar ao bem-social também (AQUINO et. al., 2014). Segundo dados do IBGE (2019), o número de bovinos, suínos e galinhas giram em torno de 214 milhões, 41 milhões e 249 milhões, respectivamente. No Brasil, hoje, cerca de $19 \%$ de sua área total é ocupada por pastagens, o que equivale a aproximadamente 163 milhões de hectares (ABIEC, 2018). Com o setor agropecuário passando de um sistema de criação extensivo para um modelo intensivo de confinamento, reduzindo custos e aumentando a eficiência no processo, tem-se intensificado problemas ambientais, muito a partir da incorporação de mais volumes de dejetos de animais mais concentrados em um só local e mais próximo dos seres humanos (KUNZ e OLIVEIRA, 2006).

Vive-se uma crise quando se trata do meio ambiente. Todas as atividades humanas 
demandam energia, seja no trabalho, em casa, na rua, passeando ou se divertindo. (COLATTO e LANGER, 2011). Os problemas de mudanças climáticas pedem urgência quanto as suas resoluções, uma vez que a emissão dos gases de efeito estufa (GEE) está alterando as características físico-químicas da atmosfera, o que compromete o equilíbrio natural da biosfera e a qualidade de vida no planeta (SANTOS; JUNIOR, 2013). Desta forma, encontram-se possibilidades e alternativas para proporcionar um destino adequado à esses resíduos, de forma a proporcionar tratamentos eficientes e possíveis benefícios ambientais, sociais e econômicos, como a biodigestão anaeróbia, oferecendo mais uma fonte energética com custo reduzido (ZANATO, 2014). A contribuição de um sistema bioenérgetico é aproveitar todo potencial calorífico do gás metano $\left(\mathrm{CH}_{4}\right)$ presente na decomposição anaeróbia dos dejetos, potencial esse que pode chegar a 12.000 kcal por metro cúbico do biogás (SANTOS; JÚNIOR, 2013). Com a existência de uma alta procura por fontes de energias limpas, a bioenergia surge como uma alternativa viável para dar finalidade à esses dejetos agrícolas, uma vez que ela diminui a capacidade poluidora desses resíduos, pois o gás emitido por esses dejetos durante a sua decomposição é destinado à produção de energia agora e não mais ao meio ambiente e a porção sólida dos dejetos é utilizado como adubo orgânico (GASPAR, 2003). Além disso, Colatto e Langer (2011) promoveram estudos para o cálculo do potencial terórico de metano oriundos de dejetos animais.

Porém no Brasil ainda há baixos índices de tratamento de dejetos como da suinoculturo (LIMA; BONILLA; CÂMARA, 2020). Conhecendo as características dos dejetos de animais, os projetos e os sistemas de tratamentos ficam mais viáveis, além de contribuir para uma melhor avaliação dos impactos negativos que o manejo e as deposições inadequadas acarretariam (SOUZA et al., 2009).

Assim, partindo de uma análise relativa às informações qualitativas e quantitativas dos dejetos de animais no Brasil, objetivou-se avaliar o impacto positivo do aproveitamento energético desses dejetos na matriz elétrica nacional, destacando aspectos relativos ao manejo dos dejetos e possibilidades de ganhos econômicos, sociais e ambientais ao setor da pecuária nos relacionados a competitividade e sustentabilidade dos empreendimentos.

\section{FUNDAMENTAÇÃO TEÓRICA}




\section{Pecuária e geração de dejetos}

Os dejetos de origem animal são constituídos por fezes, urina, água desperdiçada pelos bebedouros e de higienização, resíduos de ração, pelos, lã, poeiras e outros materiais decorrentes do processo de criação (ZANATO, 2014).

Matos (2016) define que o esterco proveniente de animais, também conhecido como dejetos de animais, é um tipo de resíduo originado da pecuária e que necessita de um tratamento, podendo contaminar lençóis freáticos quando aplicados a lavoura sem o tratamento prévio.

Os dejetos animais se apresentam em grandes quantidades nas propriedades rurais criadoras de gados, aves, equinos e suínos, fornecendo matéria prima para a produção local de biogás (OJEDA et al., 2018).

Segundo Colatto e Langer (2011), pode-se observar a produção diária de biomassa animal associado ao quanto de dejeto é liberado por dia de acordo com determinado animal. $\mathrm{Na}$ Tabela 1 são apresentados os dados do efetivo de rebanhos, por tipo de rebanho e por região no Brasil, segundo (IBGE, 2019).

Tabela 1: Efetivo de rebanhos, por tipo de rebanho e por região no Brasil

\begin{tabular}{|c|c|c|c|c|c|c|c|c|c|c|}
\hline \multirow[b]{2}{*}{$\begin{array}{l}\text { Brasil, Grande } \\
\text { Região }\end{array}$} & \multicolumn{10}{|c|}{ Tipos de Animais (número de animais) } \\
\hline & Bovino & Bubalino & Equino & $\begin{array}{c}\text { Suíno - } \\
\text { total }\end{array}$ & $\begin{array}{c}\text { Suíno - matrizes } \\
\text { de suínos }\end{array}$ & Caprino & Ovino & $\begin{array}{c}\text { Galináceos } \\
\text { - total }\end{array}$ & $\begin{array}{c}\text { Galináceos - } \\
\text { galinhas }\end{array}$ & Codornas \\
\hline Norte & $\begin{array}{c}4,96 \mathrm{E}+0 \\
7\end{array}$ & $\begin{array}{c}9,52 \mathrm{E}+0 \\
5 \\
\end{array}$ & $\begin{array}{c}1,02 \mathrm{E}+0 \\
6 \\
\end{array}$ & $\begin{array}{c}1,50 \mathrm{E}+0 \\
6 \\
\end{array}$ & $3,43 \mathrm{E}+05$ & $\begin{array}{c}1,47 \mathrm{E}+0 \\
5 \\
\end{array}$ & $5,96 \mathrm{E}+05$ & $4,93 \mathrm{E}+07$ & $1,35 \mathrm{E}+07$ & $\begin{array}{c}1,74 \mathrm{E}+0 \\
5 \\
\end{array}$ \\
\hline Nordeste & $\begin{array}{c}2,86 \mathrm{E}+0 \\
7 \\
\end{array}$ & $\begin{array}{c}1,28 \mathrm{E}+0 \\
5 \\
\end{array}$ & $\begin{array}{c}1,34 \mathrm{E}+0 \\
6 \\
\end{array}$ & $\begin{array}{c}5,86 \mathrm{E}+0 \\
6 \\
\end{array}$ & $1,08 \mathrm{E}+06$ & $\begin{array}{c}1,07 \mathrm{E}+0 \\
7 \\
\end{array}$ & $1,35 \mathrm{E}+07$ & $1,83 \mathrm{E}+08$ & $4,83 \mathrm{E}+07$ & $\begin{array}{c}2,52 \mathrm{E}+0 \\
6\end{array}$ \\
\hline Sudeste & $\begin{array}{c}3,70 \mathrm{E}+0 \\
7 \\
\end{array}$ & $\begin{array}{c}1,99 \mathrm{E}+0 \\
5\end{array}$ & $\begin{array}{c}1,35 \mathrm{E}+0 \\
6\end{array}$ & $\begin{array}{c}6,99 \mathrm{E}+0 \\
6\end{array}$ & $7,07 \mathrm{E}+05$ & $\begin{array}{c}1,58 \mathrm{E}+0 \\
5\end{array}$ & $6,03 \mathrm{E}+05$ & $3,72 \mathrm{E}+08$ & $9,49 \mathrm{E}+07$ & $\begin{array}{c}1,11 \mathrm{E}+0 \\
7\end{array}$ \\
\hline Sul & $\begin{array}{c}2,54 \mathrm{E}+0 \\
7 \\
\end{array}$ & $\begin{array}{c}1,00 \mathrm{E}+0 \\
5 \\
\end{array}$ & $\begin{array}{c}9,34 \mathrm{E}+0 \\
5 \\
\end{array}$ & $\begin{array}{c}2,01 \mathrm{E}+0 \\
7 \\
\end{array}$ & $2,00 \mathrm{E}+06$ & $\begin{array}{c}2,07 \mathrm{E}+0 \\
5 \\
\end{array}$ & $3,96 \mathrm{E}+06$ & $6,74 \mathrm{E}+08$ & $6,08 \mathrm{E}+07$ & $\begin{array}{c}2,85 \mathrm{E}+0 \\
6 \\
\end{array}$ \\
\hline Centro-Oeste & $\begin{array}{c}7,43 \mathrm{E}+0 \\
7 \\
\end{array}$ & $\begin{array}{c}5,50 \mathrm{E}+0 \\
4 \\
\end{array}$ & $\begin{array}{c}1,20 \mathrm{E}+0 \\
6 \\
\end{array}$ & $\begin{array}{c}6,14 \mathrm{E}+0 \\
6 \\
\end{array}$ & $6,70 \mathrm{E}+05$ & $\begin{array}{c}1,02 \mathrm{E}+0 \\
5 \\
\end{array}$ & $1,05 \mathrm{E}+06$ & $1,87 \mathrm{E}+08$ & $3,15 \mathrm{E}+07$ & $\begin{array}{c}8,21 \mathrm{E}+0 \\
5 \\
\end{array}$ \\
\hline Brasil & $\begin{array}{c}2,15 \mathrm{E}+0 \\
8\end{array}$ & $\begin{array}{c}1,43 \mathrm{E}+0 \\
6 \\
\end{array}$ & $\begin{array}{c}5,85 \mathrm{E}+0 \\
6 \\
\end{array}$ & $\begin{array}{c}4,06 \mathrm{E}+0 \\
7 \\
\end{array}$ & $4,79 \mathrm{E}+06$ & $\begin{array}{c}1,13 \mathrm{E}+0 \\
7 \\
\end{array}$ & $1,97 \mathrm{E}+07$ & $1,47 \mathrm{E}+09$ & $2,49 \mathrm{E}+08$ & $\begin{array}{c}1,74 \mathrm{E}+0 \\
7 \\
\end{array}$ \\
\hline
\end{tabular}

Fonte: Adaptado de IBGE (2019)

Devido ao enorme potencial poluidor dos dejetos animais com a sua disposição inadequada, se faz necessário um sistema de tratamento que busque minimizar os impactos ambientais (SILVA et. al., 2015).

Na Figura 1 é apresentada a distribuição de bovinos por região do Brasil (IBGE, 2019). 
Figura 01: Distribuição de bovinos por região do Brasil

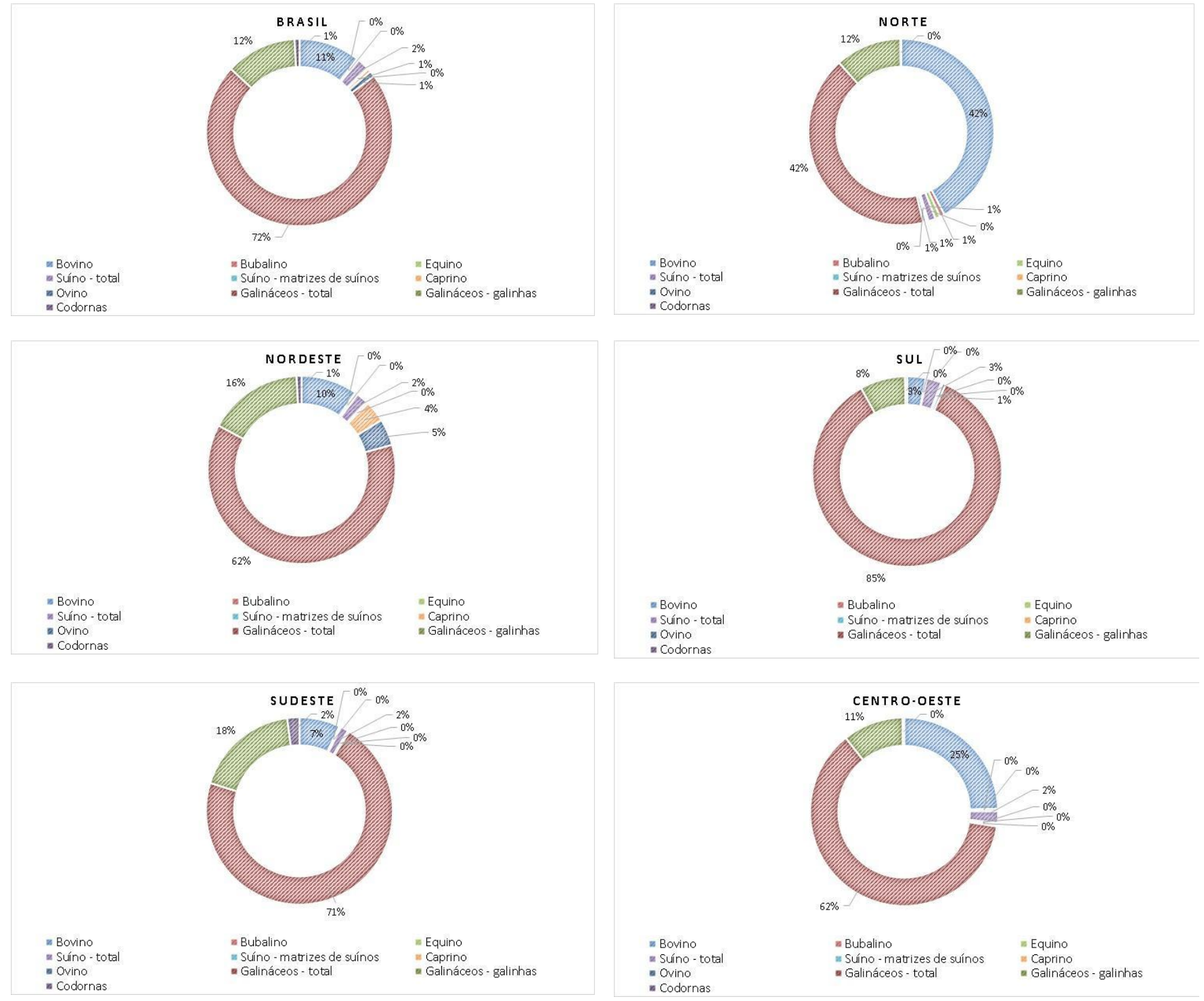

Fonte: Adaptado de IBGE (2019) 
Biodigestão anaeróbia

A biodigestão anaeróbia consiste em processo de degradação da matéria orgânica na ausência de oxigênio, produzindo uma mistura gasosa de metano $\left(\mathrm{CH}_{4}\right)$ e gás carbônico $\left(\mathrm{CO}_{2}\right)$, chamada de biogás, com alto potencial de aproveitamento energético por intermédio da queima e obtenção de energia térmica (SANTOS e JÚNIOR, 2013).

$\mathrm{Na}$ ausência total de oxigênio, a matéria orgânica será degradada a partir de colônias mistas de microrganismos que encontrarão perfeitas condições de proliferação (BLEY JR, 2015).

Segundo Júnior (2009), biodigestores são estruturas projetadas e construídas com o objetivo de produzir degradação da biomassa originada de residuos sem haver participação de oxigênio, gerando condições de degração da matéria orgânica mais acelerada de bactérias altamente consumidoras. De acordo com Motta (1986), tem-se como registro mais antigo de uso de biodigestores o ano de 1857, nas proximidades de Bombaim, na Índia, onde eram utilizados dejeto de equinos como afluente.

Segundo Kunz (2017) existem fatores que afetam a eficiência e a estabilidade da digestão anaeróbia os quais estão relacionados com as características do afluente e das condições internas do digestor. Dentre esses fatores pode-se citar o $\mathrm{pH}$ e o sistema tampão, uma vez que a atividade das bactérias responsáveis no processo dependem do $\mathrm{pH}$, além da dependencia de produção de ácidos orgânicos e da degradação desses compostos em metano. Alé disso, Kunz (2017) destaca o equilíbrio ácido-base presente, a temperatura, a homogeneização do substrato, a carga orgânica volumétrica, a inocuidade, o manejo e os agentes inibidores como fatores que também influenciam e afetam a estabilidade da digestão anaeróbia.

A utilização de biodigestores integram as atividades agropecuárias, uma vez que o resíduo agrícola de pouco valor comercial à primeira vista será reutilizado para fins que proporcionarão aumento na produção agrícola e energética (MATOS, 2016). Na França, a utilização de dejetos de animais tem-se intensificado nos trabalhos do setor de tratamento de resíduos orgânicos, incluindo a degradação anaeróbica, muito pois há um aumento na consciência ambiental nos países mais industrializados devido as limitações de demandas futuras de combustíveis fósseis, implicando na necessidade de desenvolvimento de energias renováveis (RIBEIRO et. al, 2020).

Os benefícios atribuídos aos biodigestores são grandes, preservando recursos locais, 
agregando valores econômicos nas propriedades e com uma produção acelerada de biogás, mirando uma autossuficiência em energia elétrica, agregando valor à propriedade rural e ao BIFPET produtor (COLATTO e LANGER, 2011).

A Figura 02 ilustra um sistema de biodigestão anaeróbico de dejetos de bovinos, aves, equinos e suínos.

Figura 02: Representação ilustrativa de aproveitamento energético de dejetos de animais.

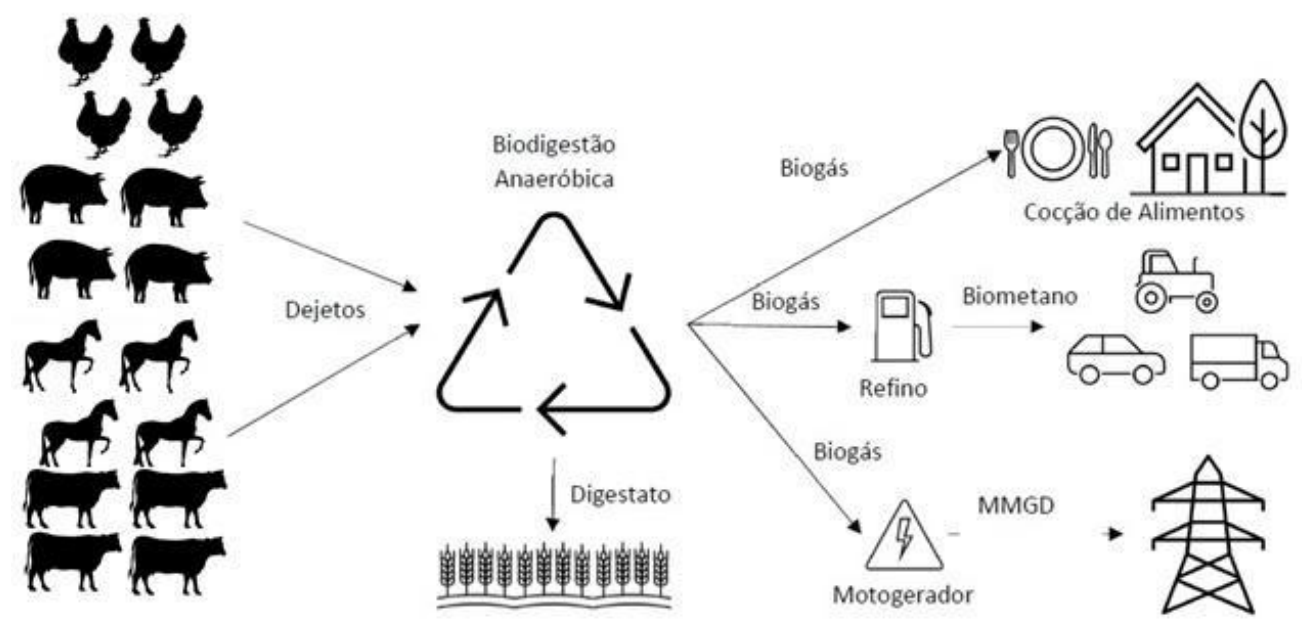

Legenda: MMGD: Micro e minigeração distribuída.

Fonte: Adaptado de EPE (2020)

\section{Biogás e metano}

Incidentalmente, foi a partir de uma demonstração da geração de gás por meio de uma mistura de estrume e água, feita por Louis Pasteur no século XIX, que o biogás, descoberto no século XVII, passou a ser considerado fonte de energia. Na década de 1940, a Índia começou a aproveitar, em plantas de geração de energia, o biogás oriundo de esterco de animais (GU et al., 2016). Biogás é composto pela mistura de gases, o metano $\left(\mathrm{CH}_{4}\right)$ consiste a $45-75 \%$ da 
mistura e o restante é de gás carbônico $\left(\mathrm{CO}_{2}\right)$ e outros gases, originados da decomposição anaeróbia da matéria orgânica (OJEDA et al., 2018). Segundo Kunz (2017), a composição típica do biogás é dada conforme a Tabela 2.

Tabela 2: Composição do biogás

$\begin{array}{cc}\text { Componente } & \text { Teor em volume \% } \\ \text { Metano } \mathrm{CH}_{4} & 50 \text { a } 75 \\ \text { Dióxido de Carbono }\left(\mathrm{CO}_{2}\right) & 25 \text { a } 40 \\ \text { Hidrogênio }\left(\mathrm{H}_{2}\right) & 1 \text { a } 3 \\ \text { Nitrogênio }\left(\mathrm{N}_{2}\right) & 0,5 \text { a } 2,5 \\ \text { Oxigênio }\left(\mathrm{O}_{2}\right) & 0,1 \text { a } 1 \\ \text { Gás Sulfídrico }\left(\mathrm{H}_{2} \mathrm{~S}\right) & 0,1 \text { a } 0,5 \\ \text { Amônio }\left(\mathrm{NH}_{3}\right) & 0,1 \text { a }, 05 \\ \text { Monóxido de carbono }(\mathrm{CO}) & 0 \text { a } 0,1 \\ \text { Água }\left(\mathrm{H}_{2} \mathrm{O}\right) & \text { Variável } \\ & \text { Fonte: Adaptado de Kunz }(2017) .\end{array}$

La Farge (1995) caracterizou o biogás quanto ao seu poder calorífico inferior, o qual representa o calor liberado pela combustão estando toda a água resultante no estado gasoso, em relação ao volume de metano concentrado conforme a Tabela 3.

Tabela 3: Poder calorífico do biogás a partir da concentração de metano presente.

$\begin{array}{cc}\mathbf{C H}_{\mathbf{4}} \% & \text { PCI (kWh/m } \\ 50 & 4,3 \\ 60 & 5,1 \\ 70 & 6,0 \\ 80 & 6,9 \\ 90 & 7,8 \\ 100 & 8,6\end{array}$

Fonte: Adaptado de La Farge (1995)

Ainda segundo La Farge (1995), o volume de metano a $0^{\circ} \mathrm{C}, 1 \mathrm{~atm}$ tem poder calorífico inferior de $9,94 \mathrm{kWh} / \mathrm{m}^{3}$ como característica média. Kunz et. al. (2014) trazem uma análise comparativa entre o biogás e outros combustíveis conforme a Tabela 4 onde é possível verificar que $1 \mathrm{~m}^{3}$ de biogás equivaleria a $1,428 \mathrm{kWh}$ segundo essa metodologia aplicada da fonte.

Tabela 4: Comparação entre o biogás e outros combistíveis

Combustíveis $1 \mathrm{~m}^{3}$ de biogás




$\begin{array}{cc}\text { Gasolina } & 0,613 \mathrm{~L} \\ \text { Querosene } & 0,579 \mathrm{~L} \\ \text { Óleo diesel } & 0,553 \mathrm{~L} \\ \text { Gás de cozinha (GLP) } & 0,454 \mathrm{~L} \\ \text { Lenha } & 1,536 \mathrm{~kg} \\ \text { Álcool hidratado } & 0,790 \mathrm{~L} \\ \text { Eletricidade } & 1,428 \mathrm{kWh}\end{array}$

Fonte: Adaptado de Gaspar (2003)

Ainda segundo Colatto e Langer (2011), o potencial de geração de energia é baseado na produção diária de biogás, o qual é considerado em termos teóricos que $1 \mathrm{~m}^{3}$ de biogás seria equivalente à $1,3 \mathrm{kWh}$, apoiando a ideia de geração de energia elétrica a partir do uso de biodigestores na degradação anaeróbia de dejetos orgânicos. O biogás ganha destaque por ser considerado uma fonte promissora de energia renovável pela sua abundância, principalmente no Brasil, e que podem trazer benefícios socioeconômicos e ambientais, propiciando destinações corretas aos dejetos, evitando contaminações do solo, lençóis freáticos, rios e açudes (VIEIRA et. al., 2019).

O biogás traz benefícios tanto ambientais como econômicos para o produtor rural, pode ser utilizado para a geração de eletricidade como também para a produção de calor (SUNADA et. al., 2012). O metano é um gás cujo efeito estufa estimado é em, no mínimo, 21 vezes a do $\mathrm{CO}_{2}$ (COLATTO e LANGER, 2011). O metano é um composto químico da classe dos hidrocarbonetos formado por um átomo de carbono e quatro átomos de hidrogênio, possuindo a fórmula molecular $\mathrm{CH}_{4}$, também chamado de gás natural quando sua concentração numa mistura gasosa é superior a 96\% em $\mathrm{CH}_{4}(\mathrm{BORGES}, 2020)$. Um meio viável para a sua formação é a queima de lixo orgânico e tem-se como uma das formas de destinação a sua utilização como fonte de energia elétrica (BORGES, 2020).

\section{Processos de biodigestão anaerobia usuais no Brasil}

Os processos de biodigestão anaeróbia mais usuais no Brasil são caracterizados por serem utilizados com biodigestores que atuam de forma contínua, ou seja, os dejetos a serem digeridos são colocados e, ao mesmo tempo, é feito o recolhimento do biogás, com o biodigestor podendo ser abastecido sempre por pequenas cargas de dejetos de forma diária ou semanal (DEGANUTTI et al., 2002). 
Com isso, segundo Lima (2021), pequisador e especialista em biogás, os modelos de biodigestores mais utilizados no Brasil são os do tipo lagoas cobertas, os quais são caracterizados por serem biodigestores escavados no solo, imperbeabilizados e recobertos com mantas plásticas, sendo normalmente PEAD ou PVC flexível. A sua adesão se dá por ser uma solução mais simples e de baixa inserção de tecnologias. Segundo Kunz (2017), o biodigestor do tipo lagoa coberta não precisa de sistema de aquecimento e nem de agitação de biomassa, porém, em contrapartida, apresenta baixa capacidade de geração de biogás, com variações entre 0,15 e $0,20 \mathrm{~m}^{3} \cdot \mathrm{kgVS}^{-1} \cdot \mathrm{d}^{-1}$. Ainda segundo Lima (2021), além desse modelo, existem processos de biodigestões anaeróbias recorrentes no Brasil que utilizam biodigestores mais industriais, como é o caso dos biodigestores de mistura completa os quais se caracterizam por serem normalmente construídos em tanques circular em concreto, acima do nível do solo, além de poderem operar com concentrações de sólidos que podem chegar a $40 \%$ por serem mais eficientes; também pode ser citado os biodigestores modelo fluxo tubular, conhecido também como fluxo pistão, definido por ser um reator de alimentação contínua e caracterizado como uma lagoa retangular coberta, permitindo que as partículas se locomovam na mesma sequência da direção em que elas entram no reator, com o material novo adcionado deslocando o mais antigo, fluindo como um pistão.

Kunz (2014) mostrou que a capacidade de geração de biogás dependerá do nível tecnológico do diferentes biodigestores conforme a Tabela 5.

Tabela 5: Capacidade de geração de biogás de reatores UASB e biodigestores para dejetos suínos

\begin{tabular}{|c|c|c|c|c|c|c|}
\hline $\begin{array}{l}\text { Geração de biogás } \\
\qquad\left(\mathrm{m}^{3} \cdot \mathrm{d}^{-1} \cdot \mathrm{m}^{-3)}\right.\end{array}$ & $\begin{array}{c}\mathrm{H}_{2} \mathrm{~S} \\
(\mathbf{p p m})\end{array}$ & $\begin{array}{l}\mathrm{CO}_{2} \\
(\%)\end{array}$ & $\begin{array}{l}\mathrm{CH}_{4} \\
(\%)\end{array}$ & $\begin{array}{c}\text { CMGB } \\
\left(\mathrm{m}^{3} \cdot \mathrm{kg} \mathrm{SV}^{-1}\right)\end{array}$ & $\begin{array}{c}\mathbf{B}_{0} \\
\left(\mathrm{~m}^{3} \cdot \mathrm{kg} \mathrm{SV}^{-1}\right)\end{array}$ & Tipo de reator (referência) \\
\hline 0,69 & 189 & 25 & 74 & 1,56 & 1,15 & $\begin{array}{l}\text { UASB escala piloto (COSTA, } \\
\text { 2007) }\end{array}$ \\
\hline 0,83 & 124 & 21 & 76 & 1,43 & 1,09 & $\begin{array}{c}\text { UASB (KUNZ e } \\
\text { ENCARNAÇÃO, 2007) }\end{array}$ \\
\hline 0,32 & 322 & 29 & 67 & 0,31 & 0,21 & BLC (KUNZ et. al., 2005) \\
\hline 0,21 & 536 & 34 & 62 & 0,33 & 0,20 & BLC (VIVAN e KUNZ, 2008) \\
\hline
\end{tabular}

Legenda: $\mathrm{BLC}=$ Biodigestor de lagoa coberta, $\mathrm{UASB}=$ Upflow Anaerobic Sludge Blanket, $\mathrm{CMGB}=$ Capacidade máxima de geração de biogás, B0=Capacidade máxima de produção de metano.

Fonte: Adaptado Kunz el al.(2014).

\section{Geração de energia elétrica com o uso do biogás}

Segundo Oliveira (2004), a geração de energia elétrica tendo o biogás como 
combustível pode ser dividida de acordo com as tecnologias a serem implementadas. Assim, inicialmente definiu o conjunto gerador de eletricidade, o qual é caracterizado por um motor de combustão interna Ciclo Otto adaptado para o uso de biogás como combustível e, além disso, ele é acoplado a um gerador de eletricidade, independendo assim do fornecimento da rede elétrica local para o seu funcionamento. Ainda segundo Oliveira (2004), tem-se o conjunto gerador economizador de eletricidade, o qual é caracterizado por um motor de combustão interna Ciclo Otto adaptado para o uso de biogás como combustível onde, além disso, está acoplado a um motor assíncrono, de dois ou quatro pólos, que passa a gerar energia ao ser conectado à rede de energia elétrica da concessionária local. Assim, a energia gerada é distribuída na propriedade e na rede externa até o transformador mais próximo.

Kunz e Oliveira, (2006) salientam que o rendimento, quando existe transformação da energia contida no biogás em elétrica, gira em torno de $25 \%$.

\section{METODOLOGIA}

A estimativa teórica da produção de metano foi realizada utilizando um dos métodos utilizáveis quando da necessidade de estimativas iniciais de produção de biogás através de determinação mais simplificada, mas baseada em dados obtidos em estudos em escala real.

Foi utilizada a metodologia de cálculo adaptada por Santos e Nardi Jr., 2013) que está sintetizada na Equação 1 e permite realizar este cálculo teórico do volume de metano. Nesta metodologia, são desconsiderados fatores tais como biodegradabilidade dos resíduos relacionados às suas características tais como estrutura química (percentagem de compostos ligno-celulósico ou recalcitrantes, por exemplo) e aspectos relacionados a toxicidade inerente aos próprios resíduos, variações ambientais de processo e operação. Desta feita seu resultado pode ser assumido como um maximo maximorum teórico ou valor máximo referencial para estimativas e posteriores correções que tornem os resultados mais próximos do potencial real.

$$
\mathrm{VCH}_{4}=\mathrm{N} \cdot \mathrm{T} \cdot \mathrm{Et} \cdot \mathrm{Pb} \cdot\left[\mathrm{CH}_{4}\right] \cdot \mathrm{VE} \mathrm{E}^{-1}
$$

Onde:

$\mathrm{VCH}_{4}$ : Volume de metano $\left(\mathrm{m}^{3}\right)$

$\mathrm{N}$ : número de animais do rebanho (unidade geradora)

T: tempo (dias)

Et: Esterco total $\left[\mathrm{kg}\right.$ dejeto. (dia. unidade geradora) $\left.{ }^{-1}\right]$ 
$\mathrm{Pb}$ : Produção de biogás [kg biogás.kg dejeto ${ }^{-1}$ ]

$\left[\mathrm{CH}_{4}\right]$ : Concentração de metano no biogás [\%]

$\mathrm{VE}^{-1}$ :Volume específico do metano $\left[\mathrm{kgCH}_{4} \cdot \mathrm{m}^{3} \mathrm{CH}_{4}\right]^{-1}$, igual a $0,670 \mathrm{kgCH}_{4}{ }^{-1} \cdot \mathrm{m}^{-3} \cdot \mathrm{CH}_{4}$

Para o cálculo do número de cabeças utilizou-se os dados compilados por tipo de animal avaliado neste estudo a partir dos dados obtidos pelo censo do IBGE (2019) em que há a representação do quantitativo total do efetivo de rebanhos apresentado na Tabela 1. Foram somados os totais por regiões dos rebanhos de suínos, bovinos, equinos e aves (galináceos totais + codornas). Para o cálculo do Et, $\mathrm{Pb}$ e concentração do biogás (\%) por diferentes tipos de resíduos utilizou-se os dados da Tabela 6 (COLATTO e LANGER, 2011). Foi considerado geração de metano anualizada ( $\mathrm{T}=365$ dias $)$.

Tabela 6: Valores de Conversão energética para alguns resíduos orgânicos animais (dejetos)

\begin{tabular}{c|c|c|c}
\hline $\begin{array}{c}\text { Origem do } \\
\text { material }\end{array}$ & $\begin{array}{c}\text { Kg de dejeto } \\
\text { (dia. unidade geradora) }^{-1} \mathbf{( E t )}\end{array}$ & $\begin{array}{c}\text { Kg de biogás. } \\
\text { Kg de dejeto }^{-1} \mathbf{( P b )}\end{array}$ & $\begin{array}{c}\text { Metano } \\
(\mathbf{\%})\left[\mathbf{C H}_{4}\right]\end{array}$ \\
\hline Suíno & 2,25 & 0,062 & $66 \%$ \\
\hline Bovinos & 10 & 0,037 & $60 \%$ \\
\hline Equinos & 12 & 0,048 & $60 \%$ \\
\hline Aves & 0,18 & 0,055 & $60 \%$ \\
\hline
\end{tabular}

Fonte: Adaptado por Colatto e Langer (2012)

A partir do recolhimento dos volumes teóricos de dados, estimou-se o potencial de energia elétrica que pode ser convertido a partir do metano em função do seu poder calorífico inferior (PCI) na faixa de 50 a 70\%, de acordo com a Tabela 3 (LA FARGE, 1995).

Foi também considerado um fator de correção de 0,25 (25\%), segundo o destacado por Kunz e Oliveira (2006) devido ao baixo rendimento da transformação energética de biogás em energia elétrica com um conjunto de motogeradores de eletricidade. Na Equação 2 apresenta-se a expressão do cálculo do Potencial médio de conversão de biogás em energia elétrica corrigido.

Onde:

$$
\text { PotmédioCH4 }=\left[\frac{P C I 50 \%+P C I 70 \%}{2}\right] .0,25(E q .2)
$$

PCI50\%: poder calorífico inferior do biogás com volume de metano a 50\% $(\mathrm{kWh})$ PCI70\%: poder calorífico inferior do biogás com volume de metano a 70\% $(\mathrm{kWh})$

A quantificação do biogás foi feita de acordo com a Equação 3, utilizando os percentuais de metano tipicos obtidos na digestão anaeróbia de cada tipo de dejeto animal 
(Tabela 6). Além disso, foi considerado um fator de correção de 0,5 (50\%) da produção de biogás em função do processo, juntamente com as perdas recorrentes de biodigestão no uso de biodigestores mais simples (biodigestores convencionais, lagoas cobertas), para a quantificação do volume de biogás real de acordo com a Equação 4.

$\frac{\text { Vbiogás }=\mathrm{VCH}_{4}}{\text { Metano }}(\%)(E q .3)$

Vbiogásreal $=$ Vbiogásteórico. $f c(E q .4)$

Onde:

$f_{c}=$ fator de correção referente a eficiência média dos processos de biodigestão mais usuais na produção de biogás para resíduos animais e perdas na produção $(0,5$, ou seja $50 \%)$

Para o cálculo do montante de energia elétrica em $\mathrm{kWh}$ foram utilizandos os resultados associdos obtidos pelas Equações 2 e 4, substituidos na Equação 5.

Energia $(k W h)=$ Vbiogásreal $*$ PotmedioCH4(Eq. 5)

\section{RESULTADOS E DISCUSSÃO}

Para o cálculo do potencial de geração de energia elétrica a partir dos principais resíduos gerados pela pecuária no ano de 2019 inicialmente procedeu-se com o cálculo do fator de conversão de biogás em energia elétrica apartir da Equação 2. O valor obtido foi de foi 1,290 kWh.m³ biogás. Este valor esteve próximo do obtido por Gaspar (2003), de 1,428 kWh.m ${ }^{3}$ biogás (Tabela 4). Na Tabela 7 são apresentados os dados síntese anuais da geração de resíduos, volumes de metano e biogás corrigidos e potencial teórico de geração de energia elétrica obtidos através das Equações 1, 2 e 4.

Tabela 7: Quantidade de resíduos, volume de metano, biogás, biogás corrigido e quivalente em energia elétrica

\begin{tabular}{l|c|c|c|c}
\hline & Bovino & Equínos & Suíno & Aves \\
\hline Quantidade de resíduos gerado (t/ano) & $7,84 \mathrm{E}+08$ & $2,56 \mathrm{E}+07$ & $3,33 \mathrm{E}+07$ & $9,75 \mathrm{E}+07$ \\
\hline
\end{tabular}




\begin{tabular}{l|c|c|c|c}
\hline Vmetano (m³/ano) & $2,60 \mathrm{E}+10$ & $1,10 \mathrm{E}+09$ & $2,03 \mathrm{E}+09$ & $4,80 \mathrm{E}+09$ \\
\hline Vbiogás $\left(\mathrm{m}^{3} /\right.$ ano) & $4,33 \mathrm{E}+10$ & $1,84 \mathrm{E}+09$ & $3,08 \mathrm{E}+09$ & $8,00 \mathrm{E}+09$ \\
\hline $\begin{array}{l}\text { Vbiogás corrigido em função do } \\
\text { processo (m/ano) }\end{array}$ & $2,17 \mathrm{E}+10$ & $9,18 \mathrm{E}+08$ & $1,54 \mathrm{E}+09$ & $4,00 \mathrm{E}+09$ \\
\hline $\begin{array}{l}\text { Equivalente em energia elétrica } \\
\text { kWh/ano) }\end{array}$ & $2,79 \mathrm{E}+10$ & $1,18 \mathrm{E}+09$ & $1,99 \mathrm{E}+09$ & $5,16 \mathrm{E}+09$ \\
\hline TOTAL (kWh/ano) & $3,63 \mathrm{E}+10$ & & & \\
\hline TOTAL (TWh/ano) & $\mathbf{3 6 , 3}$ & & & \\
\hline
\end{tabular}

Fonte: Própria (2021)

Na Figura 03 apresenta-se a participação (percentual) dos diferentes rebanhos no potencial energético de geração de energia teórico pelos principais resíduos da pecuária.

Figura 03: Participação dos diferentes rebanhos percentualamente no potencial energético de geração de energia pelos principais resíduos da pecuária

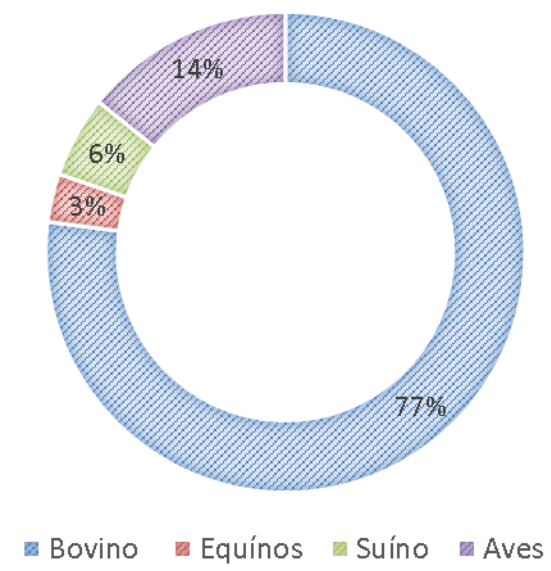

Fonte: Própria (2021)

Observou-se através do cálculo da energia eletrica potencial teórica total que seria possível gerar através unicamente dos resíduos da pecuária em 2019 cerca de 36,3 TWh.

Segundo dados do Balanço Energético Nacional 2020 (Relatório Síntese/Ano Base 2019) a oferta Interna de energia elétrica teve um avanço de 2,3\% em 2019 em relação a 2018, alcançando 651,3 TWh (BEN, 2020).

A contribuição na matriz elétrica do setor seria de cerca de 5,6\% somente com o aproveitamento energético dessse resíduo. Em relação ao ano de 2018 o aproveitamento desses resíduos seria capaz de suprir todo aumento da demanda verificada de 2018 para 2019 $(2,3 \%)$.

De acordo com o que define Resenha Mensal do Mercado de Energia Elétrica (2020), 
o consumo nas residências brasileiras foi de $162 \mathrm{kWh} /$ mês para o consumidor médio, o que corresponde a cerca de $1.944 \mathrm{kWh} /$ ano. Desta forma considerando apenas a contribuição desse potencial de $36,3 \mathrm{TWh} /$ ano calculado teríamos a possibilidade de prover de energia a cerca de 18.658 .858 residências por um ano.

O Brasil tornou-se um dos maiores produtores mundiais de gado bovino, suíno e de frangos. Em 2016, a área total de pastagens no país ocupava 230 milhões de hectares. Essa atividade produz dejetos e outros resíduos da produção cujo descarte representa fonte de poluição do solo e de recursos hídricos, bem como de emissão de gás metano (não tratado) na atmosfera.

Apesar da maior contribuição observado neste cálculo teórico proporcionalmente ter sido para os resíduos de bovinos (77\%) e aves (14\%) (Figura 03), há particularidades no manejo desses resíduos que devem ser observados. A criação de gado bovino, no Brasil, é majoritariamente, de forma extensiva, o que dificulta a coleta de seus resíduos (ABIOGÁS, 2016). Em relação aos resíduos avícolas esse é um segmento que ainda apresenta potencial restrito para a produção do biogás devido dois fatores. O primeiro é devido estes os dejetos coletados por meio da "cama de frango", são mais secos do que o ideal para seu aproveitamento na produção de biogás. O segundo é que a "cama de frango" tem outros destinos economicamente lucrativos, como, por exemplo, a venda diretamente para a fabricação de fertilizante (nitrogênio), o que pode encarecer a sua utilização como matéria-prima para o biogás.

A suinocultura por sua vez, vem se destacando nos últimos 20 anos e concentra praticamente toda a produção de biogás de origem pecuária no Brasil, apesar de, também, ainda ser diminuta.

Segundo a (ABISOLO, 2016) a suinocultura produziu, em 2015, $196 \mathrm{mil} \mathrm{Nm}^{3} / \mathrm{dia}$, o que representou $14 \%$ do total produzido no país, para um potencial de produção de cerca de $123 \mathrm{mil} \mathrm{Nm}^{3} /$ dia. A pecuária suína utiliza água de forma intensiva, o que significa, ao mesmo tempo, um elevado custo ambiental para o processo de extração de sua carne e um custo relativamente baixo para a produção do biogás, dada a facilidade de sua coleta. A esse respeito, deve ser observada a escala produtiva (USDA, 2017).

Em relação aos rejeitos dos equinos não há dados apreciáveis e poucos estudos do seu potencial aproveitamento para biogás. Geralmente estes resíduos são compostados, incorporados ao solo no próprio empreendimento ou vendidos a terceiros. 
A matriz elétrica brasileira é composta de $64,9 \%$ de energia hidráulica, tendo apenas $8,4 \%$ da oferta de energia vinda da biomassa (BEN, 2020). Há um enorme potencial de contribuição de melhor aproveitamento desses resíduos para garantir sustentabilidade e competitividade ao setor pecuário.

Mesmo com as limitações observadas deve-se destacar que a grande contribuição do melhor aproveitamento desses resíduos seria para a geração distribuída, para diversificação da matriz elétrica e nas contribuições ao meio ambiente da valorização e destinação mais adequada desses resíduos, com ganhos para os produtores localmente e a possivel utilização, a depender da escala do plantel, para geração de calor ou produção de energia a partir do biogás.

\section{CONCLUSÕES}

Segundo a metodologia utilizada, a contribuição para a produção de energia elétrica através da biodigestão anaeróbia de rejeitos dos principais rebanhos da pecuária no Brasil seria de cerca de cerca de 5,6\% em relação ao montante gerado pela da matriz energética no ano de 2019 e equivalente a uma contribuição equivalente para uma população de cerca de 18.658.858 residências por um ano, o que segundo a PNAD (2019) e o IBGE (2020) corresponde à aproximadamente 25,7\% das residências particulares do Brasil, oferecendo energia elétrica a cerca de 54,11 milhões de pessoas.

. Apesar das dificildades logísticas e operacionais para os rejeitos de bonivos e os limitantes econômicos e técnicos para os rejeitos avícolas, essa é uma alternativa factível e economicamente interessante para os pecuaristas e incentivos como os que se percebe, no caso dos rejeitos da suinocultura, seriam uma grande contribuição para a produção de energia distribuida com caráter de aumento da competitividade dos produtores locais, fechamento do ciclo produtivo e apelo sustentável aos seus empreendimentos.

\section{REFERÊNCIAS}

ABIEC. Evolução da área de pastagem e produtividade da pecuária de corte. 2018. Disponível em < http://abiec.com.br/sustentabilidade/>. Acesso em: 11/04/2021. 
Disponível em: <http://abisolo.com.br/anuario-edicoes-anteriores/>. Acesso em: 11/04/21.

ALMEIDA, C. Potencial de produção de biogás a partir de biomassa de suinocultura com culturas energéticas. 2016. 97f. Dissertação (Mestrado). Universidade Estadual do Oeste do Paraná. Programa de pós-graduação em Engenharia de Energia e Agricultura - Cascavel, 2016.

AQUINO, G.T.; BRONDANI, F.M.M.; SOUZA, R.A.A.; GERON, V.L.M.G. O uso do biogás no âmbito rural como proposta de desenvolvimento sustentável. Revista Científica da Faculdade de Educação e Meio Ambiente, v.5, n.1, p. 140-149, 2014.

BARSANO, Paulo Roberto; BARBOSA, Rildo Pereira. Meio ambiente: Guia prático e didático. São Paulo. $2^{\mathrm{a}}$ Edição 2017. Editora Saraiva.

BLEY JR, C. Biogás: a energia invisível. 2. ed. Foz do Iguaçu, PR: ITAIPU, 2015.

BORGES, Dayane. Metano, o que é? Definição, características, formação e efeito estufa.

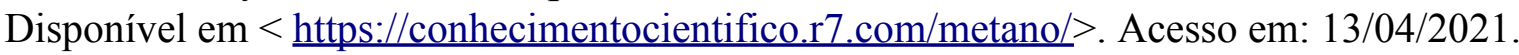

BRASIL, Ministério de Minas e Energia, 2020. BEN: Balanço Energético Nacional. Empresa de Pesquisa Energética. Disponível em: $<$ https://www.epe.gov.br/pt/publicacoes-dados-abertos/publicacoes/balanco-energetico-nacion al-2020>. Acesso em: 26/04/2021.

BRASIL, Ministério de Minas e Energia, 2020. Resenha Mensal do Mercado de Energia Elétrica. Empresa de pesquisa energética. Ano XIII, Número 148, Janeiro de 2020. Disponível

em: $<\underline{\text { https://www.epe.gov.br/sites-pt/publicacoes-dados-abertos/publicacoes/PublicacoesArquivos }}$ /publicacao-153/topico-510/Resenha\%20Mensal\%20-\%20Janeiro\%202020 v4.pdf> Acesso em: 26/04/2021.

BRASIL, Ministério de Minas e Energia, 2020. Recursos energéticos distribuídos: potencial técnico do metano da pecuária bovina. . Empresa de Pesquisa Energética. Disponível em: $<\underline{\text { https://www.epe.gov.br/sites-pt/publicacoes-dados-abertos/publicacoes/PublicacoesArquivos }}$ /publicacao-543/EPE-DEA-NT-013-2020\%20-\%20RED\%20Potencial $\% 20$ Pecu $\% \mathrm{C} 3 \%$ A1ria \%20Bovina.pdf $>$. Acesso em: 28/04/2021.

COSTA, C. C. Avaliação de sistema anaeróbio (RAC-UASB) no tratamento de água residuária de suinocultura e aplicação via fertirrigação, em feijão-vagem cultivado em ambiente protegido. 2007. 173f. Tese (Doutorado em Engenharia de Água e Solo) Universidade Federal de Lavras, Lavras.

DEGANUTTI, R.; PALHACI, M. C. J. P.; ROSSI, M.; TAVARES, R; SANTOS, C. Biodigestores rurais: modelos indiano, chinês e batelada. 2002 Disponível em: $<$ https://www.agencia.cnptia.embrapa.br/Repositorio/Biodigestores $000 \mathrm{~g} 76 \mathrm{qdzev} 02 \mathrm{wx} 5 \mathrm{ok} 0 \mathrm{w}$ tedt3spdi71p.pdf $>$. Acesso em: 26/04/2021.

GASPAR, R. Utilização de biodigestores em pequenas e médias propriedades rurais com ênfase na agregação de valor: um estudo de caso na região de Toledo-PR. 2003. 
GU, L. et al. Where is the future of China's biogas? Review, forecast, and policy implications. Petroleum Science, v. 13, p. 604-624, 2016. Disponível em: <https:// link.springer.com/article/10.1007/s12182-016-0105-6>. Acesso em: 25/04/2021.

IBGE. Efetivo dos rebanhos, por tipo de reganho, segundo o Brasil, as grandes regiões e as unidades da federação. $2019 . \quad$ Disponível em $<$ https://www.ibge.gov.br/estatisticas/economicas/agricultura-e-pecuaria/9107-producao-da-pe cuaria-municipal.html?=\&t=resultados$>$. Acesso em: 09/04/2021.

IBGE. IBGE estima população do país em 211,8 milhões de habitants. 2020. Disponível em:

$<\underline{\text { https://censo2021.ibge.gov.br/2012-agencia-de-noticias/noticias/28676-ibge-estima-populac }}$ ao-do-pais-em-211-8-milhoes-de-habitantes.html\#: :text=IBGE $\% 20$ estima $\% 20$ popula $\% \mathrm{C} 3 \%$ A7\%C3\%A3o $\% 20 \mathrm{do} \% 20 \mathrm{pa} \% \mathrm{C} 3 \% \mathrm{ADs} \% 20 \mathrm{em} \% 20211 \% 2 \mathrm{C} 8 \% 20 \mathrm{milh} \% \mathrm{C} 3 \% \mathrm{~B} 5 \mathrm{es} \% 20 \mathrm{de} \% 2$ Ohabitantes,-Editoria\%3A\%20Estatisticas\%20Sociais $>$. Acesso em: 13/05/2021.

JÚNIOR, B. C. Embrapa - Agroenergia da biomassa residual: perspectivas energéticas, socioeconômicas e ambientais. 2. ed. Foz do Iguaçu: FAO. 2009.

KUNZ, A. Embrapa - Curso: Energias renováveis processos de biodigestão. 2017. Concórdia: Embrapa.

Disponível

em:

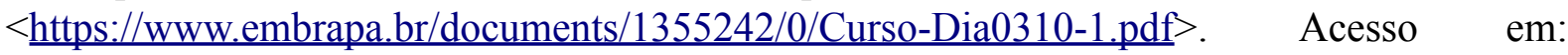

25/04/2021.

KUNZ, A.; ENCARNAÇÃO, R. Tratamento de dejetos de animais . In: GEBLER, L.;PALHARES, J. C. P. (Ed.). Gestão na agropecuária. Brasília, DF: Embrapa. Informação Tecnológica, 2007. P. 169-191.

KUNZ, A.; OLIVEIRA, P. A. V.; HIGARASHI. M. M. Biodigestor para o tratamento de dejetos suínos: influência da temperatura ambiente. Concórdia: Embrapa Suínos e Aves, 2005. 5 p. (Embrapa Suínos e Aves. Comunicado técnico, 416).

KUnZ, A.; OLIVEIRA, P. A. V.; HIGARASHI. M. M. Embrapa - Gestão Ambiental na Agropecuária. 2014. V. 2, Cap. 6, p. 236-281.

KUNZ A., OLIVEIRA P. A. V. de. Aproveitamento de dejetos de animais para geração de biogás. Revista de Política Agrícola. Nº 3, p28-35, 2006.

LA FARGE, B. de. Le biogaz: procédés de fermentation méthanique. Paris: Masson, 1995.

LIMA, H. Q. de. Biodigestor: modelos e configurações. 2021. Disponível em:

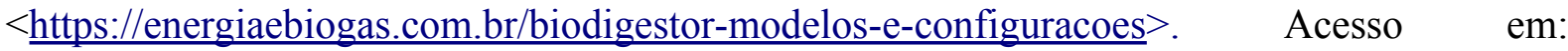
26/04/2021.

MATOS, Camila Ferreira. Produção de biogás e biofertilizante a partir de dejetos de bovinos, sob sistema orgânico e convencional de produção. 2016. 52f. Dissertação (Mestrado em Engenharia Agrícola e Ambiental). Instituto de Tecnologia, Departamento de Engenharia, Universidade Federal Rural do Rio de Janeiro, Seropédica, RJ, 2016. 
MOTTA, F. S. da; Produza sua energia: biodigestores anaeróbios. Recife: SETE, 1986.

OJEDA, L.; VASCONCELLOS, L. M.; SILVA, S. N.; Projeto de um biodigestor de dejetos de gado leiteiro para uma pequena propriedade rural. Anais do $10^{\circ}$ SALÃO INTERNACIONAL DE ENSINO, PESQUISA E EXTENSÃO - SIEPE. Universidade Federal do Pampa. Santana do Livramento, 6 a 8 de novembro de 2018.

PNAD. Pesquisa nacional por amostra de domicílios. 2019. Disponível em:

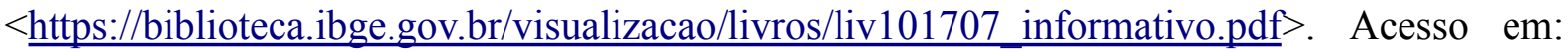
12/05/2021.

OLIVEIRA, P. A. V. de. Produção e aproveitamento do biogás. In: OLIVEIRA, P. A. V. de. Tecnologias para o manejo de resíduos na produção de suínos: manual de boas práticas. Concórdia: Embrapa Suínos e Aves, 2004. Cap. 4, p.43-55.

RIBEIRO, T.; CRESSON, R.; POMMIER, S.; PREYS, S.; ANDRÉ, L.; BÉLINE, F.; BOUCHEZ, T.; BOUGRIER, C.; BUFFIÈRE, P.; CACHO, J. et. al.; Measurement of Biochemical Methane Potential of Heterogeneous Solid Substrates: Results of a Two- Phase French Inter-Laboratory Study. Water 2020, 12, 2814. DOI:10.3390/w12102814

SANTOS, E. L. B. D.; NARDI JUNIOR, G. Produção de biogás a partir de dejetos de origem animal. Tekhne e Logos, Botucatu, SP, v.4, n.2, agosto, 2013.

SILVA, J. L G.; SILVA, A. C. C.; MITO, J. Y. L.; VENDRAME, M. G.; NASCIMENTO, K. R.; MENDES, I. S. Estimativa do potencial de produção de biogás no Brasil a partir de dejetos suínos. IV Simpósio Internacional sobre Gerenciamento de Resíduos Agropecuários e Agroindustriais. 05 a 07 de maio de 2015. Rio de Janeiro, RJ. 2015.

SOUZA, C. F.; SIQUEIRA C., CÍNARA C.; CAMPOS, J. A.; TEIXEIRA M., A.; PINTO M. F., W. Caracterização de dejetos de suínos em fase de terminação. Revista Ceres, vol. 56, núm. 2, 2009, p. 128-133. Universidade Federal de Viçosa. Viçosa, Brasil.

SUNADA, N. S.; ORRICO, A. C. A.; ORRICO JR, M. A. P.; VARGAS JR, F. M.; GARCIA, R. G.; FERNANDES, A. R. M. Potential of biogás and methane production from anaerobic digestion of poultry slaughterhouse effluent. Revista Brasileira de Zootecnica, Viçosa, v. 41, n. 11, p. 2379-2383, 2012.

USDA - UNITED STATES DEPARTMENT OF AGRICULTURE. Foreign Agricultural Service. Livestock and poultry: world markets and trade. Out. 2017. Disponível em: $<$ http://usda.mannlib.cornell.edu/MannUsda/ viewDocumentInfo.do?documentID=1488 $>$. Acesso em: 21/04/21.

VIEIRA, F. P.; DOMINGUES, E. G.; RAMALHO, S. S.; PINTO, L. S.; NETO, D. P. Análise de viabilidade econômica do aproveitamento energético do biogás e do biometano provenientes de dejetos suínos: estudo de caso. Tecnia, v.4, n.1, 2019, p. 146-167. Instituto Federal de Goiás 


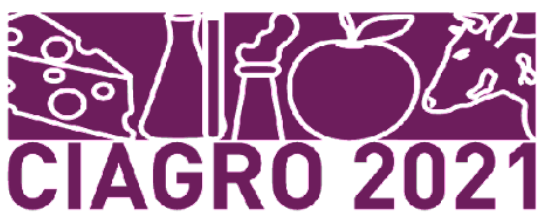

VIVAN, M.; KUNZ, A. Purificação de biogás em meio suporte sólido. In: Seminário DE DESENVOLVIMENTO DE PESQUISA, 12., 2008, Concórdia, Anais ...Concórdia: Proser SEDEPE, 2008.

ZANATO, J.A.F. Produção e Qualidade do Biogás Gerado com os Dejetos de Diferentes Espécies de Animais. São Paulo. Dissertação (doutorado) - Universidade Federal de Educação e Tecnologia de Goiás. 


\title{
CAPÍTULO 21: INVESTIGAÇÃO DAS PROPRIEDADES FISÍCO-QUÍMICAS E MORFOLÓGICAS DA CASTANHA DE CERU ( ALLANTOMA LINEATA) PARA APLICAÇÃO EM BISCOITO
}

\author{
CHAPTER 21: INVESTIGATION OF THE PHYSICOCHEMICAL AND \\ MORPHOLOGICAL PROPERTIES OF THE CHESTNUT OF CERU (ALLANTOMA \\ LINEATA) FOR APPLICATION IN CRACKERS
}

\section{CAPÍTULO 21: INVESTIGACIÓN DE LAS PROPIEDADES FISICOQUÍMICAS Y MORFOLÓGICAS DEL CASTAÑO DE CERU (ALLANTOMA LINEATA) PARA APLICACIÓN EN GALLETAS}

Edgardi Silva Contente ${ }^{1}$, Ildes Ribeiro Alves ${ }^{2}$; Giselle Cristine Melo Aires ${ }^{3}$; Suane Corrêa Barbosa ${ }^{4}$; Diego Aires da Silva ${ }^{5}$

\section{DOI: $\underline{\text { https://doi.org/10.31692/978-65-88970-19-5.317-338 }}$}

\section{RESUMO}

A Allantoma lineata ou castanha de Ceru, que é uma espécie amazônica característica das regiões de florestas de várzeas, são numerosas, finas e compridas, possuem uma aparência muito similar a uma lasca de madeira, muitas vezes sendo confundida com um galho ou pedaço de lenha. $\mathrm{O}$ objetivo deste trabalho foi caracterizar física e quimicamente, a castanha da espécie Allantoma lineata (Ceru) coletadas no interior do município de Cametá e avaliar o seu potencial nutritivo através do seu beneficiamento. Para tal, realizou-se análises de caracterização e biometria, avaliando o peso, largura, comprimento e altura das sementes, quantificando o teor de lipídio, proteína, umidade e cinzas, tanto para a amêndoa quanto para a casca da castanha de Ceru. Também foram analisadas as características físico-químicas do biscoito, quantificando o teor de acidez, $\mathrm{pH}$ e umidade. Os resultados da análise biométrica apontaram que o peso, largura, comprimento e altura das sementes, obtiveram médias de $0,86 \mathrm{~g}, 6,03 \mathrm{~mm}, 8,26 \mathrm{~mm}$ e $47,5 \mathrm{~mm}$, respectivamente. Houve uma acentuada distribuição de frequência das características avaliadas nas sementes, com exceção do parâmetro comprimento, onde ficou concentradas principalmente entre os valores de $6,15 \mathrm{~mm}$ a $9,07 \mathrm{~mm}$, relevando um potencial para a conservação e melhoramento desta espécie. Para as análises físico-química da castanha de Ceru os resultados foram $57 \%$ de lipídios, $24 \%$ de proteínas e valor calórico $680,20 \mathrm{kcal}$, números bem semelhantes a outras castanhas consumidas na região. Na avaliação da composição da casca da castanha de Ceru foi possível observar que as médias do teor de umidade, cinzas, lipídios e proteínas foram $15,97 \%$ e $3,35 \%, 9,56 \%$ e $4,17 \%$ respectivamente. O biscoito foi avaliado quanto a sua umidade $0,68 \%, \mathrm{pH} 6,36$ a uma temperatura de $24{ }^{\circ} \mathrm{C}$ e Acidez 13,89\%. O valor elevado de acidez foi atribuído a oxidação dos óleos presentes no momento da secagem em estufa. Portanto, constata-se que o beneficiamento do cerú é uma alternativa que pode gerar renda para as famílias agroextrativistas

\footnotetext{
${ }^{1}$ Tecnologia de Alimentos, Universidade do Estado do Pará diegoaires@uepa.br

2 Tecnologia de Alimentos, Universidade do Estado do Pará ildes1142@gmail.com

3 Tecnologia de Alimentos, Universidade do Estado do Pará edgardi433@gmail.com

${ }^{4}$ Tecnologia de Alimentos, Universidade do Estado do Pará suanecorrea1535@gmail.com

${ }^{5}$ Tecnologia de Alimentos, Universidade do Estado do Pará giselle.aires@uepa.br 
localizadas nas regiões de várzea do município de Cametá/PA.

Palavras-Chave: Allantoma lineata, semente oleaginosa.

\section{INTRODUÇÃO}

As sementes, as nozes e as castanhas comestíveis de plantas, têm recebido atenção especial de pesquisadores nos últimos anos, pois possuem um grande acervo, ainda inexplorado, de espécies com potencial alimentício (COSTA et al, 2010). Dentre as quais, a castanha do Brasil (Bertholletia excelsa) é uma espécie bem estabelecida no mercado. O País é um dos maiores produtores mundiais desse fruto, com uma safra média de 35 mil toneladas e uma área natural em torno de 325 milhões de hectares na Amazônia (CARDARELLI \& OLIVEIRA 2000).

As florestas brasileiras possuem uma diversidade de espécies nativas cujos frutos e sementes podem ser utilizados como fontes de nutrientes, sendo, portanto, de extrema importância o estudo dessas fontes alternativas de alimentos (CARVALHO et al, 2012). Desta forma, merece destaque, uma espécie amazônica característica das regiões de florestas de várzeas, a castanha de ceru (Allantoma lineata) (MORI, 2001).

A madeira de ceru é muito utilizada para confecção de diversos produtos da indústria madeireira (SANTOS et al, 2010). Seu fruto é um pixídio cilíndrico semelhante a um copo, medindo de 10 a $15 \mathrm{~cm}$ de comprimento, por 4 a $5 \mathrm{~cm}$ de diâmetro. Na parte superior, possui uma espécie de tampa (opérculo) que segura as amêndoas até o seu amadurecimento e podem conter em média de 8 a 12 amêndoas. Estas são numerosas, finas e compridas, e após serem liberadas são levadas pelo vento e caem no chão ou na água, restando somente o copo oco na árvore (PESCE, 2009). Suas castanhas possuem uma aparência muito similar a uma lasca de madeira, longa e fina, muitas vezes sendo confundida com um galho ou pedaço de lenha. No entanto, seu consumo fica restrito as zonas ribeirinhas visto que a sua coleta é difícil. São facilmente perdidas ao longo das várzeas ou consumidas por outros animais, como pássaros e roedores.

A morfológica de sementes é essencial, pois a biometria pode fornecer informações importantes na conservação e exploração de recursos socio-econômicos e ambientais, permitindo um incentivo contínuo da busca racional e uso eficaz de recursos naturais 
(GUSMÃO et al., 2006). Além disso, a biometria de sementes se tornou uma importante ferramenta na avaliação da variabilidade genética dentro de populações da mesma espécie, que muitas vezes pode estar associado a fatores ambientais (MACEDO et al., 2009). A farinha de castanha é um subproduto com elevado valor proteico, por apresentar diversas vantagens, tem sido muito utilizada em produtos de panificação, como na elaboração de biscoitos (OLIVEIRA, 2017).

Segundo a ANVISA - Agência Nacional de Vigilância Sanitária, na Resolução nº 263, de 22 de setembro de 2005, define biscoitos ou bolachas como produtos obtidos através de mistura de farinha(s), amido(s) e/ou fécula(s) com outros ingredientes, submetidos a processos de amassamento e cocção, podendo ser fermentados ou não. Podendo apresentar cobertura, recheio, formato e textura diversos (BRASIL, 2005).

Portanto, o objetivo deste trabalho é realizar a Caracterização físico-química e o potencial nutritivo após seu beneficiamento de castanha Allantoma lineata (Ceru), oriunda do interior do município de Cametá.

\section{REFERENCIAL TEÓRICO}

\section{Floresta de várzea}

As várzeas amazônicas são áreas inundáveis que ocupam cerca de 25 milhões de hectares (TEIXEIRA \& CARDOSO, 1991), sempre às margens do rio Amazonas, desde a nascente na Cordilheira dos Andes até o seu estuário próximo à Ilha do Marajó, abrangendo inclusive os principais afluentes desta região (RAMOS, 2000).

A várzea amazônica é um ecossistema rico e distinto no que se refere à biodiversidade e diversidade dos recursos naturais, com potencial de uso de madeira, castanha, borracha, palmito, frutos, essências aromáticas, sementes oleaginosas e pescados. Esse ecossistema possui cerca de 400 anos de exploração, com a população local mantendo uma forte Inter relação de dependência com o ambiente aquático e terrestre (RIBEIRO, 2002).

No caso da área de estudo, localizada à jusante da Usina Hidrelétrica de Tucuruí, o ambiente terrestre, precisamente as florestas nativas, que vem originando as Agro florestas, manejadas por famílias ribeirinhas, com a barragem do Rio Tocantins em 1984, assumiu uma 
importância singular na vida das famílias moradoras, fornecendo os alimentos básicos, ocupando a mão-de-obra familiar e possibilitando renda monetária, gerando a dependência dos SAF's (Sistemas Agroflorestais) para a sobrevivência (RIBEIRO, 2002).

Os moradores das várzeas, ao longo dos tempos, adaptaram-se em utilizar os vários produtos e benefícios de suas florestas, pressionados pelo isolamento de suas terras pelas inundações em que estavam sujeitos. Entre as principais riquezas extraídas para consumo próprio e algumas vezes para comercialização, estão os produtos obtidos da exploração de madeira e outros produtos da floresta, denominados comumente de produtos não madeireiros. Ainda assim, muitas espécies consideradas comerciais, não são aproveitadas pelas indústrias (RAMOS, 2000).

Torna-se extremamente importante para as pesquisas básica e aplicada ocorrentes na região Amazônica, onde o desenvolvimento econômico das diversas áreas vem acontecendo de maneira descontrolada e pouco planejada, seguindo uma lógica de interesses particulares. Nesse tipo de desenvolvimento, as regras ecológicas e as inter-relações do meio ambiente são desrespeitadas, resultando num declínio rápido e irreversível da diversidade vegetal e, consequentemente, na diminuição das opções de utilização dos recursos naturais. Para avaliar e melhorar este modelo de desenvolvimento caótico e predatório, é necessária a obtenção de maiores informações sobre a biodiversidade regional (CARVALHO, 1999).

\section{Lecythidaceae}

Segundo Mori \& Prance (1990), essa família conta com 197 espécies neotropicais descritas em 11 gêneros; desse total, 137 pertencem apenas a seis gêneros; a primeira ilustração e descrição dessa família data de 1624-1635, realizadas por Frei Cristóvão, um missionário que vivia no Estado do Maranhão; esse pode ter sido o primeiro a estudar Bertholletia excelsa Humb; \& Bonpl. (Castanha-do-Brasil). Até por volta de 1874, Lecythidaceae não era considerada como família, seus géneros faziam parte de Myrtaceae. Segundo Prance \& Mori (1979), John Miers, nos anos de 1874 e 1875, foi o primeiro a considerar Lecythidaceae como família independente (CARVALHO, 1999).

A importância econômica que as espécies de Lecythidaceae possuem na região Amazônica torna-se evidente através do aproveitamento dos frutos e sementes da castanha-do-brasil (Bertholletia ex-celsa Humb. \& Bonpl.), que por possuírem alto teor de 
proteínas, podem ser usados como alimento e na medicina alternativa (CRAVO, 1995), como também a castanha-sapucaia (Lecythis pisonis Cambess) que além da comercialização de suas sementes, também pode ser aproveitada no paisagismo, pois na época de floração, toda a copa adquire coloração lilás (LORENZI, 1992).

A situação para as sementes de outras espécies Lecythidaceae nativa das florestas tropicais amazônicas é diferente. Nenhum deles é comercializado em escala comercial e pouco se sabe sobre sua composição química. Por causa de seu potencial para servir como uma nova fonte de alimento análises químicas e morfológicas devem ser mais detalhadas para estabelecer o seu verdadeiro potencial. (ANDRADE et al. 1999).

\section{Castanha do Brasil (Bertholletia excelsa)}

A castanheira (Bertholletia excelsa) pertence à família Lecythidaceae e é popularmente conhecida no Brasil como castanheira, castanha-do-pará, castanha-do brasil e castanha da Amazônia. A Árvore é de grande porte, chega a atingir 60 metros de altura, com diâmetro altura do peito medido a $1,30 \mathrm{~m}$ do solo podendo chegar até dois metros, alcançado em torno de 500 anos de vida (SALOMÃO et al., 1995).

Seu fruto, também chamado de ouriço, é uma cápsula de aproximadamente 15 centímetros de diâmetro que se assemelha ao endocarpo do coco no tamanho, seu peso variável podendo atingir de 500 a 1500 g, possuindo de 15 a 24 sementes (castanhas) /ouriço, o que representa cerca de $25 \%$ da massa do mesmo (MÜLLER et al., 1995). A semente possui um formato triangular, com 4 a $7 \mathrm{~cm}$ de comprimento e possui a casca bastante dura e rugosa e como muitas Lecitidáceas. O fruto da castanheira possui opérculo que se desprende com a maturidade do fruto, no entanto, este é considerado funcionalmente indeiscente visto que o opérculo continua dentro do fruto mesmo após este se solta, já que o diâmetro da abertura do opérculo nunca é suficiente para a passagem do conteúdo da fruta (APARÍCIO, 2011).

A Castanha-do-Brasil é um alimento grandemente apreciado pelo seu sabor, e ainda apresenta qualidades nutricionais importantes. É constituída por 60 a 70\% de lipídios, expressivamente de ácidos graxos poli-insaturados, e de 15 a 20\% de proteína de boa qualidade biológica, além de fonte reconhecida de selênio, cálcio, fósforo, magnésio e 
vitaminas do complexo B. Tem sido ainda considerada uma boa fonte nutricional no enriquecimento e produção de alimentos como forma alternativa para alimentação da população local, em função da disponibilidade regional. (CARDARELLI \& OLIVEIRA, 2000; GLÓRIA, 2000; SOUZA, 2004).

\section{Sapucaia (Lecythis pisonis Cambess)}

Conhecida popularmente como castanha-sapucaia, marmita-de-macaco, cumbuca-de-macaco ou simplesmente "sapucaia", esta árvore da família Lecythidaceae tem origem brasileira e ocorre do Ceará até o Rio de Janeiro. Pode atingir 20 a 30 metros de altura, com tronco de 50 a 90 centímetros de diâmetro a altura do peito (LORENZI, 1992).

A semente de sapucaia, Lecythis pisonis Camb, que é popularmente utilizada como parte comestível do fruto no interior do Brasil, principalmente nos Estados de Pernambuco até São Paulo e na Amazônia, supondo-se originária da parte central leste desta região (VALLILO et al, 1998).

As amêndoas aromáticas e oleaginosas da sapucaia podem ser consumidas cruas, cozidas ou assadas, constituindo-se em excelente alimento. Um quilograma destas castanhas fornece aproximadamente 180 sementes e podem substituir, em igualdade de condições, as nozes, amêndoas ou castanhas comuns, prestando-se como ingrediente para doces, confeitos e pratos salgados (CARVALHO et al, 2011).

\section{Ceruzeiro (Allantoma lineata)}

Esta espécie é uma pequena árvore relativamente baixa medindo até $10 \mathrm{~m}$ (Figura 1), que é distribuído em toda a bacia de amazônica, muito frequente em estuário do rio Amazonas. A sua madeira é descrita de ter excelentes propriedades para a fabricação de papel (ANDRADE et al. 1999). 


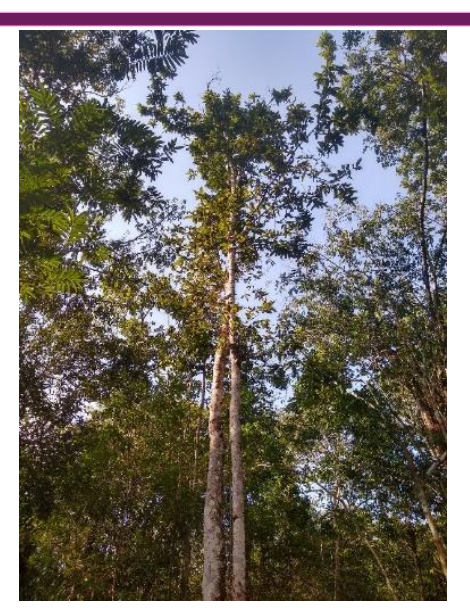

Figura 1 - Ceruzeiro (Allantoma Lineata)

Fonte: Autor (2021).

Segundo Ribeiro (2004), na várzea do Rio Juba afluente do Rio Tocantins, Cametá-PA mostrou que as árvores de Ceruzeiro possuía $0,09 \%$ de densidade relativa em 1 hectare de área (Quadro - 1.) sendo umas das principais espécies envolvida na atividade florestal madeireira, envolvendo as operações extrativas de madeiras em toras destinadas às serrarias ou para uso nas residências.

Quadro 1 - Famílias e espécies vegetais mais representativas na estrutura fitossociologia horizontal dos SAFs de várzea, Rio Juba afluente do Rio Tocantins, Cametá-PA 2001 - 1 ha

\begin{tabular}{cccc}
\hline NOME VULGAR & NOME CIENTÍFICO & $\begin{array}{c}\text { FAMÍLIA } \\
\text { BOTÂNICA }\end{array}$ & $\begin{array}{c}\text { DENSIDADE } \\
\text { RELATIVA \% }\end{array}$ \\
\hline ANDIROBA & Carapa guianensis & Meliaceae & 2,62 \\
CERUZEIRO & Allantoma lineata & Lecythidaceae & 0,09 \\
CINZEIRO & Terminalia amazonica & Combretaceae & 0,09 \\
\hline
\end{tabular}

Fonte: (RIBEIRO, 2002).

A espécie A. lineata é nativa da América do Sul e ocorre principalmente na Venezuela e na Bacia Amazônica e do Estado do Pará, Brasil, encontrada principalmente na mata pluvial Amazônica, florestas de igapó e várzeas, margens de rios e lugares pantanosos (Figura 2), é conhecida popularmente como "Cruzeiro" uma palavra indígena que significa árvores grandes e outros nomes como "Cheru", "xuru", "castanha-da-serra" e principalmente por "Ceru". Devido suas propriedades física e mecânica, é comercializada em várias partes do 


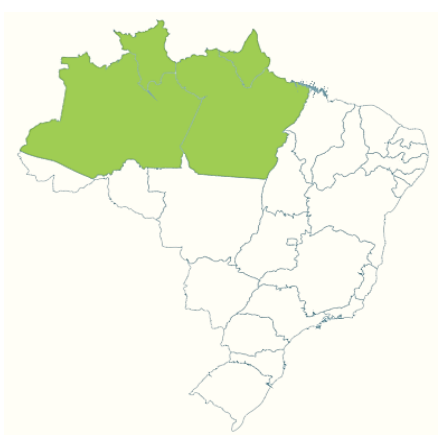

Figura 2 - Distribuição Geográfica da Espécie Allantoma Lineata.

Fonte: SMITH (2015).

O Ceru é a espécie menos importante da família das Lecythidaceae, como árvore de frutos oleaginosos (Figura 3). O fruto é um pixídio cilíndrico, de 10 a $15 \mathrm{~cm}$ de comprimento, por 4 a $5 \mathrm{~cm}$ de diâmetro, na abertura superior tem uma tampa (opérculo) que se destaca quando o fruto está maduro, deixando cair as sementes. Estas são numerosas, mas finas e compridas. Dentro de uma casca lenhosa de 3-4 mm de diâmetro, encerram uma amêndoa oleosa, fina, gostosa de comer, mas em proporção diminuta para interessar à indústria de óleos, os habitantes ribeirinhos usam como alimento. (PESCE, 2009).

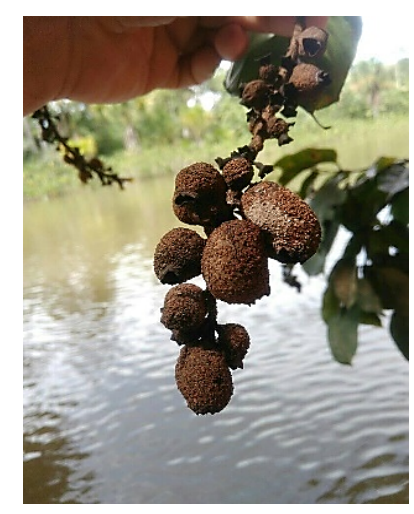

Figura 3 - Frutos de Allantoma Lineata nos estágios iniciais de desenvolvimento.

Fonte: Autor (2021).

Allantoma lineata parece ser recomendável para consumo humano visto que dispõem de quantidades relevantes de nutrientes, $\mathrm{O}$ valor biológico das proteínas está na mesma faixa que muitas outras proteínas vegetais, em um estudo de (ANDRADE et el. 1999) foi possível 
notar concentrações expressivamente altas de metionina, um aminoácido essencial.

\section{Análise biométrica}

Estudos de biometria de sementes podem fornecer informações úteis para conservação e exploração de uma fonte alimentícia de valor econômico, permitindo um incentivo contínuo da busca racional e uso eficaz de recursos naturais (GUSMÃO et al., 2006). Além disso, a biometria de frutos é uma importante ferramenta utilizada para avaliar a variabilidade dentro de uma população da mesma espécie, e as relações desta variabilidade com fatores ambientais, fornecendo maior conhecimento sobre aspectos ecológicos presentes de relevância na cultura estudada (MACEDO et al., 2009).

A biometria de sementes, pode contribuir para a tecnologia de produção de mudas de espécies nativas, contribuindo no conhecimento coletivo daquela espécie (ROELIS, 2017).

\section{Biscoito}

O biscoito surgiu na Antiguidade com a ideia de se amassar grãos entre duas pedras, misturando água àquela massa e secá-la ao fogo, tornando-a uma pasta seca e dura (SIMABESP, 2008).

Segundo Santos (2011), biscoito é o produto adquirido pelo amassamento e cozimento da massa preparada com farinhas, amidos, fermentada ou não, e outras substâncias alimentícias. Sua qualidade está relacionada com o sabor, a textura, a aparência entre outros fatores, e nos últimos anos vem se destacando como um produto de grande interesse comercial em decorrência de sua praticidade na produção, comercialização e consumo, além de possuir longa vida comercial.

Com lançamentos sempre no gatilho, expansão da oferta de produtos mais saudáveis e um parque industrial moderno, o setor brasileiro de biscoitos tem conseguido superar os contratempos macroeconômicos e apresentar resultados sólidos. Em 2014, as vendas do segmento cresceram $10,5 \%$ e totalizaram R $\$ 19,67$ bilhões em comparação a R $\$ 17,79$ bilhões no ano anterior. $\mathrm{O}$ varejo brasileiro de biscoitos é o segundo maior do mundo, com vendas na ordem de US\$ 9,19 bilhões (ABIMAPI, 2015). 


\section{METODOLOGIA}

A pesquisa foi realizada no Laboratório de Alimentos da Universidade do Estado do Pará, em Cametá. As castanhas de Ceru foram colhidas manualmente, em início de deiscência, em áreas distintas de ocorrência natural da espécie. Após colheita, os frutos foram acondicionados em sacos plásticos e levados ao laboratório. Em seguida, foram rigorosamente selecionadas segundo a presença de injúrias mecânicas e sanidade, lavadas em água corrente e assim submetidas à análise biométrica.

\section{Análise biométrica}

Para a análise biométrica, 80 (oitenta) sementes foram tomadas aleatoriamente de uma amostra composta, recém-coletada da espécie. De cada semente determinou-se a massa fresca (MF) em balança digital (SHIMADZU) e o comprimento longitudinal (CL), largura mediana (L) e a espessura mediana (E), com auxílio de um paquímetro digital (Nove, 54). $\mathrm{Na}$ Figura 5 encontra-se ilustrado as sementes de Ceru expostas para a análise biométrica.

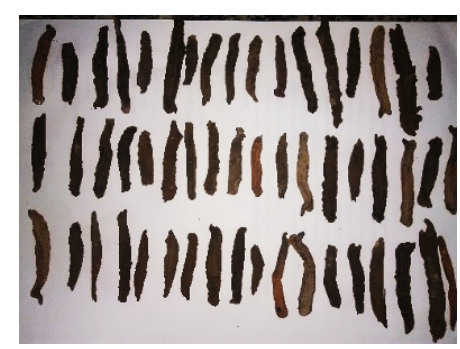

Figura 5 - Sementes dispostas de Allantoma Lineata

Fonte: Própria (2021).

\section{Processamento da amostra}

As amêndoas foram separadas e passaram por um processo de branqueamento por 15 minutos em água $90^{\circ} \mathrm{C}$, seguida de resfriamento por 5 minutos em água corrente $\left(22^{\circ} \mathrm{C}\right)$, para facilitar a remoção da casca das castanhas, inativar as enzimas que afetam a qualidade do produto e remover a quantidade de microrganismos de sua superfície.

As amostras para a análise físico-química foram obtidas a partir da trituração do material em multiprocessador da marca (Skymsen), até obtenção de uma farinha fina. 
Todas as análises a seguir foram realizadas em triplicata. As determinações dos teores de lipídios, proteínas, cinzas totais e umidade foram realizadas de acordo com as normas analíticas do Instituto Adolfo Lutz (2008), sendo os carboidratos calculados por diferença .

\section{Lipídeos}

Para a análise do perfil lipídico, foi feita uma extração contínua em um aparelho do tipo Soxhlet, com a utilização do solvente hexano de origem vegetal (INSTITUTO ADOLFO LUTZ, 2008).

\section{Umidade}

A análise de umidade foi determinada através da perda de peso da amostra após a remoção de água por evaporação, realizada em estufa com circulação e renovação de ar à temperatura de $105^{\circ} \mathrm{C}$, até peso constante (INSTITUTO ADOLFO LUTZ, 2008).

\section{Cinzas}

As amostras foram carbonizadas até cessar a liberação de fumaça e, posteriormente, calcinadas em forno mufla a uma temperatura de $540^{\circ} \mathrm{C}$, até obtenção de peso constante (INSTITUTO ADOLFO LUTZ, 2008).

\section{Acidez}

A determinação de acidez foi realizada através de titulação com $\mathrm{NaOH} 0,1 \mathrm{~N}$, tendo como indicador a fenolftaleína (INSTITUTO ADOLFO LUTZ, 2008).

\section{Cálculo de Energia}

Resolução RDC no. 360/03 da ANVISA, a qual prevê que para cálculo de energia deverão ser utilizados os fatores: $4,0 \mathrm{kcal} / \mathrm{g}$ para carboidrato, 4,0 kcal/g para proteína e 9,0 $\mathrm{kcal} / \mathrm{g}$ para lipídios (BRASIL, 2003). 
A obtenção da farinha de castanha de Ceru foi realizado através da modificação aa metodologia proposta por (COHEN, 2006) que realizou a elaboração de farinha de castanha do Brasil parcialmente desengordurada. O esquema está ilustrado na Figura 2.

\section{Fluxograma:}

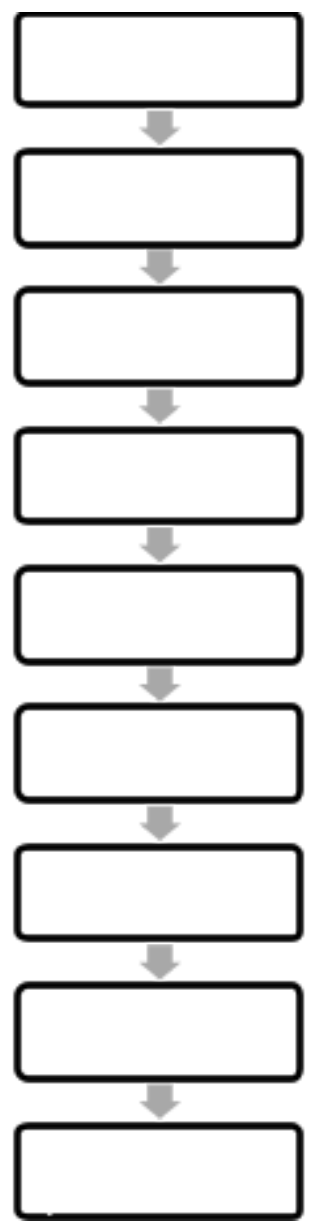

Figura 2 - Fluxograma do processo de obtenção da farinha de Allantoma Lineata.

\section{Seleção}

Primeiramente as castanhas sadias foram separadas das que apresentavam injúrias mecânicas ou sinas de decomposição (figura 3). 


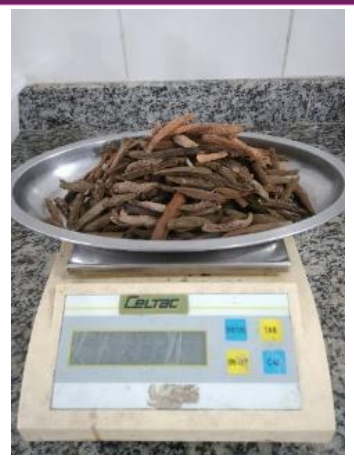

Figura 3 - Sementes de Allantoma Lineata "in natura".

Fonte: Autor (2021)

\section{Sanitização}

A lavagem com água foi empregada para a remoção das sujidades mais grosseiras da castanha e dessa forma garantir a sanidade das amêndoas para as próximas etapas. Depois de uma limpeza superficial usando apenas água corrente, as amêndoas foram submersas em água a 50 ppm de cloro ativo, durante 30 minutos.

\section{Branqueamento}

O Branqueamento foi realizado com o auxílio de uma panela e um termômetro, as castanhas permaneceram submersas na água até que o termômetro marcasse a temperatura de $90^{\circ} \mathrm{C}$. Depois desse momento, elas permaneceram por 15 minutos, depois elas foram resfriadas por 5 minutos em água corrente $\left(22^{\circ} \mathrm{C}\right)$. Essa etapa além de ajudar na remoção da casca da castanha, também inativa as enzimas que afetam a qualidade do produto e removem a quantidade de microrganismos de sua superfície, e foi realizada de forma manual com a ajuda de uma faca e uma tábua de corte.

\section{Descascamento manual}

A remoção da casca da castanha, foi feita de forma manual, com o auxílio de uma faca e uma tábua de corte.

\section{Lavagem}

Foi realizado uma lavagem utilizando água corrente $22^{\circ} \mathrm{C}$ por 5 minutos, com o 
objetivo de eliminar quaisquer sujidades que ainda poderia conter na castanha.

\section{Moagem}

A moagem foi realizada utilizando um multiprocessador (Skymsen), afim reduzir o tamanho das partículas e aumentar a superfície de contato das sementes com o ar quente da estufa e dessa forma facilitar o processo de desidratação.

\section{Secagem}

As castanhas foram secas em uma estufa com circulação de ar a uma temperatura de $70^{\circ} \mathrm{C}$ durante 48 horas. Obtendo pôr fim, a farinha da castanha de Ceru, como pode-se observar na Figura 4.

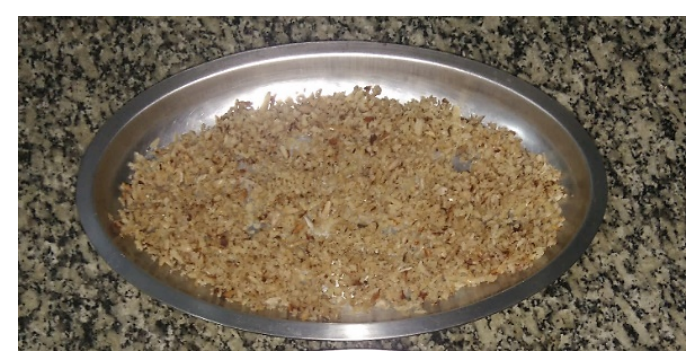

Figura 4 - Farinha da Semente sem casca de Allantoma Lineata.

Fonte: Autor (2021).

Envase em embalagem

A farinha ao fim do processo foi armazenada em um saco plástico de polietileno, depois foi retirado o ar dessa embalagem com a ajuda de uma embaladora a vácuo, e armazenada sob refrigeração a uma temperatura de $10^{\circ} \mathrm{C}$, até posteriores análises e elaboração dos biscoitos enriquecidos com a farinha de Ceru.

\section{Elaboração do biscoito a partir da farinha de Ceru}

Utilizou-se como matéria prima a amêndoa da castanha do Cruzeiro, proveniente da região de várzea do município de Cametá e os demais ingredientes (farinha de trigo, amido de milho, margarina, açúcar, ovos, sal e fermento químico) que foram adquiridos no comércio 
local.

Os biscoitos foram desenvolvidos no laboratório de Alimentos, da UEPA, Campus Cametá, por modificação da formulação proposta por Piovesana et al. (2013)

$\mathrm{Na}$ formulação do biscoito, foram acrescentados $18 \%$ de farinha de Castanha de Ceru (Tabela 1). Para o processamento dos biscoitos misturou-se a manteiga, farinha de Ceru, açúcar, trigo, fermento, amido de milho, gema de ovo e sal em um recipiente previamente senilizado, a mistura procede com a utilização das mãos até a massa apresentar textura cremosa.

Tabela 1 - Formulação única de Biscoito elaborado com adição de /farinha de Castanha de Allantoma Lineata.

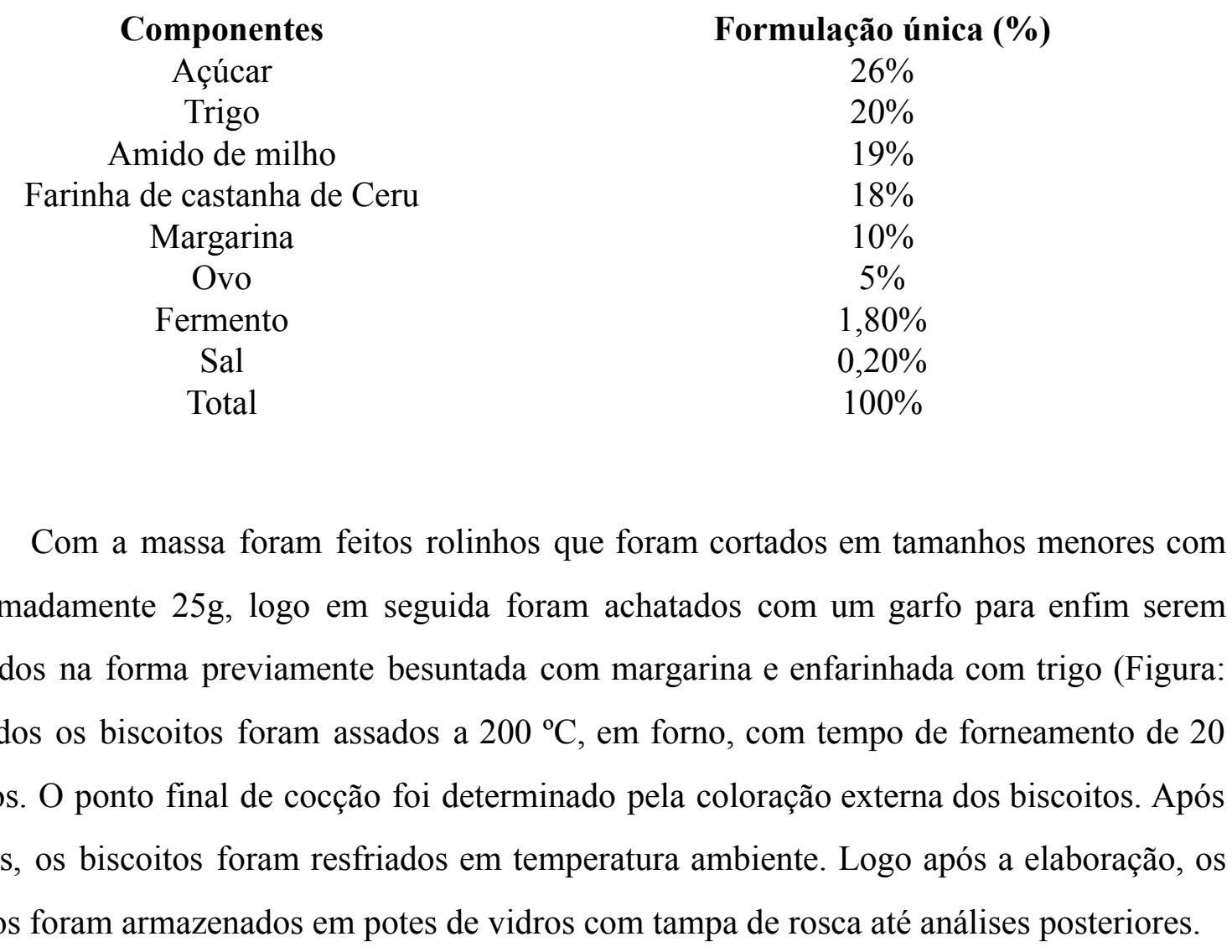

Formulação única (\%)
$26 \%$
$20 \%$
$19 \%$
$18 \%$
$10 \%$
$5 \%$
$1,80 \%$
$0,20 \%$
$100 \%$

aproximadamente $25 \mathrm{~g}$, logo em seguida foram achatados com um garfo para enfim serem colocados na forma previamente besuntada com margarina e enfarinhada com trigo (Figura: 5). Todos os biscoitos foram assados a $200{ }^{\circ} \mathrm{C}$, em forno, com tempo de forneamento de 20 minutos. O ponto final de cocção foi determinado pela coloração externa dos biscoitos. Após assados, os biscoitos foram resfriados em temperatura ambiente. Logo após a elaboração, os mesmos foram armazenados em potes de vidros com tampa de rosca até análises posteriores. 


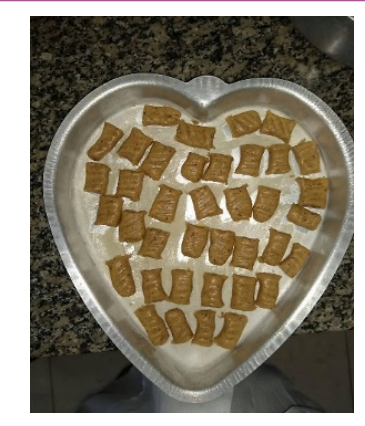

Figura 5 - Biscoito de farinha de Allantoma Lineata pronto para a cocção.

Fonte: Autor (2021).

\section{RESULTADOS E DISCUSSÃO}

\section{Análise Biométrica das castanhas}

$\mathrm{Na}$ Tabela 2 estão dispostos os resultados da análise biométrica das sementes de Allantoma Lineata. O peso das sementes variou entre $1,52 \mathrm{~g}$ e $0,32 \mathrm{~g}$ sendo respectivamente a maior e a menor, obtendo uma média de $0,86 \mathrm{~g}$, já no quesito largura, as sementes obtiveram os seguintes valores, maior $8,85 \mathrm{~mm}$ e menor $3,60 \mathrm{~mm}$, além disso a média apresentou $6,03 \mathrm{~mm}$, o Comprimento variou entre $13,45 \mathrm{~mm}$ e $6,15 \mathrm{~mm}$ com uma média de $8,26 \mathrm{~mm}$. As sementes apresentaram grande variação no parâmetro altura, observando-se que a maior foi $74,70 \mathrm{~mm}$ e a menor $29,15 \mathrm{~mm}$, obtendo uma média de $47,5 \mathrm{~mm}$, somado a isso, é possível destacar um desvio padrão elevado para este quesito o que pode estar relacionado à fatores ambientais não controlados, tais como condições naturais do ambiente, solo, clima e a idade da planta (SILVA, 2001), por outro lado, Aguiar (2018) trabalhando com duas agroindústrias de castanha do Brasil verificou que o tamanho de ambas eram semelhantes, apesar de as mesmas serem de diferentes localidades. Estudos mostraram que espécies arbóreas tropicais possuem relativa variabilidade quanto ao número de sementes e massa dos frutos (BRAGA et al., 2007; ZUFFO et al., 2014).

Tabela 2 - Resultados da biometria das sementes de Allantoma Lineata.

\begin{tabular}{cccccccc}
\hline ANÁLISE & MÉDIA & MAIOR & MENOR & VARIANCIA & DP & CV\% \\
\hline PESO DA AMENDOA (G) & 0,86 & 1,52 & 0,32 & 0,06 & 0,25 & 0,36
\end{tabular}




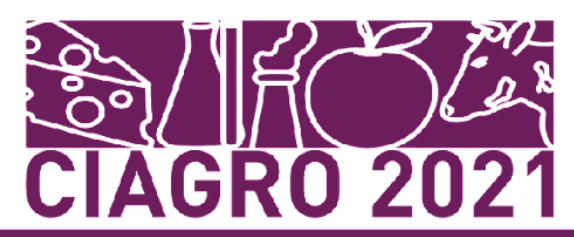

\begin{tabular}{c|cccccc|} 
ALTURA (MM) & 47,5 & 74,70 & 29,15 & 92,97 & 9,64 & 20,30 \\
LARGURA (MM) & 6,03 & 8,85 & 3,60 & 0,94 & 0,97 & 16,10 \\
COMPRIMENTO (MM) & 8,26 & 13,45 & 6,15 & 1,84 & 1,35 & 16,31 \\
\hline
\end{tabular}

Fonte: autores (2019).

Na Figura 6 encontram-se os dados referentes à distribuição de frequência para as características de Allantoma Lineata. Em relação ao peso das castanhas observadas é possível aferir que a maioria, cerca de 69\% está distribuída em duas classes que correspondem ao intervalo de $0,56 \mathrm{~g}$ a $1,04 \mathrm{~g}$, semelhante a este parâmetro a largura esteve concentrada em dois grupos correspondendo a $69 \%$ das sementes onde esteve em um intervalo de 4,65mm a $6,75 \mathrm{~mm}$. A altura das sementes ficou na classe correspondente $38,26 \mathrm{~mm}$ e $47,37 \mathrm{~mm}$ representando $39 \%$ das sementes. No quesito comprimento das sementes de A. Lineata a grande maioria das sementes $76 \%$ estavam distribuídas em duas classes, onde os valores oscilaram entre 6,15mm a 9,07mm, Estudos aplicando a Resolução 846/1976 (BRASIL, 1978) que estabelece uma Classificação e padronização para castanha do brasil, revela que a classificação das sementes quanto ao comprimento, tem grandes reflexos na comercialização de castanhas, favorecendo a baixa variabilidade. 

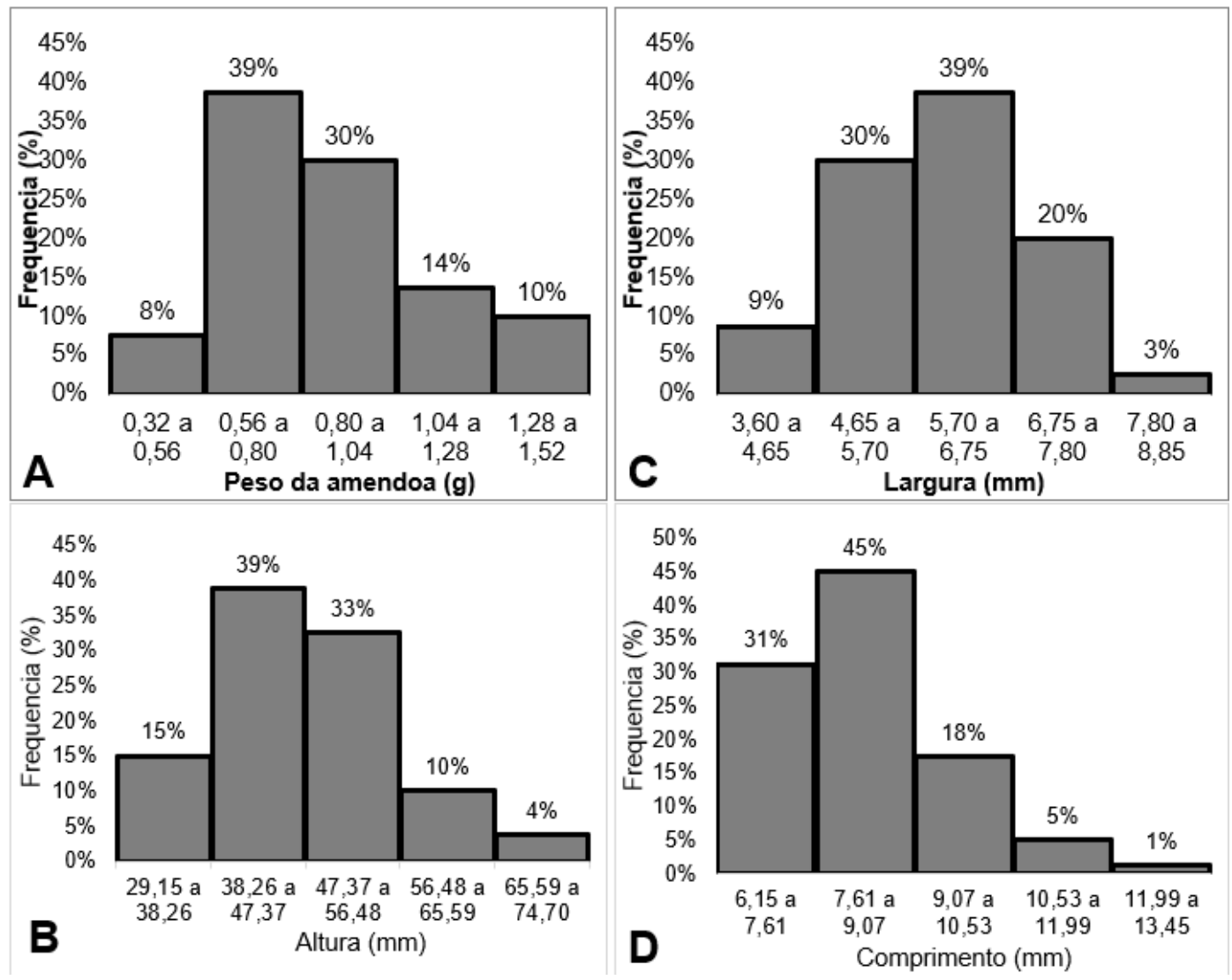

Figura 6 - Distribuição de frequência para as características de Allantoma Lineata.

Fonte: Autores (2019).

\section{Caracterização Físico-Química da Castanha de Ceru}

$\mathrm{Na}$ Tabela 3, são apresentados os resultados das análises físico-químicas das amêndoas de Ceru, com os respectivos desvios padrões, comparando com valores encontrados em literatura para castanhas da mesma família, como a castanha do Brasil e castanha de sapucaia.

A velocidade das principais reações químicas de transformação dos alimentos, como as reações de escurecimento enzimático e não enzimático, além das reações de oxidação lipídica, é geralmente aumentada pelo teor de atividade de água (Aa) (RIBEIRO, 2007). Com base nesses conhecimentos, as amêndoas da castanha de Ceru apresentaram teor de umidade em torno de 10,30\%, semelhante ao relatado por Carvalho (2012) para a castanha de sapucaia, que foi em torno de 10,20\%, o que é desfavorável ao aumento de vida de prateleira desses alimentos, pois o alto conteúdo de água prejudica na preservação desses alimentos por um 
longo período e contribui para a instabilidade química e microbiológica; já no estudo de Ferreira (2009) para a castanha do Brasil, o percentual de umidade média encontrado foi de $3,15 \%$. Estas variações refletem as diferenças das matérias primas, a mudança de safra, dentre outros aspectos.

Tabela 3 - Composição físico-química da castanha de Ceru (Allantoma lineata), castanha do Brasil (Bertholletia excelsa) e castanha de sapucaia (Ecythis pisonis).

$\begin{array}{cccc}\text { PARÂMETRO } & \begin{array}{c}\text { CASTANHA } \\ \text { DE CERU }\end{array} & \begin{array}{c}\text { CASTANHA DO BRASIL } \\ \text { (FERREIRA, 2009) }\end{array} & \begin{array}{c}\text { CASTANHA DE } \\ \text { SAPUCAIA } \\ \text { (CARVALHO, 2012) }\end{array} \\ \text { UMIDADE (\%) } & 10,30 \pm 0,30 & 3,15 \pm 0,02 & 10,20 \pm 0,68 \\ \text { LIPÍDIOS (\%) } & 57,24 \pm 1,32 & 61,00 \pm 1,32 & 54,80 \pm 4,15 \\ \text { PROTEÍNAS (\%) } & 24,57 \pm 1,58 & 15,60 \pm 0,29 & 26,82 \pm 2,60 \\ \text { CINZAS (\%) } & 2,05 \pm 0,02 & 3,13 \pm 0,04 & 3,17 \pm 0,50 \\ \text { CARBOIDRATOS (\%) } & 5,84 & 17,12 & 5,01 \\ \text { VALOR CALORICO (K } & 636,80 & 680,20 & 620,52 \\ \text { CAL. 100G -1) } & & & \end{array}$

O teor de lipídios na castanha do Brasil (61\%) é maior do que na castanha de Ceru analisada neste estudo. Já em relação a castanha de sapucaia, esta possui menor conteúdo de lipídios $(54,80 \%)$ em relação à castanha de Ceru.

A análise de proteínas totais da castanha de Ceru apresentou um valor mais elevado $(24,57 \%)$ quando comparado com o trabalho de Amaral et al. (2006) para a castanha do Brasil $(15,60 \%)$, confirmando assim sua ótima fonte energética; já para a castanha de sapucaia analisada por Carvalho (2012) o valor foi em média de 26,82\% confirmando sua riqueza também como fonte proteica. As variações podem ser explicadas por diferença de tratos culturais, local de plantio e diferença de matéria-prima.

As amêndoas da castanha de Ceru apresentaram um teor considerável de cinzas (2,05\%), esse resultado apresenta-se próximo ao encontrado por Amaral et al. (2006) e Carvalho (2012), com médias de 3,13\% e 3,17\%, respectivamente.

Os valores médios da composição centesimal, realizada na amêndoa e casca da 
castanha do Ceru encontram-se na tabela 4.

Tabela 4 - Análise físico-química da amêndoa e da casca da Allantoma lineata.

\begin{tabular}{lcc}
\hline \multicolumn{1}{c}{ ANÁLISE } & AMÊNDOA DE CERU & CASCA DE CERU \\
\hline UMIDADE (\%) & $10,30 \pm 0,30$ & $15,97 \pm 0,21$ \\
LIPÍDIOS (\%) & $57,24 \pm 1,32$ & $9,56 \pm 2,09$ \\
PROTEÍNAS (\%) & $24,57 \pm 1,58$ & $4,17 \pm 0,28$ \\
CINZAS (\%) & $2,05 \pm 0,02$ & $3,35 \pm 0,04$ \\
\hline
\end{tabular}

Fonte: Autores (2019).

O conhecimento dos constituintes físico-químicos dos alimentos é de suma importância para a avaliação do potencial da matéria-prima a ser utilizada no preparo de alimentos, bem como para o conhecimento do valor nutricional da mesma (CHISTÉ et al, 2009). Neste contexto, por efeito à carência de embasamento científico sobre a composição físico química da casca da castanha de Ceru, buscou-se comparar os parâmetros com cascas de outros frutos.

Analisando os resultados, podemos observar que o teor de umidade e cinzas para a casca da castanha de Ceru apresentaram uma média de 15,97\% e 3,35\%, respectivamente, ou seja, os valores encontrados para a casca foram maiores do que os valores da amêndoa, esses valores podem ser explicados pela absorção de umidade pelas casca, visto que está possui poros na sua superfície onde a agua pode acumular-se. Bramont et al. (2018) analisando a casca da cajarana obteve uma média para umidade em torno de $81,30 \%$, podendo ser considerada então produto de alta umidade.

O teor de lipídios se apresentou menor para a casca da castanha de Ceru $(9,56 \%)$ comparado a amêndoa $(57,24 \%)$, o mesmo aconteceu com o teor de proteína, onde a casca obteve média de $4,17 \%$ e a amêndoa $24,57 \%$.

\section{Caracterização Físico-Química do Biscoito com farinha de Ceru}

As características físico-químicas dos biscoitos adicionados de farinha de castanha de Ceru encontram-se expostos na tabela 5. 
Tabela 5 - Análise físico-química de Biscoito com farinha de semente de Allantoma Lineata.

\begin{tabular}{|c|c|}
\hline ANÁLISE & BISCOITO DE CERU \\
\hline UMIDADE (\%) & $0,68 \pm 0,18$ \\
\hline PH & 6,36 \\
\hline ACIDEZ (\%) & $13,89 \pm 3,10$ \\
\hline
\end{tabular}

Fonte: autores (2019).

O biscoito elaborado apresentou umidade de $0,68 \%$ e encontra-se em conformidade com a legislação vigente que estabelece valores de até 15\% (BRASIL, 2005). Oliveira et al. (2017) elaboraram cookies a partir de farinha da castanha de caju e encontraram valores superiores para o teor de umidade, que variaram de 2,64 a 8,09\%, que é bem superior ao teor de umidade dos cookies apresentados neste trabalho, e isso pode ser justificado pelos ingredientes utilizados, como açúcar mascavo e mel, que possuem umidade em torno de 5 e $20 \%$, respectivamente.

De acordo com Jardim (2010), mudanças físicas, como a crocância de biscoitos, dependem significativamente deste parâmetro. Segundo o autor, a viscosidade de alimentos sólidos amorfos é governada pela temperatura e pelo teor de água, acarretando mudanças na textura do produto. Dessa forma, a umidade presente traz informações importantes sobre a vida útil de um produto, bem como é um parâmetro do produto a ser modificado durante o processo de produção com o objetivo de aumentar a estabilidade dos alimentos (apud CLERICI,2013).

O pH é um fator de grande importância na limitação da capacidade de desenvolvimento de microrganismos no alimento. Em função deste parâmetro, de acordo com Soares e Freire - Júnior (1992) conforme citado por Oliveira (2017), os alimentos podem ser classificados em: pouco ácidos $(\mathrm{pH}>4,5)$, ácidos $(4,5$ a 4,0$)$ e muito ácidos $(<4,0)$. Constata-se, diante desta classificação, que o cookie de castanha de Ceru analisado é considerado pouco ácido $(6,36)$.

Os biscoitos de Ceru indicaram um teor de acidez em torno de $13,89 \%$, ou seja, apresentaram-se ácidos. Ribeiro (2007) revela que fatores como a temperatura e tempo de armazenamento estão relacionados a deterioração e aumento da acidez em óleos, condizendo com o tempo de armazenamento da farinha da castanha e o calor empregado no preparo da 
farinha, o que pode ter gerado subprodutos indesejáveis na matriz do biscoito.

\section{CONSIDERAÇÕES FINAIS}

As sementes de Allantoma Lineata apresentaram importante variação em suas características biométricas. Este comportamento se deve à variação genética e ambiental de cultivares, com isso, castanhas de outras regiões podem ser avaliadas.

A castanha de Ceru apresentou teores elevados de lipídios e proteínas, típico de sementes oleaginosas. No entanto, para a casca da castanha os valores foram inferiores. A casca apresentou teor de umidade e cinzas superior a amêndoa, demonstrando maior tendencia à degradação por microrganismos e maior quantidade de material inorgânico, respectivamente.

O biscoito elaborado com a castanha de Ceru, apresenta-se como fonte alimentícia nutritiva. Desta forma, a sua coleta e beneficiamento representa uma alternativa viável de geração de renda para famílias agroextrativistas localizadas nas regiões de várzea do município de Cametá/PA.

\section{REFERÊNCIAS}

ANDRADE, ELOISA HA, et al. Seed composition of Amazonian lecythidaceae species: part 3 in the series "Studies of edible Amazonian plants". Journal of food composition and analysis, 12.1: 37-51, 1999.

AGUIAR, AL da S.; DA SILVA, K. E.; ALVES, TCV. Biometria de sementes de Bertholletia excelsa Bonpl. em duas agroindústrias localizadas no Estado do Amazonas. In: Embrapa Amazônia Ocidental-Artigo em anais de congresso (ALICE). CONGRESSO AMAZÔNICO DE INICIAÇÃO CIENTIFICA, 3. 2018.

APARÍCIO, WC da S. Estrutura da vegetação em diferentes ambientes na Resex do Rio Cajari: interações solo-floresta e relações com a produção de castanha. Embrapa Amapá-Tese/dissertação (ALICE), 2011.

ABIMAPI. Associação brasileira das indústrias de biscoitos, massas alimentícias e pães \& bolos industrializados. Estatísticas - Biscoitos, 2015.

BRASIL. Ministério da Saúde. Agência Nacional de Vigilância Sanitária. Resolução RDC n 263, de 22 de setembro de 2005. REGULAMENTO TÉCNICO PARA PRODUTOS DE CEREAIS, AMIDOS, FARINHAS E FARELOS. Diário Oficial da República Federativa do Brasil, Poder executivo, Brasília, DF, set. 2005.

BRASIL. Ministério da Agricultura Pecuária e Abastecimento. PORTARIA Nº 846, DE 08 DE NOVEMBRO DE 1976. Especificações para a Padronização, Classificação e Comercialização Interna da Castanha do Brasil. Diário Oficial da República Federativa do 
Brasil, Poder executivo, Brasília, DF, nov. 1976.

BRASIL, Anvisa. Resolução RDC no 360, de 23 de dezembro de 2003. Ministério da Saúde - MS. Agência Nacional de Vigilância Sanitária - Anvisa. 2019

BRAMONT, W. B.. et al. Comparação da Composição Centesimal, Mineral e Fitoquímica de Polpas e Cascas de Dez Diferentes Frutas. Revista Virtual de Química, v. 10, n. 4, 2018.

BERNAL, R. A. et al. Wood anatomy of Lecythidaceae species called "Tauari". IAWA Journal, v. 32, n. 1, p. 97-112, 2011.

BRAGA, L.F. SOUSA, M.P. GILBERTI, S. CARVALHO, M.A.C. Caracterização morfométrica de sementes de castanha de sapucaia (Lecythis pisonis Cambess Lecythidaceae). Revista de Ciências Agro-Ambientais, v.5, n. 1, p.111-116, 2007.

CARDARELli, H. R.; OLIVEIRA, A. J. Conservação do leite de castanha-do-Pará. Scientia Agricola, Piracicaba, v. 57, n. 4, p. 617-622, 2000.

CARVALHO, I. M. M. et al. Caracterização química da castanha de sapucaia (lecythis pisonis cambess.) Da região da zona da mata mineira. Bioscience jornal. v. 28, n. 6, 2012.

CARVALHO, J. O. P. Dinâmica de florestas naturais e sua implicação para o manejo florestal. In: Embrapa Amazônia Oriental-Artigo em anais de congresso (ALICE). Resumos expandidos. Belém, PA: EMBRAPA-CPATU: DFID, 1999.

CARVALHO, M. G. et al. Formulation and sensory acceptance of cereal-bars made with almonds of chichá, sapucaia and gurguéia nuts. The Open Food Science Journal, 5.1. 2011.

CHISTÉ, R. C. et al. Características físicas e físico-química da casca de mangostão em três períodos da safra. Embrapa Amazônia Oriental-Artigo em periódico indexado (ALICE), 2009.

CLERICI, M. T. P. S. et al. Qualidade física, química e sensorial de biscoitos tipo cookies elaborados com a substituição parcial da farinha de trigo por farinha desengordurada de gergelim. Brazilian Journal of Food Technology, v. 16, n. 2, p. 139-146, 2013.

COSTA, P. A. et al. Phytosterols and tocopherols content of pulps and nuts of Brazilian fruits. Food Research International, v. 43, n. 6, p. 1603-1606, 2010.

CRAVO, A. B. Frutas e ervas que curam: usos, receitas e dosagens (5. ed.). São Paulo: Emus, p. 456, 1995.

FERREIRA, E. de S. et al. Caracterização físico-química da amêndoa, torta e composição dos ácidos graxos majoritários do óleo bruto da castanha-do-brasil (Bertholletia excelsa HBK). Alimentos e Nutrição Araraquara, v. 17, n. 2, p. 203-208, 2009.

GUSMÃO, Eduardo; DE ALMEIDA VIEIRA, Fábio; DA FONSECA JÚNIOR, Élcio Meira. Biometria de frutos e endocarpos de murici (Byrsonima verbascifolia Rich. ex A. Juss.). Cerne, v. 12, n. 1, p. 84-91, 2006.

GLÓRIA, M. M.; REGITANO-D'ARCE, M. A. B. Concentrado e isolado protéico de torta de Castanha-do-Pará: obtenção e caracterização química e funcional. Ciênc. Tecnol. Alim., Campinas, v.2, p. 240-245, 2000.

INSTITUTO ADOLFO LUTZ. Normas Analíticas do Instituto Adolfo Lutz: métodos químicos e físicos para análise de alimentos. 4. Ed. São Paulo, 2008.

LORENZI, H. Arvores brasileiras: manual de identificagao e cultivo de plantas arbéreas nativas do Brasil. Nova Odessa: Plantarum, p. 368, 1992.

MACEDO, M. L. C. et al. Biometria de frutos e sementes e germinação de Magonia 
pubescens ST. Hil (sapindaceae). Revista Brasileira de Sementes, v. 31, n. 2, 2009.

MORI, S. A. A família da castanha-do-pará: símbolo do Rio Negro. Florestas do Rio Negro, p. 119-142, 2001.

MÜlleR, C. H.; FIGUEIRÊDO, F. J.; KATO, A. K.; CARVALHO, J. E. U.; STEIN, R. L. B.; SILVA, A. de B. A cultura da castanha-do-brasil. Belém: EMBRAPA-CPATU Brasília, DF, 65p. 1995.

OLIVEIRA, S. N. et al. Elaboração e caracterização de biscoitos adicionados de farinha de castanha de caju com diferentes adoçantes. Revista brasileira de agrotecnologia, v. 7, n. 2, p. $145-150,2017$.

PIOVESANA, A. BUENO, M. M..; KLAJN, V. M. Elaboração e aceitabilidade de biscoitos enriquecidos com aveia e farinha de bagaço de uva. Brazilian Journal Food Technology, Campinas-SP, v. 16, n. 1, p. 68-72, 2013.

PROCÓPIO, L. C.; SECCO, R. S.. A importância da identificação botânica nos inventários florestais: o exemplo do "tauari" (Couratari spp. e Cariniana spp.-Lecythidaceae) em duas áreas manejadas no estado do Pará. 2008.

PESCE, C. Oleaginosas da Amazônia. IICA, Brasília, DF (Brasil), 2009.

TEIXEIRA, M.; CARDOSO, A. Varzeas da Amazonia. Caracterizacao e uso na Producao Agricola. Facultad de Ciencias Agrarias do para, 1991.

RAMOS, C. A. P. Possibilidades de Otimização do uso Florestal para Pequenos Produtores nas Várzeas Amazônicas: Um Estudo na Costa Amapaense. 2000.

RIBEIRO, RN da S. Avaliação do potencial de sustentabilidade de unidades produtivas agroflorestais em várzeas de influência flúvio-marinha, Cametá-pará. 2002.

RIBEIRO, E. P.; SERAVALLI, E. A. G. Química de alimentos. Editora Blucher, 2007.

RIBEIRO, R. N. S.; SANTANA, A. C.; TOURINHO, M. M. Análise exploratória da socioeconomia de sistemas agroflorestais em várzea flúvio-marinha, Cametá-Pará, Brasil. Brazilian Journal of Rural Economy and Sociology (Revista de Economia e Sociologia Rural-RESR), v. 42, n. 1346-2016-105089, p. 133-152, 2004.

ROELIS, B. V. et al. Caracterização morfológica de sementes de Castanheira-do-Brasil oriundas de floresta nativa e plantio comercial da região norte do estado Mato Grosso. In: Embrapa Agrossilvipastoril-Artigo em anais de congresso (ALICE). In: JORNADA CIENTIFICA DA UNEMAT, 8., 2017, CACERES, MT. Unemat, 2017.

SALOMÃO R. P.; ROSA N. A.; NEPSTAD D. C.; BAKK A. Estrutura populacional e breve caracterização ecológica - econômica de 108 espécies arbóreas da floresta amazônica brasileira. Interciência. v. 20, n. 1, p 20 - 29, 1995.

SANTOS, Cintieley Araújo et al. Elaboração de biscoito de farinha de buriti (Mauritia flexuosa L. f) com e sem adição de aveia (Avena sativa L.). Revista Brasileira de Tecnologia Agroindustrial, v. 5, n. 1, p. 262-273, 2011.

SIMABESP - Sindicato da Industria de Massas Alimentícias e Biscoitos no Estado de São Paulo. 2008.

SMITH, N.P.,Mori, S.A.,Prance, G.T. 2015. Lecythidaceae in Lista de Espécies da Flora do Brasil. Jardim Botânico do Rio de Janeiro, 2015.

SILVA, R. S. M.; CHAVES, L.J. NAVES, R.V. Caracterização de frutos e árvores de cagaita (Eugenia dysenterica DC.) no sudeste do estado de Goiás, Brasil. Revista Brasileira Fruticultura, v. 23, n. 2, p. 330-334, 2001.

SOUZA, M. L.; MENEZES, H. C. Processamento de amêndoa e torta de Castanha-do-Brasil e farinha de mandioca: parâmetros de qualidade. Ciênc. Tecnol. 
Alim., Campinas, v.24, n.1, p. 120-128, 2004.

VALlilO, M. I., TAVARES, M., PIMENTEL, S. A., BADOLATO, E. S. G., \& INOMATA, FEDPGE E. I. Caracterização química parcial das sementes de Lecythis pisonis Camb. (Sapucaia). Acta Amazônica, 28(2), 131-131. 1998.

ZUFFO, A.M.; ANDRADE, F.R.; ZUFFO JÚNIOR, J.M.; Caracterização biométrica de frutos e sementes de baru (Dipteryx alata Vog.) na região leste de Mato Grosso, Brasil. Revista de Ciências Agrárias, v.37, n.4, p.463-471, 2014.

SANTOS, et al. EFEITO DA GRAMATURA SOBRE A RESISTÊNCIA AO CISALHAMENTO DA LINHA DE COLA DE DUAS MADEIRAS TROPICAIS: seru (Allantoma lineata) e marupá (Simarouba amara). p40.2. 2010. 
CAPÍTULO 22: ELABORAÇÃO E CARACTERIZAÇÃO FÍSICO-QUÍMFAłE । SENSORIAL

DE GELEIA FORMULADA A PARTIR DO APROVEITAMENTO DO ALBEDO DO MARACUJÁ AMARELO

\author{
CAPÍTULO 22: ELABORACIÓN Y CARACTERIZACIÓN FÍSICO-QUÍMICA Y \\ SENSORIAL \\ DE JALEA FORMULADA A PARTIR DEL USO DE ALBEDO DO MARACUJÁ \\ AMARELO
}

\title{
CHAPTER 22: PHYSICAL-CHEMICAL AND SENSORIAL ELABORATION AND CHARACTERIZATION OF JELLY FORMULATED FROM THE USE OF ALBEDO DO MARACUJÁ AMARELO
}

\author{
Raissa Nathércia Fernandes Costa ${ }^{1}$; Álvaro Gustavo Ferreira da Silva ${ }^{2}$; Bruno Fonsêca Feitosa ${ }^{3}$ Emanuel Neto \\ Alves de Oliveira ${ }^{4}$ : Érica Milô de Freitas Felipe Rocha ${ }^{5}$
}

DOI: $\underline{\text { https://doi.org/10.31692/978-65-88970-19-5.339-353 }}$

\begin{abstract}
RESUMO
A fabricação de geleias é uma forma de aproveitamento de resíduos industriais, além de ter como resultado um produto que se encontra entre os derivados de frutos com alto valor agregado de maior importância comercial. A casca do maracujá amarelo representa mais da metade do peso total do fruto e é um resíduo industrial abundante. $\mathrm{O}$ albedo da casca do maracujá é rico fibras solúveis, como a pectina, que é um composto com potencial prebiótico e propriedades estabilizantes e geleificantes essenciais para a produção de geleias. $\mathrm{O}$ objetivo do presente estudo foi analisar físico-química e sensorialmente duas formulações de geleia produzidas a partir do aproveitamento do albedo de maracujá amarelo. Os teores de umidade (\%), cinzas (\%), pH, acidez titulável (\%), sólidos solúveis $\left({ }^{\circ}\right.$ Brix), ratio (sólidos solúveis/acidez titulável), açúcares totais $(\%)$, redutores $(\%)$ e não-redutores $(\%)$ foram avaliados. Além disto, as geleias também foram submetidas aos testes sensoriais de aceitação, intenção de compra e preferência com 60 provadores voluntários não treinados. As características físico-químicas das geleias se mantiveram dentro dos padrões exigidos pela legislação, exceto quanto à umidade, que foi superior ao permitido em ambas as formulações. As duas formulações apresentaram bons índices de aceitação sensorial, mas a formulação B obteve destaque. Os resultados mostram que a geleia produzida a partir do aproveitamento do albedo do maracujá amarelo pode ser uma alternativa viável para a indústria processadora de frutas, visto que o produto foi bem aceito e contribuiu na diminuição da geração de resíduos pela utilização da casca do maracujá.
\end{abstract}

Palavras-Chave: Passiflora edulis flavicarpa, casca, aproveitamento, geleia.

\section{RESUMEN}

La fabricación de jaleas es una forma de aprovechar los residuos industriales, además de dar como resultado un producto que se encuentra entre los derivados de frutas con alto valor agregado de mayor importancia comercial. La piel amarilla de maracuyá representa más de la mitad del peso total de la fruta y es un abundante residuo industrial. El albedo de la piel de maracuyá es rico en fibras solubles, como la pectina, que es un compuesto con potencial prebiótico y propiedades estabilizantes y gelificantes imprescindibles para la elaboración de mermeladas. El objetivo del presente estudio fue analizar física y sensorialmente dos formulaciones de gelatina producidas a partir del uso de albedo de maracuyá amarilla. El contenido de humedad (\%), ceniza (\%), pH, acidez titulable (\%), sólidos

1 Técnica em Alimentos, IFRN, erica.rocha@ifce.edu.br

2 Engenharia de Alimentos, UFCG, alvarogustavosilva@gmail.com

3 Engenharia de Alimentos, UFCG, brunofonsecafeitosa@live.com

4 Docente do Curso Técnico em Alimentos, IFRN, emanuel.oliveira16@gmail.com

5 Docente do Curso Técnico em Alimentos, IFCE, erica.rocha@ifce.edu.br 


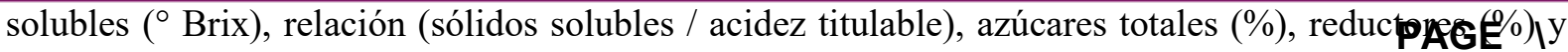
no- Se evaluaron agentes reductores (\%). Además, las medusas también fueron sometidas a pruebas te aceptación sensorial, intención de compra y preferencia con 60 catadores voluntarios no capacitados. 


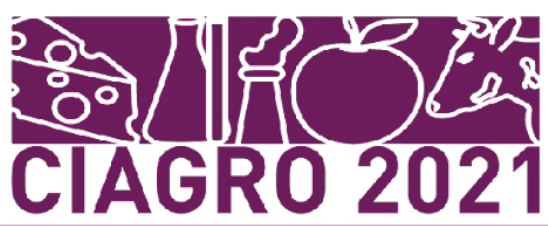

O fruto do maracujazeiro é utilizado principalmente na produção de suco, gepaAłeunpa quantidade bastante expressiva de resíduos resultantes desse processamento. Consequentemente, torna-se necessário pensar em formas de reaproveitar esses resíduos, principalmente devido à grande quantidade de componentes importantes descartados. Assim, a casca do maracujá não pode ser vista só como resíduo, mas também como matéria-prima (RICARDINO et al., 2020). Dessa forma, as cascas também podem ser utilizadas para elaborar produtos, pois são ricas em pectina (componente que possui propriedades estabilizantes e geleificantes), o que torna possível o seu aproveitamento na fabricação de doces e geleias, por exemplo, além de contribuir para a diminuição do acúmulo de resíduos e o aumento do seu valor comercial (NOVAIS JÚNIOR et al., 2020).

Segundo Pinheiro (2007), cerca de 90\% das cascas e sementes de maracujá provenientes das indústrias de sucos e polpas são descartadas, porém já existem diversos estudos que visam reaproveitar estes resíduos, afim de evitar o seu desperdício. Produtores rurais que já praticam o reaproveitamento estão utilizando tais resíduos na suplementação da alimentação animal, como ração para bovinos e aves, ainda sem muita informação técnica adequada. Estes mesmos resíduos também estão sendo utilizados na alimentação humana como, por exemplo, na produção de farinha da casca do maracujá, a qual é utilizada no enriquecimento de bebidas e sobremesas, na produção de óleo comestível extraído das sementes, que possui sabor agradável e odor suave, além da utilização da casca para extração de pectina. Como o volume de resíduos descartado representa inúmeras toneladas, agregar valor a estes subprodutos é de interesse econômico, científico e tecnológico (FERRARI et al., 2004).

\section{Geleia}

Por definição tecnológica, entende-se geleia como o produto obtido pela concentração da polpa ou suco de fruta com determinada porção de açúcar, pectina e ácido até o ${ }^{\circ}$ Brix suficiente para que ocorra a geleificação durante o resfriamento (LIMA, 2008). Quando se adicionam pedaços de fruta, a geleia costuma ser chamada de geleiada (BRASIL, 1978).

Vale ressaltar que quase todos os tipos de fruta podem ser usados na elaboração de geleias, mesmo aqueles com quantidades insuficientes de pectina e ácido, bastando apenas que estes ingredientes, essenciais à formação do gel, sejam adicionados durante o processamento (LOPES, 2007). Uma geleia de boa qualidade tecnológica deve manter-se sem sofrer alterações; ao ser retirada do vidro, deve tremer sem escorrer, sendo macia ao cortar, 
porém, firme, e permanecer com os ângulos definidos. Não deve ser açucarada, pegajosa ou viscosa, devendo conservar o sabor e o aroma da fruta original, uma vez que a Legislação nã permite o uso de corantes ou aromatizantes artificiais neste produto (TORREZAN, 1998).

\section{METODOLOGIA}

\section{Produção das geleias}

Maracujás amarelos foram adquiridos no comércio local de José da Penha, Rio Grande do Norte, Brasil e levados ao Laboratório de Alimentos do Instituto Federal de Educação, Ciência e Tecnologia do Rio Grande do Norte (IFRN) - Campus Pau dos Ferros. No laboratório, os maracujás foram lavados, sanitizados em solução clorada ( $2 \%$ de cloro livre) por cerca de 15 minutos, enxaguadas e cortados ao meio com auxílio de facas de aço inoxidável. A polpa foi utilizada para a produção do suco e as cascas foram cozidas sob pressão por 30 minutos. O albedo foi removido das cascas cozidas e homogeneizado em liquidificador. Foram elaboradas duas formulações de geleia: A (50\% albedo e 50\% açúcar) e B (42,9\% albedo, 42,9\% açúcar e 14,3\% suco). As geleias foram obtidas através da cocção dos ingredientes até a obtenção de uma massa homogênea. O envase foi realizado em embalagens plásticas devidamente higienizadas.

\section{Análises físico-químicas}

As análises físico-químicas foram realizadas em triplicata, conforme as orientações do Instituto Adolf Lutz (2008). Foram determinados os teores de: umidade (aquecimento da amostra em estufa a $105^{\circ} \mathrm{C}$ até massa constante); cinzas (incineração da amostra em mufla a $550^{\circ} \mathrm{C}$ ); $\mathrm{pH}$ (leitura direta potenciômetro digital); acidez (método titulométrico utilizando solução de hidróxido de sódio $0,1 \mathrm{~N}$ ); sólidos solúveis (determinação do ${ }^{\circ}$ Brix utilizando um refratômetro digital); ratio (relação ${ }^{\circ}$ Brix sobre o teor de acidez); açúcares totais totais e redutores (determinados pelo método de Lane Eynon, utilizando as soluções de Fehling A e Fehling B) e não redutores (obtidos por diferença).

\section{Análise sensorial}

A análise sensorial foi realizada com 60 provadores voluntários não treinados, de ambos os gêneros. As amostras de geleia foram servidas em copos descartáveis, codificados com números aleatórios de três dígitos. Os copos foram servidos acompanhados de bolachas água e sal e um copo de $150 \mathrm{~mL}$ com água para os provadores consumirem entre as amostras, 


\section{fazendo a limpeza do palato. As duas formulações de geleia foram avaliadas quanto aos testes} de preferência, intenção de compra e aceitação (atributos: aparência, sabor, aroma, textura e aceitação global). Os atributos foram avaliados com a utilização de uma ficha contendo uma escala hedônica de nove pontos, variando de 1 "desgostei muitíssimo" a 9 "gostei muitíssimo" (INSTITUTO ADOLF LUTZ, 2008). O índice de aceitabilidade (IA) (1) dos atributos sensoriais foi avaliado (DUTCOSKY, 2011).

$$
\operatorname{IA}(\%)=\mathrm{A} \times 100 / \mathrm{B}
$$

Em que, $\mathrm{A}=$ média obtida para o atributo, $\mathrm{B}$ = nota máxima para o atributo.

\section{Análise Estatística}

Os resultados obtidos foram submetidos à análise de variância (ANOVA) e as médias comparadas pelo teste $\mathrm{F}$ a um nível de 95\% de confiança através do software Assistat 7.7 beta (SILVA, 2016).

\section{RESULTADOS E DISCUSSÃO}

\section{Análises físico-químicas}

Os teores de $\mathrm{pH}$ e ratio foram maiores na formulação $\mathrm{A}$, enquanto os teores de umidade, acidez, açúcares totais e redutores foram maiores na formulação B. Não houve diferença significativa nos teores de cinzas, sólidos solúveis e açúcares não redutores (Tabela 2).

Tabela 2: Caracterização físico-química das geleias do albedo do maracujá amarelo.

\begin{tabular}{lcc}
\hline \multirow{2}{*}{ Parâmetros } & \multicolumn{2}{c}{ Formulações } \\
\cline { 2 - 3 } & $48,30 \mathrm{~b} \pm 0,08$ & $\mathbf{B}$ \\
\hline Umidade (\%) & $0,30 \mathrm{a} \pm 0,02$ & $55,51 \mathrm{a} \pm 0,44$ \\
Cinzas (\%) & $4,62 \mathrm{a} \pm 0,12$ & $0,29 \mathrm{a} \pm 0,03$ \\
$\mathrm{pH}$ & $0,28 \mathrm{~b} \pm 0,08$ & $4,10 \mathrm{~b} \pm 0,02$ \\
Acidez titulável (\%) & $65,00 \mathrm{a} \pm 0,00$ & $0,53 \mathrm{a} \pm 0,02$ \\
Sólidos Solúveis ( ${ }^{\circ}$ Brix) & $240,74 \mathrm{a} \pm 64,91$ & $62,00 \mathrm{a} \pm 0,00$ \\
Ratio (\%) & $26,82 \mathrm{~b} \pm 1,46$ & $117,79 \mathrm{~b} \pm 3,45$ \\
Açúcares Totais $(\%)$ & $4,13 \mathrm{~b} \pm 0,12$ & $33,40 \mathrm{a} \pm 0,36$ \\
Açúcares Redutores $(\%)$ & $11,65 \mathrm{a} \pm 0,54$
\end{tabular}




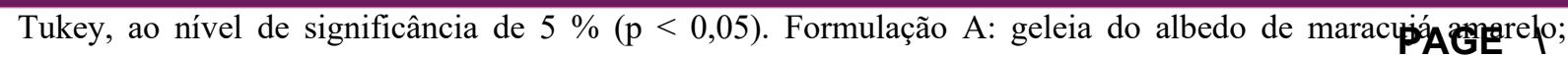
Formulação B: geleia do albedo e do suco de maracujá amarelo.

Os maiores teores de umidade e acidez titulavel na formulação A estão relacionados a adição do suco de maracujá. Sucos são constituídos majoritariamente de água, fazendo com que haja aumento no teor de umidade da formulação na qual o suco foi adicionado. $O$ teor de umidade das duas formulações está acima do permitido pela Resolução Normativa $\mathrm{n}^{\circ} 12$ de 1978, que estabelece o limite máximo de $38 \%$ p/p de umidade para geleias (BRASIL, 1978). No entanto, valores semelhantes foram encontrados por Mota (2006), ao avaliar geleias elaboradas a partir de sete cultivares de amora-preta e obter teores de umidade de $42,84 \%$ a 49,82\% e aos dados obtidos por Lachman et al. (2014), que encontraram médias de 55,76 \% de umidade ao estudarem geleia de maçã adicionada de inulina. A polpa de maracujá possui concentração elevada de ácidos orgânicos, principalmente os ácidos cítrico e málico (JULIAN et al., 2021). Outros ácidos, como ácido isocaprônico, ácido acrílico, ácido n-valeriânico, ácido químico e éster etílico estão presentes em menores quantidades (ADHIKARY et al., 1987). A maioria dos ácidos orgânicos presentes na polpa permanecem no suco, explicando assim o processo de acidificação causada na formulação B.

Os teores de cinzas não diferiram significativamente entre as formulações pois a polpa de maracujá é pobre em cinzas (OLIVEIRA et al., 2020). Os valores médios foram similares aos obtidos por Lachman et al. (2014), que encontraram 0,29\% de cinzas em geleia de maçã adicionada de inulina. $\mathrm{O}$ pH é um parâmetro inversamente proporcional à acidez, por isso diminui quando a acidez aumenta. Os resultados obtidos são positivos, uma vez que valores abaixo de 3,0 podem provocar desidratação e hidrólise da pectina, causando o rompimento do gel, que por sua vez promove a liberação de líquido do seu interior (fenômeno conhecido como sinérese) (OLIVEIRA et al., 2014). Os valores de $\mathrm{pH}$ encontrados foram próximos aos obtidos por Pinto (2014), que obteve 4,20 ao estudar geleia mista de maracujá e melão.

Não houve diferença significativa entre os teores de sólidos solúveis, mostrando que a utilização de suco não interfere nesse parâmetro. Os teores de sólidos solúveis estão em conformidade com o exigido pela legislação vigente, que estabelece no mínimo $62 \%$ e no máximo $65 \%$ de sólidos solúveis (BRASIL, 1987). A ratio se refere à razão entre os teores de sólidos solúveis e acidez titulável, sendo utilizado como indicativo de suavidade e doçura do produto, em que valores elevados indicam suavidade e valores baixos indicam acidez elevada (GALVÃO et al., 2018). Nesse sentido, os resultados indicam uma maior suavidade e doçura da formulação A em relação à B. Esse comportamento é resultante da utilização de suco de 
maracujá na formulação B, que promoveu o aumento na sua acidez e, consequqpạente, reduziu a ratio.

Os teores de açúcares totais e redutores foram maiores na formulação B devido à adição do suco de maracujá. É importante ressaltar que os açúcares redutores são essenciais na elaboração de geleias, pois conferem brilho e retardam a cristalização da sacarose (GOMES et al., 2013). Não houve diferença significativa nos teores de açúcares não redutores das formulações porque o suco de maracujá é naturalmente pobre nesse tipo de açúcar (PINHEIRO et al., 2006).

\section{Análise Sensorial}

Os atributos aparência e aroma tiveram maior aceitação sensorial na formulação B, produzida com adição de suco de maracujá. Não houve diferença significativa na aceitação do sabor, textura e aceitação global das geleias (Tabela 3).

Tabela 3. Resultados do teste de aceitação de geleias do albedo do maracujá amarelo

\section{Atributos}

\section{Formulações}

\begin{tabular}{lcc} 
& A & B \\
\hline Aparência & $6,82 \mathrm{~b} \pm 2,20$ & $7,77 \mathrm{a} \pm 1,63$ \\
Aroma & $6,55 \mathrm{~b} \pm 1,99$ & $7,38 \mathrm{a} \pm 1,68$ \\
Sabor & $6,35 \mathrm{a} \pm 2,42$ & $6,68 \mathrm{a} \pm 2,15$ \\
Textura & $7,25 \mathrm{a} \pm 1,97$ & $7,67 \mathrm{a} \pm 1,54$ \\
Aceitação Global & $6,72 \mathrm{a} \pm 2,03$ & $7,35 \mathrm{a} \pm 1,62$ \\
\hline
\end{tabular}

Valores médios seguidos de letras diferentes na mesma linha diferem significativamente entre si, pelo teste de Tukey, ao nível de significância de $5 \%(\mathrm{p}<0,05)$. Formulação A: geleia do albedo de maracujá amarelo; Formulação B: geleia do albedo e do suco de maracujá amarelo.

A aparência é um atributo importante na qualidade e aceitação de alimentos, pois a primeira impressão do consumidor é formada pela observação visual (Salgado et al., 2021). O aroma é outro atributo essencial quando se trata de produtos à base de frutas, uma vez que o consumidor associa diretamente o produto à fruta utilizada (BESSA; SILVA, 2018). A formulação A obteve médias de aparência e aroma referentes a "gostei ligeiramente" enquanto a formulação B obteve médias referentes a "gostei moderadamente". A aparência e o aroma da formulação B obtiveram maior aceitação devido a adição do suco de maracujá, que promoveu uma cor amarelada mais intensa, que influenciou positivamente na aparência, e 


\section{um aroma característico do maracujá.}

\section{PAGE 1}

Não houve diferença significativa na aceitação dos atributos sabor e textura, demonstrando que a adição do suco do maracujá na formulação B não foi suficiente para promover alterações perceptíveis ao paladar dos provadores. O sabor obteve médias classificadas como "gostei ligeiramente" na escala hedônica, enquanto a textura foi classificada como "gostei moderadamente", tanto para a formulação A como para a B. A boa aceitação da textura das geleias é resultante dos teores elevados de pectina no albedo, que proporcionaram uma boa e rápida geleificação em ambas as formulações. A aceitação global, por sua vez, refere-se à avaliação geral do produto (BESSA; SILVA, 2018). Embora a formulação A tenha obtido média referente a "gostei ligeiramente" e a B "gostei moderadamente", não houve diferença significativa nesse atributo, indicando que a adição do suco de maracujá amarelo não causou diferenças perceptíveis na aceitação global das geleias.

Figura 1. Índice de aceitabilidade (IA) das geleias do albedo do maracujá amarelo.

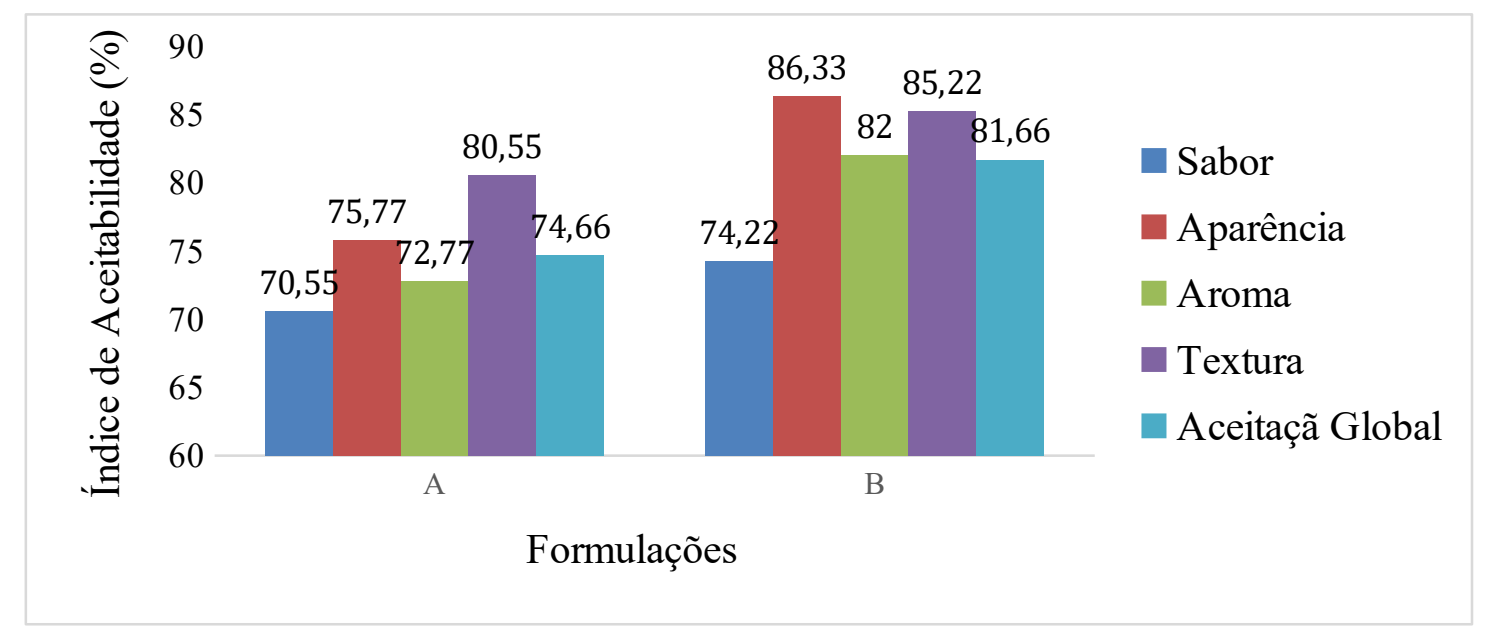

Fonte: autores (2021).

Um produto é considerado bem aceito quanto obtém IA igual ou superior a $70 \%$ (PEUCKERT et al., 2010). Todos os atributos foram bem aceitos, com IA variando de 70,55 a $86,33 \%$. O sabor foi o atributo com menor aceitação, provavelmente porque a oferta de produtos elaborados a partir do albedo do maracujá é baixa e os provadores não estão com o paladar adaptado ao seu sabor (FIGUEIREDO et al., 2009). A textura, por outro lado, teve as maiores médias de IA porque o albedo é rico em fibras, como a pectina (MACÊDO et al., 2019), responsável pela formação do gel em geleias (LIMA et al., 2017). 
A formulação B foi a preferida de $66,66 \%$ dos provadores, enquanto PÁGÉ⿴囗十a preferida dos 33,33\% restantes (Figura 2).

Figura 2. Análise de preferência das geleias do albedo do maracujá amarelo.

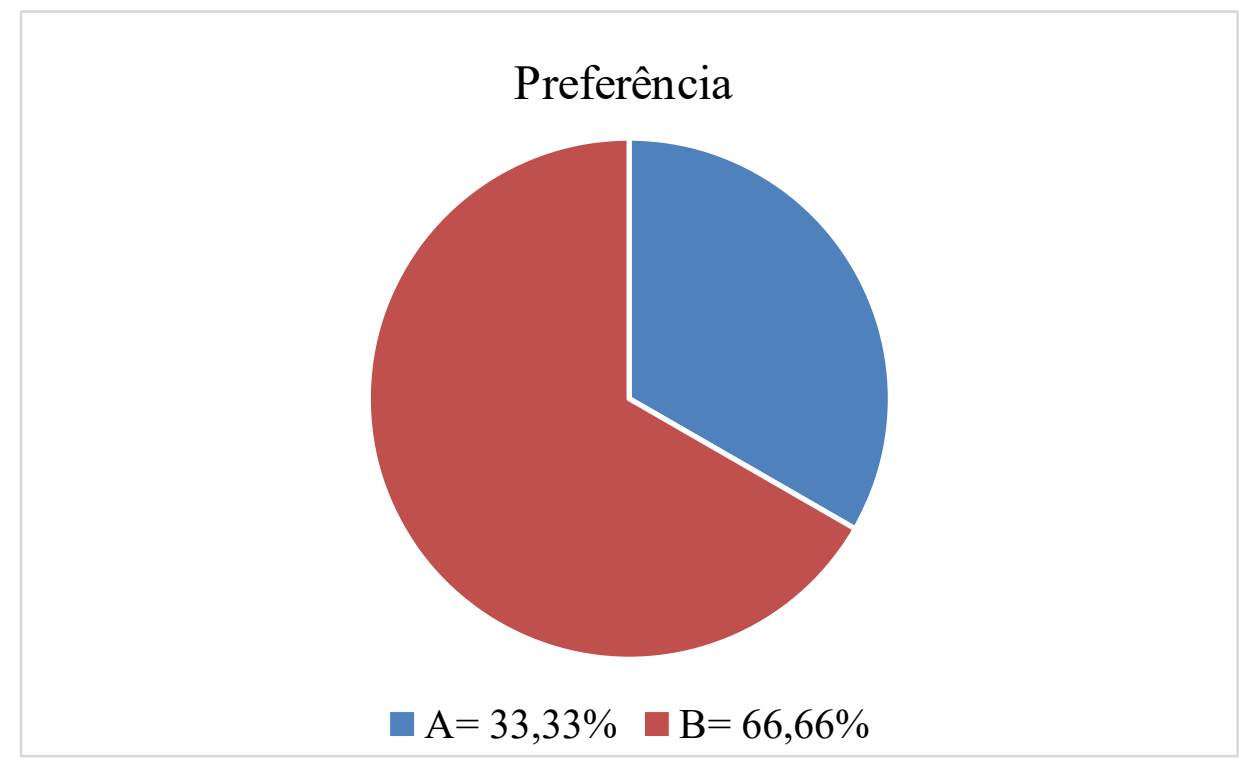

Fonte: autores (2021).

A preferência da formulação B pela maioria dos provadores está relacionada com a adição do suco do maracujá amarelo, que modificou positivamente a aparencia e aroma do produto, tornando essa a formulação preferida.

Figura 3. Intenção de compra das geleias do albedo do maracujá amarelo.

Fonte: autores (2021).

Não houve diferença significativa na intenção de compra das geleias. No entanto, por arredondamento, a formulação A teve média classificada como "indiferente", enquanto a B teve média referente a "provavelmente compraria", na escala de intenção de compra adotada, sendo, portanto, a formulação mais indicada para produção comercial.

\section{CONSIDERAÇÕES FINAIS}

As duas formulações de geleia do albebo do maracujá amarelo apresentaram os parâmetros físico-químicos dentro do permitido pela legislação vigente, com excessão do teor de umidade.

A formulação B, com adição do suco de maracujá amarelo, foi a mais aceita nos testes 


\section{REFERÊNCIAS}

ADHIKARY, S. K.; HARKARE, W. P.; GOVINDAN, K. P.; CHIKKAPPAJI, K. C.; SAROJA, S.; NANJUNDASWAMY, A. M. Deacidification of fruit juices by electrodialysis. 2. Indian Journal of Technology, v. 25, n. 1, p. 24-27, 1987.

AGROSTAT. Estatísticas de Comércio Exterior do Agronegócio Brasileiro. Disponível em: http://indicadores.agricultura.gov.br/agrostat/index.htm. Acesso em: 13 mai. 2021.

ANDRADE, P. F. S. Análise da conjuntura agropecuária. Paraná: Secretaria da Agricultura e do Abastecimento-SEAB, Departamento De Economia Rural-DERAL, fev. 2012.

BESSA, M. M.; SILVA, A. G. F. Elaboração e caracterização físico-química e sensorial de iogurte prebiótico de tamarindo. Revista do Instituto de Laticínios Cândido Tostes, v. 73, n. 4, p. 185-195, 2018.

BRASIL. Resolução - Cnnpa no 12, de 24 de janeiro de 1978. Geléia de Frutas. São Paulo, Disponível em: <http://www.anvisa.gov.br>. Acesso em: 13 maio 2015.

CAO, Q; TENG, J.; WEI, B.; HUANG, L.; \& XIA, N. Phenolic compounds, bioactivity, and bioaccessibility of ethanol extracts from passion fruit peel based on simulated gastrointestinal digestion. Food Chemistry, v. 356, p. 129682, 2021.

COSTA, A. C. R. O potencial fruticultor Do Rio Grande Do Norte gerando oportunidades no mercado internacional. In: CONGRESSO DE PESQUISA E INOVAÇÃO DA REDE NORTE NORDESTE DE EDUCAÇÃO TECNOLÓGICA, 2., 2007, João Pessoa. Artigo. Natal: CEFET, 2007. p. 3 - 9.

CUNHA, J. Fruticultura: o Nordeste em transformação. 2009. Elaborada por Rio Bravo Investimentos. Disponível em: $<$ http://www.riobravo.com.br>. Acesso em: 13 mai. 2021 DOMÍNGUEZ-RODRÍGUEZ, G.; GARCÍA, M. C.; PLAZA, M.; MARINA, M. L.

Revalorization of Passiflora species peels as a sustainable source of antioxidant phenolic compounds. Science of the Total Environment, v. 696, p. 134030, 2019.

DUTCOSKY, S.D. Análise Sensorial de Alimentos. $3^{\mathrm{a}}$ ed. Curitiba: Editora Champagnat, 2011. 426p.

FERRARI, R. A.; COLUSSI, F.; AYUB, R. A. Caracterização de subprodutos da industrialização do maracujá- Aproveitamento das sementes. Revista Brasileira de Fruticultura, Jaboticabal, v. 26, n. 1, p.101-102, 5 mar. 2004. Trimestral.

FIGUEIREDO, L. P.; VALENTE, W. A.; DIAS, M. V.; BORGES, S. V.; PEREIRA, P. A. P.; PEREIRA, A. G. T.; CLEMENTE, P. R. Efeito da adição de suco de maracujá e tempo de cozimento sobre a qualidade de doces do albedo de maracujá em calda. Food Science and Technology, v. 29, n. 4, p. 840-846, 2009.

FREITAS, G. F. Análise de viabilidade econômica da produção de maracujá-azedo. 2018. GALVÃO, T. H. B.; COSTA, F. B.; NASCIMENTO, A. M.; BRASIL, Y. L.; SILVA, Á. G. 
F.; SILVA, K. G.; GADELHA, T. M. Physico-chemical Quality Changes of Young Cladodes of" Mexican Elephant Ear" Minimally Processed during Refrigerated Storage. Journal of Experimental Agriculture International, p. 1-9, 2018.

GOMES, R.; SANTOS, M.; CARDOSO, R. L.; TAVARES, J.; CUNHA, D. Elaboração e avaliação físico-químico e sensorial de geleia de maracujá com cenoura. Enciclopédia Biosfera, v. 9, n. 16, 2013.

GOMES, S. L. C. Desenvolvimento e caracterização de geleia mista de maracujá e acerola. 2014. 49 f. TCC (Graduação) - Curso de Tecnologia de Alimentos, Tecnologia de Alimentos, Universidade Federal da Paraíba, João Pessoa, 2014.

GOMES, S. L. S. Desenvolvimento e caracterização de geleia mista de maracujá e acerola. 2014. 49 f. TCC (Graduação) - Curso de Tecnologia de Alimentos, Tecnologia de Alimentos, Universidade Federal da Paraíba, João Pessoa, 2014.

INSTITUTO ADOLFO LUTZ. Métodos físico-químicos para análise de alimentos. $4^{\mathrm{a}}$ edição/ $1^{\mathrm{a}}$ edição digital. São Paulo: Instituto Adolfo Lutz, 2008. 1020p.

JULIAN, H.; KHOIRUDDIN, K.; JULIES, N.; EDWINA, V.; WENTEN, I. G. Pineapple juice acidity removal using electrodeionization (EDI). Journal of Food Engineering, v. 304, p. 110595, 2021.

LACHMAN, C.; GALVÃO, R.; CRISTO, T. W.; BRECAILO, M. K.; SANTOS, E. F.; SILVA, É. C.; NOVELLO, D. Geleia de maçã adicionada de inulina: parâmetros físicoquímicos e avaliação sensorial entre crianças. Revista da Universidade Vale do Rio Verde, Três Corações, v. 12, n. 1, p.57-69, jul. 2014. Semestral.

LI, C.; XIN, M.; LI, L.; HE, X.; YI, P.; TANG, Y.; LI, Z.. Characterization of the aromatic profile of purple passion fruit (Passiflora edulis Sims) during ripening by HS-SPME-GC/MS and RNA sequencing. Food Chemistry, v. 355, p. 129685, 2021.

LIMA, C. M. G.; JESUS SANTOS, J.; MIRANDA, R. F.; VIANA, R. B. B.; SANTOS, M. S.; BARBOSA, E. A. . Aceitabilidade de geleia de pimenta dedo-de-moça com pectina da casca do pequi. The Journal of Engineering and Exact Sciences, v. 3, n. 6, p. 0786-0791, 2017.

LIMA, U. A. Agroindustrialização de Frutas. 2. ed. Piracicaba: Fealq, 2008. 164 p.

LOPES, R. L. T. Dossiê técnico: fabricação de geleias. Minas Gerais: Serviço Brasileiro de Respostas Técnicas-SBRT, 2007.

MACÊDO, J. C. B.; BEZERRA, K. C. B.; LANDIM, L. A. D. S. R. Desenvolvimento da farinha do albedo do maracujá amarelo. Nutrição Brasil, v. 18, n. 3, p. 151-156, 2019.

MELO, E. A.; LIMA, V. L. A. GALVÃO; NASCIMENTO, P. P. Formulação e avaliação físico-química e sensorial de geléia mista de pitanga (eugenia uniflora 1.) E acerola (malpighia sp) enayde. Boletim do Centro Pesquisa Processamento de AlimentosCEPPA, Curitiba, v. 17, n. 1, p.33-44, jan. 1999. Semestral. 
MOTA, R. V. Caracterização física e química de geleia de amora-preta. Ciências e Tecnologia de Alimentos, Campinas, v. 26, n. 3, p.539-543, 2006.

NASCIMENTO, T. A.; CALADO, V.; CARVALHO, C. W. P. Development and characterization of flexible film based on starch and passion fruit mesocarp flour with nanoparticles. Food Research International, v. 49, n. 1, p. 588-595, 2012.

NAVA, D. E. Perspectivas do sistema de manejo integrado de mosca das frutas: um caminho para o desenvolvimento sustentável da fruticultura no Brasil. In: Embrapa Clima Temperado-Artigo em anais de congresso (ALICE). CONGRESSO BRASILEIRO DE FITOSSANIDADE, 5., 2019; Desafios e Avanços da Fitossanidade: Curitiba. Anais... Curitiba: CONBRAF, 2019., 2019.

NOVAIS JÚNIOR, M. M.; FERREIRA, L. G.; FONSECA, A. A. O.; CARDOSO, R. L.; SOUZA HANSEN, D. Desenvolvimento de geleia de maracujá do mato (Passiflora Cincinnata): caracterização microbiológica, física, química e estudo da estabilidade. Brazilian Journal of Development, v. 6, n. 7, p. 43403-43414, 2020.

OLIVEIRA, C. F.; GIORDANI, D.; GURAK, P. D.; CLADERA-OLIVERA, F.; \& MARCZAK, L. D. F. Extraction of pectin from passion fruit peel using moderate electric field and conventional heating extraction methods. Innovative Food Science \& Emerging Technologies, v. 29, p. 201-208, 2015.

OliveirA, E. N. A. D.; SANTOS, D. D. C.; ROCHA, A. P. T.; GOMES, J. P. Desenvolvimento, caracterização e estabilidade de geleia tradicional de umbu-cajá. Revista Brasileira de Fruticultura, v. 36, n. 3, p. 628-639, 2014.

OLIVEIRA, P. N.; SANTOS GOMES, P. C.; ALCARDE, A. R.; BORTOLETTO, A. M.; NETA, M. T. S. L.; NARAIN, N.; JÚNIOR, A. M. O. Characterization and volatile profile of passion fruit spirit. International Journal of Gastronomy and Food Science, v. 21, p. $100223,2020$.

PEUCKERT, Y. P. Caracterização e aceitabilidade de barras de cereais adicionadas de proteína texturizada de soja e camu-camu (Myrciaria dubia). Revista Alimentos e Nutrição, Araraquara, v. 21, n. 1, p. 147-152, 2010

PINHEIRO, A. M.; FERNANDES, A. G.; FAI, A. E. C.; PRADO, G. M. D.; SOUSA, P. H. M. D.; MAIA, G. A. Avaliação química, físico-química e microbiológica de sucos de frutas integrais: abacaxi, caju e maracujá. Food Science and Technology, v. 26, n. 1, p. 98-103, 2006.

PINHEIRO, E. R. Pectina da casca do maracujá amarelo (passiflora Edulis flavicarpa): otimização da extração com ácido Cítrico e caracterização físico-química. 2007. $79 \mathrm{f}$. Dissertação (Mestrado) - Curso de Ciência dos Alimentos, Ciências e Tecnologia de Alimentos, Universidade Federal de Santa Catarina, Florianópolis, 2007.

PINTO, M. L. M. Elaboração e caracterização físico-química e sensorial de geleia mista de maracujá e melão. 2014. 29 f. TCC - Curso de Técnico em Alimentos, do Instituto Federal de Educação, Ciência e Tecnologia do Rio Grande do Norte - Campus Pau dos Ferros, Pau dos Ferros, 2014. 


\section{CIAGRO 2021}

PAGE I

RICARDINO, I. E. F.; SOUZA, M. N. C.; SILVA NETO, I. F. Vantagens e Possibilidades do reaproveitamento de resíduos agroindustriais. Alimentos: Ciência, Tecnologia e Meio Ambiente, v. 1, n. 8, p. 55-79, 2020.

SALGADO, M. J. G.; RAMOS, M. S.; ASSIS, D. J.; OTERO, D. M.; OLIVEIRA, R. L.; RIBEIRO, C. V. D. M.; OLIVEIRA, C. A. A. Impact of fiber-rich donkey milk yogurt on apparent viscosity and sensory acceptance. LWT, p. 111494, 2021.

SANTOS, E. A.; RIBEIRO, A. E. C.; BARCELlOS, T. T.; MONTEIRO, M. L. G.; MÁRSICO, E. T.; CALIARI, M.; JÚNIOR, M. S. S. Exploitation of byproducts from the passion fruit juice and tilapia filleting industries to obtain a functional meat product. Food Bioscience, p. 101084, 2021.

SANTOS, R. T. S.; BIASOTO, A.C. P.; RYBKAB, C. D. C.; CASTRO, S. T.; AIDARB, G. C., BORGES, F. L. H. Physicochemical characterization, bioactive compounds, in vitro antioxidant activity, sensory profile and consumer acceptability of fermented alcoholic beverage obtained from Caatinga passion fruit (Passiflora cincinnata Mast.). LWT - Food Science and Technology, V. 1, P. 111714, 2021.

SILVA, F. ASSISTAT: Versão 7.7 beta. Campina Grande: Universidade Federal de Campina Grande. Centro de Tecnologia e Recursos Naturais. Departamento de Engenharia Agrícola, 2016.

TLAIS, A. Z. A.; FIORINO, G. M.; POLO, A.; FILANNINO, P.; DI CAGNO, R. High-Value Compounds in Fruit, Vegetable and Cereal Byproducts: An Overview of Potential Sustainable Reuse and Exploitation. Molecules, v. 25, n. 13, p. 2987, 2020.

TORREZAN, R. Manual para a produção de geleias de frutas em escala industrial. Rio de Janeiro: EMBRAPA - CTAA, 1998. 
CAPÍTULO 23: DESAFIOS DA PRODUÇÃO DE CAFÉ ORGÂNICO: CERTIFICAÇÃO, MERCADO E SUSTENTABILIDADE

\title{
CAPÍTULO 23: DESAFÍOS DE LA PRODUCCIÓN DE CAFÉ ORGÁNICO: CERTIFICACIÓN, MERCADO Y SOSTENIBILIDAD
}

\section{CHAPTER 23: CHALLENGES OF ORGANIC COFFEE PRODUCTION: CERTIFICATION, MARKET AND SUSTAINABILITY}

\author{
Maria Vitória Lima Costa Donato; Wallysson Wagner Vilela Santos²; Ana Letícia Toté Medeiros ${ }^{3}$; Suzana \\ Pedroza da Silva ${ }^{4}$
}

DOI: $\underline{\text { https://doi.org/10.31692/978-65-88970-19-5.354-368 }}$

\begin{abstract}
RESUMO
Diante das preocupações com a saúde e com o aumento da expectativa de vida dos brasileiros, tem se tornado evidente a mudança de hábitos alimentares em busca de alimentação mais saudável. Observa-se também uma maior presença de alimentos orgânicos nas gôndolas dos supermercados, o que não é diferente para o setor do café. Os cafés orgânicos têm chamado a atenção do consumidor em diversos aspectos, tais como a não utilização dos agroquímicos sintéticos e uma gestão agrícola sustentável. Este trabalho tem como objetivo mostrar as vantagens e desvantagens da produção orgânica de café e entender os desafios quanto à certificação, mercado e sustentabilidade. Utilizou-se as principais plataformas de buscas como SciELO, Google Scholar, Portal de Periódicos CAPES, Springer e Science Direct para a coleta dos artigos relacionados a produção orgânica de café e seus desafios de registros formais, mercados e sustentabilidade. A agricultura orgânica, fundamentada em princípios agroecológicos e na conservação de recursos naturais, visa ofertar alimentos saudáveis e livres de contaminantes, além de garantir preservação da diversidade biológica dos ecossistemas naturais com o propósito de manter a integridade e as qualidades orgânicas e vitais do alimento em todas as etapas. A discussão sobre produção sustentável de café vem crescendo entre os produtores de café, com a preocupação de que se criem processos de produção e métodos de gestão inovadores, encontrando espaço no mercado e que seja coerente em relação ao conceito de sustentabilidade e as normas de certificação, sendo possível obter um grão de maior qualidade, por meio de práticas sustentáveis e com maior rentabilidade.
\end{abstract}

Palavras-chave: Agricultura orgânica; Café orgânico; Certificação; Mercado; Sustentabilidade.

\section{RESUMEN}

Ante las preocupaciones de salud y el aumento de la esperanza de vida de los brasileños, se ha hecho evidente el cambio de hábitos alimentarios en busca de alimentos más saludables. También hay una mayor presencia de alimentos orgánicos en las góndolas de los supermercados, lo que no es diferente para el sector cafetero. Los cafés orgánicos han atraído la atención del consumidor en varios aspectos, como el no uso de agroquímicos sintéticos y el manejo agrícola sustentable. Este trabajo tiene como objetivo mostrar las ventajas y desventajas de la producción de café orgánico y comprender los

\footnotetext{
${ }^{1}$ Engenharia de Alimentos, Universidade Federal do Agreste de Pernambuco, vitoriadonato57@.gmail.com

${ }^{2}$ Engenharia de Alimentos, Universidade Federal do Agreste de Pernambuco, wallysson70@gmail.com

${ }^{3}$ Engenharia de Alimentos, Universidade Federal do Agreste de Pernambuco, analeticiatote@gmail.com

${ }^{4}$ Doutora em Engenharia Química, Universidade do Federal Agreste de Pernambuco, suzana.pedroza@ufape.edu.br
} 
desafíos en materia de certificación, mercado y sostenibilidad. Las principales plataformas de búsqueda como SciELO, Google Scholar, CAPES Journal Portal, Springer y Science Direct se utilizaron para recopilar artículos relacionados con la producción de café orgánico y sus desafíos en registros formales, mercados y sostenibilidad. La agricultura orgánica, basada en principios agroecológicos y la conservación de los recursos naturales, tiene como objetivo ofrecer alimentos saludables y libres de contaminantes, además de garantizar la preservación de la diversidad biológica de los ecosistemas naturales con el propósito de mantener la integridad y las cualidades orgánicas y vitales. del alimento en cuestión, todos los pasos. La discusión sobre la producción sostenible de café ha ido creciendo entre los productores de café, con la preocupación de crear procesos de producción y métodos de gestión innovadores, encontrando espacio en el mercado y siendo consistentes con el concepto de sostenibilidad y estándares de certificación, siendo posible obtener un grano de mayor calidad. calidad, a través de prácticas sostenibles y con mayor rentabilidad.

Palabras llave: Agricultura orgánica; Café orgánico; Certificación; Mercado; Sustentabilidad.

\begin{abstract}
In the face of health concerns and the increase in life expectancy of Brazilians, the change in eating habits in search of healthier food has become evident. There is also a greater presence of organic foods on supermarket shelves, which is no different for the coffee sector. Organic coffees have attracted the consumer's attention in several aspects, such as the non-use of synthetic agrochemicals and sustainable agricultural management. This work aims to show the advantages and disadvantages of organic coffee production and understand the challenges regarding certification, market and sustainability. The main search platforms such as SciELO, Google Scholar, CAPES Journal Portal, Springer and Science Direct were used to collect articles related to organic coffee production and its challenges in formal records, markets and sustainability. Organic agriculture, based on agroecological principles and the conservation of natural resources, aims to offer healthy food and free from contaminants, in addition to guaranteeing the preservation of the biological diversity of natural ecosystems in order to maintain the integrity and the organic and vital qualities of the food in question. all steps. The discussion on sustainable coffee production has been growing among coffee producers, with the concern to create innovative production processes and management methods, finding space in the market and being consistent with the concept of sustainability and certification standards, being possible to obtain a grain of higher quality, through sustainable practices and with greater profitability.
\end{abstract}

Keywords: Organic agriculture; Organic coffee; Certification; Marketplace; Sustainability.

\title{
INTRODUÇÃO
}

As atividades agrícolas sempre exerceram grandes pressões sobre o meio ambiente, sendo um grande desafio conciliar crescimento econômico, conservação dos recursos naturais e alimentação saudável. A agricultura orgânica vem ganhando maior visibilidade com a crescente necessidade de desenvolvimento sustentável, garantindo o atendimento das necessidades do presente sem comprometer as gerações futuras. No Brasil, a partir de intervenções públicas e privadas, busca-se o atendimento as necessidades relacionadas à produção e comercialização dos produtos orgânicos diante do conceito de sustentabilidade.

Para a obtenção de selos de certificação da qualidade, denominação de origem e de alimento orgânico são exigidos procedimentos de registro formal, para garantia de 
conformidade e mais importante ainda para segurança alimentar. $\mathrm{O}$ que nem sempre é um caminho fácil, principalmente para os pequenos agricultores, tornando a prática complexa e repleta de dificuldades.

No setor cafeeiro, a produção do café orgânico e atividades sustentáveis em toda

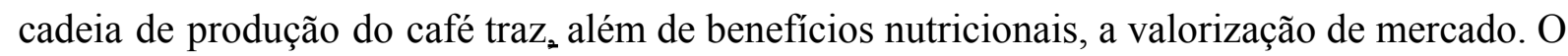
café orgânico vem sendo comercializado inclusive para exportação e por grandes torrefadoras de café, que expõem seus projetos sustentáveis conquistando o consumidor cada vez mais. O café orgânico está nas prateleiras de supermercado junto aos cafés gourmets e especiais, o que é interessante para valorização de mercado ${ }_{2}$ mas ao mesmo tempo, está cada vez mais distante dos consumidores de baixa renda, não oportunizando-os uma alimentação saudável, nutritiva.

Logo, o presente estudo teve como objetivo mostrar as vantagens e desvantagens da produção orgânica de café e entender os desafios a serem enfrentados quanto a certificação, mercado e sustentabilidade a partir de levantamento bibliográfico.

\section{FUNDAMENTAÇÃO TEÓRICA}

É evidente e crescente a preocupação da população com a saúde, qualidade de vida e meio ambiente, com maior nível de informação e exigência, levando também os consumidores a procurarem produtos de empresas/produtores que valorizem essas questões, o que se encontra no contexto de produção sustentável, ambientalmente correta e socialmente justa (SOUZA, 2003; RICCI, 2004; SÁ et al., 2014).

A agroecologia define-se nos princípios da ecologia apoiando-se no processo de transição em direção à sustentabilidade, utilizando-se de conhecimentos e da cultura local, para preservação biológica e cultural (GLIESSMAN, 1990; GLIESSMAN, 2009).

A agricultura orgânica é fundamentada em princípios agroecológicos e de conservação de recursos naturais. O seu conceito e sua prática estão em constante debate e trazem a necessidade de se chegar as camadas mais pobres da população, minimizando os modelos de produção que agridem o meio ambiente, revisando assim as dificuldades impostas pelas tecnologias e organizações sociais (BARDEN et al., 2016).

A Agenda 21 em seu capítulo 40 apresenta propostas que reduz as diferenças de acesso e disponibilização de informações entre os países, indicando os estados e tendências 
das variáveis socioeconômicas quanto aos recursos naturais e ecossistema do planeta. E, a orientação é que sejam tomadas decisões que levem a um desenvolvimento sustentável, sendo utilizados indicadores ambientais, sociais e econômicos, além de atributos como produtividade, estabilidade e resiliência dos agrossistemas sustentáveis, para que possam compor relatórios e banco de dados de amplo acesso. A utilização destes indicadores de sustentabilidade auxilia na gestão das propriedades rurais pelos agricultores no aspecto legal da avaliação das conformidades e da garantia da qualidade de produto orgânico (BARDEN et al., 2016).

A sustentabilidade dos agrossistemas é baseada nos princípios, conceitos e metodologias da agroecologia dentro de um conjunto de dimensões que interagem e auxiliam a alcançar os indicadores, como por exemplo a diversificação da produção como forma de garantir a sustentabilidade dos agrossistemas (CAPORAL e COSTABEBER, 2002; CAPORAL e COSTABEBER, 2007).

A busca por produtos orgânicos cresce no mundo todo, criando assim oportunidades, principalmente para pequenos e médios produtores, inclusive da agricultura familiar entrarem na concorrência das grandes cadeias produtivas para oferecerem seus produtos no mercado interno e externo com valor agregado (NEVES et al., 2004).

Borguini e Torres (2006) estimaram que 90\% dos produtores de produtos orgânicos do país são de origem da agricultura familiar e responsáveis por $70 \%$ de toda produção do Brasil, sendo os $10 \%$ restantes provenientes de empresas privadas e concentradas no sudeste do país.

O Decreto $\mathrm{n}^{\mathrm{o}} 6.323$ de 27 de dezembro de 2007, que regulamenta a Lei $\mathrm{n}^{\circ} 10.831$ de 2003 (BRASIL, 2017) possibilita a certificação da produção orgânica a nível nacional. Esta avaliação pode ser realizada por meio de Organismos de Avaliação da Conformidade (OAC), previamente credenciados junto ao Ministério da Agricultura, Pecuária e Abastecimento (MAPA), no âmbito do sistema brasileiro de avaliação da conformidade orgânica (SisOrg) e assim é possível também realizar a venda direta ao consumidor sem a certifícação (MARINI et al., 2016).

É uma exigência do mercado nacional e internacional a certificação dos produtos orgânicos. O cafeicultor deve garantir a certificação da produção para expandir melhores valores no mercado do café orgânico sustentável. Entre os diversos órgãos que emitem os certificados de sustentabilidade destacam-se a Associação Brasileira da Indústria do Café (ABIC) e o Cecafé. 
Os instrumentos de certificação de produtos orgânicos existentes na legislação brasileira são: Certificação por Auditoria (CA), Organização Participativa de Avaliação da Conformidade Orgânica (OPAC) e Organização de Controle Social (OCS) (BRASIL, 2017), cada um com suas vantagens e desvantagens, que trataremos no desenvolvimento do trabalho. Sendo também sistematizadas informações do Cadastro Nacional de Produtores Orgânicos (CNPO) do Ministério da Agricultura, Pecuária e Abastecimento (MAPA), referentes a 2015 e 2018.

Galhardo, Silva e Lima (2019) buscaram a quantidade de produtores orgânicos cadastrados e verificaram que houve um aumento de 61,9\% em setembro de 2018 em comparação com março de 2015. Verificaram também que o sistema de certificação por auditoria havia registrado 6.360 produtores certificados no Brasil, estando em sua maioria nos estados do Pará (955), seguido de São Paulo (952). O Paraná e o Rio Grande do Sul, apresentaram maiores números de organismos participativos de avaliação da conformidade (OPAC), 1.446 e 1.230, respectivamente. Quanto aos produtores que optam por venda direta de produtos orgânicos sem certificação, classificados como (OCS), São Paulo liderava com 984, seguido de Pernambuco com 578.

De acordo com o Estadão (2020) o Brasil produziu 49,31 milhões de sacas de 60 quilos de café em 2019, destas, 40,6 milhões foram exportadas para 128 países com preço médio de US\$ 125,49 por saca. Os cafés com certificação de sustentabilidade tiveram 7,5 milhões de sacas vendidas para o exterior a um preço médio de US\$ 159,19 , cerca $12 \%$ superior ao grão produzido no sistema convencional, o que vêm chamando a atenção dos cafeicultores brasileiros pela produção sustentável.

O mercado dos produtos orgânicos está em constante expansão e cresce mais rapidamente que o mercado dos produtos provenientes de sistemas de produção tradicionais, movimentando dezenas de bilhões anualmente no Brasil (NASCIMENTO et al., 2012; SÁ et al., 2014). Salientando que cerca de $24 \%$ de todas as exportações de cafés diferenciados no Brasil está associada a padrões, selos, programas ou certificações de sustentabilidade, como Rainforest, UTZ, Fair Trade, 4C, Certifica Minas, Starbucks C.A.F.E., Nestlé AAA, entre outros (CECAFÉ, 2019).

Diante do exposto faz-se necessário discutir as vantagens e desvantagens da produção orgânica de café e entender os desafios a serem enfrentados quanto à certificação, mercado e sustentabilidade. 


\section{METODOLOGIA}

A pesquisa realizada caracteriza-se como qualitativa do tipo exploratória. Foram utilizadas as principais plataformas de buscas como SciELO (Scientific Electronic Library Online), Google Scholar, Portal de Periódicos CAPES (Coordenação de Aperfeiçoamento de Pessoal de Nível Superior), Springer e Science Direct para a coleta dos artigos relacionados à produção orgânica de café e seus desafios de registros formais, mercados e sustentabilidade. Utilizou-se as seguintes palavras-chave: Agricultura orgânica; Sustentabilidade; Certificação; Mercado; Café orgânico e os mesmos na língua inglesa.

\section{RESULTADOS E DISCUSSÃO}

Atualmente, a crescente preocupação com o meio ambiente e a qualidade de vida difunde a ideologia da agricultura alternativa (FONTANÉTTI, 2006). Embora, em comparação aos alimentos convencionais, a procura por produtos orgânicos ainda seja pequena observa-se uma demanda mundial progressiva por esta categoria de alimentos (SEBRAE, 2008).

O comércio mundial de produtos orgânicos caracteriza-se pela predominância dos países subdesenvolvidos como exportadores de matérias primas orgânicas certificadas e os países desenvolvidos como comercializadores de produtor com maior valor agregado (BUAIMAIN; BATALHA, 2007).

De acordo com Wegner, Bliska e Turco (2011), como apresentado no Quadro 01, as principais vantagens da produção orgânica são: o respeito à saúde do trabalhador, o equilíbrio do agroecossistema, a possibilidade de receber um preço maior em relação ao café convencional e o fato de as propriedades familiares adquirem possibilidade de inserção no mercado internacional com um produto de alto valor agregado. As principais desvantagens são: o requerimento de orientação quanto à maneira de uso de adubos e fertilizantes, o que apresenta um custo elevado e a burocracia envolvida com a certificação.

Quadro 01: Vantagens e desvantagens da produção de café orgânico

\begin{tabular}{|c|c|}
\hline Vantagens & Desvantagens \\
\hline Respeito à saúde do trabalhador & $\begin{array}{c}\text { Requerimento de orientação quanto ao uso de adubos } \\
\text { e fertilizantes }\end{array}$ \\
\hline
\end{tabular}




\begin{tabular}{|c|c|}
\hline Ausência de substâncias químicas & Dependência da demanda externa \\
\hline Equilíbrio do agroecossistema & Prática intensiva de mão-de-obra \\
\hline $\begin{array}{c}\text { Aumento de preço em relação ao café } \\
\text { convencional }\end{array}$ & Custo elevado \\
\hline Produto de alto valor agregado & Burocracia para certificação \\
\hline Inserção no mercado internacional & Dificuldade de inserção no mercado interno \\
\hline
\end{tabular}

Fonte: Wegner, Bliska e Turco (2011)

Vale ressaltar a relação entre o uso direto de agrotóxicos e os problemas de saúde dos trabalhadores rurais e de comunidades que vivem próximas às áreas de plantações (CARNEIRO et al., 2015). O estudo realizado por Fenzke et al (2018) revela que dependendo dos fatores de riscos aos quais estes trabalhadores estão expostos, devido ao fato da não utilização ou uso inadequado de Equipamentos de Proteção Individual (EPIs) e atrelado a questão financeira, tipos específicos de doenças seriam manifestadas a curto ou a longo prazo. Sendo o sistema respiratório e nervoso como os mais afetados, citando a presença de problemas respiratórios agudos ou crônicos (rinite alérgica, asma e doença obstrutiva crônica) e casos de intoxicação, doença de Parkinson e neuropatia periférica como resultantes.

A decisão de compra de produtos orgânicos pelos consumidores tem maior foco em aspectos relacionados à saúde. A utilização de agrotóxicos no Brasil ainda é alta e sua aplicação é realizada de forma incorreta, não respeitando o período de carência do produto, gerando um residual ainda maior de agrotóxicos nos alimentos e no meio ambiente. A importância da ausência de substâncias químicas, a questão ambiental e o sabor são as razões primárias por comprar alimentos orgânicos. Além disso, a saúde e segurança em relação ao alimento também são motivos importantes quanto à aquisição destes produtos (GRACIA e MAGISTRIS, 2008; ALENCAR et al., 2013).

Em síntese, para a sustentabilidade econômica do café orgânico, vários desafios se apresentam. Principalmente no tocante à comercialização que, se em relação ao manejo convencional, pequeno e médio agricultores estariam em vantagem devido ao processo de certificação, a manutenção no mercado internacional requer combinação de escala, alta qualidade e boas cotações. Aos cafeicultores que destinam seu produto somente ao mercado interno, o principal desafio é encontrar fontes seguras e, que considerem o respeito a valores sociais e ambientais, quanto ao escoamento do produto (WEGNER et al., 2011). 
O desenvolvimento da produção orgânica é lento. A agricultura orgânica ainda é uma atividade destinada a agricultura familiar e conduzida por pequenos produtores. $\mathrm{O}$ crescimento da produção orgânica certificada no Brasil é bastante limitado por problemas de oferta e de organização do mercado e por insuficiências nas políticas de estímulo à conversão e à produção propriamente dita (BUAINAIN e BATALHA, 2007).

A certificação de produtos orgânicos é o procedimento pelo qual uma certificadora, credenciada pelo MAPA e pelo Inmetro, assegura por escrito que determinado produto, processo ou serviço obedece às normas e práticas da produção orgânica. Após isso, os produtos passam a utilizar o Selo do Sistema Brasileiro de Avaliação da Conformidade Orgânica - SISORG (Figura 01) (ORGANICSNET, 2011; MAPA, 2012). Selo do Sistema Brasileiro de Avaliação da Conformidade Orgânica - SISORG

Figura 01. Selo do Sistema Brasileiro de Avaliação da Conformidade Orgânica - SISORG

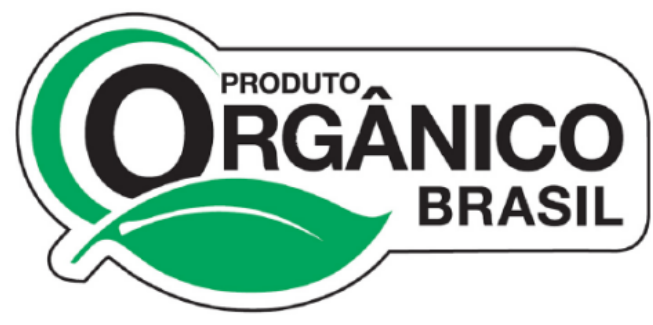

Fonte: BRASIL/MAPA,2012

As normas do sistema de certificação da Rainforest Alliance ${ }^{\mathrm{TM}}$ (Figura 02) são exemplo de inovação para a sustentabilidade da agricultura mundial, uma vez que apoiam o produtor na melhoria da gestão da propriedade, aumenta a eficiência e a produtividade, cumprem a legislação ambiental e trabalhista, conservam os recursos naturais e preservam o bem-estar dos agricultores, assegurando que o produto seja proveniente de fazendas e florestas locais e sustentáveis que conservam a biodiversidade (IMAFLORA, 2021).

Figura 02. Rainforest Alliance Certified 


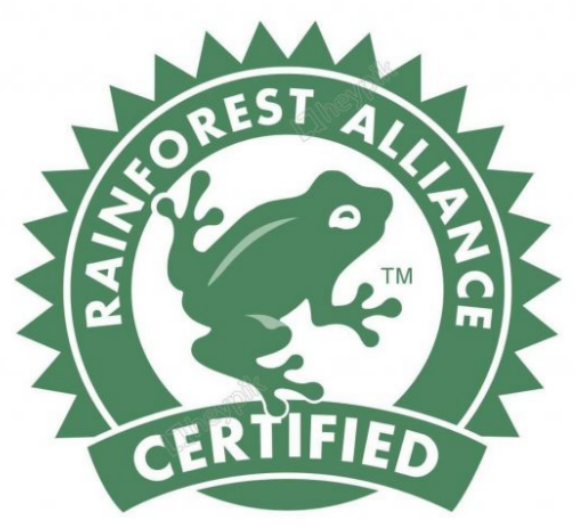

singer PICDETE

Fonte: IMAFLORA, 2021

A certificação orgânica é um fator importante e decisivo para averiguar se um produto realmente tem os atributos de um sistema agrícola orgânico (NASCIMENTO et al., 2012). Os processos de certificação se originam da evolução de movimentos ambientalistas e da conscientização da população ao perceber os impactos negativos que a agricultura convencional exerce sobre o meio ambiente e a qualidade de vida dos consumidores e produtores (FERRAZ, 2000).

De acordo com o Instituto Biodinâmico de Desenvolvimento Rural (1999), a concessão da certificação exige dos produtores cuidados que vão além do manejo sustentado e da obtenção de produtos isentos de agrotóxicos e adubação química. É exigido que a relação com os agricultores envolvidos seja repensada, adequadamente remunerada e que estes tenham participação nos lucros. Além disto, a atividade geradora do produto a ser certificado, em hipótese alguma pode oferecer, em nenhuma etapa do seu processo, qualquer tipo de risco ao meio ambiente. Além disso, Latimore (2020) afirma que o custo é de longe o maior obstáculo para os agricultores, principalmente os pequenos, que consideram a certificação orgânica.

Segundo Dantas et al. (2011), um dos maiores desafios do mercado de produtos orgânicos é que o crescimento não acontece na mesma intensidade entre os grandes centros urbanos e os pequenos. No interior, a oferta de produtos orgânicos costuma ser menor e o nível de conhecimento dos consumidores acerca desses alimentos também é apontado como uma das causas da baixa procura. Os cafeicultores que destinam seu produto somente ao mercado interno, veem dificuldade em encontrar fontes seguras e, que considerem o respeito a valores sociais e ambientais, quanto ao escoamento do produto (WEGNER et al., 2011). 
A partir disso, o MAPA (2019a) registrou mais de 17 mil produtores (Figura 03) e de 22 mil unidades de produção orgânica (Figura 04) em 2018. Constatando um crescimento médio anual de 19\% de unidades de produção orgânica, entre 2010 e 2018, e um aumento médio anual de quase $17 \%$ do número de produtores orgânicos registrados nos últimos sete anos no país. De acordo com Lira (2018), essas unidades de produção orgânica estão distribuídas em todas as regiões brasileiras com maior concentração na região Nordeste, na região Sul e em parte dos estados de São Paulo, Rio de Janeiro e Espírito Santo.

Figura 03: Número de produtores orgânicos cadastrados no Ministério da Agricultura, Pecuária e Abastecimento.

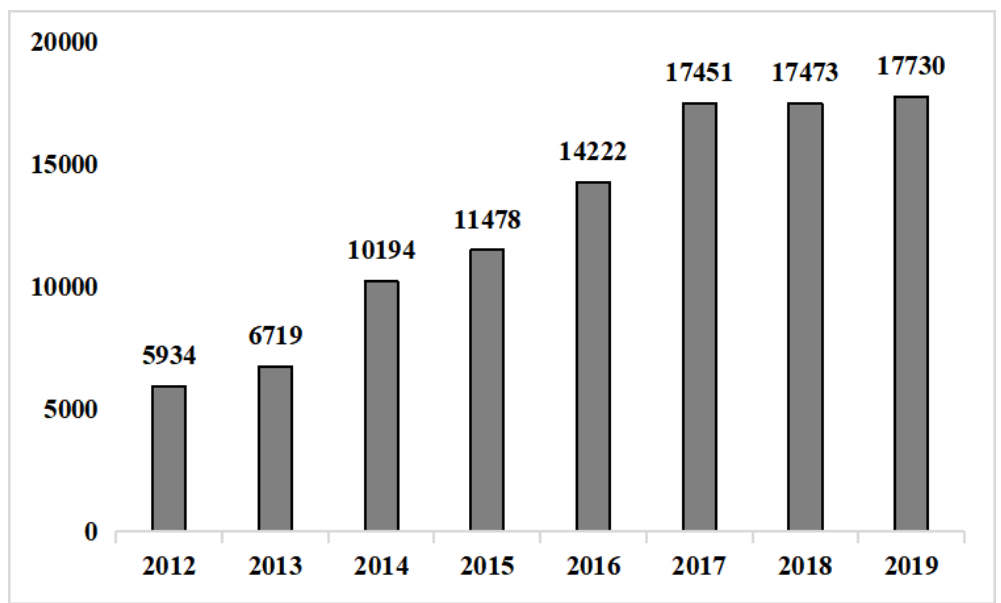

Fonte: MAPA (2019a)

Figura 04: Número de unidades de produção cadastradas no Ministério da Agricultura, Pecuária e Abastecimento

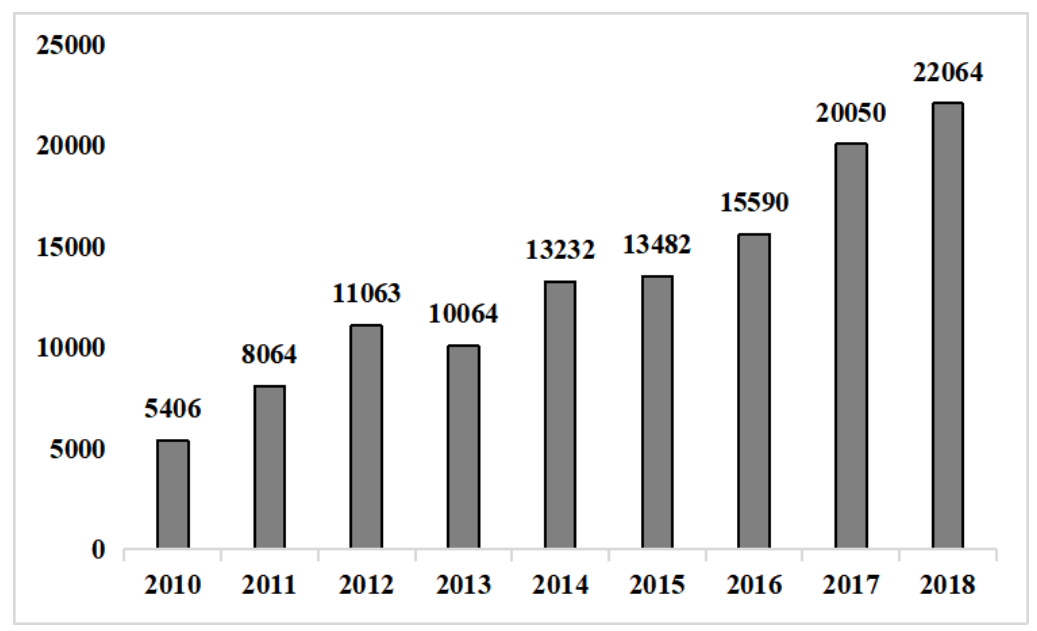

Fonte: MAPA (2019a)

Apesar do crescimento desse mercado, os orgânicos no Brasil têm encontrado espaço em nichos regionais relativamente restritos e de consumidores com poder aquisitivo alto. Porém, nos últimos anos esses produtos vêm tomando impulso e atraindo o interesse das 
grandes redes de supermercados, que buscam fornecer um produto diferenciado e saudável, conquistando e fidelizando clientes (SÁ, GONÇALVES, SOUZA E LAPOLLI, 2014).

O conceito de sustentabilidade envolve o modo de produção de determinado produto e a percepção dos consumidores sobre ele (THøGERSEN; HAUGAARD; OLESEN, 2010). E, segundo Darolt (2002), à medida que a agricultura orgânica vai se consolidando o perfil do produtor orgânico, a capacidade produtiva e o uso dos recursos naturais, a rentabilidade estável a longo prazo e as políticas públicas tendem ao equilíbrio.

De acordo com a Organização Internacional do Café - OIC (2005), a sustentabilidade no agronegócio café age como um conjunto de ações e iniciativas com o intuito de assegurar a continuidade e a viabilidade da atividade cafeeira, abrangendo a preservação ambiental, relações sociais e econômicas no trabalho, e garantindo condições dignas de trabalho e de remuneração justa, além de melhoria na qualidade do produto e desenvolvimento do mercado e do consumo.

A sustentabilidade na agroindústria cafeicultora está relacionada à busca pelo desenvolvimento sustentável na atividade cafeeira, no qual o meio ambiente, o bem-estar social e a atividade econômica formam uma base com o objetivo de continuar produzindo café sem comprometer o desenvolvimento das gerações futuras (PEREIRA, 2013).

De acordo com o Canal Agro Estadão (2020), uma melhor rentabilidade é conseguida por meio de práticas sustentáveis que resultam em um grão de maior qualidade. Dessa forma, aumenta-se o valor agregado do produto, proporcionando maior renda para o produtor. A aplicação de boas práticas também reduz o desperdício, melhora a gestão da propriedade, economiza insumos e capacita melhor os agricultores, garantindo aumento da segurança do trabalho. Além disso, a sustentabilidade na produção gera benefícios para o meio ambiente, preservando o solo e a água da propriedade, e para o consumidor final, que recebe uma bebida de melhor qualidade.

\section{CONCLUSÕES}

A agricultura orgânica visa ofertar produtos saudáveis e livres de contaminantes, além de garantirem preservação da diversidade biológica dos ecossistemas naturais com o propósito de manter a integridade e as qualidades orgânicas e vitais do produto em todas as etapas. Neste sentido, a certificação orgânica é um fator importante para maior credibilidade dos 


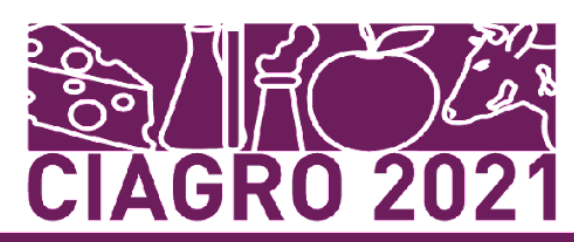

consumidores, estimulando a exportação desses produtos e conferindo transparência às práticas e os princípios utilizados na produção.

A discussão sobre produção sustentável de café vem sendo notória entre os produtores. A preocupação é que se criem processos de produção, serviços ou métodos de gestão inovadores, mas que sejam coerentes com o conceito de sustentabilidade, positivos para a sociedade como um todo e para o meio ambiente. Criando assim um equilíbrio entre os aspectos econômico, ambiental e social, agregando valor ao produto.

Para isso é necessário adotar práticas que valorizem a humanização da rotina de trabalho na lavoura, com registro e proteção; práticas que preservem os recursos hídricos, a biodiversidade e a qualidade do ar; o cumprimento quanto ao uso de agrotóxicos, no caso dos cafés orgânicos o não uso destes e, a gestão de resíduos. Bem como, buscar produzir grãos de melhor qualidade, com boa aceitação, destacando-se no mercado interno e externo.

Os cafeicultores que desejam serem certificados pela Associação Brasileira da Indústria do Café (ABIC) com o selo Cafés Sustentáveis do Brasil precisam seguir todas etapas de produção sustentável, preencher o termo de adesão, ter seu processo e propriedade auditada para se avaliar o cumprimento da regulamentação e só assim receber o selo de certificado sustentável. Mesmo que o cafeicultor também utilize do sistema convencional de plantio pode solicitar na parte da propriedade que cumpre as exigências quanto a sustentabilidade a obtenção do selo.

Em síntese, para a sustentabilidade econômica do café orgânico, vários desafios se apresentam. Principalmente no tocante à comercialização que, se em relação ao manejo convencional, pequeno e médio agricultores estariam em vantagem devido ao processo certificador, a manutenção no mercado internacional requer combinação de escala, alta qualidade e boas cotações. Um dos maiores desafios do mercado de produtos orgânicos é o fato de o crescimento não acontecer na mesma intensidade entre os grandes centros urbanos e cidades do interior, levando em consideração a oferta e o nível de conhecimento dos consumidores.

\section{AGRADECIMENTOS}


À UFAPE/CNPQ e a FACEPE pelo financiamento de bolsas estudantis e pelo apoio à pesquisa.

\section{REFERÊNCIAS}

ALENCAR, G.V. de; MENDONÇA, E. de. S.; OLIVEIRA, T.S. de; JUCKSCH, I.; CECON, P.R. Percepção ambiental e uso do solo por agricultores de sistemas orgânicos e convencionais na Chapada da Ibiapaba, Ceará. Revista de Economia e Sociologia Rural, v. 51, p.217-236, 2013. Disponível em: http://www.doi.org/10.1590/S0103-20032013000200001. Acesso em: 09 de março de 2021.

BARDEN, J.E.; SINDELAR, F. C. W.; LAROQUE, L. F. S.; MORIGI, V. J.; SCHULTZ, G. Sustentabilidade em Sistemas Orgânicos: uma proposta de avaliação em propriedades rurais. In: XVIII Encontro Internacional sobre Gestão Empresarial e Meio Ambiente ENGEMA. Anais. p. 1-15. São Paulo. Issn:2359-1048. 2016.

BORGUINI, R. G.; TORRES, E. A. Alimentos orgânicos: Qualidade nutritiva e segurança do alimento. Segurança Alimentar e Nutricional, Campinas, v.13, n.2, p.64-75, 2006. Disponível

em: http://www.ciorganico.agr.br/wpcontent/uploads/2012/10/12-Alimentosorganicos-qualidade-n utritiva-eseguran\% C3\%A7a-do-alimento-.pdf. Acesso em fevereiro/2021.

BRASIL. Ministério da Agricultura, Pecuária e Abastecimento (MAPA). Produto Orgânico: melhor para a vida de todos e do planeta. 2012. Disponível em: https://www.gov.br/agricultura/pt-br/assuntos/sustentabilidade/organicos/semana-dos-org anicos-1. Acesso em: 29 mar. 2021.

BRASIL. Ministério da Agricultura, Pecuária e Abastecimento, Cadastro Nacional da Produção Orgânica [online]. $2017 . \quad$ Disponível em: https://www.gov.br/agricultura/pt-br/assuntos/sustentabilidade/organicos. Acesso em: 29 mar. 2021.

BRASIL. Ministério da Agricultura, Pecuária e Abastecimento - MAPA, Produtos Orgânicos [online]. $2017 . \quad$ Disponível em: https://www.gov.br/agricultura/pt-br/assuntos/sustentabilidade/organicos/legislacao-organicos. Acesso em: 29 mar. 2021.

BRASIL. Ministério da Agricultura, Pecuária e Abastecimento. Em 7 anos, triplica o número de produtores orgânicos cadastrados no ministério. Brasília: Mapa 2019a. Disponível em: https://bit.ly/2HTzG9d. Acesso em: 06 abr. 2021.

BUAINAIN, A. M.; BATAlHA, M. O. Cadeia Produtiva de Produtos Orgânicos. Brasília: Ministério da Agricultura, Pecuária e Abastecimento (MAPA); Secretaria de Política Agrícola (SPA); Instituto Interamericano de Cooperação para a Agricultura (IICA). Série Agronegócios, Vol. 5, 2007. 
BUAINAIN, A. M.; BATAlHA, M. O. Cadeia Produtiva de Produtos Orgânicos. Brasília: Ministério da Agricultura, Pecuária e Abastecimento (MAPA); Secretaria de Política Agrícola (SPA); Instituto Interamericano de Cooperação para a Agricultura (IICA). Série Agronegócios, vol. 5, 2007.

CAPORAL, F. R.; COSTABEBER, J. A. Agroecologia: alguns conceitos e princípios. 2.ed. Brasília, DF: MADA: SAF: DATER-IICA, 2007. 24p.

CAPORAL, F.; COSTABEBER, J. A. Agroecologia: enfoque científico e estratégico para apoiar o desenvolvimento rural sustentável. Série Programa de Formação Técnico Social da Emater/RS - Sustentabilidade e Cidadania, Porto Alegre: Emater/Ascar, v.5. 2002.

CARNEIRO, F.F.; AUGUSTO, L.G.S.; RIGOTTO, R.M., FRIEDRICH, K., BÚRIGO, A.C. Dossiê ABRASCO: um alerta sobre os impactos dos agrotóxicos na saúde. Rio de Janeiro: EPSJV; São Paulo: Expressão Popular. 2015.

CECAFÉ. Sustentabilidade, compromissos sociais e ambientais do Café Brasileiro. 2021. Disponível https://www.cecafe.com.br/sem-categoria/sustentabilidade-compromissos-sociais-e-ambientai s-do-cafe-brasileiro-20190911/. Acesso em: março de 2021.

DAROLT, M. R. Agricultura orgânica: inventando o futuro. IAPAR. Londrina. 2002.

ESTADÃO. Cultivo com sustentabilidade eleva o preço do café. 2020. Disponível em: https://summitagro.estadao.com.br/noticias-do-campo/cultivo-com-sustentabilidade-eleva-o-preco -do-cafe/. Acesso em: março de 2021.

FERRAZ， J. M. G; PRADA， L. S.; PAIXÃO, M. Certificação socio-ambiental do setor sucro-alcooleiro. EMBRAPA Meio Ambiente. São Paulo. 2000.

FENZKE, M.N.; MELLO, M.C.V.A; SANTOS, K.N.S.C.; CEZAR-VAZ, M.R.Adoecimentos e fatores relacionados à saúde do trabalhador rural/Sicknesses and factors related to rural workers 'health. Rev. Enfermagem UFPE on line; 12(8): 2214-2226, 2018.

FONTANÉTTI, A.; CARVALHO, G. J.; GOMES, L. A. A.; ALMEIDA, K.; MORAES, S. R. G.; TEIXEIRA, C. M. Adubação verde na produção orgânica de alface americana e repolho. Horticultura Brasileira, v. 24 n. 2. 2006.

GALHARDO, L. R.; SILVA, L. F. S.; LIMA, A. S. F. Produtores orgânicos no Brasil e seus organismos certificadores. Revista Ciência, Tecnologia \& Ambiente. v.8, n.1, p.37-45; 2018 .

GLIESSMAN, S. R. Agroecology: researching the basis for sustainable agriculture. New York: Verlag, 1990.

GLIESSMAN, S. R. Agroecologia: processos ecológicos em agricultura sustentável. 4. ed. Porto Alegre: Ed. Universidade/UFRGS, 2009. 
GRACIA, A.; MAGISTRIS, T. The demand for organic foods in South of Italy: a discrete choice model. Food Policy, v. 3, n. 5, p.386-396, 2008.

IBD. INSTITUTO BIODINÂMICO DE DESENVOLVIMENTO RURAL - Diretrizes Para o Padrão de Qualidade Orgânico. 8ed. 1999.

IMAFLORA. Certificação Agrícola. 2021 Disponível em: https://www.imaflora.org/o-que-fazemos/certificacoes/rainforest-alliance. Acesso em: 05 abr. 2021.

LATIMORE, Z. Os prós e contras do cultivo de café orgânico. Perfect Daily Grind. 2020. Disponível

em: https://perfectdailygrind.com/pt/2020/06/14/os-pros-e-contras-do-cultivo-de-cafe-organic o/. Acesso em: 02 abr. 2021.

LIRA, V. M. C. Produção orgânica no Brasil. Brasília: MAPA, 2018. Disponível em: https://bit.ly/2nfbd5i. Acesso em: 06 abr. 2021.

MARINI, F. S.; XAVIER, L. H.; SILVA, D. V.; BARROS, J. R. L.; BARBOSA, G. J.; SILVA, F. J. A; SILVA, V. Panorama da certificação de produtos orgânicos no Brasil e dos instrumentos nacionais de garantia da conformidade: uma análise a partir do Cadastro Nacional de Produtores Orgânicos. Gaia Scientia, v.10, n.4, p.574-588, 2016. http://dx.doi.org/10.21707/gs.v10.n04a43.

NASCIMENTO, K. O. et al. A importância do estímulo à certificação de produtos orgânicos. Acta Tecnológica, v.7, n2, p55-64, 2012. Disponível em: http://portaldeperiodicos.ifma.edu.br/portaldeperiodicos/index.php/actatecnologica/article/vie w/85. Acesso em março/2021.

NEVES, M. C. P.; ALMEIDA, D. L. de; DE-POLLI, H.; GUERRA, J. G. M.; RIBEIRO, R.de L. D. Agricultura orgânica-uma estratégia para o desenvolvimento de sistemas agrícolas sustentáveis. Seropédica: Editora Universidade Federal Rural do Rio de Janeiro, 2004. 113p.

ORGANICSNET. Certificação de Orgânicos. Disponível em: http://www.organicsnet.com.br/certificação/. Acesso em: 02 abr. 2021

ORGANIZAÇÃO INTERNACIONAL DO CAFÉ. Informe suscinto preliminar sobre la conferencia mundial del café. São Paulo, 2005. 7 p. (Documentos, ICC 94-13).

PEREIRA, S. P. Caracterização de propriedades cafeeiras com relação às boas práticas agrícolas: aplicação das análises de "Cluster" e discriminante. Lavras: UFLA, 2013. 138 p.

RICCI, M.S.F. Cultivo do Café Orgânico. Seropédica: Embrapa Agrobiologia, 2004. 95p. (Embrapa Agrobiologia. Sistemas de Produção, 2).

SÁ, M.A.; GONÇALVES, E.B.; SOUZA, V.A.B.; LAPOLLI, É. Mafra. Produtores orgânicos e a sustentabilidade. Revista Brasileira de Agroecologia, v 9, n. 2, p. 84-97, 2014. 


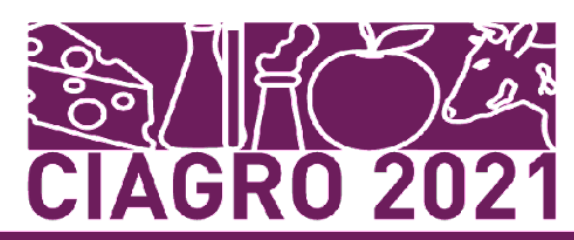

SEBRAE. Conhecer SEBRAR agronegócios: A qualificação dos orgânicos. n.2. 2008. Disponível

em:

Paseare

http:7201.2.114.147/bds/BDS.nsf/51B801B2C330530983267605004AFDC5/\$File/NT0003

A4CE.pdf. Acesso em: 02 abr. 2021.

SOUZA, M.C.M. Aspectos institucionais do sistema agroindustrial de produtos orgânicos. Informações Econômicas. 2003; 33(3): 7-16.

THØGERSEN, J.; HAUGAARD, P.; OLESEN, A. Consumer responses to ecolabels. European Journal of Marketing, Bradford, v. 44, n. 11/12, p. 1787-1810, 2010.

WEGNER, R.C.; BLISKA, F.M.; TURCO, P.H.N. Viabilidade da produção de café orgânico no Brasil: vantagens e desvantagens. In: VII Simpósio de Pesquisa dos Cafés do Brasil. Anais. Araxá-MG. 2011. 


\title{
CAPÍTULO 24: REAPROVEITAMENTO DE RESÍDUOS NA CADEIA AGROINDUSTRIAL DO PESCADO: UMA REVISÃO
}

\author{
CAPÍTULO 24: REUTILIZACIÓN DE RESIDUOS EN LA CADENA \\ AGROINDUSTRIAL PESQUERA: UNA REVISIÓN
}

\section{CHAPTER 24: REUSE OF WASTE IN THE FISH AGROINDUSTRIAL CHAIN: A REVIEW}

\author{
Diana Carla Fernandes Oliveira ${ }^{1}$; Francielly Corrêa Albergaria ${ }^{2}$; Anderson Henrique Venâncio ${ }^{3}$; Maria Emília de \\ Sousa Gomes ${ }^{4}$; Rilke Tadeu Fonseca de Freitas ${ }^{5}$
}

\section{DOI:https://doi.org/10.31692/978-65-88970-19-5.369-388}

\section{RESUMO}

O setor pesqueiro consiste em uma atividade econômica de grande importância no Brasil e no mundo. Entretanto, com esse crescimento, surgem problemas relacionados à destinação dos resíduos sólidos (escamas, peles, carcaças, vísceras, cabeças) produzidos pela cadeia produtiva do pescado. Atualmente, um dos principais obstáculos da cadeia produtiva é o reduzido aproveitamento do resíduo gerado a partir do processamento do pescado. Estima-se que $50 \%$ da matéria-prima processada seja responsável pela geração de resíduos e o descarte inadequado pode ocasionar sérios impactos ambientais.O aproveitamento deste material é importante, pois trata se de proteína animal de excelente qualidade nutricional, com a utilização de diversas tecnologias esses resíduos podem ser destinados para: consumo humano, ração para animais, fertilizantes, produtos químicos, produção de biofilmes e embalagens. A utilização de resíduos comestíveis, além de diminuir custos e aumentar a eficiência de produção, minimiza os problemas de poluição ambiental oriundos da falta de destino adequado. $O$ presente artigo tem como objetivo realizar uma revisão de literatura sobre o reaproveitamento de resíduos da indústria pesqueira.

Palavras-Chave: Beneficiamento, Pescado, Processamento, Sustentabilidade

\section{RESUMEN}

El sector pesquero constituye una actividad económica de gran importancia en Brasil y en el mundo. Sin embargo, con este crecimiento, surgen problemas relacionados con el destino de los residuos sólidos (escamas, pieles, canales, vísceras, cabezas) producidos por la cadena producción pesquera. Actualmente, uno de los principales obstáculos en la cadena productiva es el reducido uso de residuos generados por el procesamiento del pescado. Se estima que el $50 \%$ de la materia prima procesada es responsable de la generación de residuos y una disposición inadecuada puede ocasionar graves impactos ambientales. El uso de este material es importante, por tratarse de proteína animal de excelente calidad nutricional, con el uso de diversas tecnologías estos residuos pueden ser destinados a: consumo humano, alimentación animal, fertilizantes, químicos, producción de biofilms y empaques. El uso de residuos comestibles, además de disminuir costos y aumentar la eficiencia productiva, minimiza los problemas de contaminación ambiental derivados de la falta de un destino adecuado.

\footnotetext{
${ }^{1}$ Pós-Graduação em Zootecnia, Universidade Federal de Lavras, diana_zootecnista@yahoo.com.br

${ }^{2}$ Pós-Graduação em Ciência dos Alimentos, Universidade Federal de Lavras, franalbergaria@hotmail.com

${ }^{3}$ Pós-Graduação em Ciência dos Alimentos, Universidade Federal de Lavras, anderson123dfgh21@gmail.com

${ }^{4}$ Professora, Departamento de Ciência dos Alimentos, Universidade Federal de Lavras, maria.emilia@ufla.br

${ }^{5}$ Professor, Departamento de Zootecnia, Universidade Federal de Lavras, rilke@ufla.br
} 
Este artículo tiene como objetivo realizar una revisión de la literatura sobre la reutilización de residuos de la industria pesquera.

Palabras Clave: Procesamiento, Pescado, Procesamiento, Sostenibilidad

\section{ABSTRACT}

The fishing sector consists of an economic activity of great importance in Brazil and in the world. However, with this growth, problems are arise regarding to the destination of solid residues (scales, skins, carcasses, viscera, heads) produced by the fish production chain. Currently, one of the main obstacles in the production chain is the reduced use of waste generated from fish processing. It is estimated that $50 \%$ of the raw material processed is responsible for the generation of waste and improper disposal can cause serious environmental impacts. The use of this material is important, as it is animal protein of excellent nutritional quality, with the use of several technologies these residues can be destined for: human consumption, animal feed, fertilizers, chemicals, production of biofilms and packaging. The use of edible waste, in addition to reducing costs and increasing production efficiency, minimizes environmental problems pollution arising from the lack of a suitable destination. This article aims to conduct a literature review on the reuse of waste from the fishing industry.

Keywords: Processing, Fish, Processing, Sustainability

\section{INTRODUÇÃO}

A indústria de beneficiamento de pescado constitui-se em uma das principais atividades econômicas de diversos países, sendo a proteína do pescado considerada uma fonte essencial de nutrientes (PIRES et al., 2014), contêm, grandes quantidades de vitaminas lipossolúveis (A e D) e minerais, além de possuir uma das mais importantes fontes protéicas de alto valor biológico com maior digestibilidade (SOARES \& GONÇALVES, 2012). A composição lipídica dos peixes contrasta com a de mamíferos por conter elevada proporção de ácidos graxos poli-insaturados de cadeia longa (SARTORI \& AMANCIO, 2012).

Em nível mundial, o pescado provê em torno de $17 \%$ do consumo total de proteína animal para 4,3 bilhões de indivíduos (TAHERGOABI et al., 2013). Entretanto, aproximadamente $60 \%$ do pescado processado é responsável pela geração de resíduos, enquanto apenas 40\% é designado para o consumo humano (CHALAMAIAH et al., 2012).

O Brasil é uma das principais potências no que diz respeito à indústria da pesca e consequentemente gera um alto índice de resíduos, podendo variar entre 50\% e 70\% do peso fresco, de acordo com cada espécie (COSTA, 2012; HE et al., 2013; SILVA et al., 2014). Entretanto, no setor produtivo brasileiro, o aproveitamento de resíduos da indústria pesqueira não é uma prática recorrente (SUCASAS, 2011). Estes resíduos são principalmente vísceras, cauda, coluna vertebral, barbatana, escamas e restos de carne (FELTES et al., 2010). Os principais destinos desses resíduos são os aterros sanitários e o 
descarte direto em rios e mares, os quais causam sérios problemas ambientais (REBOUÇAS et al., 2012) e econômicos que podem afetar a viabilidade da pesca e da indústria aquícola

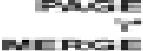

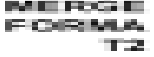
(ZAMORA-SILLERO et al., 2018).

Contudo, esses resíduos apresentam alto valor nutricional que, quando ocorre o aproveitamento de seu potencial. Com base no exposto, tem havido estudos e investigações direcionadas a encontrar novas formas de exploração de resíduos de pescado, a fim de minimizar os problemas ambientais (SHERIFF, SUNDARAM, RAMAMOORTHY, \& PONNUSAMY, 2014), agregam valor ao produto final gerando lucro e diminuindo o impacto ambiental (AGUIAR; LIMBERGER; SILVEIRA, 2014). Uma quantidade significativa de resíduos que podem ser direcionados para várias modalidades de aproveitamento: alimentos para consumo humano e consumo animal, fertilizantes ou adubos orgânicos, produtos químicos e ainda aproveitá-los no desenvolvimento de produtos funcionais, sendo uma grande parte destinada à produção de farinha (GONÇALVES, 2011).

No que diz respeito a produção aquícola marinha brasileira, a mesma pode ser dividida basicamente em dois tipos: a malacocultura, que se refere à produção de moluscos, e a carcinicultura, que se refere à produção de crustáceos.

O cultivo de moluscos tem crescido progressivamente, no entanto, a deposição de conchas que restam após a retirada dos moluscos em locais inapropriados, causa grave impacto ambiental e econômico (PIRES et al., 2014). Tristão et al. (2009) avaliaram a viabilidade técnica deste material ser utilizado para a fabricação de cal e a posterior produção de argamassa, demonstrando que estes resíduos atendem aos pré-requisitos para tal fabricação, sendo, portanto, possível realizar seu reaproveitamento.

Considerando o crescimento da produção de pescado, a importância socioeconômica da cadeia produtiva, assim como a problemática da geração de resíduos sólidos, objetivou-se realizar uma revisão de literatura acerca da geração de resíduos na indústria do pescado e as opções para o correto aproveitamento deste material, contribuindo para a sustentabilidade da pesca e aquicultura.

\section{METODOLOGIA}

O estudo foi desenvolvido mediante uma revisão de literatura científica, abordando temas referentes ao reaproveitamento de resíduos na cadeia agroindustrial do pescado. Realizou-se uma pesquisa bibliográfica abrangente usando bases de dados de literatura 
científica: Science Direct, Scopus, Scielo e Periódicos Capes, com os seguintes descritores: reaproveitamento de pescado, resíduos de peixes, processamento de pescado, coprodutos de pescados. Os trabalhos encontrados passaram por uma análise de título e resumo para refinar os artigos que estavam relacionados ao tema. Foram excluídos do presente estudo trabalhos que não apresentassem texto completo, que não estivessem publicados em revistas indexadas, e que não se adequassem ao tema abordado.

\section{PRODUÇÃO E CONSUMO DE PEIXE}

A aquicultura é um dos setores de produção de proteína animal que mais cresce em relação a outros setores do mesmo segmento (GODOY et al., 2013; LI \& PONZONI, 2015). Atualmente, o mercado global de alimentos vem sofrendo grandes mudanças nos padrões alimentares, gerando aumento na procura por alimentos de melhor qualidade nutricional, dentre eles o pescado (ZANARDI, 2011).

A produção global de peixes atingiu cerca de 179 milhões de toneladas em 2018, segundo estimativas da Organização das Nações Unidas para a Agricultura e Alimentação (FAO, 2018) das quais 82 milhões de toneladas são provenientes da aquicultura. A Piscicultura brasileira produziu 722.560 toneladas de peixes de cultivo em 2018, esse resultado é 4,5\% superior ao de 2017 (691.700 t) (PEIXE BR, 2020), sendo a tilápia a espécie mais produzida. Atualmente, a produção atingiu 486.155 toneladas, consolidando o Brasil como o quarto maior produtor de tilápias (PEIXE BR, 2021).

Apesar dos benefícios do pescado já terem sido comprovados, o consumo em muitos países ainda é a baixo. O recomendado pela Organização Mundial da Saúde (OMS) é de no mínimo de $12 \mathrm{~kg}$ / hab/ano, entretanto, no Brasil, em 2013, o consumo per capita de pescado foi de 10,87 kg/hab/ano (FAOSTAT, 2016). Segundo a FAO (2020) os dados globais sobre o consumo de peixe ocultam considerável variação regional. As diferenças nos níveis de renda também representam um fator importante nas diferenças de consumos, assim como disponibilidade e preço de proteínas substituíveis (DOS SANTOS FOGAÇA et al., 2015).

Melhorias na manipulação, no processamento para comercialização são fatores que favorecem a expanão, aumentam a qualidade dos produtos e reduz as perdas e despesas de produção (CHOWDHURY et al., 2010). Contudo, faz-se necessário a aplicação de estratégias políticas, científicas e empresariais que realmente incentivem o consumo de pescado no Brasil (GONÇALVES, 2011). Para tanto, é fundamental que ocorra um esforço conjunto entre 
produtores, comerciantes, órgãos governamentais e consumidores, com o propósito de exigir e assegurar melhor qualidade do produto disponível no mercado, a um preço acessível (OETTERER; GALVÃO; SAVAY-DA-SILVA, 2014).

\section{APROVEITAMENTO DE RESÍDUOS}

Por definição, resíduo é todo material que não é aproveitado durante a produção ou consumo, devido a limitações tecnológicas ou mercadológicas, que não apresenta valor de uso ou mercado, podendo resultar em danos ao meio ambiente quando não manejado de forma adequada (SUCASAS, 2011; REBOUÇAS et al., 2012; PIRES et al., 2014).

Durante o processo de beneficiamento do pescado (Figura 1), são gerados diversos resíduos, os coprodutos obtidos em termos percentuais são compostos de cortes musculares (15-20\%), pele e barbatanas (1-3\%), ossos (9-15\%), cabeças (9-12\%), vísceras $(12-18 \%)$ e escamas (5\%) (MARTÍNEZ-ALVAREZ, CHAMORRO, \& BRENES, 2015 ).

Figura 1. Fluxograma geral do processo de beneficiamento de pescados, com a indicação do processamento (setas contínuas) e dos resíduos gerados (setas pontilhadas).

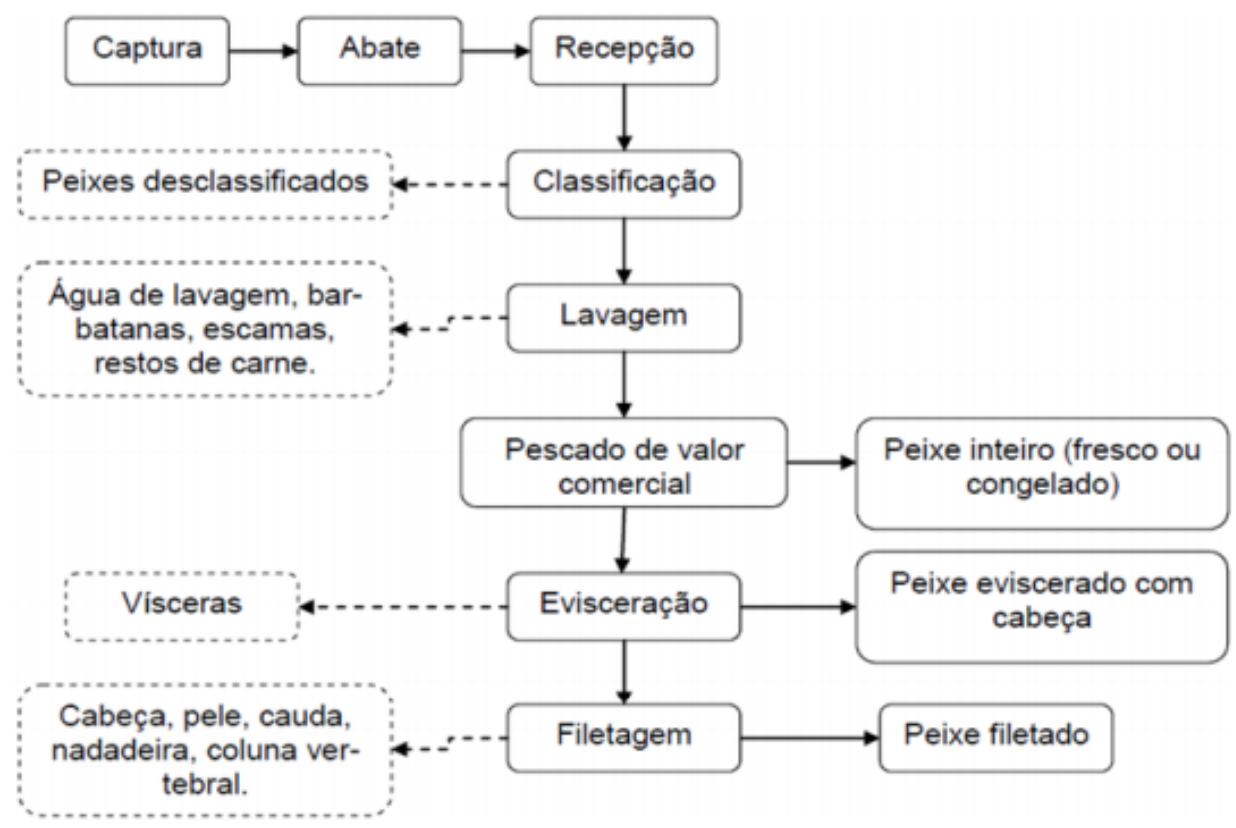

Fonte: Adaptado de Feltes et al. (2010).

O aumento da produção e do consumo de pescado está diretamente ligado à necessidade de se viabilizar tecnologias para o reaproveitamento dos resíduos gerados pela indústria aquícola. Na Figura 2 são apresentados os principais saídas de potenciais industriais 


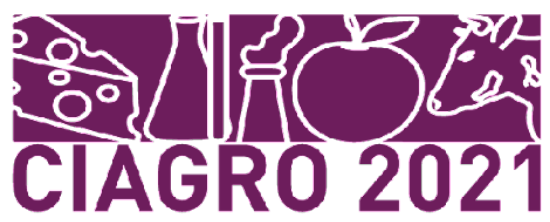

para os resíduos de peixes. Dos subprodutos obtidos após o processamento do pescado, uma grande variedade de compostos de alta qualidade pode ser recuperada e usada para consumo $P=-15$ humano e alimentação animal (VÁZQUEZ et al., 2019).

A maior parte dos resíduos destina-se à produção de farinha de peixe (NUNES, 2011; VIDOTTI; GONÇALVES; MARTINS, 2011; HU et al., 2013) e óleo (PRENTICE-HERNÁNDEZ, 2011; GONÇALVES; FERROLI; VIEGAS, 2012), para a produção de ração animal (BOSCOLO et al., 2010), reduzindo os custos de produção. Entretanto, os resíduos da industrialização podem ser direcionados para diversas modalidades de aproveitamento, tais como: alimentos para consumo humano (MAHBOOB, 2015; RADZIEMSKA et al., 2019; YUVARAJ et al., 2019; GOVINDHARAJ; ROOPAVATH; RATH, 2019; NAWAZ et al., 2020); fertilizantes de sistemas agrícolas (LÓPEZ-MOSQUERA et al., 2011), silagem e compostos (VIDOTTI, 2011; OLIVEIRA et al., 2014) ou hidrolisados (DIETERICH, 2014; FERREIRA et al., 2020); extração de colágeno (escamas e pele) para indústria farmacêutica e alimentícia.

Figura 2. Diagrama esquemático e resultados possíveis de um peixe durante o processamento.

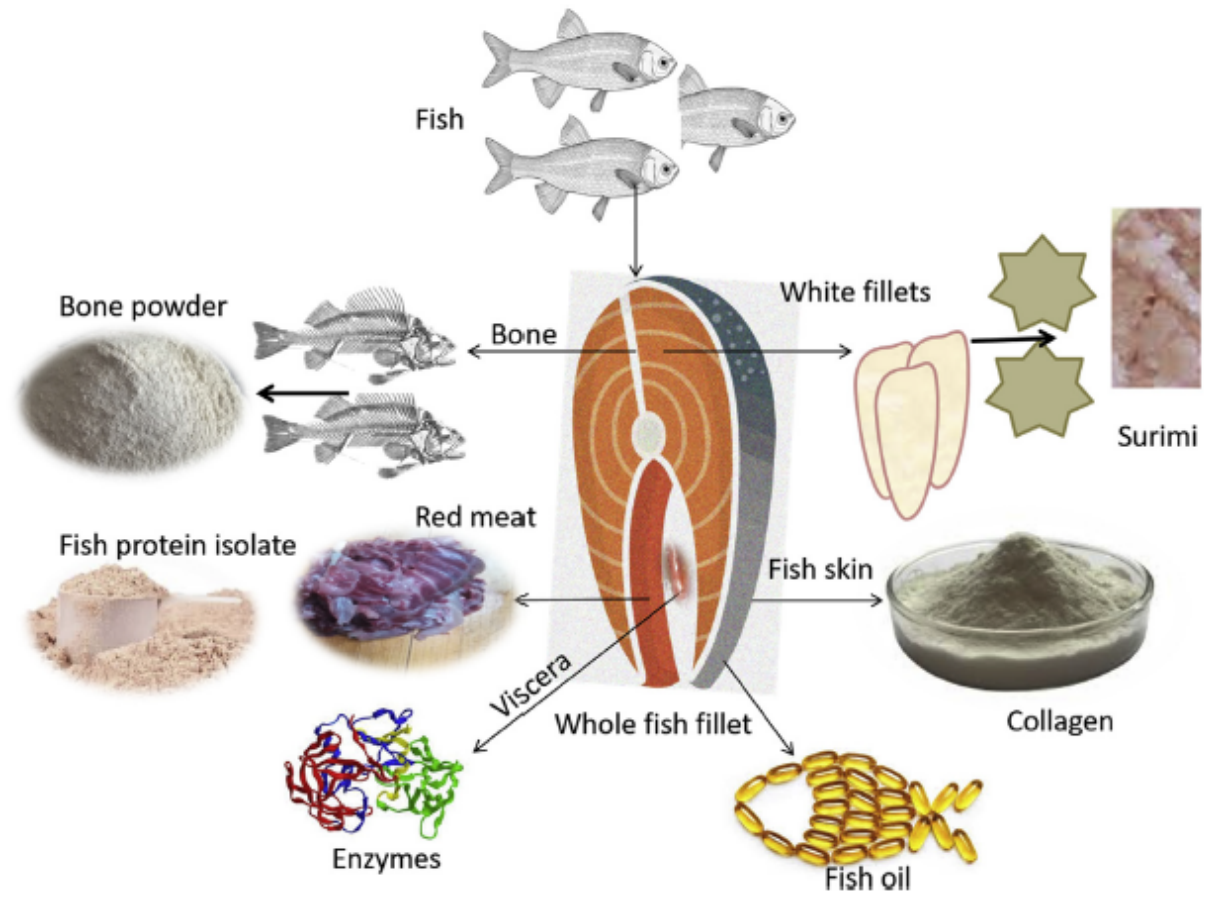

Fonte: NAWAZ et al., 2020

\section{APROVEITAMENTO PARA ALIMENTAÇÃO HUMANA}

Em geral, durante o beneficiamento de pescados, gera-se uma quantidade expressiva 
de resíduos que podem ser encaminhados para várias modalidades de aproveitamento. $\mathrm{O}$ desenvolvimento de novos produtos industrializados de maior valor agregado, evita desperdícios (GONÇALVES 2011). Com o uso de máquinas tecnológicas, é possível a aplicação do processo de extração de carne mecanicamente separada (KIRSCHNIK, 2007). Tal processo é capaz de recuperar grande parte da carne ainda aderida na carcaça (OLIVEIRA et al., 2012). A partir da carne mecanicamente separada (CMS) de peixe é possível desenvolver variedades de produtos e outras preparações que forneçam energia e que favoreçam a boa aceitação do produto pelo público em geral (BOSCOLO et al., 2009; FREITAS et al., 2012). Pode ser utilizada inclusive para a produção de farinha (DE MELO, 2018).

A CMS Pode ser utilizada como base em diferentes formulações, de forma a agregar valor ao produto final, como "fishburgers" (MARENGONI et al., 2009), almôndegas (OLIVEIRA et al., 2012; LUSTOSA-NETO et al., 2018); empanados (SIGNOR et al., 2020); patês (FREITAS et al., 2012); croquete (BORDIGNON et al., 2010); biscoito (NEIVA et al., 2011); mortadela (MELO et al., 2011) ; salsisha (LAGO et al., 2018); quenelle (ANGELINI et al., 2013) e também na produção de farinha através da secagem em um secador de circulação forçada (OLIVEIRA et al., 2015).

Nesse sentido, alguns autores se beneficiaram da utilização da farinha de peixe no enriquecimento de pães (BASTOS et al., 2014; SHANKAR), biscoitos e bolachas, caldo e sopa (BARRETO; ROCHA; LEDO, 2015), macarrão (GOES et al., 2016). Veit et al. (2012) estudaram a adição de $20 \%$ e $12 \%$ de filés de tilápia cozidos e triturados em bolo de chocolate e cenoura respectivamente. Essa é uma excelente estratégia de aumentar a ingestão de peixe no país, haja visto que o consumo é abaixo do recomendado e onde atualmente as pessoas estão comprando mais produtos alimentícios industrializados e de fácil preparo (GOES et al., 2016).

A elaboração de pratos utilizando farinha de peixe na merenda escolar de escolas públicas têm sido sugerido por vários autores, de modo a oferecer um alimento com elevado teor nutricional (ROCHA et al., 2011). Godoy et al. (2010) avaliou a aceitação de caldos e canjas elaborados com farinhas aromatizadas, elaborados com resíduo da filetagem, desenvolvidas a partir de carcaças de tilápia, carpa e pacu defumados. Os caldos e as canjas elaborados a partir das farinhas aromatizadas tiveram boa aceitabilidade pelos consumidores, podendo ser empregados, no caso da farinha, no enriquecimento de produtos para consumo 


\section{humano (BARRETO; ROCHA; LEDO, 2015).}

Os pescados subutilizados de baixo valor econômico, espécies pelágicas de pequeno tamanho, que podem vir durante a despesca, podem ser aproveitados para a obtenção da Carne Triturada de Pescado (CTP). O produto é obtido através da passagem do filé sem pele e/ou aparas por um moinho elétrico comercial. A CTP é empregada na elaboração de diversos produtos, podendo ser adquirida a partir de uma única espécie ou de uma mistura de espécies com características sensoriais similares (NEIVA e GONÇALVES, 2011; PIRES et al., 2014).

\section{FARINHA DE PEIXE}

A farinha de peixe é obtida após moagem e secagem de diferentes espécies de peixes inteiros, restos de peixes ou outros subprodutos resultantes do processamento de peixes (PIRES et al., 2014). A elaboração da farinha de resíduos principalmente oriundos do processo de filetagem apresenta-se com baixo valor comercial ou descarte, sendo estes processados, agrega valor podendo ser aproveitados no processamento de farinha de peixe (FOLLMANN; CENTENARO, 2013). A farinha de peixe é o principal subproduto obtido no provesso de beneficamento do pescado, podendo ser utilizada tanto em alimentação humana, como sitado anteriormente, como para a alimentação animal.

$\mathrm{Na}$ aquicultura, como em qualquer cultura animal, a ração comercial corresponde a uma alta porcentagem dos custos (DANTAS FILHO, 2017; BELETE, 2015; BATALHA et al., 2017), ultrapassam 80\% dos custos de produção (BELETE, 2015; PEREA-ROMÁN et al., 2018). Por isso, faz-se necessário buscar alternativas de reduzir os custos com alimentação, com a substituições de matérias não tradicionais que muitas vezes são desperdiçadas ou descartada pela indústria do pescado, isso sem comprometer a dieta e o desempenho dos peixes.

Vários estudos têm sido realizados para identificar fontes proteicas alternativas que permitiriam uma redução no custo da alimentação e simultaneamente aproveitar resíduos agroindustriais (SILVA, 2016; BATALHA et al., 2017). A farinha de peixe é considerada a melhor fonte de proteína para peixes devido ao seu excelente perfil de aminoácidos, alto teor de proteína bruta, alta palatabilidade e alta digestibilidade (FRABEGAT et al., 2011).

\section{ÓLEO DE PEIXE}

O óleo de peixe é a fração lipídica extraída de peixes e subprodutos de 
peixes. Atualmente, a produção de óleo de peixe está se tornando mais exigente, visto que há uma demanda considerável e crescente no mercado mundial por óleos de peixe de alta qualidade. Além de seus vários usos como óleos consumíveis, também é apreciável tanto na indústria farmacêutica quanto na indústria (ABDULKADIR et al., 2010 ). Nos últimos anos, o óleo de peixe, fonte de ácido ômega-3, vem sendo utilizado para fins de suplemento e fortificação pelas indústrias farmacêutica (MOZZAFARIAN e WU, 2011) e alimentícias, sendo utilizado como óleo enlatado, para a produção de margarina e maionese (HERNANDEZ, 2011).

Segundo Aguiar, Limberger e Silveira (2014), os benefícios do óleo de peixe têm sido apontados em estudos recentes na alimentação de seres humanos e animais e isso está relacionado, pelo fato de este produto apresentar considerável interesse bioquímico, metabólico, nutricional e farmacêutico. O óleo de peixe é um ingrediente comumente usado na dieta de animais aquático devido ao seu alto valor nutricional, além de fornecer ácidos graxos essenciais, melhora a palatabilidade da ração (TANTIKITTI, 2014).

Outra alternativa para o aproveitamento do óleo de peixe seria para a produção de biodiesel. Gomes et al. (2015) extraíram lipídeos das vísceras de sardinha-verdadeira para produção de biodiesel. O óleo extraído apresentou um bom rendimento $(18,75 \%)$ para a produção de biodiesel.

\section{SILAGEM DE RESÍDUOS}

A silagem de pescado é definida como produto líquido, em primeira instância, no qual são adicionados ácidos, enzimas ou bactérias produtoras de ácido láctico, resultando na liquefação da massa (VIDOTTI, 2011), podendo ser oriunda do peixe inteiro ou partes dele (PANTOJA et al., 2011).

A fabricação de silagem a partir da comercialização de resíduos de processamento de pescado visando a obtenção de ingrediente alimentar de aquicultura tem sido amplamente estudada nos últimos anos (SILVA, 2016; BATALHA et al., 2017). Além do mais, o baixo custo do produto da silagem, especialmente quando comparado à farinha de peixe e/ou rações comerciais é bastante atraente (SALES; OLIVEIRA, 2015). Aplicada a pequenas unidades comerciais, a silagem representa uma proposta vantajosa em vista do crescente aumento de resíduos da industrialização do pescado (MAIA JÚNIOR e SALES, 2013), uma vez que sua fabricação não requer altos investimentos tampouco equipamentos específicos (ROMAN et 
al., 2017). Apesar das alterações que acontecem no processo de elaboração, as silagens de peixe conservam as suas características químicas e nutricionais semelhantes ao material de origem (VIDOTTI; GONÇALVES, 2006).

\section{COMPOSTAGEM DE RESÍDUOS}

O processo de compostagem é uma das formas mais empregada para o aproveitamento de resíduos, para atividades agrícolas, no entanto, existe outra forma de utilização destes resíduos, que é a fermentação do material (SANES et al., 2015). O composto resultante da fermentação aeróbica ou anaeróbica do resíduo de pescado, apresenta-se como uma viável fonte de nutrientes para sistemas produtivos de base ecológica.

Contudo, a compostagem de resíduso pesqueiros não é devidamente divulgada no Brasil pela falta de conhecimentos sobre os benefícios de utilização desses compostos (BARREIRA; PHILIPPI; RODRIGUES, 2005). Segundo Coelho (2008), a compostagem utiliza diferentes tipos de resíduos na produção de adubo, proporcionando melhores características de produtividade e qualidade do vegetal quando adicionado ao solo.

\section{BIOFILMES E EMBALAGENS}

A utilização de materias plásticos aumentou devido às suas boas propriedades, acessibilidade, facilidade de processamento, leveza e baixo custo. Entretanto, os materias plásticos são preparados por processo de plomerização por condensação ou polimerização de monômeros de diferentes hidrocarbonetos, todos têm origem na indústria petroquímica, o que os torna não renováveis e não biodegradáveis (COSTA et al., 2012). Atualmente, há uma demanda crescente de matérias-primas baseadas em biomaterias, a fim de reduzir os problemas de eliminação de resíduos (GARAVAND et al., 2017). Muitas dessas embalagens tem sido desenvolvida a partir de matérias-primas naturais e renováveis, como proteínas, polissacarídeos e lipídeos oriundos do reaproveitamento de resíduos de pescado (LECETA et al., 2014).

Neste contexto, a quitina e a quitosana (polissacarídeos), possuem grande valor no mercado, o que faz com que seja viável a obtenção a partir dos resíduos de pesca (RODRIGUES et al., 2020). Dentre suas várias aplicações, a quitosana pode ser designada para a produção de um polímero, denominado biofilme. O biofilme é um filme fino preparado a partir de materiais biológicos, que age como barreira a elementos externos e, 
consequentemente, pode proteger o produto embalado de danos físicos e biológicos e aumentar a sua vida útil. (HENRIQUE et al., 2008).

A quitina e seus derivados, têm muitas aplicações importantes nas áreas farmacêutica, alimentícia, agricultura, bioengenharia e cosméticos (DUAN et al., 2012). É encontrada comercialmente nos produtos de resíduos da indústria de processamento de alimentos marinhos (LIMAM et al., 2011), e apresenta diversas propriedades benéficas, tais como: anti-inflamatória (YANG et al., 2010); neuroprotetora (PANGESTUTI \& KIM, 2010); antitumoral (QUAN et al., 2009) e antifúngica e antibacteriana (FERNANDES et al., 2008).

As peles de pescado são uma valiosa fonte de obtenção de gelatina, que é uma proteína com diferentes propriedades funcionais e aplicações, incluindo a capacidade de formação de filme e aplicação como cobertura na proteção de alimentos (HOSSEINI et al., 2013). Entretanto, os filmes produzidos a partir da gelatina, possuem algumas desvantagens, como alta solubilidade em água e fracas propriedades mecânicas, o que limita sua faixa de aplicação e utilização. Contudo, o desempenho físico e microbiológico de filmes à base de gelatina de pescado podem ser melhorados através de combinação, em sua matriz, com outros materias renováveis de resíduos marinhos, como quitosana e ácidos graxos (LECETA et al., 2014; JRIDI et al., 2014; GÓMEZ-ESTECA et al., 2011).

\section{ARTESANATO E MODA}

$\mathrm{Na}$ sociedade atual, a pesca artesanal continua se reafirmando como atividade importante tanto do ponto de vista econômico (como geração de renda e produção de alimento) quanto social e culturalmente (COSTA et al., 2016). No Brasil, a utilização de escamas de peixe em artesanato é uma técnica que vem sendo difundida há pouco tempo, porém existem alguns projetos estão sendo desenvolvidos em comunidades como na de Barra de Serinhaém, em Ipojuca - PE (Figura 3). As escamas, avaliadas como produto de alta qualidade e durabilidade, contribuem para a geração de renda e equidade de comunidades que vivem da pesca artesanal.

Figura 3- Flores confeccionadas com as escamas de peixe, com destaque para a flor confeccionada em escama de camurupim na comunidade da Barra de Serinhaém, Ipojuca-PE. 

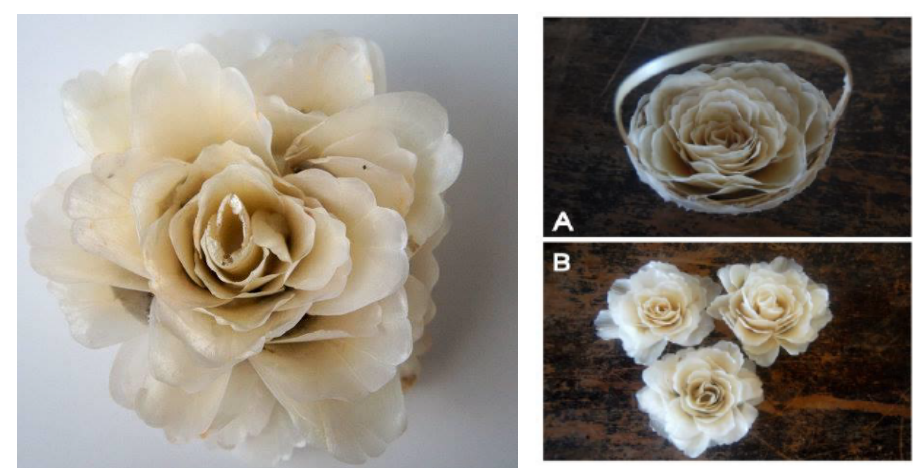

Fonte: (COSTA et al., 2016)

A indústria da moda sempre esteve entre as indústrias que mais emitem carga de resíduos ambientais. A pele de peixe surge, então, como uma nova alternativa para o design sustentável, constituindo-se como um material diferenciado e resistente, cujo processo de produção pode se adequar às leis de preservação e sustentabilidade, desde que o curtimento seja realizado de forma que não prejudique o meio ambiente (CARDOSO, 2010) (Figura 4).

Figura 4- Aspecto final após curtimento da pele de peixe.

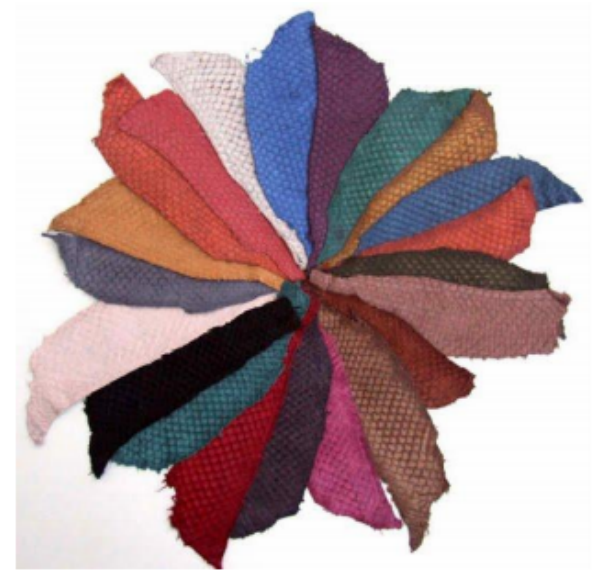

Fonte: Criecologico (2012)

Após passar por um processo de bebeficiamento têxtil, o couro de peixe se torna um objeto durável e resistente, apresentando o dobro de resistência do couto bovino. Entretanto, a resistência do couro é influenciada por fatores como a espécie do peixe, sua idade e peso, sentido da pele (transversal ou longitudinal em relação ao comprimento do peixe), conservação e processo de curtimento (NUPÉLIA, 2014). A existência de mercado consumidor para couro de peixes e seu potencial de crescimento, são os principais fatores de maior abrangência dessa oportunidade de negócio (SOUZA, 2010). 


\section{CONCLUSÕES}

A melhor forma de se destinar produtos de descarte de reíduos pesqueiros é, por meio do desenvolvimento de novos produtos. A elaboração dos mesmos é uma forma de reduzir os impactos negativos da atividade industrial ao meio ambiente, ao mesmo tempo, que pode ser uma provável solução para problemas de má nutrição, atribuídos à carência ou deficiência de proteínas de elevado valor nutricional na dieta alimentar. Embora diversas tecnologias se mostrem viáveis para a fabricação de subprodutos de alto valor agregado a partir dos resíduos de pescado, o mesmo ainda tem sido realizado de forma não recorrente.

\section{REFERÊNCIAS}

ABDULKADIR, M., Abubakar, GI, \& Mohammed, A. Produção e caracterização de óleos de peixes. Journal of Engineering and Applied Sciences, v.5, n. 7, p. 769-776, 2010.

AGUIAR, G. P. S.; LIMBERGER, G. M.; SILVEIRA, E. L. "Altermativas tecnológicas para o aproveitamento de resíduos provenientes da industrialização de pescados". Revista Eletrônica Interdisciplinar, Barra do Garça, v. 1, n. 11, p. 225-229, 2014.

ANGELINI, M. F. C. et al M. Shelf life and sensory assessment of tilapia quenelle during frozen storage. Pesquisa Agropecuária Brasileira, v. 48, n. 8, p. 1080-1087, 2013.

ARVANITOYANNIS, I. S. (2010). Waste management for the food industries. Academic Press.

BARREIRA, L.P.; PHILIPPI A.J.; RODRIGUES M.S. Usinas de compostagem: avaliação da qualidade dos compostos e processos de produção. 2005.

BARRETO, N., ROCHA, J. B. S.; LEDO, C. A. S. Elaboração de biscoitos e sopa usando farinha de peixe. 2015 .

BASTOS, S. C. et al. Resíduos da filetagem de peixes para enriquecimento de pão de trigo: características químicas e sensoriais. Jornal de ciência e tecnologia de alimentos , v. 51, n. 9, pág. 2240-2245, 2014.

BATALHA, S.S. et al Digestibility and physico-chemical characteristics of acid silage meal made of pirarucu waste in diets for commercial laying hens. Acta Scientiarum Animal Sciences, v.39, n.3, p.251-257, 2017.

BELETE, N.A.S. Impacto ambiental, desempenho produtivo e econômico do uso de diferentes taxas de alimentação no cultivo do pirarucu Arapaima gigas (CUVIER, 1829). 2015. 38f. Dissertação (Mestrado em Ciências Ambientais) - Universidade Federal de Rondônia, Rolim de Moura-RO, 2015. 
BELETE, N.A.S. Impacto ambiental, desempenho produtivo e econômico do uso de diferentes taxas de alimentação no cultivo do pirarucu Arapaima gigas (CUVIER, 1829). 2015. 38f. Dissertação (Mestrado em Ciências Ambientais) - Universidade Federal de Rondônia, Rolim de Moura-RO, 2015.

BORDIGNON, A. C. et al. Elaboração de croquete de tilápia do Nilo (Oreochromis niloticus) a partir de CMS e aparas do corte em "V" do filé e sua avaliação físico-química, microbiológica e sensorial. Maringá, v.32, n.1, p.109-116, 2010.

BORGHESI, R. et al. Influencia da nutrição sobre a qualidade do pescado: especial referência aos ácidos graxos- Corumbá : Embrapa Pantanal; Dourados : Embrapa Agropecuária Oeste, p. 21, 2013.

BOSCOLO, W. E. et al. Peixe na Merenda escolar: Educar e formar novos consumidores. GFM Gráfica e Editora Ltda Editoração. Toledo - PR, 2009.

CARDOSO, Juliana. O design industrial como ferramenta para a sustentabilidade: estudo de caso do couro de peixe. Revista espaço acadêmico, n114, novembro 2010.

CHAMALAIAH, M. et al. Fish protein hydrolysates: Proximate composition, amino acid composition, antioxidant activities and applications: A review. Food Chemistry, v. 135, p. 3020-3038, 2012.

COELHO, F.C. Composto Orgânico. Manual Técnico, 03. Niterói: Programa Rio Rural, 2008. COSTA, S. R; SOUZA, P. A. R. O impacto dos resíduos de pescado: o caso da "Feira do Bagaço" no município de Parintins no Amazonas. DELOS Revista Desarrollo Local Sostenible, v.5, n.14, p. $01-11,2012$.

COSTA, T. L. E. et al. Avaliação de coberturas comestíveis compostas por quitosana e argila no revestimento em tomates sob refrigeração pelo método dipping. Revista Verde de Agroecologia e Desenvolvimento Sustentável, p, 12-19, 2014.

COSTA, W. M. et al. Aproveitamento de resíduos de pescado: o artesanato com escamas de peixe. Rev. Ciênc. Ext. v.12, n.2, p.8-17, 2016.

Criecologico. Curtume de peixes. Dísponivel em: https://criecologico.blogspot.com/2010/05/reciclando-os-peixes.html. Acesso em: 10/04/2021.

DANTAS FILHO, J.V. Gestão de Custos na Piscicultura no Município de Presidente Médici-Rondônia-Brasil. AB Custos, v.12, n.2, p.29-53, 2017.

De MELO, M. P. F., SANTOS, A. D. S., PIRES, C. R. F., de ALMEIDA, H. C. G., \& de SOUSA, D. N. Desenvolvimento tecnológico e caracterização nutricional de massa alimentícia enriquecido com farinha de peixe. In Embrapa Pesca e Aquicultura-Artigo em anais de congresso (ALICE). In: SIMPÓSIO DE CONTROLE DE QUALIDADE DO PESCADO, 7., São Paulo, 2016. Estratégias para aumentar o consumo do pescado: proceedings. São Paulo: Instituto de Pesca, 2018. 
DIETERICH, F. et al. Development and Characterization of Protein Hydrolysates Originated from Animal Agro Industrial Byproducts. Journal of Dairy, Veterinary \& Animal Research, v. 1, p. 12-19, 2014.

DOS SANTOS FOGAÇA, F. H. et al. Caracterização de surimi obtido a partir da carne mecanicamente separada de tilápia do Nilo e elaboraçãso de fishburger. Semina:Ciencias Agrarias, v. 36, n. 2, p. 765-776, 2015.

DUAN, S. et al. Improved production of chitin from shrimp waste by fermentation with epiphytic lactic acid bacteria. Carbohydrate Polymers, v.89, n. 4, 1283-1288, 2012.

FAO. Food and Agriculture Organization of the United Nations. The State of World Fisheries and Aquaculture 2018 - Meeting the sustainable development goals. Roma, 2018. Disponível em: < http://www.fao.org/3/i9540en/I9540EN.pdf $>$. Acesso em 09/04/2021.

FAO. 2020. $A$ Situação Mundial da Pesca e Aquicultura 2020 .

FAOSTAT. Evolução do consumo de pescado per capita no Brasil. 2016.

FELTES, M. C.M. et al. Alternativas para a agregação de valor aos resíduos da industrialização de peixe. Revista Brasileira de Engenharia Agrícola e Ambiental, v.14, n.6, p.669-677, 2010.

FERNANDES, J.C. et al. Antimicrobial effects of chitosans and chitooligosaccharides, upon Staphylococcus aureus and Escherichia coli, in food model systems. Food Microbiology, v. 25, p. 922-928, 2008.

FERREIRA, H. K. A, et al. Hidrolisados proteicos de resíduos da indústria de processamento de tilápia: caracterização centesimal, microbiológica e aminoácidos. Brazilian Journal of Development, v. 6, n. 8, p. 59516-59527, 2020.

FOLLMANN, A. M. C., \& CENTENARO, A. I. Elaboração de bolo de laranja adicionado com diferentes concentrações de farinha de carcaça de Tilápia do Nilo (Oreochromis niloticus) (Bachelor's thesis, Universidade Tecnológica Federal do Paraná), 2013.

FREITAS, D.G.C.; RESENDE, A.L.S.S.; FURTADO, A.A.L.; TASHIMA, L.; BECHARA, H.M. The sensory acceptability of a tilapia (Oreochromis niloticus) mechanically separated meat-based spread. Brazilian Journal of Food Technology, 15: 166-173, 2012.

GODOY, L. C. et al. Análise sensorial de caldos e canjas elaborados com farinha de carcaças de peixe defumadas: aplicação na merenda escolar. Ciência e Tecnologia de Alimentos, v.30, p.86-89, 2010.

GODOY, L.C. et al. Development, Preservation, and Chemical and Fatty Acid Profiles of Nile Tilapia Carcass Meal for Human Feeding. Jour. Food Proc. Preser., v.37, p.93-99, 2013.

GOES, E. S. dos R. et al. Fresh pasta enrichment with protein concentrate of tilapia nutritional and sensory characteristics. Food Science and Technology, v. 36, n. 1, p. 76-82, 2016. 
GÓMEZ-ESTACA, J. Effects of gelatin origin, bovine-hide and tuna-skin, on the properties of compound gelatin-chitosan films. Food Hydrocolloids, v. 25, n. 6, p. 1461-1469, 2011.

GOMES, A. F; SANTOS, A. G. D; SOUZA, L. D; PINTO, C. H. C; MATIAS, L. G. O; BEATRIZ, A. Síntese e caracterização de biodiesel com material lipídico extraído das vísceras da Sardinella brasiliensis. Revista Geintec, v.5, n.2, p.2181-2194, 2015.

GONÇAlVES A. A. Tecnologia do Pescado: Ciência, Tecnologia, Inovação e Legislação. São Paulo: Editora Atheneu, 2011. 608 p.

GONÇALVES, L. U.; FERROLI, F.; VIEGAS, E. M. M. Effect of the inclusion of fish residue oils in diets on the fatty acid profile of muscles of males and females lambari (Astyanax altiparanae). Revista Brasileira de Zootecnia, Viçosa, MG, v. 41, n. 9, p. 1967-1974, 2012

GOVINDHARAJ, M.; ROOPAVATH, U. K.; RATH, S. N. Valorization of discarded Marine Eel fish skin for collagen extraction as a $3 \mathrm{D}$ printable blue biomaterial for tissue engineering. Journal of Cleaner Production, v. 230, p. 412-419, 2019.

GARAVAND, F. et al. Improving the integrity of naturak biopolymer films used in food packaging by crosslinking approach. A review. International Journal of Biological Macromolecules, v. 104, p. 687-707. 2017.

HERnANDEZ, C.P. Óleo de Pescado. In: GONÇALVES, A.A. Tecnologia do Pescado: Ciência, Tecnologia, Inovação e Legislação. São Paulo: Editora Atheneu, 2011. p.372-380.

HOSSEINI, S. F. et al. Preparation and functional properties of fish gelatin-chitosan blend edible films. Food Chemistry, v. 136, n. 3-4, p. 1490-1495, 2013.

HU, L. et al. Effects of fish meal quality and fish meal substitution by animal protein blend on growth performance, flesh quality and liver histology of Japanese seabass (Lateolabrax japonicas). Aquaculture, Amsterdam, v. 372-375, p. 52-61, 2013.

JRIDI, M. et al. Physical, structural, antioxidant and antimicrobial properties of gelatin-chitosan composite edible films, International Journal of Biological Macromolecules, v. 67, p. 373-379, 2014.

KIRSCHNIK, P. G. Avaliação da estabilidade de produtos obtidos de carne mecanicamente separada de tilápia nilótica (Oreochromis niloticus). 2007. 102 f. Tese (Doutorado em Aquicultura) - Universidade Estadual Paulista, Jaboticabal, 2007.

KUBITZA, F.; CAMPOS, J. L. O aproveitamento dos subprodutos do processamento de pescado. Panorama da Aquicultura, Laranjeiras, v. 16, n. 94, p. 23-29, 2006.

LAGO, A. M. T. et al. Fish sausages prepared with inclusion of Nile tilapia minced: Correlation between nutritional, chemical, and physical properties. Journal of Food Processing and Preservation, v. 42, n. 10, 2018. 
LECETA, I. et al. Biobased films prepared with by-products and wastes. Environmental assessment. Journal of Cleaner Production, v. 64, p. 218-227, 2014.

LI, Y \& PONZONI, R. W. Some aspects of design and analysis of selection programmes in aquaculture species. Journal of Animal Breeding and Genetics, v. 132, p.169-175, 2015.

LIMAM, Z.; SELMI, S.; SADOK, S.; EL-ABED, A. Extraction and characterization of chitin and chitosan from crustacean by-products: biological and physico-chemical properties. African Journal of Biotechnology, v.10, n.4, p. 640-647, 2011.

LÓPEZ-MOSQUERA, M. E. et al. Composting fish waste and seaweed to produce a fertilizer for use in organic agriculture. Procedia Environmental Science, Amsterdam, v. 9, p. $113-117,2011$.

LUSTOSA-NETO, A.D. Almôndegas de pirarucu e tilápia nilótica: caracterização e aplicação na merenda escolar, Acta of fisheries and aquatic resources, v. 6, n. 2, p. 1-12, 2018.

MAHBOOB, S. Isolamento e caracterização do colágeno de resíduos de peixes - pele, escamas e nadadeiras de Catla catla e Cirrhinus mrigala. Journal of Food Science and Technology , v. 52, n. 7, pág. 4296-4305, 2015.

MAIA JUNIOR, W. M. Adequação do processamento de silagens de resíduos de tilápia (Oreochromis niloticus Linnaeus, 1757): caracterização química e funcional da fração seca em pó e lipídios. 1998. Dissertação (Mestrado em Ciência e Tecnologia de Alimentos) Universidade Federal da Paraíba, João Pessoa.

MALUF, M. L. F.; HILBIG, C. C. Curtimento ecológico de peles de animais para agregação de valor através da confecção de artesanato. Revista Varia Scientia, Cascavel, v. 9, n. 15, p. 75-79, 2010.

MARTÍNEZ-ALVAREZ, O., CHAMORRO, S., \& BRENES, A. Protein hydrolysates from animal processing by-products as a source of bioactive molecules with interest in animal feeding: A review. Food Research International, v. P.73, 204-212, 2015.

MARENGONI, N. G. et al. Caracterização microbiológica, sensorial e centesimal de fishburgers de carne de tilápia mecanicamente separada. Revista Brasileira de Saúde e Produção Animal, v.10, n.1, p.168-176, 2009.

MÉLO, H. M. G. Viabilidade da utilização da carne mecanicamente separada (CMS) de Tilápia do nilo na elaboração de um produto tipo "mortadela". ARS Veterinaria, v. 27, n. 1, p. 22-29, 2011.

MOZZAFARIAN, D.; WU, J. H. Y. Omega 3 Fatty Acids and Cardiovascular Disease. Journal of the American College of Cardiology, v.58, n.20, p.2047-2067, 2011.

NAWAZ, A. et al. Valorização dos subprodutos da pesca: Desafios e preocupações técnicas para a indústria alimentar. Trends in Food Science \& Technology , v. 99, p. 34-43, 2020. 
NEIVA, C. R. P.; GONÇALVES, A.A. Carne Mecanicamente Separada (CMS) de Pescado e Surimi. In: GONÇALVES, A.A. Tecnologia do Pescado: Ciência, Tecnologia, Inovação e Legislação. São Paulo: Editora Atheneu, p.197-207, 2011.

NEIVA, C.R.P. et al. Fish crackers development from minced fish and starch: an innovative approach to a traditional product. Ciência e Tecnologia de Alimentos, v. 31, n.4, p. 973-979, 2011.

Núcleo de pesquisa nuélia. Disponível em: http://peixe.nupelia.uem.br. Acesso em $10 / 04 / 2021$.

NUNES, M. L. C. Farinha de pescado. In: GONÇALVES, A. A. Tecnologia do pescado: ciência, tecnologia, inovação e legislação. São Paulo: Atheneu, 2011. 608 p.

OETTERER, M.; BORGHESI, R.; ARRUDA, L. F. Como preparar a silagem de pescado. Série Produtor Rural. Piracicaba: ESALQ, n. 15, 2001. 16 p.

OETTERER, M.; GALVÃO, J. A.; SAVAY-DA-SILVA, L. K. Qualidade do pescado: sistemas para padronização. In: GALVÃO, J. A.; OETTERER, M. (Org.). Qualidade e processamento de pescado. 1 ed. Rio de Janeiro: Elsevier, p. 31-71, 2014.

OLIVEIRA, I.S. et al. Composition of MSM from Brazilian catfish and technological properties of fish flour. Food Control, 50: 38-44, 2015.

OLIVEIRA, M. C.; CRUZ, G. R . B; ALMEIDA, N. M. Características microbiológicas, físico-químicas e sensoriais de "almôndegas" à base de polpa de Tilápia (Oreochromis niloticus). Ciências Biológicas e da Saúde, v. 14, n. 1, p. 37-44, 2012.

OLIVEIRA, M.C.; CRUZ, G.R.B.; ALMEIDA, N.M. Características Microbiológicas, Físico-Químicas e Sensoriais de "Almôndegas" à Base de Polpa de Tilápia (Oreochromis niloticus). Revista Unopar Científica Ciências Biológicas e da Saúde, 14(1): 37-44, 2012.

OLIVEIRA, P. R. et al. Sensorial, físico -química e microbilógica do pirarucu (Arapaima gigas, Schinz, 1822) durante estocagem em gelo. Braziliam Journal of Food Technology. v.17, p. 67-74, 2014.

PANTOJA, A.O.; SANCHEZ, S.M.; HOYOS, J.L. Obtención de un alimento extruido para tilapia roja (Oreochromis spp) utilizando ensilaje biológico de pescado. Biotecnología em el Sector Agropecuário y Agroindustrial, v.9, n.2, 2011.

PEIXE BR. Associação Brasileira da Piscicultura. Anuário PeixeBR da Piscicultura 2020.

PEIXE BR. Associação Brasileira da Piscicultura. Anuário PeixeBR da Piscicultura 2021.

PEREA-ROMÁN, C. et al. Valoración económica del uso de ensilaje de residuos piscícolas en la alimentación de Oreochromis spp. Biotecnologia en el sector agropecuário y agroindustrial, v.16, n.1, p.43-51, 2018. 
PIMENTA, M. E. S. G.; FREATO, T. A.; DE OLIVEIRA, G. R. Silagem de pescado: Uma forma interessante de aproveitamento de resíduos do processamento de peixes. Revista Eletrônica Nutrime. v. 5, n. 4, Minas Gerais, 2008.

PIRES, D. R. et al. Aproveitamento do resíduo comestível do pescado: Aplicação e viabilidade. Revista Verde de Agroecologia e Desenvolvimento Sustentável, v. 9, n. 5, p. 34-46, 2014.

PRENTICE-HERNÁdEZ, C. Óleo de Pescado. In: GONÇALVES, A. A. Tecnologia do pescado: ciência, tecnologia, inovação e legislação. São Paulo. p.608. 2011.

QUAN, H. et al. Mechanism of anti-angiogenic activities of chitooligosaccharides may be through inhibiting heparanase activity. Medical Hypotheses, v. 73, p. 205-206, 2009.

RADZIEMSKA, M. et al. Valorização de composto de dejetos de pescado como fertilizante para uso agrícola. Valorização de Resíduos e Biomassa, v. 10, n. 9, pág. 2537-2545, 2019.

REBOUÇAS, M. C. et al. Caracterização do concentrado proteico de peixe obtido a partir dos resíduos da filetagem da tilápia do Nilo. Semina: Ciências Agrárias, v.33, n.2, p.697-704, 2012.

ROCHA, J.B.S. et al. Composição e estabilidade de farinha de tilápia (Oreochromis niloticus) produzida artesanalmente para o consumo humano. Magistra, v. 23, n. 4, p. 215-220, 2011.

RODRIGUES, L. O. et al. Produção de biofilme de quitosana, reduzida da quitina, extraída de exoesqueleto de crustáceos: proposta e disponibilização sustentável. Brazilian Applied Science Review, v. 4, n. 1, p. 218-239, 2020.

ROMAN, C.P. et al. Evaluación de procesos para obtener ensilaje de residuos piscícolas para alimentación animal. Ciencia en Desarrollo, v.8, n.2, p.39-50, 2017.

SALES, R.O.; OLIVEIRA, A.C. Evaluation of chemical composition, mineral, amino acid profile and fatty acid acid silage of Nile tilapia Oreochromis niloticus (Linnaeus) cultured in Indaiatuba - SP 1. Brazilian Journal of Hygiene and Animal Sanity, v.9, n.3, 2015.

SANES, F. S. M. et al. Compostagem e fermentação de resíduos de pescado para a produção de fertilizantes orgânicos. Semina: Ciências Agrárias, v. 36, n.3, p.1241-1252, 2015.

SIGNOR, F. R. P. et al. Increase in the nutritional quality of tilapia mechanically separated meat and application in fish patties. Brazilian Journal of Development, v. 6, n. 7, p. 47047-47061, 2020.

SHANKAR, T. J. et al. Storage Properties of Low Fat Fish and Rice Flour Coextrudates. Food and Bioprocess Technology, v.3, n.4, p.481-490, 2010.

SHIRAHIGUE, L. D. et al. The feasibility of increasing lipid extraction in Tilapia (Oreochromis niloticus) waste by proteolysis. Journal of Aquatic Food Product Technology, 25, 265-271, 2016. 
SILVA, C. M., DOS SANTOS DA FONSECA, R. A., \& PRENTICE, C. Comparing the hydrolysis degree of industrialization byproducts of Withemouth croaker (Micropogonias furnieri) using microbial enzymes. International Food Research Journal, v. 21, n. 5,p. 1757-1761, 2014.

SILVA, M. F. da. Elaboração e caracterização de silagem ácida de resíduos de tambaqui (Colossoma macropomum). Dissertação de Mestrado. Manaus. 2016.

SARTORI, A. G. DE O. \& AMANCIO, R. D. Pescado: importância nutricional e consumo no Brasil. Segur Alim Nutr, v.19, n. 2, p. 83-93, 2012.

SOARES, K. M. D. P. \& GONÇALVES, A. A. Seafood quality and safety. Revista do Instituto Adolfo Lutz, v. 71, n. 1, p. 1-10, 2012.

SOFIA. The State of World Fisheries and Aquaculture 2020 - Meeting the sustainable development goals. Rome, 2020.

SOUZA, M. L. R. Tecnologia para processamento das peles de peixes. Maringá: EDUEM, 2010.

SUCASAS, L. F. A. Avaliação do resíduo do processamento de pescado e desenvolvimento de co-produtos visando o incremento da sustentabilidade da cadeia produtiva. 2011. 166f. Tese de Doutorado (Doutorado em Ciências). Universidade de São Paulo, São Paulo.

TAHERGORABI, R. et al. Chemical properties of $\mathrm{x}-3$ fortified gels made of protein isolate recovered with isoelectric solubilisation/precipitation from whole fish. Food Chemistry, n.139, p.777-785, 2013.

TANTIKITTI, C. Palatabilidade da ração e as fontes alternativas de proteína na alimentação de camarões. Songklanakarin Journal of Science and Technology, v. 36, n. 1, p. 51-55, 2014.

TORRES S.M.; PEREIRA, F.D.A.R.; SOUZA, C.C.D.; FERREIRA, M.B. Análise da eficiência da produção da piscicultura na região de Dourados - MS. Rev Espacios, v. 38 n. 52, 2017.

TRISTÃO, F.A.; CALDERÓN, B.R.S.; REMBISKI, F.D. Utilização das conchas de mexilhão para a fabricação de cal para produção de argamassas históricas. In: Encontro Nacional, 5, e Encontro Latino-Americano, 3, sobre Edificações e Comunidades Sustentáveis, 2009, Recife. Resumos... Recife: ANTAC, 2009. p.

VÁZQUEZ, J. A. et al. Produção de compostos valiosos e metabólitos bioativos de subprodutos de descartes de peixes usando processamento químico, hidrólise enzimática e fermentação bacteriana. Drogas marinhas , v. 17, n. 3, pág. 139, 2019.

VEIT, J. C. et al. Desenvolvimento e caracterização de bolos de chocolate e de cenoura com filé de tilápia do Nilo (Oreochromis niloticus). Alimentos e Nutrição, v.23, n.3, p.427-433, 2012. 
VIDOTTI, R. M. Silagem de Pescado. In: Alex Augusto Gonçalves. (Org.). Tecnologia do Pescado. São Paulo: Atheneu, 2011. p. 399 - 406.

VIDOTTI, R.M.; GONÇALVES, G.S. Produção e caracterização de silagem, farinha e óleo de tilápia e sua utilização na alimentação animal. Boletim do Instituto de Pesca, 2006.

YANG, E.J.; KIM, J.G.; KIM, J.Y.; KIM, S.; LEE, N. Anti-inflammatory effect of chitosan oligosaccharides in RAW 264.7 cells. Central European Journal of Biology, v.5, p. 95-102, 2010 .

YUVARAJ, D. et al.. Production of biofuels from fish wastes: An overview. Biofuels, v.10, n. 3, 301-307, 2019

ZAMORA-SILLERO J, GHARSALLAOUI A, PRENTICE C: Peptides from fish by-product protein hydrolysates and its functional properties: an overview. Mar Biotechnol, 20:118-130, 2018.

ZANARDI, M.F. et al. Desempenho produtivo e reversão sexual em tilápias em dois métodos hormonal. Revista Medicina Veterinária e Zootecnia, v.18, p.45-52, 2011. 


\title{
CAPÍTULO 25: AGRICULTURA 4.0: UNA VISIÓN GENERAL DE LAS INNOVACIONES TECNOLÓGICAS PARA AUMENTAR LA PRODUCTIVIDAD AGRÍCOLA
}

\section{CHAPTER 25: AGRICULTURE 4.0: AN OVERVIEW OF TECHNOLOGICAL INNOVATIONS IN INCREASING AGRICULTURAL PRODUCTIVITY}

\author{
Afonso Henrique da Silva Júnior ${ }^{1}$; Éllen Francine Rodrigues ${ }^{2}$; Lisandro Simão $^{3}$ Luís Antonio Lourenço $^{4}$; Carlos \\ Rafael Silva de Oliveira ${ }^{5}$
}

DOI:https://doi.org/10.31692/978-65-88970-19-5.389-404

\begin{abstract}
RESUMO
A agricultura 4.0 está atrelada às inovações tecnológicas de alta performance inseridas no segmento agrícola, em que proporcionam autonomia, flexibilidade, aumento de produtividade e entre outros pontos positivos ao produtor rural. Os pilares da agricultura 4.0 estão pautados na integração da computação, comunicação e controle por meio de redes e processos físicos, ou seja, os sistemas ciberfísicos. Nesse contexto, as tecnologias inseridas na agricultura 4.0 são a computação em nuvem, o aprendizado de máquina, a realidade virtual, a inteligência artificial e etc. E é através dessas ferramentas que é possível a obtenção de insights, modelos preditivos, reconhecimento de padrões, imagens de satélite, sensores, hardwares, softwares e entre outros para a visualização de maneira ampla as necessidades da propriedade e a realização de previsões da produtividade da cultura. Diante disso, o Brasil como um dos principais produtores de alimentos do mundo tem papel importante nesse progresso agrícola, pois sua adesão a essas tecnologias possibilitará aumentar a atual performance da produtividade agrícola e a modernização das lavouras em território nacional. Contudo, um grande desafio para a inserção dessas tecnologias inerentes à agricultura 4.0 é a disponibilidade de internet no campo, pois na maior parte é necessário a integração de computadores e sensores através desse recurso. Assim, a presente revisão objetiva abordar as diferentes ferramentas digitais presentes na agricultura 4.0 e como essas tecnologias podem auxiliar no aumento da produção agrícola ao longo dos anos, seja em aumento de produtividade e/ou na tomada de decisões diante dos desafios da lavoura. Por último, também foram apresentados os potenciais e as limitações da inserção dessas tecnologias no contexto do produtor rural brasileiro e de países emergentes.
\end{abstract}

Palavras-Chave: Tomada de decisão, Inteligência artificial, Big data, Aprendizado de máquina, Internet of things.

RESUMEN

\footnotetext{
${ }^{1}$ Engenheiro Agroindustrial-Agroquímico (Universidade Federal do Rio Grande - FURG), Mestrando em Engenharia Química (Universidade Federal de Santa Catarina - UFSC), afonso.silva@posgrad.ufsc.br

${ }^{2}$ Engenheira de Alimentos (Universidade de Passo Fundo - UPF), Doutora em Engenharia Química (Universidade Federal de Santa Catarina - UFSC), ellenfrodrigues@gmail.com

${ }^{3}$ Engenheiro Ambiental (Universidade do Extremo Sul Catarinense - UNESC), Doutor em Ciência e Engenharia de Materiais (Universidade Federal de Santa Catarina - UFSC), lisandrosimao@gmail.com

${ }^{4}$ Engenheiro Químico, Instituto Latino-Americano de Tecnologia, Infraestrutura e Território (ILATIT), Universidade Federal da Integração Latino-Americana (UNILA), luis.lourenco@unila.edu.br

${ }^{5}$ Engenheiro Têxtil (Universidade Estadual de Maringá - UEM), Doutor em Engenharia Química

(Universidade Federal de Santa Catarina - UFSC), carlos.oliveira@ufsc.br
} 
La agricultura 4.0 está ligada a innovaciones tecnológicas de alto desempeño insertadas en el segmento agrícola, donde proporcionan autonomía, flexibilidad, aumento de la productividad y, entre otros puntos positivos a los productores rurales. Los pilares de la agricultura 4.0 se basan en la integración de la informática, la comunicación y el control a través de redes y procesos físicos, es decir, sistemas ciberfísicos. En este contexto, las tecnologías insertadas en la agricultura 4.0 son la computación en la nube, el aprendizaje automático, la realidad virtual, la inteligencia artificial, etc. Y es a través de estas herramientas que es posible obtener insights, modelos predictivos, reconocimiento de patrones, imágenes satelitales, sensores, hardware, software y otros, para una visión amplia de las necesidades de las propiedades y la realización de pronósticos de la productividad de la cultura. Ante esto, Brasil como uno de los principales productores de alimentos del mundo tiene un papel importante en este avance agrícola, ya que su adhesión a estas tecnologías permitirá incrementar el desempeño actual de la productividad agrícola y la modernización de los cultivos en el territorio nacional. Sin embargo, un gran desafío para la inserción de estas tecnologías inherentes a la agricultura 4.0 es la disponibilidad de internet en el campo, ya que en la mayoría de los casos es necesario integrar computadoras y sensores a través de este recurso. Así, esta revisión tiene como objetivo abordar las diferentes herramientas digitales presentes en la agricultura 4.0 y cómo estas tecnologías pueden ayudar a aumentar la producción agrícola a lo largo de los años, ya sea en el aumento de la productividad y/o en la toma de decisiones frente a los desafíos de los cultivos. Finalmente, también se presentaron las potencialidades y limitaciones de la inserción de estas tecnologías en el contexto de productores rurales en Brasil y en países emergentes.

Palabras Clave: Toma de decisiones, Inteligencia artificial, Big data, Machine learning, Internet de las cosas.

\section{ABSTRACT}

Agriculture 4.0 is linked to high-performance technological innovations inserted in the agricultural segment, in which they provide autonomy, flexibility, increased productivity, and, among other positive points, to rural producers. The pillars of agriculture 4.0 are based on the integration of computing, communication, and control through networks and physical processes, that is, cyber-physical systems. In this context, the technologies inserted in agriculture 4.0 are cloud computing, machine learning, virtual reality, artificial intelligence, etc. And it is through these tools that it is possible to obtain insights, predictive models, pattern recognition, satellite images, sensors, hardware, software, and others, to broadly visualize the needs of the property and to make forecasts of the productivity of the crops. Given this, Brazil as one of the main food producers in the world has an important role in this agricultural progress, as its adherence to these technologies will make it possible to increase the current performance of agricultural productivity and the modernization of crops in the national territory. However, a major challenge for the insertion of these technologies inherent to agriculture 4.0 is the availability of the internet in the field, since in most part it is necessary to integrate computers and sensors through this resource. Thus, this review aims to address the different digital tools present in agriculture 4.0 and how these technologies can increase agricultural production over the years, whether in increasing productivity and/or in decision-making in the face of crop challenges. Finally, the potentials and limitations of the insertion of these technologies in the context of rural producers in Brazil and emerging countries were also presented.

Keywords: Decision making, Artificial intelligence, Big data, Machine learning, Internet of things.

\section{INTRODUÇÃO}

De acordo com a previsão da Organização das Nações Unidas (ONU), a população mundial atingirá a marca de no mínimo 9,5 bilhões de habitantes no ano de 2050 (ANGOM; VISWANATHAN; RAMESH, 2021). Essa expectativa pode ser superada, devido ao rápido 
crescimento populacional ao longo dos últimos anos em países emergentes, por exemplo, na Índia. Nos últimos 10 anos, a Índia passou de 1,234 bilhão de habitantes para 1,366 bilhão, um aumento de mais de 100 milhões de pessoas (SAHU et al., 2020). E isso também é perceptível em outras nações, o que vem causando preocupação às entidades mundiais, principalmente no que diz respeito à demanda de alimentos daqui 30 anos 2050 (ANGOM; VISWANATHAN; RAMESH, 2021). Segundo a Organização das Nações Unidas para a Alimentação e a Agricultura (FAO), a disponibilidade de terras agrícolas está localizada em poucos países e somente na América Latina, há a possibilidade de expansão de áreas para o cultivo de aproximadamente 90\% (BJORNLUND; BJORNLUND, 2019; FUENTES-LLANILLO et al., 2021). O Brasil, por exemplo, é um dos produtores mais importantes do mundo e tem grande potencial de aumentar exponencialmente a sua oferta de alimentos (ZILLI et al., 2020).

A agricultura em território nacional vem apresentando alterações com o passar do tempo, principalmente com relação à expansão de terras destinadas para o plantio de commodities (FUENTES-LLANILLO et al., 2021). Contudo, por causa de restrições e a inserção de novas tecnologias no campo, organizações apostam na possibilidade de aumentar a produção agrícola com o espaço que se utiliza hoje em dia. O progresso científico relacionado ao mundo do agronegócio e principalmente associado aos esforços de aumento da produção podem ser visualizados em diferentes vertentes, como na evolução da genética e das técnicas agronômicas. Apesar disso, existem desafios envolvidos no que diz referência aos estudos genéticos, por exemplo, alto custo e demanda altamente qualificada de profissionais da área. Diante disso, as tecnologias habilitadoras dentro do contexto de agricultura 4.0 vêm se tornando uma aliada no desafio do aumento da produção agrícola (JUNG et al., 2021).

As tecnologias habilitadoras estão presentes em diferentes cenários, seja na indústria de transformação para a automatização do processo produtivo ou no cotidiano das pessoas que utilizam ferramentas digitais para a análise de dados. Além disso, essas tecnologias estão associadas principalmente à otimização do tempo, na redução de custos e na tomada de decisões (KAKANI et al., 2020). Os pilares da agricultura 4.0 estão pautados na integração da computação, comunicação e controle por meio de redes e processos físicos, ou seja, os sistemas ciberfísicos.

De acordo com o Instituto Nacional de Padrões e Tecnologia (NIST), esses sistemas são capazes de combinar o mundo físico com o cibernético, utilizando ferramentas digitais 
que podem responder em tempo real aos seus respectivos ambientes (AFOLALU et al., 2021). Dentre essas tecnologias estão a computação em nuvem, o aprendizado de máquina, a realidade virtual, a inteligência artificial e entre outras ferramentas (BALDUCCI; IMPEDOVO; PIRLO, 2018). Com isso, através de insights, modelos preditivos, reconhecimento de padrões, imagens de satélite, sensores, hardwares, softwares e entre outros é possível visualizar de maneira ampla as necessidades da propriedade e a produtividade da lavoura (TALAVIYA et al., 2020). Portanto, compreende-se o quanto é positivo a aplicação desses conceitos na agricultura contemporânea.

Diante do exposto anteriormente, a presente revisão objetiva abordar as diferentes ferramentas digitais presentes na agricultura 4.0 e como essas tecnologias podem auxiliar no aumento da produção agrícola ao longo dos anos, seja em aumento de produtividade e/ou na tomada de decisões diante dos desafios da lavoura. Por último, também foram apresentados os potenciais e as limitações da inserção dessas tecnologias no contexto do produtor rural brasileiro e de países emergentes.

\section{AGRICULTURA 4.0 E AS TECNOLOGIAS HABILITADORAS}

O termo agricultura 4.0 está atrelado às inovações tecnológicas de alta performance inseridas no segmento agrícola, em que proporcionam autonomia, flexibilidade, aumento de produtividade e entre outros pontos positivos ao produtor rural. No entanto, para o melhor entendimento desse termo dentro da agricultura é fundamental conhecer um pouco sobre a evolução do cenário agrícola que está acompanhado ao progresso da humanidade (JONES et al., 2017).

Há 10 mil anos atrás, ainda quando a sociedade era nômade e vivia apenas da caça e dos frutos que encontrava pelas florestas, não via a necessidade de produzir seu próprio alimento. Contudo, com a escassez de comida, o desenvolvimento de ferramentas auxiliares para o ofício do dia a dia e o aprimoramento das primeiras impressões sobre o manejo do solo, começaram a formação de grupos sedentários. Esses grupos ao longo dos anos perceberam que era melhor se fixarem nas proximidades de rios, pois tinham próximo um elemento essencial para a vida e para o cultivo, a água. Além disso, possuía também por perto terras férteis, favorecendo a agricultura. Com o passar do tempo, o ser humano começou a acumular conhecimento sobre o processo de semeadura, o uso de ferramentas e as influências do meio externo sobre a produção agrícola (POLOZ, 2021). Mas, ainda permaneceram por 
muitos séculos "parado" no tempo, utilizando como força de tração animais (cavalos, bois e entre outros) e o cultivo era realizado manualmente, limitando a produtividade da lavoura (AFOLALU et al., 2021).

Isso tudo começou a mudar somente no século XVIII, quando ocorreu a Primeira Revolução Industrial. Nesse período foi possível visualizar grandes veículos a vapor nos campos, promovendo os primeiros eventos rumo à mecanização da agricultura (POLOZ, 2021). Já na Segunda Revolução Industrial, no século XIX, com o avanço das pesquisas científicas relacionadas à fertilização e proteção das plantas juntamente com os motores a combustão, começaram de fato a evolução agrícola até o que conhecemos hoje, com a inserção de tecnologias digitais para a otimização da produção (AFOLALU et al., 2021). Assim, com a adoção de recursos computacionais e decisões baseadas na análise de dados, iniciou-se a agricultura 4.0, o que está sendo vivenciado hoje em dia.

\section{Big data}

Big data é geralmente referido a uma coleta muito grande de dados ou informações que não podem ser definidas ou de certa forma descrita precisamente em alguma linguagem computacional. O big data pode ser descrito como os cinco "V"s (KAMILARIS; KARTAKOULLIS; PRENAFETA-BOLDÚ, 2017):

- Volume: diz respeito ao tamanho dos dados coletados para que seja realizado a análise;

- Velocidade: os dados são gerados com muita rapidez, ou seja, a velocidade é o intervalo de tempo em que esses dados são úteis e relevantes. Uma aplicação na agricultura que está relacionado à velocidade está na identificação de pragas, pois devem ser analisados com muita rapidez para que seja tomada uma decisão no que tange esse problema;

- Variedade: os dados podem ser advindos de diversas fontes e em diferentes tempos, tais como imagens, vídeos, áudios, documentos em geral, planilhas e entre outros. Além disso, em diferentes domínios de aplicação, assim são necessárias a identificação e a melhor forma de serem armazenados;

- Veracidade: está relacionado à qualidade e confiabilidade dos dados, porém, com a análise estatística desse grande volume de informações pode-se compensar as informações "incorretas" que estão armazenadas; e 
- Valor: a geração de valor a partir do volume de dados, ou seja, a capacidade de propagar o conhecimento/inovação.

Apesar do big data ser descrito por diferentes pesquisadores como os cinco "V"s mencionados acima, não necessariamente precisa satisfazer todas essas cinco dimensões (KAMILARIS; KARTAKOULLIS; PRENAFETA-BOLDÚ, 2017). A sua aplicação no segmento agrícola o torna fundamental nas tomadas de decisões, porém, há a necessidade de grandes investimentos em processamento de dados e de espaço para armazenamento. Isso, porque deve ser aplicado na maioria das vezes em tempo real para diversas situações dentro da lavoura, por exemplo, a previsão do tempo (TRIPATHI; SRINIVAS; NANJUNDIAH, 2006). Nas bases científicas encontra-se diversos trabalhos em que aplicam técnicas de análise de big data na agricultura. Na Tabela 01 mostra alguns desses estudos e a descrição do problema analisado.

Tabela 01: Lista de alguns trabalhos encontrados na literatura em que utilizaram técnicas de análise de big data aplicados às problemáticas da agricultura.

\begin{tabular}{|c|c|c|}
\hline Problemática & Título do trabalho & Referência \\
\hline $\begin{array}{c}\text { Previsão das } \\
\text { mudanças climáticas }\end{array}$ & $\begin{array}{c}\text { Downscaling of precipitation for climate } \\
\text { change scenarios: a support vector machine } \\
\text { approach }\end{array}$ & $\begin{array}{c}\text { (TRIPATHI; } \\
\text { SRINIVAS; } \\
\text { NANJUNDIAH, } \\
\text { 2006) }\end{array}$ \\
\hline $\begin{array}{l}\text { Melhorar a precisão } \\
\text { da previsão de } \\
\text { produtividade das } \\
\text { culturas }\end{array}$ & $\begin{array}{c}\text { Superior fuzzy enumeration crop prediction } \\
\text { algorithm for big data agriculture } \\
\text { applications }\end{array}$ & $\begin{array}{l}\text { (VELMURUGAN; } \\
\text { KANNAGI; } \\
\text { VARSHA, 2021) }\end{array}$ \\
\hline $\begin{array}{l}\text { O uso do big data } \\
\text { para a visualização e } \\
\text { análise de dados na } \\
\text { ciência climática }\end{array}$ & $\begin{array}{l}\text { MERRA Analytic Services: meeting the big } \\
\text { data challenges of climate science through } \\
\text { cloud-enabled climate analytics-as-a-service }\end{array}$ & $\begin{array}{c}\text { (SCHNASE et al., } \\
\text { 2017) }\end{array}$ \\
\hline $\begin{array}{l}\text { Caracterização de } \\
\text { solos e plantas }\end{array}$ & $\begin{array}{l}\text { Intensified fuzzy clusters for classifying } \\
\text { plant, soil, and residue regions of interest } \\
\text { from color images }\end{array}$ & $\begin{array}{l}\text { (MEYER et al., } \\
\text { 2004) }\end{array}$ \\
\hline $\begin{array}{l}\text { Os efeitos nos } \\
\text { oxidantes } \\
\text { autotróficos de } \\
\text { amônia em solos } \\
\text { agrícolas }\end{array}$ & $\begin{array}{l}\text { Investigations of soil autotrophic ammonia } \\
\text { oxidizers in farmlands through genetics and } \\
\text { big data analysis }\end{array}$ & $\begin{array}{l}\text { (ZHANG; GUAN; } \\
\text { JIANG, 2021) }\end{array}$ \\
\hline
\end{tabular}

Fonte: Autores, (2021). 
Para a análise de big data são requeridas diversas técnicas e abordagens, tais como aprendizado de máquina, análise estatística, plataformas em nuvem, modelagem, análise mercer geoespacial, processamento de imagens e entre outros. E são a partir dessas ferramentas combinadas ou não que podem apresentar soluções/saídas para diferentes problemas enfrentados na agricultura, como saúde do solo e das plantas, mudanças climáticas, ervas daninhas e etc.

\section{Internet of things (IoT)}

A internet das coisas, ou em inglês Internet of Things (IoT), é uma técnica que combina os recursos existentes na internet para o controle de dispositivos. O conceito inicial de internet das coisas foi introduzido pelo Massachusetts Institute of Technology (MIT) Auto-ID Labs na década de 1990 e aplicado primeiramente em uma cafeteira no de 1999. Passando alguns meses, também aplicaram pela primeira vez em uma torradeira, em que podia ser ligada e desligada de modo remoto através da internet. Diante disso, ao longo dos anos foram aparecendo diferentes conceitos atribuídos ao IoT, porém, sempre com o mesmo princípio que é a sincronização de objetos por meio da intervenção de pessoas. Figura 01 mostra a relação entre os três aspectos da internet das coisas.

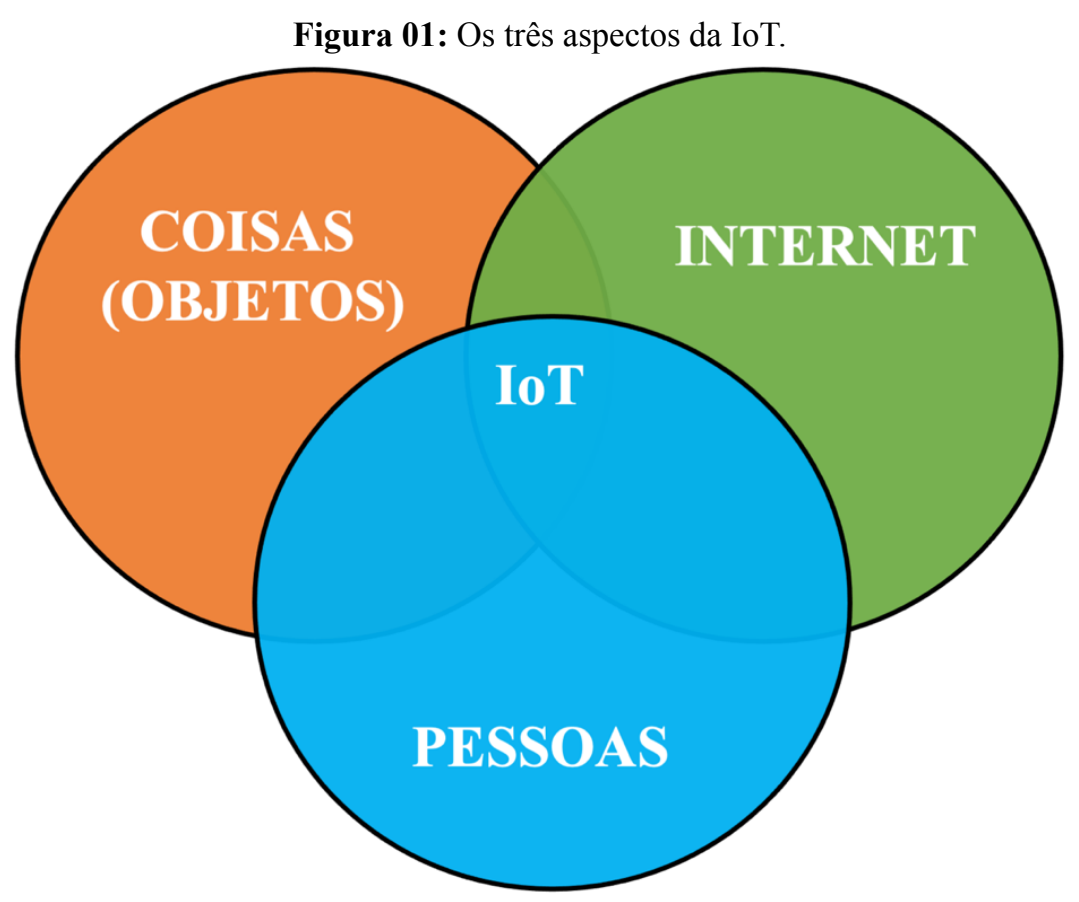

Fonte: Autores, (2021). 
Hoje em dia, graças à internet é possível encaminhar e-mails associados com grande quantidade de conteúdo, anexos e vídeos ou mesmo interagir com pessoas de todo o mundo via redes sociais. Em outros âmbitos, por exemplo o acadêmico, o industrial e o agropecuário, utilizam-se de IoT para o estudo e desenvolvimento de sensores para o controle de variáveis importantes envolvidas em determinado processo/problemática (BANDYOPADHYAY; SEN, 2011). Aplicado na agricultura, encontra-se a IoT inserida em abordagens de gerenciamento agrícola com a finalidade de garantir o desenvolvimento adequado e saudável da planta, sem que use em excesso defensivos agrícolas ou mesmo fertilizantes. Um grupo de pesquisa abordou a integração de redes de controle e de IoT em uma situação real na produção agrícola em estufa, em que propuseram um sistema de monitoramento remoto com internet e comunicações sem fio combinadas (JI-CHUN ZHAO et al., 2010). Por fim, obtiveram ótimos resultados com a plantação em estufa utilizando a tecnologia, promovendo um excelente crescimento das plantas em estudo.

Uma das inúmeras vantagens do uso da internet das coisas dentro da agricultura é a possibilidade da previsão do desempenho da cultura em diferentes circunstâncias. Assim, o uso de sensores sem fio baseado em IoT podem ser usados para a coleta de diversas variáveis, tais como do clima e da quantidade de fertilizantes/defensivos. O desenvolvimento de um novo design da plataforma SmartFarmNet utilizando IoT foi reportada, em que possibilitou automatizar a coleta de dados ambientais, do solo, fertilização e irrigação (JAYARAMAN et al., 2016). Além de correlacionar automaticamente esses dados e filtrar os dados inválidos da perspectiva da avaliação do desempenho da cultura e calcular as previsões da safra. A plataforma SmartFarmNet possibilita integrar virtualmente qualquer dispositivo IoT, desde sensores, câmeras e até mesmo estações meteorológicas e entre outros disponíveis no mercado para o armazenamento de dados na nuvem e assim analisar. Na Tabela 02 mostra algumas pesquisas científicas baseadas em IoT aplicado na agricultura.

Tabela 02: Lista de alguns trabalhos encontrados na literatura baseados em IoT aplicado na agricultura.

$\begin{array}{ccc}\text { Problemática } & \text { Título do trabalho } & \text { Referência } \\ & & \\ \text { Conexão entre } & \text { Internet of things: applications and } & \text { (BANDYOPADHY } \\ \text { consumidores e } & \text { challenges in technology and } & \text { AY; SEN, 2011) } \\ \text { produtores rurais } & \text { standardization } & \end{array}$




\begin{tabular}{|c|c|c|}
\hline $\begin{array}{l}\text { Gerenciamento de } \\
\text { inúmeros } \\
\text { dispositivos na } \\
\text { lavoura }\end{array}$ & $\begin{array}{c}\text { Farm management systems and the future } \\
\text { internet era }\end{array}$ & $\begin{array}{l}\text { (KALOXYLOS et } \\
a l ., 2012)\end{array}$ \\
\hline $\begin{array}{c}\text { Otimizar o modo } \\
\text { operacional de coleta } \\
\text { de dados através de } \\
\text { uma plataforma } \\
\text { virtual }\end{array}$ & $\begin{array}{l}\text { Internet of things platform for smart } \\
\text { farming: experiences and lessons learnt }\end{array}$ & $\begin{array}{l}\text { (JAYARAMAN et } \\
\text { al., 2016) }\end{array}$ \\
\hline $\begin{array}{c}\text { Mudanças de } \\
\text { percepções dos } \\
\text { pequenos produtores } \\
\text { rurais com relação } \\
\text { ao uso de } \\
\text { tecnologias }\end{array}$ & $\begin{array}{l}\text { Adoption of precision agriculture } \\
\text { technologies by German crop farmers }\end{array}$ & $\begin{array}{l}\text { (PAUSTIAN; } \\
\text { THEUVSEN, 2017) }\end{array}$ \\
\hline $\begin{array}{l}\text { O uso de modelos } \\
\text { para a análise de } \\
\text { dados }\end{array}$ & $\begin{array}{l}\text { Machine learning applications on } \\
\text { agricultural datasets for smart farm } \\
\text { enhancement }\end{array}$ & $\begin{array}{l}\text { (BALDUCCI; } \\
\text { IMPEDOVO; } \\
\text { PIRLO, 2018) }\end{array}$ \\
\hline
\end{tabular}

Portanto, como observado anteriormente, o conceito de IoT pode ser correlacionado com "coisas" que estão associadas pela internet. Contudo, são muitos os desafios para a sua utilização na lavoura, principalmente em pequenas propriedades rurais que não tem acesso à internet $\mathrm{e}$ às tecnologias de ponta. Mas, mesmo assim, a internet das coisas é uma aliada na agricultura 4.0 e na agricultura de precisão, em que se utiliza sensores, bluetooth, imagens e etc para alcançar o aumento sustentável da produção agrícola mundial.

\section{Inteligência artificial e outras tecnologias}

A inteligência artificial (IA) é uma das grandes apostas atualmente no mercado, seja no segmento do varejo ou mesmo no agronegócio. Aliás, o uso de IA no mundo dos negócios está favorecendo muitas empresas, pois através dessa tecnologia permite delinear o perfil e as necessidades dos seus consumidores, em que providenciam produtos e serviços de acordo com o que buscam (POLOZ, 2021). Além de oferecer vantagens financeiras para quem os contrata ou compra algum objeto, mediante uma análise de todas as marcas que estão na rede, ou seja, os seus concorrentes diretos. Diante disso, aplicada na agricultura é possível observar inúmeras finalidades da IA, seja no controle remoto de veículo aéreo não tripulado ou mesmo na predição de chuva e temperatura no campo (LEZOCHE et al., 2020).

A inteligência artificial é caracterizada por um conjunto de ferramentas 
computacionais e estatísticas para que computadores façam tarefas que exija ações humanas. O termo IA foi incialmente apresentado por John McCarthy na década de 1950 em uma conferência nos EUA (MARCUS, 2004). A IA geralmente é executada mediante um conjunto de ferramentas e áreas, por exemplo, a análise de dados e machine learning. Machine learning (ML) envolve a análise multidisciplinar entre probabilidade, estatística, algoritmo e entre outras teorias (PARTEL; CHARAN KAKARLA; AMPATZIDIS, 2019). Com o progresso e o intenso uso da ferramenta ML, cada vez mais outras áreas estão utilizando modelos para a realização de previsões sobre o futuro e assim, possa facilitar na tomada de decisões racionais com base nessas análises preditivas (BALDUCCI; IMPEDOVO; PIRLO, 2018). Logo, a agricultura que no presente momento necessita aumento contínuo da produção e práticas mais sustentáveis na lavoura, a aplicação de ML e IA são em conjunto uma grande vantagem ao setor. Além disso, a implementação de inteligência artificial na agricultura para a otimização da irrigação e aplicação de pesticidas e herbicidas é reportada constantemente na literatura como uma aliada na reversão de desperdícios de água e defensivos. Na Tabela 03 mostra alguns trabalhos que utilizaram inteligência artificial aplicado na lavoura.

Tabela 03: Lista de alguns trabalhos encontrados na literatura que utilizaram inteligência artificial aplicado na lavoura.

Cultura

Cana-de-açúcar

Pimenta e entre outras

Development and evaluation of a low-cost management utilizing artificial intelligence

Arroz

Arroz

Arroz and smart technology for precision weed

Título do trabalho

Weed detecting robot in sugarcane fields using fuzzy real time classifier

\section{(SUJARITHA et al.,} 2017)

(PARTEL; CHARAN KAKARLA; AMPATZIDIS, 2019)

(MARUYAMA; NARUSE, 2014) rice fields

Investigation of weeding ability and plant damage for rice field weeding robots

(NAKAMURA $e t$ al., 2017)

(ELAHI et al., 2019)

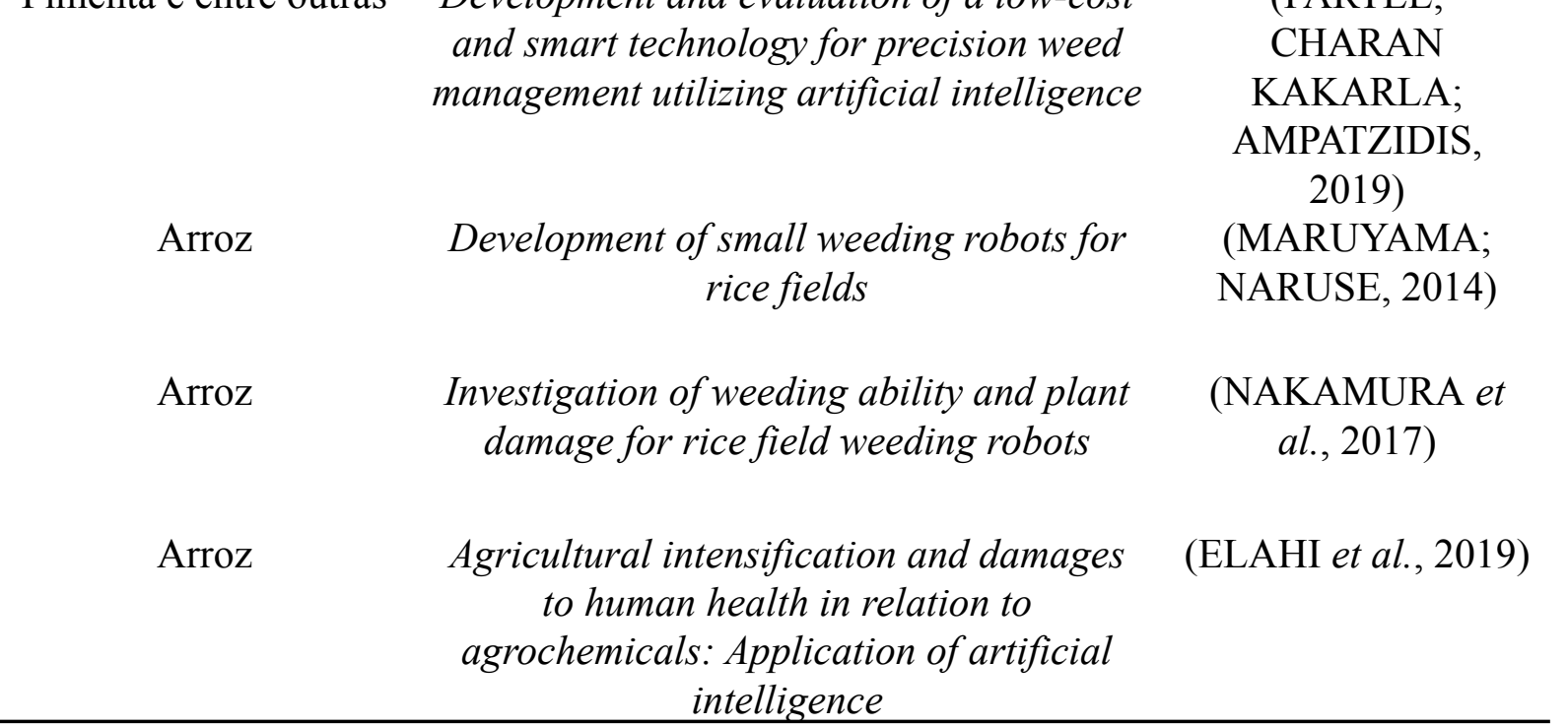

Fonte: Autores, (2021). 
Uma temática importante dentro da agricultura é o uso adequado de defensivos, desde que não se torne prejudicial à saúde das plantas e nem das pessoas que os aplicam. Assim, a redução dos impactos dos agroquímicos no meio ambiente e na saúde humana é fundamental para a sustentabilidade agrícola e uma produção mais limpa. Contudo, até o momento, os estudos reportados são limitados e são focados apenas nas questões de intensificação do uso de defensivos nas culturas. Um método de rede neural artificial foi reportado para reduzir a quantidade de pesticidas e nitrogênio puro em 45,2 e 37,2\%, respectivamente, em uma plantação de arroz (ELAHI et al., 2019). Os resultados foram promissores, pois utilizaram de estudos de casos envolvendo agricultores e observaram através de modelos de regressão que o uso de roupas e de óculos de proteção reduziram significativamente a irritação dos olhos e da pele dos aplicadores de pesticidas. Também, a utilização de máscaras diminuiu grandemente os casos de tosse, tontura e náusea. Por fim, com base nos resultados que encontraram sugeriram algumas políticas de boas práticas para a aplicação de agroquímicos no campo, por exemplo, a utilização de sementes melhoradas em que apresentem resistência à diversas pragas. Assim, reduzindo o número de aplicações de defensivos na cultura.

Também, o uso de robôs está presente em alguns estudos aplicados no segmento agrícola. O desenvolvimento de um robô agrícola de baixo custo para aplicação de fertilizantes e pesticidas na agricultura, além de também exercer o papel de monitoramento da safra foi reportado recentemente (GHAFAR et al., 2021). O protótipo apresentado é um robô de duas rodas que consistiu em uma base móvel, um mecanismo de pulverização, um controlador sem fio para o movimento do robô e uma câmera para monitorar a saúde e o crescimento da cultura, além de detectar a presença de pragas no campo agrícola. Os pesquisadores observaram que nos testes de produtividade realizados com o protótipo foi ligeiramente inferior à de um funcionário humano, porém, a economia de mão de obra proporcionada pelo robô é muito maior, pois o mesmo funciona completamente no modo autônomo. Além disso, o sistema proporcionou maior economia de recursos e redução da contaminação de águas subterrâneas, atingindo os objetivos inerente à agricultura de precisão. Também, o protótipo apresentou excelente duração da bateria. Com isso, percebe-se que o uso de robótica é um ponto positivo e apresenta inúmeras soluções inerente à agricultura, como a reversão da falta de mão de obra, redução dos custos com defensivos e o uso adequado das quantidades de agroquímicos. 
Por fim, percebe-se que o uso de IA atrelado às ferramentas tecnológicas é vantajoso na agricultura, principalmente no monitoramento através de drones, sensores e modelos preditivos. Também, com a inserção de robótica no campo pode facilitar a busca por soluções sustentáveis e o aumento de produtividade em pouco espaço, reduzindo o desperdício e os custos operacionais. No entanto, a utilização dessas tecnologias ainda está restrita aos grandes produtores e empresas do ramo. Ou mesmo, ainda não são adequadas para operar na realidade, sendo necessário mais testes e estudos, por exemplo, os robôs.

\section{POTENCIAIS E LIMITAÇÕES}

O produtor rural brasileiro e de países emergentes, os quais são considerados atualmente a grande aposta para o aumento da produtividade de alimentos para suprir as necessidades da população mundial, ainda não presenciam na sua maioria a conectividade (internet) em suas propriedades. Isso, é um grande desafio para a inserção das tecnologias inerentes à agricultura 4.0, pois na maior parte é necessário a integração de computadores e sensores através desse recurso. No entanto, grandes empresas vêm unindo forças para suprir essa necessidade e que isso não seja um fator limitante ao pequeno agricultor utilizar as tecnologias 4.0. Também, há iniciativas que promovem o desenvolvimento de empresas de tecnologia voltadas para o agronegócio (Agritechs), principalmente para que desenvolvam ferramentas computacionais para o monitoramento de lavouras e facilitem na tomada de decisão do pequeno agricultor. As vantagens do uso de tecnologias da agricultura 4.0 são diversas, como (LEZOCHE et al., 2020):

- Aumento da produtividade;

- Monitoramento das atividades agrícolas por meio de sensores, georreferenciamento, veículo aéreo não tripulado e etc;

- Redução dos custos e dos desperdícios de defensivos e fertilizantes na lavoura;

- Facilidade na tomada de decisão;

- Otimização da gestão do negócio;

- Longevidade do uso do solo;

- Desenvolvimento de modelos preditivos que envolvam a performance da cultura frente às diversas variáveis, como o clima e solo; e

- Acompanhamento da plantação à distância.

Apesar de inúmeros pontos positivos do uso de tecnologia 4.0 na agricultura, também 
existem limitações, como:

- Custos de implantação;

- Falta de internet no local;

- Adequação das ferramentas à propriedade;

- Falta de profissionais qualificados dentro da área de tecnologia $4.0 \mathrm{e}$ especificamente na agricultura; e

- Dificuldade na análise de dados.

Assim, percebe-se que são diversos os desafios presentes para a implementação de recursos tecnológicos no campo, porém, essas limitações podem ser revertidas em um curto prazo em retorno financeiro ao produtor e entre outros pontos positivos ao meio ambiente/sociedade em geral, tais como o uso consciente da água na irrigação, tratamento adequado ao solo e redução do uso de defensivos agrícolas. Além disso, os pontos positivos do manejo sustentável na agricultura integrado com as tecnologias atuais podem atingir diretamente e/ou indiretamente na diminuição das embalagens agrícolas e em iniciativas sociais para as comunidades rurais.

\section{CONCLUSÃO}

Os benefícios da agricultura 4.0 são perceptíveis ao longo da revisão e é possível visualizar através desse progresso um mundo em que as lavouras apresentem maior produtividade e consequentemente, seja possível suprir as necessidades da população mundial. Contudo, ainda é necessário tornar essas ferramentas sustentáveis e viáveis para os produtores, principalmente às pequenas propriedades. Diante disso, o Brasil como um dos principais produtores de alimentos do mundo tem papel importante nesse progresso agrícola, pois sua adesão a essas tecnologias possibilitará aumentar a atual performance da produtividade agrícola e a modernização das lavouras em território nacional. Além disso, hoje em dia percebe-se uma adesão gradual dos proprietários rurais quanto ao uso dessas tecnologias e assim, à medida que aumentar o número de usuários dessas ferramentas são desmistificados os pré-conceitos que estão presentes nessa temática.

\section{REFERÊNCIAS}

AFOLALU, S. A.; IKUMAPAYI, O. M.; ABDULKAREEM, A.; SOETAN, S. B.; 
EMETERE, M. E.; ONGBALI, S. O. Enviable roles of manufacturing processes in sustainable fourth industrial revolution - A case study of mechatronics. Materials Today: Proceedings, 2021. Disponível em: https://doi.org/10.1016/j.matpr.2021.01.099

ANGOM, J.; VISWANATHAN, P. K.; RAMESH, M. V. The dynamics of climate change adaptation in India: A review of climate smart agricultural practices among smallholder farmers in Aravalli district, Gujarat, India. Current Research in Environmental Sustainability, v. 3, p. 100039, 2021. Disponível em: https://doi.org/10.1016/j.crsust.2021.100039

BALDUCCI, F.; IMPEDOVO, D.; PIRLO, G. Machine Learning Applications on Agricultural Datasets for Smart Farm Enhancement. Machines, v. 6, n. 3, p. 38, 2018. Disponível em: https://doi.org/10.3390/machines6030038

BANDYOPADHYAY, D.; SEN, J. Internet of things: Applications and challenges in technology and standardization. Wireless Personal Communications, v. 58, n. 1, p. 49-69, 2011. Disponível em: https://doi.org/10.1007/s11277-011-0288-5

BJORNLUND, V.; BJORNLUND, H. Understanding agricultural water management in a historical context using a socioeconomic and biophysical framework. Agricultural Water Management, v. 213, n. November 2017, p. 454-467, 2019. Disponível em: https://doi.org/10.1016/j.agwat.2018.10.037

ELAHI, E.; WEIJUN, C.; ZHANG, H.; NAZEER, M. Agricultural intensification and damages to human health in relation to agrochemicals: Application of artificial intelligence. Land Use Policy, v. 83, n. February, p. 461-474, 2019. Disponível em: https://doi.org/10.1016/j.landusepol.2019.02.023

FUENTES-LLANILLO, R.; TELLES, T. S.; SOARES JUNIOR, D.; DE MELO, T. R.; FRIEDRICH, T.; KASSAM, A. Expansion of no-tillage practice in conservation agriculture in Brazil. Soil and Tillage Research, v. 208, n. June 2020, p. 104877, 2021. Disponível em: https://doi.org/10.1016/j.still.2020.104877

GHAFAR, A. S. A.; HAJJAJ, S. S. H.; GSANGAYA, K. R.; SULTAN, M. T. H.; MAIL, M. F.; HUA, L. S. Design and development of a robot for spraying fertilizers and pesticides for agriculture. Materials Today: Proceedings, 2021. Disponível em: https://doi.org/10.1016/j.matpr.2021.03.174

JAYARAMAN, P.; YAVARI, A.; GEORGAKOPOULOS, D.; MORSHED, A.; ZASLAVSKY, A. Internet of Things Platform for Smart Farming: Experiences and Lessons Learnt. Sensors, v. 16, n. 11, p. 1884, 2016. Disponível em: https://doi.org/10.3390/s16111884

JI-CHUN ZHAO; JUN-FENG ZHANG; YU FENG; JIAN-XIN GUO. The study and application of the IOT technology in agriculture. In: 2010, 2010 3rd International Conference on Computer Science and Information Technology. : IEEE, 2010. p. 462-465. Disponível em: https://doi.org/10.1109/ICCSIT.2010.5565120

JONES, J. W. et al. Brief history of agricultural systems modeling. Agricultural Systems, v. 155, p. 240-254, 2017. Disponível em: https://doi.org/10.1016/j.agsy.2016.05.014 
JUNG, J.; MAEDA, M.; CHANG, A.; BHANDARI, M.; ASHAPURE, A.;

LANDIVAR-BOWLES, J. The potential of remote sensing and artificial intelligence as tools to improve the resilience of agriculture production systems. Current Opinion in Biotechnology, v. 70, p. 15-22, 2021. Disponível em: https://doi.org/10.1016/j.copbio.2020.09.003

KAKANI, V.; NGUYEN, V. H.; KUMAR, B. P.; KIM, H.; PASUPULETI, V. R. A critical review on computer vision and artificial intelligence in food industry. Journal of Agriculture and Food Research, v. 2, n. February, p. 100033, 2020. Disponível em: https://doi.org/10.1016/j.jafr.2020.100033

KALOXYLOS, A. et al. Farm management systems and the Future Internet era. Computers and Electronics in Agriculture, v. 89, p. 130-144, 2012. Disponível em: https://doi.org/10.1016/j.compag.2012.09.002

KAMILARIS, A.; KARTAKOULliS, A.; PRENAFETA-BOLDÚ, F. X. A review on the practice of big data analysis in agriculture. Computers and Electronics in Agriculture, v. 143, n. September, p. 23-37, 2017. Disponível em: https://doi.org/10.1016/j.compag.2017.09.037

LEZOCHE, M.; PANETTO, H.; KACPRZYK, J.; HERNANDEZ, J. E.; ALEMANY DÍAZ, M. M. E. Agri-food 4.0: A survey of the Supply Chains and Technologies for the Future Agriculture. Computers in Industry, v. 117, p. 103187, 2020. Disponível em: https://doi.org/10.1016/j.compind.2020.103187

MARCUS, M. The 2003 Benjamin Franklin Medal in computer and cognitive science presented to John McCarthy (Stanford California). John McCarthy's multiple contributions to the foundations of artificial intelligence and computer science. Journal of the Franklin Institute, v. 341, n. 3, p. 215-221, 2004. Disponível em: https://doi.org/10.1016/j.jfranklin.2003.12.023

MARUYAMA, A.; NARUSE, K. Development of small weeding robots for rice fields. In: 2014, 2014 IEEE/SICE International Symposium on System Integration. : IEEE, 2014. p. 99-105. Disponível em: https://doi.org/10.1109/SII.2014.7028019

MEYER, G. .; CAMARGO NETO, J.; JONES, D. D.; HINDMAN, T. W. Intensified fuzzy clusters for classifying plant, soil, and residue regions of interest from color images. Computers and Electronics in Agriculture, v. 42, n. 3, p. 161-180, 2004. Disponível em: https://doi.org/10.1016/j.compag.2003.08.002

NAKAMURA, K.; KIMURA, M.; ANAZAWA, T.; TAKAHASHI, T.; NARUSE, K. Investigation of weeding ability and plant damage for rice field weeding robots. SII 2016 2016 IEEE/SICE International Symposium on System Integration, p. 899-905, 2017. Disponível em: https://doi.org/10.1109/SII.2016.7844114

PARTEL, V.; CHARAN KAKARLA, S.; AMPATZIDIS, Y. Development and evaluation of a low-cost and smart technology for precision weed management utilizing artificial intelligence. Computers and Electronics in Agriculture, v. 157, n. January, p. 339-350, 2019. 
Disponível em: https://doi.org/10.1016/j.compag.2018.12.048

PAUSTIAN, M.; THEUVSEN, L. Adoption of precision agriculture technologies by German crop farmers. Precision Agriculture, v. 18, n. 5, p. 701-716, 2017. Disponível em: https://doi.org/10.1007/s11119-016-9482-5

POLOZ, S. S. Technological progress and monetary policy: Managing the fourth industrial revolution. Journal of International Money and Finance, p. 102373, 2021. Disponível em: https://doi.org/10.1016/j.jimonfin.2021.102373

SAHU, K. K.; MISHRA, A. K.; LAL, A.; SAHU, S. A. India Fights Back: COVID-19 Pandemic. Heart \& Lung, v. 49, n. 5, p. 446-448, 2020. Disponível em: https://doi.org/10.1016/j.hrtlng.2020.04.014

SCHNASE, J. L.; DUFFY, D. Q.; TAMKIN, G. S.; NADEAU, D.; THOMPSON, J. H.; GRIEG, C. M.; MCINERNEY, M. A.; WEBSTER, W. P. MERRA Analytic Services: Meeting the Big Data challenges of climate science through cloud-enabled Climate Analytics-as-a-Service. Computers, Environment and Urban Systems, v. 61, p. 198-211, 2017. Disponível em: https://doi.org/10.1016/j.compenvurbsys.2013.12.003

SUJARITHA, M.; ANNADURAI, S.; SATHEESHKUMAR, J.; KOWSHIK SHARAN, S.; MAHESH, L. Weed detecting robot in sugarcane fields using fuzzy real time classifier. Computers and Electronics in Agriculture, v. 134, p. 160-171, 2017. Disponível em: https://doi.org/10.1016/j.compag.2017.01.008

TALAVIYA, T.; SHAH, D.; PATEL, N.; YAGNIK, H.; SHAH, M. Implementation of artificial intelligence in agriculture for optimisation of irrigation and application of pesticides and herbicides. Artificial Intelligence in Agriculture, v. 4, p. 58-73, 2020. Disponível em: https://doi.org/10.1016/j.aiia.2020.04.002

TRIPATHI, S.; SRINIVAS, V. V.; NANJUNDIAH, R. S. Downscaling of precipitation for climate change scenarios: A support vector machine approach. Journal of Hydrology, v. 330, n. 3-4, p. 621-640, 2006. Disponível em: https://doi.org/10.1016/j.jhydrol.2006.04.030

VELMURUGAN, P.; KANNAGI, A.; VARSHA, M. Superior fuzzy enumeration crop prediction algorithm for big data agriculture applications. Materials Today: Proceedings, 2021. Disponível em: https://doi.org/10.1016/j.matpr.2021.02.578

ZHANG, L.; GUAN, Y.; JIANG, S. C. Investigations of soil autotrophic ammonia oxidizers in farmlands through genetics and big data analysis. Science of The Total Environment, v. 777, p. 146091, 2021. Disponível em: https://doi.org/10.1016/j.scitotenv.2021.146091

ZILLI, M.; SCARABELLO, M.; SOTERRONI, A. C.; VALIN, H.; MOSNIER, A.; LECLÈRE, D.; HAVLÍK, P.; KRAXNER, F.; LOPES, M. A.; RAMOS, F. M. The impact of climate change on Brazil's agriculture. Science of The Total Environment, v. 740, p. 139384, 2020. Disponível em: https://doi.org/10.1016/j.scitotenv.2020.139384 


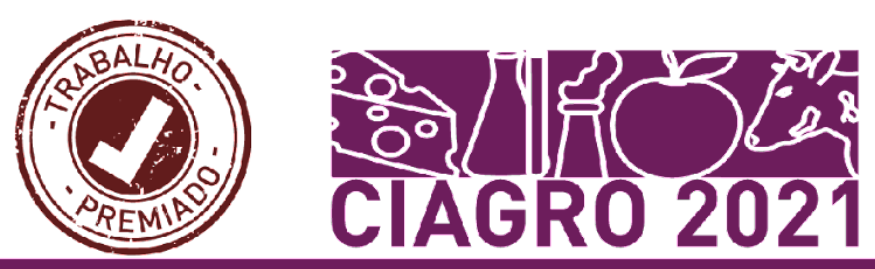

\title{
CAPÍTULO 26: AVALIAÇÃO DO CUSTO DE PRODUÇÃO DE CELULOSE BACTERIANA USANDO SUBPRODUTOS AGROINDUSTRIAIS
}

\section{CAPÍTULO 26: EVALUACIÓN DEL COSTE DE PRODUCCIÓN DE CELULOSA BACTERIANA UTILIZANDO SUBPRODUCTOS AGROINDUSTRIALES}

\section{CHAPTER 26: EVALUATION OF BACTERIAL CELLULOSE COST PRODUCTION USING AGRO-INDUSTRIAL BY-PRODUCTS}

\author{
Pires, M.C. S $^{1}$ Souza, E.F.'; Gottschalk, L.M.F ${ }^{2}$ \\ DOI: https://doi.org/10.31692/978-65-88970-19-5.405-410
}

\section{INTRODUÇÃO}

Os biopolímeros exibem alto potencial de uso em substituição a plásticos e polímeros sintéticos, por serem materiais biodegradáveis e renováveis. Dentre estes, a celulose bacteriana $(\mathrm{CB})$ tem sido usada em aplicações farmacêuticas, biomédicas, membranas condutoras, cosméticos e embalagens comestíveis/inteligentes mas seu potencial pode ser muito maior se a produção ocorrer em larga escala. No entanto, a produção em escala industrial esbarra em limitações como o alto custo dos meios de cultivo e baixo rendimento. A solução para reduzir o custo pode estar no uso de subprodutos da agroindústria como meio de cultivo, por serem boas fontes nutricionais, ao passo que minimizam os impactos ambientais causados pela deposição do subproduto no ambiente. O objetivo do presente trabalho foi comparar o rendimento de produção da CB nos métodos agitado e estático, usando o meio padrão HS e meios alternativos com suco de caju e melaço de soja. Além disso, o custo de produção dos meios utilizados foi avaliado economicamente.

\section{FUNDAMENTAÇÃO TEÓRICA}

$\mathrm{A} C \mathrm{~B}$ se destaca por sua estrutura reticulada ultrafina, alta cristalinidade, resistência à tração, hidrofilicidade e biocompatibilidade (LIN et al., 2013; ROUABHIA et al., 2014).

Vários microrganismos podem produzir celulose bacteriana. Komagataeibacter xylinus se destaca pela capacidade de produzir CB com diferentes fontes de carbono e

\footnotetext{
${ }^{1}$ Graduanda em farmácia, Universidade Estadual da Zona Oeste moniqueserpi@gmail.com

${ }^{2}$ Embrapa Agroindústria de Alimentos, erika.fraga@embrapa.br

Embrapa Agroindústria de Alimentos, leda.fortes@embrapa.br
} 


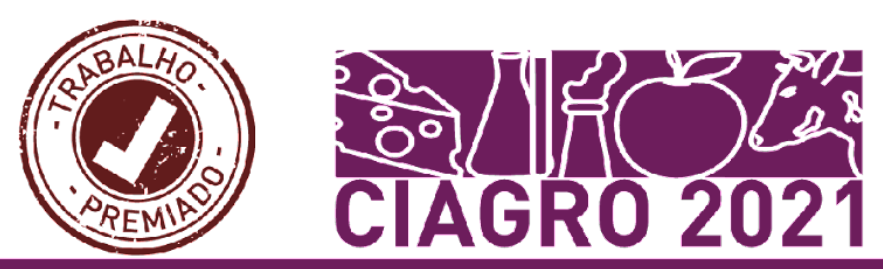

nitrogênio (HUANG et al, 2014). O método de produção pode ser estático, bem elucidado, entretanto, inviável para escala industrial devido longo tempo de biossíntese ou agitado, que exibe alto rendimento e grande potencial para uso em escala comercial, mas o produto formado tem qualidade inferior e pode levar a formação de células mutantes negativas que crescem, turvam o meio e não produzem celulose (RECOUVREUX et al., 2011; WANG et al., 2016).

O Brasil é o segundo maior produtor de soja do Brasil e o nordeste brasileiro é um grande produtor de caju, cujo produto de maior importância é a castanha (FONTES et al., 2013, EMBRAPA, 2019). O suco de caju (SC) é rico em carboidratos e pobre em nitrogênio, necessitando de suplementação, que pode ser feita com o melaço de soja, rica fonte desse nutriente. Estudos realizados por Duarte et al., (2015), Pinheiro (2016) e Souza et al., (2020) têm mostrado o uso desses subprodutos na produção de celulose bacteriana.

\section{METODOLOGIA}

\section{Substratos}

Os reagentes utilizados na elaboração dos meios foram adquiridos na empresa Merck ${ }^{\circledR}$. O suco de caju foi coletado em Pacajus (Ceará, Brasil), o melaço de soja foi gentilmente doado pela Selecta ${ }^{\circledR}$ soybean(Araguarí, Minas Gerais, Brasil), armazenados em recipientes a $4^{\circ} \mathrm{C}$ até a sua utilização.

\section{Caracterização de substratos}

O teor de proteínas foi determinado pelo método de Lowry (LOWRY et al., 1951), os lipídios foram determinados com extração com éter usando um sistema automático (Ankom XT15, EUA). Os açúcares redutores totais (glicose e frutose) foram determinados pelo método DNS (MILLER, 1959). Os resultados serão apresentados com a média da triplicata.

\section{Microrganismo e meios de cultura}

A cepa K. xylinus ATCC 53582 foi utilizada para produção de CB. Para o pré-inóculo, a bactéria foi inoculada em tubos contendo $5 \mathrm{~mL}$ de meio padrão $\mathrm{HS}$. Os tubos foram 


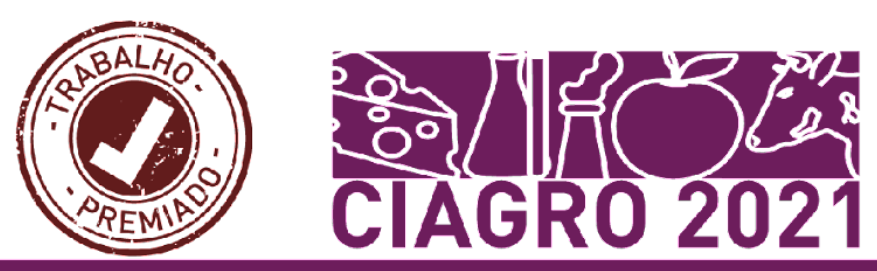

incubados a $30{ }^{\circ} \mathrm{C}$ por $48 \mathrm{~h}$. Após este período, os pré-inóculos foram misturadas e usadas para inocular o meio.

\section{Meios de cultura}

Meio HS: O meio padrão usado neste estudo foi composto por $\left(\mathrm{g} \mathrm{L}^{-1}\right)$ : glicose - 20; peptona - 5; extrato de levedura - 5; fosfato dissódico (anidro) - 2,7; ácido cítrico (monohidrato) - 1,15.

Meio suco de caju com extrato de levedura: O SC foi filtrado através de um filtro de papel qualitativo (Unifil, Alemanha) para separar o material sólido em suspensão. Os açúcares redutores foram determinados pelo método DNS e o suco foi diluído com água destilada até a concentração final de açúcares redutores de $20 \mathrm{~g} \mathrm{~L}-1$. Separadamente uma solução de extrato de levedura $\left(10 \mathrm{~g} \mathrm{~L}^{-1}\right)$ foi preparada e adicionada ao meio.

Meio suco de caju com melaço de soja: O SC filtrado foi diluído com água destilada para $20 \mathrm{~g} \mathrm{~L}^{-1}$ de açúcares redutores. O melaço de soja diluído a $12 \mathrm{~g} \mathrm{~L}^{-1}$ foi adicionado como fonte de nitrogênio.

Nos meios usados no cultivo agitado foram adicionados de $1,5 \%$ de carboximetilcelulose.

\section{Condições de produção CB}

Após o preparo, em triplicata, os meios preparados foram distribuídos, $50 \mathrm{~mL}$ de cada meio em Erlenmeyer de $250 \mathrm{~mL}$ e autoclavado a $121^{\circ} \mathrm{C}$ por 15 . O inóculo foi realizado de acordo com a D.O. obtida. Os cultivos foram realizados a $30^{\circ} \mathrm{C}$ durante 3 dias em condições estáticas e agitadas em Shaker 150 rpm para comparação.

\section{Recuperação e purificação da celulose bacteriana}

Após a fermentação, o meio foi centrifugado (Thermo Fisher Sci-entific, Waltham, MA, EUA) a $4000 \mathrm{rpm}$ por $15 \mathrm{~min}$. As membranas e géis de CB foram colhidos e purificadas por tratamento com $\mathrm{NaOH} 1 \mathrm{M}$ a $80^{\circ} \mathrm{C}$ durante $1 \mathrm{~h}$ (A CB produzida em meio alternativo passou por uma etapa prévia com SDS). Por fim, a CB foi lavada com água destilada até pH 7,0 e submetida a secagem em estufa por $24 \mathrm{~h}$ a $60^{\circ} \mathrm{C}$.

\section{RESULTADOS E DISCUSSÃO}




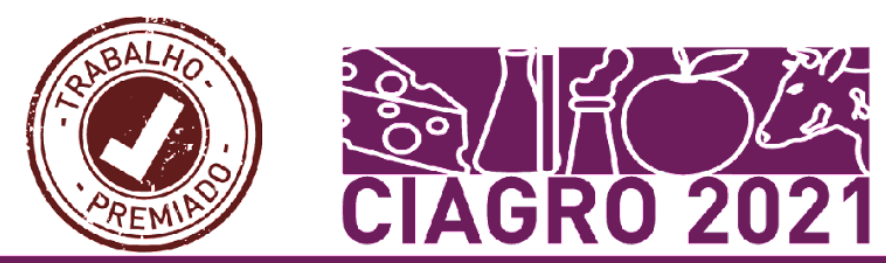

\section{Caracterização do substrato}

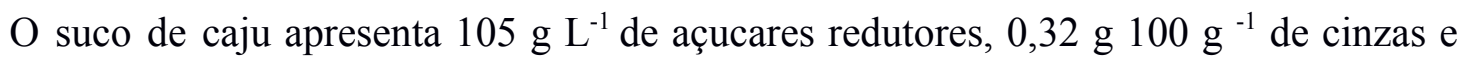
Finare $0,05 \mathrm{~g} 100 \mathrm{~g}^{-1}$ de nitrogênio total. O melaço contém $153 \mathrm{~g} \mathrm{~L}^{-1}$ de açúcares redutores, $67 \mathrm{~g} \mathrm{~L}^{-1}$

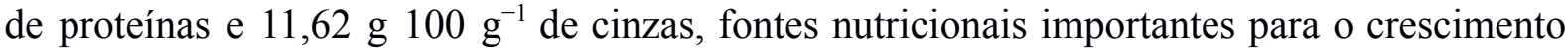
bacteriano (SIQUEIRA et al., 2008). Considerando que o suco de caju apesar de ser rico em açucares, é pobre em nitrogênio, o extrato de levedura e melaço de soja foram avaliados como fonte de nitrogênio.

\section{Produção de celulose bacteriana}

Devido a tendência de formação de células mutantes negativas em cultivo agitados, estudos sugerem o uso de aditivos que inibam esse processo, como os polímeros, capazes de reduzir a mutação por interferir na viscosidade do meio. Nesse estudo foi utilizada a carboximetilcelulose por demonstrar considerável aumento na produção de $\mathrm{CB}$, além de favorecer a formação de pellets (CHENG et al., 2009). Os resultados obtidos no cultivo estático foram $2,02 \mathrm{~g} / \mathrm{L}, 2,27 \mathrm{~g} / \mathrm{L}$ e $2,25 \mathrm{~g} / \mathrm{L}$ respectivamente para o meio padrão $\mathrm{HS}$ e alternativos caju com extrato e caju com melaço. Os resultados obtidos no cultivo agitado foram 2,86 g/L, 2,91 g/L e 2,66 g/L respectivamente para o meio padrão $\mathrm{HS}$ e alternativos caju com extrato e caju com melaço.

Figura 01: Rendimento de celulose bacteriana em cultivo estático e agitado com meio padrão e meios alternativos após 3 dias

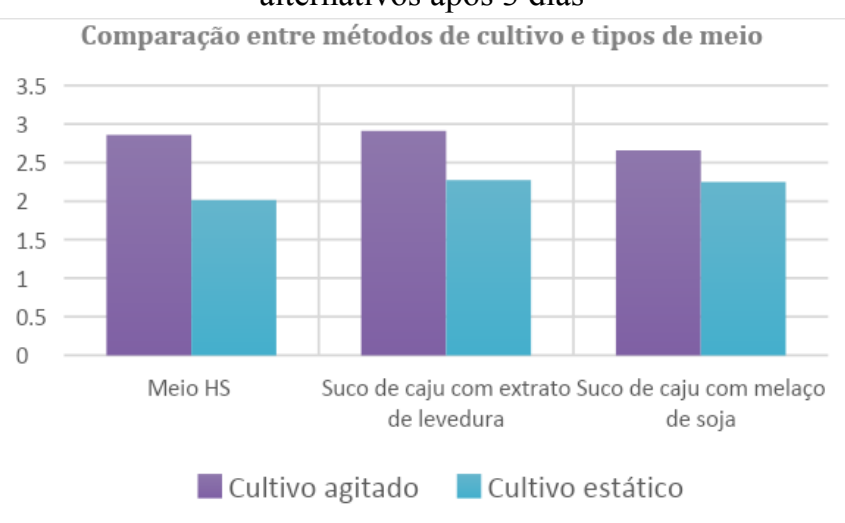

Fonte: Própria (2021)

A adição de $\mathrm{CMC}$ ao cultivo agitado levou ao aumento do rendimento de $\mathrm{CB}$, em comparação ao cultivo estático para todos os meios testados, conforme pode ser observado na Figura 1, viabilizando dessa forma o cultivo agitado em detrimento ao estático. Dentre os 


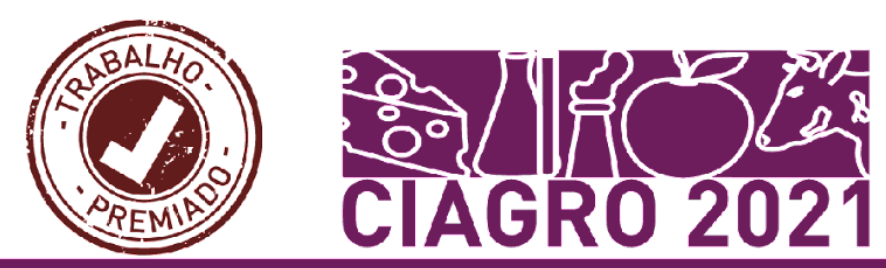

meios alternativos analisados, o cultivo agitado no meio suco de caju com extrato de levedura levou ao maior rendimento $(2,91 \mathrm{~g} / \mathrm{L})$. Ainda assim, o meio suco de caju com melaço de soja também se mostrou com rendimento satisfatório nas condições testadas.

\section{Custo dos meios de cultivo}

Ao longo dos anos, diferentes subprodutos agroindustriais foram avaliados para a produção de CB (Fan et al., 2016; Güzel e Akipinar 2019) e a associação entre melaço de soja e suco de caju (Souza et al., 2019) apresentou resultado superior aos demais. Como pode ser observado no Quadro 01 o uso de subprodutos agroindustriais suco de caju e melaço de soja possibilitou a redução dos custos do meio de cultivo. O meio suco de caju com extrato de levedura reduziu em $40 \%$, enquanto o meio suco de caju com melaço de soja reduziu em $70 \%$ em comparação com o custo estimado para a produção em meio HS.

Quadro 01: Custo do meio de cultivo padrão e alternativo sob agitação.

\begin{tabular}{|c|c|c|c|c|c|}
\hline \multicolumn{2}{|l|}{ Meio HS } & \multicolumn{2}{|c|}{ R\$ Kg-1 reagente } & g L-1 & Custo médio \\
\hline \multicolumn{2}{|l|}{ Glicose } & \multicolumn{2}{|c|}{456} & 20 & 9,12 \\
\hline \multicolumn{2}{|l|}{ Extrato de levedura } & \multicolumn{2}{|c|}{933} & 5 & 4,66 \\
\hline \multicolumn{2}{|l|}{ Peptona } & \multicolumn{2}{|c|}{1760} & 5 & 8,80 \\
\hline \multicolumn{2}{|l|}{ Ácido Cítrico } & \multicolumn{2}{|c|}{560} & 1,5 & 0,84 \\
\hline \multicolumn{2}{|l|}{ Fosfato dissódico (anidro) } & \multicolumn{2}{|c|}{738} & 2,7 & 1,99 \\
\hline \multicolumn{2}{|l|}{ Carboximetilcelulose } & \multicolumn{2}{|c|}{912} & 10 & 9,12 \\
\hline \multicolumn{5}{|c|}{ Meio HS RS L-1 } & 34,54 \\
\hline $\begin{array}{c}\text { Meio suco de caju com extrato de } \\
\text { levedura }\end{array}$ & \multicolumn{2}{|c|}{$\mathrm{R} \$ \mathrm{~L}-1$ reagente } & mL L-1 & g L-1 & Custo médio \\
\hline Suco de caju & \multicolumn{2}{|c|}{4,4} & 200 & AT & 0,88 \\
\hline Extrato de levedura & \multicolumn{2}{|c|}{933} & - & 12 & 11,20 \\
\hline Carboximetilcelulose & \multicolumn{2}{|c|}{912} & - & 10 & 9,12 \\
\hline \multicolumn{5}{|c|}{ Meio suco de caju com extrato de levedura R\$ L-1 } & 21,20 \\
\hline $\begin{array}{c}\text { Meio suco de caju com melaço de } \\
\text { soja }\end{array}$ & $\begin{array}{c}\text { RS L-1 } \\
\text { reagen } \\
\text { te } \\
\end{array}$ & mL L-1 & g L-1 & $\begin{array}{l}\text { Custo } \\
\text { médio }\end{array}$ & \\
\hline Suco de caju & 4,4 & 200 & $\mathrm{AT}$ & 0,88 & \\
\hline Melaço de soja & 0,3 & 150 & AT & 0,04 & \\
\hline Carboximetilcelulose & 912 & - & 10 & 9,12 & \\
\hline \multicolumn{4}{|c|}{ Meio suco de caju com melaço de soja R\$ L-1 } & 10,05 & \\
\hline
\end{tabular}

\section{CONCLUSÃO}

Foi possível produzir a celulose bacteriana usando meios alternativos tanto no método agitado quanto no estático. Em todos os meios avaliados, a produção no cultivo agitado adicionado de carboximetilcelulose $1 \%$ foi maior do que no cultivo estático. A maior 


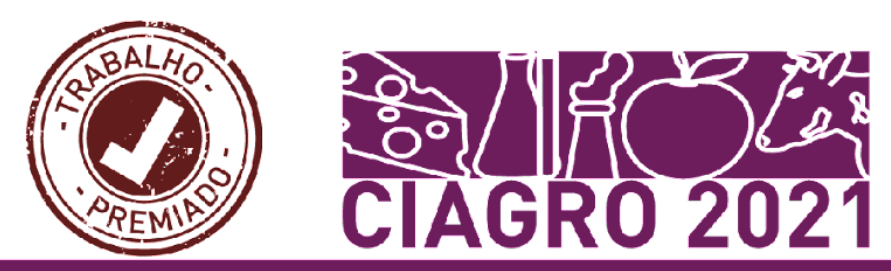

produção de celulose $(2,91 \mathrm{~g} / \mathrm{L})$ foi obtida em suco de caju com extrato de levedura, sendo esse rendimento próximo ao obtido com o meio padrão HS e com custo $40 \%$ inferior.

\section{REFERENCIAS}

CHENG, Kuan-Chen; CATCHMARK, Jeffrey M.; DEMIRCI, Ali. Effect of different additives on bacterial cellulose production by Acetobacter xylinum and analysis of material property. Cellulose, v. 16, n. 6, p. 1033-1045, 2009.

DUARTE, Eden B. et al. Utilização de resíduos agroindustriais na elaboração de bionanocompósitos baseados em celulose bacteriana e Hidroxiapatita. In: Embrapa Agroindústria de Alimentos-Artigo em anais de congresso (ALICE). In: CONGRESSO BRASILEIRO DE POLÍMEROS, 13., 2015, Natal. São Carlos: Associação Brasileira de Polímeros], 2015., 2015.

FAN, Xin et al. Production of nano bacterial cellulose from beverage industrial waste of citrus peel and pomace using Komagataeibacter xylinus. Carbohydrate polymers, v. 151, p. 1068-1072, 2016.

GUBA, E. G.; LINCOLN, Y. S. Fourth generation evaluation. Newbury Park, London, New Delhi: Sage, 1989.

GÜZEL, Melih; AKPINAR, Özlem. Production and characterization of bacterial cellulose from citrus peels. Waste and biomass valorization, v. 10, n. 8, p. 2165-2175, 2019.

HUANG, Yang et al. Recent advances in bacterial cellulose. Cellulose, v. 21, n. 1, p. 1-30, 2014.

LIN, Shin-Ping et al. Biosynthesis, production and applications of bacterial cellulose. Cellulose, v. 20, n. 5, p. 2191-2219, 2013.

LOWRY, Oliver H. et al. Protein measurement with the Folin phenol reagent. Journal of biological chemistry, v. 193, p. 265-275, 1951.

MILLER, Gail Lorenz. Use of dinitrosalicylic acid reagent for determination of reducing sugar. Analytical chemistry, v. 31, n. 3, p. 426-428, 1959.

PINHEIRO, JOSÉ AURÉLIO. Aspectos técnicos e avaliação de ciclo de vida da extração de nanocristais de celulose bacteriana produzida em suco de caju. Embrapa Agroindústria Tropical-Tese/dissertação. 2016.

RECOUVREUX, D., RAMBO, C., BERTI, F., CARMINATTI, C., ANTÔNIO, R., PORTO, L. Novel threedimensional cocoon-like hydrogels for soft tissue regeneration. Mater. Sci. Eng., v. 31, p. 151- 157, 2011. 


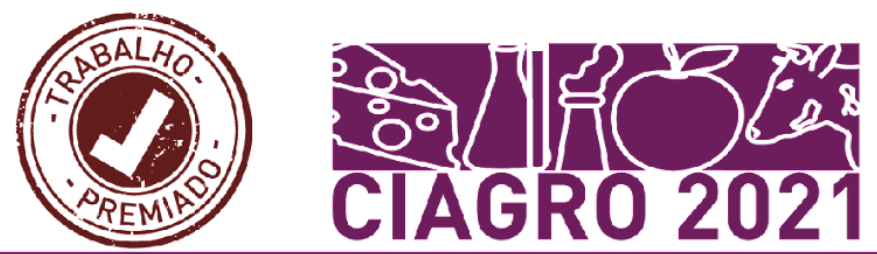

ROUABHIA, Mahmoud et al. Production of biocompatible and antimicrobial bacterial cellulose polymers functionalized by RGDC grafting groups and gentamicin. ACS Applied PIn: Materials \& Interfaces, v. 6, n. 3, p. 1439-1446, 2014.

SIQUEIRA, Paula F. et al. Produção de bioetanol a partir de melaço de soja por Saccharomyces cerevisiae em escala de laboratório, piloto e industrial. Tecnologia Bioresource, v. 99, n. 17, pág. 8156-8163, 2008.

SOUZA, Erika F. et al. Production and characterization of Gluconacetobacter xylinus bacterial cellulose using cashew apple juice and soybean molasses. International journal of biological macromolecules, v. 146, p. 285-289, 2020.

WANG, Z.-G. et al. Preparation of an inoculum of Gluconacetobacter xylinus without mutants in shaken culture. Journal of applied microbiology, v. 121, n. 3, p. 713-720, 2016. 